Mauro Leandro Menegotto

\title{
PREVISÃO DA CURVA TENSÃO-RECALQUE DE ENSAIOS DE PLACA EM SOLO NÃO SATURADO
}

Tese apresentada à Escola de Engenharia de São Carlos, da Universidade de São Paulo, como parte dos requisitos para obtenção do título de Doutor em Geotecnia.

Orientador: Prof. Dr. José Carlos A. Cintra Co-Orientador: Prof. Dr. Nelson Aoki 
Dedico este trabalho à minha esposa Andrea, à minha mãe Maria de Lurdes e ao meu pai Eloy (in memoriam). 


\section{AGRADECIMENTOS}

A Deus, que não se cansa de nos iluminar.

Aos Professores José Carlos A. Cintra e Nelson Aoki, pela orientação, incentivo e amizade.

A todos os meus familiares que dedicaram carinho, apoio e compreenderam a ausência em diversos momentos.

Aos amigos Benedito Carneiro, Marcos Macacari, Yuri Jatobá Costa, Tulia Ribeiro dos Santos, Jeselay Cordeiro dos Reis, Kleber Dourado e Ana Paula Vianna pelo apoio durante a execução das provas de carga.

A todos os colegas, professores e funcionários do Departamento de Geotecnia da USP/São Carlos agradeço pela amizade ao longo do desenvolvimento deste trabalho.

A Coordenadoria de Aperfeiçoamento Pessoal de Nível - CAPES, pela bolsa de estudos concedida.

Ao Centro Tecnológico da UNOCHAPECÓ pelo apoio concedido para a conclusão deste trabalho. 
RESUMO

MENEGOTTO, M. L. (2004). Previsão da curva tensão-recalque de ensaios de placa em solo não saturado. 224p. Tese (Doutorado) - Escola de Engenharia de São Carlos, Universidade de São Paulo, São Carlos. 2004.

Apresenta-se um método para a previsão da curva tensão-recalque a ser obtida em provas de carga em placa circular, instalada a diferentes profundidades e com vários diâmetros, para diversos níveis de sucção em solo não saturado. Também é proposto um procedimento para correção dos recalques medidos em ensaio com carregamento do tipo rápido, para a obtenção dos correspondentes recalques estabilizados de um ensaio lento. A previsão realizada apresenta resultados bastante próximos dos obtidos em provas de carga, verificando-se assim a aplicabilidade do método proposto para reproduzir o comportamento do sistema solo-placa neste tipo de solo. Além disso, este trabalho apresenta um estudo do módulo de deformabilidade a partir de ensaios de campo e de laboratório, para o solo do Campo Experimental de Fundações da EESC/USP, aplicando conceitos da mecânica dos solos não saturados. Em campo, o módulo de deformabilidade foi obtido por meio de provas de carga em placa circular com e sem inundação prévia do solo. Em laboratório, o módulo foi obtido a partir de ensaios de compressão confinada e triaxiais, ambos com sucção controlada. Observouse que a sucção matricial tem grande influência no módulo de deformabilidade do solo.

Palavras-chave: ensaio de placa; curva tensão-recalque; solos não saturados, módulo de deformabilidade. 


\begin{abstract}
MENEGOTTO, M. L. (2004). Stress-settlement curve prediction of plate load tests on unsaturated soil. 224p. Ph.D. Thesis - Escola de Engenharia de São Carlos, Universidade de São Paulo, São Carlos. 2004.

This thesis presents a method for prediction the stress-settlement curve to be obtained in circular plate load tests, at different depths and with several diameters, to differents suction levels on unsaturated soil. A procedure is also proposed for correction the settlement measured with a quick maintained load (QML) tests to obtain the stabilized settlement in a slow maintained load (SML) tests. This prediction presents quite results of the real measured stress-settlement curve through load tests, thus verifying the applicability of the proposed method to reproduce the behavior the soil-plate system in this soil. Besides, this work presents a study of the deformation modulus using field and laboratory tests, to the soil of the Foundations Experimental Field of EESC/USP, applying concepts of the unsaturated soil mechanics. In field, the deformation modulus was obtained by means of circular plate load tests with and without previous soaking of the soil. In laboratory, the modulus was obtained using confined compression and triaxial tests, both with controlled suction. It was observed that the matric suction has great influence in the soil deformation modulus.
\end{abstract}

Keywords: plate load test; stress-settlement curve; unsaturated soils, deformation modulus. 


\section{LISTA DE FIGURAS}

Figura 2.1 - Tipos de sistemas de reação: (a) caixões de areia, (b) plataformas carregadas, (c) estruturas ou vigas ancoradas no terreno (BARATA, 1984).

Figura 2.2 - Tipos de placa utilizadas: (a) convencional, (b) helicoidal 6 (VELLOSO; LOPES, 1996).

Figura 2.3 - Curvas tensão-recalque típicas dos diferentes tipos de ensaios 9 (FELLENIUS, 1975).

Figura 2.4 - Curvas tensão-recalque típicas (TERZAGHI, 1943). 10

Figura 2.5 - Constatação de colapso na carga admissível (CINTRA, 1998). 14

Figura 2.6 - Carga de colapso superior à carga admissível (CINTRA, 1998). 14

Figura 2.7 - Carga de colapso determinada com inundação prévia do solo 15 (CINTRA, 1998).

Figura 2.8 - Curva característica típica de um solo siltoso (FREDLUND; XING, 20 1994). 
Figura 2.9 - Esquema de um tensiômetro convencional (FREDLUND; 22 RAHARDJO, 1993).

Figura 2.10 - Curva típica de carregamento e definição dos módulos de 25 elasticidade (PINTO, 1996).

Figura 2.11 - Detalhes de instalação e correção para medidores não axiais 29 (MELLO; CEPOLINA, 1978)..

Figura 2.12 - Curva típica de um ensaio pressiométrico (SCHNAID, 2000)

Figura 2.13 - Variação do módulo de deformabilidade com a sucção matricial 32 para um solo argiloso (RICHARDS, 1974).

Figura 2.14 - Curvas tensão x deformação de ensaios triaxiais com sucção controlada (DELAGE; SURAJ DE SILVA; LAURE, 1987).

Figura 2.15 - Relação entre a deformabilidade do solo e a sucção (JUCÁ; ESCARIO, 1991).

Figura 2.16 - Variação do módulo de cisalhamento com a sucção em uma argila 34 de alta plasticidade (MARINHO; CHANDLER; CRILLY, 1995).

Figura 3.1 - Seção esquemática da geologia de pequena profundidade em São 36 Carlos (BORTOLUCCI, 1983).

Figura 3.2 - Locação dos ensaios de campo (SPT e CPT) realizados no Campo Experimental de Fundações .

Figura 3.3 - Perfil do terreno associado às sondagens à percussão (modificado de SANTOS, 2001).

Figura 3.4 - Resultados de ensaios penetrométricos de SPT e CPTu. 
Figura 3.5 - Curvas granulométricas obtidas para as profundidades de 3,0, 5,0 e 41 8,0 m, em relação à superfície do terreno (MACHADO, 1998).

Figura 3.6 - Curva característica de sucção do solo para a profundidade de 2,0 m (MACHADO, 1998).

Figura 3.7 - Curva característica de sucção do solo para a profundidade de 5,0 m (MACHADO, 1998).

Figura 3.8 - Curva característica de sucção do solo para a profundidade de 8,0 m (MACHADO, 1998).

Figura 4.1 - Locação das provas de carga em placa no Campo Experimental de 46 Fundações da EESC/USP.

Figura 4.2 - Esquema de montagem da prova de carga para distância entre 49 estacas de reação igual a 3,0 m.

Figura 4.3 - Esquema de montagem da prova de carga para distância entre estacas de reação igual a 4,0 m.

Figura 4.4 - Bomba elétrica utilizada nos ensaios de placa.

Figura 4.5 - Detalhe do indicador de deformações, cronômetro e controle da bomba elétrica.

Figura 4.6 - Detalhe do macaco hidráulico, célula de carga, rótula e disposição dos extensômetros.

Figura 4.7 - Detalhe da torre de transferência de carga utilizada para a profundidade de $1,5 \mathrm{~m}$.

Figura 4.8 - Hastes para acompanhamento de recalque e torre de transferência de carga para ensaios na profundidade de $1,5 \mathrm{~m}$.

Figura 4.9 - Hastes para acompanhamento de recalque e torre de transferência de carga para ensaios nas profundidades de 4,0 e 6,0 m.

Figura 4.10 - Tensiômetros instalados no fundo da cava.

Figura 4.11 - Detalhe do pórtico utilizado para serviços diversos.

Figura 5.1 - Curvas tensão-recalque dos ensaios lentos inundados (sucção $=0$ $\mathrm{kPa})$, profundidade de $1,5 \mathrm{~m}$.

Figura 5.2 - Curva tensão-recalque do ensaio lento S1 (sucção = $10 \mathrm{kPa}$ ), 60 profundidade de $1,5 \mathrm{~m}$.

Figura 5.3 - Curva tensão-recalque do ensaio lento S2 (sucção = $31 \mathrm{kPa}$ ), 60 
profundidade de $1,5 \mathrm{~m}$.

Figura 5.4 - Curvas tensão-recalque dos ensaios rápidos inundados (sucção $=0$ $\mathrm{kPa}$ ), profundidade de $1,5 \mathrm{~m}$.

Figura 5.5 - Curva tensão-recalque do ensaio rápido Q1 (sucção = $15 \mathrm{kPa}$ ), 61 profundidade de $1,5 \mathrm{~m}$.

Figura 5.6 - Curva tensão-recalque do ensaio rápido Q2 (sucção $=22 \mathrm{kPa}$ ), 62 profundidade de $1,5 \mathrm{~m}$.

Figura 5.7 - Curva tensão-recalque do ensaio rápido Q3 (sucção $=33 \mathrm{kPa}$ ), 62 profundidade de $1,5 \mathrm{~m}$.

Figura 5.8 - Curvas tensão-recalque dos ensaios mistos inundados (sucção $=0$ $\mathrm{kPa})$, profundidade de $1,5 \mathrm{~m}$.

Figura 5.9 - Curva tensão-recalque do ensaio misto M1 (sucção = $28 \mathrm{kPa}$ ), 63 profundidade de $1,5 \mathrm{~m}$.

Figura 5.10 - Curva tensão-recalque do ensaio rápido inundado QS3 (sucção = $0 \quad 64$ $\mathrm{kPa}$ ), profundidade de 4,0m.

Figura 5.11 - Curva tensão-recalque do ensaio rápido Q4 (sucção = $18 \mathrm{kPa}$ ), 64 profundidade de 4,0m.

Figura 5.12 - Curva tensão-recalque do ensaio rápido Q5 (sucção = $28 \mathrm{kPa}$ ), 65 profundidade de 4,0m.

Figura 5.13 - Curvas tensão-recalque dos ensaios rápidos inundados (sucção $=0$ $\mathrm{kPa}$ ), profundidade de 6,0 $\mathrm{m}$.

Figura 5.14 - Curva tensão-recalque do ensaio rápido Q6 (sucção $=12 \mathrm{kPa}$ ), 66 profundidade de $6,0 \mathrm{~m}$.

Figura 5.15 - Curva tensão-recalque do ensaio rápido Q7 (sucção = $15 \mathrm{kPa}$ ), 66 profundidade de $6,0 \mathrm{~m}$.

Figura 5.16 - Curva tensão-recalque do ensaio rápido inundado QS6 (sucção = 0 $\mathrm{kPa}$ ), diâmetro de 0,2 m e profundidade de 1,5 m.

Figura 5.17 - Curva tensão-recalque do ensaio rápido Q8 (sucção $=15 \mathrm{kPa}$ ), 67 diâmetro de $0,2 \mathrm{~m}$ e profundidade de $1,5 \mathrm{~m}$.

Figura 5.18 - Curva tensão-recalque do ensaio rápido Q9 (sucção $=17 \mathrm{kPa}$ ), 68 diâmetro de $0,2 \mathrm{~m}$ e profundidade de $1,5 \mathrm{~m}$.

Figura 5.19 - Curva tensão-recalque do ensaio rápido inundado QS7 (sucção = 0 $\mathrm{kPa}$ ), diâmetro de 0,4 m e profundidade de 1,5 m. 
Figura 5.20 - Curva tensão-recalque do ensaio rápido Q10 (sucção $=12 \mathrm{kPa}$ ), 69 diâmetro de $0,4 \mathrm{~m}$ e profundidade de $1,5 \mathrm{~m}$.

Figura 5.21 - Curva tensão-recalque do ensaio rápido Q11 (sucção = $13 \mathrm{kPa}$ ), 69 diâmetro de 0,4 m e profundidade de $1,5 \mathrm{~m}$.

Figura 5.22 - Curva tensão-recalque do ensaio rápido inundado QS8 (sucção = 0 $\mathrm{kPa}$ ), diâmetro de $1,5 \mathrm{~m}$ e profundidade de $1,5 \mathrm{~m}$.

Figura 5.23 - Curva tensão-recalque do ensaio rápido Q12 (sucção = $22 \mathrm{kPa}$ ), 70 diâmetro de $1,5 \mathrm{~m}$ e profundidade de $1,5 \mathrm{~m}$.

Figura 5.24 - Curva tensão-recalque do ensaio rápido Q13 (sucção = $21 \mathrm{kPa}$ ), 71 diâmetro de $1,5 \mathrm{~m}$ e profundidade de $1,5 \mathrm{~m}$.

Figura 6.1 - Curva tensão-recalque da equação (6.1).

Figura 6.2 - Condições limites da equação (6.1).

Figura 6.3 - Curva de variação da tensão de cedência em função da sucção para a 77 profundidade de 1,0 m (MACHADO, 1998).

Figura 6.4 - Curva de variação da tensão de cedência em função da sucção para a 77 profundidade de 2,0 m (MACHADO, 1998).

Figura 6.5 - Curva de variação da tensão de cedência em função da sucção para a 78 profundidade de 4,0 m (MACHADO, 1998).

Figura 6.6 - Curva de variação da tensão de cedência em função da sucção para a 78 profundidade de 5,0 m (MACHADO, 1998).

Figura 6.7 - Curva de variação da tensão de cedência em função da sucção para a 79 profundidade de 7,0 m (MACHADO, 1998).

Figura 6.8 - Curva de variação da tensão de cedência em função da sucção para a 79 profundidade de 8,0 m (MACHADO, 1998).

Figura 6.9 - Verificação da influência do parâmetro c em ensaios lentos e 82 rápidos.

Figura 6.10 - Variação da relação (c / $\sigma_{y}$ ) com o diâmetro da placa para ensaios rápidos inundados.

Figura 6.11 - Variação da relação (c / $\sigma_{y}$ ) com o diâmetro da placa e com a 84 sucção para ensaios rápidos não inundados.

Figura 6.12 - Recalques ao longo do tempo de acordo com as equações 86 utilizadas. 
Figura 6.13 - Coeficiente de adensamento do solo não saturado em função da sucção.

Figura 6.14 - Variação do parâmetro B em função do nível de tensão, para 88 ensaios inundados.

Figura 6.15 - Variação do parâmetro B em função do nível de tensão e da sucção, 88 para ensaios não inundados.

Figura 6.16 - Ensaios rápidos medidos e corrigidos (profundidade de 1,5 m e 90 placa com diâmetro de $0,8 \mathrm{~m})$.

Figura 6.17 - Comparação entre os ensaios rápidos corrigidos com os ensaios 91 lentos (solo inundado).

Figura 6.18 - Comparação entre os ensaios mistos corrigidos com os ensaios lentos (solo inundado).

Figura 6.19 - Curvas tensão-recalque dos ensaios lentos inundados (sucção $=0$ $\mathrm{kPa}$ ), diâmetro de $0,8 \mathrm{~m}$ e na profundidade de $1,5 \mathrm{~m}$.

Figura 6.20 - Curvas tensão-recalque do ensaio lento S1 (sucção $=10 \mathrm{kPa}$ ), 95 diâmetro de 0,8 m e na profundidade de $1,5 \mathrm{~m}$.

Figura 6.21 - Curvas tensão-recalque do ensaio lento S2 (sucção = $31 \mathrm{kPa}$ ), 96 diâmetro de 0,8 m e na profundidade de 1,5 m.

Figura 6.22 - Curvas tensão-recalque dos ensaios rápidos inundados (sucção = $0 \quad 96$ $\mathrm{kPa}$ ), diâmetro de $0,8 \mathrm{~m}$ e na profundidade de $1,5 \mathrm{~m}$.

Figura 6.23 - Curvas tensão-recalque do ensaio rápido Q1 (sucção = $15 \mathrm{kPa}$ ), 97 diâmetro de 0,8 m e na profundidade de 1,5 m.

Figura 6.24 - Curvas tensão-recalque do ensaio rápido Q2 (sucção = $22 \mathrm{kPa}$ ), 97 diâmetro de 0,8 m e na profundidade de $1,5 \mathrm{~m}$.

Figura 6.25 - Curvas tensão-recalque do ensaio rápido Q3 (sucção = $33 \mathrm{kPa}$ ), 98 diâmetro de 0,8 m e na profundidade de $1,5 \mathrm{~m}$.

Figura 6.26 - Curvas tensão-recalque dos ensaios mistos inundados (sucção $=0 \quad 98$ $\mathrm{kPa}$ ), diâmetro de 0,8 m e na profundidade de 1,5 m.

Figura 6.27 - Curvas tensão-recalque do ensaio misto M1 (sucção = $28 \mathrm{kPa}$ ), 99 diâmetro de $0,8 \mathrm{~m}$ e na profundidade de $1,5 \mathrm{~m}$.

Figura 6.28 - Curvas tensão-recalque do ensaio rápido QS3 (sucção $=0 \mathrm{kPa}$ ), 100 diâmetro de 0,8 m e na profundidade de 4,0m. 
Figura 6.29 - Curvas tensão-recalque do ensaio rápido Q4 (sucção = $18 \mathrm{kPa}$ ), 100 diâmetro de 0,8 m e na profundidade de 4,0m.

Figura 6.30 - Curvas tensão-recalque do ensaio rápido Q5 (sucção = $28 \mathrm{kPa}$ ), 101 diâmetro de 0,8 m e na profundidade de 4,0m.

Figura 6.31 - Curvas tensão-recalque dos ensaios rápidos inundados (sucção = 0101 $\mathrm{kPa}$ ), diâmetro de 0,8 m e na profundidade de 6,0 m.

Figura 6.32 - Curvas tensão-recalque do ensaio rápido Q6 (sucção = $12 \mathrm{kPa}$ ), 102 diâmetro de 0,8 m e na profundidade de 6,0m.

Figura 6.33 - Curvas tensão-recalque do ensaio rápido Q7 (sucção = 15 kPa), 102 diâmetro de 0,8 m e na profundidade de 6,0m.

Figura 6.34 - Curvas tensão-recalque do ensaio rápido QS6 (sucção = $0 \mathrm{kPa}$ ), 103 diâmetro de 0,2 m e na profundidade de 1,5 m.

Figura 6.35 - Curvas tensão-recalque do ensaio rápido Q8 (sucção = 15 kPa), 104 diâmetro de 0,2 m e na profundidade de $1,5 \mathrm{~m}$.

Figura 6.36 - Curvas tensão-recalque do ensaio rápido Q9 (sucção = 17 kPa), 104 diâmetro de 0,2 m e na profundidade de 1,5 m.

Figura 6.37 - Curvas tensão-recalque do ensaio rápido QS7 (sucção = $0 \mathrm{kPa}$ ), 105 diâmetro de 0,4 m e na profundidade de 1,5 m.

Figura 6.38 - Curvas tensão-recalque do ensaio rápido Q10 (sucção = $12 \mathrm{kPa}$ ), 105 diâmetro de 0,4 m e na profundidade de 1,5 m.

Figura 6.39 - Curvas tensão-recalque do ensaio rápido Q11 (sucção = 13 kPa), 106 diâmetro de 0,4 m e na profundidade de $1,5 \mathrm{~m}$.

Figura 6.40 - Curvas tensão-recalque do ensaio rápido QS8 (sucção = 0 kPa), 106 diâmetro de $1,5 \mathrm{~m}$ e na profundidade de $1,5 \mathrm{~m}$.

Figura 6.41 - Curvas tensão-recalque do ensaio rápido Q12 (sucção = 22 kPa), 107 diâmetro de 1,5 m e na profundidade de 1,5 m.

Figura 6.42 - Curvas tensão-recalque do ensaio rápido Q13 (sucção = $21 \mathrm{kPa}$ ), 107 diâmetro de $1,5 \mathrm{~m}$ e na profundidade de $1,5 \mathrm{~m}$.

Figura 6.43 - Comparação entre as tensões de ruptura convencional medidas no 110 ensaio e previstas.

Figura 6.44 - Comparação entre as energias de deformação medidas e previstas. 
Figura 6.45 - Variação das curvas tensão-recalque com a sucção para ensaios de 114 placa do tipo lento e rápido (diâmetro de 0,8 m e profundidade de 1,5 m).

Figura 6.46 - Variação da tensão de ruptura com a sucção (diâmetro de 0,8 m e 114 profundidade de $1,5 \mathrm{~m}$ ).

Figura 6.47 - Variação das curvas tensão-recalque com a sucção para ensaios de 115 placa do tipo lento e rápido (diâmetro de 0,8 m e profundidade de 4,0 m).

Figura 6.48 - Variação da tensão de ruptura com a sucção (diâmetro de 0,8 m e 115 profundidade de 4,0 m).

Figura 6.49 - Variação das curvas tensão-recalque com a sucção para ensaios de 116 placa do tipo lento e rápido (diâmetro de 0,8 m e profundidade de 6,0 m).

Figura 6.50 - Variação da tensão de ruptura com a sucção (diâmetro de 0,8 m e 117 profundidade de $6,0 \mathrm{~m}$ ).

Figura 6.51 - Variação da curva tensão-recalque com o diâmetro da placa 118 (profundidade de $1,5 \mathrm{~m}$ e sucção de $0 \mathrm{kPa}$ ).

Figura 6.52 - Variação da curva tensão-recalque com o diâmetro da placa 118 (profundidade de 1,5 m e sucção de $10 \mathrm{kPa}$ ).

Figura 6.53 - Variação da curva tensão-recalque com o diâmetro da placa (profundidade de 1,5 m e sucção de $20 \mathrm{kPa}$ ).

Figura 6.54 - Variação da curva tensão-recalque com o diâmetro da placa 119 (profundidade de $1,5 \mathrm{~m}$ e sucção de $30 \mathrm{kPa}$ ).

Figura 7.1 - Variação do módulo de deformabilidade com a sucção matricial 121 (ensaios de placa em diferentes profundidades).

Figura 7.2 - Módulo de deformabilidade em função da sucção (profundidades de 122 $1,0$ e $2,0 \mathrm{~m})$.

Figura 7.3 - Módulo de deformabilidade em função da sucção (profundidades de 3,0, 4,0 e 5,0 m).

Figura 7.4 - Módulo de deformabilidade em função da sucção (profundidade de $7,0$ e $8,0 \mathrm{~m})$.

Figura 7.5 - Variação do módulo de deformabilidade secante obtido nos ensaios triaxiais com a sucção.

Figura 7.6 - Variação do módulo de deformabilidade tangente inicial obtido nos ensaios triaxiais com a sucção. 
Figura 7.7 - Comparação entre os resultados de campo (profundidade de 1,5 m) e 126 laboratório (profundidade de 2,0 m).

Figura 7.8 - Comparação entre os resultados de campo (profundidades de 4,0 e 126 6,0 m) e laboratório (profundidade de 5,0 m).

Figura A.1 - Curvas $\left(\mathrm{e} / \mathrm{e}_{\mathrm{o}}\right) \times\left(\sigma_{\mathrm{v}}-\mathrm{u}_{\mathrm{a}}\right)$ obtidas para a profundidade de $1,0 \mathrm{~m} 214$ (MACHADO, 1998).

Figura A.2 - Curvas $\left(\mathrm{e} / \mathrm{e}_{\mathrm{o}}\right) \times\left(\sigma_{\mathrm{v}}-\mathrm{u}_{\mathrm{a}}\right)$ obtidas para a profundidade de 2,0 m 214 (MACHADO, 1998).

Figura A.3 - Curvas $\left(\mathrm{e} / \mathrm{e}_{\mathrm{o}}\right) \times\left(\sigma_{\mathrm{v}}-\mathrm{u}_{\mathrm{a}}\right)$ obtidas para a profundidade de 3,0 m 215 (MACHADO, 1998).

Figura A.4 - Curvas $\left(\mathrm{e} / \mathrm{e}_{\mathrm{o}}\right) \times\left(\sigma_{\mathrm{v}}-\mathrm{u}_{\mathrm{a}}\right)$ obtidas para a profundidade de 4,0 m 215 (MACHADO, 1998).

Figura A.5 - Curvas $\left(\mathrm{e} / \mathrm{e}_{\mathrm{o}}\right) \times\left(\sigma_{\mathrm{v}}-\mathrm{u}_{\mathrm{a}}\right)$ obtidas para a profundidade de 5,0 m 216 (MACHADO, 1998).

Figura A.6 - Curvas $\left(\mathrm{e} / \mathrm{e}_{\mathrm{o}}\right) \times\left(\sigma_{\mathrm{v}}-\mathrm{u}_{\mathrm{a}}\right)$ obtidas para a profundidade de 7,0 m 216 (MACHADO, 1998).

Figura A.7 - Curvas $\left(\mathrm{e} / \mathrm{e}_{\mathrm{o}}\right) \times\left(\sigma_{\mathrm{v}}-\mathrm{u}_{\mathrm{a}}\right)$ obtidas para a profundidade de 8,0 m 217 (MACHADO, 1998).

Figura B.1 - Resultados dos ensaios CID sat para a profundidade de 2,0 m, sucção 219 nula (MACHADO, 1998).

Figura B.2 - Resultados dos ensaios triaxiais em estágios múltiplos e com 219 controle de sucção para a profundidade de $2,0 \mathrm{~m}$, sucção de $80 \mathrm{kPa}$ (MACHADO, 1998).

Figura B.3 - Resultados dos ensaios triaxiais em estágios múltiplos e com 220 controle de sucção para a profundidade de 2,0 m, sucção de $120 \mathrm{kPa}$ (MACHADO, 1998).

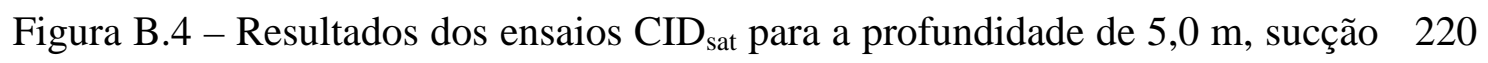
nula (MACHADO, 1998).

Figura B.5 - Resultados dos ensaios triaxiais em estágios múltiplos e com 221 controle de sucção para a profundidade de 5,0 m, sucção de $40 \mathrm{kPa}$ 
(MACHADO, 1998).

Figura B.6 - Resultados dos ensaios triaxiais em estágios múltiplos e com 221 controle de sucção para a profundidade de 5,0 m, sucção de $80 \mathrm{kPa}$ (MACHADO, 1998).

Figura B.7 - Resultados dos ensaios triaxiais em estágios múltiplos e com 222 controle de sucção para a profundidade de 5,0 m, sucção de $160 \mathrm{kPa}$ (MACHADO, 1998).

Figura B.8 - Resultados dos ensaios CID sat para a profundidade de 8,0 m, sucção 222 nula (MACHADO, 1998).

Figura B.9 - Resultados dos ensaios triaxiais em estágios múltiplos e com 223 controle de sucção para a profundidade de 8,0 m, sucção de $40 \mathrm{kPa}$ (MACHADO, 1998).

Figura B.10 - Resultados dos ensaios triaxiais em estágios múltiplos e com 223 controle de sucção para a profundidade de $8,0 \mathrm{~m}$, sucção de $80 \mathrm{kPa}$ (MACHADO, 1998).

Figura B.11 - Resultados dos ensaios triaxiais em estágios múltiplos e com 224 controle de sucção para a profundidade de 8,0 m, sucção de $120 \mathrm{kPa}$ (MACHADO, 1998).

Figura B.12 - Resultados dos ensaios triaxiais em estágios múltiplos e com 224 controle de sucção para a profundidade de 8,0 m, sucção de $160 \mathrm{kPa}$ (MACHADO, 1998).

\section{LISTA DE SÍMBOLOS}

a - é aproximadamente o valor de entrada de ar do solo

A - parâmetro da equação que se refere à forma da curva de estabilização dos recalques;

a, b e c - parâmetros da equação do método proposto

$\mathrm{B}_{\mathrm{i}}$ - parâmetro da equação que se refere ao recalque inicial logo após o acréscimo de carga em cada estágio de carregamento

$\mathrm{B}_{\mathrm{p}}$ - largura ou diâmetro da placa 
$\mathrm{B}_{\mathrm{s}}$ - largura ou diâmetro da sapata

$\mathrm{C}_{\mathrm{V}}{ }^{*}$ - coeficiente de adensamento do solo não saturado

D - diâmetro da placa

$\mathrm{dP} / \mathrm{dV}$ - declividade da fase pseudo-elástica da curva pressiométrica;

e - índice de vazios

E - módulo de deformabilidade do solo

E - módulo de deformabilidade

$E_{\sigma}$ - módulo de deformabilidade correspondente a uma tensão $\sigma$

$\mathrm{E}_{0}$ - módulo de deformabilidade tangente inicial

$\mathrm{E}_{50}$ - módulo de deformabilidade corresponde um acréscimo de tensão igual a $50 \%$ daquela que provocaria a ruptura

$\mathrm{E}_{\mathrm{a}}$ - módulo correspondente à pressão atmosférica

$\mathrm{E}_{\mathrm{D}}$ - módulo dilatométrico

$\mathrm{E}_{\mathrm{m}}$ - módulo pressiométrico

$\mathrm{E}_{\mathrm{s} 0}$ - módulo de deformabilidade secante a partir da origem

$\mathrm{E}_{\mathrm{sec}}$ - módulo de deformabilidade secante

$\mathrm{E}_{\mathrm{tg}}$ - módulo de deformabilidade tangencial

G - módulo de cisalhamento

$\mathrm{H}$ - distância de drenagem

$\mathrm{k}$ - coeficiente de recalque do solo

$\mathrm{K}$ - módulo de deformabilidade volumétrico

m - parâmetro relacionado ao teor de umidade residual

M - módulo edométrico

$\mathrm{m}_{\mathrm{v}}$ - coeficiente de variação volumétrica do solo

$\mathrm{n}$ - coeficiente que pode assumir valores entre 0 e 1

n - parâmetro que controla a inclinação no ponto de inflexão da curva

$\mathrm{P}_{0}$ - pressão corrigida correspondente ao deslocamento nulo da membrana

$\mathrm{P}_{1}$ - pressão corrigida correspondente ao deslocamento de $1,1 \mathrm{~mm}$ do centro da membrana

$\mathrm{P}_{\mathrm{a}}$ - pressão atmosférica

$\mathrm{R}$ - raio da placa 
t - tempo após a aplicação do acréscimo de tensão

t - tempo de duração dos estágios na prova de carga do tipo rápida

$\operatorname{tg} \theta$ - coeficiente angular da assíntota à curva tensão-recalque quando o recalque tende para o infinito

$\mathrm{u}_{\mathrm{a}}$ - pressão no ar existente nos vazios do solo

$\mathrm{u}_{\mathrm{w}}$ - pressão na água existente nos vazios do solo

$\left(\mathrm{u}_{\mathrm{a}}-\mathrm{u}_{\mathrm{w}}\right)$ - sucção matricial

$\mathrm{V}$ - volume de uma amostra de solo

$\mathrm{V}_{\mathrm{f}}$ - volume correspondente ao final da fase elástica

$\mathrm{V}_{\mathrm{i}}$ - volume inicial da célula de medição

$\mathrm{V}_{\mathrm{S}}$ - energia de deformação armazenada no sistema durante a fase de carregamento

$\mathrm{V}_{\mathrm{w}}$ - volume de água presente numa amostra de solo

$\mathrm{V}_{0}$ - volume da célula de medida no início do trecho elástico

$\mathrm{w}$ - teor de umidade

$\mathrm{w}_{\mathrm{L}}$ - limite de liquidez

$\mathrm{w}_{\mathrm{ot}}$ - teor de umidade ótimo

$\mathrm{w}_{\mathrm{P}}$ - limite de plasticidade

z - profundidade na qual a medição é realizada

$\Delta \mathrm{e}$ - variação do índice de vazios correspondente a $\Delta \sigma$

$\Delta \rho_{\mathrm{i}, \mathrm{t}}-$ acréscimo de recalque no estágio $i$ num tempo $t$ após a aplicação do incremento de tensão

$\Delta \rho_{\infty \mathrm{i}}$ - acréscimo de recalque total do estágio

$\Delta \sigma-$ incremento de tensão

$\varepsilon_{\mathrm{v}}-$ deformação volumétrica

$\gamma$ - peso específico natural

$\gamma_{\mathrm{d}}$ - peso específico seco

$\gamma_{\mathrm{d} \max }-$ peso específico seco máximo

$\gamma_{\mathrm{s}}$ - peso específico dos sólidos

$v$ - coeficiente de Poisson

$\pi$ - sucção osmótica

$\theta$ - umidade volumétrica 
$\theta_{\mathrm{r}}$ - umidade volumétrica residual

$\theta_{\mathrm{s}}-$ umidade volumétrica do solo saturado

$\rho$ - recalque

$\rho_{\mathrm{a}}-$ recalque admissível

$\rho_{\mathrm{d}}-$ massa específica do solo seco

$\rho_{\mathrm{i}, \mathrm{t}}$ - recalque total até o estágio $i$ no tempo $t$ após a aplicação do acréscimo de tensão

$\rho_{\mathrm{p}}$ - recalque da placa

$\rho_{\mathrm{s}}-$ recalque da sapata

$\rho_{\mathrm{w}}$ - massa específica da água ou da solução do solo

$\rho_{z}$ - deslocamento medido na profundidade $z$

$\rho_{\infty i}$ - recalque final do estágio

$\rho_{\infty \mathrm{i}-1}$ - recalque final do estágio anterior

$\sigma$ - tensão aplicada à placa

$\sigma_{10}$ - tensão que provoca na placa um recalque de $10 \mathrm{~mm}$

$\sigma_{25}$ - tensão que provoca na placa um recalque de $25 \mathrm{~mm}$

$\sigma_{\mathrm{a}}-$ tensão admissível

$\sigma_{\mathrm{r}}-$ tensão de ruptura ou tensão de ruptura convencional

$\sigma_{\mathrm{u}}-$ tensão última

$\sigma_{\mathrm{y}}-$ tensão de cedência

$\sigma_{\rho \text { máx }}-$ tensão que provoca o recalque máximo

$\psi$ - sucção total

$\Psi_{\mathrm{r}}$ - sucção correspondente ao teor de umidade residual, $\theta_{\mathrm{r}}$ 
RESUMO iv

ABSTRACT v v

LISTA DE FIGURAS vi vi

LISTA DE SÍMBOLOS XV XV

1. INTRODUÇÃO 1

2. REVISÃO BIBLIOGRÁFICA 3

2.1. Prova de carga em placa 3

2.1.1. Classificação das provas de carga em placa 5

2.1.1.1. Quanto ao sistema de reação 5

2.1.1.2. Quanto ao tipo de placa 5

2.1.1.3. Quanto ao modo de carregamento 6

2.1.2. Curva tensão-recalque do ensaio 9

2.1.3. Interpretação dos resultados 10

2.1.3.1. Obtenção da tensão admissível 10

2.1.3.2. Estimativa de recalques imediatos de sapatas 12

2.1.4. Realização de provas de carga em placa em solos colapsíveis 13

2.2. Sucção no solo $\quad 18$

2.2.1. Curva de retenção de água no solo ou curva característica 19

2.2.2. Métodos para medida da sucção no campo 21

$\begin{array}{ll}\text { 2.2.2.1. Tensiômetro } & 21\end{array}$

$\begin{array}{ll}\text { 2.2.2.2. Psicrômetro } & 23\end{array}$

2.2.2.3. Papel Filtro 23

2.3. Módulo de deformabilidade $\quad 24$

2.3.1. Obtenção do módulo de deformabilidade a partir de ensaios 24

2.3.1.1. Ensaio de compressão triaxial 24

2.3.1.2. Ensaio de compressão isotrópica 26

2.3.1.3. Ensaio de compressão confinada (edométrico) 26

$\begin{array}{ll}\text { 2.3.1.4. Ensaio de placa } & 27\end{array}$

2.3.1.5. Ensaio pressiométrico (pré-perfurado) 29 
2.3.2. Módulo de cisalhamento 31

2.3.3. Relação tensão-deformação nos solos não saturados 32

3. LOCAL DA PESQUISA

3.1. Aspectos gerais 35

3.2. Aspectos geológicos 35

3.3. Caracterização geotécnica 37

3.3.1. Ensaios in situ 37

3.3.2. Ensaios de laboratório 39

4. MATERIAIS E MÉTODOS 44

$\begin{array}{ll}\text { 4.1. Provas de carga em placa } & 44\end{array}$

4.2. Equipamentos e materiais utilizados nos ensaios de placa 48

4.2.1. Estacas de reação 48

4.2.2. Vigas de reação $\quad 48$

4.2.3. Placas $\quad 50$

4.2.4. Macaco hidráulico e bomba 50

4.2.5. Células de carga

4.2.6. Indicador de deformações 51

4.2.7. Rótula

4.2.8. Torres de transferência de carga 52

4.2.9. Extensômetros

4.2.10. Dispositivos de referência 54

4.2.11. Hastes para acompanhamento de recalque 54

4.2.12. Tensiômetros 56

4.2.13. Barraca de proteção 56

4.2.14. Pórtico metálico 57

5. APRESENTAÇÃO DOS RESULTADOS 58

5.1. Medidas de sucção nos ensaios de placa 58

5.2. Curvas tensão-recalque $\quad 59$ 
6. MÉTODO PARA PREVISÃO DA CURVA TENSÃO-RECALQUE 72

6.1. Proposição 72

6.2. Parâmetros da curva tensão-recalque

6.3. Correção de ensaios rápidos para lentos $\quad 84$

6.3.1. Parâmetros da estabilização dos recalques 86

6.3.2. Extrapolação dos ensaios rápidos 89

6.4. RESUMO DE APLICAÇÃO DOS MÉTODOS PROPOSTOS 92

6.4.1. Previsão da curva tensão-recalque de ensaios lentos 92

6.4.2. Previsão da curva tensão-recalque de ensaios rápidos 93

6.5. Aplicações $\quad 94$

6.5.1. Ensaios de placa com diâmetro de 0,8 m na profundidade de 1,5 $\mathrm{m} \quad 94$

6.5.2. Ensaios de placa com diâmetro de 0,8 m nas profundidades de 4,0 e 6,0 m 99

6.5.3. Ensaios de placa com diâmetros de 0,2, 0,4 e 1,5 m na profundidade 103 de $1,5 \mathrm{~m}$

6.6. Comparações entre as curvas tensão-recalque medidas e previstas $\quad 108$

6.7. Previsões adicionais da curva tensão-recalque 113

6.7.1. Influência da sucção e profundidade 113

6.7.2. Influência da sucção e do diâmetro da placa 117

7. INFLUÊNCIA DA SUCÇÃO NO MÓDULO DE DEFORMABILIDADE 120

$\begin{array}{ll}\text { 7.1. Provas de carga em placa } & 120\end{array}$

7.2. Ensaios de compressão confinada 122

7.3. Ensaios de compressão triaxial 123

7.4. Comparação entre os resultados de campo e laboratório 125

$\begin{array}{lr}\text { 8. CONCLUSÕES } & 128\end{array}$

REFERÊNCIAS BIBLIOGRÁFICAS 131 
APÊNDICE A - Planilhas dos ensaios de placa

APÊNDICE B - Coeficientes de adensamento

APÊNDICE C - Coeficiente de Poisson

ANEXO A - Resultados dos ensaios de compressão confinada

213

ANEXO B - Resultados dos ensaios de compressão triaxial 


\section{INTRODUÇÃO}

Quando se aplicam carregamentos em fundações, surgem deformações que causam deslocamentos verticais, ou seja, recalques. A estimativa desses recalques é de grande importância para a engenharia de fundações, com o intuito de controlar e evitar danos estéticos e estruturais que os mesmos possam causar. No caso de solos não saturados a previsão de recalques deve levar em consideração a ação da sucção, uma vez que ela exerce influência na rigidez e na resistência ao cisalhamento do solo.

Neste contexto, o presente trabalho apresenta um método para a previsão da curva tensão-recalque a ser obtida em provas de carga em placa circular, para diversos níveis de sucção, em solo não saturado. Em princípio, o método foi calibrado para a previsão de resultados de ensaios de placa circular com diâmetro de 0,8 m. Posteriormente, foi generalizado para placas com vários diâmetros e instaladas em diferentes profundidades, visando uma possível estimativa do comportamento de sapatas e tubulões.

Também é proposta uma maneira para correção aos recalques medidos em estágios de ensaios com carregamento do tipo rápido para obtenção dos correspondentes recalques estabilizados de um ensaio lento.

Em complementação, realiza-se um estudo do módulo de deformabilidade para o solo não saturado do Campo Experimental de Fundações do Departamento de Geotecnia da EESC/USP. Em campo, tal parâmetro é obtido a partir dos resultados de provas de carga em placa nas condições de umidade natural e com inundação prévia da cava por um período mínimo de 24 horas. Em laboratório, tal módulo é obtido por meio de ensaios de compressão confinada e triaxiais, ambos com sucção controlada.

Deste modo, constituem objetivos desta pesquisa:

- Propor um método para a previsão da curva tensão-recalque a ser obtida em provas de carga em placa no solo não saturado;

- Propor um procedimento para corrigir os recalques medidos nos estágios de ensaios de placa do tipo rápido para obter os recalques estabilizados de ensaios lentos;

- Verificar a influência da sucção no módulo de deformabilidade do solo, através de ensaios de placa, edométricos e triaxiais, sendo todos os ensaios realizados com controle de sucção.

A organização do texto deste trabalho foi realizada em oito capítulos, a começar por esta introdução. 
O Capítulo 2 apresenta uma revisão bibliográfica onde se aborda a execução de provas de carga em placa, a sucção e o módulo de deformabilidade do solo.

No Capítulo 3 descreve-se o local da pesquisa, com os aspectos geológicos da Região de São Carlos e a caracterização geotécnica do Campo Experimental de Fundações do Departamento de Geotecnia da EESC/USP.

O Capítulo 4 relaciona os materiais e métodos utilizados para a execução das provas de carga em placa. No Capítulo 5 apresentam-se os resultados das sucções e das curvas tensão-recalque referentes aos ensaios de placa.

No Capítulo 6 é proposto um método para a previsão da curva tensãorecalque a ser obtida nos ensaios de placa e um procedimento para correção dos recalques medidos em ensaio do tipo rápido para obter os recalques estabilizados de um ensaio lento.

No Capítulo 7 são analisados os resultados das provas de carga em placa com diâmetro de 0,8 m e de ensaios laboratoriais quanto à influência da sucção no módulo de deformabilidade do solo.

Finalmente, no capítulo 8, são apresentadas as principais conclusões. 


\section{REVISÃO BIBLIOGRÁFICA}

\subsection{PROVA DE CARGA EM PLACA}

A prova de carga em placa se constitui em um ensaio de compressão realizado diretamente na superfície ou em determinada profundidade do terreno, por meio de uma placa metálica e rígida. O ensaio procura reproduzir o comportamento da fundação sob a ação das solicitações provenientes da superestrutura, sendo a cota de realização do ensaio definida de acordo com a necessidade do projeto.

Segundo Barata (1984) este é o mais antigo ensaio in situ de compressão. No Brasil, um dos primeiros trabalhos sobre o assunto é de autoria de Cunha ${ }^{1}$ (1920 apud AGNELLI, 1997), que apresenta vários ensaios em terrenos para o estudo de fundações. Também podem ser citados como precursores os trabalhos de Machado (1954) que realiza uma prova de carga em areia fina compacta na cidade de Santos, de Napoles Neto (1954) que desenvolve estudos de recalques em um solo de alteração de gnaisse e do Instituto de Pesquisas Tecnológicas (IPT, 1954) que utiliza resultados de três provas de carga sobre placa nas profundidades de aproximadamente 1,0, 5,0 e 7,0 m, a fim de se verificar mais objetivamente a viabilidade ou não de fundações diretas para as instalações da Escola de Engenharia de São Carlos.

De acordo com Barata (1984), internacionalmente, são pioneiros os trabalhos de Enger (1916), Goldbeck (1925), Terzaghi (1925, 1932).

Housel $^{2}$ (1929 apud BARATA, 1966) propõe para a determinação da tensão admissível de fundações diretas a realização de três provas de carga em placas circulares de diferentes diâmetros à mesma profundidade, demonstrando existir uma relação linear entre a tensão que produz um certo recalque e quociente entre o perímetro e a área da placa. Segundo Bowles (1996) este método foi amplamente utilizado até meados 1950.

\footnotetext{
${ }^{1}$ CUNHA, D.J.S. (1920). Experimentação dos terrenos para o estudo das fundações. Revista Brasileira de Engenharia. v.1, n.1, Rio de Janeiro.

2 HOUSEL, W. S. (1929). A practical method for the selection of foundations based on fundamental research in soil mechanics. Universidade de Michigan, Ann Harbor, USA. Dept. Eng. Research. Bull. 13.
} 
Press $^{3}$ (1930 apud FEDA, 1978) apresenta a variação do recalque em função da área de placas quadradas, para um valor de tensão constante, a partir de resultados de provas de carga em placas realizadas em areia e silte argiloso.

As provas de carga em placa são utilizadas para obter as características de resistência e deformabilidade do solo em um local específico. Entretanto, são geralmente realizadas sobre áreas pequenas enquanto que a informação requerida é ação a ser esperada para casos de grandes áreas carregadas. A menos que os efeitos das diferenças no tamanho entre a placa e a fundação sejam apropriadamente levados em conta, a prova de carga pode levar a um senso falso de segurança ou, por outro lado, levar a projeto anti-econômico (TAYLOR, 1948).

O ensaio tem maior aplicabilidade no caso de terrenos cuja deformabilidade é praticamente imediata à ação das cargas, tais como: a) os terrenos pedregulhosos, arenosos e silto-arenosos, em qualquer grau de saturação; b) terrenos argilosos e siltoargilosos, em baixo grau de saturação (BARATA,1966).

Entretanto, segundo Mello e Cepollina (1978) o ensaio deve reproduzir as condições de funcionamento previstas para a estrutura. No caso de estruturas cuja sobrecarga é grande em relação ao seu peso próprio e, além disto, é aplicada instantaneamente (por exemplo, fundação de silos e tanques), os fenômenos de ruptura são geralmente condicionantes. Nas estruturas em que os critérios de recalques admissíveis são condicionantes para o projeto, o ensaio deve sempre atingir a estabilização dos efeitos sob cada incremento de carga.

\subsubsection{CLASSIFICAÇÃO DAS PROVAS DE CARGA EM PLACA}

\subsubsection{Quanto ao sistema de reação}

Os esforços são transmitidos à placa por meio de macacos hidráulicos, os quais reagem contra um sistema de reação que pode ser de diversos tipos (Figura 2.1), como: caixões de areia, plataformas carregadas, estruturas ou vigas ancoradas no terreno, etc..

\footnotetext{
${ }^{3}$ PRESS, H. (1930). Baugrundbelastungsversuche mit Flächen verschiedenerGrösse. Die Bautechnik 8 , 42, p. 641-643.
} 


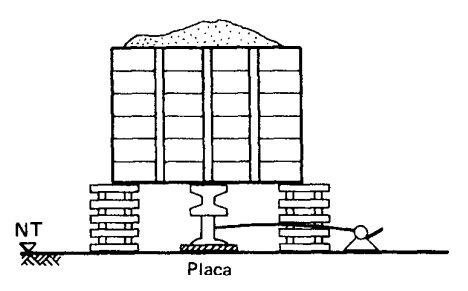

(a)

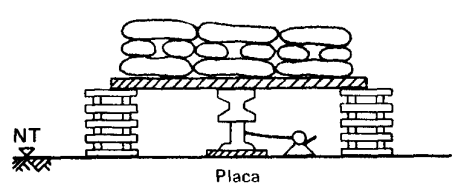

(b)

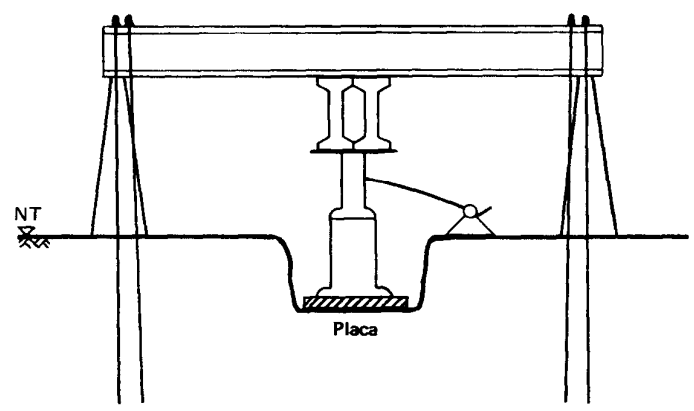

(c)

Figura 2.1 - Tipos de sistemas de reação: (a) caixões de areia, (b) plataformas carregadas, (c) estruturas ou vigas ancoradas no terreno. (BARATA, 1984)

\subsubsection{Quanto ao tipo de placa}

a) Placa convencional

A placa convencional é formada por uma chapa de aço, a qual pode ser circular ou retangular (Figura 2.2a), sendo perfeitamente plana a face que fica em contato com o solo.

b) Placa helicoidal (screw-plate)

Consiste basicamente de uma lâmina helicoidal de aço de um único ciclo, a qual é inserida no solo através de rotação (Figura 2.2b). É recomendada para solos em que a retirada de amostras fica muito comprometida. Entretanto, este tipo de placa tem sido utilizado para a medida in situ das propriedades geotécnicas de solos coesivos e não coesivos. 
Brown (1988) descreve os procedimentos para a realização e a interpretação dos resultados de provas de carga com placa helicoidal. Relata que por meio deste ensaio pode-se determinar a capacidade de carga, o módulo de deformabilidade drenado e não drenado, bem como o coeficiente de adensamento do solo. Para a obtenção destes dois últimos parâmetros, o ensaio pode durar várias horas, ao menos que, o solo seja permeável ou a placa helicoidal tenha um diâmetro pequeno.

(a)

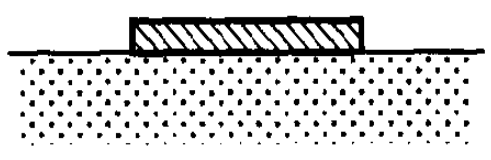

(b)

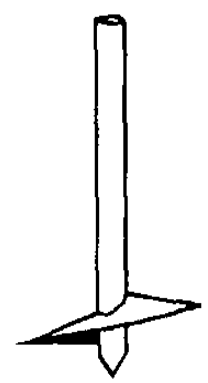

Figura 2.2 - Tipos de placa utilizadas: (a) convencional, (b) helicoidal. (VELLOSO; LOPES, 1996)

\subsubsection{Quanto ao modo de carregamento}

a) Ensaio com taxa de penetração constante (Constant Ratio of Penetration - CRP)

Neste tipo de ensaio, a placa é forçada a recalcar a uma velocidade constante pré-determinada, normalmente $0,5 \mathrm{~mm} / \mathrm{min}$, e a força necessária para provocar tal penetração é medida. O ensaio é conduzido até uma penetração de 50 a $75 \mathrm{~mm}$, ou quando o recalque aumenta sob carga constante (FELLENIUS, 1975).

O ensaio possui as vantagens de ser realizado em curto período de tempo (aproximadamente 2 a 3 horas) e de oferecer uma boa definição da curva tensãorecalque resultante. Como desvantagem, é necessária a utilização de equipamentos especiais, como um macaco hidráulico com fluxo de óleo constante.

Tomlinson (1995) indica uma velocidade de ensaio de $2,5 \mathrm{~mm} / \mathrm{min}$ no caso de ser exigida a carga de ruptura do terreno em condições não drenadas, ou quando não há uma indicação clara da ruptura com o aumento da carga. De acordo com o autor a 
tensão de ruptura é definida pela tensão que provoca um recalque de 15\% do diâmetro da placa.

b) Ensaio Lento (Slow Maintained Load Test - SML)

No Brasil este ensaio é normatizado pela NBR 6489/84, a qual especifica que o carregamento deve ser aplicado à placa em estágios sucessivos de, no máximo, 20\% da provável tensão admissível e, em cada estágio, os recalques devem ser lidos imediatamente após a aplicação da carga e após intervalos de tempo sucessivamente dobrados (1, 2, 4, 8, 15, 30, 60 minutos, 2, 4 horas, etc.). Novo acréscimo de carga só deverá ser aplicado após a estabilização dos recalques, o que ocorre quando a diferença entre duas leituras sucessivas não ultrapassa $5 \%$ do recalque total ocorrido durante o estágio em questão.

Caso não ocorra a ruptura do solo, a prova de carga deve prosseguir até se observar um recalque de, pelo menos, $25 \mathrm{~mm}$, ou até que se atinja uma tensão equivalente ao dobro da tensão admissível prevista, mantendo-se a tensão máxima por no mínimo 12 horas.

O descarregamento deverá ser realizado em estágios sucessivos, não superiores a 25\% da carga total, lendo-se os recalques de maneira idêntica à do carregamento e mantendo-se cada estágio até a estabilização dos recalques, dentro da precisão admitida.

c) Ensaio rápido ( Quick Maintained Load Test - QML)

Para a realização deste tipo de ensaio adota-se um intervalo de tempo fixo para a duração de cada estágio de carregamento, independente da estabilização dos recalques. Os deslocamentos devem ser lidos obrigatoriamente no início e término de cada estágio, sendo a carga aplicada não superior a 10\% da tensão admissível prevista. Fellenius (1975) sugere que cada estágio de carregamento seja mantido por um período de $15 \mathrm{~min}$, com leitura de recalques a cada $3 \mathrm{~min}$. 
Caso não ocorra a ruptura ou recalque excessivo do solo, o ensaio deverá ser conduzido até que se atinja o dobro da tensão admissível prevista. Uma vez atingida a tensão máxima do ensaio, efetua-se o descarregamento em quatro estágios, com leituras dos respectivos deslocamentos. Deve ser realizada uma última leitura dez minutos após o descarregamento total.

Fellenius (1975) comenta que pode ser realizado um ensaio combinando o método rápido com o CRP, uma vez que o trecho inicial das curvas carga-recalque nos dois ensaios são aproximadamente iguais. Então, inicia-se com o ensaio rápido e, posteriormente, muda-se para o ensaio CRP, quando a velocidade do movimento da placa atinge cerca de $0,5 \mathrm{~mm} / \mathrm{min}$, ou seja, na eminência da ruptura. Também propõe a troca dos ensaios lentos pelos rápidos, afirmando que a utilização destes últimos pode ser justificada pelo menor custo e pelo fato do ensaio poder ser completado em apenas um dia de trabalho.

\section{d) Ensaio cíclico}

Neste ensaio carrega-se a placa até $1 / 3$ da tensão admissível prevista, posteriormente efetua-se um descarregamento até a metade desta tensão, repetindo esta operação por 20 vezes. Então, a tensão máxima do ciclo anterior é aumentada 50\%, repetindo-se o procedimento (FELLENIUS, 1975).

O ensaio cíclico é bastante utilizado em projetos de pavimentos rodoviários e de aeroportos, para uma avaliação do efeito repetitivo das solicitações aplicadas pelos veículos sobre o pavimento.

As curvas típicas dos diversos tipos de carregamentos são apresentadas na Figura 2.3. 


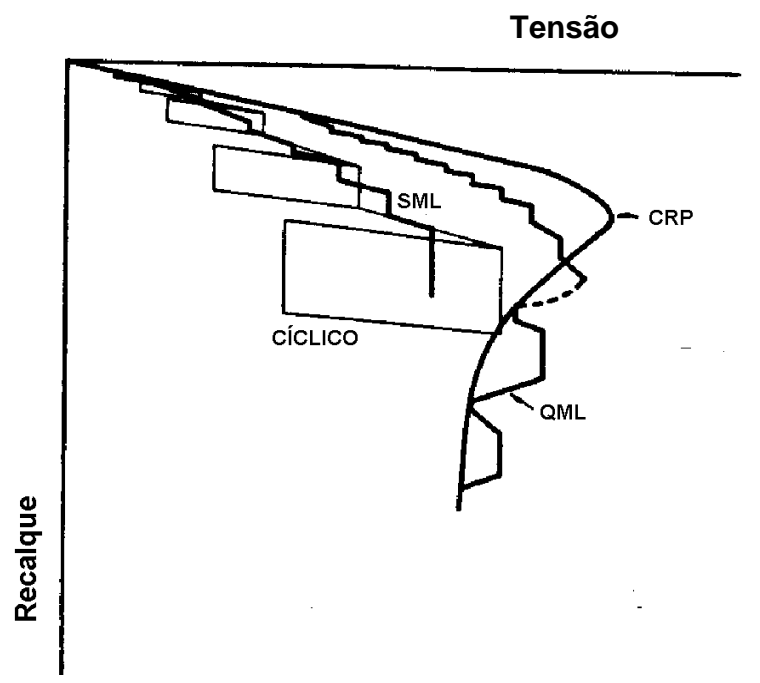

Figura 2.3 - Curvas tensão-recalque típicas dos diferentes tipos de ensaios.

(FELLENIUS, 1975).

\subsubsection{CURVA TENSÃO-RECALQUE DO ENSAIO}

Segundo Reznik (1995a), a curva tensão-recalque obtida nos ensaios de placa ou em sapatas serve como a principal fonte de informação para o projeto de fundações superficiais. A magnitude dos recalques medidos e a forma das curvas não dependem apenas das propriedades físicas e mecânicas e da história de carregamento do solo, mas também são influenciadas pela dimensão e forma da placa, bem como pelos procedimentos de preparação do ensaio.

Na maioria dos casos, a curva tensão-recalque pode ser representada entre os dois casos extremos indicados na Figura 2.4. Segundo Terzaghi (1943), se o solo é bastante compacto ou rijo, a curva tensão-recalque é semelhante à curva $\mathrm{C}_{1}$, com uma tensão de ruptura $\sigma_{r}$ bem definida. Por outro lado, se o solo é fofo ou mole a curva se assemelha à $\mathrm{C}_{2}$, sem uma nítida definição do valor da tensão de ruptura. Neste caso, a capacidade de carga pode ser admitida igual à abscissa $\sigma_{r}$ do ponto em que a curva de recalque torna-se retilínea. 


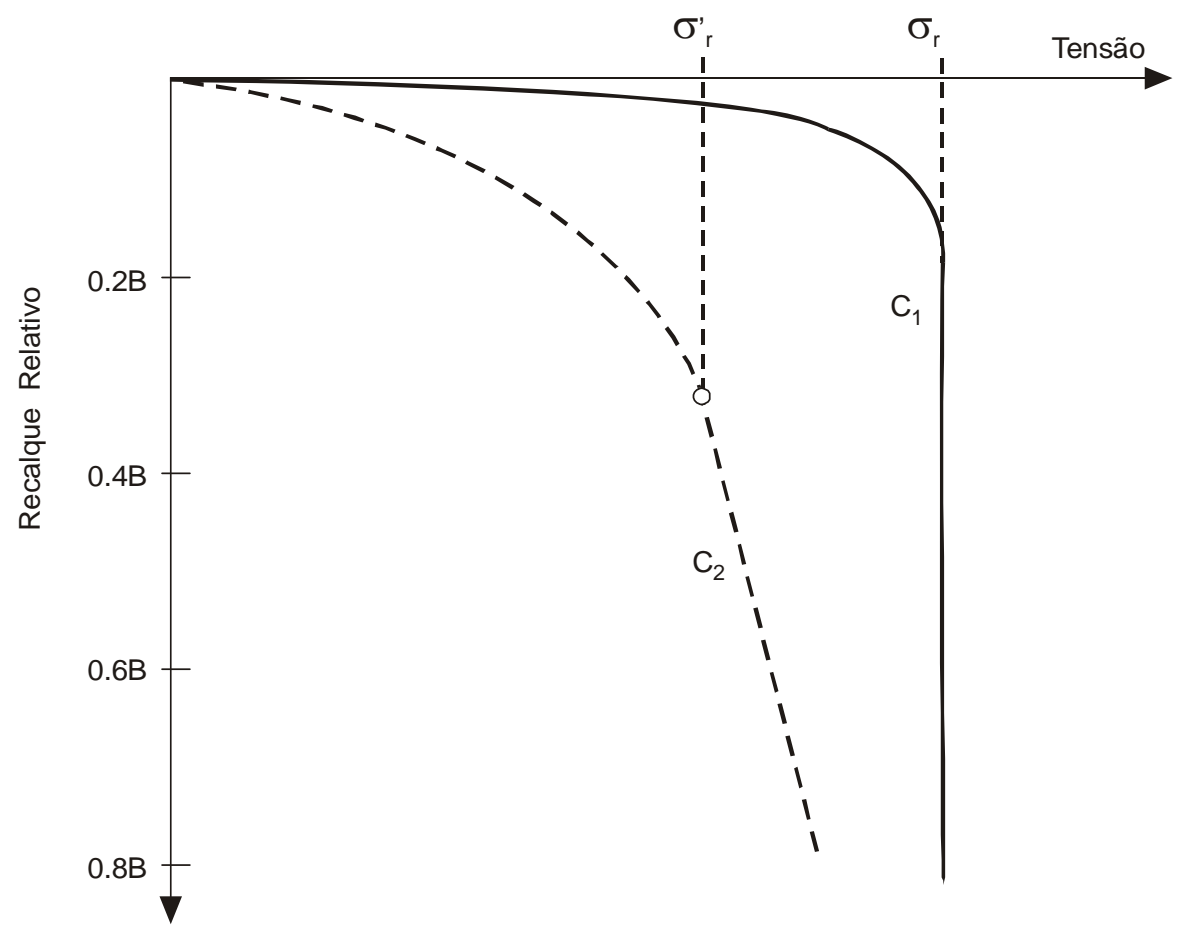

Figura 2.4 - Curvas tensão-recalque típicas (TERZAGHI, 1943).

Pode ocorrer que, ao se realizar a prova de carga não se caracterize a tensão de ruptura do solo. Entretanto, ao identificar que se trata de ruptura física, pode-se estimar a capacidade de carga ajustando-se a curva tensão-recalque a uma equação matemática, por exemplo, aplicando o critério de Van der Veen (1953) ou o de Chin (1970). No caso de não se tratar de ruptura física, normalmente recorre-se a um critério de ruptura convencional para a sua determinação.

Ainda com relação à interpretação de provas de carga, Massad (1986), demonstrou matematicamente que os métodos de Van der Veen (1953) e Mazurkiewicz (1972), são equivalentes, fornecendo a mesma carga de ruptura. Além disso, propôs um método gráfico baseado nas mesmas premissas dos métodos anteriores.

\subsubsection{INTERPRETAÇÃO DOS RESULTADOS}

\subsubsection{Obtenção da tensão admissível}


A interpretação dos resultados de uma prova de carga em placa deve atender sempre aos critérios de ruptura e recalques, os quais são requisitos necessários em qualquer projeto de fundações.

Cintra, Aoki e Albiero (2003) apresentam interpretações para a obtenção da tensão admissível quando a curva tensão-recalque evidencia ou não a ruptura.

No primeiro caso, a tensão admissível $\left(\sigma_{\mathrm{a}}\right)$ é obtida mediante a aplicação de um fator de segurança igual a 2,0 ao valor da tensão de ruptura $\left(\sigma_{\mathrm{r}}\right)$, ou seja:

$$
\sigma_{\mathrm{a}} \leq \frac{\sigma_{\mathrm{r}}}{2}
$$

Para satisfazer o critério de recalque aplica-se de um fator de segurança igual a 1,5 à tensão que provoca o recalque máximo $\left(\sigma_{\rho \text { máx }}\right)$, ou então determina-se a tensão correspondente ao recalque admissível, ou seja:

$$
\sigma_{\mathrm{a}} \leq \frac{\sigma_{\rho \text { máx }}}{1,5}
$$

$\mathrm{ou}$

$$
\rho_{\mathrm{a}} \leftrightarrow \sigma_{\mathrm{a}}
$$

Quando a curva tensão-recalque não evidencia a ruptura, isto é, quando a tensão passa a aumentar continuamente de forma quase linear com os recalques, pode-se empregar o critério código de obras da cidade de Boston.

O código de obras da cidade de Boston, desenvolvido para placa quadrada de 0,30 m de lado, considera que a tensão admissível corresponde ao menor entre os seguintes valores:

$$
\sigma_{\mathrm{a}} \leq\left\{\begin{array}{l}
\sigma_{10} \\
\frac{\sigma_{25}}{2}
\end{array}\right.
$$

onde:

$\sigma_{10}-$ tensão que provoca na placa um recalque de $10 \mathrm{~mm}$; 
$\sigma_{25}-$ tensão que provoca na placa um recalque de $25 \mathrm{~mm}$.

Na expressão (2.4), o primeiro valor define a tensão correspondente a um recalque admissível de $10 \mathrm{~mm}$, enquanto que o segundo constitui um critério de ruptura convencional em que a tensão de ruptura está associada ao recalque de $25 \mathrm{~mm}$. No entanto, Teixeira e Godoy (1996), a partir de vários resultados de provas de carga, verificam que na maioria dos casos, o critério de ruptura é sempre mais rigoroso que o de recalque admissível.

\subsubsection{Estimativa de recalques imediatos de sapatas}

Recalques imediatos de sapatas, tanto em solos argilosos como arenosos, podem ser estimados através de resultados de provas de carga em placa.

Segundo Cintra, Aoki e Albiero (2003), para argilas sobreadensadas é razoável supor que, para uma mesma tensão aplicada, os recalques imediatos cresçam linearmente com a dimensão da sapata. A própria fórmula da teoria da elasticidade para cálculo de recalques imediatos exibe essa proporcionalidade.

Assim, determinado o recalque $\rho_{p}$ numa placa circular de diâmetro $B_{p}$, para uma certa tensão $\sigma$ de interesse, o recalque imediato $\rho_{s}$ de uma sapata de diâmetro $B_{s}$, sob a mesma tensão, será expresso pela equação (2.5). No caso de sapatas retangulares ou de formas irregulares, pode-se considerar a sapata circular de área equivalente.

$$
\rho_{\mathrm{s}}=\rho_{\mathrm{p}} \frac{\mathrm{B}_{\mathrm{s}}}{\mathrm{B}_{\mathrm{p}}}
$$

Terzaghi e Peck (1948) baseados em dados empíricos derivados de provas de carga em modelo reduzido em areia, de ensaios de placa em camadas de areia relativamente homogênea e de observações de recalques de edifícios, apresentam a 
equação (2.6) para extrapolar recalque $\left(\rho_{\mathrm{p}}\right)$ de placa quadrada de $0,30 \mathrm{~m}$ de lado para recalque $\left(\rho_{s}\right)$ de sapata quadrada com largura $B_{s}$ em metros.

$$
\rho_{\mathrm{s}}=\rho_{\mathrm{p}}\left(\frac{2 \mathrm{~B}_{\mathrm{s}}}{\mathrm{B}_{\mathrm{s}}+0,30}\right)^{2}
$$

Da equação de Terzaghi-Peck, constata-se que o recalque da placa circular de diâmetro de 0,80 m (com área equivalente a uma placa quadrada de 0,70 m) recomendada pela norma brasileira, corresponde o dobro do recalque da placa quadrada de $0,3 \mathrm{~m}$.

Assim, para aplicar a extrapolação de Terzaghi-Peck, de recalque da placa da norma brasileira para sapata quadrada de lado $B_{s}$ o recalque deveria ser dividido por 2,0 (CINTRA; AOKI; ALBIERO, 2003).

Sowers (1962) propõe para extrapolar o recalque obtido em placa quadrada de qualquer dimensão $B_{p}$ para uma sapata quadrada de lado $B_{s}$, a seguinte equação:

$$
\rho_{\mathrm{s}}=\rho_{\mathrm{p}}\left[\frac{\mathrm{B}_{\mathrm{s}}\left(\mathrm{B}_{\mathrm{p}}+0,30\right)}{\mathrm{B}_{\mathrm{p}}\left(\mathrm{B}_{\mathrm{s}}+0,30\right)}\right]^{2}
$$

Cintra, Aoki e Albiero (2003) demonstram que a equação de Sowers (1962) representa o caso geral da equação de Terzaghi e Peck (1948).

Ensaios realizados por D’Appolonia et al. (1968) e Briaud e Gibbens (1996) mostram que o recalque da sapata aumenta praticamente na proporção direta com a sua largura. Portanto, as equações de Terzaghi-Peck e de Sowers para extrapolação de recalques de placas para sapatas, em areia, podem subestimar os recalques das sapatas. 


\subsubsection{REALIZAÇÃO DE PROVAS DE CARGA EM PLACA EM SOLOS COLAPSÍVEIS}

O solo colapsível caracteriza-se por sofrer uma brusca e acentuada redução de volume quando o seu teor de umidade for aumentado até atingir um determinado valor crítico, mesmo sem alcançar uma saturação completa, estando submetido a um determinado estado de tensões.

Devido ao seu comportamento, os solos colapsíveis podem causar danos a estruturas apoiadas tanto em fundações superficiais como em profundas, motivo pelo qual a colapsibilidade deve ser considerada nos projetos de fundação. Assim, a prova de carga em placa pode ser utilizada para o estudo da colapsibilidade do solo e sua influência na capacidade de carga e nos recalques.

Cintra (1998) relata que no início, os trabalhos sobre comportamento de fundações em solos colapsíveis tinham como único objetivo verificar a ocorrência ou não de colapso na carga admissível da fundação. Uma primeira prova de carga era realizada para determinar a carga de ruptura na condição de solo não inundado. Depois, a fundação era recarregada até a carga admissível e, então, mantida esta carga constante e com o recalque estabilizado, procedia-se à inundação do solo através de uma cava superficial, aberta em torno do elemento de fundação, e aguardava-se a ocorrência do colapso, isto é, de um recalque adicional brusco e significativo (Figura 2.5).
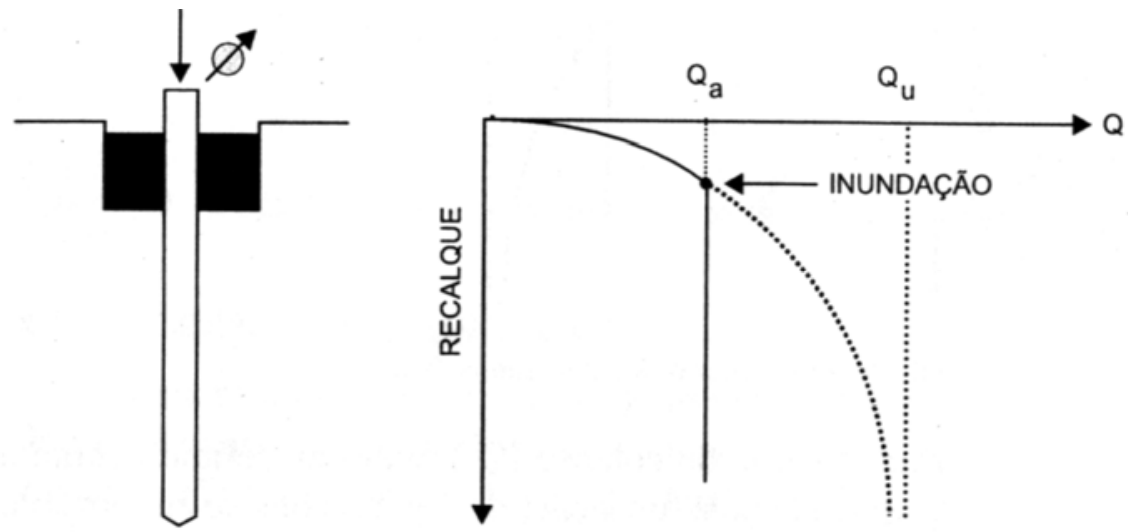

Figura 2.5 - Constatação de colapso na carga admissível (CINTRA, 1998).

No caso de não ocorrência do colapso em um tempo predeterminado, finalizava-se o ensaio concluindo-se que a fundação apresentaria um bom comportamento para aquela carga admissível, mesmo que o solo viesse a ser inundado. 
Posteriormente, compreendeu-se que, para ocorrer o colapso do solo, além do grau de saturação aumentar até um certo valor crítico também é necessário que a carga aplicada pela fundação esteja acima de um limite inferior, que apenas ocasionalmente coincidiria com a carga admissível.

Como conseqüência, toda prova de carga em que não houvesse colapso do solo deveria ser prosseguida com novos estágios de carga, mantendo-se a inundação, até atingir a carga de colapso (Figura 2.6). No outro caso, em que houvesse colapso na carga admissível, o ensaio deveria ser refeito com inundação em estágio inferior à carga admissível para quantificar a carga de colapso. Em relação à carga última, determinada com o solo não inundado, a carga de colapso representa uma redução da capacidade de carga devida à inundação do solo.

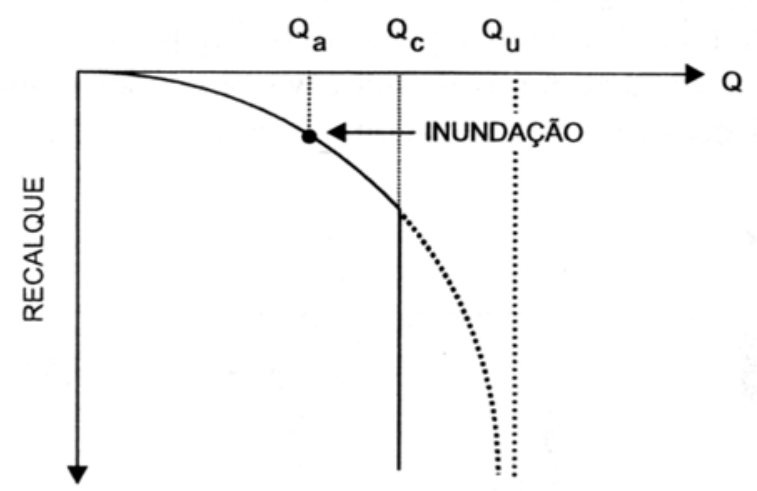

Figura 2.6 - Carga de colapso superior à carga admissível (CINTRA, 1998).

Mais recentemente, o procedimento foi novamente alterado. Antes do segundo ensaio o solo é pré-inundado por 48 h e, mantida a inundação, a prova de carga é realizada até atingir a carga de colapso. Nesse caso, a curva carga-recalque não apresenta o degrau característico do colapso, porém mostra claramente a redução da capacidade de carga devida à inundação do solo (Figura 2.7). 


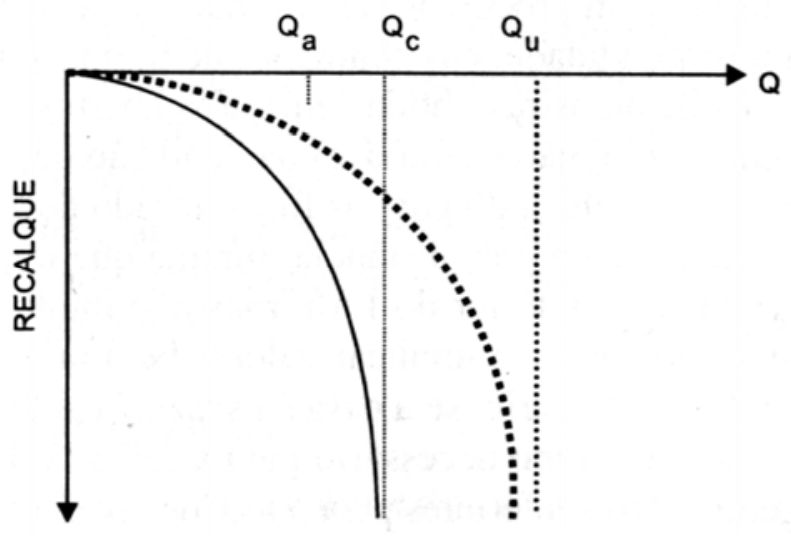

Figura 2.7 - Carga de colapso determinada com inundação prévia do solo (CINTRA, 1998).

Carvalho e Souza (1990) apresentam os resultados de dois ensaios de placa realizados na cidade de Ilha Solteira/SP, a 0,60 m da superfície do terreno, em solo areno-argiloso, nos quais constatam o caráter colapsível do solo. Primeiramente realizou-se uma prova de carga com o solo não inundado, levando-se até a ruptura. A seguir, executou-se uma prova de carga com carregamento progressivo até atingir um valor correspondente a um terço da carga máxima obtida no ensaio anterior. Estabilizados os recalques, deu-se início a colocação de água no solo adjacente à placa, e, como conseqüência, houve um início imediato de recalques, caracterizando um estado de colapso da estrutura do solo.

Ferreira, Peres e Benvenuto (1990) executam seis provas de carga em placa nas profundidades de 1,0, 2,0 e 4,0 m, num solo constituído de areia fina pouco argilosa da região centro-oeste do Estado de São Paulo. Os ensaios foram realizados sem inundação do solo e inundado a uma tensão próxima da tensão geostática atuante na cota da placa. Constatam que o colapso do solo é governado pelo teor de umidade.

Agnelli (1992) apresenta os resultados de 12 provas de carga em placa no Campus da UNESP de Bauru/SP, em um solo constituído de areia fina argilosa de baixa compacidade. Foram executadas seis provas de carga nas profundidades de 1,0 m e 2,0 m, três com o terreno em seu estado natural de umidade e a outras três com inundação do solo a diferentes níveis de tensões. Com esses resultados pode-se evidenciar o caráter colapsível do solo estudado, observando que quanto maior a tensão de inundação, maior é o recalque por colapso. 
Reznik (1993, 1994) apresenta os resultados de curvas tensão-recalque para o solo nas condições inundado e não inundado, onde pode-se notar uma redução da capacidade de carga em decorrência da inundação.

Reznik (1993), medindo o teor de umidade após a realização das provas de carga em placa, verifica que o grau de saturação do solo na região afetada pelo ensaio situava-se entre 70 a $80 \%$.

Souza e Cintra (1994) relatam a realização de quatro ensaios de placa em placa sobre o solo colapsível de Ilha Solteira/SP, numa profundidade de 0,70 m. Primeiramente executou-se uma prova de carga sem inundação e outra com inundação na tensão de $60 \mathrm{kPa}$. Em seguida, os autores realizam outras duas provas de carga com as mesmas características anteriores, porém com o solo compactado. Pode-se observar que com a compactação do solo abaixo da placa, tendo o mesmo sido inundado na mesma tensão, ocorreu uma diminuição de $86 \%$ nos recalques devido ao colapso e um acréscimo de mais de 100\% na tensão admissível.

Ismael e Al-Sanad (1993) realizam provas de carga em placa circular com diâmetros de 0,3, 0,46 e 0,61 m em uma areia cimentada com o objetivo de avaliar as características de resistência e deformabilidade. O solo foi ensaiado na condição inundado e não inundado. Constatam que a capacidade de carga do sistema placa-solo inundado corresponde em média a 55 \% da obtida para o solo não inundado. A inundação do solo acarreta uma redução no módulo de deformabilidade de aproximadamente 50 \% em relação ao não inundado para as placas de diâmetro 0,3 e 0,46 m e uma redução de 59 \% para a placa de 0,61m.

Ferreira e Lacerda (1993) apresentam um ensaio de campo utilizando um aparelho denominado expansocolapsômetro, o qual permite avaliar as deformações dos solos em diferentes profundidades, submetidos a determinado estado de tensão. O ensaio é semelhante a uma prova de carga executada no fundo de uma vala com inundação controlada. De acordo com os autores, a variação de volume do solo, medida através do expansocolapsômetro, é inferior em média a 11\% dos valores mínimos medidos através de ensaios de laboratório. Já, o potencial de colapso medido em laboratório é cerca de $13 \%$ maior do que os correspondentes medidos em ensaios de campo. 
Mahmoud, Houston, W. e Houston, S. (1995) apresentam um aparelho que permite carregar o solo e controlar a forma de inundação. O inconveniente deste arranjo está na pequena área carregada.

Agnelli (1997) avalia o colapso do solo mediante a inundação de líquidos de diferentes composições, através de provas de carga em placa. Tal pesquisa foi desenvolvida no campo experimental da UNESP de Bauru/SP, o qual apresenta da superfície até a profundidade de $20 \mathrm{~m}$ uma areia fina argilosa. O efeito da inundação do solo solução de hidróxido de sódio foi mais agressivo do que o da inundação com água potável.

Conciani (1997) apresenta um estudo de solos colapsíveis utilizando provas de carga em placa executadas com inundação da cava em diferentes níveis de tensão. Durante o ensaio a sucção e a inundação da cava foram monitoradas, respectivamente, por tensiômetros instalados em diferentes profundidades e pelo uso da técnica da reflectometria no domínio do tempo (TDR). Deste modo, acompanha-se a evolução da frente de inundação e da sucção no decorrer de todo o ensaio, para conhecer a profundidade de influência do colapso no maciço do solo.

Sousa (2003) realiza um estudo experimental em uma argila porosa de Brasília/DF, reforçada por estacas de solo-cimento compactado e estacas de compactação com material granular, ambas de pequeno diâmetro $(0,10 \mathrm{~m})$. Foram realizadas provas de carga em sapatas, com o solo na condição inundada e não inundada. No caso do solo inundado o efeito de inclusão das estacas foi amplamente benéfico, aumentando a capacidade de carga e diminuindo a queda de rigidez do sistema pós-colapso.

Pode-se verificar até o presente momento que todas as pesquisas em solos colapsíveis mostram que a realização de provas de carga em placa fica incompleta quando não é medida a sucção do solo, uma vez que a resistência neste tipo de solo varia de acordo com a sucção. Portanto, todos os trabalhos que apresentam uma porcentagem de redução da capacidade de carga com a inundação perdem o sentido, uma vez que a sucção do solo não foi tomada como base de comparação. Os ensaios podem ter sido realizados após um período chuvoso ou de estiagem, apresentando uma porcentagem de redução da capacidade de carga menor ou maior, respectivamente. 


\subsection{SUCÇÃO NO SOLO}

A existência de sucção em solos não saturados decorre dos efeitos combinados de capilaridade, de adsorção e de osmose devida a presença de íons dissolvidos na água (RICHARDS, 1928).

A sucção total $(\psi)$ de um solo apresenta duas componentes, a sucção matricial e a sucção osmótica. Em forma de equação, pode-se escrever:

$$
\Psi=\left(\mathrm{u}_{\mathrm{a}}-\mathrm{u}_{\mathrm{w}}\right)+\pi
$$

onde:

$\left(\mathrm{u}_{\mathrm{a}}-\mathrm{u}_{\mathrm{w}}\right)$ - sucção matricial;

$\mathrm{u}_{\mathrm{a}}$ - pressão no ar existente nos vazios do solo;

$\mathrm{u}_{\mathrm{w}}-$ pressão na água existente nos vazios do solo;

$\pi$ - sucção osmótica.

A sucção matricial decorre dos efeitos combinados de adsorção e de capilaridade, que surgem devido à interação entre a água e a matriz do solo. É expressa pela diferença entre a pressão no ar e a pressão na água presentes nos vazios do solo. Quando a pressão no ar dos vazios do solo é a atmosférica, o valor numérico da sucção matricial é igual à pressão na água.

A parcela da sucção decorrente de efeitos osmóticos está associada à presença de sais na água existente nos vazios do solo. A sucção osmótica equivale à sucção total quando o solo se encontra saturado, ou seja, quando não ocorre a componente matricial, restando apenas o efeito da concentração de solutos.

A sucção na água dos solos pode variar dentro de uma extensa faixa de valores, dependendo do tipo de solo, estrutura e grau de saturação.

No contexto da mecânica dos solos tem prevalecido a opinião de que a sucção matricial governa o comportamento mecânico e hidráulico do solo. Entretanto, deve-se reconhecer a importância da sucção osmótica em certas situações, como no caso dos solos expansivos e dos solos dispersivos e, em alguns casos, quando o solo é percolado por soluções contento íons em diferentes concentrações (VILAR et al., 1995).

No presente trabalho considerou-se apenas a influência da sucção matricial para o estudo do comportamento do solo. 


\subsubsection{CURVA DE RETENÇÃO DE ÁGUA NO SOLO OU CURVA CARACTERÍSTICA}

A curva característica de um solo é definida como a relação entre o teor de umidade (ou umidade volumétrica, ou grau de saturação) e a sucção do solo. Uma vez determinada a curva característica de um solo, pode-se estimar a sucção matricial conhecendo-se o teor de umidade do solo e vice-versa.

A umidade volumétrica $(\theta)$ é definida pela razão entre o volume de água presente numa amostra de solo e o volume da amostra.

$$
\theta=\frac{\mathrm{V}_{\mathrm{w}}}{\mathrm{V}}
$$

O procedimento mais conveniente para a determinação da umidade volumétrica é medir o teor de umidade (w) e depois multiplicá-lo pela relação entre a massa específica do solo seco $\left(\rho_{\mathrm{d}}\right)$ e a massa específica da água ou da solução do solo $\left(\rho_{w}\right)$.

$$
\theta=\mathrm{w} \cdot \frac{\rho_{\mathrm{d}}}{\rho_{\mathrm{w}}}
$$

A Figura 2.8 mostra uma curva característica típica de um solo siltoso, destacando algumas características importantes. O valor de entrada de ar do solo corresponde à sucção matricial onde o ar começa a entrar nos poros maiores do solo. A umidade volumétrica residual $\left(\theta_{\mathrm{r}}\right)$ é aquela na qual é exigida uma mudança grande da sucção para remover a água adicional do solo. O valor $\theta_{\mathrm{s}}$ corresponde à umidade volumétrica do solo saturado. Também podem ser observadas duas curvas, uma obtida pelo processo de secagem e outra por umedecimento. Geralmente estas curvas não coincidem, ou melhor, apresentam histerese. O ponto final da curva de umedecimento pode diferir do ponto inicial da curva de secagem devido à presença do ar retido no solo. 


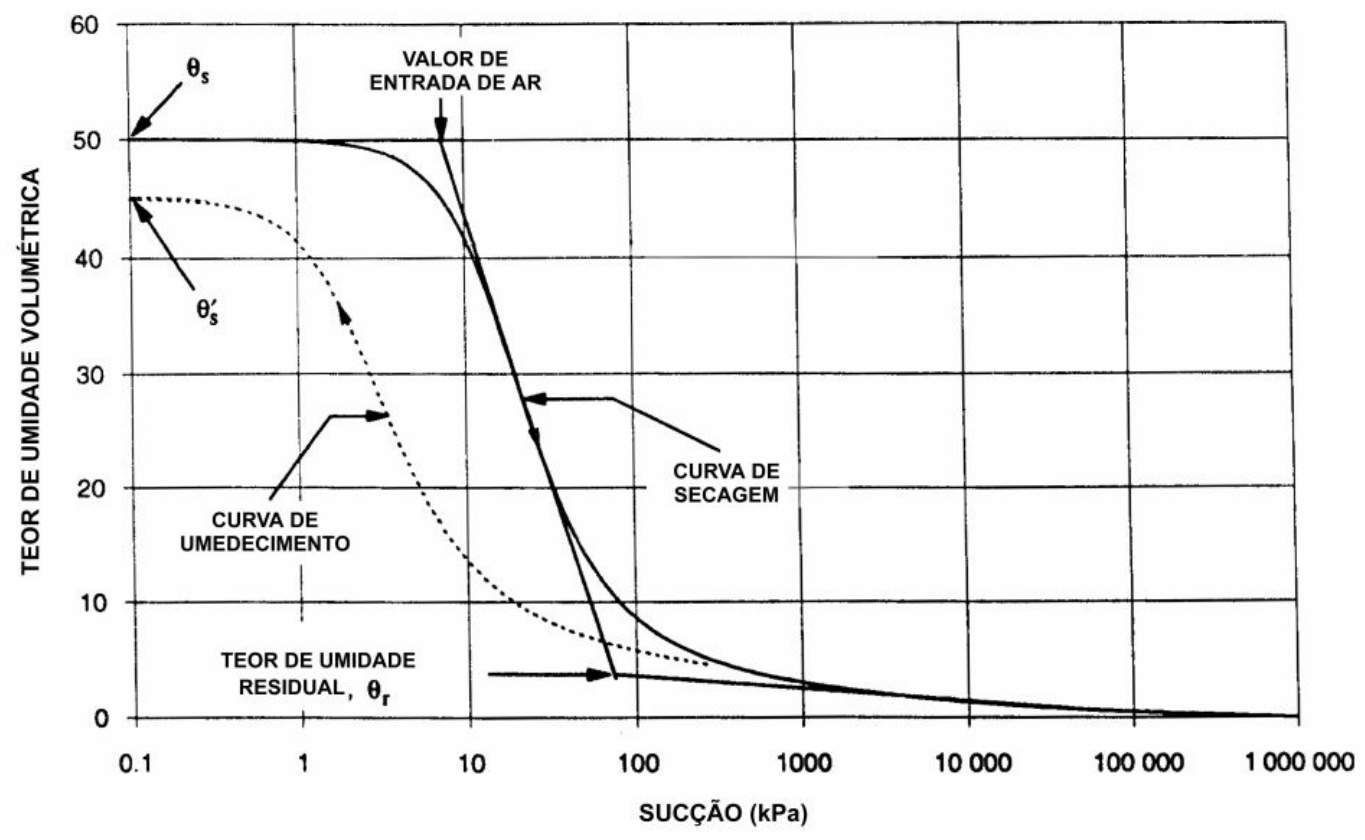

FIGURA 2.8 - Curva característica típica de um solo siltoso.

(FREDLUND; XING, 1994)

Na literatura existem algumas propostas de modelos para o ajuste da curva característica do solo. A equação 2.11 demonstra a proposta de Fredlund e Xing (1994):

$$
\theta=\left[1-\frac{\ln \left(1+\frac{\psi}{\psi_{\mathrm{r}}}\right)}{\ln \left(1+\frac{1000.000}{\psi_{\mathrm{r}}}\right)}\right] \cdot \frac{\theta_{\mathrm{s}}}{\left\{\ln \left[\mathrm{e}+\left(\frac{\psi}{\mathrm{a}}\right)^{\mathrm{n}}\right]\right\}^{\mathrm{m}}}
$$

onde:

$\theta$ - umidade volumétrica;

$\theta_{\mathrm{s}}-$ umidade volumétrica do solo saturado;

$\Psi_{\mathrm{r}}$ - é a sucção correspondente ao teor de umidade residual, $\theta_{\mathrm{r}}$.

e - base dos logaritmos neperianos;

a - é aproximadamente o valor de entrada de ar do solo;

n - é um parâmetro que controla a inclinação no ponto de inflexão da curva;

m - é um parâmetro relacionado ao teor de umidade residual; 


\subsubsection{MÉTODOS PARA MEDIDA DA SUCÇÃO NO CAMPO}

Os procedimentos empregados em laboratório geralmente baseiam-se na técnica da translação de eixos, proposta por Hilf (1956), que consiste na aplicação de uma pressão de ar que compense a pressão negativa da água, tornando-a mensurável por equipamentos convencionais.

No campo são empregados equipamentos para medida direta da sucção ou indireta através de parâmetros que se correlacionem com ela. A sucção total do solo pode ser medida por meio de psicrômetros ou pelo método do papel filtro. Já a sucção matricial, de forma direta, pode ser medida utilizando-se o tensiômetro, ou de modo indireto empregando-se blocos porosos, blocos térmicos, blocos de pressão (CAMPOS, 1994), e a técnica da Reflectometria no Domínio do Tempo, (CONCIANI et al., 1996). Esses aparelhos medem as propriedades elétricas ou térmicas do solo e por meio de uma calibração estima-se a sucção matricial do solo. A sucção matricial do solo pode também ser medida pelo método do papel filtro, desde que se garanta o contato do mesmo com o solo.

\subsubsection{Tensiômetro}

O tensiômetro consiste de um tubo impermeável cheio de água, dotado de um medidor de pressão na extremidade superior e uma pedra porosa com alta resistência à entrada de ar quando saturada, a qual é colocada em contato com o solo. O tubo normalmente é constituído de material plástico devido a sua baixa condução de calor e para evitar problemas de corrosão. Um exemplo de tensiômetro é apresentado na Figura 2.9 .

Antes da instalação do tensiômetro deve-se garantir a saturação completa da cápsula porosa, pois este pode ser um fator que conduz a leituras incorretas no tensiômetro (TARANTINO; MONGIOVÌ, 2001). Também, durante a instalação do tensiômetro deve-se tomar cuidados, de modo a garantir um bom contato entre a cápsula porosa e o solo. Quando é atingido o equilíbrio entre o solo e o sistema de medida, a água dentro do tensiômetro apresenta a mesma pressão negativa da água dos vazios do solo. Esta pressão negativa é numericamente igual à sucção matricial quando o ar dos vazios do solo está submetido à pressão atmosférica. 

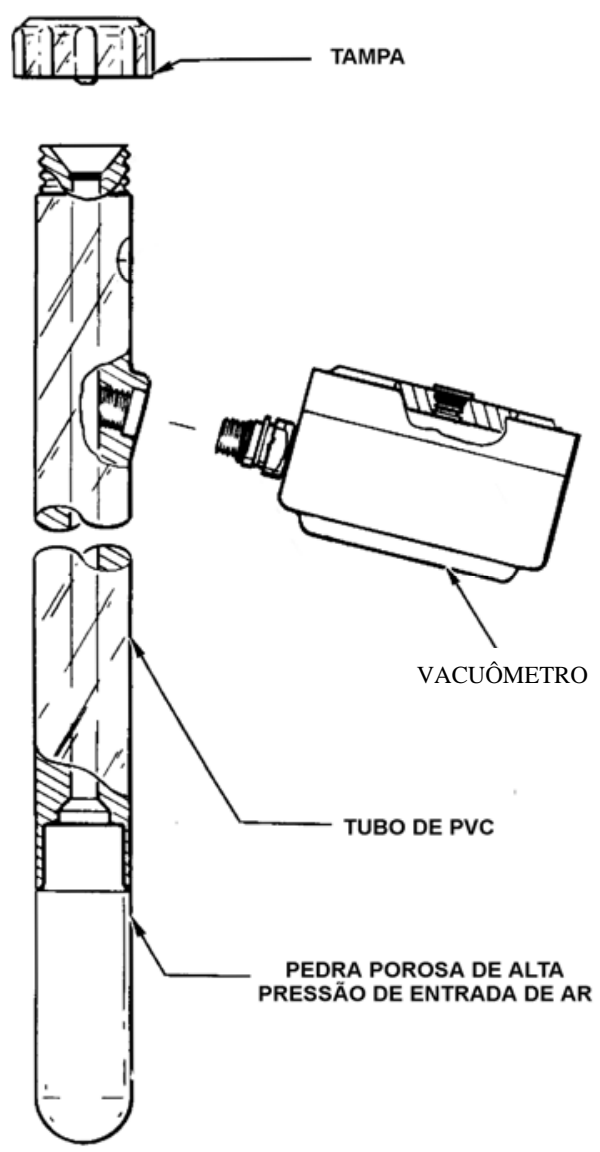

FIGURA 2.9 - Esquema de um tensiômetro convencional.

(FREDLUND; RAHARDJO, 1993)

A medida da pressão negativa é realizada por meio de sensores elétricos ou mecânicos, porém a grande limitação do uso do tensiômetros reside na necessidade de uma coluna contínua de água entre a pedra porosa e o sistema de medição, a qual está sujeita à ocorrência do fenômeno de cavitação. Este fenômeno implica o aparecimento de bolhas de ar, as quais geram descontinuidades na coluna d'água, limitando o uso desses equipamentos para sucções de até aproximadamente $90 \mathrm{kPa}$.

Fleming, Campos e Vargas (1994) apresentam um relato sobre a automação de leituras dos tensiômetros utilizando transdutores elétricos. Este equipamento permite a realização de leituras à distância, porém, ainda são exigidas a verificação do nível d'água interno e a eliminação de eventuais bolhas de ar.

Nos últimos anos, os tensiômetros têm sido desenvolvidos de modo a permitir a medida de altos valores de sucção. O princípio básico de funcionamento destes equipamentos é a redução da distância entre a cápsula porosa e o transdutor de 
pressão e a conseqüente diminuição do volume do reservatório de água, para aproximadamente $3,0 \mathrm{~mm}^{3}$, de modo a reduzir a possibilidade de cavitação (TAKE; BOLTON, 2003 e RIDLEY et al., 2003).

\subsubsection{Psicrômetro}

Os psicrômetros são aparelhos utilizados para determinar a sucção total do solo através da medida da umidade relativa do ar em equilíbrio com a interface soloágua existente nos vazios do solo ou na região de influência do mesmo.

O aparelho é composto basicamente de uma cápsula porosa fina, que entra em contato com o solo, de um termopar ligado a um microvoltímetro e a uma fonte de alimentação elétrica, e de um sensor de temperatura. Os psicrômetros permitem a medida de sucções de 100 a $8000 \mathrm{kPa}$.

Richards (1974) referindo-se ao tempo de resposta do psicrômetro menciona que varia de poucas horas para valores elevados de sucção, a em torno de duas semanas para sucções da ordem de $100 \mathrm{kPa}$.

\subsubsection{Papel Filtro}

O uso do papel filtro foi inicialmente proposto por Gardner (1937), como uma maneira indireta de medir a sucção do solo. Neste método o papel filtro, cuja curva característica de sucção é conhecida inicialmente, é colocado em contanto com o solo, caso se pretenda medir a sucção matricial, ou sem contato com o solo, para obter o valor da sucção total, em um recipiente hermeticamente fechado. Determinando-se o teor de umidade de equilíbrio do papel filtro e utilizando a curva de calibração prévia do papel, obtêm-se indiretamente o valor da sucção.

Segundo Fredlund e Rahardjo (1993) o tempo de resposta do papel filtro é da ordem de uma semana. A técnica exige um manuseio cuidadoso do papel e precisão na medida de sua massa em balança com resolução de 0,001 g.

Os tipos de papéis filtro mais utilizados são o Schleicher \& Schuell $\mathrm{n}^{\circ} .589$ e o Whatman $n^{\circ} .42$ (MARINHO, 1994). A faixa de medida do papel é bastante ampla, podendo variar de $10 \mathrm{kPa}$ a $10 \mathrm{MPa}$ (CAMPOS, 1994). 


\subsection{MÓDULO DE DEFORMABILIDADE}

O comportamento tensão-deformação dos solos é bastante complexo, pois depende de vários fatores como a origem, a composição granulométrica, o índice de vazios, o grau de saturação, a permeabilidade e a trajetória de tensões.

No estudo da deformabilidade do solo é usual recorrer à Teoria da Elasticidade, embora o solo não seja um material elástico, pois com o descarregamento as deformações não são recuperáveis ou então são reversíveis apenas parcialmente.

A utilização da Teoria da Elasticidade aos solos pode ser justificada por ser razoável a hipótese de comportamento tensão-deformação linear até tensões admissíveis suficientemente afastadas da ruptura. Entretanto, costuma-se substituir o termo módulo de elasticidade por módulo de deformabilidade (VARGAS, 1977).

\subsubsection{OBTENÇÃO DO MÓDULO DE DEFORMABILIDADE A PARTIR DE ENSAIOS}

\subsubsection{Ensaio de compressão triaxial}

A curva tensão-deformação obtida em ensaios triaxiais é, geralmente, da forma da Figura 2.10. Como não se trata de uma reta, a relação entre a tensão e a deformação correspondente não pode ser expressa por um único valor numérico e, então, é preciso definir como será calculado o valor do módulo de deformabilidade. Segundo Pinto (1996), dois procedimentos têm sido empregados: a) módulo de deformabilidade tangencial $\left(\mathrm{E}_{\mathrm{tg}}\right)$, que indica a relação $\mathrm{d} \sigma / \mathrm{d} \varepsilon$ no ponto considerado; b) módulo de deformabilidade secante $\left(\mathrm{E}_{\mathrm{sec}}\right)$, que indica a relação $\sigma / \varepsilon$ entre dois pontos. Muito utilizado é o módulo secante a partir da origem, indicado pelo símbolo $\mathrm{E}_{\mathrm{s} 0}$. Este é o módulo correntemente referido, quando não há outra observação. Na origem, os dois módulos são coincidentes, caracterizando o módulo tangente inicial $\left(\mathrm{E}_{0}\right)$.

O módulo secante varia de acordo com o estágio de carregamento, por isso é usual referenciar os módulos sob um determinado nível de tensão ou de deformação. O símbolo $\mathrm{E}_{50}$, por exemplo, indica que o módulo corresponde um acréscimo de tensão 
igual a 50\% daquela que provocaria a ruptura. Indicando, portanto, a deformabilidade do solo quando solicitado com um fator de segurança igual a dois.

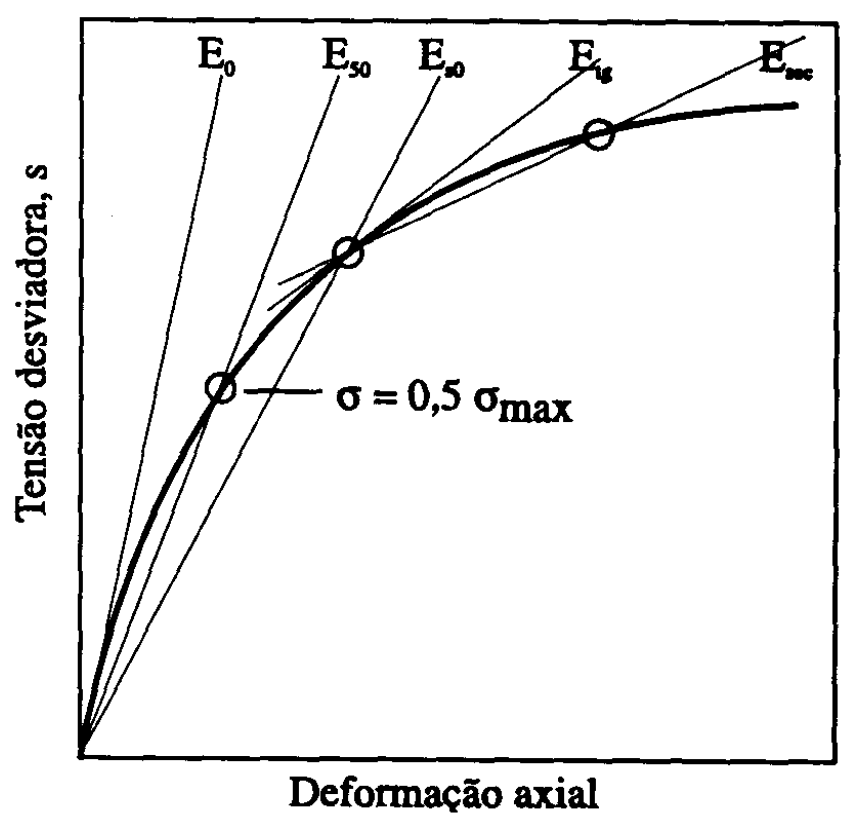

Figura 2.10 - Curva típica de carregamento e definição dos módulos de elasticidade (PINTO, 1996).

Pela proposta de Janbu (1962 apud PINTO, 1996), pode-se associar valores do módulo de deformabilidade sob diferentes tensões de confinamento pela expressão:

$$
\mathrm{E}_{\sigma}=\mathrm{E}_{\mathrm{a}} \cdot \mathrm{P}_{\mathrm{a}} \cdot\left(\frac{\sigma}{\mathrm{P}_{\mathrm{a}}}\right)^{\mathrm{n}}
$$

onde:

$E_{\sigma}-$ módulo de deformabilidade correspondente a tensão $\sigma$;

$\mathrm{E}_{\mathrm{a}}-$ módulo correspondente à pressão atmosférica $\left(\mathrm{P}_{\mathrm{a}}=101,3 \mathrm{kPa}\right)$;

$\mathrm{n}$ - coeficiente que pode assumir valores entre 0 e 1 .

Esta expressão se aplica a módulos de deformabilidade secantes para carregamentos até cerca de 50 \% da tensão desviadora de ruptura, sendo questionável sua aplicação para níveis maiores de tensão, ou para módulos tangentes. 


\subsubsection{Ensaio de compressão isotrópica}

O módulo de deformabilidade volumétrico (K) é obtido no ensaio de compressão isotrópica, no qual se aplicam ao corpo de prova três tensões ortogonais de igual valor numérico.

Então, analogamente ao módulo E, o módulo de deformabilidade volumétrico pode ser obtido pela seguinte relação:

$$
\mathrm{K}=\frac{\sigma}{\varepsilon_{\mathrm{v}}}=\frac{\mathrm{E}}{3 \cdot(1-2 v)}
$$

\subsubsection{Ensaio de compressão confinada (edométrico)}

O módulo edométrico é definido pela relação:

$$
\mathrm{M}=\frac{\Delta \sigma}{\Delta \varepsilon}=\left(\frac{1+\mathrm{e}}{\Delta \mathrm{e}}\right) \cdot \Delta \sigma
$$

onde:

e - índice de vazios antes da aplicação do incremento de tensão $\Delta \sigma$;

$\Delta \mathrm{e}$ - variação do índice de vazios correspondente a $\Delta \sigma$.

O módulo edométrico varia com o nível de tensões e assim, para a aplicação de seus resultados devem ser referidos ao nível de tensões de interesse.

Este módulo difere do módulo de deformabilidade pelas condições de confinamento do corpo de prova, pois neste ensaio a amostra não pode deformar-se transversalmente.

A partir do módulo edométrico pode-se obter do módulo de deformabilidade por:

$$
\mathrm{E}=\frac{(1+v) \cdot(1-2 v)}{1-v} \cdot \mathrm{M}
$$

onde:

$v$ - coeficiente de Poisson. 
Ressalta-se que o módulo edométrico corresponde ao inverso do coeficiente de variação volumétrica do solo $\left(\mathrm{m}_{\mathrm{v}}\right)$.

\subsubsection{Ensaio de placa}

a) Ensaio convencional

Para a determinação do módulo de deformabilidade do solo a partir de ensaios de placa, procede-se uma retroanálise utilizando a solução de Boussinesq, válida para placa circular rígida em meio homogêneo, através da equação (2.16).

$$
\mathrm{E}=\frac{\sigma \cdot \mathrm{D}}{\rho} \cdot\left(1-v^{2}\right) \cdot \frac{\pi}{4}
$$

onde:

E - Módulo de deformabilidade;

$\sigma$ - tensão média aplicada à placa;

D - diâmetro da placa;

$\rho$ - recalque provocado pela tensão $\sigma$;

$v$ - coeficiente de Poisson;

Para utilizar a equação (2.16), conhecendo-se a curva tensão-recalque, é necessário adotar o coeficiente de Poisson. Valores típicos do coeficiente de Poisson são apresentados na Tabela 2.1. Segundo Mello e Cepollina (1978), na maioria dos solos residuais e de aterro, em condições normais drenadas, $v$ varia de 0,2 a 0,4.

Han et al. (1993), Ismael e Al-Sanad (1993), Resnik (1992, 1995b) determinam o módulo de deformabilidade do solo através de ensaios de placa. No Brasil, pode-se citar os trabalhos de Mello e Cepollina (1978), Velloso, Grillo e Penedo (1978), Werneck, Jardim e Almeida (1980), Nakata et al. (1982). 
Tabela 2.1 - Valores típicos do Coeficiente de Poisson (modificado de BOWLES, 1996).

\begin{tabular}{cc}
\hline Solo & $v$ \\
\hline Argila saturada & $0,4-0,5$ \\
\hline Argila não saturada & $0,1-0,3$ \\
\hline Argila arenosa & $0,2-0,3$ \\
\hline Silte & $0,3-0,35$ \\
\hline Areia média a compacta & $0,3-0,4$ \\
\hline Areia fofa a média & $0,2-0,35$ \\
\hline
\end{tabular}

b) Ensaio com uma medição de recalque dentro do bulbo de tensões.

Mello e Cepollina (1978) visando contornar os problemas devido à execução de uma prova de carga, na qual se medem os deslocamentos da superfície da placa através de extensômetros, utilizam medidores de recalque posicionados dentro do bulbo de pressões.

A instalação dos medidores deve ser executada através de furos com o menor diâmetro possível, garantindo-se a perpendicularidade das hastes e um mínimo de perturbação do solo.

Assim o módulo de deformabilidade do solo pode ser estimado pela expressão proposta por Michell e Gardner (1975):

$$
E=\frac{\sigma \cdot R}{\rho_{z}}\left\{\left(1-v^{2}\right) \cdot\left[\frac{\pi}{2}-\operatorname{arctg}\left(\frac{z}{R}\right)\right]+\frac{z / R(1-v)}{1+(z / R)^{2}}\right\}
$$

onde:

$\sigma$ - tensão aplicada à placa;

$\mathrm{R}$ - raio da placa;

$v$ - coeficiente de Poisson;

$\mathrm{z}$ - profundidade na qual a medição é realizada;

$\rho_{z}$ - deslocamento medido na profundidade $z$.

c) Ensaio com duas medições de recalque dentro do bulbo de pressões.

Ainda segundo Mello e Cepollina (1978), pode-se idealizar o solo compreendido entre os medidores como submetido às tensões representativas da sua 
profundidade média entre os medidores. Desse modo, para o caso de medidores instalados à profundidade $R$ e $2 R$ e no eixo de simetria, tem-se:

$$
\mathrm{E}=\frac{\sigma \cdot \mathrm{R}}{\Delta \rho}\{0,4240-v[(1+2 v)-1,664(1+v)+0,576]\}
$$

Para medidores de recalque instalados próximo ao eixo vertical deve-se introduzir um fator de correção na equação (2.18) e, considerando-se também como pequena a influência das tensões principais horizontais, têm-se os valores apresentados na Figura 2.11.
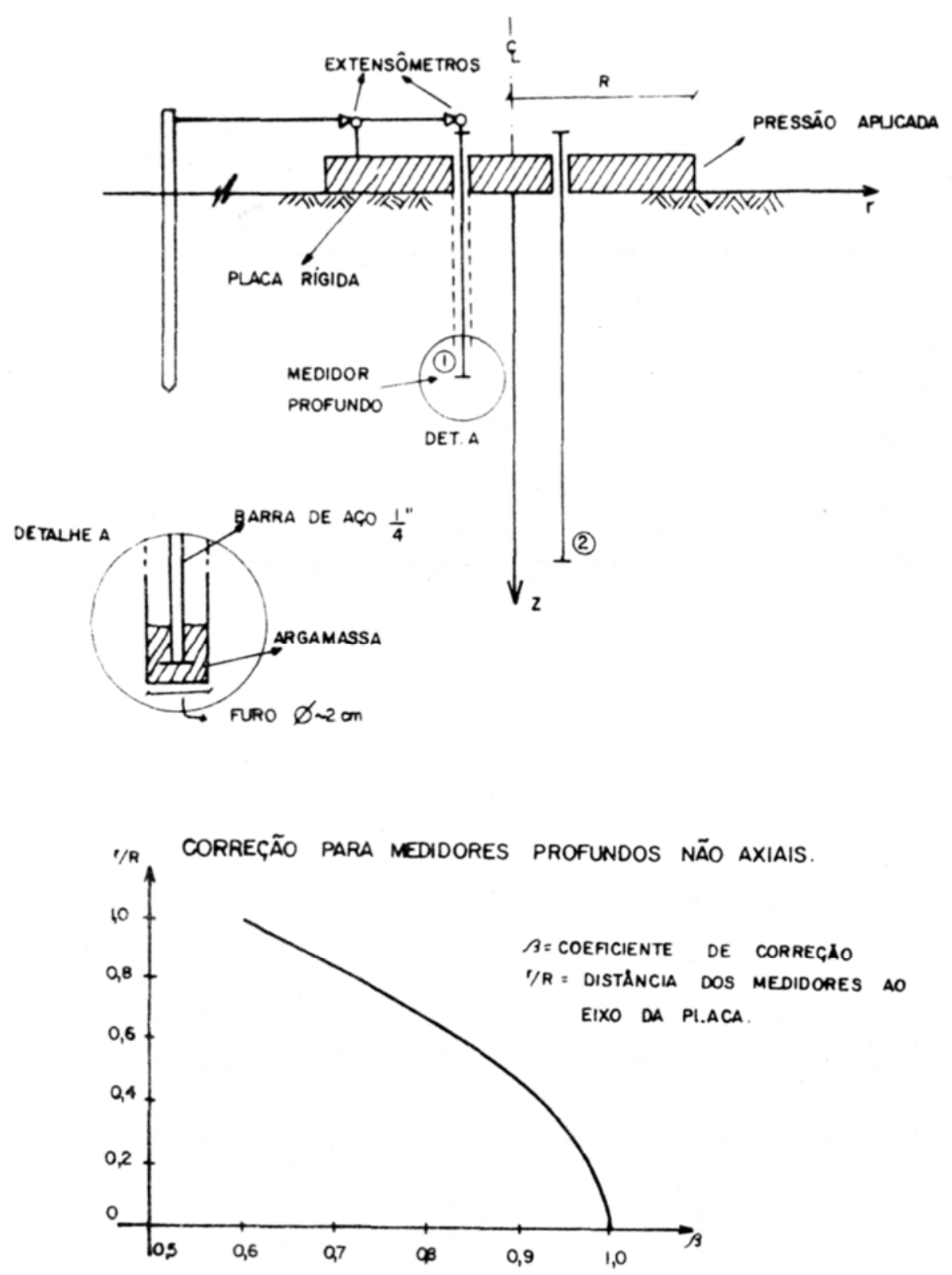

Figura 2.11 - Detalhes de instalação e correção para medidores não axiais. (MELLO; CEPOLINA, 1978). 


\subsubsection{Ensaio pressiométrico (pré-perfurado)}

O ensaio pressiométrico, idealizado por Louis Ménard, permite a determinação de características dos solos referentes à resistência e à deformabilidade, sendo especialmente vantajoso quando não se consegue extrair amostras indeformadas do maciço. O equipamento do ensaio é constituído de um elemento cilíndrico, projetado para aplicar pressões uniformes às paredes de um furo de sondagem através de uma membrana flexível. Durante o ensaio são medidas as pressões aplicadas e a correspondente expansão da cavidade cilíndrica na massa de solo. Com pares de valores de pressão e variação de volume, traça-se um diagrama do tipo apresentado na Figura 2.12, o qual é denominado de curva pressiométrica.

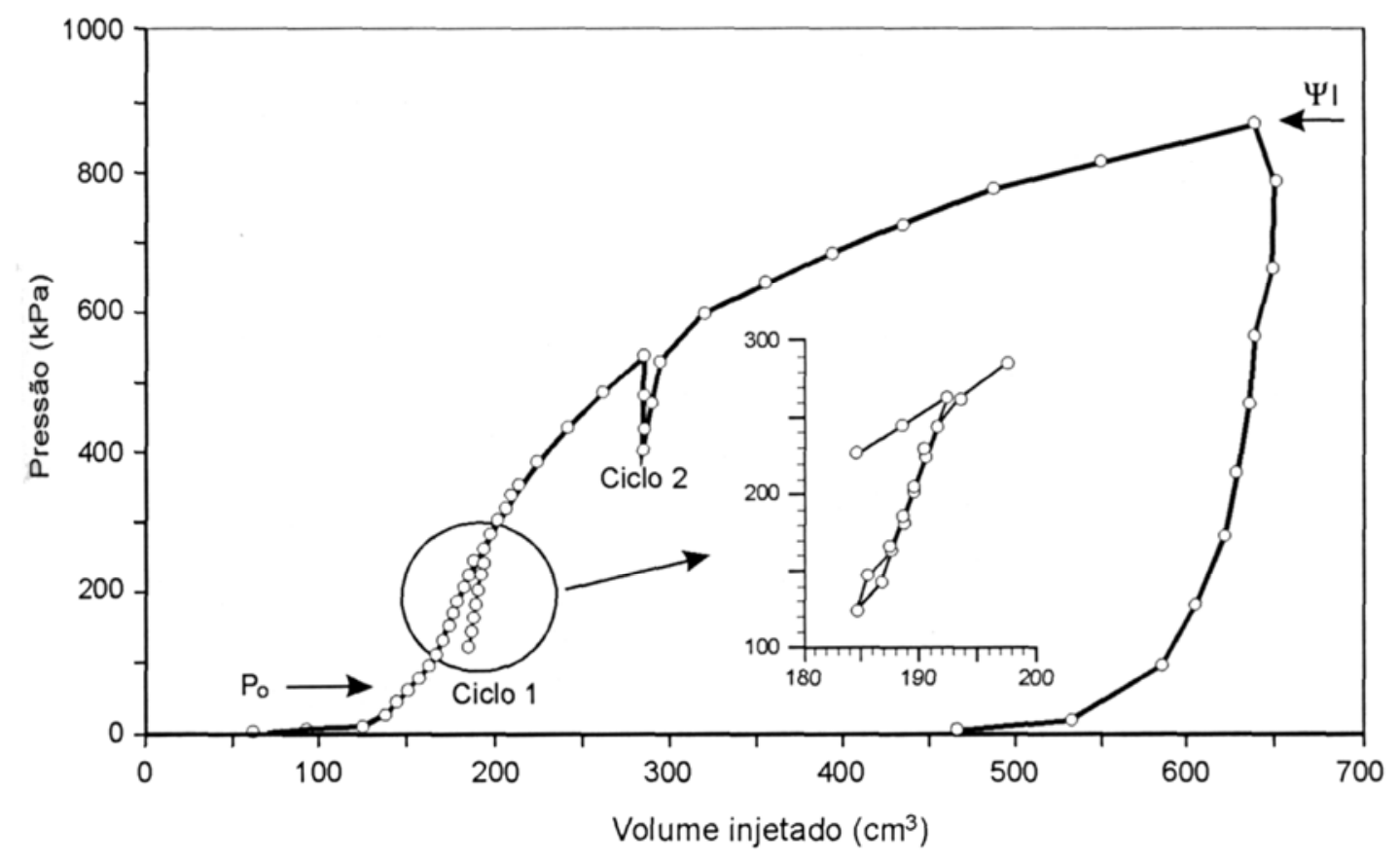

Figura 2.12 - Curva típica de um ensaio pressiométrico (SCHNAID, 2000)

O módulo pressiométrico $E_{m}$ é obtido pela seguinte expressão:

$$
E_{m}=2 \cdot(1+v) \cdot\left[V_{i}+\left(\frac{V_{f}-V_{0}}{2}\right)\right] \cdot \frac{d_{1}}{d V_{1}}
$$

sendo:

$\mathrm{V}_{0}$ - volume da célula de medida no início do trecho elástico; 
$\mathrm{V}_{\mathrm{i}}$ - volume inicial da célula de medição;

$\mathrm{V}_{\mathrm{f}}$ - volume correspondente ao final da fase elástica;

$\mathrm{dP} / \mathrm{dV}$ - declividade da fase pseudo-elástica da curva pressiométrica;

$v$ - coeficiente de Poisson.

Schnaid, Consoli e Mantaras (1995) discutem a aplicação do ensaio pressiométrico na previsão de parâmetros de deformabilidade e resistência de solos não saturados. A interpretação dos resultados é realizada com base em um modelo elastoplástico que utiliza a solução analítica de expansão de uma cavidade cilíndrica e em previsões numéricas acopladas a um modelo não-linear elástico.

\subsubsection{Ensaio dilatométrico (DMT)}

O ensaio dilatométrico, desenvolvido por Marchetti (1975), consiste na cravação da lâmina metálica rígida no terreno, para em seguida aplicar uma pressão de gás para expandir uma membrana circular de aço no interior da massa do solo. A partir do ensaio pode-se determinar o módulo dilatométrico $\left(E_{D}\right)$, o qual é obtido com a utilização da teoria da elasticidade e, para um deslocamento de 1,1 mm da membrana, é dado por:

$$
E_{D}=34,7 \cdot\left(P_{1}-P_{0}\right)
$$

onde:

$\mathrm{P}_{1}$ - pressão corrigida correspondente ao deslocamento de $1,1 \mathrm{~mm}$ do centro da membrana;

$\mathrm{P}_{0}$ - pressão corrigida correspondente ao deslocamento nulo da membrana.

\subsubsection{MÓDULO DE CISALHAMENTO}

A deformabilidade de um material também pode ser caracterizada pelo módulo de cisalhamento (G), definido pela relação entre uma tensão cisalhante aplicada e a distorção por ela provocada. O módulo de cisalhamento se relaciona ao módulo de deformabilidade segundo a seguinte equação: 


$$
\mathrm{G}=\frac{\mathrm{E}}{2 \cdot(1+v)}
$$

\subsubsection{RELAÇÃO TENSÃO-DEFORMAÇÃO NOS SOLOS NÃO SATURADOS}

De forma geral, consta na literatura técnica que a sucção altera a rigidez do solo e, conseqüentemente, os seus parâmetros de deformabilidade. Este efeito da sucção tem sido investigado por diversos pesquisadores, utilizando diferentes metodologias.

Richards (1974) encontra, para uma argila compactada, uma relação linear entre o módulo de deformabilidade e a sucção matricial, conforme mostra a Figura 2.13. O módulo de deformabilidade foi obtido a partir de resultados de ensaios triaxiais com deformações verticais e horizontais controladas.

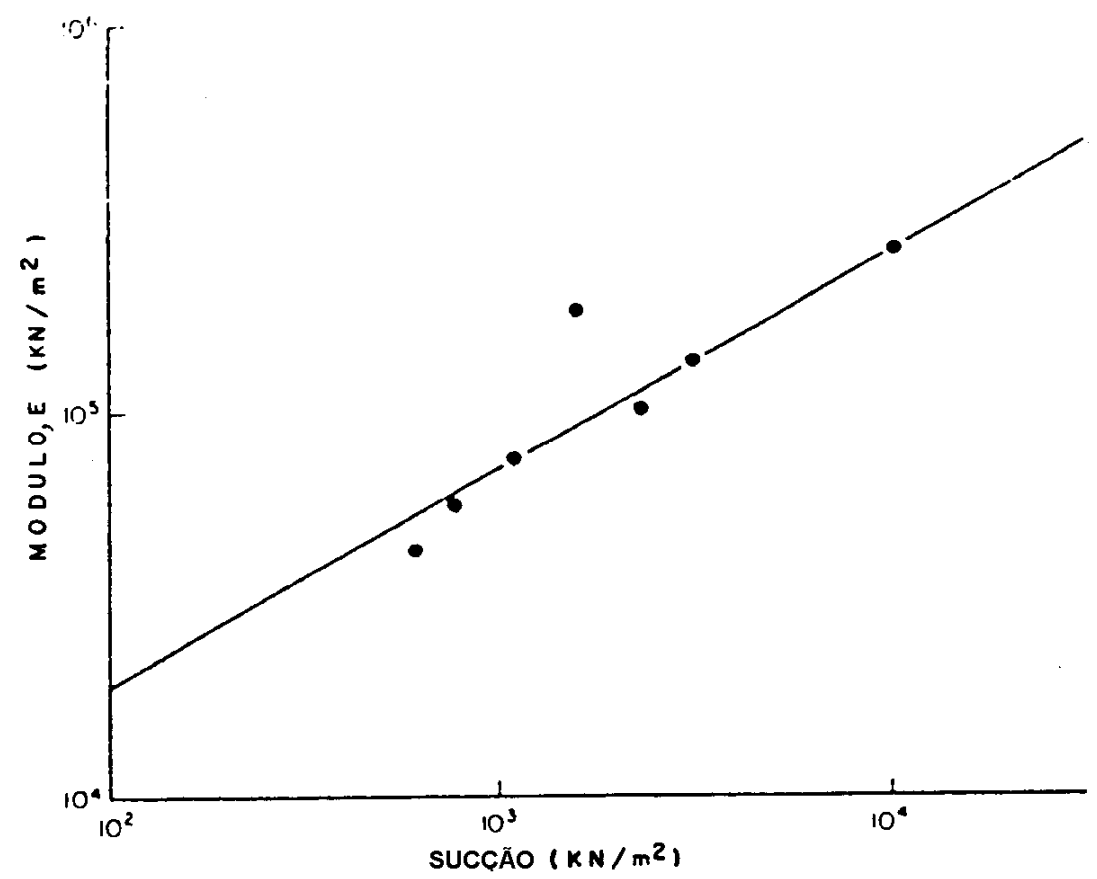

Figura 2.13 - Variação do módulo de deformabilidade com a sucção matricial para um solo argiloso (RICHARDS, 1974). 
Os resultados de ensaios triaxiais com sucção controlada apresentados por Delage, Suraj de Silva e Laure (1987) mostrados na Figura 2.14, também indicam um aumento do módulo de deformabilidade com a sucção.

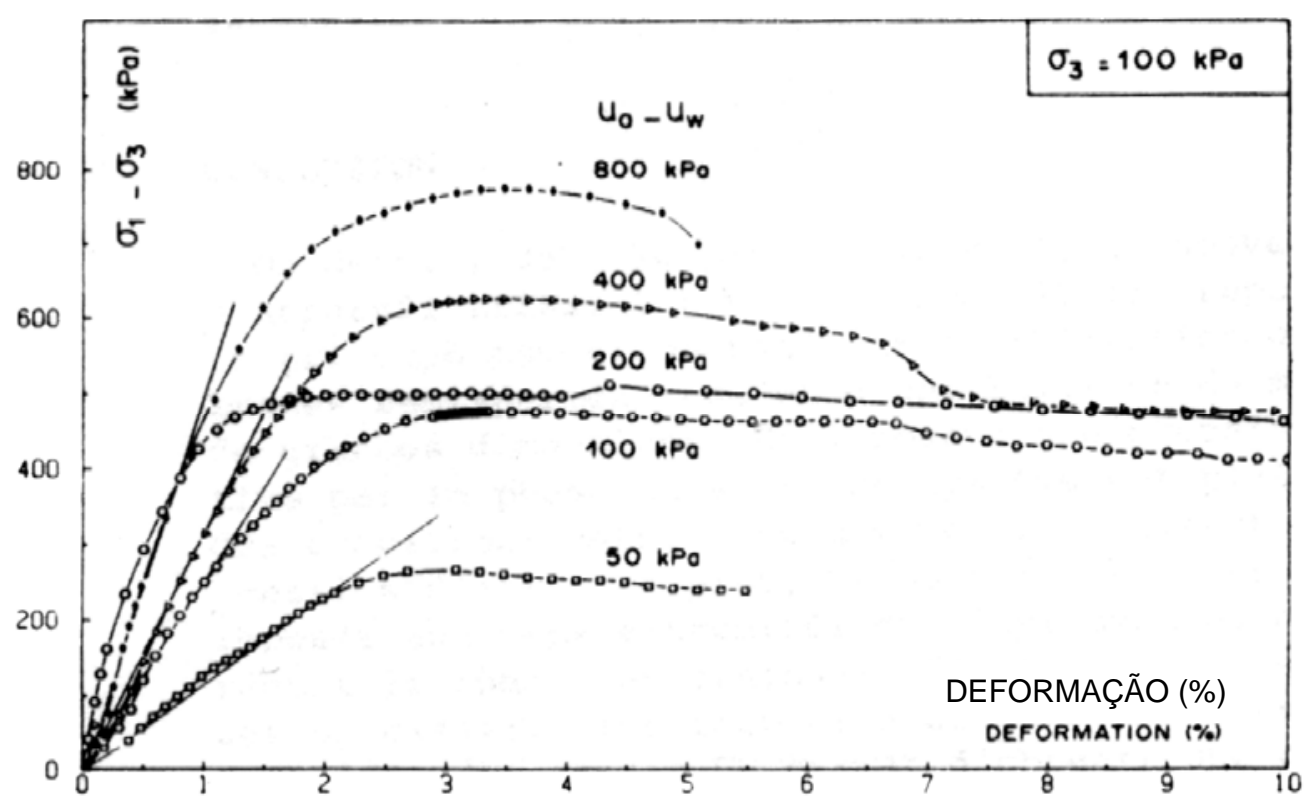

Figura 2.14 - Curvas tensão x deformação de ensaios triaxiais com sucção controlada (DELAGE; SURAJ DE SILVA; LAURE, 1987)

Jucá e Escario (1991) encontram relações não lineares deste tipo de comportamento em solos argilosos compactados. Inicialmente, ocorreu um aumento do módulo de deformabilidade com a sucção, porém, esta tendência de aumento tornou-se menos pronunciada e atingiu um valor máximo para sucções mais elevadas (Figura 2.15). 


\section{Deformabilidade (MPa)}

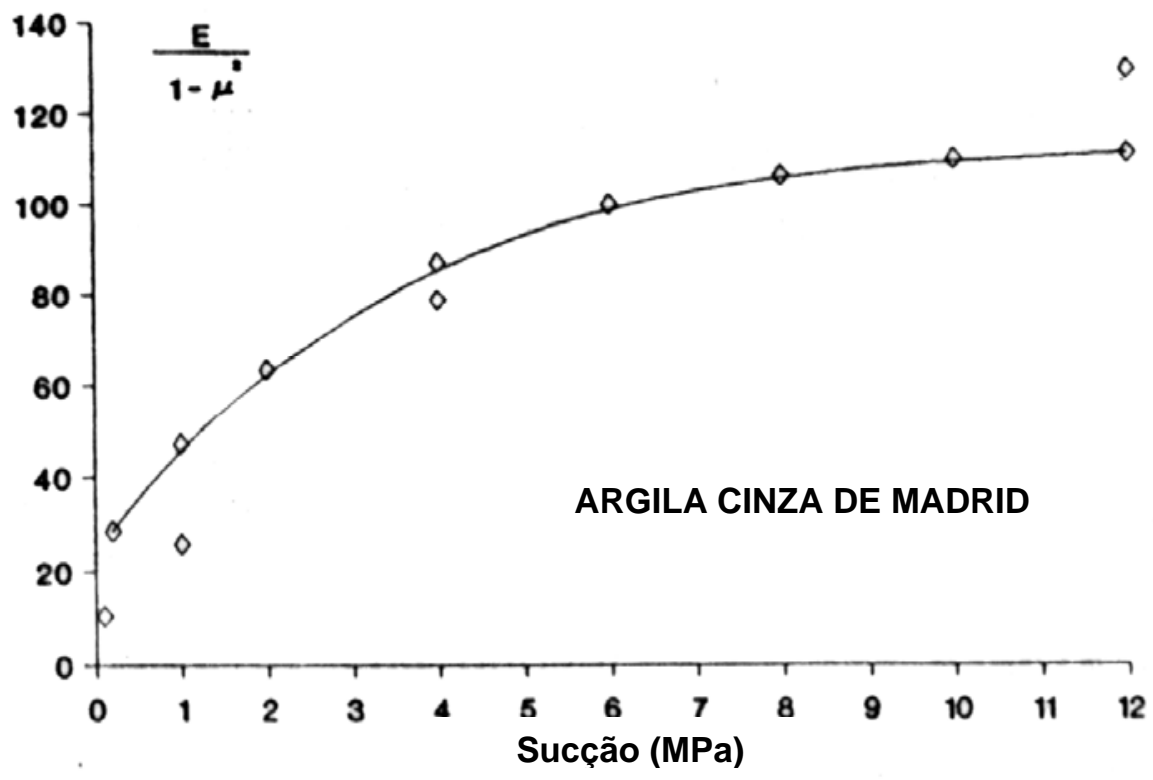

Figura 2.15 - Relação entre a deformabilidade do solo e a sucção (JUCÁ; ESCARIO, 1991)

Reznik (1995b), a partir de ensaios de placa realizados em solo colapsível da Ucrânia (loess), encontrou valores de módulo de deformabilidade crescentes com a redução do grau de saturação em diferentes profundidades e para vários índices de vazios.

Através de ensaios de compressão simples sob diversas sucções matriciais em amostras de caulim compactado, Edil, Montan e Toha (1981) verificam que o módulo de deformabilidade aumenta com a sucção matricial, até um valor crítico, a partir do qual o módulo começa a diminuir. 
Marinho, Chandler e Crilly (1995) apresentam a variação do módulo de cisalhamento com a sucção matricial para uma argila de alta plasticidade (Figura 2.16). Concluem que o módulo de cisalhamento cresce com o aumento da sucção até um valor crítico, passando então a decrescer ou manter-se constante, e que este valor crítico está associado ao valor de entrada de ar no corpo de prova.

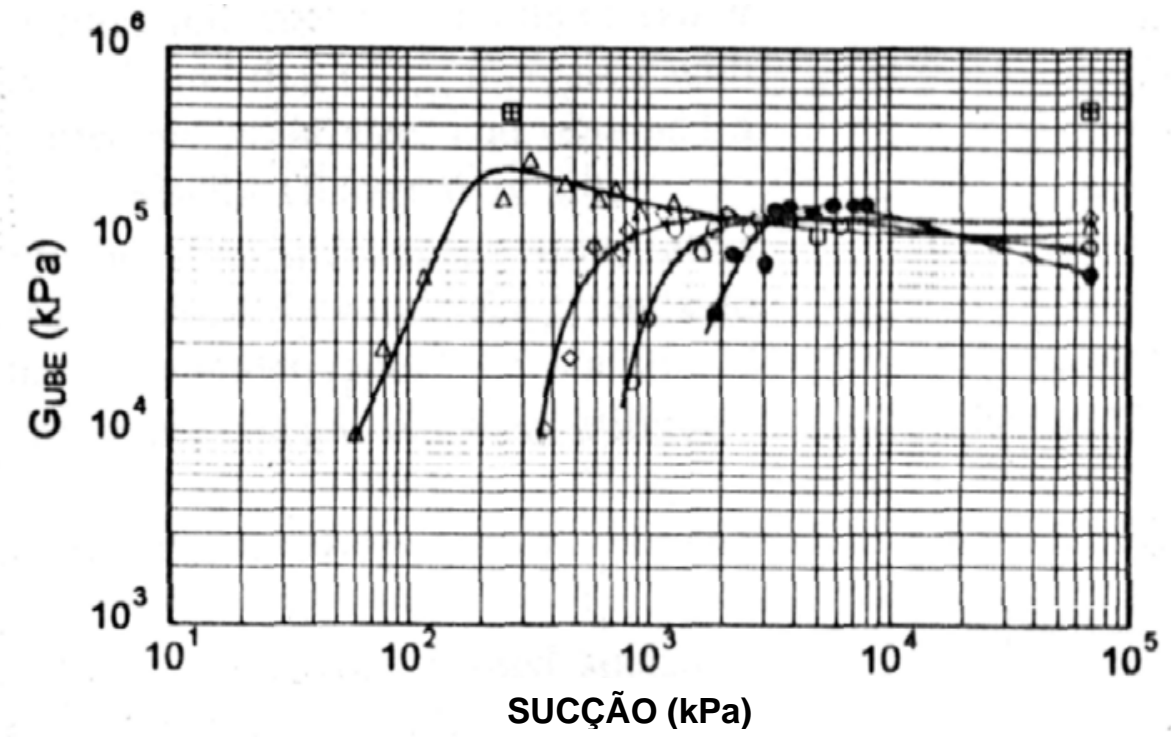

Figura 2.16 - Variação do módulo de cisalhamento com a sucção em uma argila de alta plasticidade (MARINHO; CHANDLER; CRILLY, 1995). 


\section{LOCAL DA PESQUISA}

\subsection{ASPECTOS GERAIS}

A pesquisa desenvolveu-se no Campo Experimental de Fundações do Departamento de Geotecnia da Escola de Engenharia de São Carlos (EESC), o qual foi implantado em 1988, e está situado no extremo sul do campus da USP/São Carlos, em uma área cujo perfil geológico-geotécnico é considerado representativo da região centro-oeste do Estado de São Paulo (CINTRA et al., 1991).

A cidade de São Carlos está localizada na parte centro-oriental do Estado de São Paulo e tem sua posição geográfica dada pelas coordenadas $22^{\circ} 01^{\prime} 22^{\prime \prime}$ de latitude sul e $47^{\circ} 53^{\prime} 38$ ” de latitude oeste. Seu relevo apresenta altitudes variáveis, oscilando entre 750 e $950 \mathrm{~m}$.

\subsection{ASPECTOS GEOLÓGICOS}


A região de São Carlos está assentada sobre rochas do grupo São Bento, constituídas pelos arenitos da Formação Botucatu, e pelos magmatitos básicos da Formação Serra Geral. Acima dessas formações rochosas ocorrem conglomerados e arenitos do Grupo Bauru e cobrindo toda a região, aparecem os Sedimentos Cenozóicos (BORTOLUCCI, 1983).

Segundo Bortolucci (1983), os Sedimentos Cenozóicos são produtos do retrabalhamento dos materiais do Grupo Bauru e das Formações Serra Geral e Botucatu, através de pequeno transporte em meio aquoso de razoável competência. Esses sedimentos foram submetidos à ação de intemperismo sob condições climáticas típicas de região tropical, com elevadas temperaturas e intensa precipitação pluviométrica. Deste modo, esse material apresenta a característica de ser pouco compacto, muito poroso e colapsível.

Em toda a região urbana a espessura da camada de solo superficial de Sedimento Cenozóico não excede 12,0 m, predominando valores entre 5,0 e 7,0 m. Seu contato inferior com solo residual do Grupo Bauru é feito através de uma fina camada de seixos de quartzo e limonita.

O Grupo Bauru é representado na região por arenitos de granulação média a conglomeráticos, com grãos angulosos, seleção pobre, ricos em feldspatos, minerais pesados e instáveis.

A Figura 3.1 apresenta um perfil típico da geologia de pequena superfície na área urbana da cidade de São Carlos, com a descrição táctil-visual das litologias predominantes e mostra ainda a localização do campus da USP neste perfil geológico. 


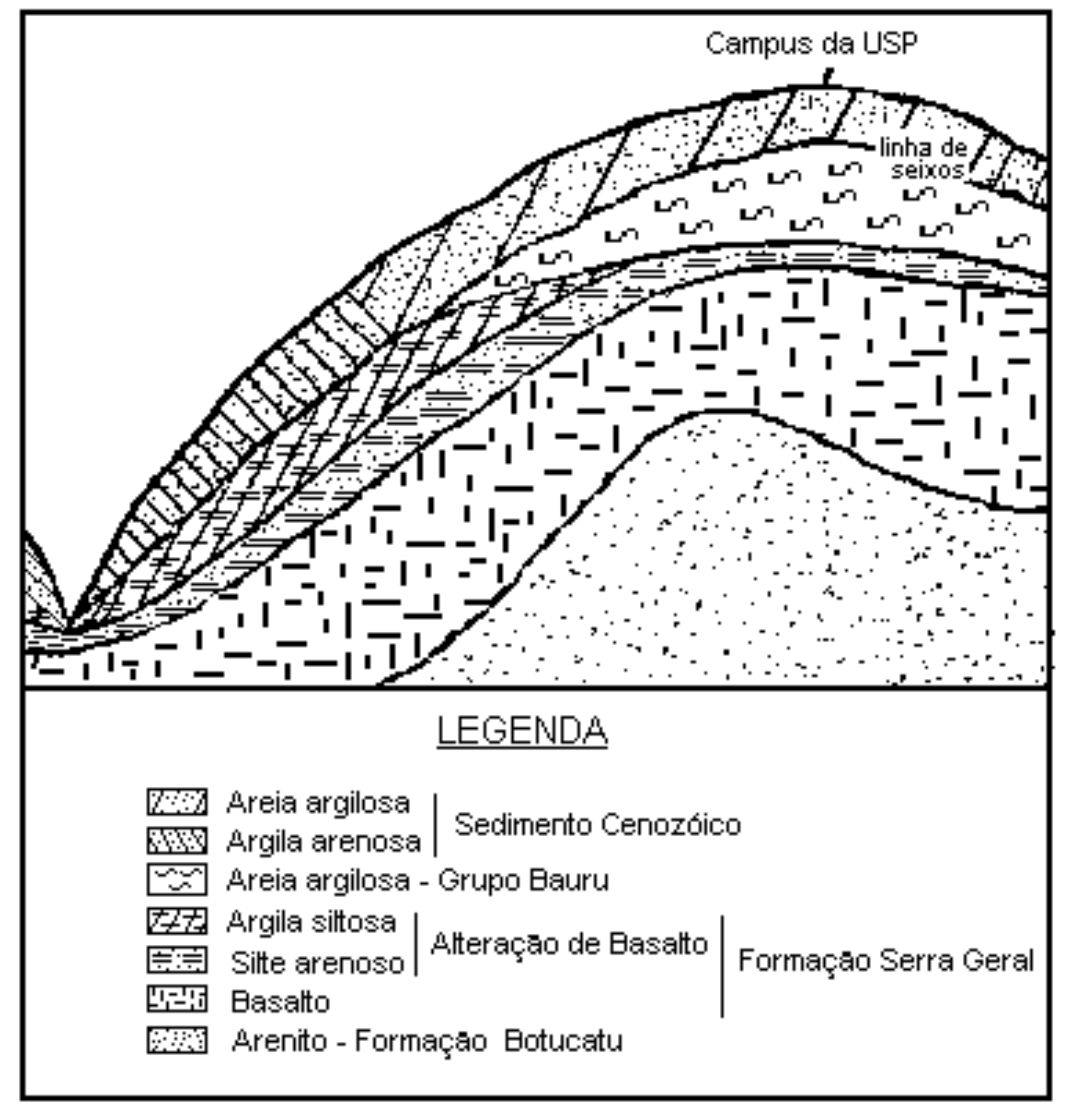

Figura 3.1 - Seção esquemática da geologia de pequena profundidade em São Carlos (BORTOLUCCI, 1983).

\subsection{CARACTERIZAÇÃO GEOTÉCNICA}

\subsubsection{ENSAIOS IN SITU}

Desde a implantação do Campo Experimental foram realizados diversos ensaios de campo, dentre os quais 15 sondagens de simples reconhecimento (SPT) divididas em três campanhas de cinco furos, e dez ensaios de penetração estática (CPT) em duas campanhas com cinco furos cada uma. Na primeira campanha dos ensaios de CPT utilizou-se um cone mecânico e na segunda utilizou-se um cone elétrico com medida de pressão neutra. A Figura 3.2. mostra a locação destes ensaios no local da pesquisa. 


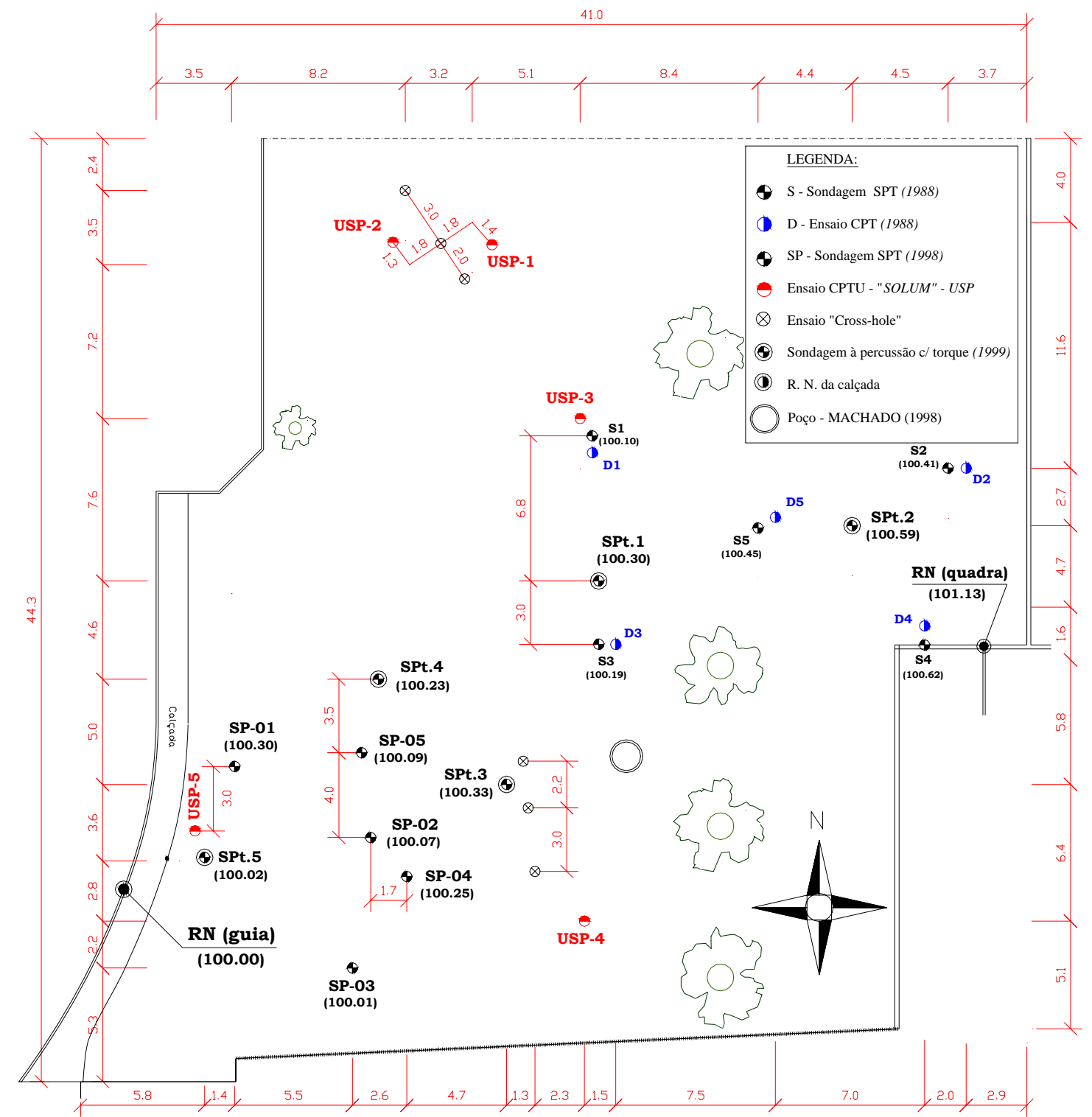

Figura 3.2 - Locação dos ensaios de campo (SPT e CPT) realizados no Campo Experimental de Fundações

A Figura 3.3 mostra o perfil estratigráfico do maciço de solo no Campo Experimental, baseado nas sondagens SPT-T da terceira campanha. Nesta figura observa-se que o maciço de solo do local pode ser dividido em três camadas principais até o impenetrável. 

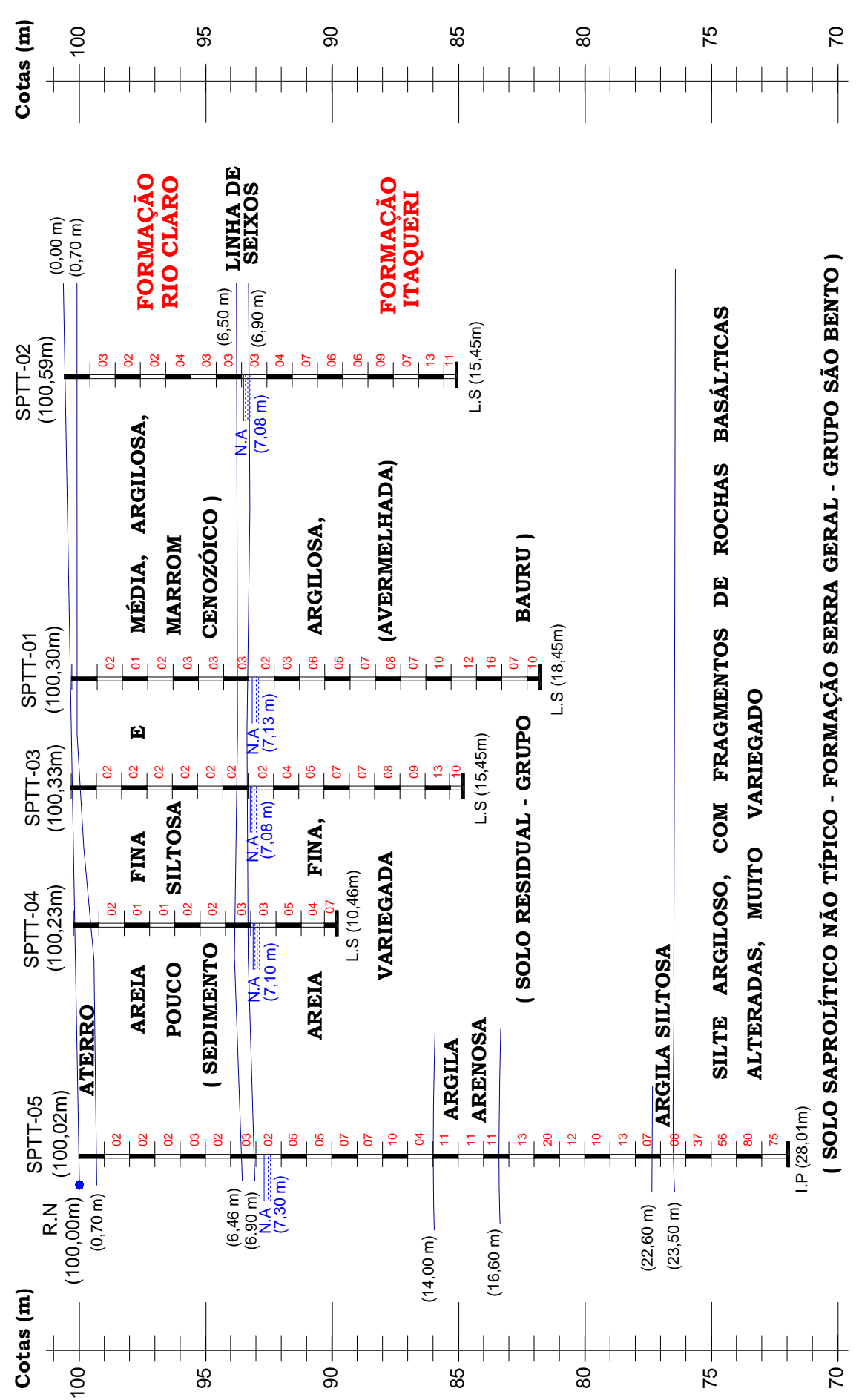

Figura 3.3 - Perfil do terreno associado às sondagens à percussão (modificado de SANTOS, 2001).

A primeira camada é composta por uma areia fina argilosa marrom e fofa (Sedimento Cenozóico) que atinge aproximadamente $6,4 \mathrm{~m}$ de profundidade. Abaixo desta camada aparece uma linha de seixos com espessura variando de 0,1 a 0,5 m. A segunda camada é composta por uma areia fina argilosa marrom avermelhada, pouco a medianamente compacta, a qual atinge uma profundidade de cerca de 24,0 m (Solo Residual do Grupo Bauru). Finalmente, a terceira camada é composta por um silte 
argiloso variegado, compacto a muito compacto (Formação Serra Geral - Grupo São Bento).

A profundidade do nível do lençol freático varia entre 7,0 e 10,0 m, dependendo da época do ano.

A Figura 3.4 apresenta os valores mínimos, médios e máximos dos resultados de ensaios penetrométricos de SPT e CPTu, ao longo do perfil de solo.

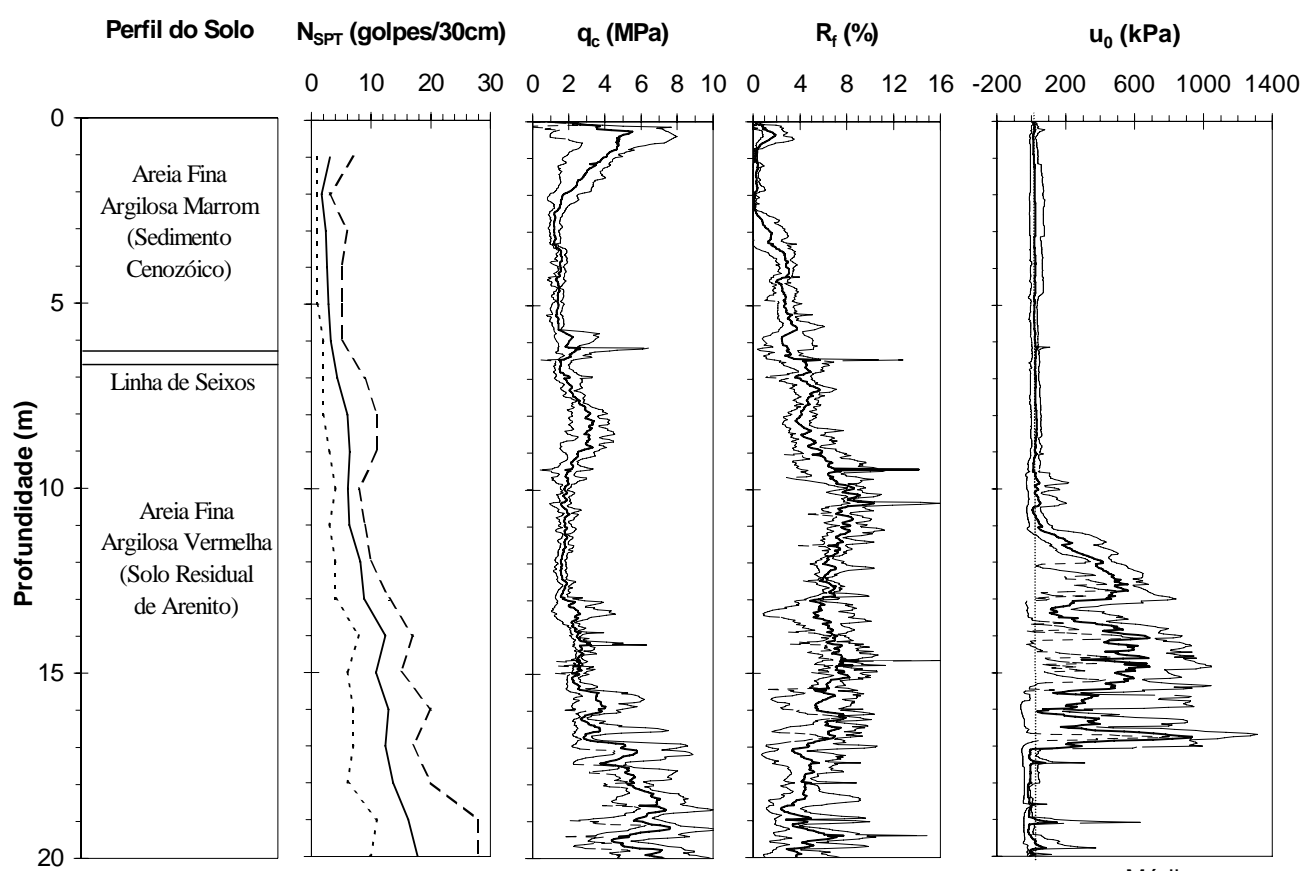

Figura 3.4 - Resultados de ensaios penetrométricos de SPT e CPTu.

\subsubsection{ENSAIOS DE LABORATÓRIO}

Machado (1998) realizou ensaios de laboratório em amostras indeformadas extraídas a cada metro, de um poço com diâmetro de 1,2 m, até uma profundidade de aproximadamente $10,0 \mathrm{~m}$. Para todas as amostras realizaram-se ensaios de caracterização, ensaios de compressão confinada convencional saturada e com controle de sucção. Para as amostras coletadas nas profundidades de 2,0, 5,0, e 8,0 m também se determinaram as curvas de retenção de umidade do solo e executaram-se ensaios triaxiais convencionais saturados e com sucção controlada.

A Tabela 3.1 mostra os valores de umidade e de peso específico seco obtidos, ao longo do perfil de coleta dos blocos indeformados. O valor do peso 
específico seco representa a média dos valores calculados a partir dos corpos de prova empregados nos ensaios de compressão confinada e triaxiais.

Tabela 3.1 - Valores de peso específico seco e umidade obtidos ao longo do perfil de coleta de blocos indeformados (MACHADO, 1998).

\begin{tabular}{cccccccccc}
\hline Prof. (m) & $\mathbf{1 , 0}$ & $\mathbf{2 , 0}$ & $\mathbf{3 , 0}$ & $\mathbf{4 , 0}$ & $\mathbf{5 , 0}$ & $\mathbf{6 , 0}$ & $\mathbf{7 , 0}$ & $\mathbf{8 , 0}$ & $\mathbf{9 , 0}$ \\
\hline $\mathrm{w}(\%)$ & 13,7 & 14,6 & 15,8 & 16,8 & 16,4 & 17,2 & 19,1 & 16,7 & 18,3 \\
\hline$\gamma_{\mathrm{d}}\left(\mathrm{kN} / \mathrm{m}^{3}\right)$ & 12,5 & 13,6 & 13,8 & 14,3 & 14,4 & 14,7 & 15,2 & 16,1 & 16,6 \\
\hline$\gamma\left(\mathrm{kN} / \mathrm{m}^{3}\right)$ & 14,2 & 15,6 & 16,0 & 16,7 & 14,8 & 17,1 & 18,1 & 18,8 & 19,6 \\
\hline $\mathrm{e}$ & 1,17 & 0,99 & 0,96 & 0,90 & 0,88 & 0,84 & 0,78 & 0,68 & 0,63 \\
\hline
\end{tabular}

A Tabela 3.2 apresenta os resultados obtidos a partir dos ensaios de caracterização para as profundidades de 3,0, 5,0 e 8,0 m. Os valores de $\gamma_{\mathrm{d} \text { máx }}$ e $\mathrm{w}_{\text {ot }}$ foram obtidos em ensaios de compactação utilizando-se a energia do Proctor Normal.

Tabela 3.2 - Resultados dos ensaios de caracterização e compactação (MACHADO, 1998).

\begin{tabular}{cccccc}
\hline Prof. (m) & $\gamma_{\mathbf{d} \text { máx }}\left(\mathbf{k N} / \mathbf{m}^{3}\right)$ & $\mathbf{w}_{\mathbf{0 t}} \mathbf{( \% )}$ & $\mathbf{w}_{\mathbf{L}} \mathbf{( \% )}$ & $\mathbf{w}_{\mathbf{P}} \mathbf{( \% )}$ & $\boldsymbol{\gamma}_{\mathbf{s}}\left(\mathbf{k N} / \mathbf{m}^{\mathbf{3}}\right)$ \\
\hline 3,0 & 18,7 & 14,0 & 27,9 & 16,0 & 27,1 \\
\hline 5,0 & 18,4 & 14,8 & 30,9 & 19,8 & 27,5 \\
\hline 8,0 & 18,9 & 11,2 & 28,4 & 17,2 & 27,1 \\
\hline
\end{tabular}

A Figura 3.5 mostra as curvas granulométricas obtidas para a profundidades de 3,0, 5,0 e 8,0 m. A Tabela 3.3 apresenta as frações granulométricas constituintes de cada profundidade. Observa-se que os resultados obtidos para as profundidades de 3,0 e 5,0 m são muito próximos, porém o solo da profundidade de 8,0 m apresenta um percentual de argila menor do que os anteriores. 


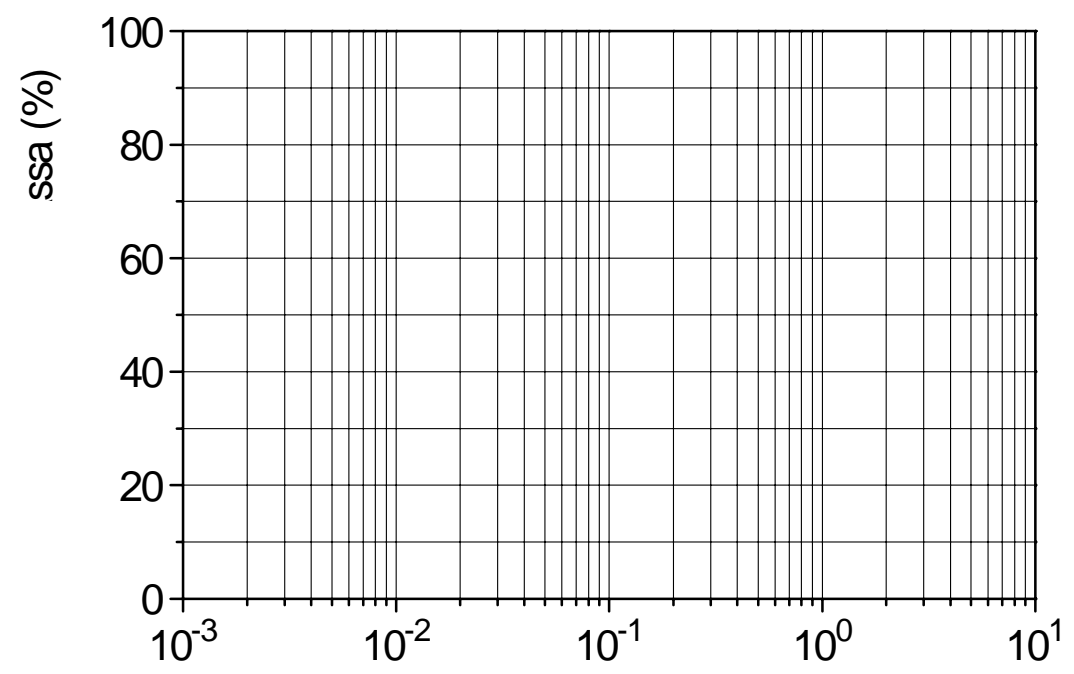

Figura 3.5 - Curvas granulométricas obtidas para as profundidades de 3,0, 5,0 e 8,0 m, em relação à superfície do terreno (MACHADO, 1998).

Tabela 3.3 - Frações granulométricas constituintes dos solos (MACHADO, 1998).

\begin{tabular}{cccc}
\hline Prof. (m) & Areia (\%) & Silte (\%) & Argila (\%) \\
\hline 3,0 & 60,8 & 11,9 & 27,3 \\
\hline 5,0 & 66,7 & 5,90 & 27,4 \\
\hline 8,0 & 68,9 & 13,7 & 17,4 \\
\hline
\end{tabular}

As Figuras 3.6, 3.7 e 3.8 apresentam, respectivamente, as curvas características de sucção matricial obtidas para as profundidades de 2,0, 5,0 e 8,0 m, juntamente com o ajuste para cada curva utilizando a equação (2.11) proposta por Fredlund e Xing (1994). Pode-se observar nestas figuras que os valores de entrada de ar em todas as profundidades ensaiadas são muito baixos, praticamente nulos. Isto ocorre porque o solo ensaiado apresenta estrutura com macro poros de grande diâmetro, visíveis a olho nu (MACHADO, 1998).

A Tabela 3.4 resume os valores adotados por Machado (1998) para os parâmetros apresentados na equação (2.11). 


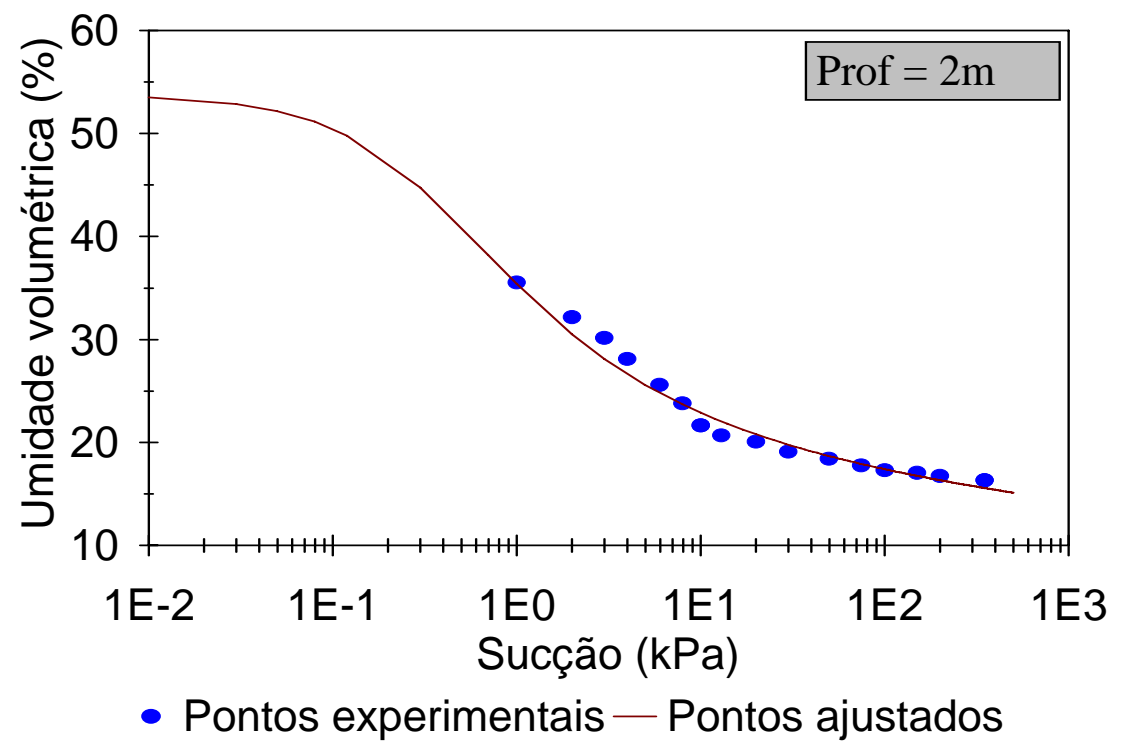

Figura 3.6 - Curva característica de sucção do solo para a profundidade de 2,0 m (MACHADO, 1998).

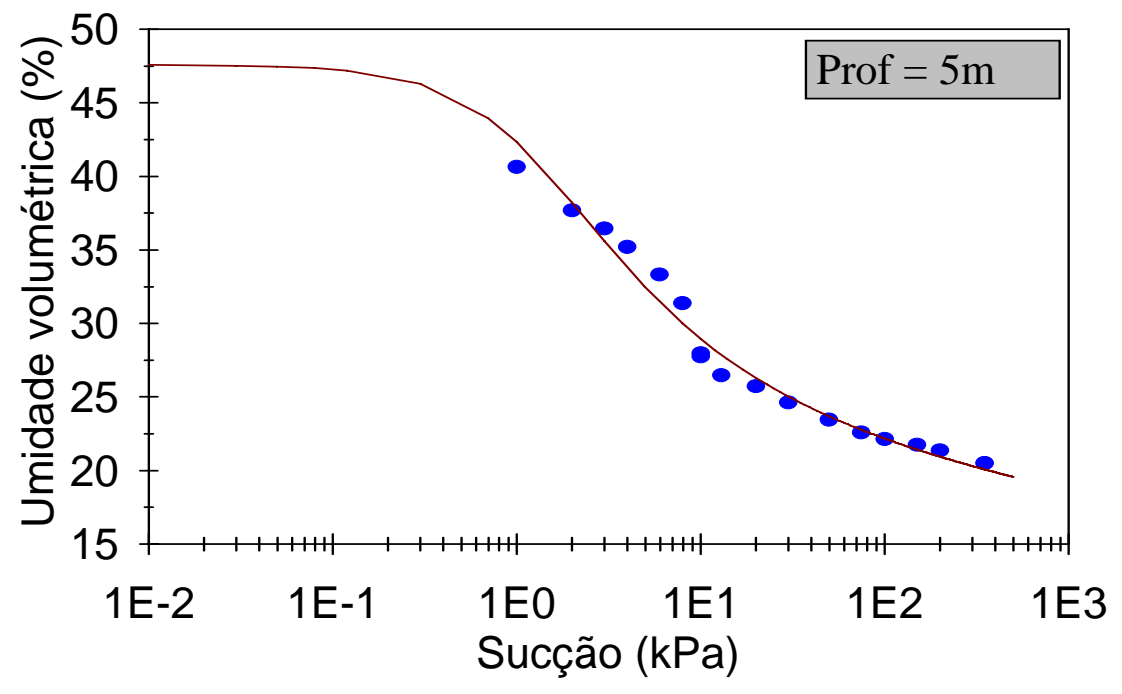

- Pontos experimentais - Pontos ajustados

Figura 3.7 - Curva característica de sucção do solo para a profundidade de 5,0 m (MACHADO, 1998). 


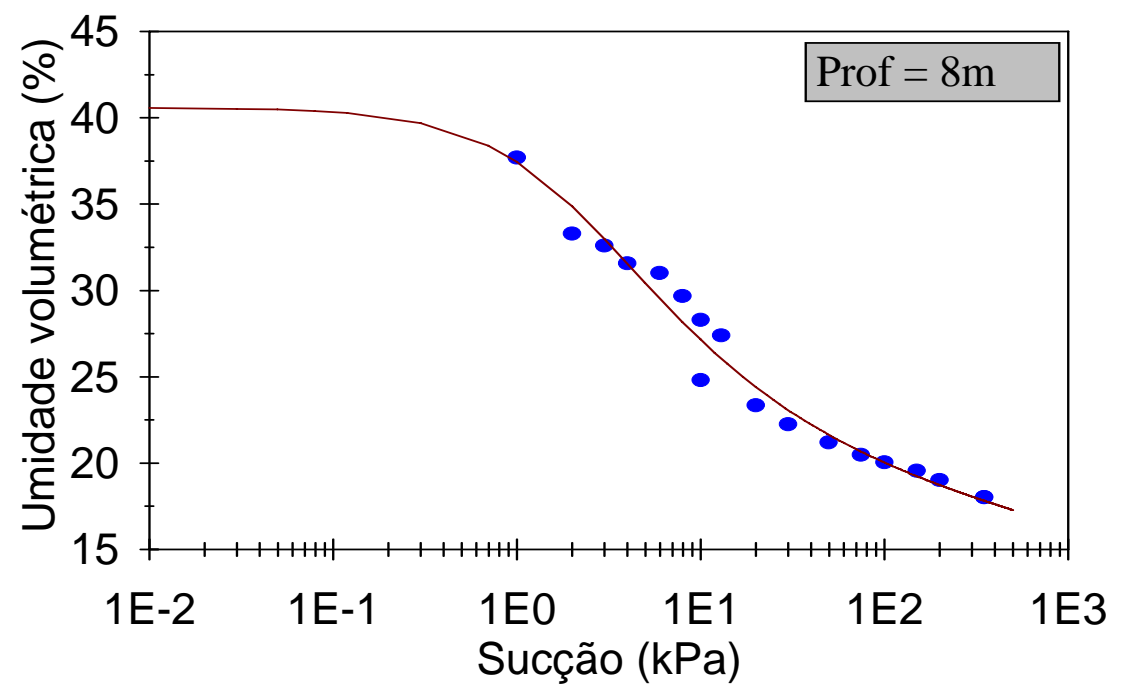

- Pontos experimentais - Pontos ajustados

Figura 3.8 - Curva característica de sucção do solo para a profundidade de 8,0 m (MACHADO, 1998).

Tabela 5.1 - Valores dos principais parâmetros utilizados no ajuste dos dados experimentais à equação proposta por Fredlund e Xing (1994) (MACHADO, 1998).

\begin{tabular}{cccccccc}
\hline Profundidade & $\boldsymbol{\theta}_{\text {sat }}(\mathbf{\%})$ & $\boldsymbol{\psi}_{\mathbf{r}}$ & $\mathbf{a ~ ( k P a )}$ & $\mathbf{n}$ & $\boldsymbol{\theta}_{\mathbf{r}} \mathbf{( \% )}$ & $\mathbf{m}$ & $\mathbf{r}^{\mathbf{2}}$ \\
\hline $2 \mathrm{~m}$ & 53,8 & 20000 & 0,25 & 1,20 & 10,0 & 0,57 & 0,984 \\
\hline $5 \mathrm{~m}$ & 47,6 & 20000 & 0,95 & 1,40 & 13,6 & 0,41 & 0,984 \\
\hline $8 \mathrm{~m}$ & 40,6 & 10000 & 1,50 & 1,20 & 12,4 & 0,43 & 0,977 \\
\hline
\end{tabular}




\section{MATERIAIS E MÉTODOS}

\subsection{PROVAS DE CARGA EM PLACA}

Inicialmente foram realizadas 21 provas de carga em placa circular de 0,80 m de diâmetro, no Campo Experimental de Fundações do Departamento de Geotecnia da EESC/USP. Esses ensaios foram executados com as placas assentadas no terreno a 1,5 m, 4,0 m, e 6,0 m de profundidade, dentro do projeto de pesquisa que incluiu os trabalhos de Costa (1999) e Macacari (2001).

Onze desses ensaios foram executados com inundação por um período mínimo de 24 horas, utilizando água potável proveniente da rede pública. Tomou-se o cuidado de manter uma lâmina de água mínima de 5,0 cm no fundo da cava, de modo a garantir que a sucção do solo apresentasse valores muito próximos de zero. Os demais ensaios foram realizados com o solo na condição não inundada, sendo a sucção medida através tensiômetros convenientemente instalados ao redor da placa.

As cavas destinadas à realização das provas de cargas foram escavadas manualmente com um diâmetro de $0,90 \mathrm{~m}$, resultado em uma folga de aproximadamente $5,0 \mathrm{~cm}$ em volta da placa. Esta folga permitia a instalação dos tensiômetros e um melhor posicionamento da placa de ensaio em relação à viga de reação, além de contribuir com a infiltração da água no solo nos ensaios inundados. O fundo da cava foi nivelado, utilizando-se uma colher de pedreiro e um nível de bolha metálico.

Para determinação da sucção matricial média do solo abaixo da placa, nos ensaios não inundados, eram instalados tensiômetros no solo do fundo das cavas nas profundidades de 0,1 m, 0,3 m, 0,6 m e 0,8 m abaixo da cota de assentamento da placa. A maior profundidade de instalação dos tensiômetros correspondeu ao diâmetro da placa.

A instalação dos tensiômetros era realizada pelo menos 24 horas antes do início da prova de carga, para que a medida já estivesse estabilizada para iniciar o ensaio. Para a instalação dos tensiômetros inicialmente abria-se um pré-furo até 
aproximadamente $10 \mathrm{~cm}$ acima de sua cota final, com auxílio de um trado com diâmetro um pouco menor que o da haste do tensiômetro. Após uma inspeção para verificar a existência de possíveis fraturas na sua pedra porosa e se o vacuômetro estava apresentando a leitura correspondente à altura de coluna d'água dentro da haste, o tensiômetro era acondicionado no pré-furo e nos últimos centímetros procedia-se sua cravação por prensagem, de modo a garantir o contato da pedra porosa com solo.

Quanto ao modo de carregamento aplicado durante as provas de carga foram realizadas cinco do tipo lento (SML), doze do tipo rápido (QML) e quatro do tipo misto (MML). A Tabela 4.1 mostra as principais características de cada ensaio bem como a sua designação. Um esquema da locação das provas de carga no Campo Experimental é apresentado na Figura 4.1.

Tabela 4.1 - Características das provas de carga em placa com diâmetro de 0,80 m.

\begin{tabular}{|c|c|c|c|c|}
\hline Ensaio & $\begin{array}{c}\text { Tipo de } \\
\text { Carregamento }\end{array}$ & Estado do solo & $\begin{array}{c}\text { Profundidade } \\
\text { (m) }\end{array}$ & Designação \\
\hline 1 & lento & inundado & 1,5 & SS1 \\
\hline 2 & lento & inundado & 1,5 & SS2 \\
\hline 3 & lento & inundado & 1,5 & SS3 \\
\hline 4 & lento & não inundado & 1,5 & S1 \\
\hline 5 & lento & não inundado & 1,5 & $\mathrm{~S} 2$ \\
\hline 6 & rápido & inundado & 1,5 & QS1 \\
\hline 7 & rápido & inundado & 1,5 & QS2 \\
\hline 8 & rápido & não inundado & 1,5 & Q1 \\
\hline 9 & rápido & não inundado & 1,5 & Q2 \\
\hline 10 & rápido & não inundado & 1,5 & Q3 \\
\hline 11 & misto & inundado & 1,5 & MS1 \\
\hline 12 & misto & inundado & 1,5 & MS2 \\
\hline 13 & misto & inundado & 1,5 & MS3 \\
\hline 14 & misto & não inundado & 1,5 & M1 \\
\hline 15 & rápido & inundado & 4,0 & QS3 \\
\hline 16 & rápido & não inundado & 4,0 & Q4 \\
\hline 17 & rápido & não inundado & 4,0 & Q5 \\
\hline 18 & rápido & inundado & 6,0 & QS4 \\
\hline 19 & rápido & inundado & 6,0 & QS5 \\
\hline 20 & rápido & não inundado & 6,0 & Q6 \\
\hline 21 & rápido & não inundado & 6,0 & Q7 \\
\hline
\end{tabular}




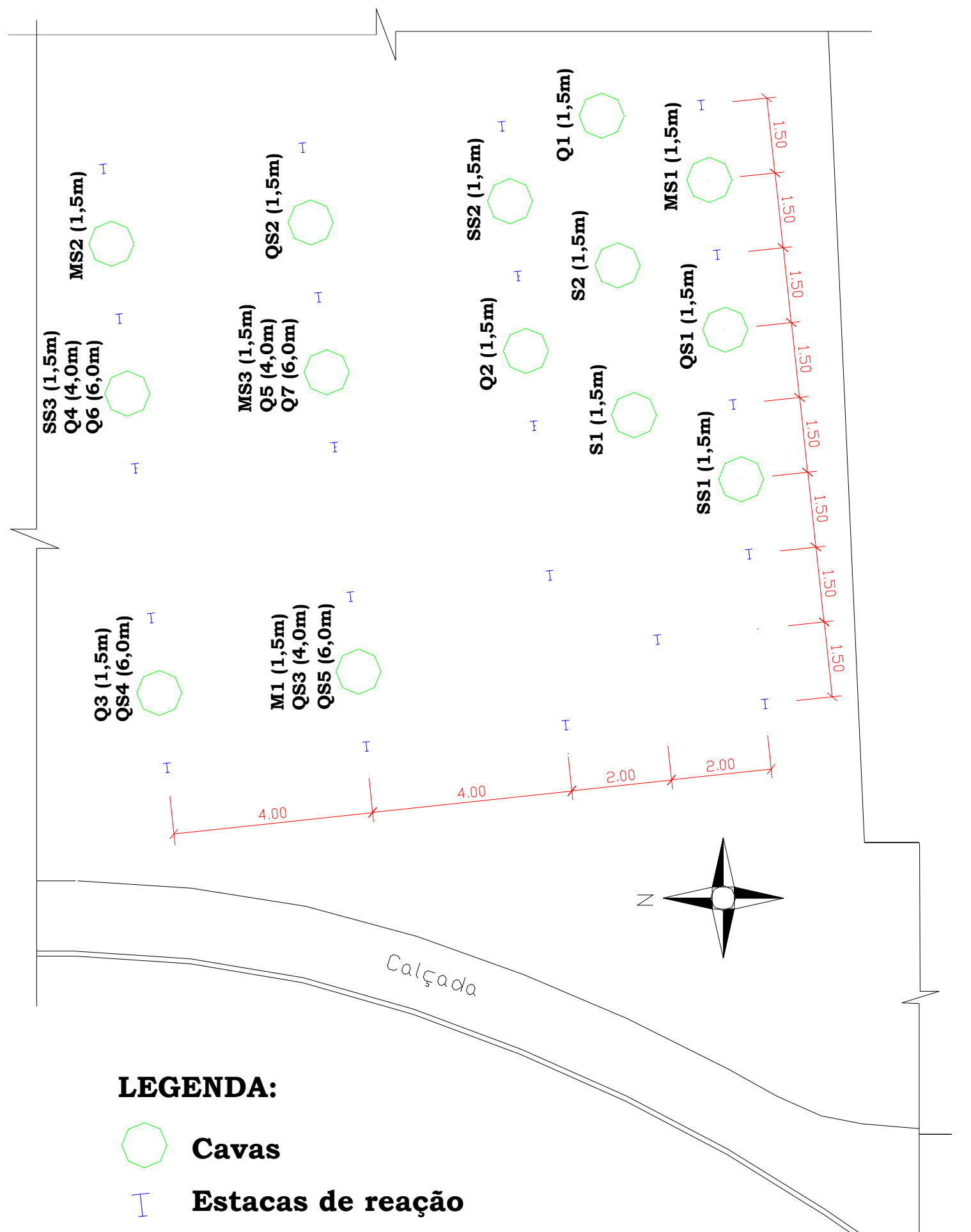

Figura 4.1 - Locação das provas de carga em placa no Campo Experimental de Fundações da EESC/USP. 
A execução dos ensaios lentos foi realizada de acordo com a norma brasileira NBR 6489/84. Nestes ensaios, procurou-se aplicar estágios de carregamento com aproximadamente $20 \%$ da tensão admissível provável. Somente era aplicado novo acréscimo de carregamento depois de verificada a estabilização dos recalques.

Nos ensaios do tipo rápido, a duração dos estágios de carregamento foi de 15 minutos, segundo a recomendação de Fellenius (1975), com incrementos de carga de aproximadamente $10 \%$ da tensão admissível prevista. As leituras de recalque eram realizadas nos tempos de $0,1,2,3,6,9,12$ e 15 minutos após a aplicação dos carregamentos.

Os ensaios mistos foram iniciados com aplicação de carregamento do tipo lento até a provável tensão admissível, e garantindo-se um recalque de no mínimo $10 \mathrm{~mm}$, passando então à utilização de carregamento do tipo rápido até o final da prova de carga. Os acréscimos de tensão da fase rápida correspondiam à metade dos acréscimos aplicados na fase lenta.

Independente do tipo de carregamento, antes do início do descarregamento interrompeu-se a reposição de carga, aguardando-se a sua estabilização bem como a dos recalques.

Em uma segunda etapa foram realizados mais nove ensaios de placa com diâmetros diferentes de $0,8 \mathrm{~m}$, profundidade de $1,5 \mathrm{~m}$, dentro do projeto de pesquisa que incluiu a tese de doutorado de Vianna (em fase de elaboração) ${ }^{4}$. As características destes ensaios e a designação dadas aos mesmos no presente trabalho encontram-se na Tabela 4.2. Deste modo, neste trabalho foram analisados um total de 30 ensaios de placa.

\footnotetext{
${ }^{4}$ VIANNA, A.P.F. Influência da dimensão de sapatas na capacidade de carga em solos colapsíveis. Tese (Doutorado) - Escola de Engenharia de São Carlos, Universidade de São Paulo, São Carlos. 2004.
} 
Tabela 4.2 - Características das provas de carga em placa com diâmetros diferentes de $0,80 \mathrm{~m}$ na profundidade de $1,5 \mathrm{~m}$.

\begin{tabular}{ccccc}
\hline Ensaio & Tipo de Carregamento & Estado do solo & Diâmetro (m) & Designação \\
\hline 1 & rápido & não inundado & 0,2 & QS6 \\
\hline 2 & rápido & inundado & 0,2 & Q8 \\
\hline 3 & rápido & inundado & 0,2 & Q9 \\
\hline 4 & rápido & não inundado & 0,4 & QS7 \\
\hline 5 & rápido & inundado & 0,4 & Q10 \\
\hline 6 & rápido & inundado & 0,4 & Q11 \\
\hline 7 & rápido & não inundado & 1,5 & QS8 \\
\hline 8 & rápido & inundado & 1,5 & Q12 \\
\hline 9 & rápido & inundado & 1,5 & Q13 \\
\hline
\end{tabular}

\subsection{EQUIPAMENTOS E MATERIAIS UTILIZADOS NOS ENSAIOS DE PLACA}

\subsubsection{ESTACAS DE REAÇÃO}

As estacas de reação eram metálicas, do tipo trilho TR-68, de 26 a $27 \mathrm{~m}$ de comprimento, reforçadas lateralmente com duas estacas Strauss, de $20 \mathrm{~cm}$ de diâmetro, até a profundidade de $16 \mathrm{~m}$. Estas estacas de reação foram reaproveitadas de provas de carga em tubulões a céu aberto realizadas por Carneiro (1999). As cavas dos ensaios de placa situavam-se no ponto médio dos lados dos retângulos formados pelas quatro estacas de reação utilizadas nos ensaios dos tubulões.

Para sustentação da viga de reação, na extremidade superior da estaca metálica foi soldada uma luva de aço do tipo Dywidag na qual posteriormente era fixada a composição de barras de aço de $32 \mathrm{~mm}$ de diâmetro.

\subsubsection{VIGAS DE REAÇÃO}

Foram utilizadas duas vigas de reação. Nas cavas em que as estacas de reação ficavam distanciadas $3,0 \mathrm{~m}$ umas das outras, utilizou-se uma viga metálica retilínea, com seção transversal em I com 0,30 x 0,65 m, comprimento de 3,30 m e massa de 800 kg (Figura 4.2). Esta viga suporta uma solicitação de até 800 kN aplicada no seu centro.

Para as cavas em que as estacas de reação distanciavam-se 4,0 m umas das outras, utilizou-se uma outra viga metálica (forma de I, em planta) com capacidade de suportar uma solicitação de até $2000 \mathrm{kN}$, com comprimento de 4,3 m, massa de $2000 \mathrm{~kg}$ 
(Figura 4.3). Esta viga é composta por quatro perfis I metálicos, sendo dois perfis centrais ligados por meio de parafusos aos laterais. Para aumentar a rigidez do conjunto, as extremidades dos perfis laterais eram ligadas ao meio dos perfis centrais através de quatro cantoneiras de aço.

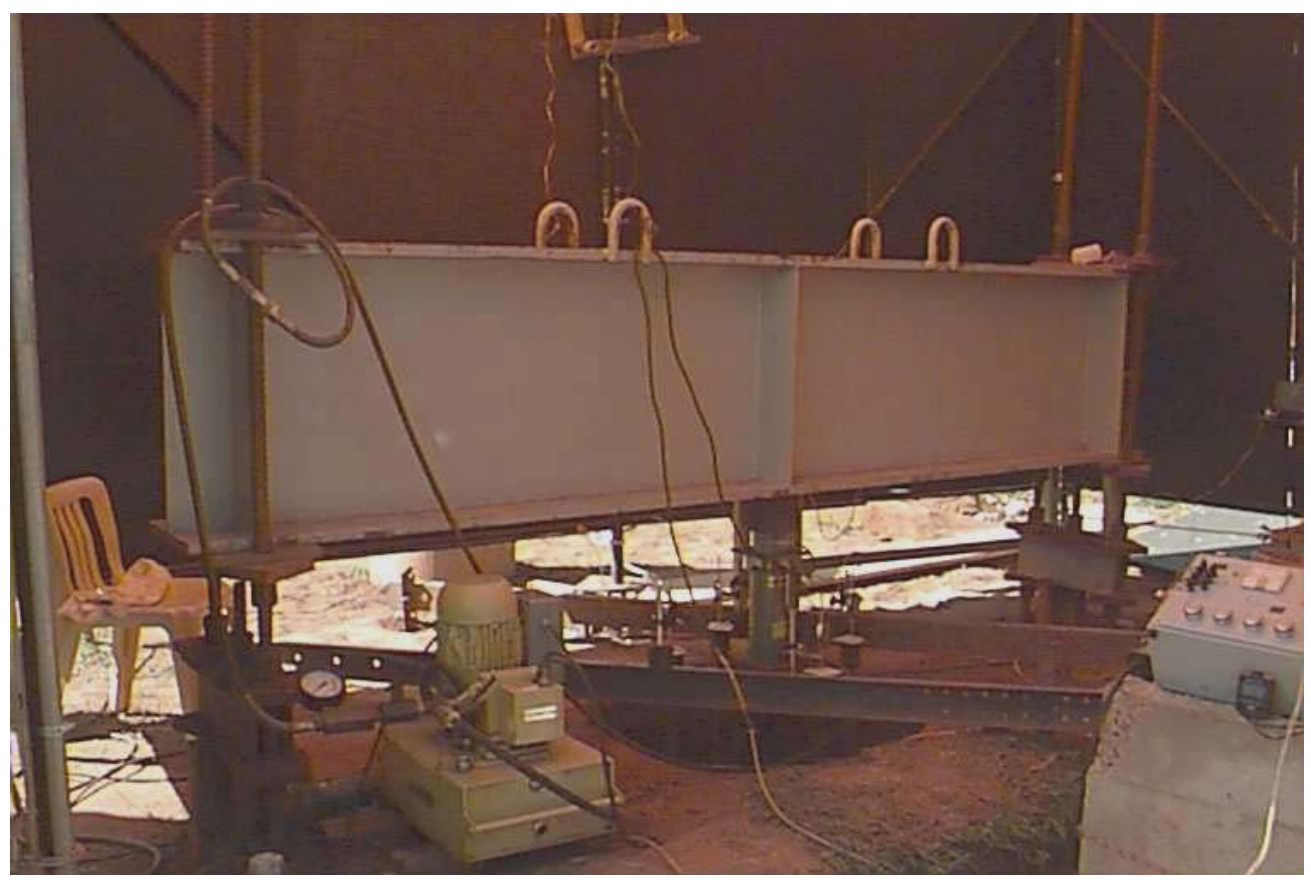

Figura 4.2 - Esquema de montagem da prova de carga para distância entre estacas de reação igual a 3,0 m.

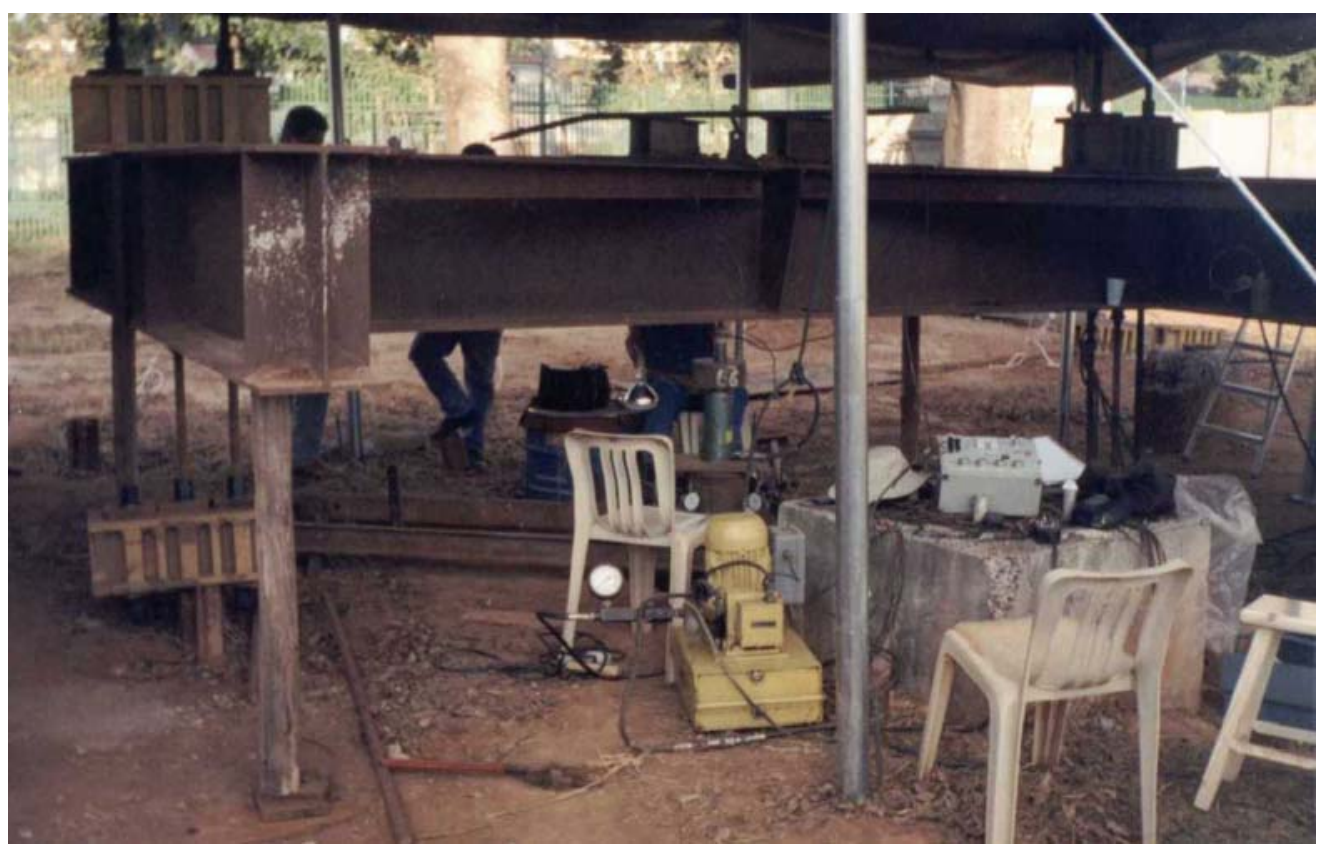


Figura 4.3 - Esquema de montagem da prova de carga para distância entre estacas de reação igual a 4,0 m.

\subsubsection{PLACAS}

Nos ensaios realizados a profundidade de $1,5 \mathrm{~m}$, utilizou-se uma placa de aço de formato circular com 0,80 m de diâmetro e espessura de $25 \mathrm{~mm}$. Para aumentar sua rigidez, no centro da parte superior foi soldada uma outra chapa circular com $25 \mathrm{~mm}$ de espessura, com 0,30 m de diâmetro, resultando uma massa total de $105 \mathrm{~kg}$.

Para as profundidades maiores, a placa utilizada era constituída por chapa de 12,7 mm de espessura, também com formato circular com 0,80 m de diâmetro. Para garantir sua rigidez, soldou-se na sua parte superior uma outra chapa de mesma espessura e de 0,60 m de diâmetro, resultando uma massa total de $79 \mathrm{~kg}$.

\subsubsection{MACACO HIDRÁULICO E BOMBA}

Para a execução das provas de carga utilizou-se um macaco hidráulico, com capacidade de aplicação de carga de até $200 \mathrm{kN}$, conectado por meio de engates rápidos a uma bomba elétrica com motor trifásico da marca Yellow Power (Figura 4.4). O acionamento da bomba elétrica para aplicação e manutenção do carregamento era realizado por um controle a distância com fio.

No início do ensaio procurou-se manter o êmbolo do macaco hidráulico recolhido ao máximo, preenchendo eventuais folgas com calços de aço, para que nenhum ensaio tivesse que ser interrompido por falta de curso do mesmo.

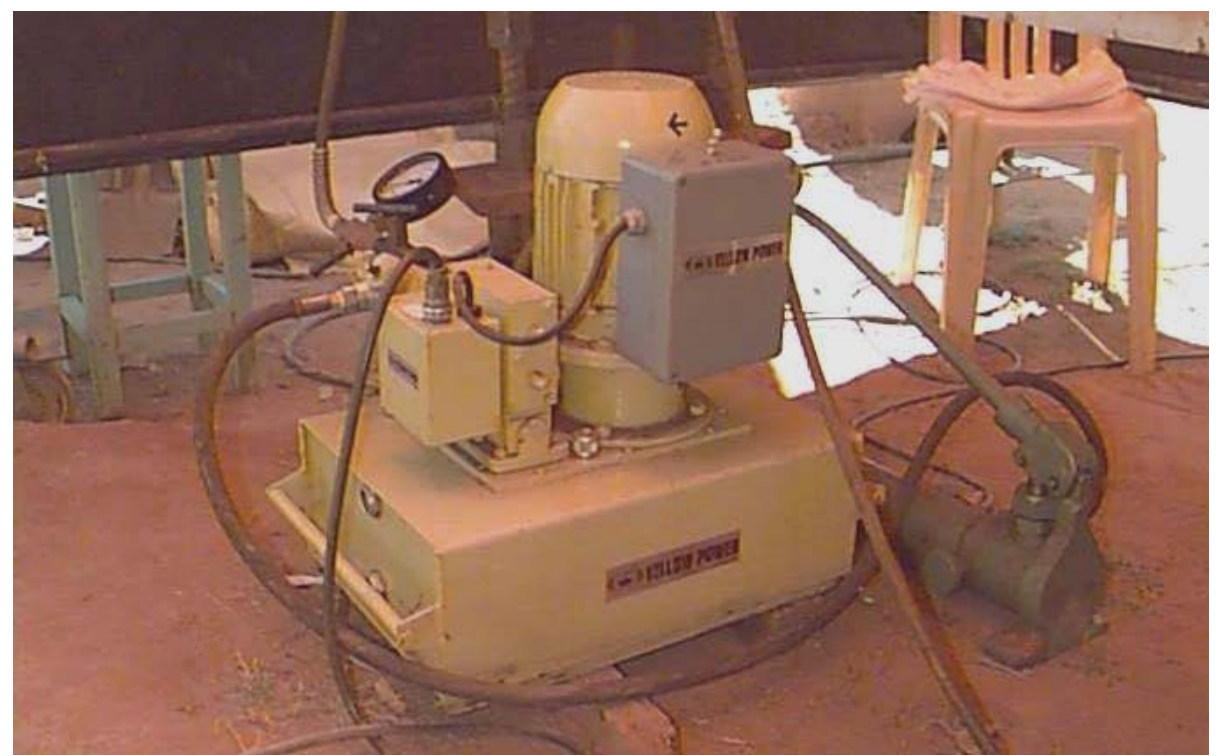

Figura 4.4 - Bomba elétrica utilizada nos ensaios de placa.

\subsubsection{CÉLULAS DE CARGA}

Foram utilizadas duas células de carga, uma com capacidade de carga de $200 \mathrm{kN}$ e outra de $500 \mathrm{kN}$, dependendo da carga máxima a ser atingida, em função da profundidade da placa e da condição do solo (inundado ou não). Antes da realização dos 
ensaios, as células de carga foram devidamente calibradas no laboratório de Mecânica da Rochas do Departamento de Geotecnia da EESC/USP.

\subsubsection{INDICADOR DE DEFORMAÇÕES}

Um indicador de deformações da marca Transdutec, modelo T832 (resolução de $1 \mu$ strain e capacidade de leitura de $\pm 50000 \mu$ strains), foi empregado para as leituras de deformações específicas dos “strain-gages” instalados na célula de carga (Figura 4.5).

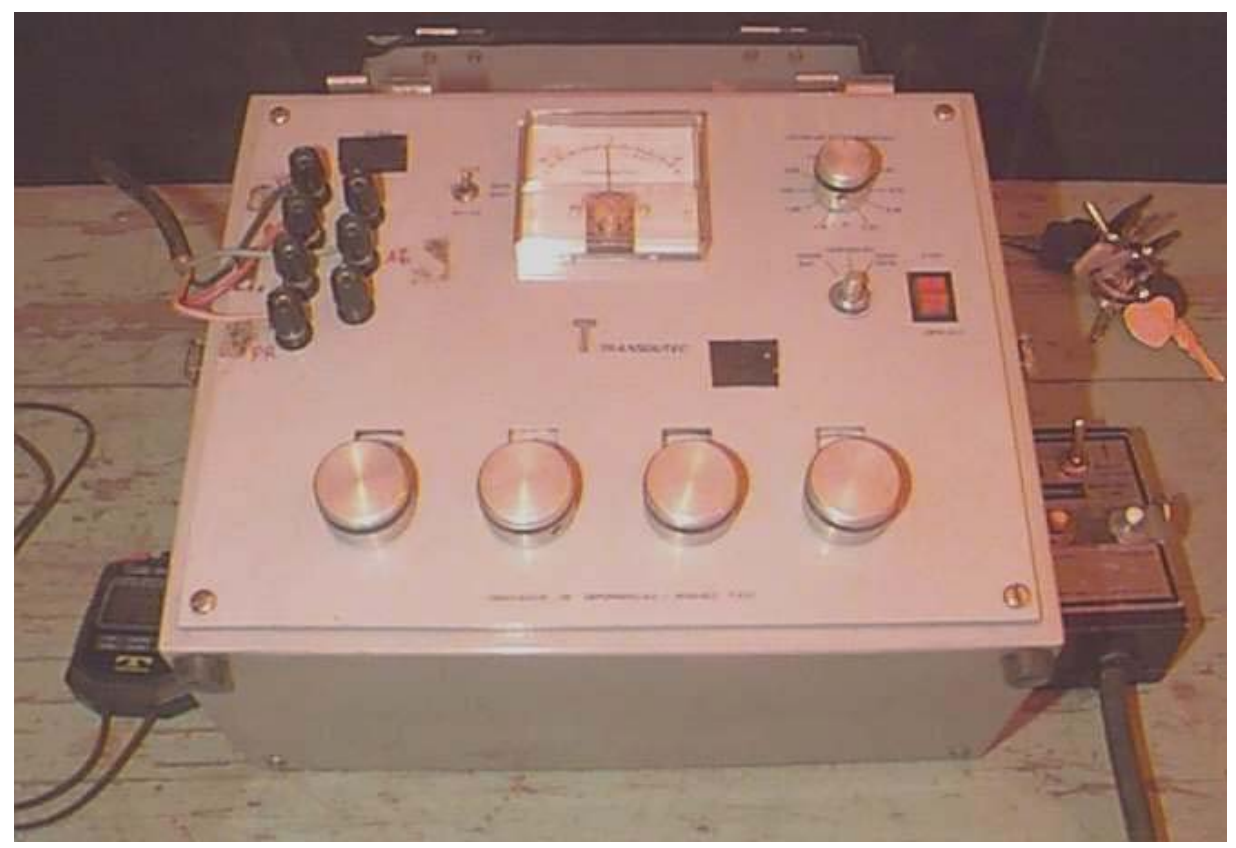

Figura 4.5 - Detalhe do indicador de deformações, cronômetro e controle da bomba elétrica.

\subsubsection{RÓTULA}

Com o objetivo de garantir a ortogonalidade do carregamento foi inserida uma rótula de aço entre a célula de carga e a viga de reação, conforme ilustrado na Figura 4.6. 


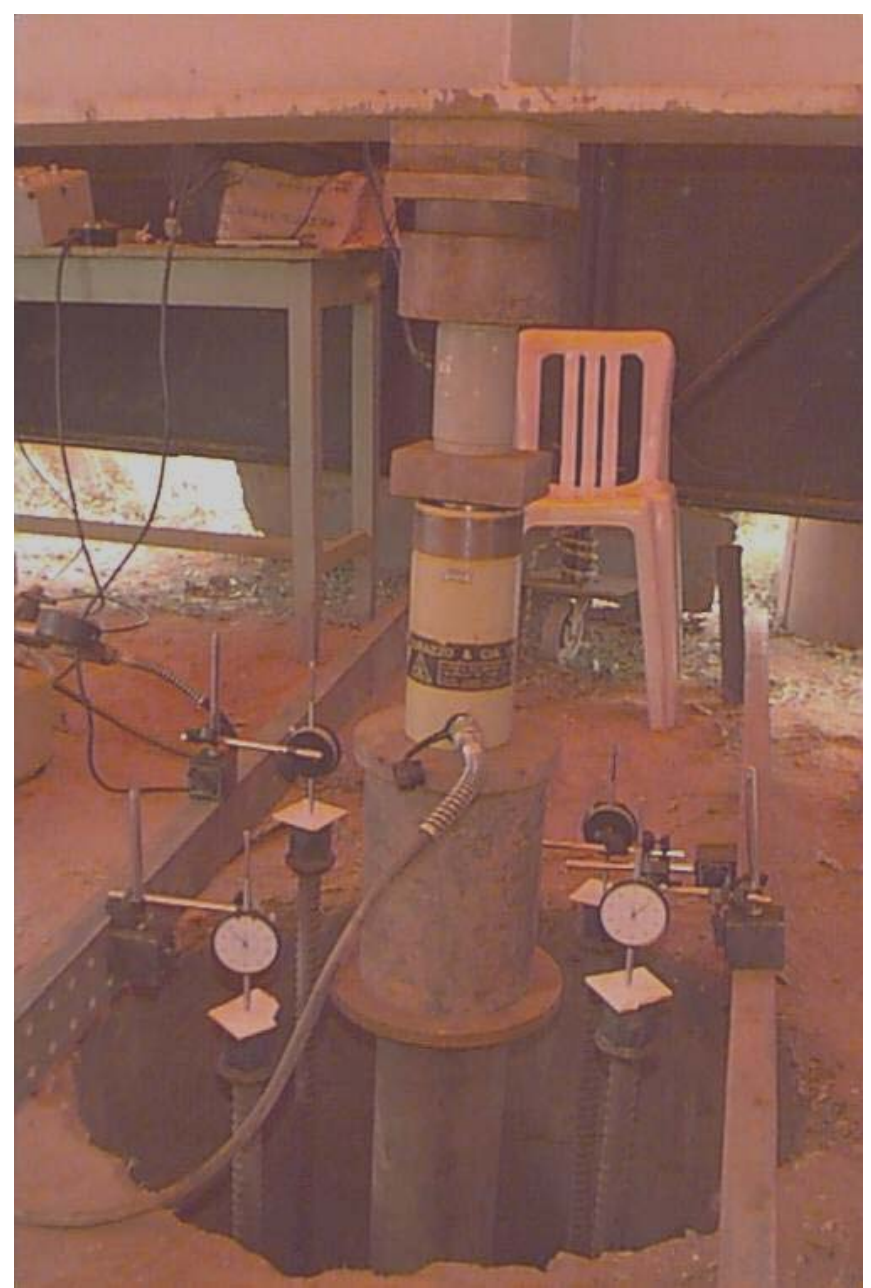

Figura 4.6 - Detalhe do macaco hidráulico, célula de carga, rótula e disposição dos extensômetros.

\subsubsection{TORRES DE TRANSFERÊNCIA DE CARGA}

A carga aplicada pelo macaco hidráulico, situado próximo à superfície do terreno, era transferida até a placa por meio de dois tipos de torre de aço, sendo que a opção de utilização dependia da profundidade do ensaio.

Para os ensaios realizados na profundidade de 1,5 m utilizou-se uma torre composta de um tubo de aço de 1,53 m de comprimento, $170 \mathrm{~mm}$ de diâmetro externo e parede com espessura de $10 \mathrm{~mm}$, com duas chapas circulares de 0,30 m de diâmetro e $25 \mathrm{~mm}$ de espessura, soldadas nas extremidades do tubo. Para um melhor manuseio desta torre, foram soldadas duas alças na metade de sua altura, conforme ilustrado na Figura 4.7. Este conjunto apresenta uma massa de aproximadamente $80 \mathrm{~kg}$. 


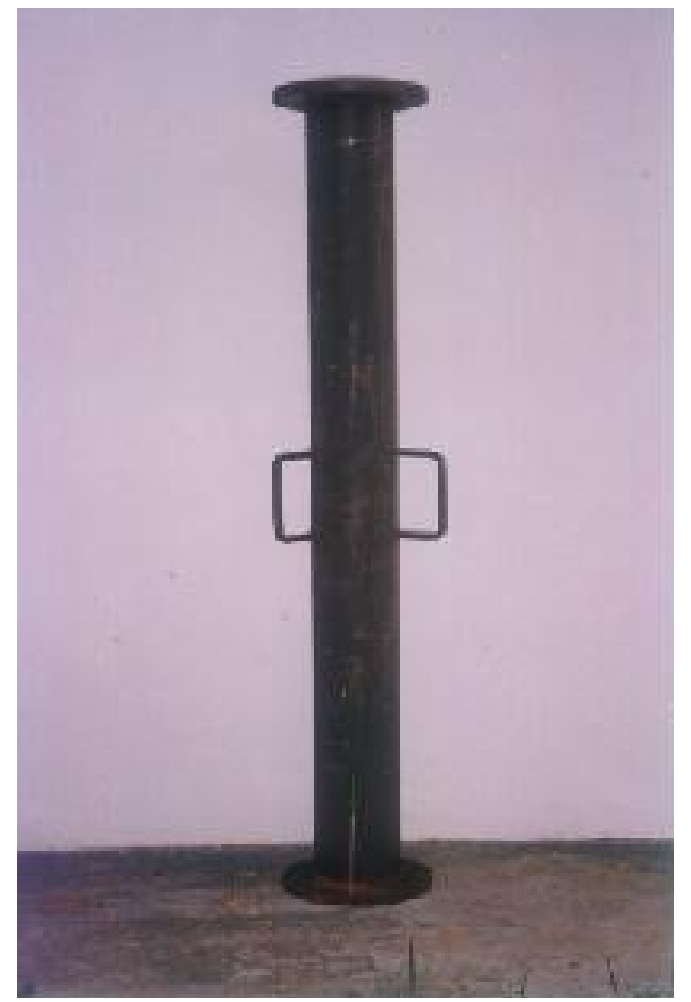

Figura 4.7 - Detalhe da torre de transferência de carga utilizada para a profundidade de $1,5 \mathrm{~m}$.

Para as profundidades maiores empregou-se uma torre metálica com seção quadrada de 280 x $280 \mathrm{~mm}$, montada em módulos de 2,0 m de comprimento. A Figura 4.9 mostra estes módulos, os quais foram construídos com perfis de 31,8 mm x 6,4 mm, para as longarinas, 25,4 $\mathrm{mm} \times 4,8 \mathrm{~mm}$, para as transversinas, resultando uma massa de $120 \mathrm{~kg}$. Quando havia a necessidade de utilização de mais de um módulo, eles eram interligados por meio de quatro parafusos de aço de 50,8 $\mathrm{mm}$ x 12,7 mm.

\subsubsection{EXTENSÔMETROS}

Em cada prova de carga foram utilizados quatro extensômetros mecânicos da marca Mitutoyo, com resolução de $0,01 \mathrm{~mm}$ e curso total de $50 \mathrm{~mm}$, para as medidas de recalque. Para sua fixação nos dispositivos de referência utilizaram-se bases magnéticas articuláveis. Posteriormente adotou-se o recalque correspondente à média aritmética dos quatro extensômetros instalados diametralmente opostos, como valor representativo do ensaio.

\subsubsection{DISPOSITIVOS DE REFERÊNCIA}

Duas vigas de aço com perfil em $\mathrm{U}$ e com 3,30 m de comprimento foram empregadas como dispositivos de referência para as medidas de recalque. As vigas eram parafusadas nas suas extremidades em pontaletes de ferro previamente cravados no solo, para que a rigidez do sistema de referência fosse garantida. Esses pontaletes ficavam distanciados no mínimo 1,5 m do centro da placa e 1,0 m do centro das estacas de 
reação, para garantir que o sistema de referência não sofresse qualquer perturbação proveniente de possíveis deformações do solo.

\subsubsection{HASTES PARA ACOMPANHAMENTO DE RECALQUE}

Para a profundidade de $1,5 \mathrm{~m}$ foram utilizadas como hastes para acompanhamento de recalque, barras de aço com rosca do tipo Dywidag de $32 \mathrm{~mm}$ de diâmetro, permitido que os extensômetros fossem instalados acima da superfície do terreno. Essas hastes eram rosqueadas em luvas de aço previamente soldadas na placa e na sua extremidade superior colocou-se um azulejo, fixado em uma porca, para apoio dos extensômetros, conforme ilustrado na Figura 4.8.

Para profundidades maiores, utilizaram-se hastes de alumínio de $25 \mathrm{~mm}$ de diâmetro, as quais moviam-se livremente no sentido vertical dentro de alças metálicas com diâmetro ligeiramente superior, de modo a acompanhar o recalque da placa e eliminar a influência de uma possível deformação da torre de transferência de carga. Na parte inferior destas hastes foi soldada uma pequena barra de aço pontiaguda para diminuir sua superfície de contato com a placa, ficando neste caso simplesmente apoiadas. Os extensômetros eram apoiados em uma fina chapa metálica solidarizada na extremidade superior, conforme pode ser visualizado na Figura 4.9.

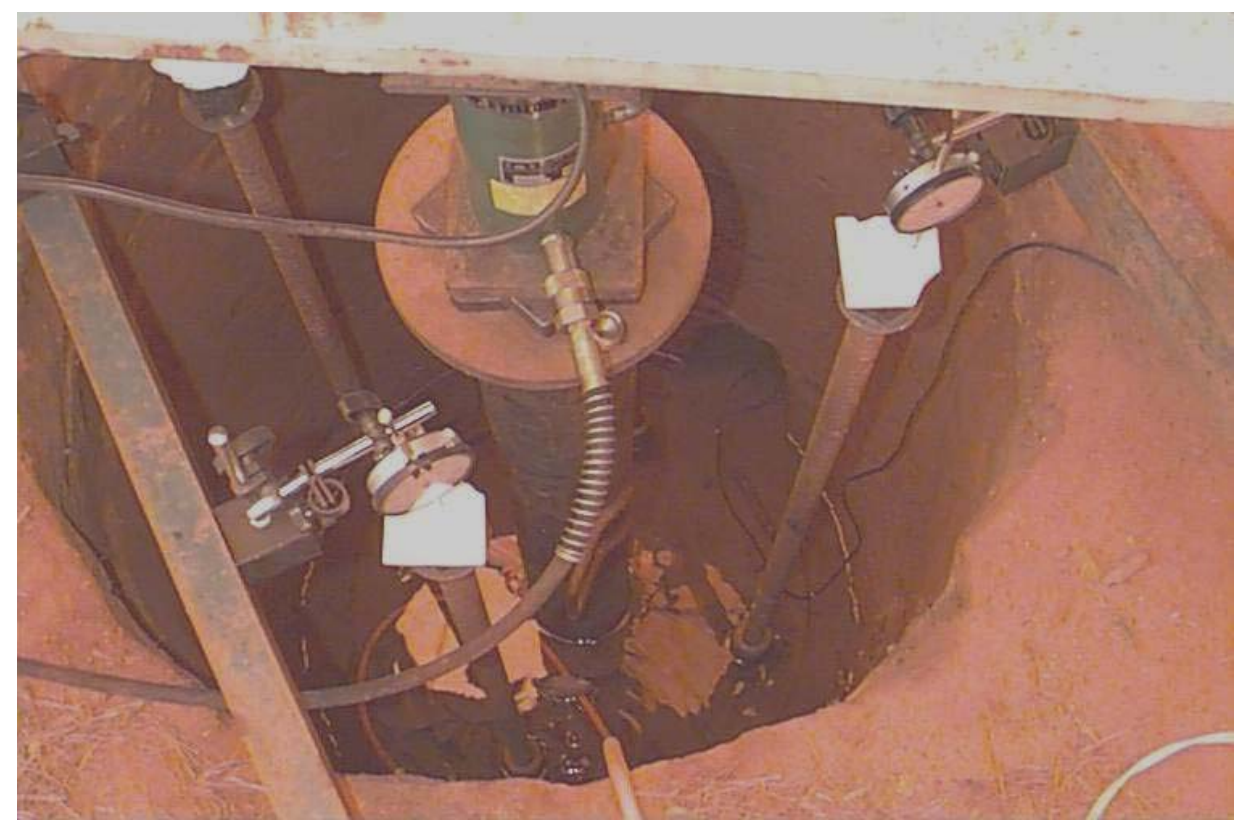

Figura 4.8 - Hastes para acompanhamento de recalque e torre de transferência de carga para ensaios na profundidade de $1,5 \mathrm{~m}$. 


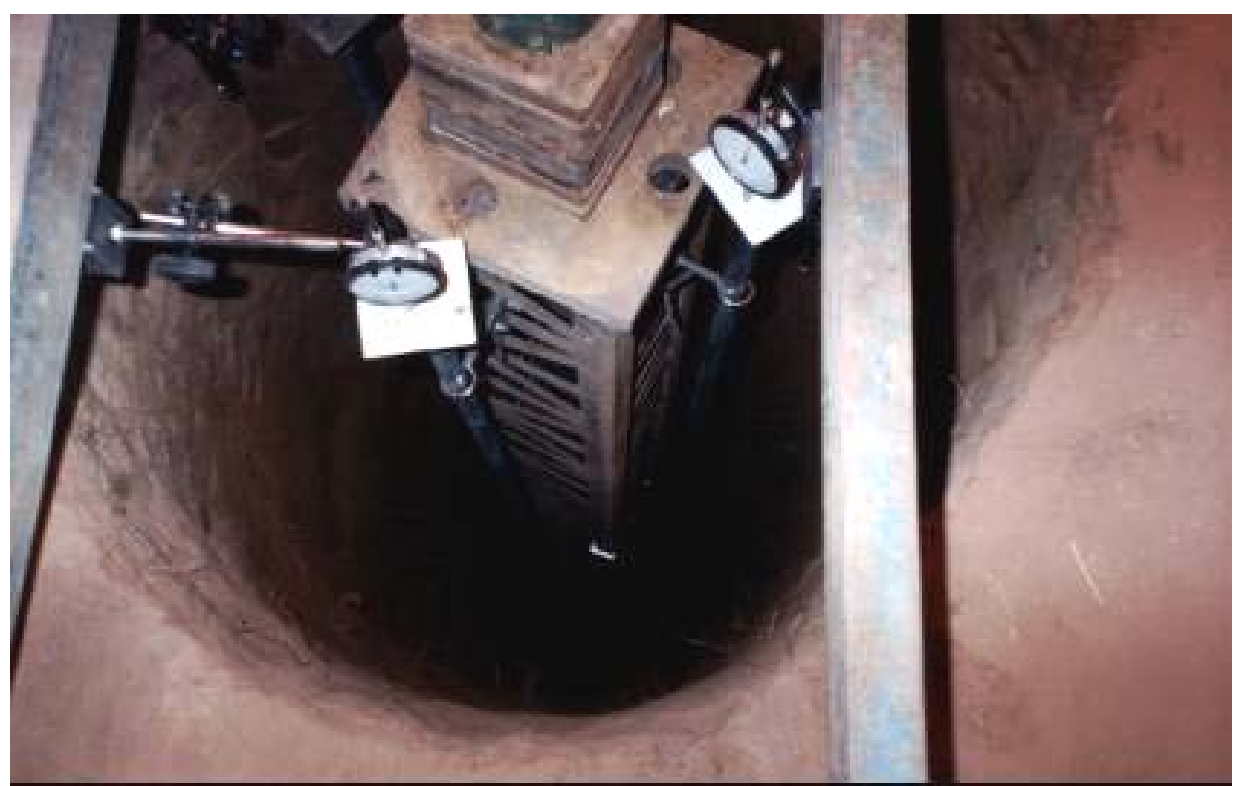

Figura 4.9 - Hastes para acompanhamento de recalque e torre de transferência de carga para ensaios nas profundidades de 4,0 e 6,0 m.

\subsubsection{TENSIÔMETROS}

Foram empregados tensiômetros com diâmetro externo de 20 mm, da marca Soil Moisture, os quais possuem como elemento de medida da pressão negativa da água, vacuômetro do tipo Bourdon. Os tensiômetros também eram providos de um reservatório, na sua parte superior, utilizado para complementação do nível de água dentro do tubo e para auxiliar na retirada de bolhas de ar que se apresentassem no sistema (Figura 4.10). A cápsula porosa de alta resistência à entrada de ar possui um coeficiente de permeabilidade aproximadamente igual a $10^{-5} \mathrm{~cm} / \mathrm{s}$. 


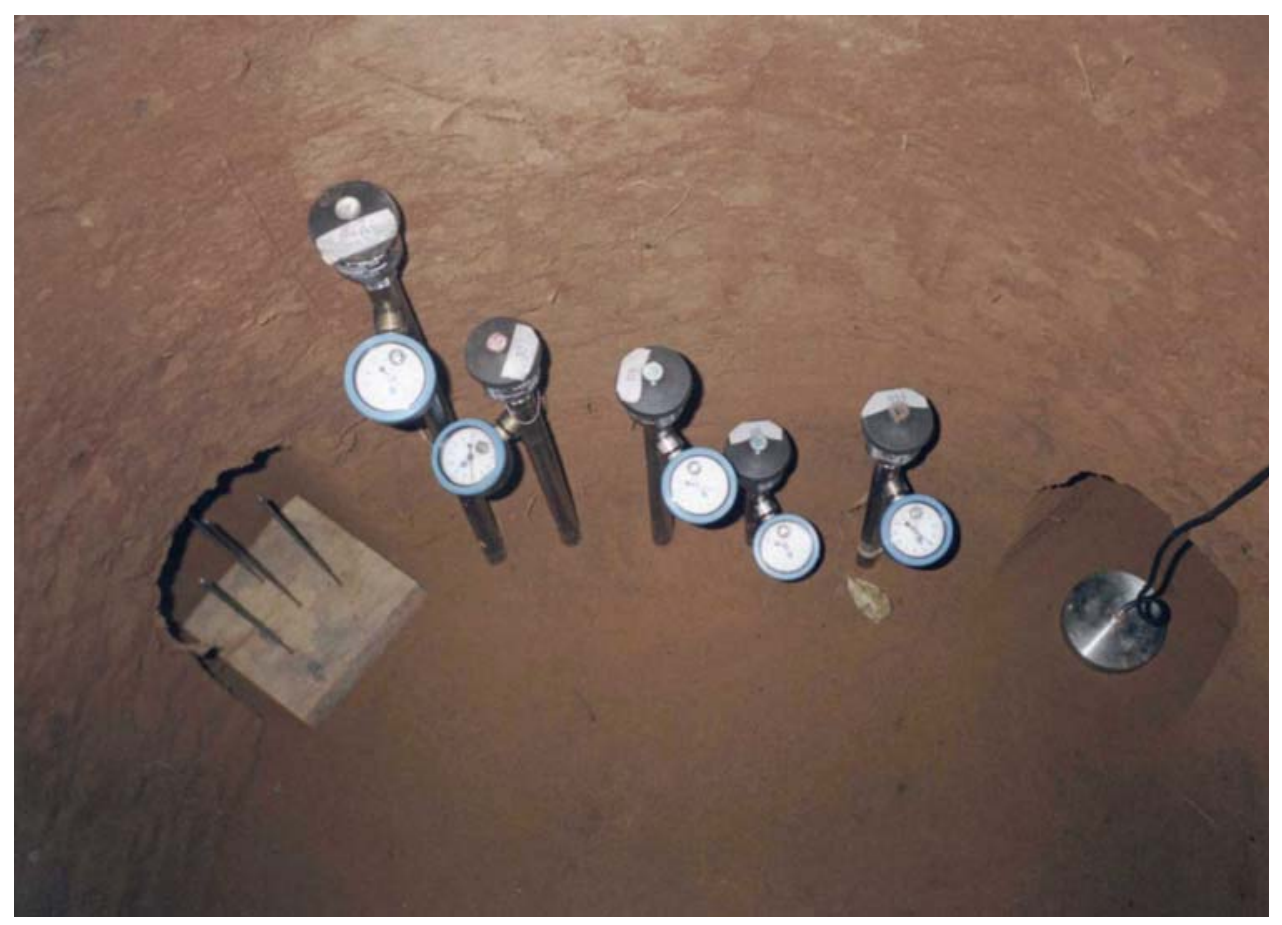

Figura 4.10 - Tensiômetros instalados no fundo da cava.

\subsubsection{BARRACA DE PROTEÇÃO}

Para proteção do local de realização dos ensaios contra as intempéries, foi utilizada uma barraca construída em painéis de 2,2 x 2,2 m, com estrutura formada por tubos de ferro galvanizado, fechamento lateral em compensados de madeira e cobertura de lona.

\subsubsection{PÓRTICO METÁLICO}

A colocação e retirada da placa e da torre de transferência de carga nas cavas eram realizadas utilizando-se um sistema de roldanas, deslizante em pórtico metálico sobre rodas (Figura 4.11). 


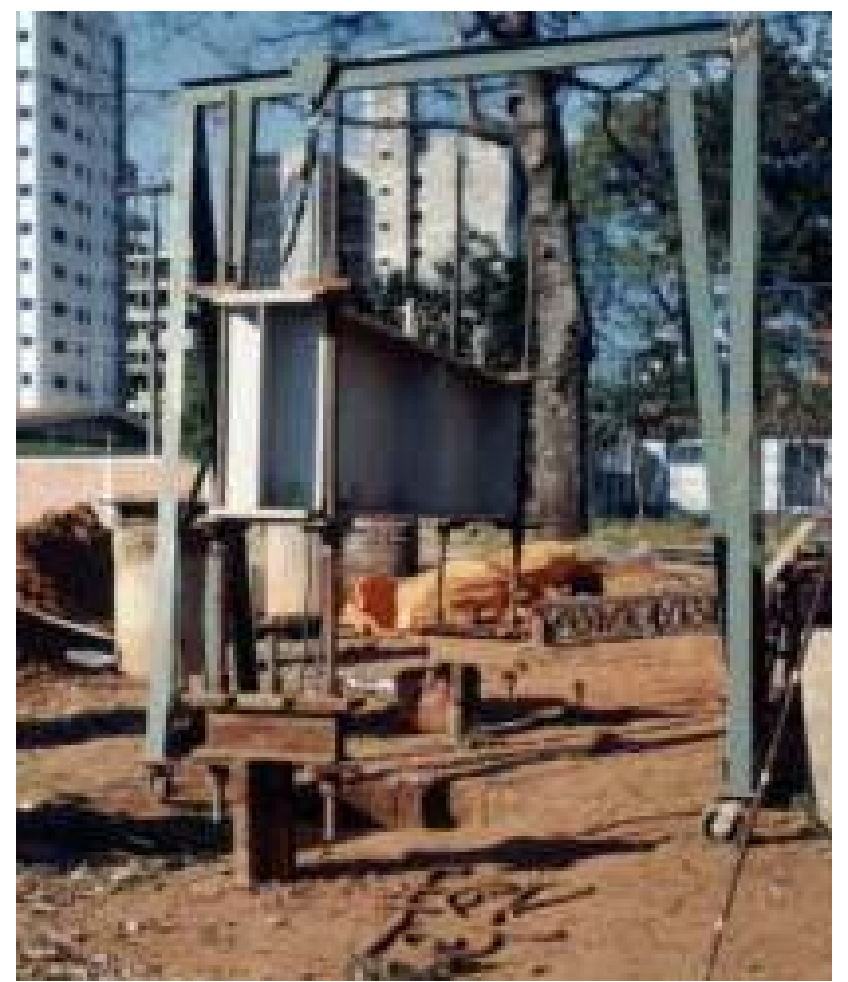

Figura 4.11 - Detalhe do pórtico utilizado para serviços diversos.

\section{APRESENTAÇÃO DOS RESULTADOS}

\subsection{MEDIDAS DE SUCÇÃO NOS ENSAIOS DE PLACA}

Antes do início de cada ensaio não inundado, realizava-se a leitura dos tensiômetros instalados ao redor da placa. Os valores de sucção matricial obtidos estão apresentados na Tabela 5.1. Nos ensaios realizados à profundidade de 1,5 m, devido a maior facilidade de leituras, observou-se que a sucção matricial praticamente não se alterou durante a realização dos mesmos.

Para as análises posteriores, convencionou-se como representativa de cada ensaio não inundado a sucção média determinada pelos tensiômetros até a profundidade 
igual ao diâmetro da placa. Nas provas de carga com inundação, a sucção foi considerada igual a zero.

Tabela 5.1 - Medidas da sucção matricial nas provas de carga não inundadas, diâmetro de $0,8 \mathrm{~m}$

\begin{tabular}{|c|c|c|c|c|c|c|}
\hline \multirow{2}{*}{ Ensaio } & \multirow{2}{*}{$\begin{array}{l}\text { Piof do } \\
\text { elsailo } \\
\text { (in) }\end{array}$} & \multicolumn{4}{|c|}{ Profundidade daxo daplaca (m) } & \multirow{2}{*}{$\begin{array}{l}\text { Sucfäo } \\
\text { média } \\
(\mathrm{kPa})\end{array}$} \\
\hline & & $0,10 \mathrm{~m}$ & $0,70 \mathrm{~m}$ & $0,60 \mathrm{~m}$ & $0,00 \mathrm{~m}$ & \\
\hline S1 & 1,5 & 13 & (1) & 11 & 9 & 10 \\
\hline$\$ 2$ & 1,5 & 35 & 30 & 31 & 29 & 31 \\
\hline Q1 & 1,5 & 24 & 14 & 12 & 9 & 15 \\
\hline$Q 2$ & 1,5 & 42 & 22 & 15 & 11 & 22 \\
\hline 03 & 1,5 & 38 & 34 & 27 & - & 33 \\
\hline M1 & 1,5 & 34 & 33 & 21 & 25 & 28 \\
\hline 04 & 4,0 & 20 & 16 & 18 & - & 18 \\
\hline 05 & 40 & 30 & 32 & 25 & 25 & 28 \\
\hline 06 & 8,0 & 12 & 12 & 12 & 11 & 12 \\
\hline 07 & 6,0 & 16 & 18 & 15 & 13 & 15 \\
\hline
\end{tabular}

\subsection{CURVAS TENSÃO-RECALQUE}

Nas Figuras 5.1 a 5.15, apresentam-se os resultados das curvas tensãorecalque obtidas nos ensaios realizados com placa de $0,8 \mathrm{~m}$ nas profundidades de 1,5 , 4,0 e 6,0 m. No Apêndice A, encontram-se as respectivas planilhas de ensaio com os recalques medidos ao longo do tempo em cada estágio de carregamento.

Observa-se nas curvas tensão-recalque dos ensaios mistos (Figuras 5.8 e 5.9) a ocorrência de um comportamento particular na transição do carregamento do tipo lento para o rápido. Nos ensaios em que o acréscimo de carga na fase rápida corresponde à metade do incremento na fase lenta, os recalques são praticamente desprezíveis no primeiro estágio rápido causando uma descontinuidade na curva. A partir do segundo estágio da fase rápida, a deformação volta a ocorrer mais acentuadamente. 
As Figuras 5.16 a 5.24 mostram as curvas tensão-recalque obtidas nas provas de carga em placa com diâmetro de 0,2, 0,4 e 1,5 m na profundidade de 1,5 m.

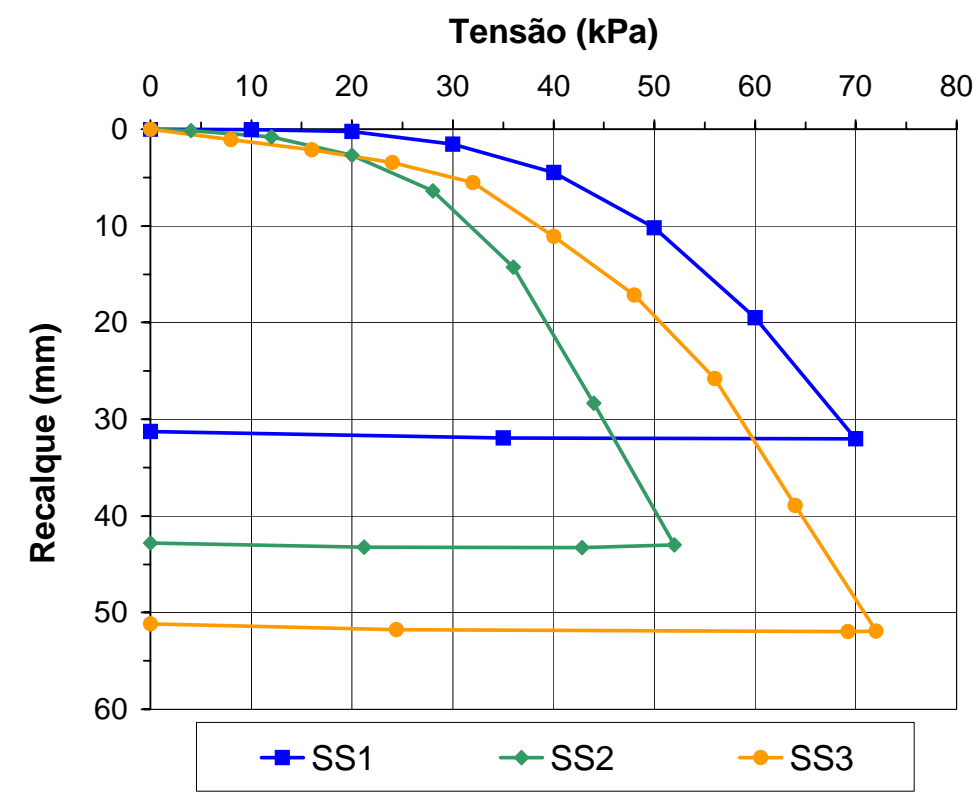

Figura 5.1 - Curvas tensão-recalque dos ensaios lentos inundados (sucção $=0 \mathrm{kPa}$ ), profundidade de $1,5 \mathrm{~m}$.

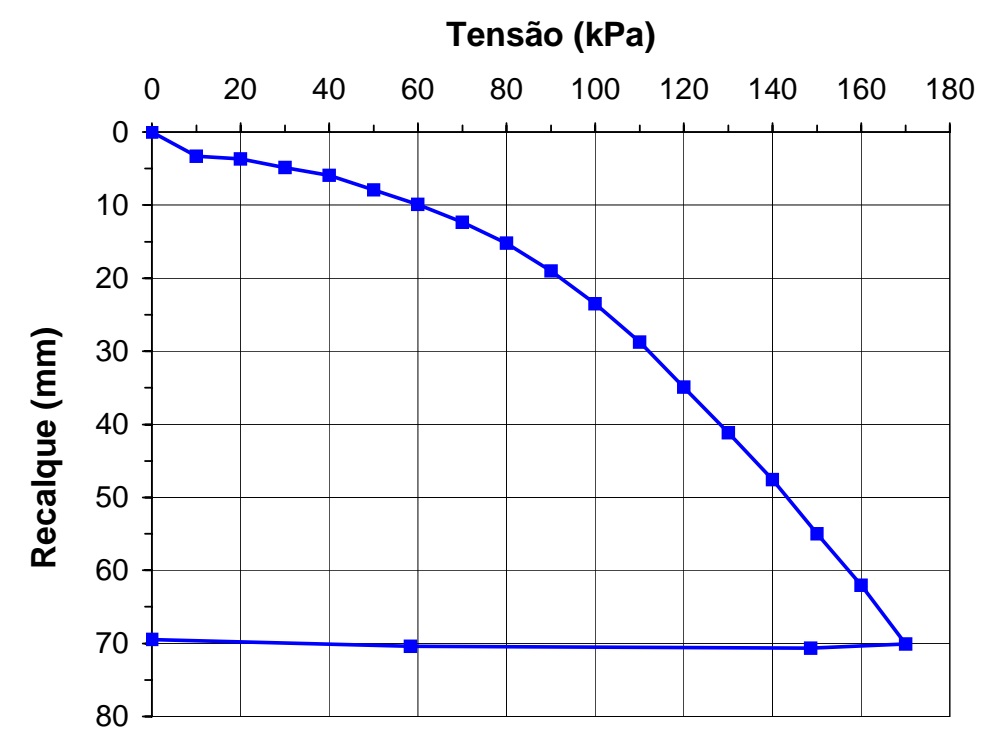

Figura 5.2 - Curva tensão-recalque do ensaio lento S1 (sucção = $10 \mathrm{kPa}$ ), profundidade de $1,5 \mathrm{~m}$. 


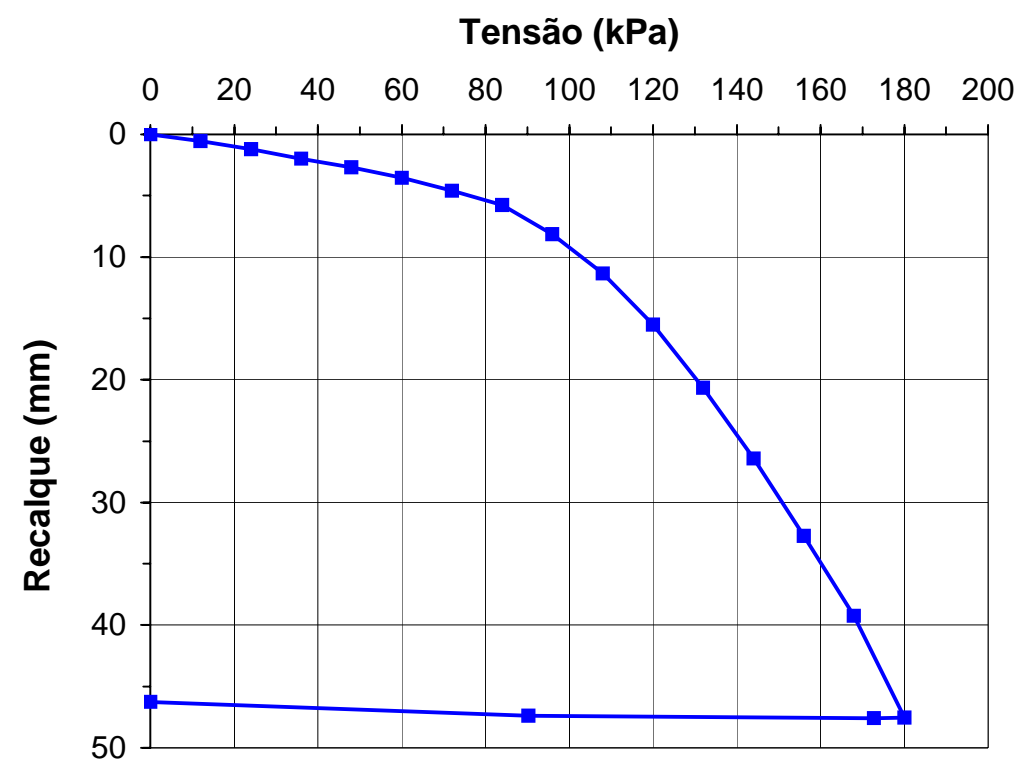

Figura 5.3 - Curva tensão-recalque do ensaio lento S2 (sucção = $31 \mathrm{kPa}$ ), profundidade de $1,5 \mathrm{~m}$.

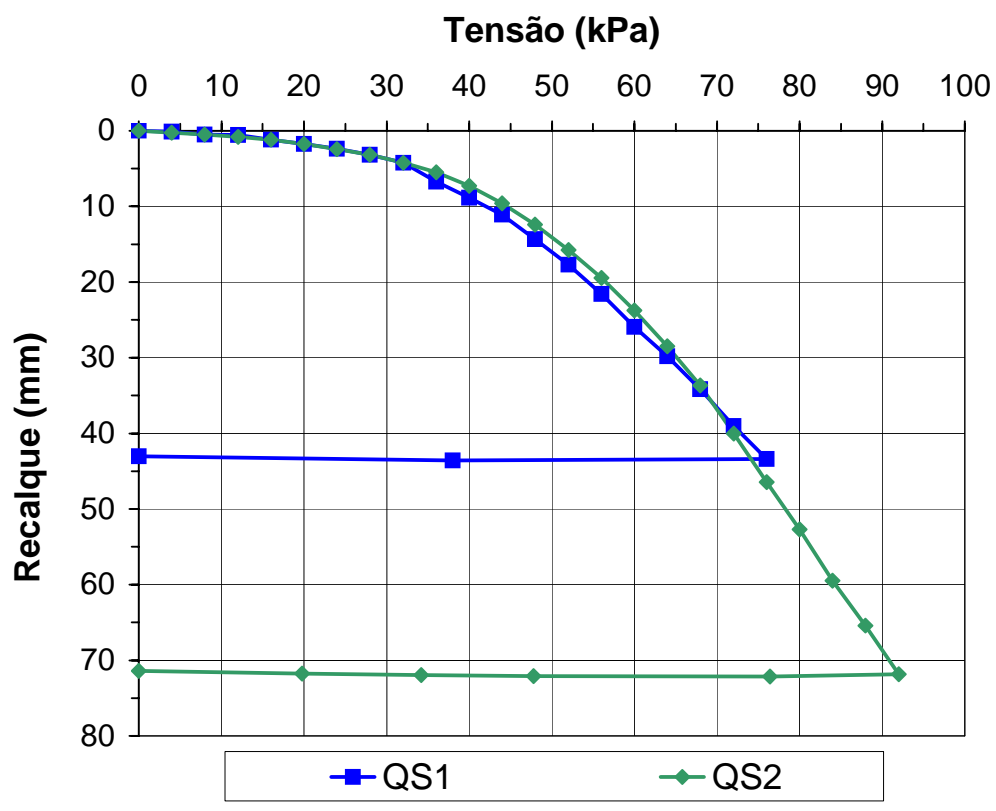

Figura 5.4 - Curvas tensão-recalque dos ensaios rápidos inundados (sucção = 0 kPa), profundidade de $1,5 \mathrm{~m}$. 


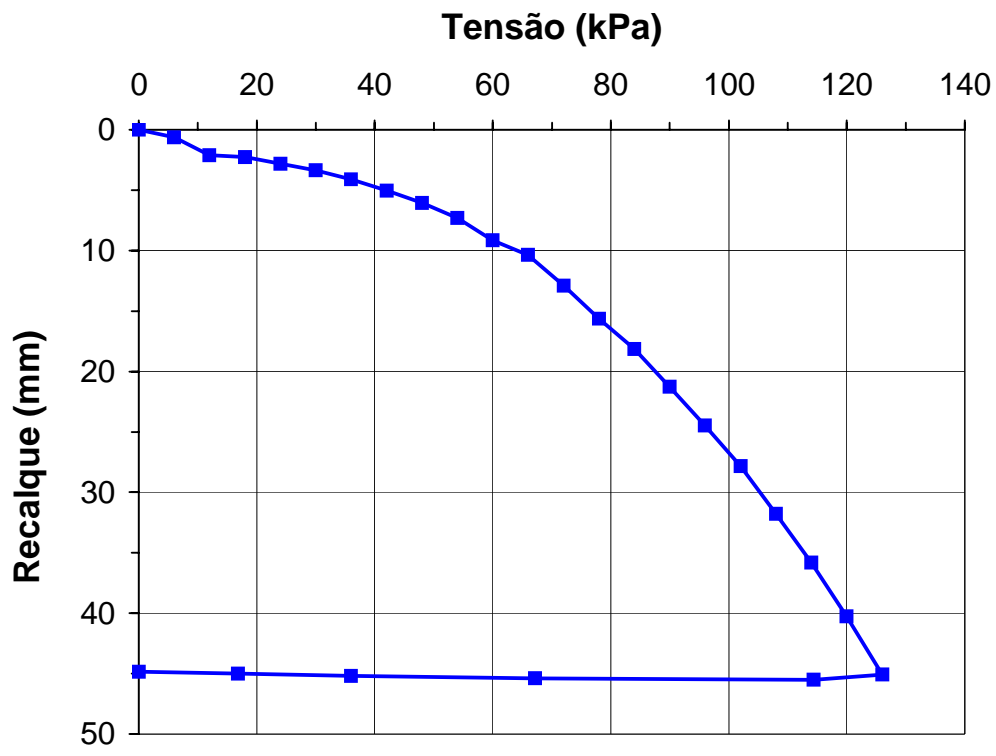

Figura 5.5 - Curva tensão-recalque do ensaio rápido Q1 (sucção = 15 kPa), profundidade de $1,5 \mathrm{~m}$.

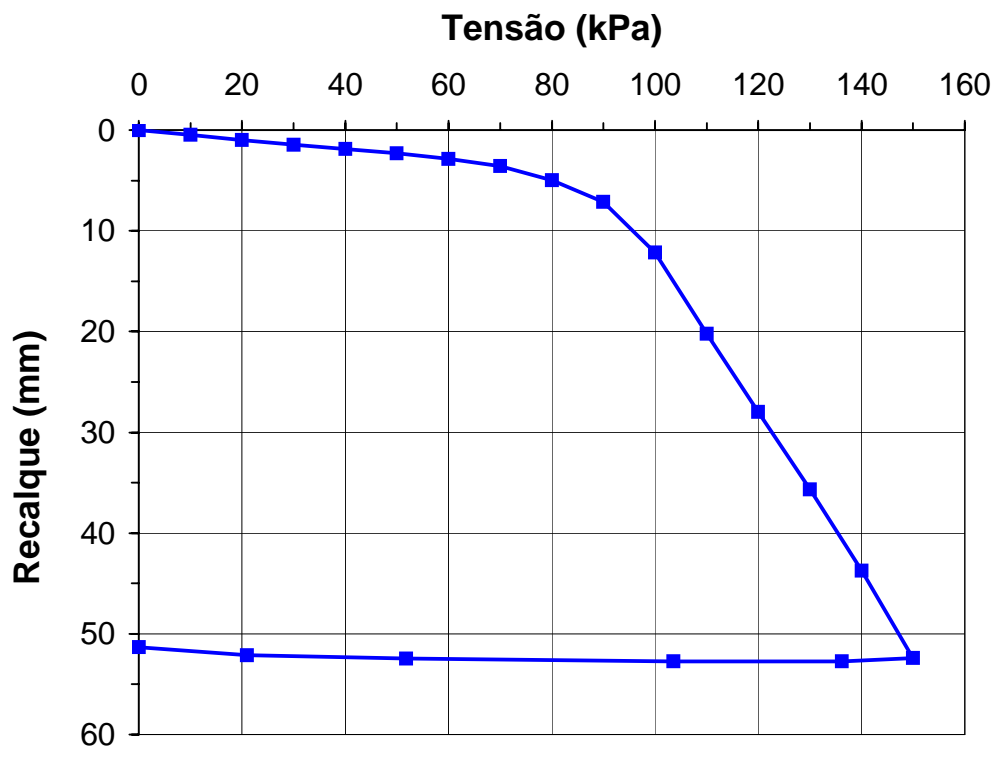

Figura 5.6 - Curva tensão-recalque do ensaio rápido Q2 (sucção = 22 kPa), profundidade de $1,5 \mathrm{~m}$. 


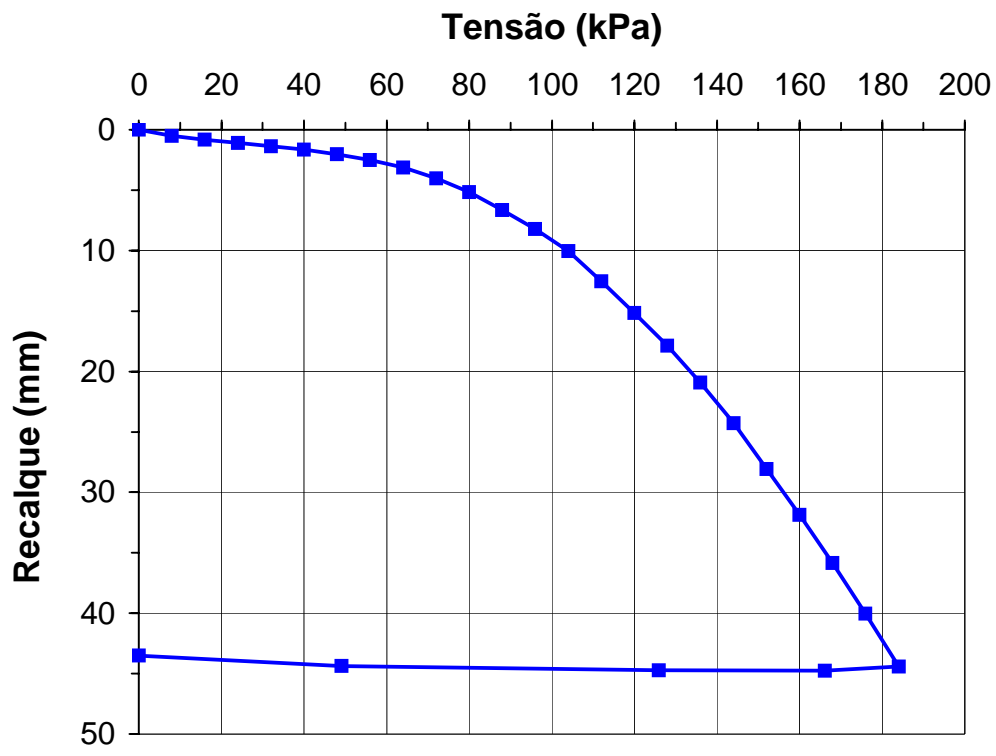

Figura 5.7 - Curva tensão-recalque do ensaio rápido Q3 (sucção = 33 kPa), profundidade de $1,5 \mathrm{~m}$.

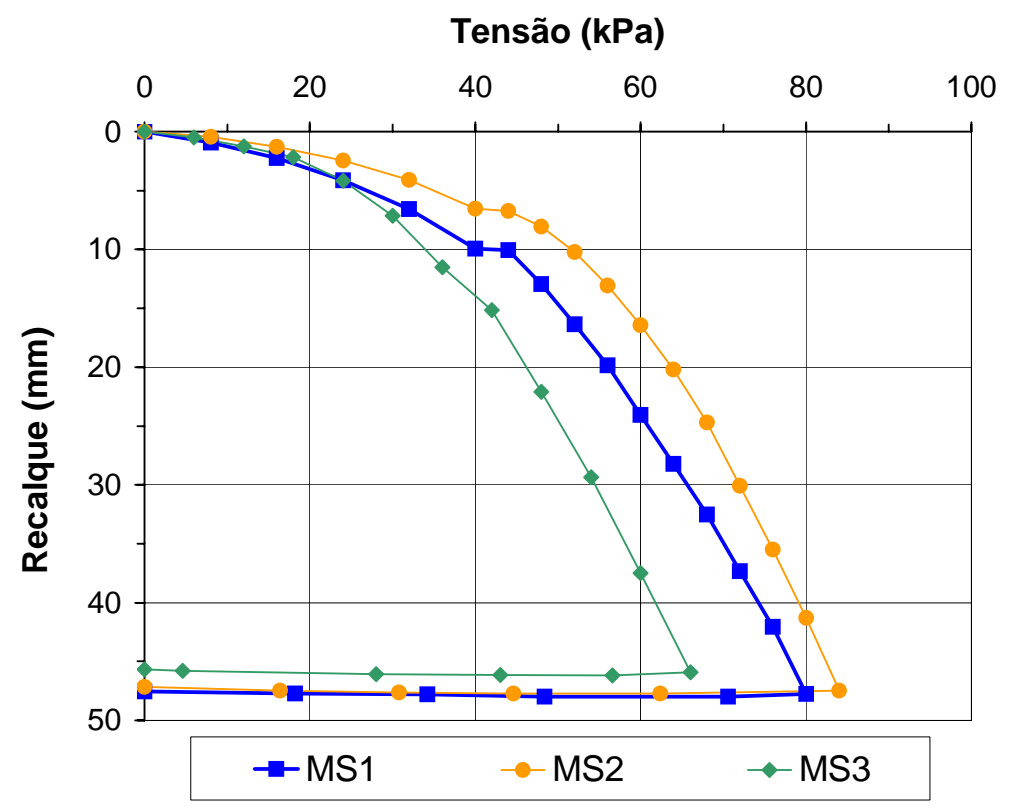

Figura 5.8 - Curvas tensão-recalque dos ensaios mistos inundados (sucção = 0 kPa), profundidade de $1,5 \mathrm{~m}$. 


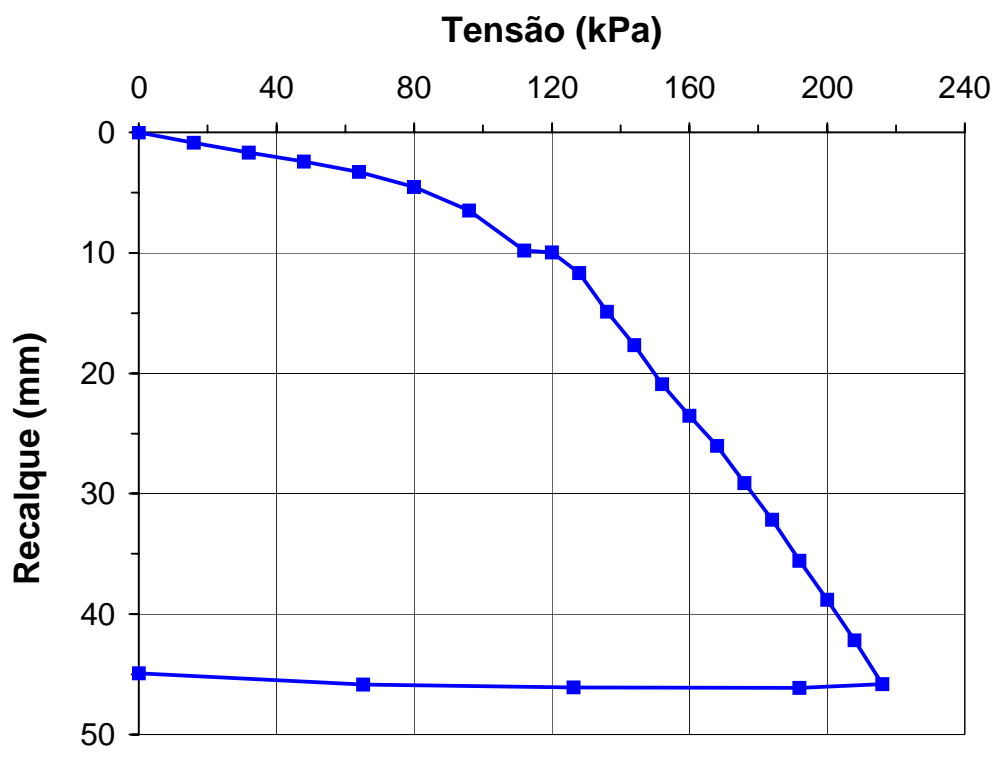

Figura 5.9 - Curva tensão-recalque do ensaio misto M1 (sucção = $28 \mathrm{kPa}$ ), profundidade de $1,5 \mathrm{~m}$.

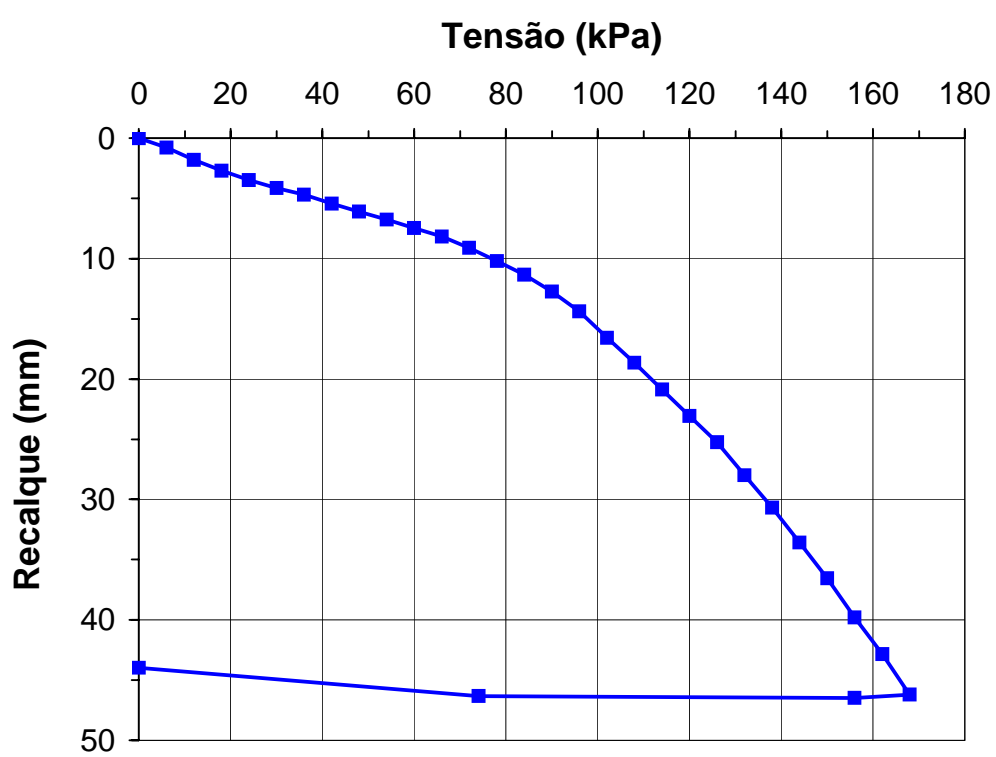

Figura 5.10 - Curva tensão-recalque do ensaio rápido inundado QS3 (sucção = $0 \mathrm{kPa}$ ), profundidade de 4,0m. 


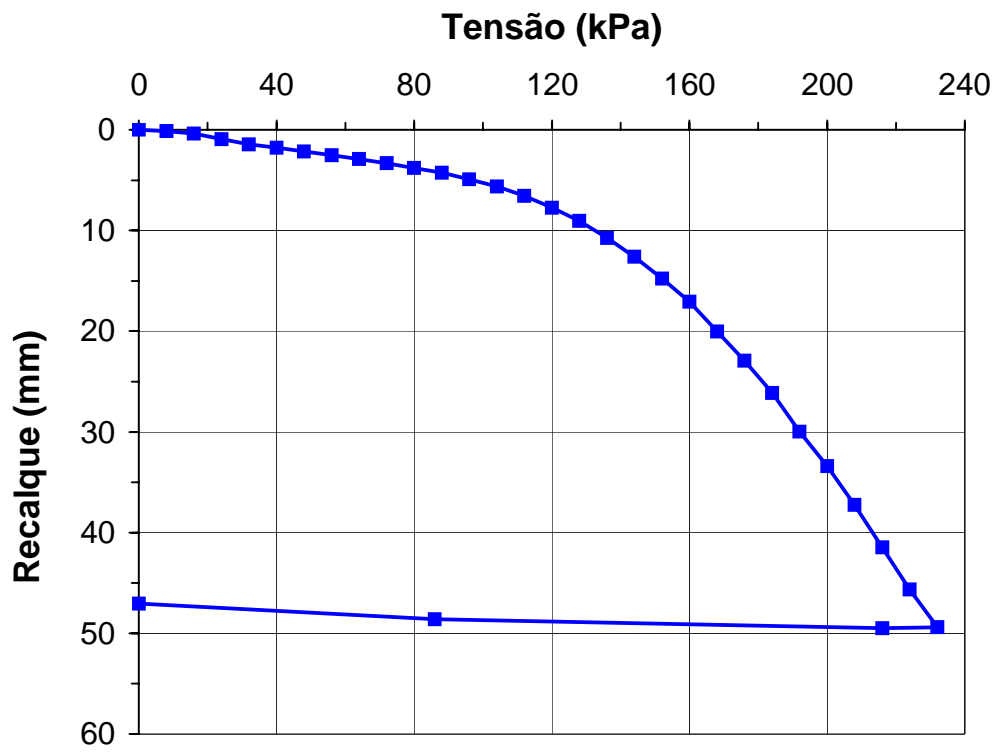

Figura 5.11 - Curva tensão-recalque do ensaio rápido Q4 (sucção = 18 kPa), profundidade de $4,0 \mathrm{~m}$.

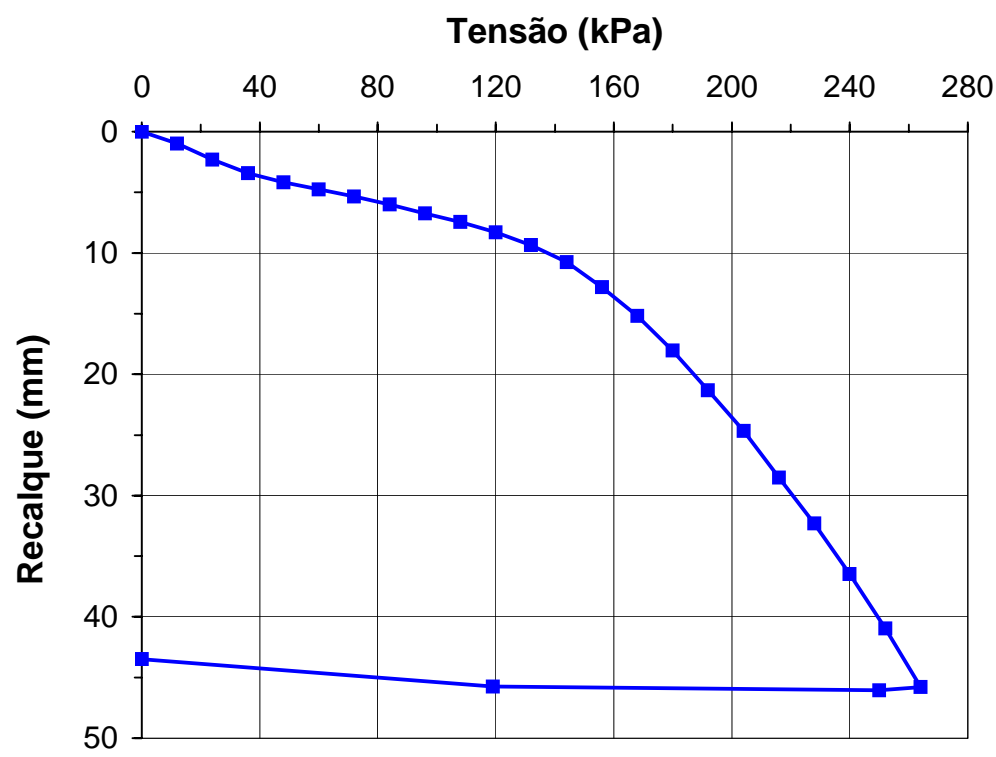

Figura 5.12 - Curva tensão-recalque do ensaio rápido Q5 (sucção = 28 kPa), profundidade de $4,0 \mathrm{~m}$. 


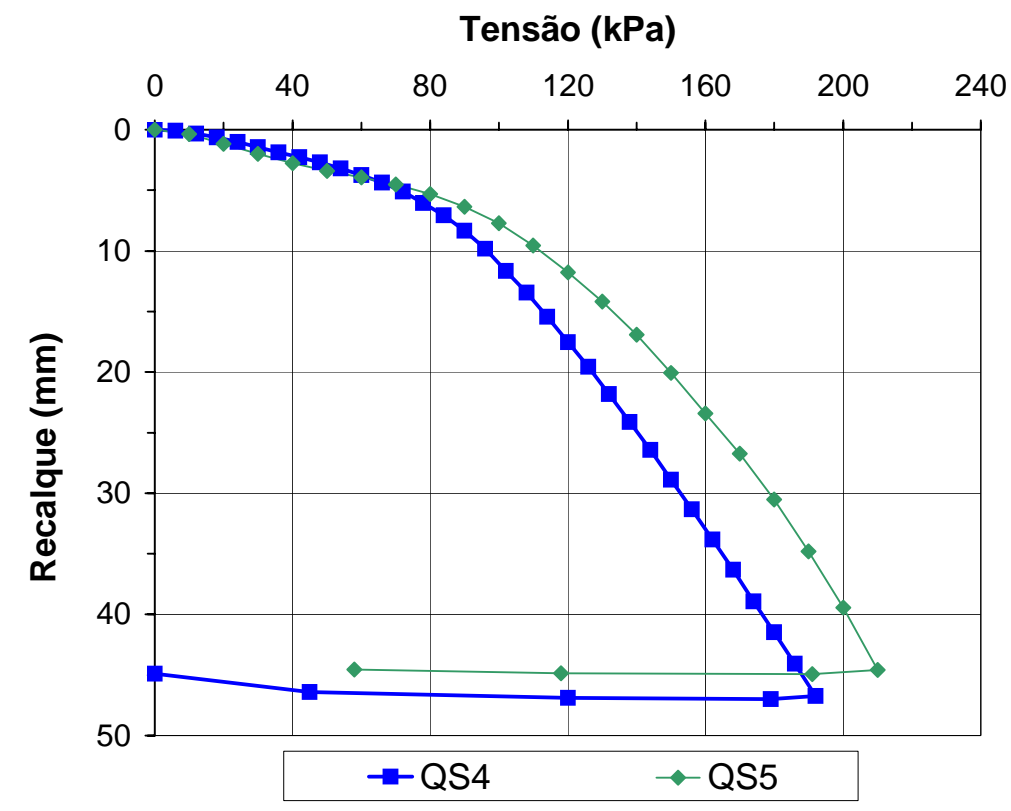

Figura 5.13 - Curvas tensão-recalque dos ensaios rápidos inundados (sucção = 0 Pa), profundidade de 6,0 $\mathrm{m}$.

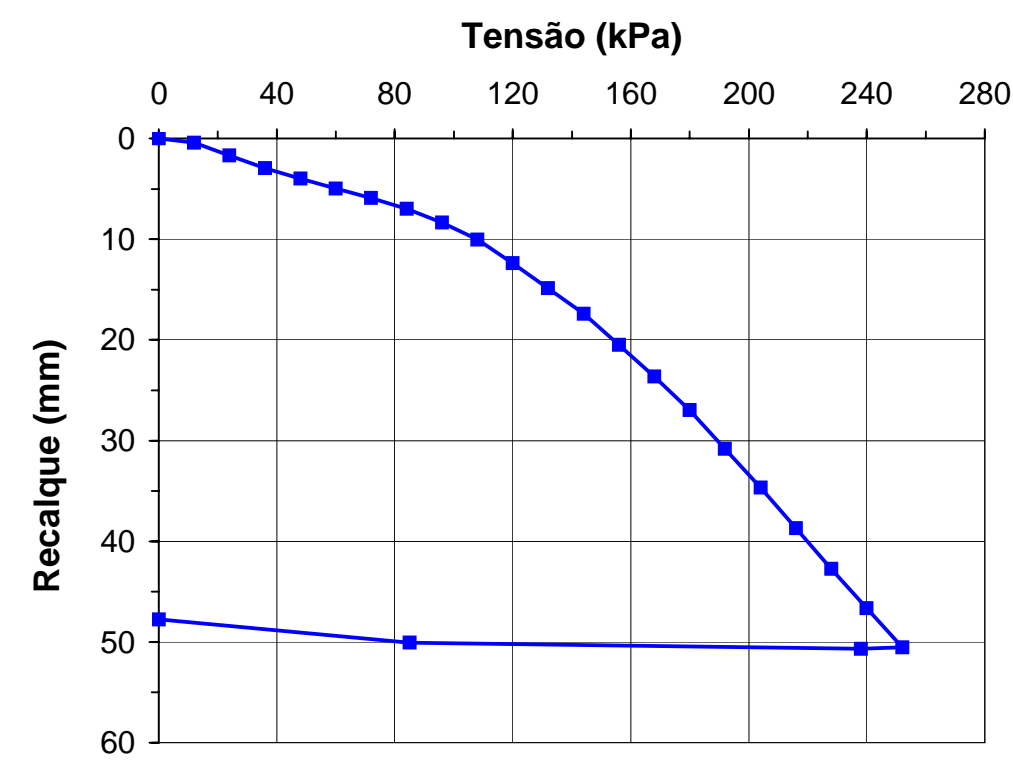

Figura 5.14 - Curva tensão-recalque do ensaio rápido Q6 (sucção = 12 kPa), profundidade de $6,0 \mathrm{~m}$. 


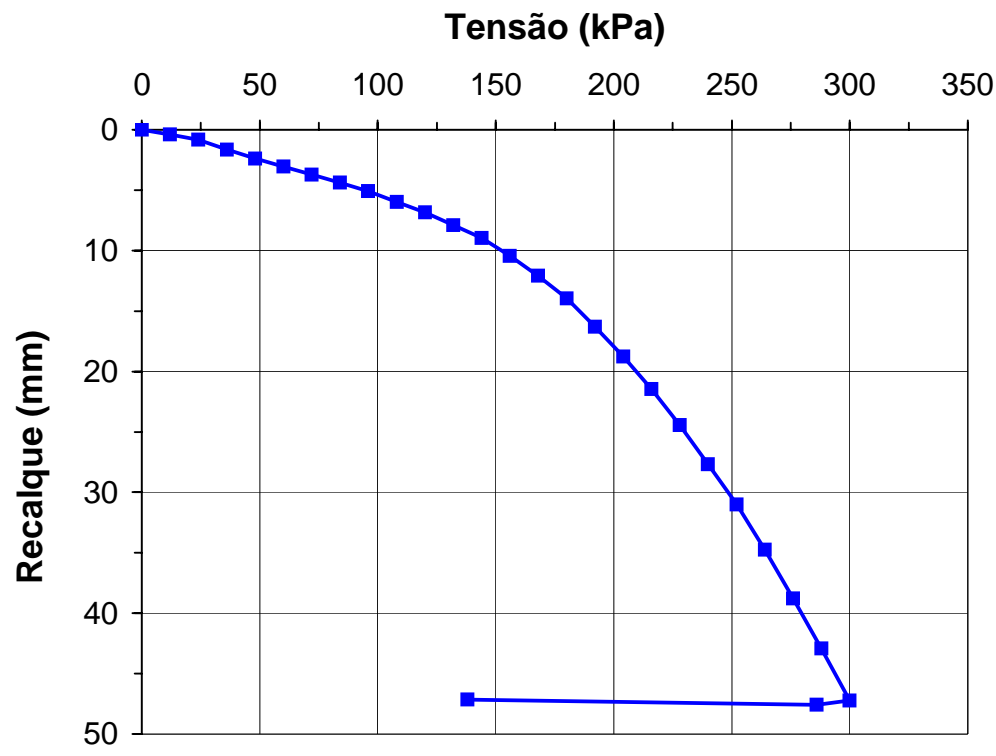

Figura 5.15 - Curva tensão-recalque do ensaio rápido Q7 (sucção = 15 kPa), profundidade de $6,0 \mathrm{~m}$.

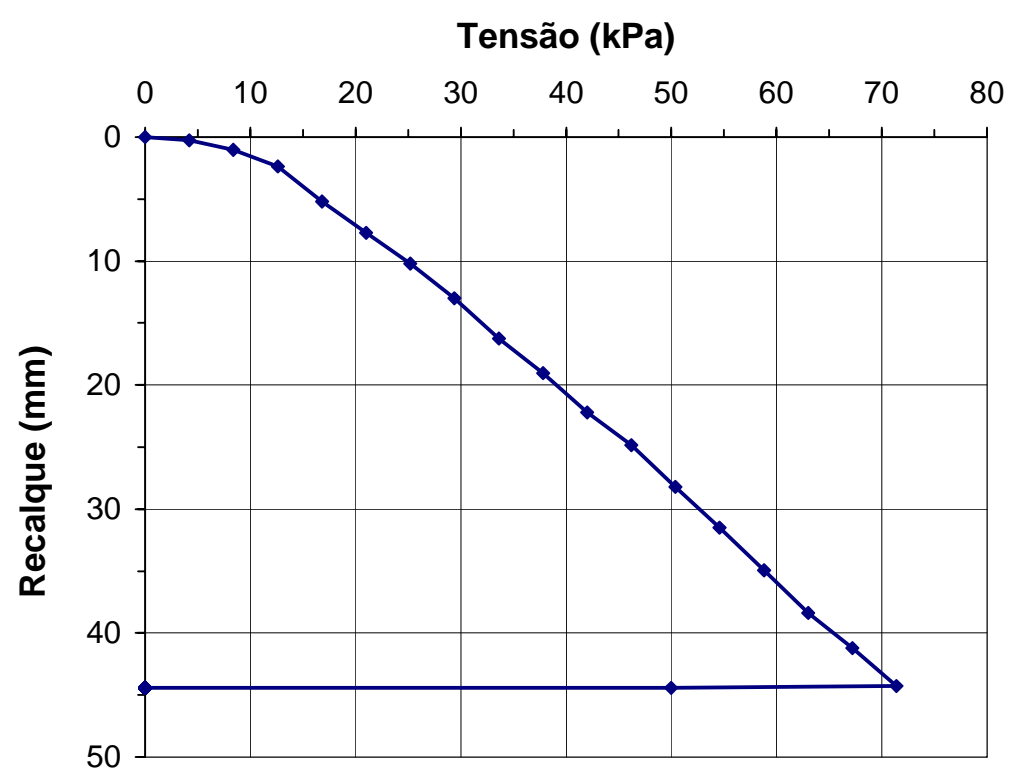

Figura 5.16 - Curva tensão-recalque do ensaio rápido inundado QS6 ( $\operatorname{sucção~}=0 \mathrm{kPa}$ ), diâmetro de 0,2 m e profundidade de $1,5 \mathrm{~m}$. 


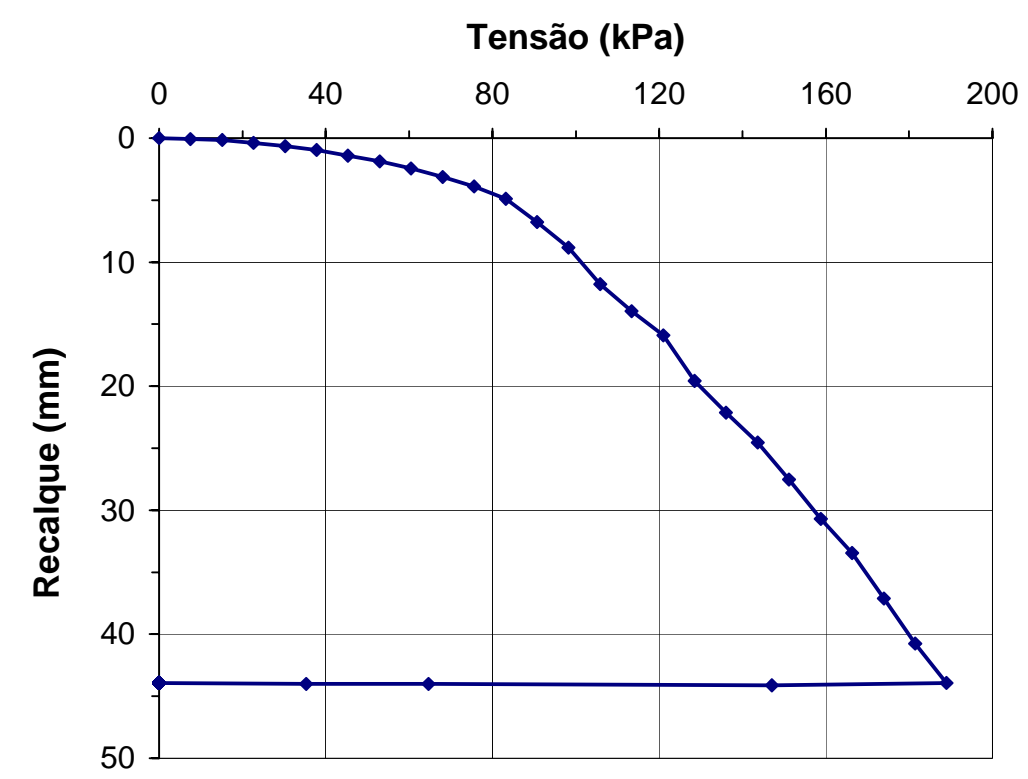

Figura 5.17 - Curva tensão-recalque do ensaio rápido Q8 (sucção = 15 kPa), diâmetro de $0,2 \mathrm{~m}$ e profundidade de $1,5 \mathrm{~m}$.

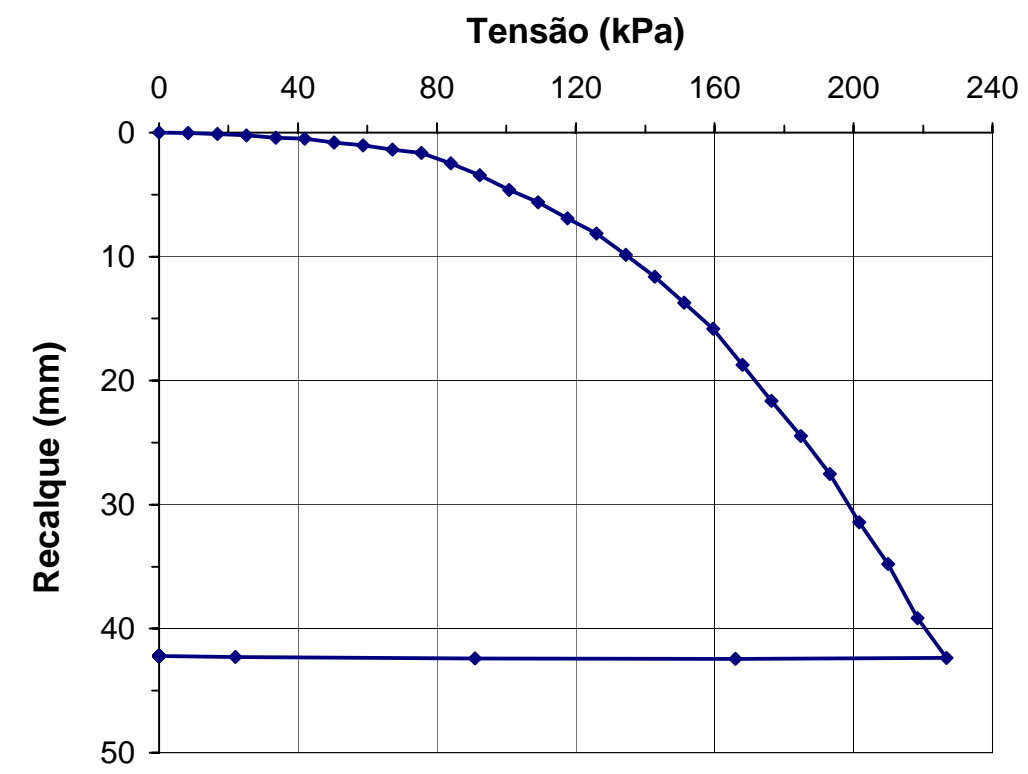

Figura 5.18 - Curva tensão-recalque do ensaio rápido Q9 (sucção = 17 kPa), diâmetro de $0,2 \mathrm{~m}$ e profundidade de $1,5 \mathrm{~m}$. 


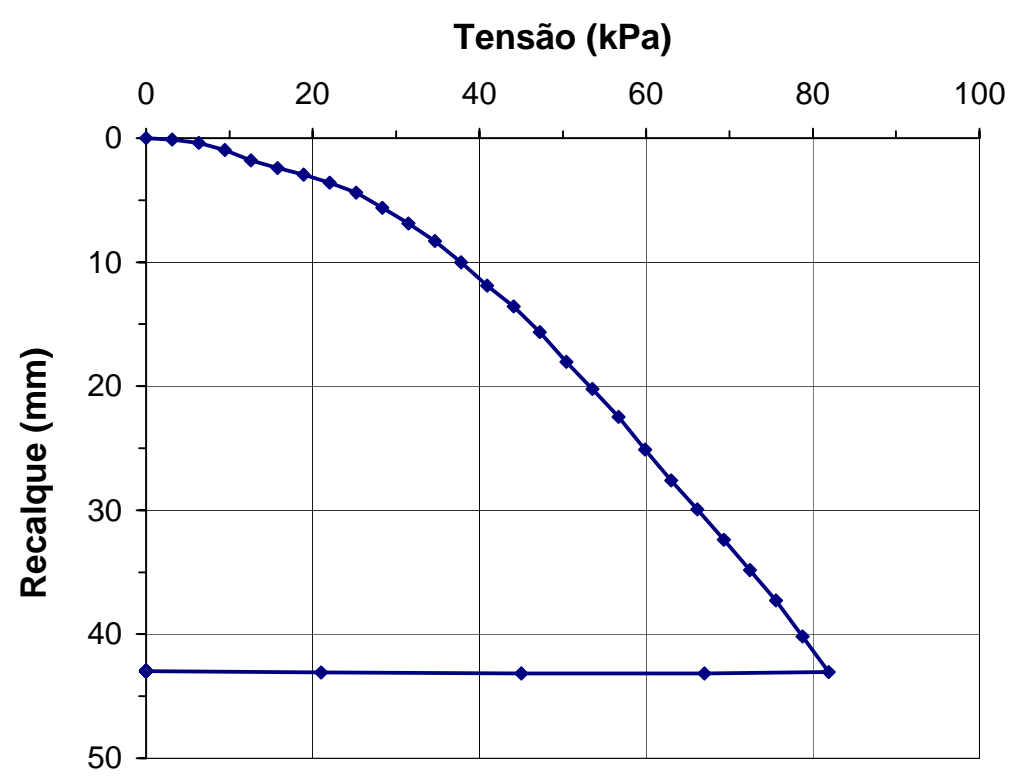

Figura 5.19 - Curva tensão-recalque do ensaio rápido inundado QS7 (sucção $=0 \mathrm{kPa}$ ), diâmetro de 0,4 m e profundidade de 1,5 m.

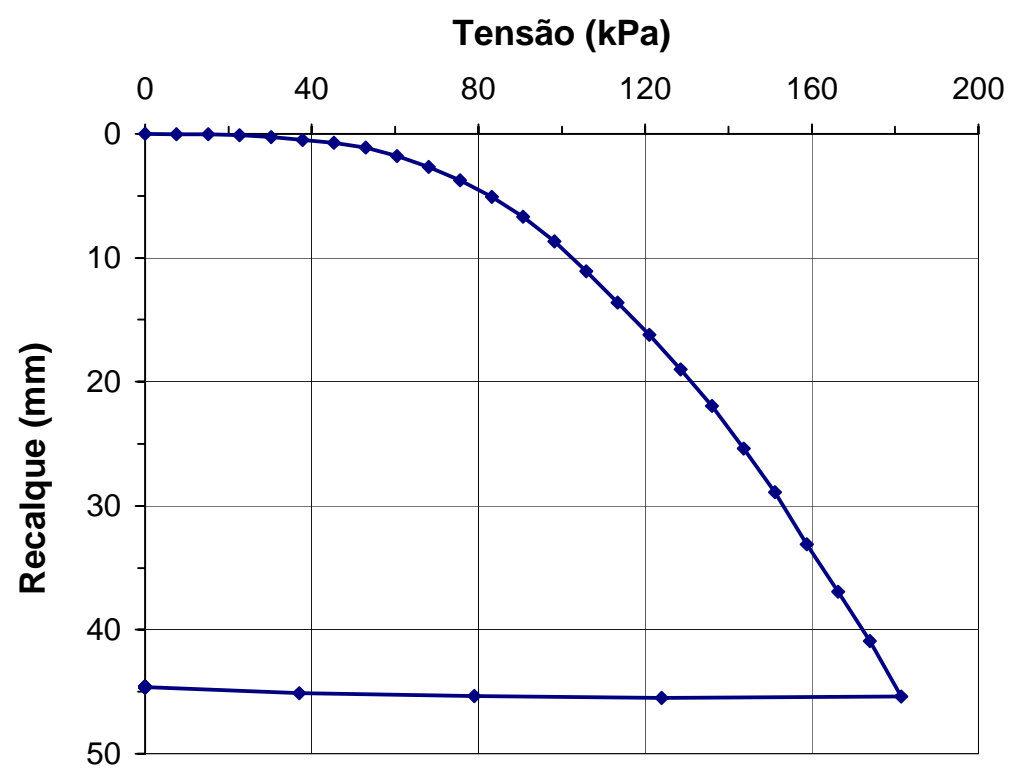

Figura 5.20 - Curva tensão-recalque do ensaio rápido Q10 (sucção = 12 kPa), diâmetro de $0,4 \mathrm{~m}$ e profundidade de $1,5 \mathrm{~m}$. 


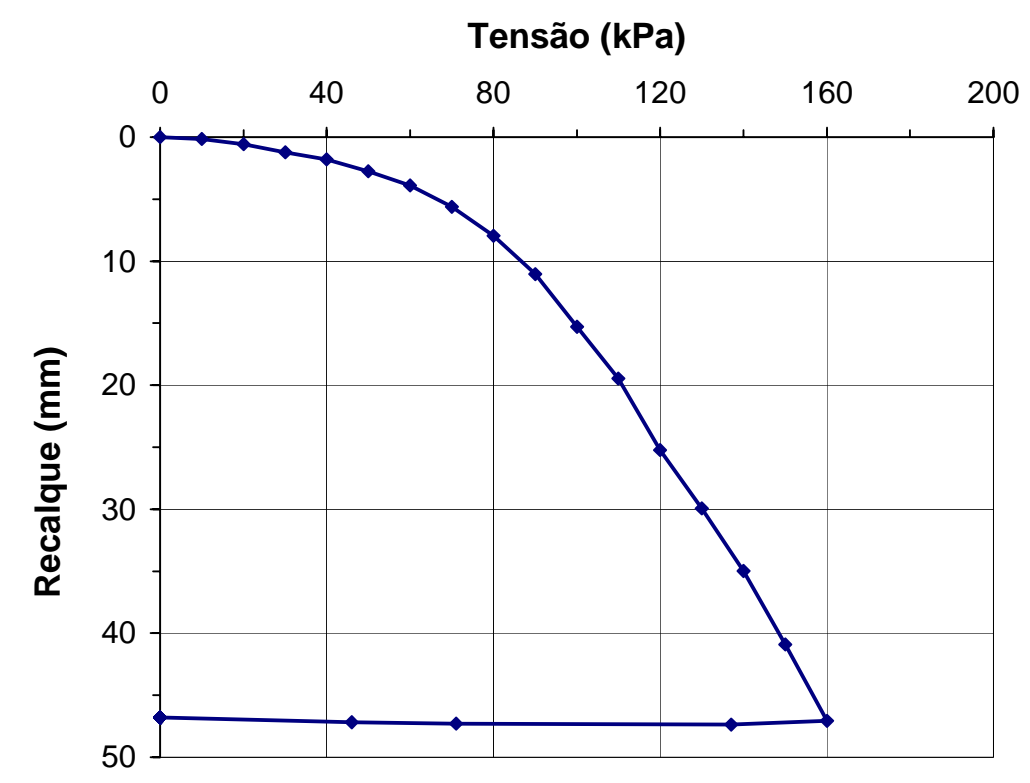

Figura 5.21 - Curva tensão-recalque do ensaio rápido Q11 (sucção = 13 kPa), diâmetro de $0,4 \mathrm{~m}$ e profundidade de $1,5 \mathrm{~m}$.

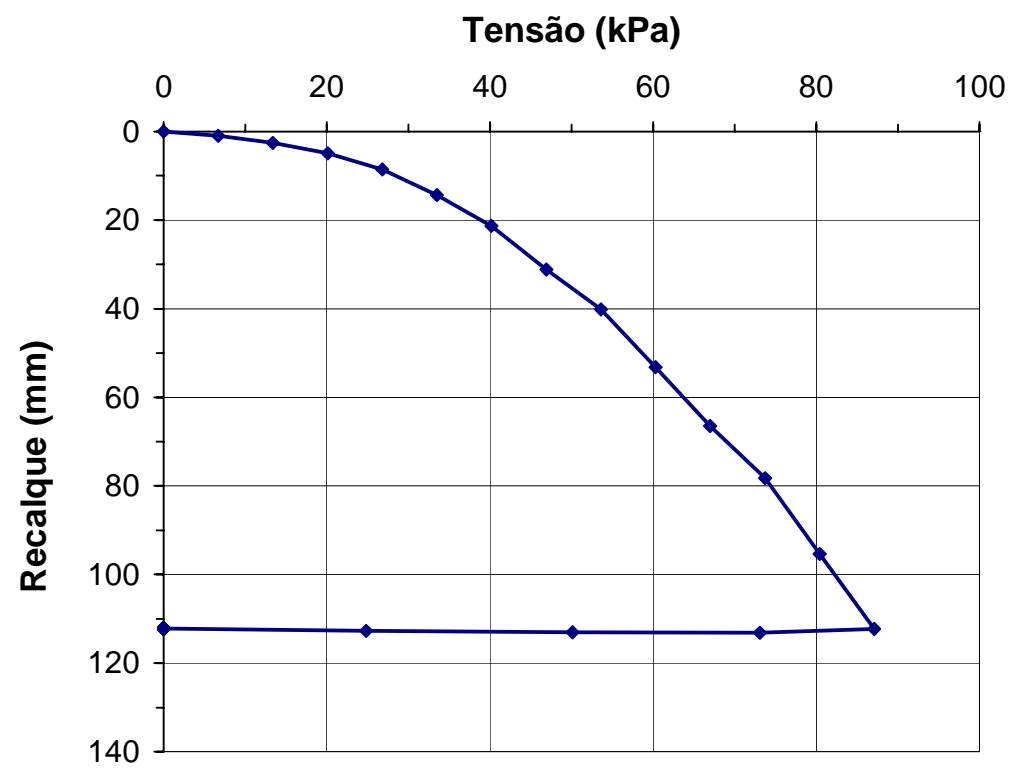

Figura 5.22 - Curva tensão-recalque do ensaio rápido inundado QS8 ( (ucção $=0 \mathrm{kPa}$ ), diâmetro de $1,5 \mathrm{~m}$ e profundidade de $1,5 \mathrm{~m}$. 


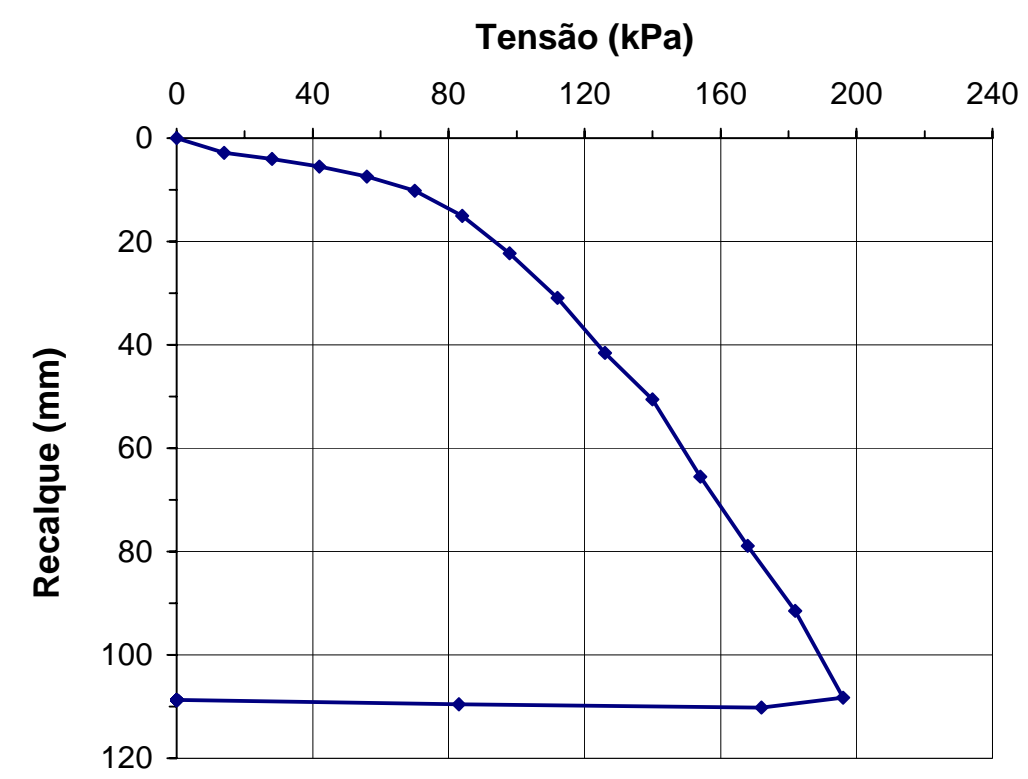

Figura 5.23 - Curva tensão-recalque do ensaio rápido Q12 (sucção = 22 kPa), diâmetro de $1,5 \mathrm{~m}$ e profundidade de $1,5 \mathrm{~m}$.

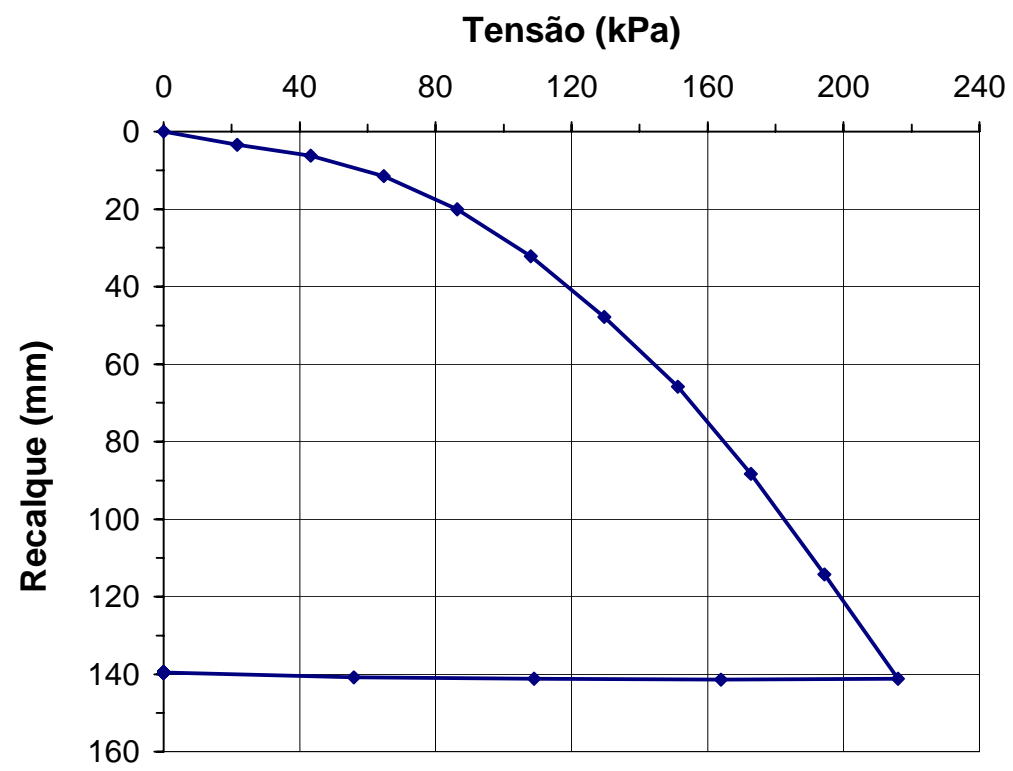

Figura 5.24 - Curva tensão-recalque do ensaio rápido Q13 (sucção = 21 kPa), diâmetro de $1,5 \mathrm{~m}$ e profundidade de $1,5 \mathrm{~m}$. 


\section{MÉTODO PARA PREVISÃO DA CURVA TENSÃO- RECALQUE}

\subsection{PROPOSIÇÃO}

As curvas tensão-recalque obtidas nos ensaios de placa em solos não saturados do interior do Estado de São Paulo apresentam uma forma muito parecida com a da curva carga-recalque de Schultze (1976), originalmente definida para o caso de um sistema solo-estaca sem ruptura física. Este autor representou a curva cargarecalque por duas funções, sendo o trecho inicial representado por uma função hiperbólica e, após um certo nível de recalque, por uma função linear.

Nesta pesquisa, adaptaram-se as expressões matemáticas originais de Schultze (1976), para o caso de provas de carga em placa, trabalhando-se com tensões em vez de cargas. Além disso, de modo a eliminar nas previsões a necessidade de se definir o nível de recalque a partir do qual inicia-se o trecho linear, agruparam-se as duas funções em uma única equação. Portanto, para a previsão das curvas tensãorecalque, utilizou-se a seguinte expressão:

$$
\sigma=\frac{\rho}{a+b \cdot \rho}+c \cdot \rho
$$

sendo:

$\rho$ - recalque correspondente a uma tensão $\sigma$;

a, b e c - parâmetros da equação. 
A Figura 6.1 representa a curva tensão-recalque que se obtém utilizando a equação (6.1).

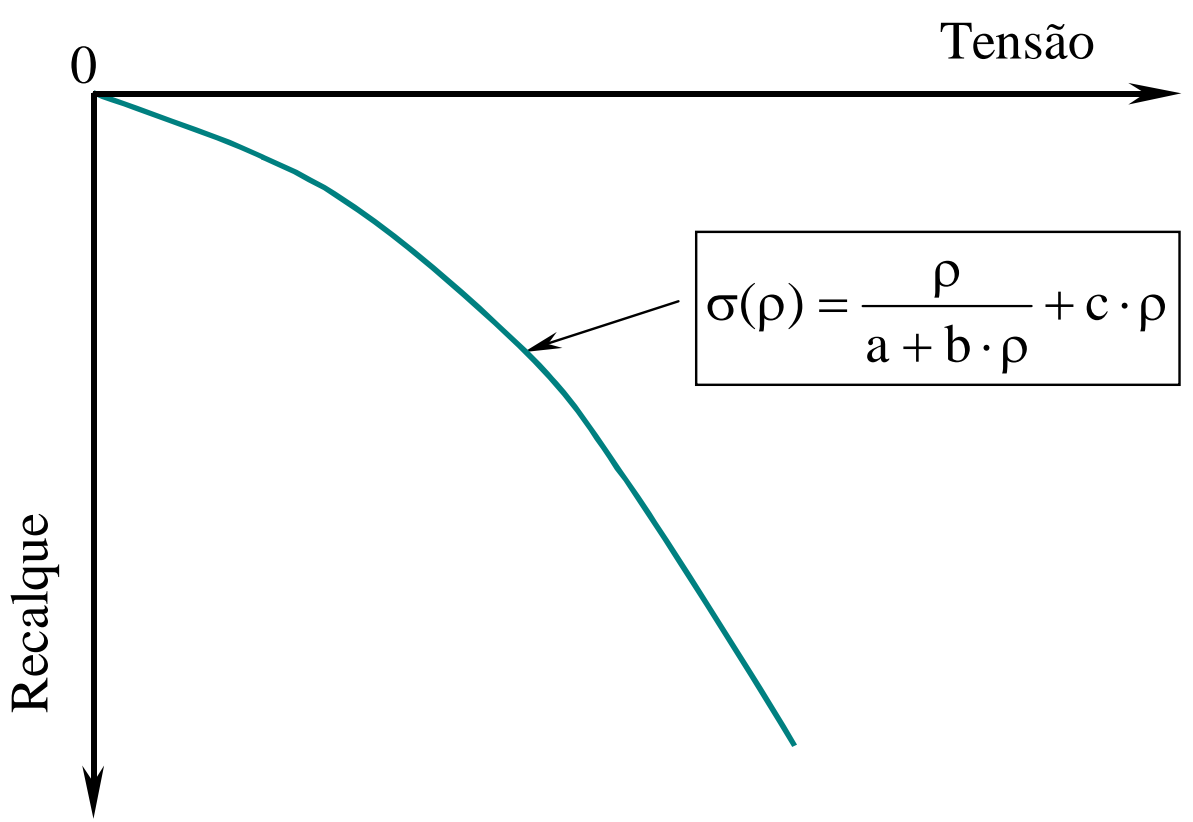

Figura 6.1 - Curva tensão-recalque da equação (6.1).

A utilização deste formato de curva justifica-se pelo fato de que, geralmente, nos solos não saturados do interior do Estado de São Paulo, as curvas tensão-recalque a partir de um certo ponto apresentam um comportamento de encruamento, ou seja, a tensão aumenta linearmente com a mobilização do recalque. Essa forma de curva já havia sido observada por Terzaghi (1943) em solos compressíveis.

A Figura 6.2 mostra a forma da curva nos casos particulares em que $a$ ou $c$ se anulam. No primeiro caso, a função torna-se uma reta com coeficiente linear $\sigma_{u}$ igual a $1 / b$ e coeficiente angular $\operatorname{tg} \theta$ igual a $c$. No segundo caso, a função torna-se uma hipérbole que define uma tensão última $\sigma_{u}$ também igual a $1 / b$, representando uma situação de ruptura física. Ressalta-se que a tensão última não pode ser diretamente visualizada na curva original. 


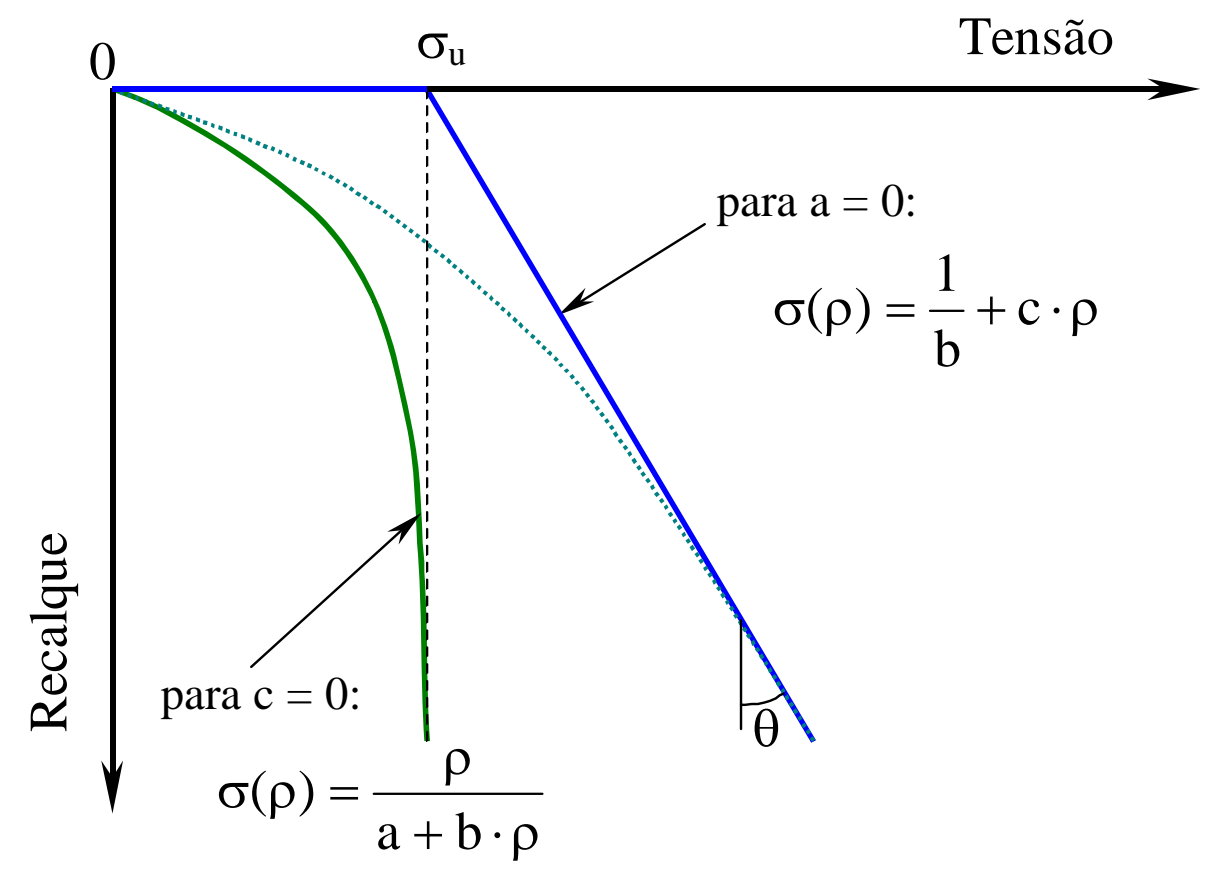

Figura 6.2 - Condições limites da equação (6.1).

Derivando-se a equação (6.1) em relação ao recalque, e substituindo-o por zero e por infinito, obtêm-se, respectivamente, os parâmetros $a$ e $c$.

$$
\frac{d \sigma}{d \rho}=\frac{a}{(a+b \cdot \rho)^{2}}+c
$$

para $\rho=0$,

$$
\begin{aligned}
& \frac{\mathrm{d} \sigma}{\mathrm{d} \rho}=\frac{1}{\mathrm{a}}+\mathrm{c}=\mathrm{k} \\
& \mathrm{a}=\frac{1}{\mathrm{k}-\mathrm{c}}
\end{aligned}
$$

para $\rho=\infty$,

$$
\begin{aligned}
& \frac{\mathrm{d} \sigma}{\mathrm{d} \rho}=\mathrm{c}=\operatorname{tg} \theta \\
& \mathrm{c}=\operatorname{tg} \theta
\end{aligned}
$$


sendo:

$\mathrm{k}$ - coeficiente de recalque do solo;

$\operatorname{tg} \theta$ - coeficiente angular da assíntota à curva tensão-recalque quando o recalque tende para o infinito.

O coeficiente de recalque depende da sucção matricial do solo durante o ensaio e pode ser determinado, para placas circulares rígidas, com base na Teoria da Elasticidade Linear por:

$$
\mathrm{k}=\frac{\sigma}{\rho}=\frac{4 \cdot \mathrm{E}}{\mathrm{D} \cdot\left(1-v^{2}\right) \cdot \pi}
$$

onde:

E - módulo de deformabilidade do solo;

D - diâmetro da placa;

$v$ - coeficiente de Poisson.

O parâmetro $b$ da equação (6.1), como visto anteriormente, é definido pela expressão (6.5) quando os parâmetros $a$ ou $c$ se anulam.

$$
\mathrm{b}=\frac{1}{\sigma_{\mathrm{u}}}
$$

\subsection{PARÂMETROS DA CURVA TENSÃO-RECALQUE}

\section{a) Parâmetro “a”}

Como visto anteriormente este parâmetro depende do coeficiente de recalque $(\mathrm{k})$ o qual por sua vez tem relação direta com o módulo de deformabilidade do solo. Como se trata de solo não saturado, ambos dependem da sucção matricial.

O módulo de deformabilidade do solo pode ser considerado como sendo o módulo tangente inicial $\left(\mathrm{E}_{0}\right)$ de curvas tensão-deformação, obtidas por meio de ensaios triaxiais com sucção controlada. 
Conforme será apresentado no item 7.3, no Campo Experimental de Fundações da EESC/USP, a variação do módulo tangente inicial com a sucção matricial para as profundidades de 2,0, 5,0 e 8,0 m é representada, respectivamente, pelas equações (6.6), (6.7) e (6.8). Estas equações são válidas para o intervalo de sucções de 0 a $80 \mathrm{kPa}$, o qual é suficiente para abranger os valores medidos em campo.

$$
\begin{aligned}
& \mathrm{E}_{0}=0,23 \cdot\left(\mathrm{u}_{\mathrm{a}}-\mathrm{u}_{\mathrm{w}}\right)+1,95 \\
& \mathrm{E}_{0}=0,42 \cdot\left(\mathrm{u}_{\mathrm{a}}-\mathrm{u}_{\mathrm{w}}\right)+7,26 \\
& \mathrm{E}_{0}=0,10 \cdot(\mathrm{MPa}) \\
& \left(\mathrm{u}_{\mathrm{a}}-\mathrm{u}_{\mathrm{w}}\right)+15,84 \quad(\mathrm{MPa})
\end{aligned}
$$

onde:

$$
\left(\mathrm{u}_{\mathrm{a}}-\mathrm{u}_{\mathrm{w}}\right) \text { - sucção matricial em } \mathrm{kPa} \text {. }
$$

\section{b) Parâmetro “b”}

Este parâmetro é o inverso da tensão última $\left(\sigma_{\mathrm{u}}\right)$, cujo valor numérico foi admitido como sendo igual ao da tensão de cedência $\left(\sigma_{y}\right)$. A tensão de cedência em solos não saturados tem definição semelhante à tensão de pré-adensamento das argilas saturadas. O valor de $\sigma_{y}$, que depende da sucção, pode ser obtido por meio de ensaios de compressão confinada com controle de sucção.

As Figuras 6.3 a 6.8 obtidas por Machado (1998), mostram as curvas de variação da tensão de cedência em função da sucção para corpos de prova de amostras indeformadas de solo retiradas em diferentes profundidades em um poço situado no Campo Experimental de Fundações da EESC/USP. 


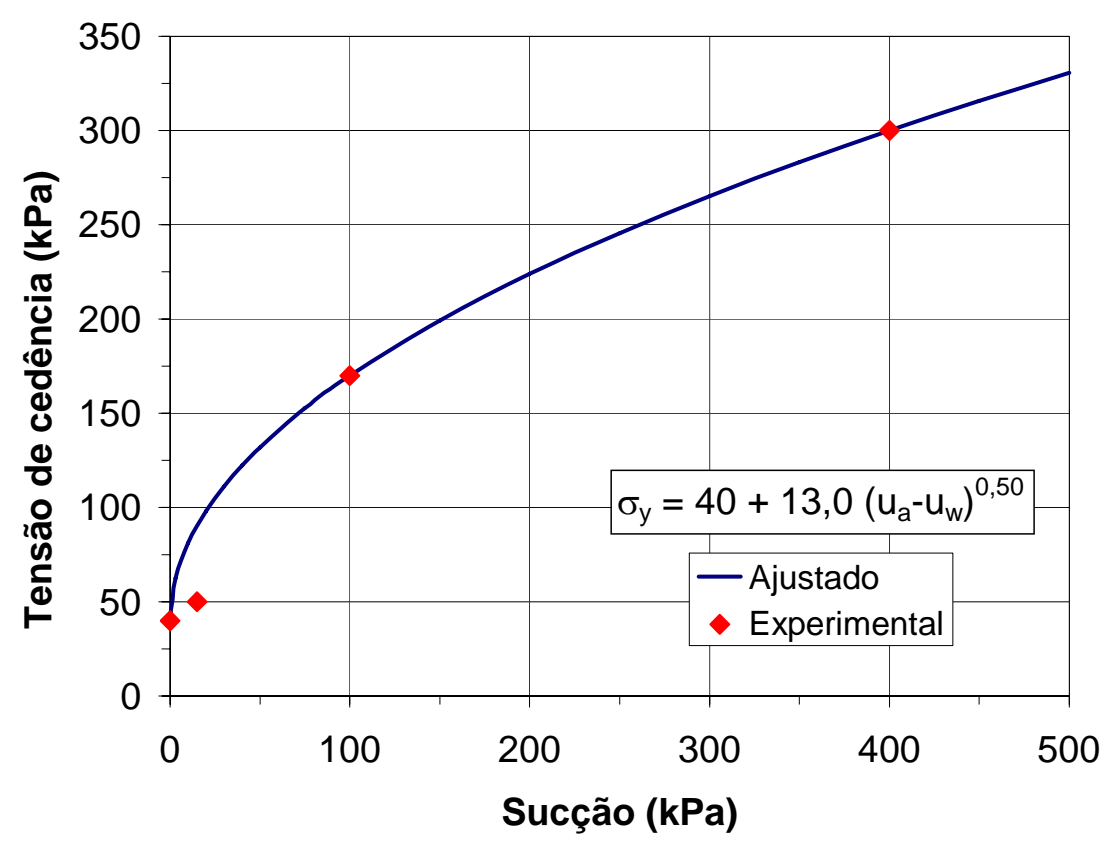

Figura 6.3 - Curva de variação da tensão de cedência em função da sucção para a profundidade de 1,0 m (MACHADO, 1998).

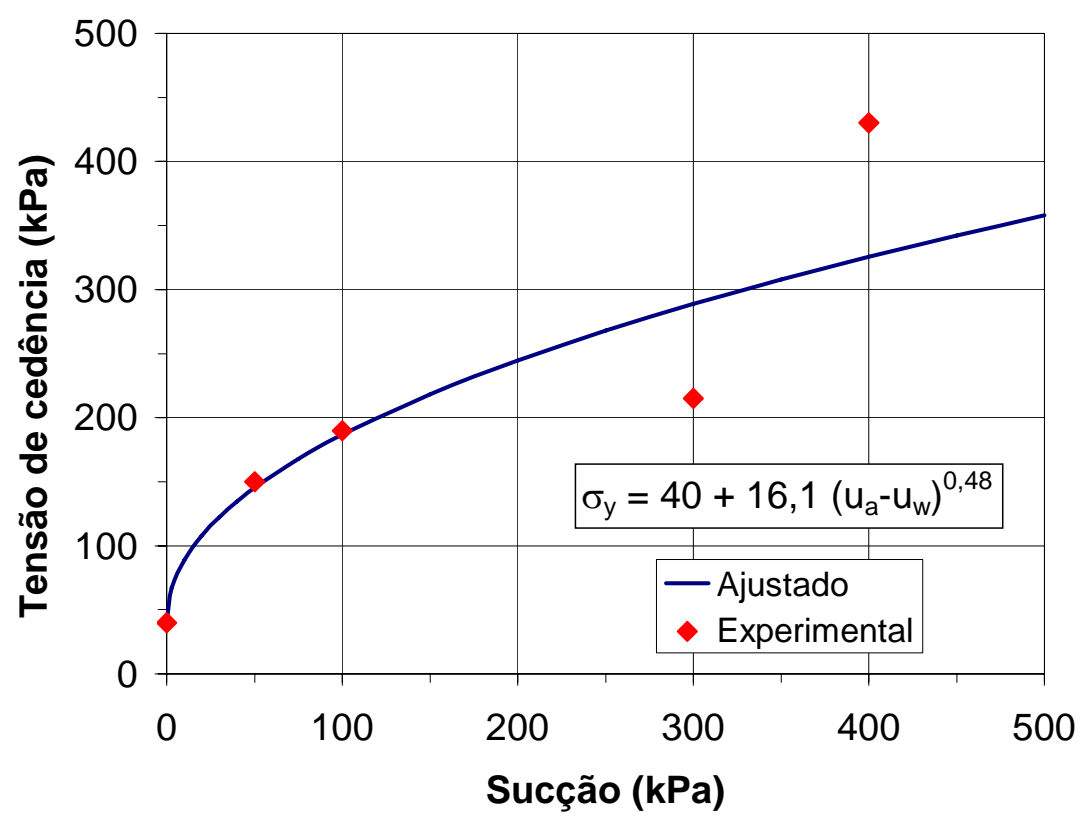

Figura 6.4 - Curva de variação da tensão de cedência em função da sucção para a profundidade de 2,0 m (MACHADO, 1998). 


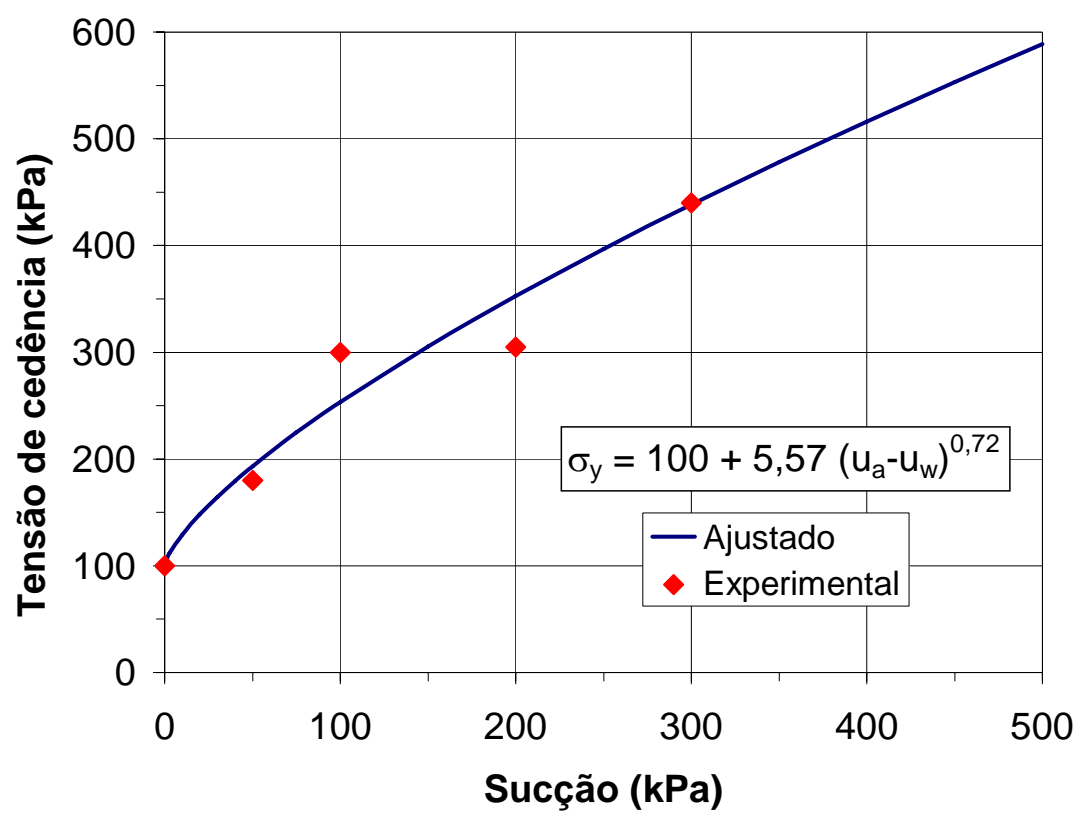

Figura 6.5 - Curva de variação da tensão de cedência em função da sucção para a profundidade de 4,0 m (MACHADO, 1998).

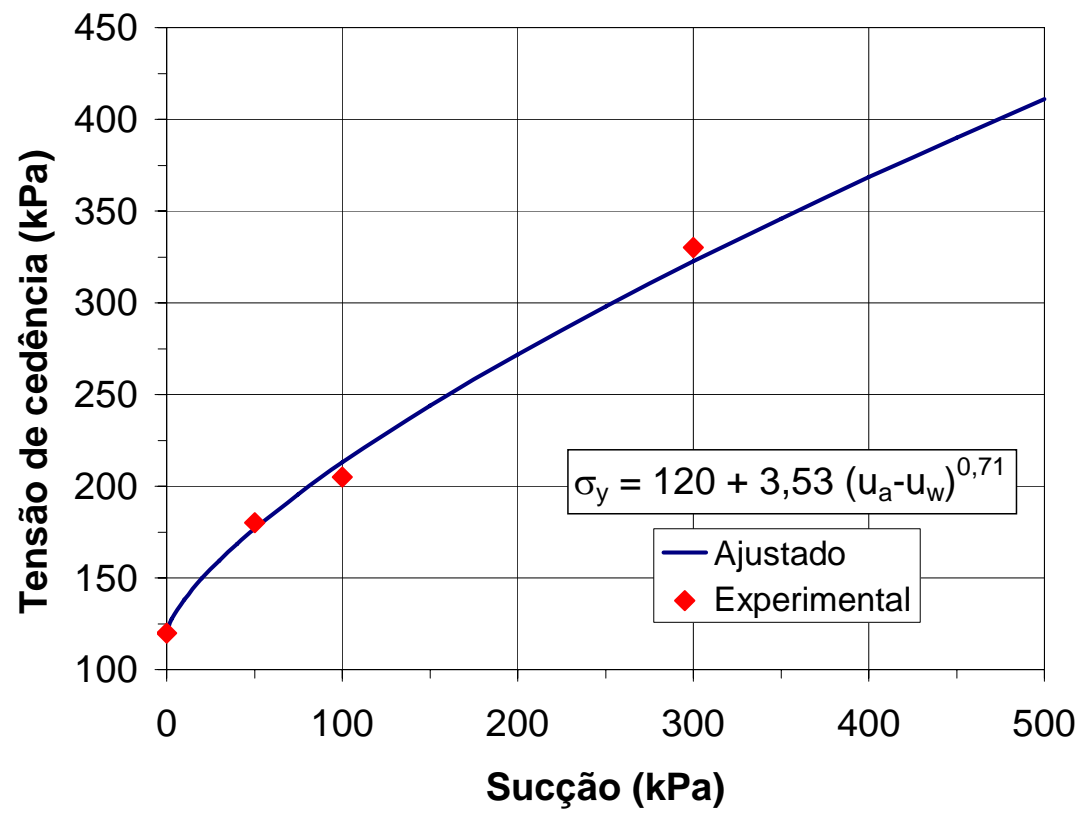

Figura 6.6 - Curva de variação da tensão de cedência em função da sucção para a profundidade de 5,0 m (MACHADO, 1998). 


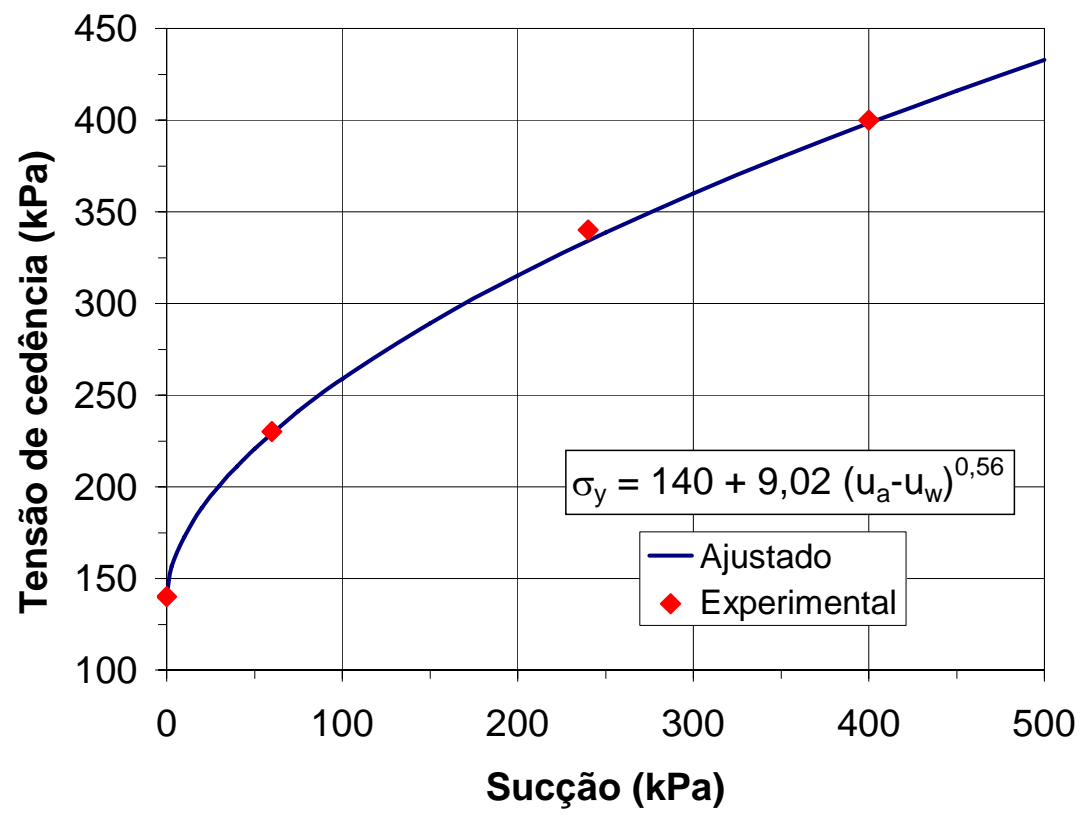

Figura 6.7 - Curva de variação da tensão de cedência em função da sucção para a profundidade de 7,0 m (MACHADO, 1998).

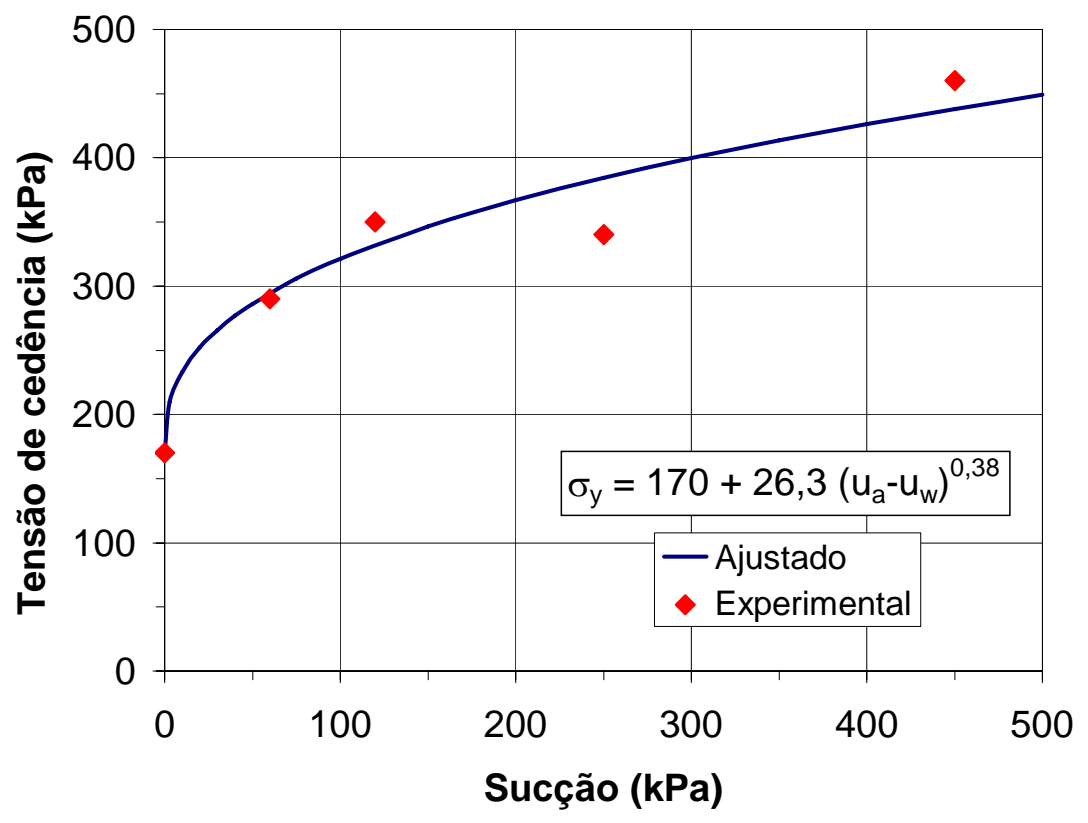

Figura 6.8 - Curva de variação da tensão de cedência em função da sucção para a profundidade de 8,0 m (MACHADO, 1998). 
Como os parâmetros $a$ e $b$ são obtidos de ensaios de compressão confinada (com estabilização das deformações do corpo de prova) e de ensaios triaxiais consolidados drenados, as curvas tensão-recalque a serem previstas vão se referir a provas de carga do tipo lento. Caso pretenda-se estimar esta curva para um ensaio com carregamento do tipo rápido devem-se corrigir os recalques, conforme será apresentado em item específico.

\section{c) Parâmetro “c”}

Para a obter o parâmetro $c$, retroanalisaram-se os trechos lineares finais de carregamento dos ensaios de placa de diâmetro igual a $0,80 \mathrm{~m}$ com medida de sucção, realizados a 1,5 m de profundidade, executados no Campo Experimental da EESC/USP. Em seguida, obteve-se a relação $c / \sigma_{y}$ para cada nível de sucção. As Tabelas 6.1 e 6.2 apresentam os valores de $c$ para os ensaios lentos e rápidos, respectivamente, os valores da tensão de cedência $\left(\sigma_{y}\right)$ determinados por Machado (1998), e as relações $c / \sigma_{y}$. Para cada prova de carga considerou-se a tensão de cedência média entre as profundidades de 1,0 e 2,0 m, uma vez que as provas de carga foram executadas na profundidade de 1,5 $\mathrm{m}$.

Tabela 6.1 - Relações $c / \sigma_{y}$ ( $c$ obtido em ensaios de placa lentos a $1,5 \mathrm{~m}$ de profundidade).

\begin{tabular}{|c|c|c|c|c|c|}
\hline Ensaio & $\begin{array}{c}\text { Sucção } \\
\text { (kPa) }\end{array}$ & $\begin{array}{c}\mathrm{c}=\operatorname{tg} \theta \\
(\mathrm{kPa} / \mathrm{mm})\end{array}$ & $\begin{array}{c}\sigma_{\mathrm{y}} \\
(\mathbf{k P a})\end{array}$ & $\begin{array}{l}\mathrm{c} / \sigma_{\mathrm{y}} \\
\left(\mathrm{m}^{-1}\right)\end{array}$ & $\begin{array}{c}\text { c / } \sigma_{\mathrm{y}} \text { (médio) } \\
\left(\mathrm{m}^{-1}\right)\end{array}$ \\
\hline SS1 & 0 & 0,7995 & 40 & 19,99 & \multirow{3}{*}{16,41} \\
\hline SS2 & 0 & 0,5572 & 40 & 13,93 & \\
\hline SS3 & 0 & 0,6119 & 40 & 15,30 & \\
\hline $\mathrm{S} 1$ & 10 & 1,4210 & 85 & 16,72 & 16,72 \\
\hline \multirow[t]{4}{*}{$\mathrm{S} 2$} & 31 & 1,7924 & 118 & 15,19 & 15,19 \\
\hline & & \multicolumn{3}{|c|}{ Média } & 16,11 \\
\hline & & \multicolumn{3}{|c|}{ Desvio Padrão } & 0,81 \\
\hline & & & \multicolumn{2}{|c|}{$\mathrm{cV}(\%)$} & 5,0 \\
\hline
\end{tabular}


Tabela 6.2 - Relações $c / \sigma_{y}$ (c obtido em ensaios de placa rápidos a $1,5 \mathrm{~m}$ de profundidade).

\begin{tabular}{|c|c|c|c|c|c|}
\hline Ensaio & $\begin{array}{c}\text { Sucção } \\
\text { (kPa) }\end{array}$ & $\begin{array}{c}c=\operatorname{tg} \theta \\
(\mathrm{kPa} / \mathrm{mm})\end{array}$ & $\begin{array}{c}\sigma_{\mathbf{y}} \\
(\mathbf{k P a})\end{array}$ & $\begin{array}{l}\mathbf{c} / \sigma_{\mathbf{y}} \\
\left(\mathbf{m}^{-1}\right)\end{array}$ & $\begin{array}{c}\text { c / } \sigma_{\mathrm{y}} \text { (médio) } \\
\left(\mathbf{m}^{-1}\right)\end{array}$ \\
\hline QS1 & 0 & 0,9303 & 40 & 23,26 & \multirow{2}{*}{19,48} \\
\hline QS2 & 0 & 0,6278 & 40 & 15,70 & \\
\hline Q1 & 15 & 1,3938 & 95 & 14,67 & 14,67 \\
\hline $\mathrm{Q} 2$ & 22 & 1,2525 & 106 & 11,82 & 11,82 \\
\hline \multirow[t]{4}{*}{ Q3 } & 33 & 1,9874 & 120 & 16,56 & 16,56 \\
\hline & & \multicolumn{3}{|c|}{ Média } & 15,63 \\
\hline & & & \multicolumn{2}{|c|}{ Desvio Padrão } & 3,22 \\
\hline & & & \multicolumn{2}{|c|}{ CV (\%) } & 20,6 \\
\hline
\end{tabular}

Observa-se nessas tabelas que a relação $c / \sigma_{y}$ é praticamente constante com o tipo de ensaio. Para os ensaios lentos a relação média foi de $16,11 \mathrm{~m}^{-1}$ com um coeficiente de variação de 5,0\%. Nos ensaios rápidos a relação média foi de 15,63 $\mathrm{m}^{-1}$, valor muito próximo do obtido nos ensaios lentos, com um coeficiente de variação de $20,6 \%$.

Determinou-se, também, o valor médio da relação $c / \sigma_{y}$ a partir dos ensaios de placa realizados nas profundidades de 4,0 e 6,0 m resultando em 17,20 e 18,20 m respectivamente. Assim, pode-se verificar um pequeno aumento desta relação com a profundidade.

Para verificar a influência da diferença entre as relações médias ( $c / \sigma_{y}$ ) obtidas nos ensaios lentos e rápidos construíram-se duas curvas tensão-recalque utilizando-se a equação (6.1) mantendo-se constantes os valores de $a, b$ e $\sigma_{y}$ e variando o valor de $c$ (Figura 6.9). Observa-se que esta diferença é desprezível e, portanto, esta relação será aplicada para retroanalisar os ensaios rápidos com diâmetros diferentes de $0,8 \mathrm{~m}$ e, juntamente com os parâmetros $a$ e $b$, obter a previsão das curvas dos ensaios lentos. 


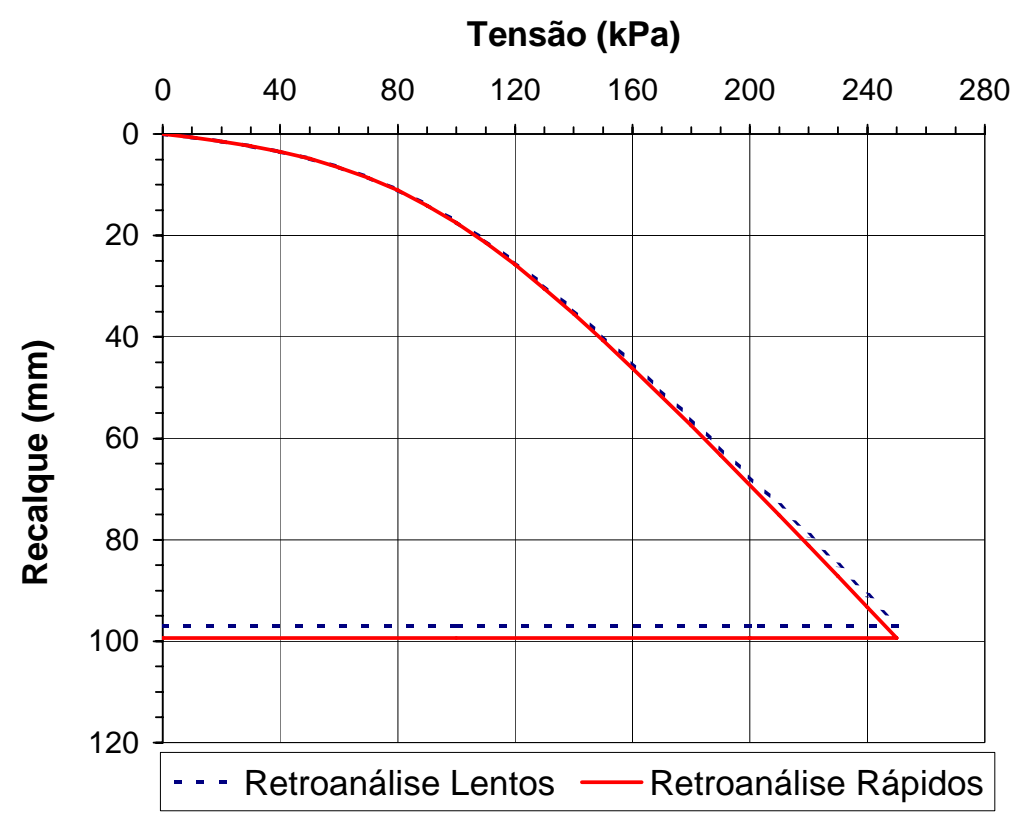

Figura 6.9 - Verificação da influência do parâmetro $c$ em ensaios lentos e rápidos.

Para considerar a variação do parâmetro $c$ com o diâmetro da placa realizouse uma retroanálise incluindo os ensaios rápidos com placas de 0,2, 0,4 e 1,5 m executados também na profundidade de $1,5 \mathrm{~m}$ por Vianna (em fase de elaboração) ${ }^{5}$. A Tabela 6.3 apresenta os resultados desta análise, bem como a designação atribuída aos ensaios com diâmetro diferente de $0,8 \mathrm{~m}$.

\footnotetext{
${ }^{5}$ VIANNA, A.P.F. Influência da dimensão de sapatas na capacidade de carga em solos colapsíveis.
} Tese (Doutorado) - Escola de Engenharia de São Carlos, Universidade de São Paulo, São Carlos. 2004. 
Tabela 6.3 - Relações $c / \sigma_{y}$ ( $c$ obtido em ensaios de placa rápidos a 1,5 m de profundidade com diferentes diâmetros).

\begin{tabular}{|c|c|c|c|c|c|}
\hline Ensaio & $\begin{array}{c}\text { Diâmetro } \\
(\mathbf{m})\end{array}$ & $\begin{array}{c}\text { Sucção } \\
\text { (kPa) }\end{array}$ & $\begin{array}{c}\sigma_{\mathrm{y}} \\
(\mathbf{k P a})\end{array}$ & $\begin{array}{c}c=\operatorname{tg} \theta \\
(\mathrm{kPa} / \mathrm{mm})\end{array}$ & $\begin{array}{l}c / \sigma_{y} \\
\left(\mathrm{~m}^{-1}\right) \\
\end{array}$ \\
\hline \multicolumn{2}{|c|}{$\mathrm{QS6}_{0,2}$} & 0 & 40 & 1,3434 & 33,59 \\
\hline Q8 & 0,2 & 15 & 95 & 2,4685 & 25,98 \\
\hline Q9 & 0,2 & 17 & 98 & 2,3052 & 23,52 \\
\hline QS7 & 0,4 & 0 & 40 & 1,2768 & 31,92 \\
\hline Q10 & 0,4 & 12 & 89 & 1,9350 & 21,74 \\
\hline Q11 & 0,4 & 13 & 91 & 1,8430 & 20,25 \\
\hline QS1 e QS2 & 0,8 & 0 & 40 & 0,7791 & 19,48 \\
\hline Q1 & 0,8 & 15 & 95 & 1,3938 & 14,67 \\
\hline Q2 & 0,8 & 22 & 106 & 1,2525 & 11,82 \\
\hline Q3 & 0,8 & 33 & 120 & 1,9874 & 16,56 \\
\hline QS8 & 1,5 & 0 & 40 & 0,4700 & 11,75 \\
\hline Q12 & 1,5 & 22 & 106 & 0,9893 & 9,33 \\
\hline Q13 & 1,5 & 21 & 104 & 0,8568 & 8,24 \\
\hline
\end{tabular}

Com os dados da tabela anterior plotaram-se dois gráficos da relação (c / $\left.\sigma_{y}\right)$ em função do diâmetro (D) da placa, sendo um para os ensaios inundados (Figura 6.10) e outro para os ensaios não inundados (Figura 6.11).

Para os ensaios com sucção nula, observa-se que a função exponencial dada pela equação (6.9), ajusta-se relativamente bem aos valores encontrados. Já, para os ensaios sem inundação, efetuou-se uma regressão múltipla para avaliar a influência do diâmetro da placa e da sucção na relação $\left(c / \sigma_{y}\right)$. Na Figura 6.11 pode-se constatar que a variação da sucção apresenta pouca influência sendo, portando, desprezada. Deste modo, para esta condição do solo, a relação é dada pela equação (6.10).

$$
\begin{aligned}
& \frac{C}{\sigma_{y}}=40,50 \cdot e^{-0,855 \cdot D} \\
& \frac{C}{\sigma_{y}}=27,61 \cdot e^{-0,815 \cdot D}
\end{aligned}
$$

em que:

e - base dos logaritmos neperianos;

D - diâmetro da placa. 


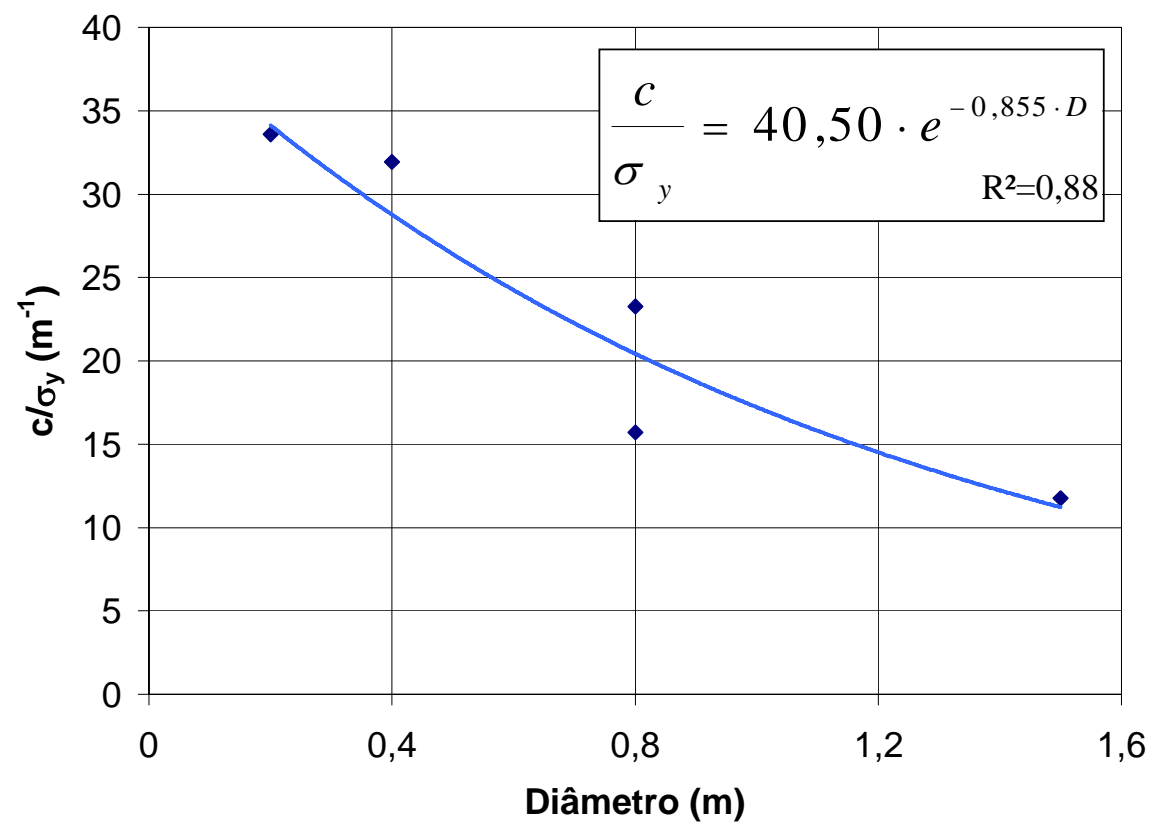

Figura 6.10 - Variação da relação (c / $\left.\sigma_{y}\right)$ com o diâmetro da placa para ensaios rápidos inundados.

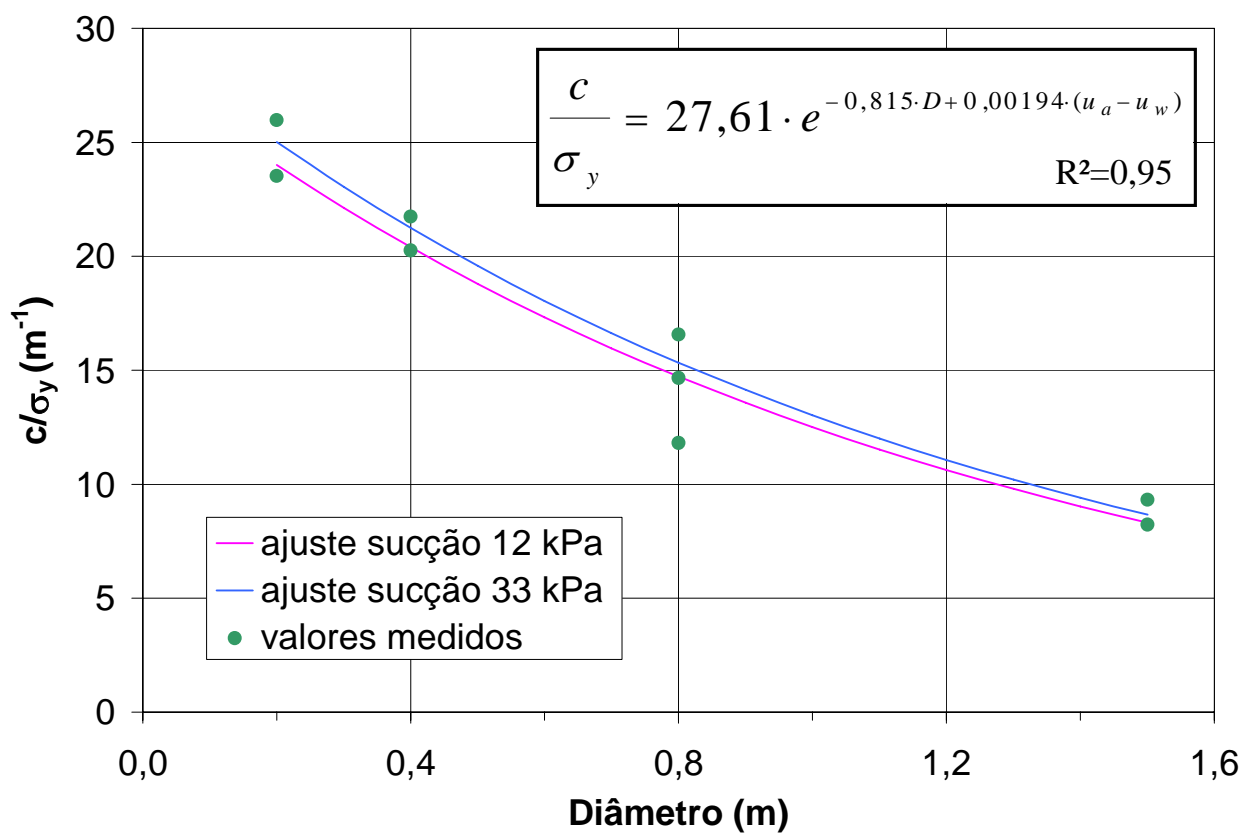

Figura 6.11 - Variação da relação (c / $\left.\sigma_{y}\right)$ com o diâmetro da placa e com a sucção para ensaios rápidos não inundados. 
Assim, basta determinar vários pontos $(\sigma, \rho)$, correspondentes aos estágios de carregamento de uma prova de carga, para obter a curva tensão-recalque pelo método proposto.

O trecho de descarregamento das previsões pode ser considerado constante, sendo o valor do recalque após a retirada dos carregamentos igual ao máximo previsto, uma vez que este tipo de solo praticamente não apresenta recuperação elástica nesta fase do ensaio.

\subsection{CORREÇÃO DE ENSAIOS RÁPIDOS PARA LENTOS}

Este item tem por objetivo obter um procedimento para corrigir os recalques medidos numa prova de carga do tipo rápido para se estimar os correspondentes recalques estabilizados num ensaio lento.

Admitindo-se que a estabilização dos recalques nos estágios de carregamento de uma prova de carga em placa do tipo lento segue o método proposto por Asaoka ${ }^{6}$ (1978 apud MASSAD, 1982), utilizaram-se as equações seguintes para o cálculo do acréscimo de recalque $\left(\Delta \rho_{\mathrm{i}, \mathrm{t}}\right)$ no estágio $i$ num tempo $t$ após a aplicação do incremento de tensão.

$$
\Delta \rho_{i, t}=\Delta \rho_{\infty_{i}} \cdot\left[1-e^{-\left(A \cdot t+B_{i}\right)}\right]
$$

onde:

$\Delta \rho_{\infty_{\mathrm{i}}}$ - acréscimo de recalque total do estágio, ou seja:

$$
\begin{aligned}
& \Delta \rho_{\infty \mathrm{i}}=\rho_{\infty \mathrm{i}}-\rho_{\infty \mathrm{i}-1} \\
& \rho_{\infty \mathrm{i}}-\text { recalque final do estágio; } \\
& \rho_{\infty \mathrm{i}-1}-\text { recalque final do estágio anterior; }
\end{aligned}
$$

A - parâmetro da equação que se refere à forma da curva de estabilização dos recalques;

$B_{i}$ - parâmetro da equação que se refere ao recalque inicial logo após o acréscimo de carga em cada estágio de carregamento;

${ }^{6}$ ASAOKA, A. (1978). Observational Procedure of Settlement Prediction. Soils and Foundations, Janpanese Society of Soil Mechanics and Foundation Engineering: 18 (4),Dec. 1978. 
O parâmetro “A” é calculado pela equação:

$$
\mathrm{A}=\frac{2,47 \cdot \mathrm{C}_{\mathrm{v}}{ }^{*}}{\mathrm{H}^{2}}
$$

sendo:

$$
\begin{aligned}
& \mathrm{C}_{\mathrm{V}}{ }^{*} \text { - coeficiente de adensamento do solo não saturado; } \\
& \mathrm{H} \text { - distância de drenagem, considerada como a metade do diâmetro da } \\
& \quad \text { placa. }
\end{aligned}
$$

Finalmente, o recalque total $\left(\rho_{\mathrm{i}, \mathrm{t}}\right)$ até o estágio $i$ no tempo $t$ após a aplicação do acréscimo de tensão será determinado pela equação (6.14).

$$
\rho_{i, t}=\rho_{\infty_{i-1}}+\Delta \rho_{i, t}
$$

Substituindo as equações (6.11) e (6.12) em (6.14), tem-se:

$$
\rho_{i, t}=\rho_{\infty_{i}-1} \cdot\left(\rho_{\infty_{i}}-\rho_{\infty_{i}-1}\right) \cdot\left\lfloor 1-e^{-\left(A \cdot t+B_{i}\right)}\right\rfloor
$$

A Figura 6.12 mostra um esquema dos recalques ao longo do tempo de acordo com as equações utilizadas.

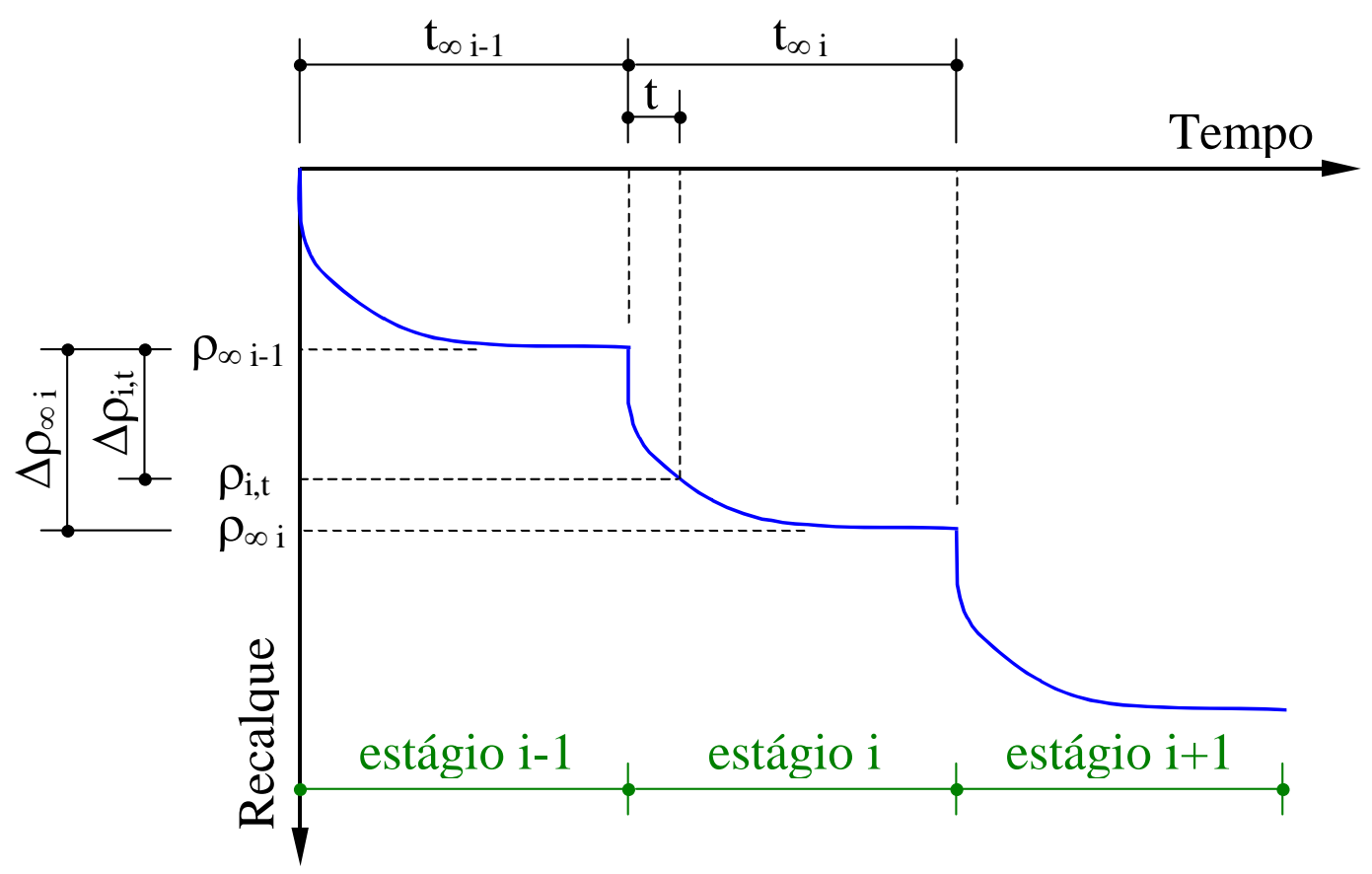

Figura 6.12 - Recalques ao longo do tempo de acordo com as equações utilizadas. 


\subsubsection{PARÂMETROS DA ESTABILIZAÇÃO DOS RECALQUES}

\section{a) Parâmetro “A”}

Para a definição deste parâmetro, determinaram-se os valores do coeficiente de adensamento do solo não saturado da Cidade de São Carlos por meio dos ensaios de compressão confinada realizados por Machado (1995) e Alfaro Soto (em fase de elaboração) ${ }^{7}$. Os resultados dos coeficientes de adensamento médios, para vários níveis de sucção, obtidos pelo método de Taylor, são apresentados na Figura 6.13. As tabelas com os valores para cada nível de tensão podem ser encontradas no Apêndice B.

Nesta figura, pode-se observar que o coeficiente de adensamento deste solo é praticamente constante com sucção, sendo que a diferença entre o maior e o menor valor encontrado foi de $0,05 \mathrm{~cm}^{2} / \mathrm{s}$. Deste modo, adotou-se um valor médio de $0,23 \mathrm{~cm}^{2} / \mathrm{s}$ para todas as análises posteriores.

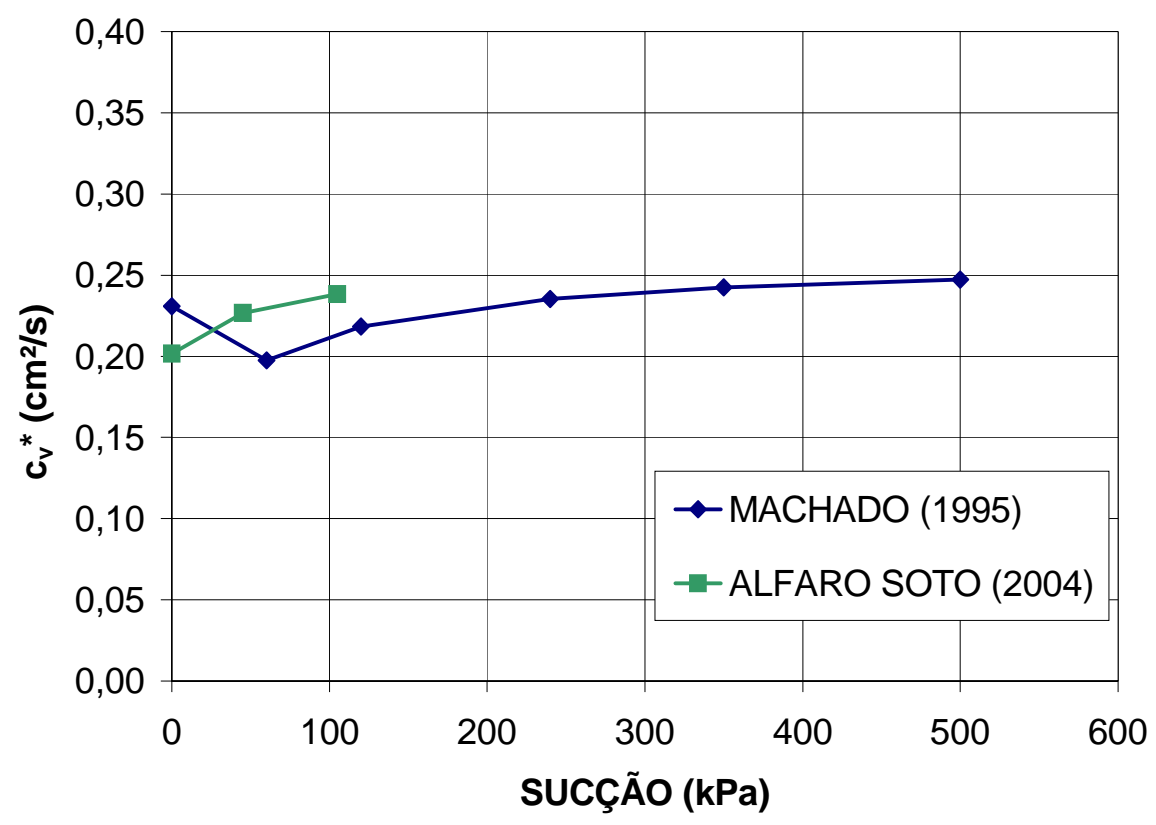

Figura 6.13 - Coeficiente de adensamento do solo não saturado em função da sucção.

\footnotetext{
${ }^{7}$ ALFARO SOTO, M.A. (2004). Análise comparativa entre métodos de controle e imposição de sucção em ensaios com solo não saturado. Tese (Doutorado) - Escola de Engenharia de São Carlos, Universidade de São Paulo, São Carlos. 2004.
} 


\section{b) Parâmetro "B"}

A partir dos resultados dos ensaios com carregamento do tipo lento determinou-se o parâmetro $B$, para cada estágio de carregamento, por meio de retroanálise, utilizando a equação (6.11). Os valores encontrados, em função do nível de tensão aplicado e da sucção medida no ensaio, são apresentados nas Figuras 6.14 e 6.15, respectivamente, para ensaios com e sem inundação.

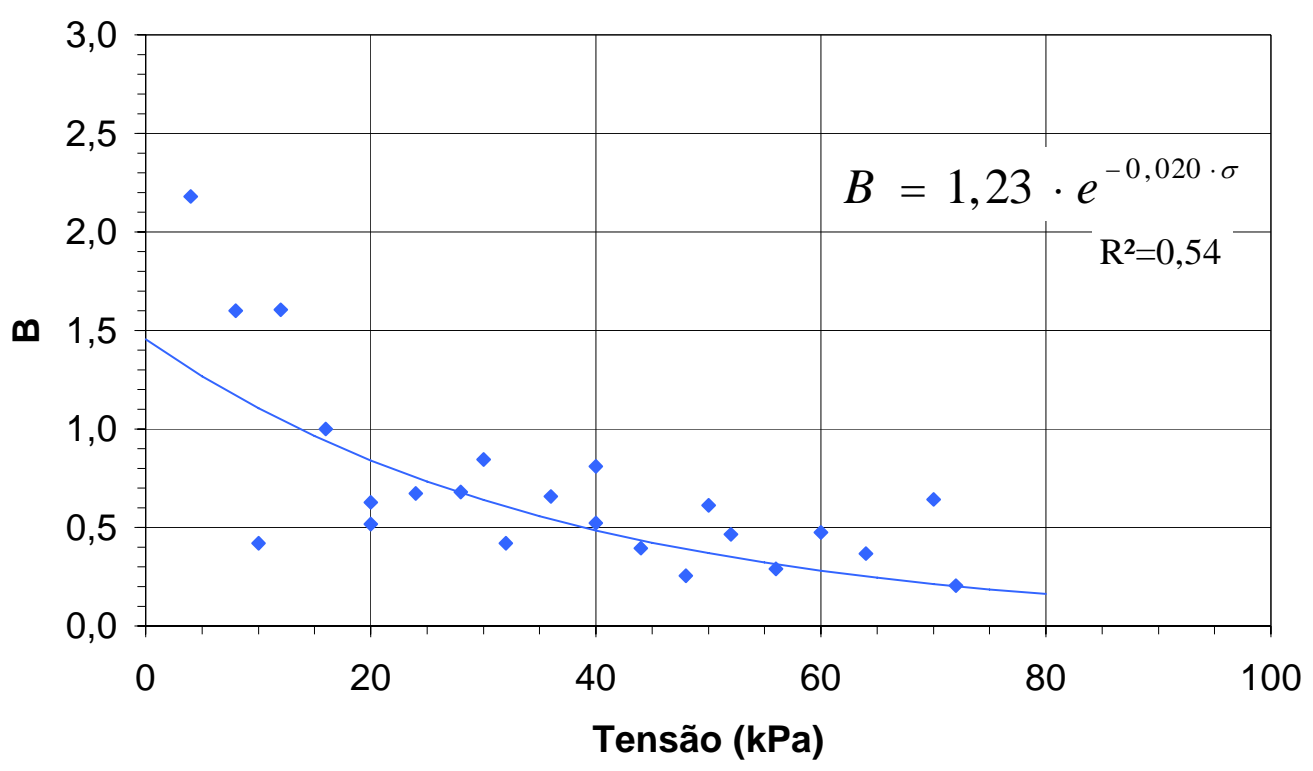

Figura 6.14 - Variação do parâmetro B em função do nível de tensão, para ensaios inundados. 


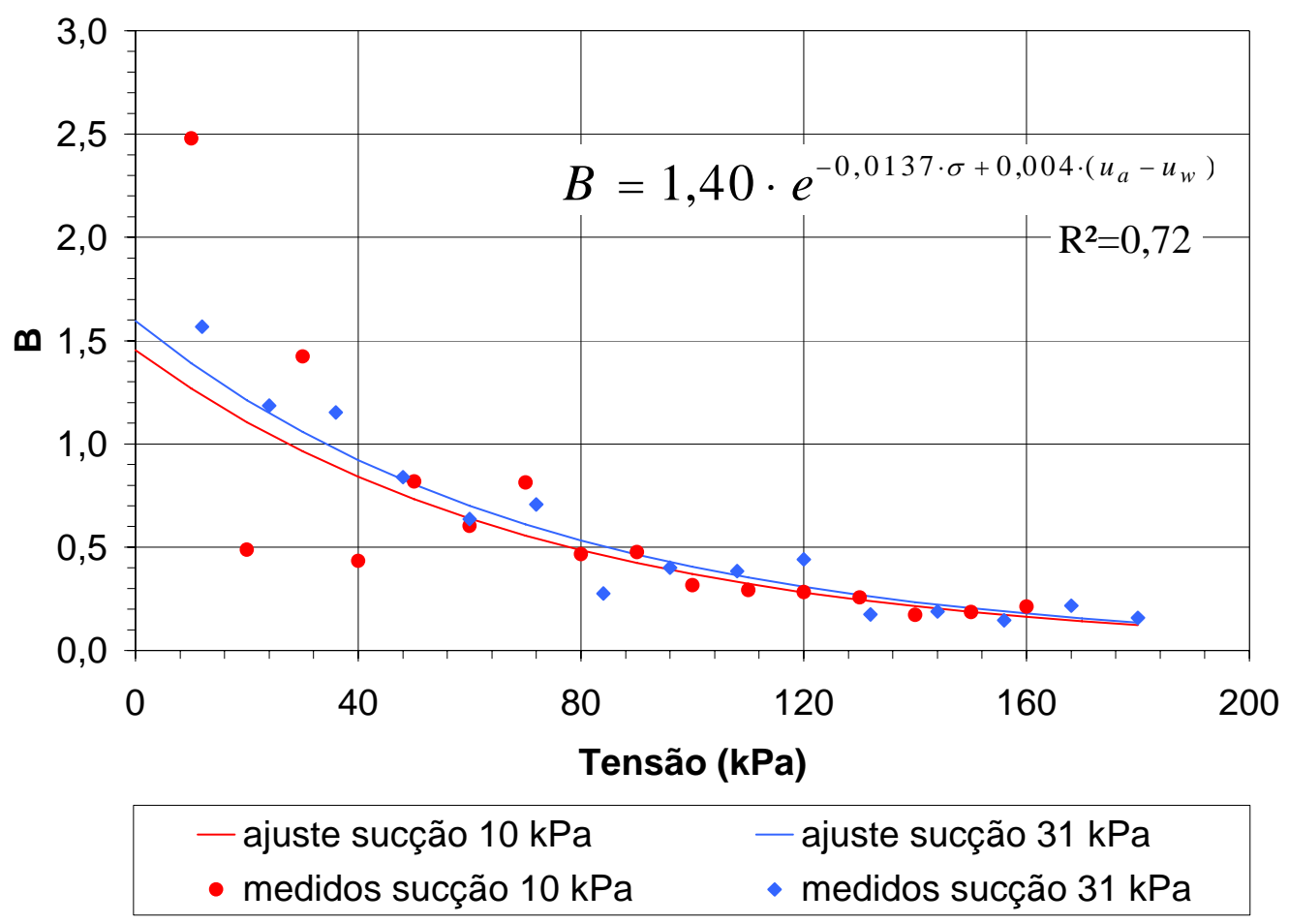

Figura 6.15 - Variação do parâmetro B em função do nível de tensão e da sucção, para ensaios não inundados.

Observa-se nestas figuras que o parâmetro $B$ apresenta uma tendência de diminuir com o aumento do nível de tensão. Para os ensaios com sucção nula (Figura 6.14), representou-se este comportamento pela equação (6.16). E para os demais ensaios, efetuou-se uma regressão múltipla para avaliar também a influência da sucção no valor de $B$. Na Figura 6.15 pode-se constatar que a sucção tem pouca influência sobre este parâmetro, podendo ser desconsiderada. Deste modo, para os ensaios não inundados o parâmetro $B$ é dado pela equação (6.17).

$$
\begin{aligned}
& \mathrm{B}=1,23 \cdot \mathrm{e}^{-0,020 \cdot \sigma} \\
& \mathrm{B}=1,40 \cdot \mathrm{e}^{-0,014 \cdot \sigma}
\end{aligned}
$$




\subsubsection{EXTRAPOLAÇÃO DOS ENSAIOS RÁPIDOS}

Substituindo-se as equações 6.11 e 6.12 na 6.15, pode-se fazer uma extrapolação dos recalques medidos nos ensaios rápidos para se obter os recalques estabilizados de um ensaio lento por:

$$
\rho_{\infty \mathrm{i}}=\frac{\left(\rho_{\mathrm{i}, \mathrm{t}}-\rho_{\mathrm{i}-1, \mathrm{t}}\right)}{\left[1-\mathrm{e}^{-\left(\mathrm{A} \cdot \mathrm{t}+\mathrm{B}_{\mathrm{i}}\right)}\right]}+\rho_{\mathrm{i}-1, \mathrm{t}}
$$

Nesta equação, o tempo $t$ se refere ao tempo fixo de estágio utilizado na prova de carga do tipo rápida que, no caso dos ensaios deste trabalho, corresponde a 15 minutos.

A título de exemplificação, na Figura 6.16 são apresentados os resultados de alguns ensaios rápidos medidos e estabilizados teoricamente, sendo estes em média $15 \%$ superiores aos medidos.

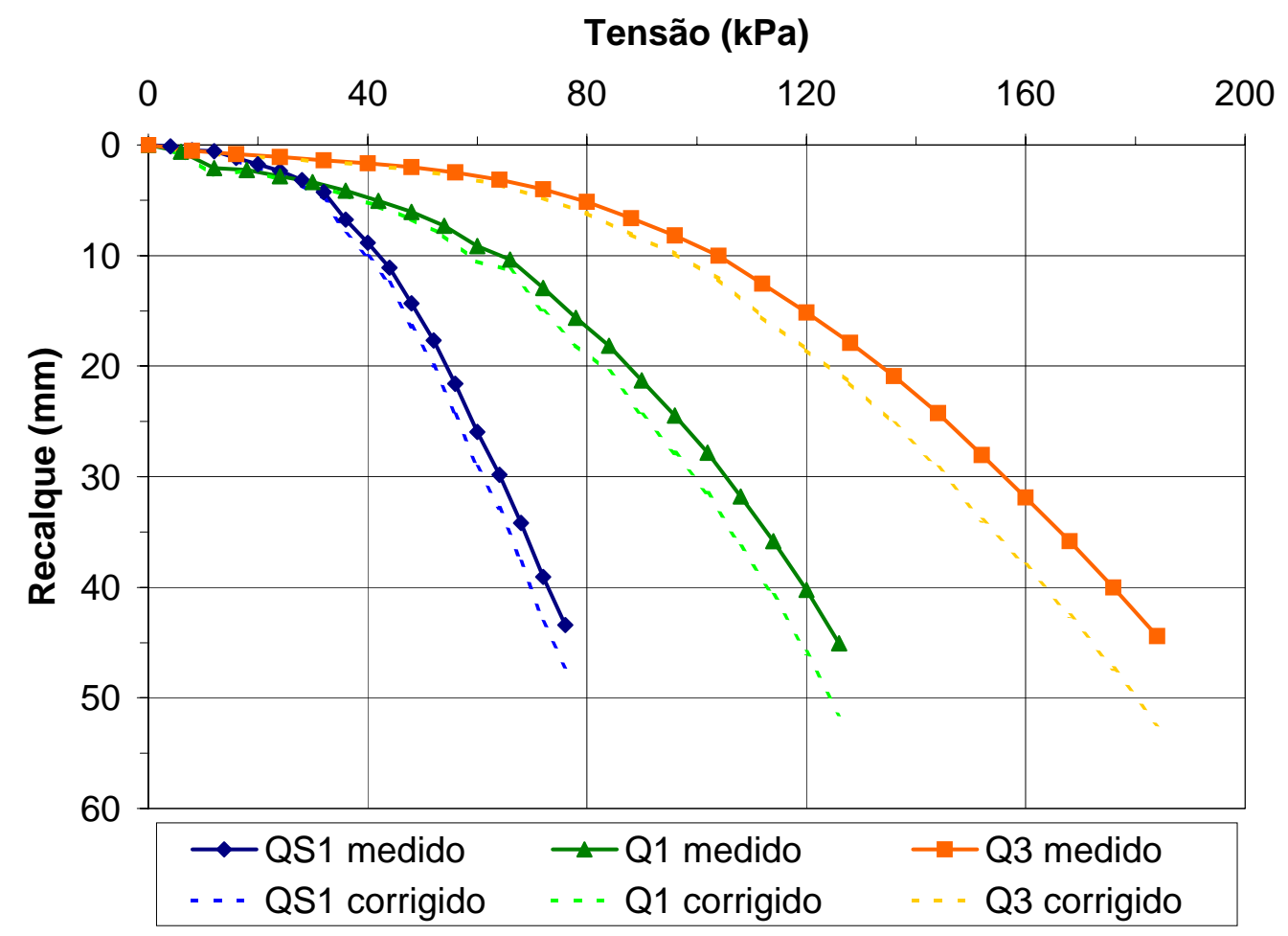

Figura 6.16 - Ensaios rápidos medidos e corrigidos (profundidade de 1,5 m e placa com diâmetro de $0,8 \mathrm{~m}$ ). 
A Figura 6.17 mostra a comparação das curvas tensão-recalque de dois ensaios rápidos (QS1 e QS2) corrigidos com as de três ensaios lentos (SS1, SS2 e SS3), todos com o solo inundado. De modo semelhante, a Figura 6.18 mostra as curvas de três ensaios mistos (MS1, MS2 e MS3), nos quais foi corrigida a fase rápida, e as dos três ensaios lentos (SS1, SS2 e SS3), também, com o solo inundado. Pode-se verificar que as extrapolações estão situadas na mesma faixa dos valores medidos em campo, o que comprova a eficiência do método proposto.

No caso da previsão da curva tensão-recalque de um ensaio rápido a partir da curva de um ensaio lento, como proposto no item 6.1, esta correção será utilizada de maneira inversa, ou seja, uma vez determinados os recalques estabilizados procede-se ao cálculo do recalque parcial, correspondente a um estágio com duração de 15 minutos.

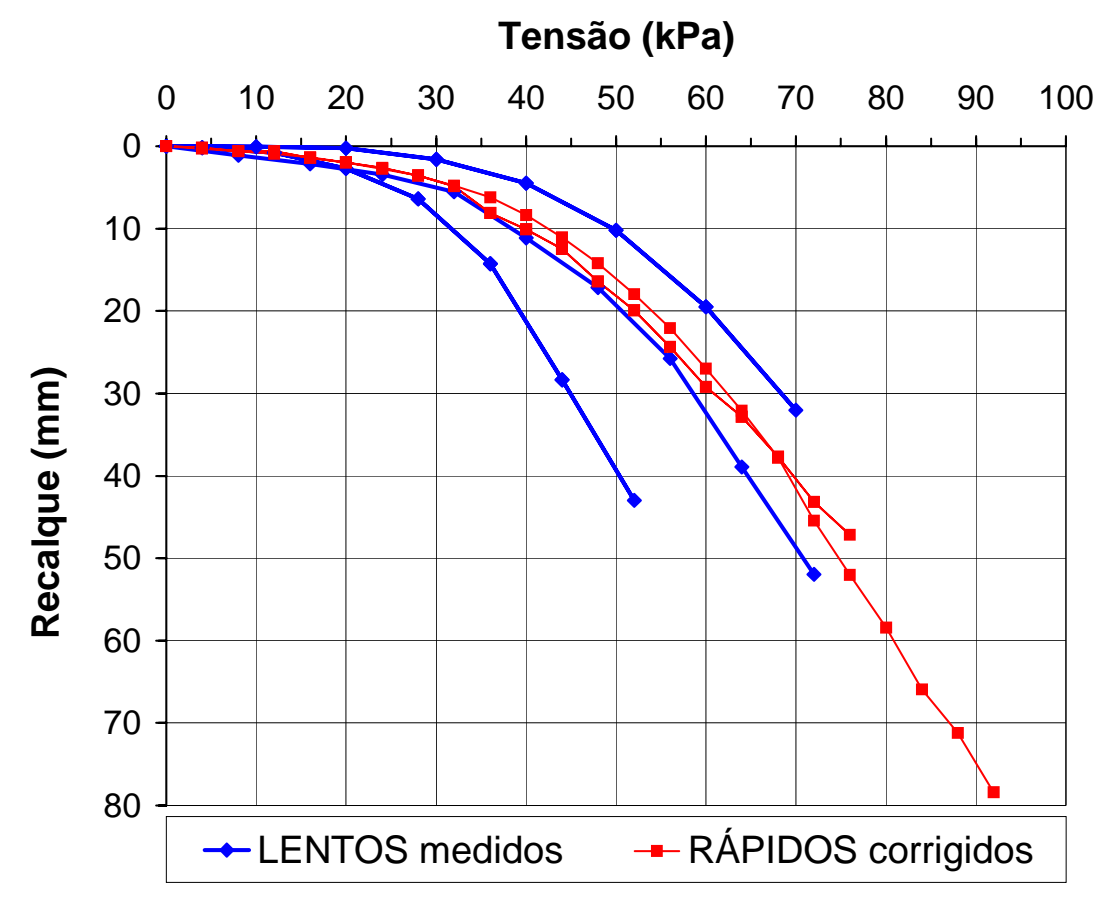

Figura 6.17 - Comparação entre os ensaios rápidos corrigidos com os ensaios lentos (solo inundado). 


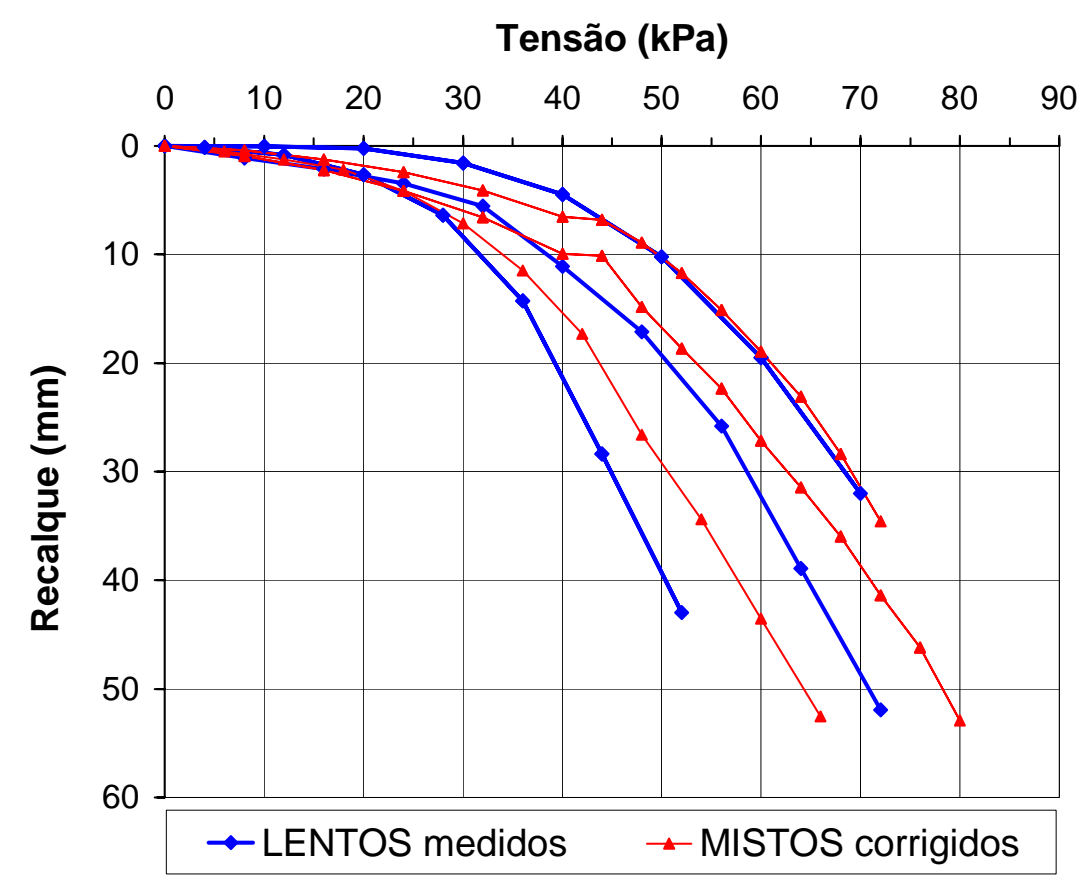

Figura 6.18 - Comparação entre os ensaios mistos corrigidos com os ensaios lentos (solo inundado).

\subsection{RESUMO DE APLICAÇÃO DOS MÉTODOS PROPOSTOS}

A seguir apresenta-se um resumo da aplicação dos métodos propostos com o objetivo de facilitar suas utilizações.

\subsubsection{PREVISÃO DA CURVA TENSÃO-RECALQUE DE ENSAIOS LENTOS}

Para a previsão da curva tensão-recalque devem ser seguidos os itens abaixo.

a) utilizar a expressão (6.1) para representar a curva tensão-recalque a ser obtida em ensaios de placa em solos não saturados do interior do Estado de São Paulo.

$$
\sigma=\frac{\rho}{a+b \cdot \rho}+c \cdot \rho
$$


b) determinar o coeficiente de recalque (k) pela expressão (6.4), na qual o valor de E é considerado como sendo o módulo tangente inicial $\left(\mathrm{E}_{0}\right)$ de curvas tensão-deformação, obtidas por meio de ensaios triaxiais com sucção controlada.

$$
\mathrm{k}=\frac{4 \cdot \mathrm{E}}{\mathrm{D} \cdot\left(1-v^{2}\right) \cdot \pi}
$$

c) determinar a tensão de cedência $\left(\sigma_{y}\right)$, em função da sucção desejada, por meio de ensaios de compressão confinada com controle de sucção.

d) calcular o valor do parâmetro " $b$ " pela expressão (6.5), na qual o valor de $\left(\sigma_{u}\right)$ é considerado como sendo igual à tensão de cedência $\left(\sigma_{y}\right)$.

$$
\mathrm{b}=\frac{1}{\sigma_{\mathrm{u}}}
$$

e) calcular o parâmetro “c” de acordo com o estado de inundação do solo. Para:

- ensaios inundados pela equação (6.9):

$$
\frac{\mathrm{c}}{\sigma_{\mathrm{y}}}=40,50 \cdot \mathrm{e}^{-0,855 \cdot \mathrm{D}}
$$

- ensaios não inundados pela equação (6.10):

$$
\frac{\mathrm{C}}{\sigma_{\mathrm{y}}}=27,61 \cdot \mathrm{e}^{-0,815 \cdot \mathrm{D}}
$$

f) determinar o parâmetro “ $a$ ” pela equação (6.2).

$$
\mathrm{a}=\frac{1}{\mathrm{k}-\mathrm{c}}
$$

g) definidos os parâmetros da equação (6.1), determinar vários pontos $(\sigma, \rho)$, correspondentes aos estágios de carregamento de uma prova de carga, para obter a curva tensão-recalque pelo método proposto. 


\subsubsection{PREVISÃO DA CURVA TENSÃO-RECALQUE DE ENSAIOS RÁPIDOS}

Uma vez prevista a curva tensão-recalque de um ensaio lento pode-se, a partir do recalque estabilizado de cada estágio de carregamento, calcular o recalque parcial correspondente por:

a) utilizar a expressão (6.15) para calcular o recalque parcial correspondente ao tempo de duração dos estágios de carregamento.

$$
\rho_{i, t}=\rho_{\infty_{i}-1} \cdot\left(\rho_{\infty_{i}}-\rho_{\infty_{i}-1}\right) \cdot\left[1-e^{-\left(A \cdot t+B_{i}\right)}\right\rfloor
$$

b) determinar o valor do parâmetro “A” pela equação (6.13), na qual o valor do coeficiente de adensamento do solo não saturado $\left(\mathrm{C}_{\mathrm{V}}{ }^{*}\right)$ obtido por meio dos ensaios de compressão confinada.

$$
\mathrm{A}=\frac{2,47 \cdot \mathrm{C}_{\mathrm{v}}{ }^{*}}{\mathrm{H}^{2}}, \quad \text { onde } \quad \mathrm{H}=\frac{\mathrm{D}}{2}
$$

c) determinar o valor do parâmetro "B” de acordo com o estado de inundação do solo. Para:

$\begin{array}{ll}\text { - ensaios inundados pela equação (6.16): } & B=1,23 \cdot e^{-0,020 \cdot \sigma} \\ \text { - ensaios não inundados pela equação (6.17): } & B=1,40 \cdot e^{-0,014 \cdot \sigma}\end{array}$

\subsection{APLICAÇÕES}

Neste item apresentam-se os resultados obtidos aplicando-se os métodos expostos anteriormente aos ensaios realizados no Campo Experimental da EESC/USP, considerando as correspondentes sucções medidas em campo.

Para a profundidade de $1,5 \mathrm{~m}$, consideraram-se nos cálculos a tensão de cedência média, em função da sucção, entre as profundidades de 1,0 m e 2,0 m (Figuras 6.3 e 6.4) e no caso dos ensaios realizados à 6,0 m, a tensão de cedência média entre as profundidades de 5,0 m e 7,0 m (Figuras 6.6 e 6.7). 
O valor do coeficiente de Poisson adotado nas análises foi de 0,20, correspondendo ao valor médio obtido a partir dos ensaios triaxiais com sucção controlada realizados por Machado (1998). Os valores do coeficiente de Poisson em função da sucção encontram-se no Apêndice C.

Os recalques obtidos nas previsões se referem aos estabilizados para os ensaios lentos e início dos mistos, e aos correspondentes a estágios de 15 minutos para os ensaios rápidos e final dos mistos. Nestes últimos, os valores dos recalques foram determinados através do exposto no item 6.3.

\subsubsection{ENSAIOS DE PLACA COM DIÂMETRO DE 0,8 m NA PROFUNDIDADE}

\section{DE 1,5 m}

Os resultados das previsões das curvas tensão-recalque para as placas com diâmetro de $0,80 \mathrm{~m}$ na profundidade de 1,5 m, juntamente com os experimentais, são mostrados nas Figuras 6.19 a 6.27. Além disso, as figuras apresentam os valores dos parâmetros $a, b$ e $c$ das curvas previstas. Para os ensaios rápidos e o final dos mistos as curvas foram ainda corrigidas conforme descrito no item 6.3.

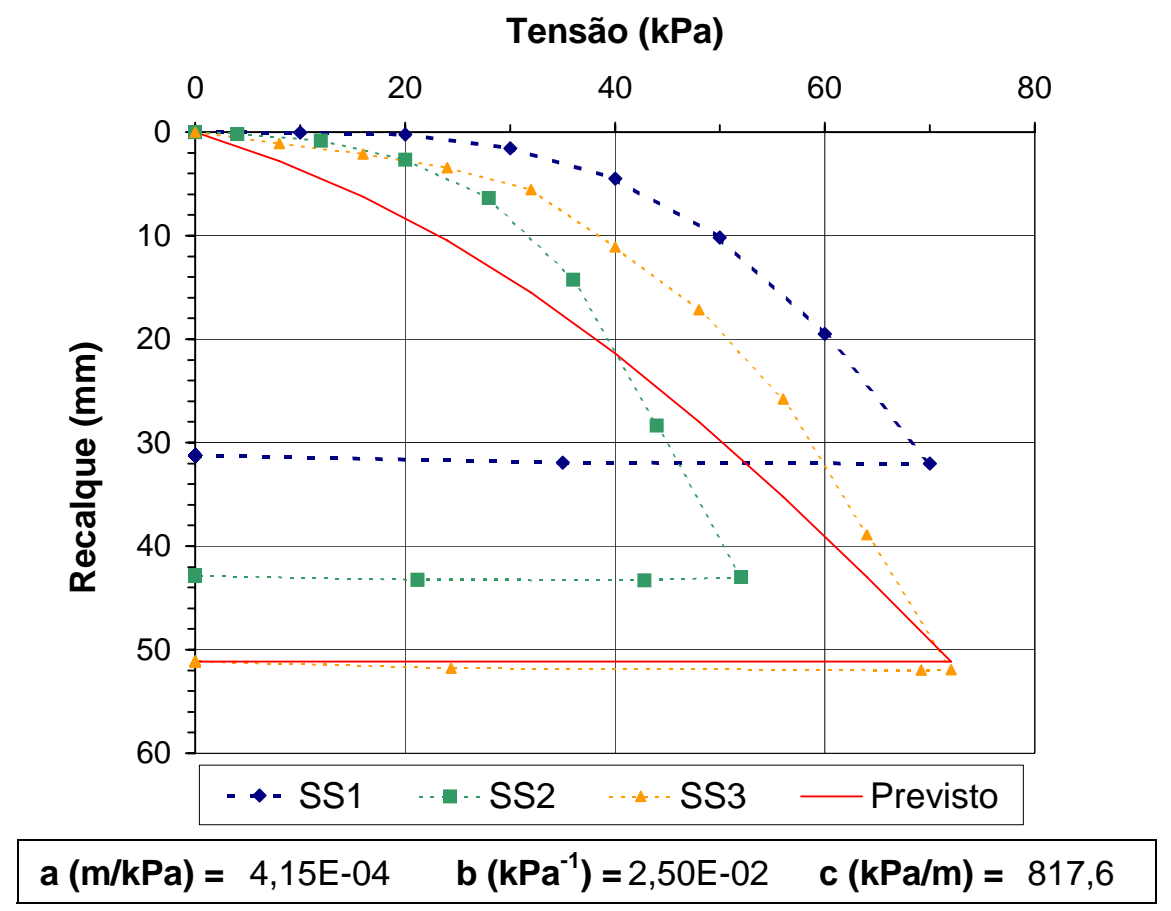

Figura 6.19 - Curvas tensão-recalque dos ensaios lentos inundados (sucção = $0 \mathrm{kPa}$ ), diâmetro de $0,8 \mathrm{~m}$ e na profundidade de $1,5 \mathrm{~m}$. 


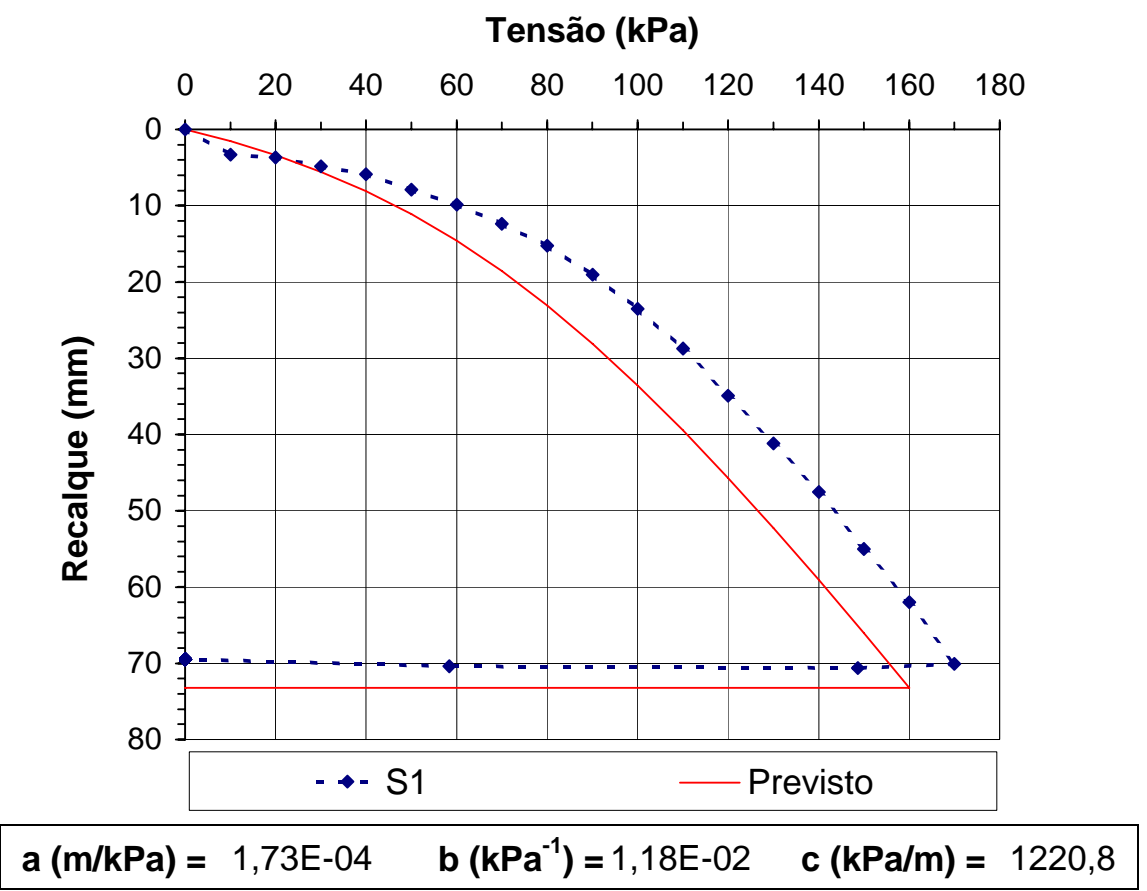

Figura 6.20 - Curvas tensão-recalque do ensaio lento S1 (sucção = 10 kPa), diâmetro de $0,8 \mathrm{~m}$ e na profundidade de $1,5 \mathrm{~m}$.

Tensão (kPa)

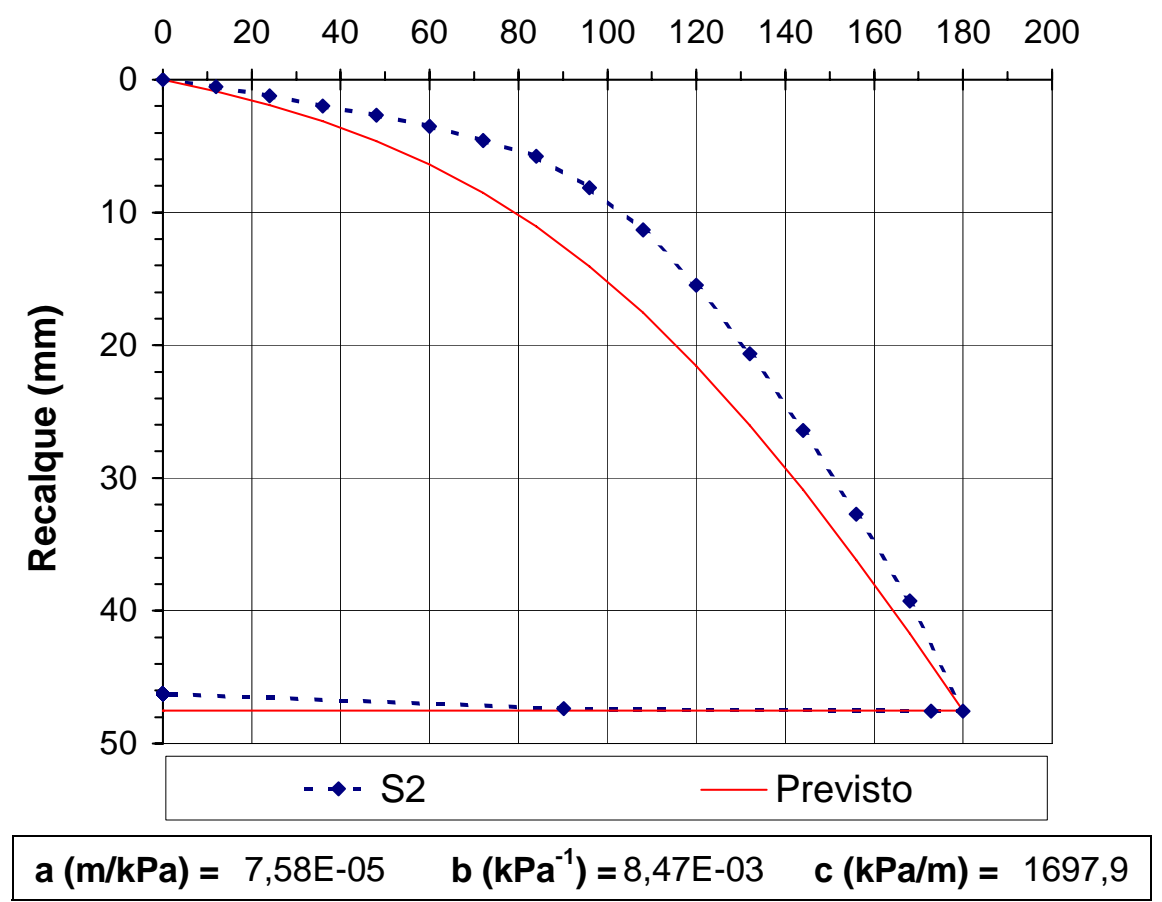

Figura 6.21 - Curvas tensão-recalque do ensaio lento S2 (sucção = $31 \mathrm{kPa}$ ), diâmetro de $0,8 \mathrm{~m}$ e na profundidade de $1,5 \mathrm{~m}$. 


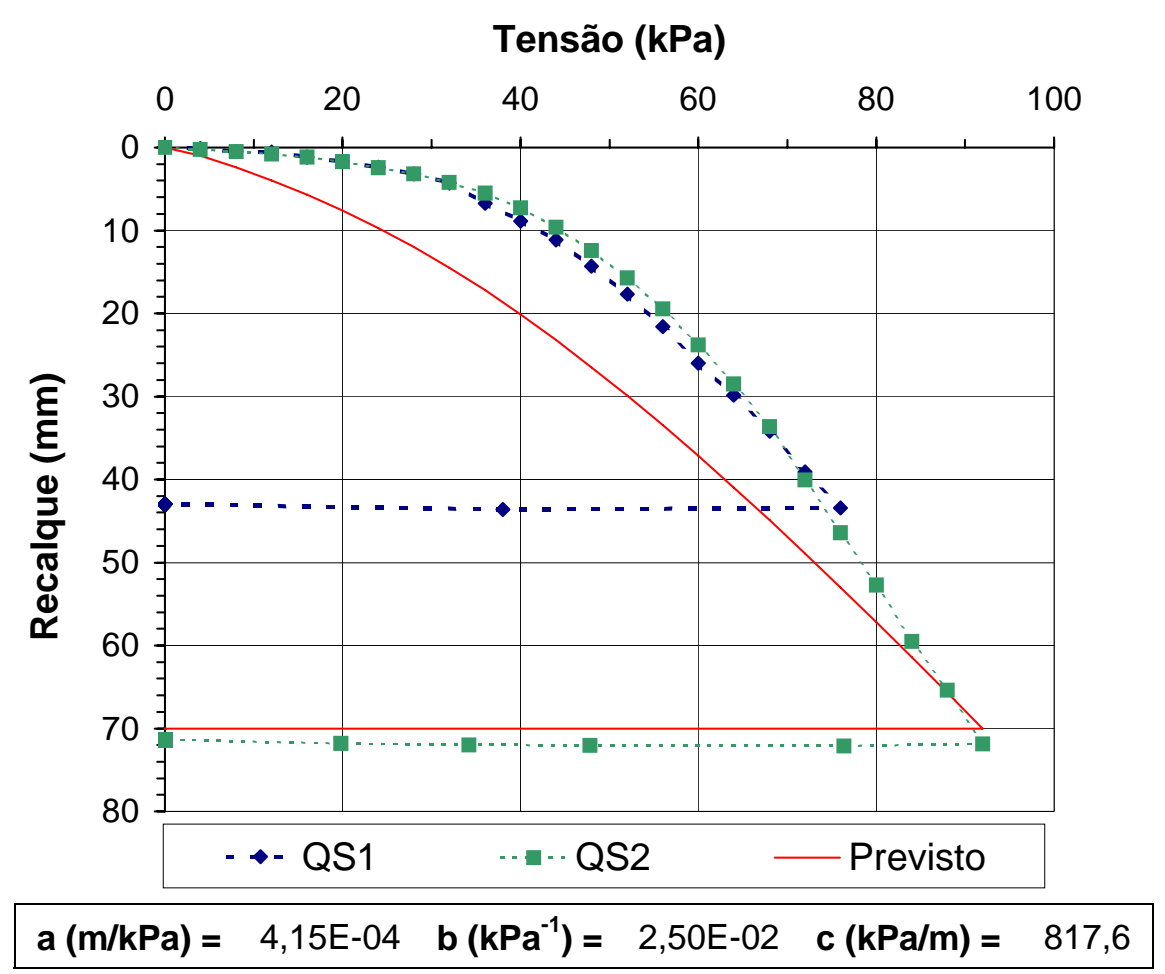

Figura 6.22 - Curvas tensão-recalque dos ensaios rápidos inundados (sucção $=0 \mathrm{kPa}$ ), diâmetro de $0,8 \mathrm{~m}$ e na profundidade de $1,5 \mathrm{~m}$.

Tensão (kPa)

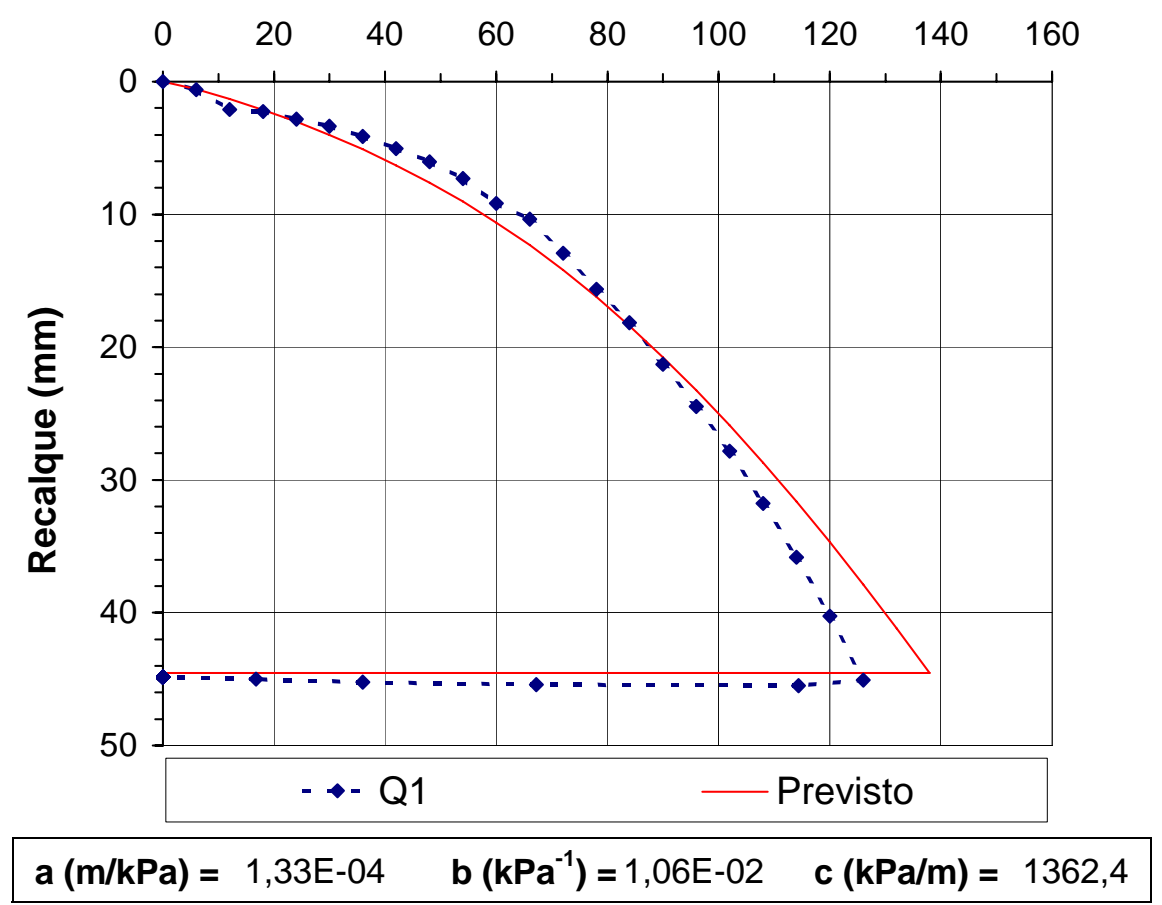

Figura 6.23 - Curvas tensão-recalque do ensaio rápido Q1 (sucção = 15 kPa), diâmetro de $0,8 \mathrm{~m}$ e na profundidade de $1,5 \mathrm{~m}$. 


\section{Tensão (kPa)}

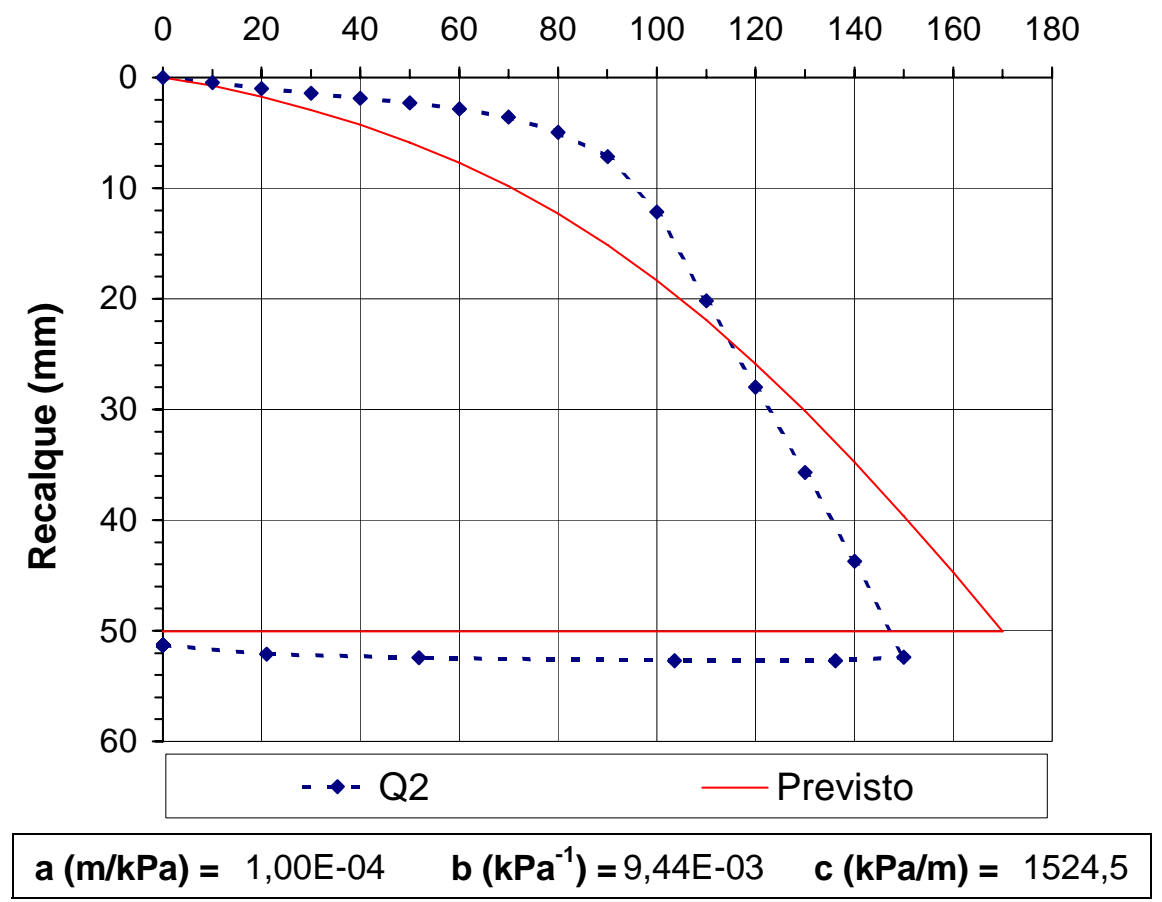

Figura 6.24 - Curvas tensão-recalque do ensaio rápido Q2 (sucção = $22 \mathrm{kPa}$ ), diâmetro de $0,8 \mathrm{~m}$ e na profundidade de $1,5 \mathrm{~m}$.

\section{Tensão (kPa)}

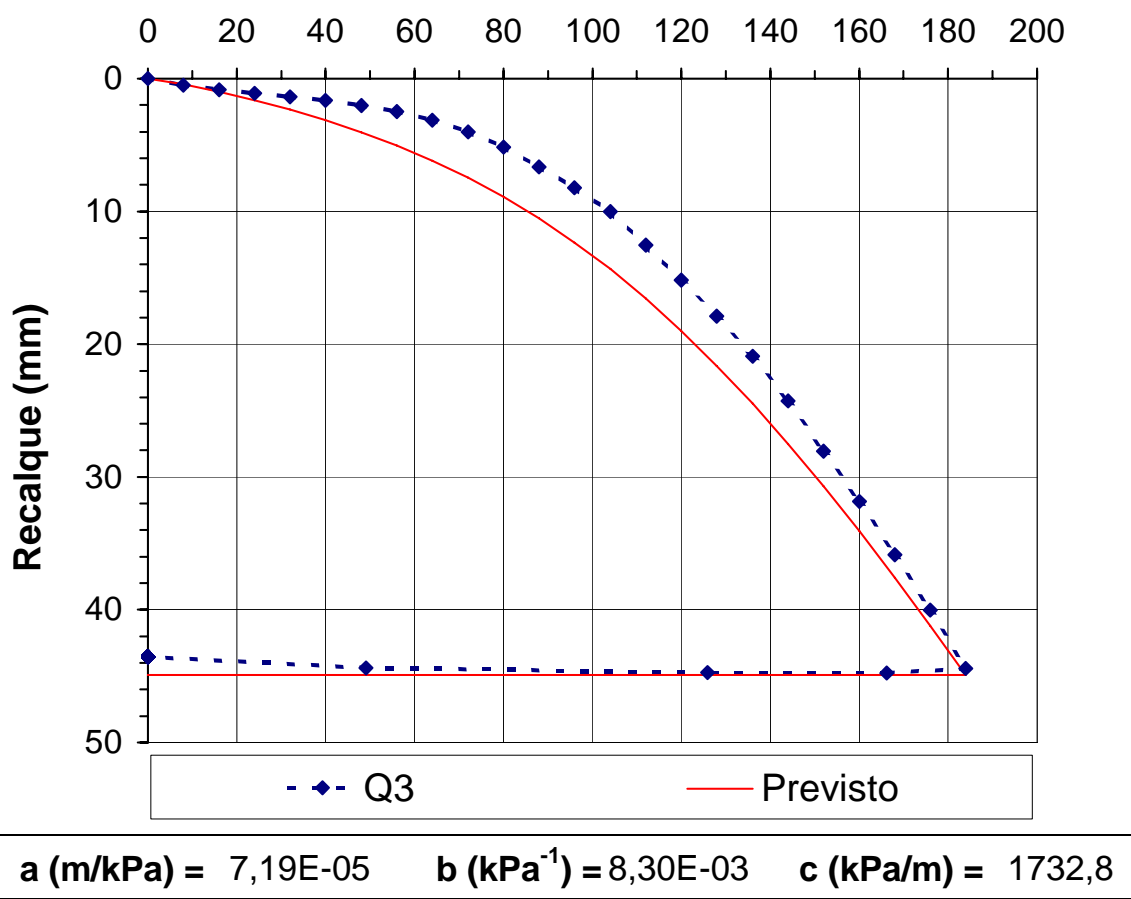

Figura 6.25 - Curvas tensão-recalque do ensaio rápido Q3 (sucção = 33 kPa), diâmetro de $0,8 \mathrm{~m}$ e na profundidade de $1,5 \mathrm{~m}$. 


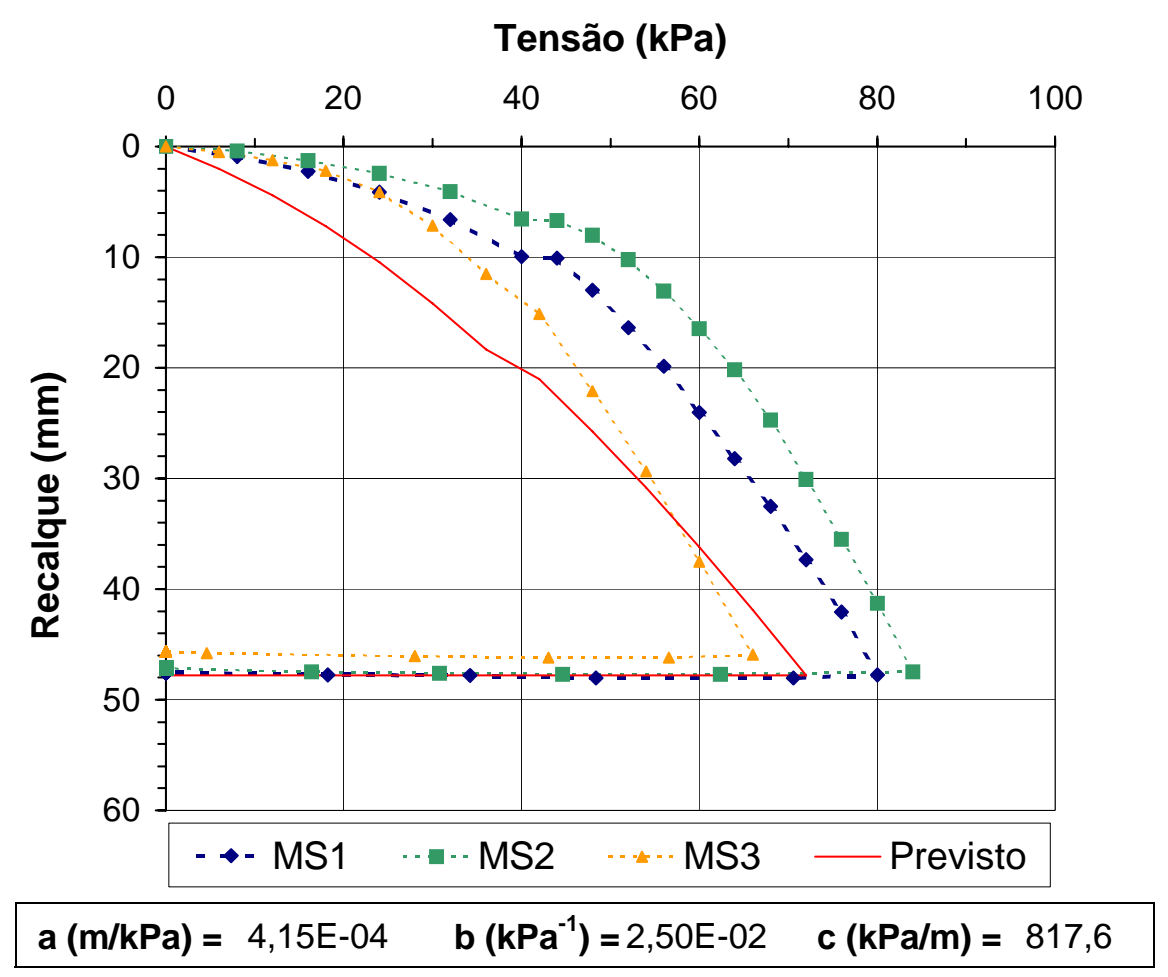

Figura 6.26 - Curvas tensão-recalque dos ensaios mistos inundados (sucção $=0 \mathrm{kPa}$ ), diâmetro de $0,8 \mathrm{~m}$ e na profundidade de $1,5 \mathrm{~m}$. 


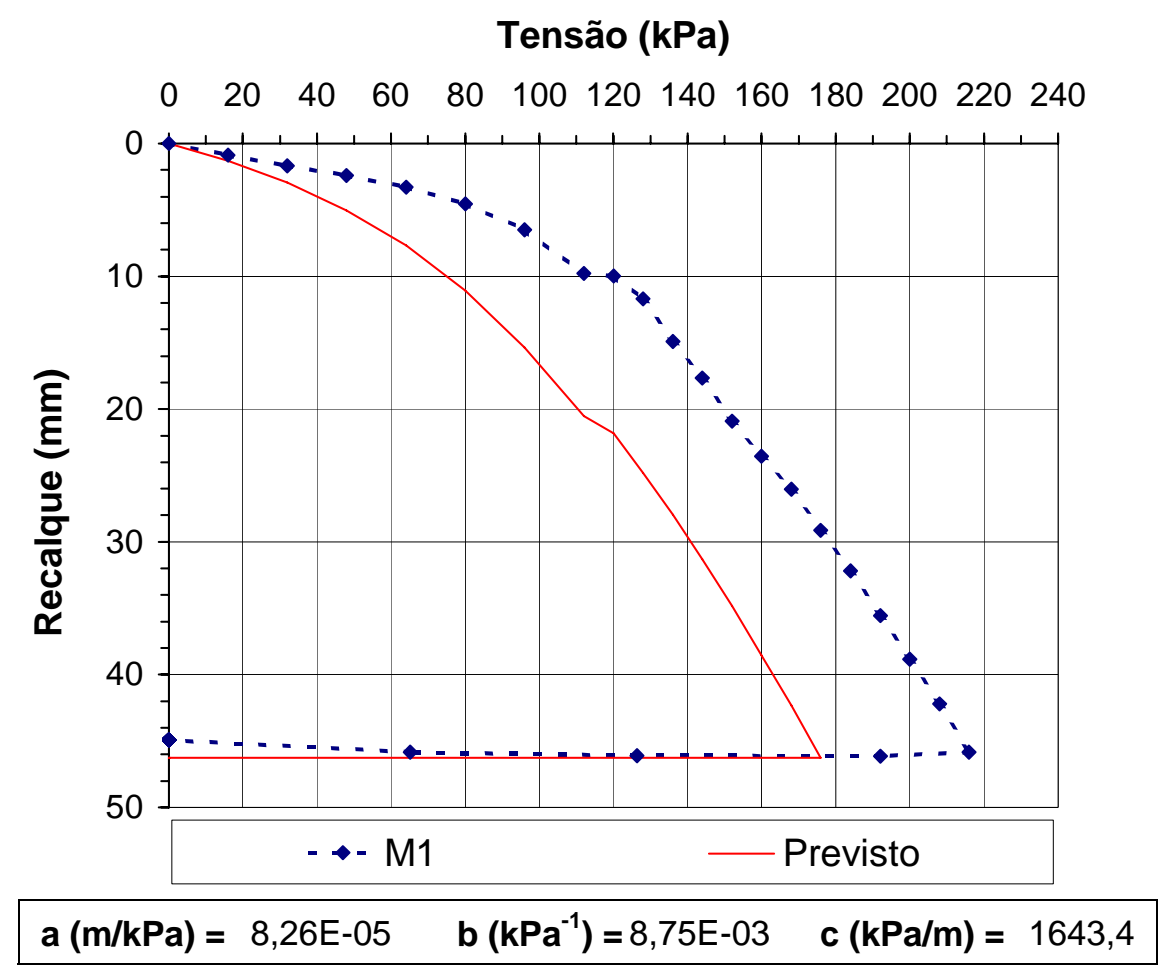

Figura 6.27 - Curvas tensão-recalque do ensaio misto M1 (sucção = 28 kPa), diâmetro de $0,8 \mathrm{~m}$ e na profundidade de $1,5 \mathrm{~m}$.

\subsubsection{ENSAIOS DE PLACA COM DIÂMETRO DE PROFUNDIDADES DE 4,0 E 6,0 m}

Os resultados das previsões das curvas tensão-recalque, juntamente com os experimentais, são apresentados nas Figuras 6.28 a 6.30, para as placas com diâmetro de 0,80 m na profundidade de 4,0 m, e nas Figuras 6.31 a 6.33, para os ensaios na profundidade de $6,0 \mathrm{~m}$. 


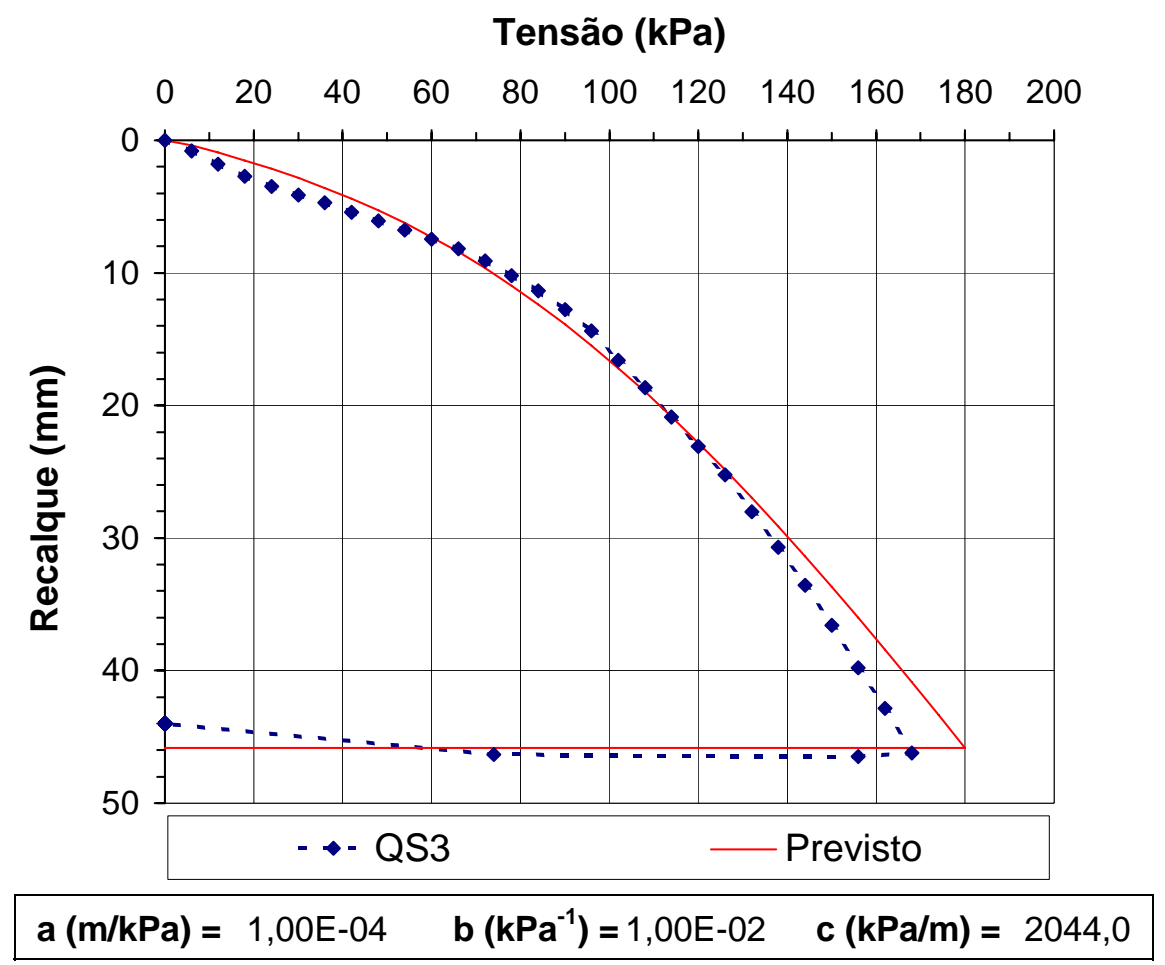

Figura 6.28 - Curvas tensão-recalque do ensaio rápido QS3 (sucção = 0 kPa), diâmetro de $0,8 \mathrm{~m}$ e na profundidade de $4,0 \mathrm{~m}$.

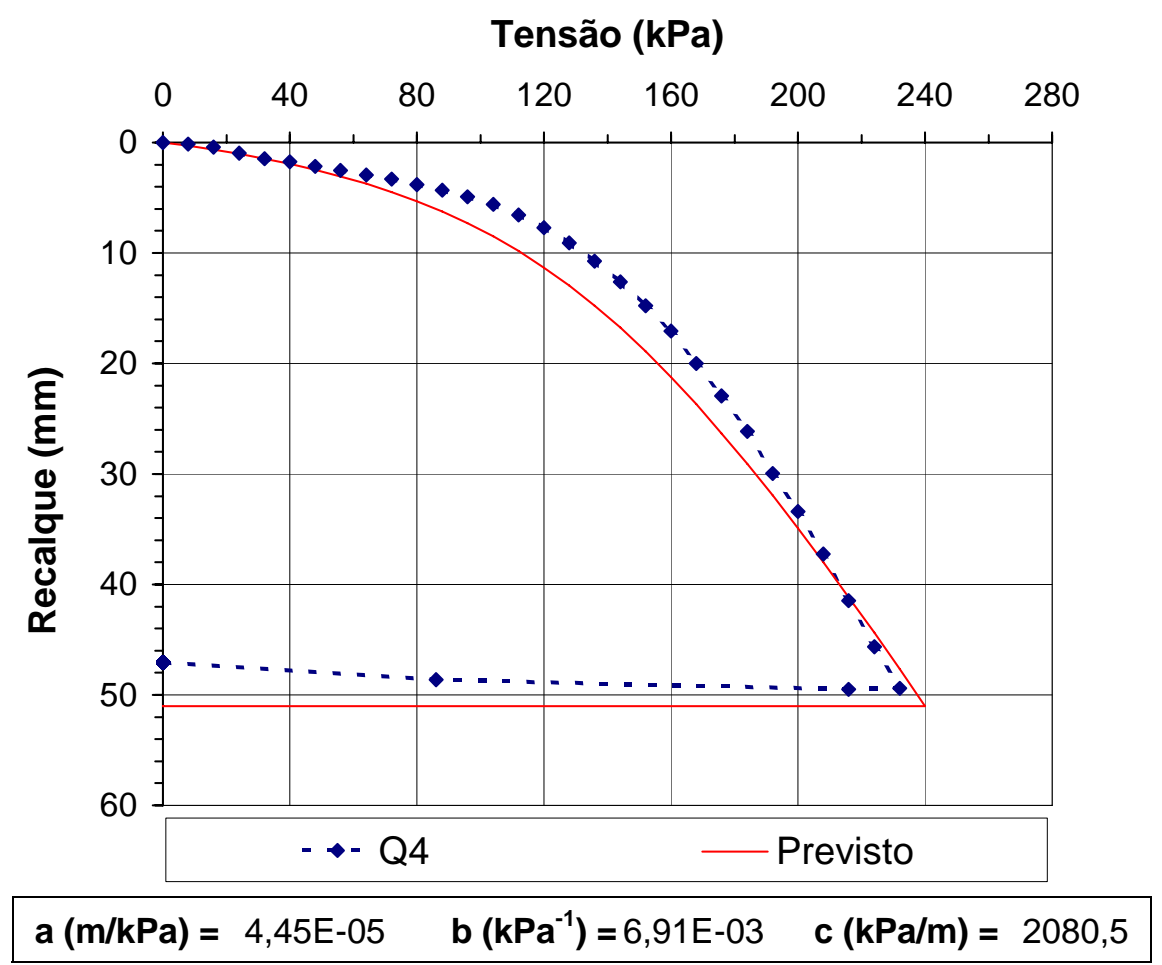

Figura 6.29 - Curvas tensão-recalque do ensaio rápido Q4 (sucção = 18 kPa), diâmetro de $0,8 \mathrm{~m}$ e na profundidade de $4,0 \mathrm{~m}$. 


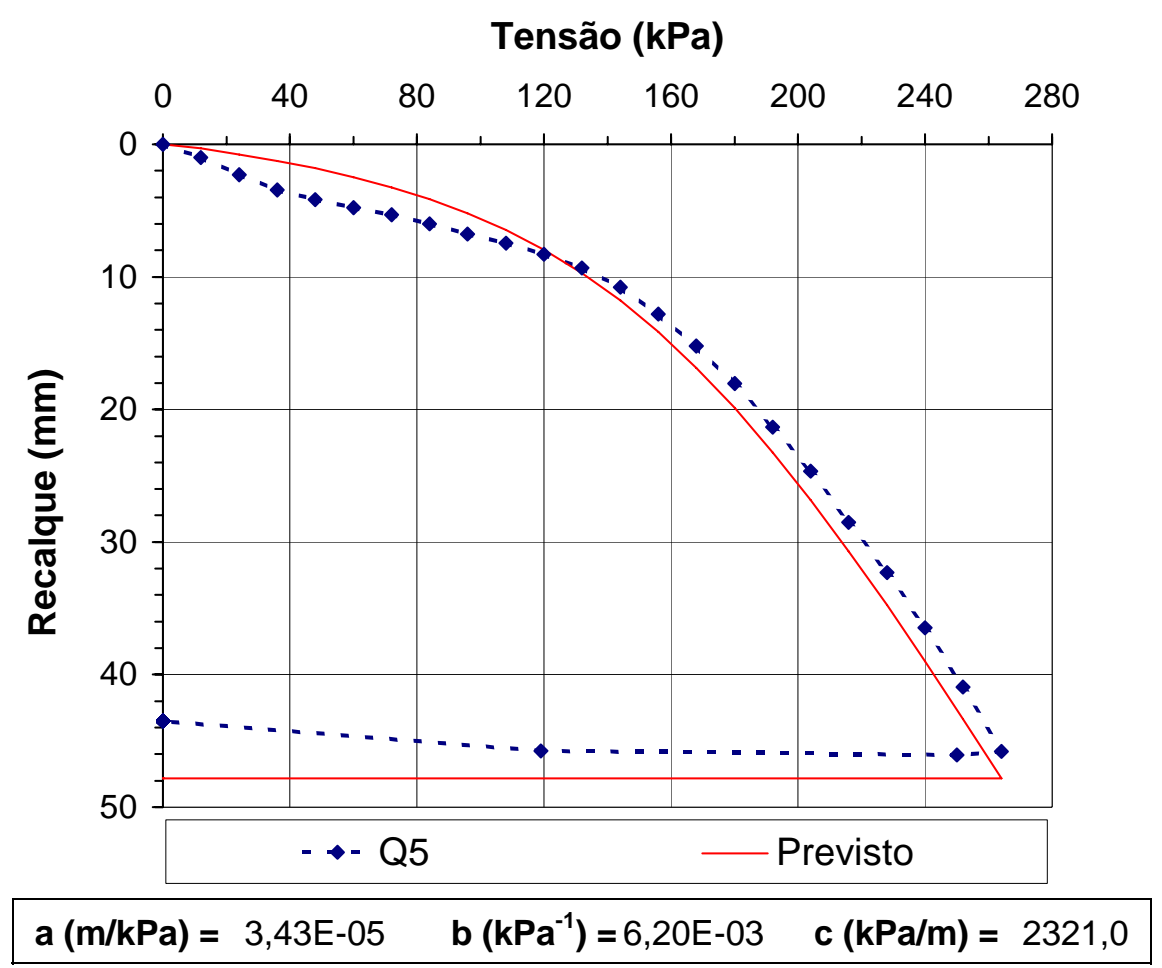

Figura 6.30 - Curvas tensão-recalque do ensaio rápido Q5 (sucção = 28 kPa), diâmetro de $0,8 \mathrm{~m}$ e na profundidade de $4,0 \mathrm{~m}$.

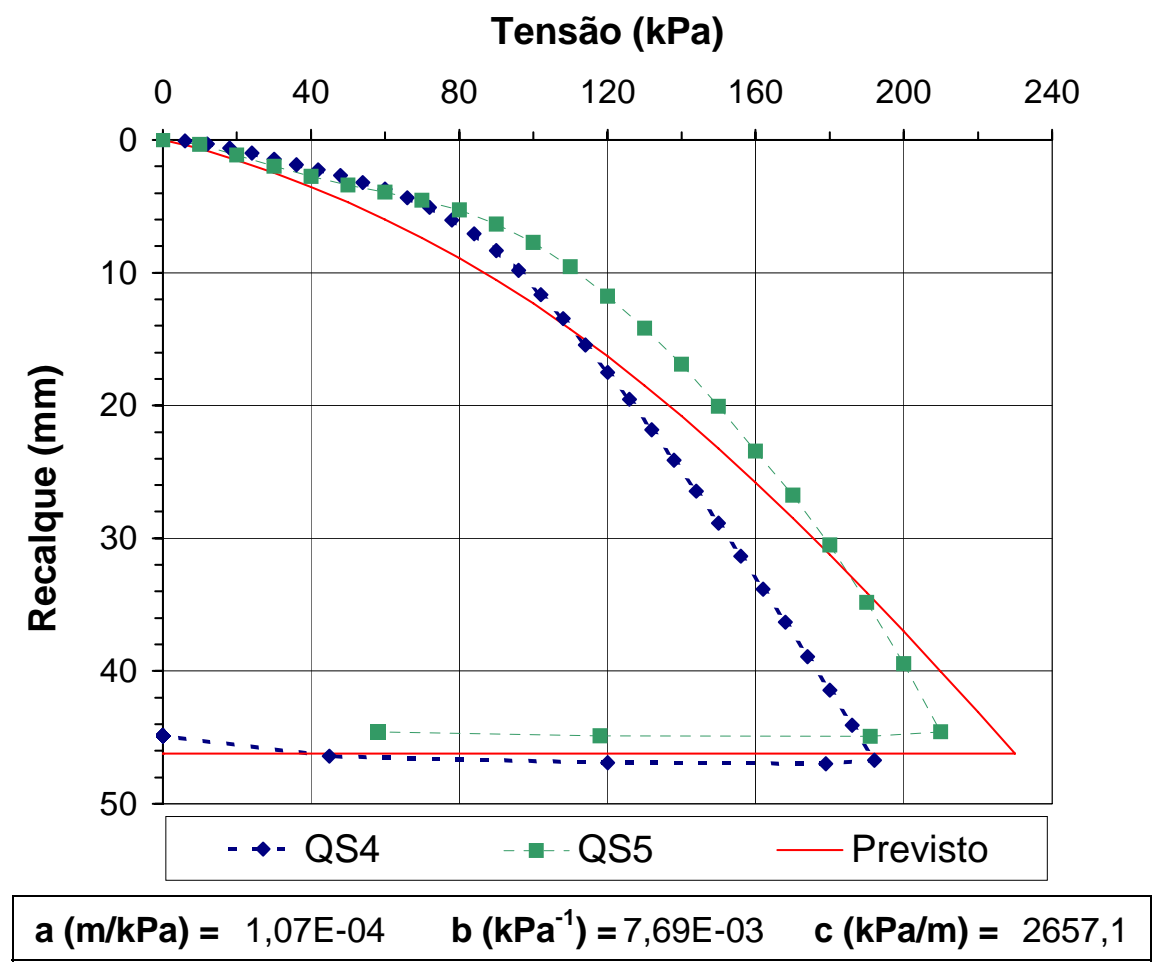

Figura 6.31 - Curvas tensão-recalque dos ensaios rápidos inundados (sucção = $0 \mathrm{kPa}$ ), diâmetro de 0,8 m e na profundidade de 6,0 m. 


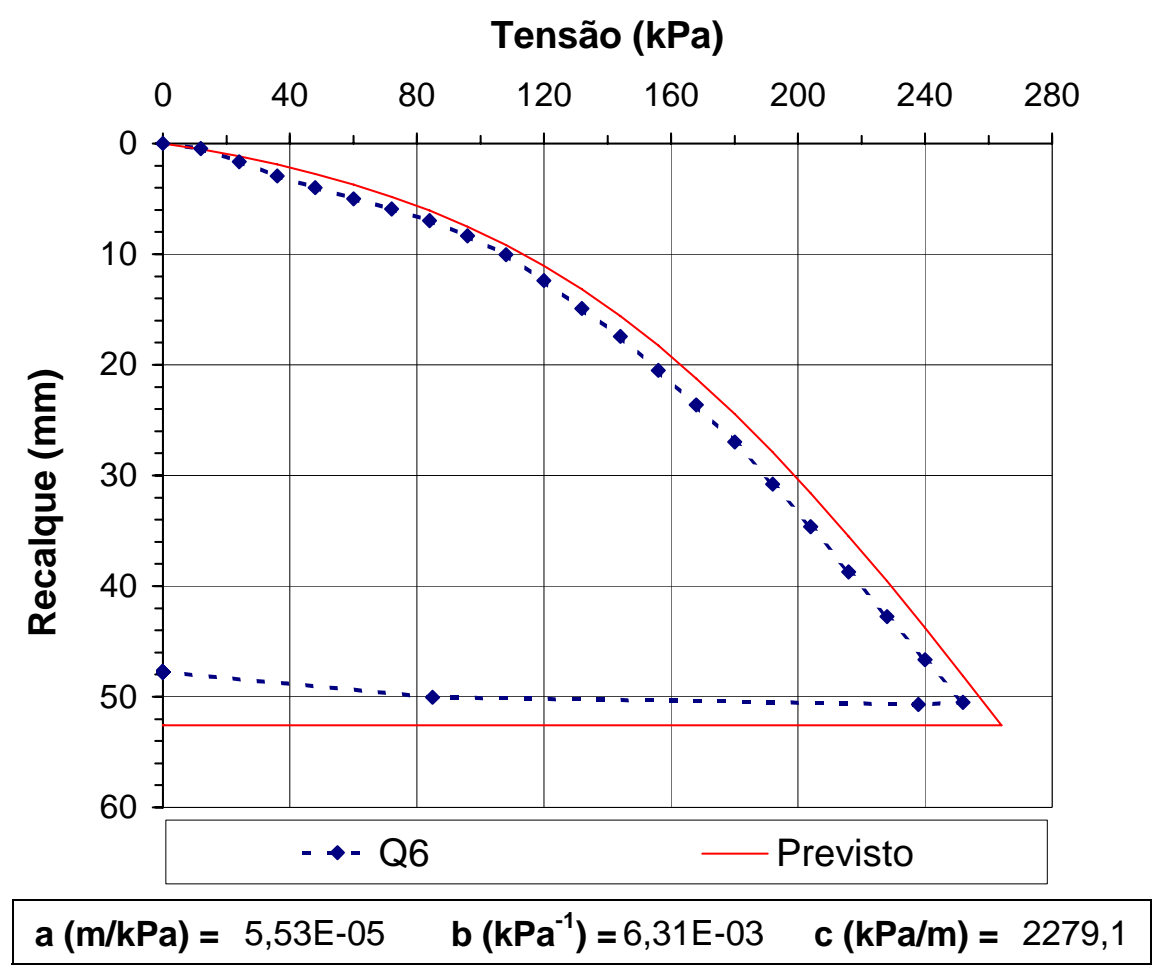

Figura 6.32 - Curvas tensão-recalque do ensaio rápido Q6 (sucção = $12 \mathrm{kPa}$ ), diâmetro de $0,8 \mathrm{~m}$ e na profundidade de $6,0 \mathrm{~m}$.

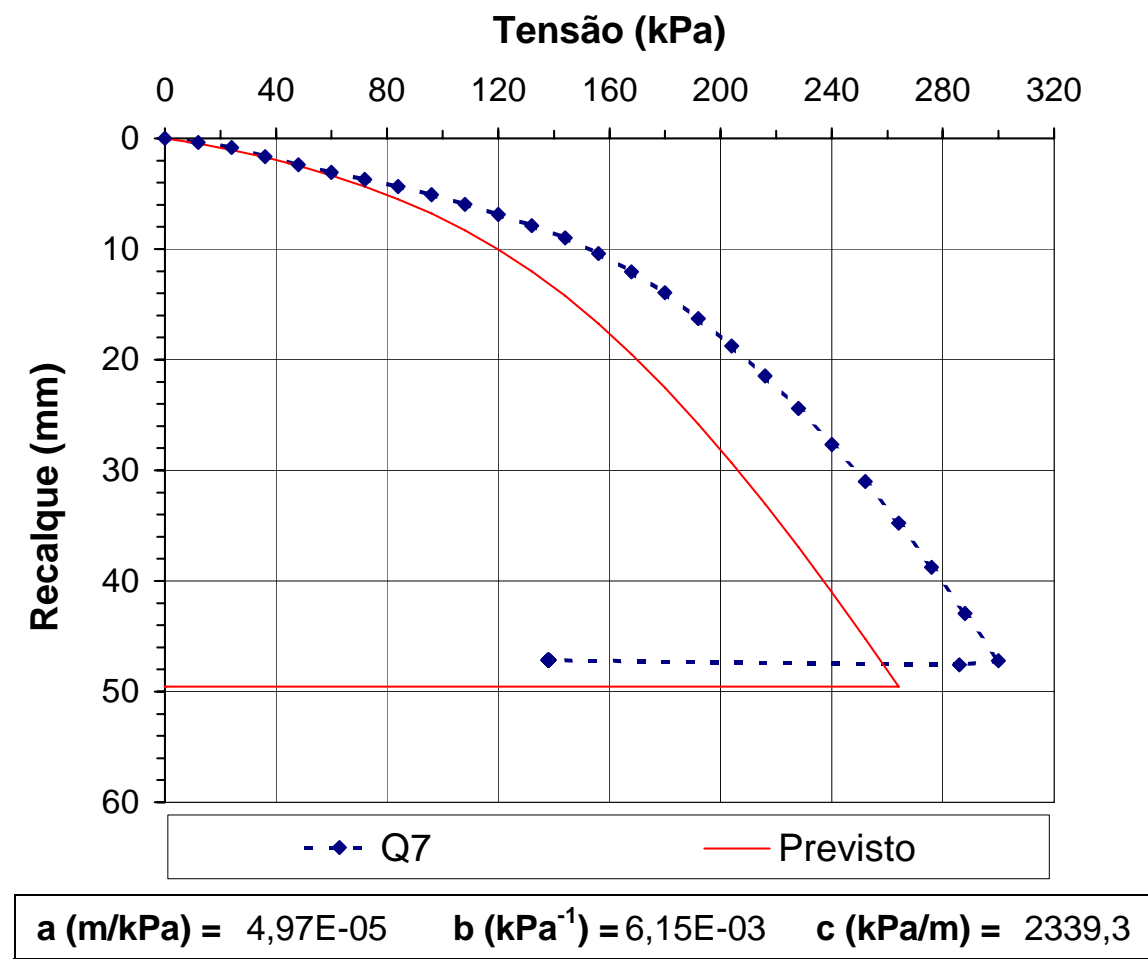

Figura 6.33 - Curvas tensão-recalque do ensaio rápido Q7 (sucção = 15 kPa), diâmetro de $0,8 \mathrm{~m}$ e na profundidade de $6,0 \mathrm{~m}$. 


\subsubsection{ENSAIOS DE PLACA COM DIÂMETROS DE $0,2,0,4$ E 1,5 m NA PROFUNDIDADE DE $1,5 \mathrm{~m}$}

Os resultados das previsões das curvas tensão-recalque para os demais ensaios realizados na profundidade de 1,5 m, porém, com placas de diâmetros diferentes de 0,80 m, são mostrados nas Figuras 6.34 a 6.42. Os ensaios com placa de 0,20 m são mostrados nas Figuras 6.34 a 6.36, os de placa igual a 0,4 m nas Figuras 6.37 a 6.39 e, finalmente, os ensaios de 1,5m de diâmetro podem ser visualizados nas Figuras 6.40 a 6.42 .

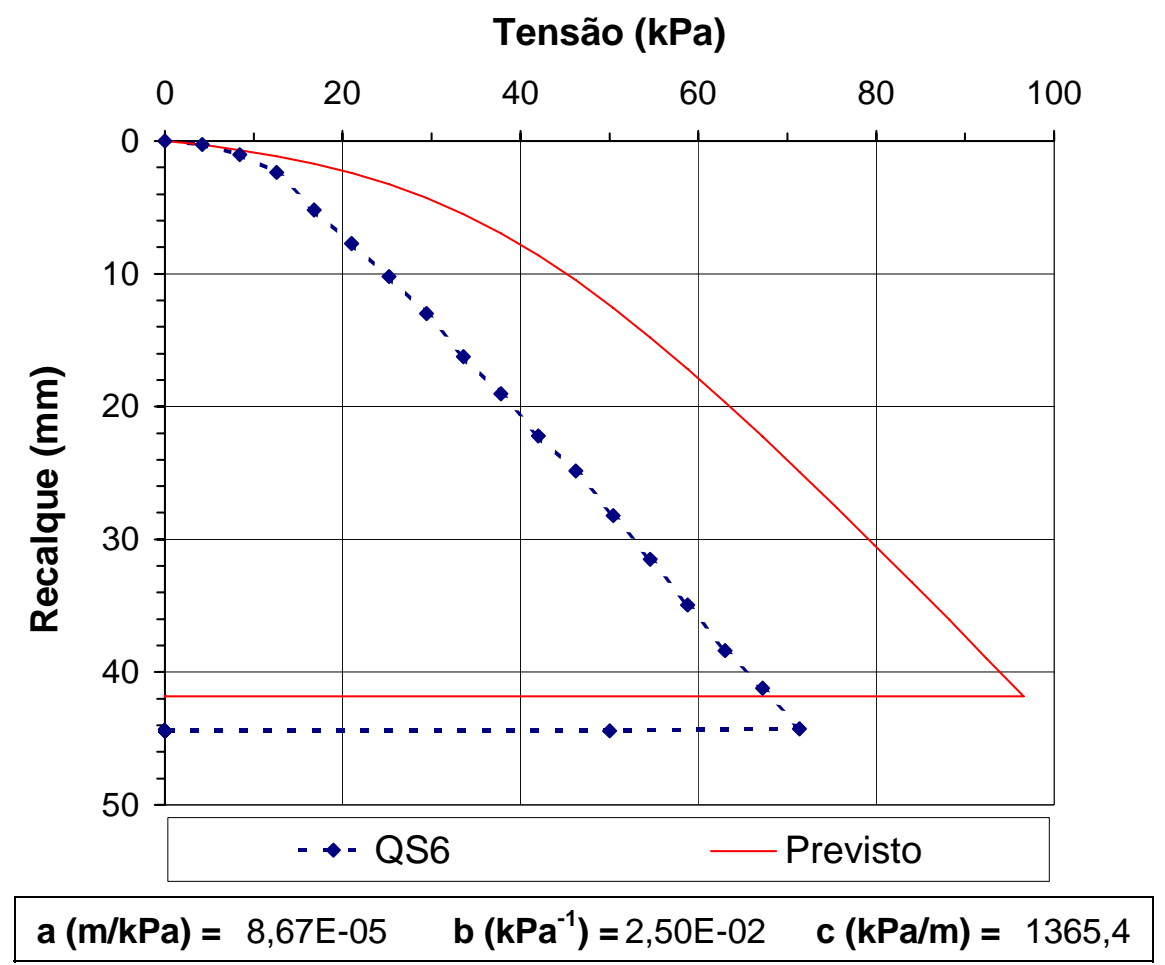

Figura 6.34 - Curvas tensão-recalque do ensaio rápido QS6 (sucção = 0 kPa), diâmetro de $0,2 \mathrm{~m}$ e na profundidade de $1,5 \mathrm{~m}$. 


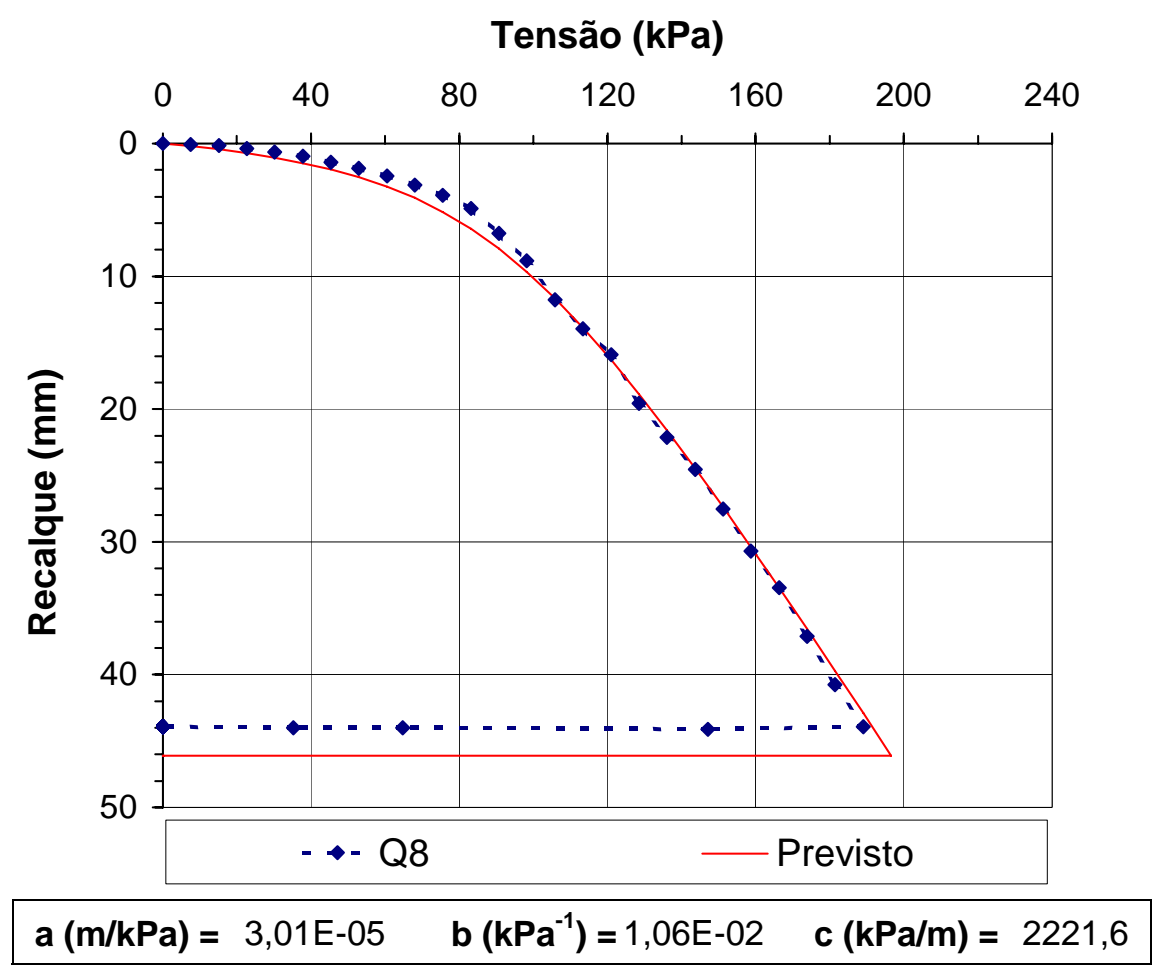

Figura 6.35 - Curvas tensão-recalque do ensaio rápido Q8 (sucção = $15 \mathrm{kPa}$ ), diâmetro de $0,2 \mathrm{~m}$ e na profundidade de $1,5 \mathrm{~m}$.

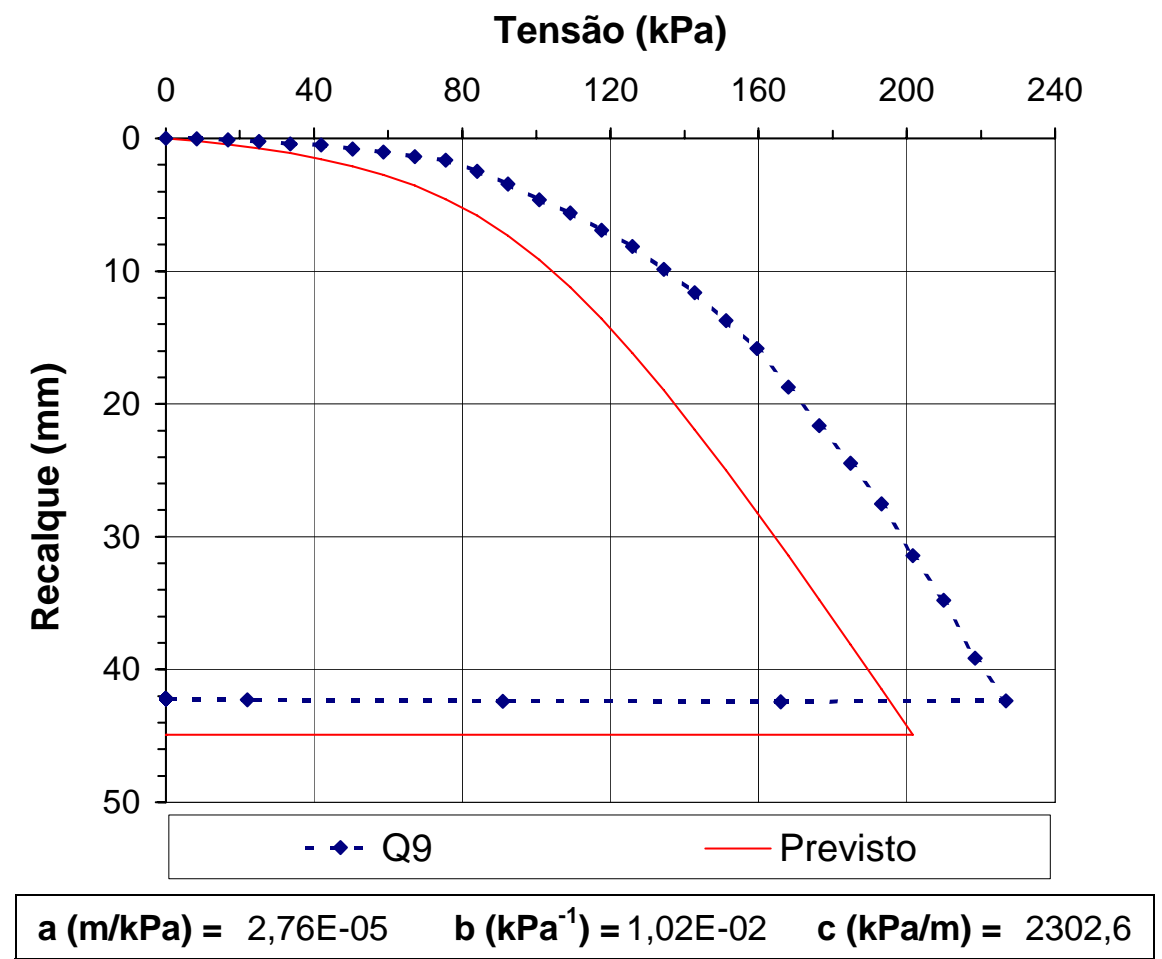

Figura 6.36 - Curvas tensão-recalque do ensaio rápido Q9 (sucção = 17 kPa), diâmetro de $0,2 \mathrm{~m}$ e na profundidade de $1,5 \mathrm{~m}$. 


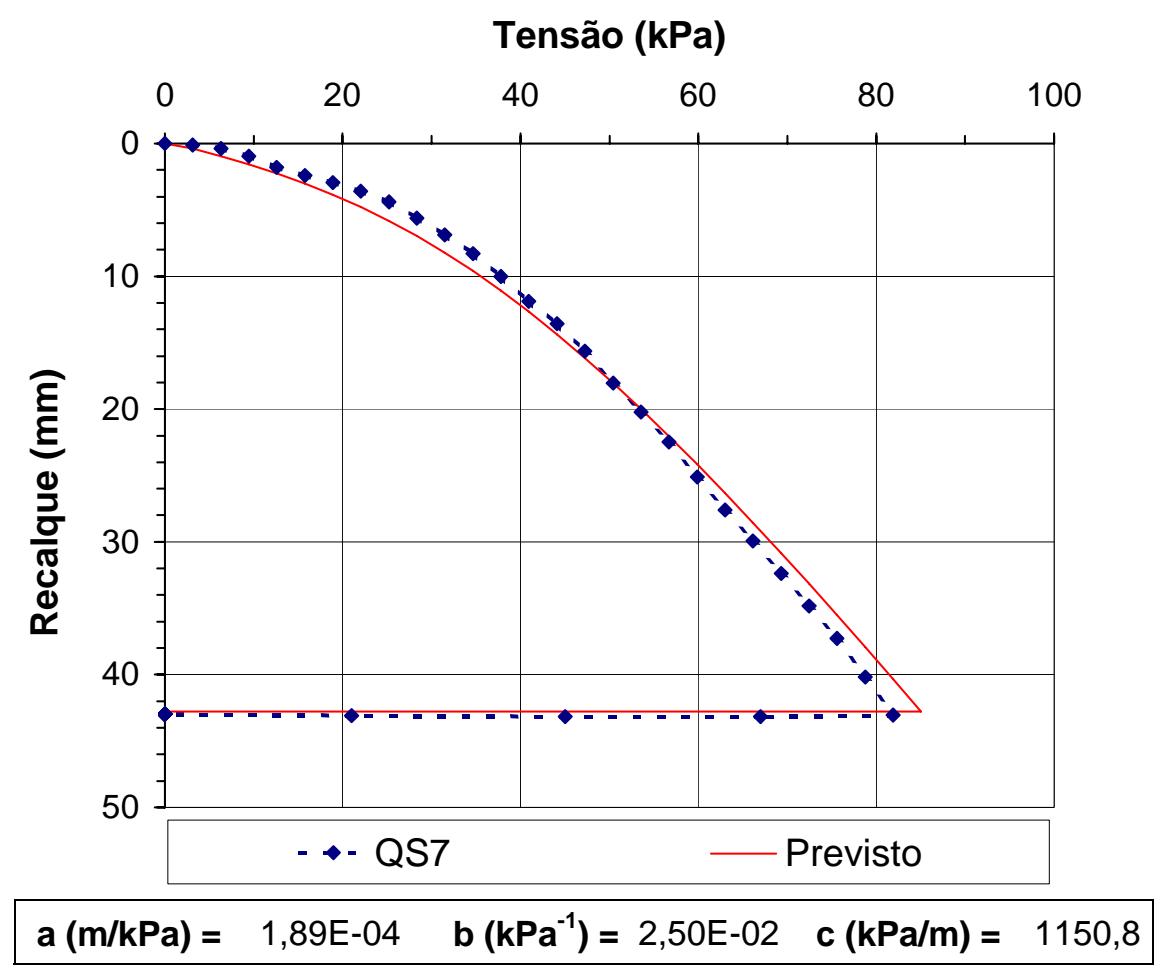

Figura 6.37 - Curvas tensão-recalque do ensaio rápido QS7 (sucção = 0 kPa), diâmetro de $0,4 \mathrm{~m}$ e na profundidade de $1,5 \mathrm{~m}$.

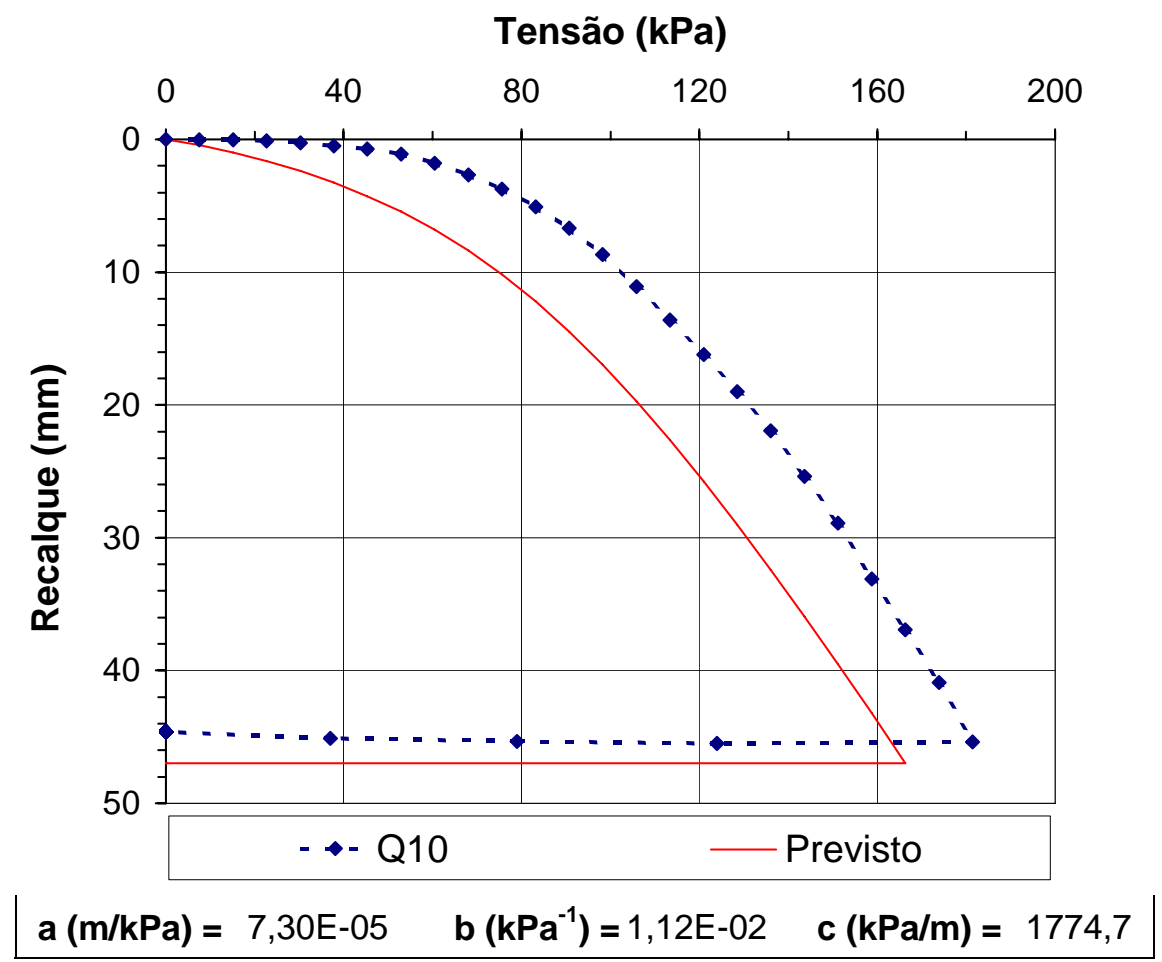

Figura 6.38 - Curvas tensão-recalque do ensaio rápido Q10 (sucção = $12 \mathrm{kPa}$ ), diâmetro de 0,4 m e na profundidade de 1,5 m. 


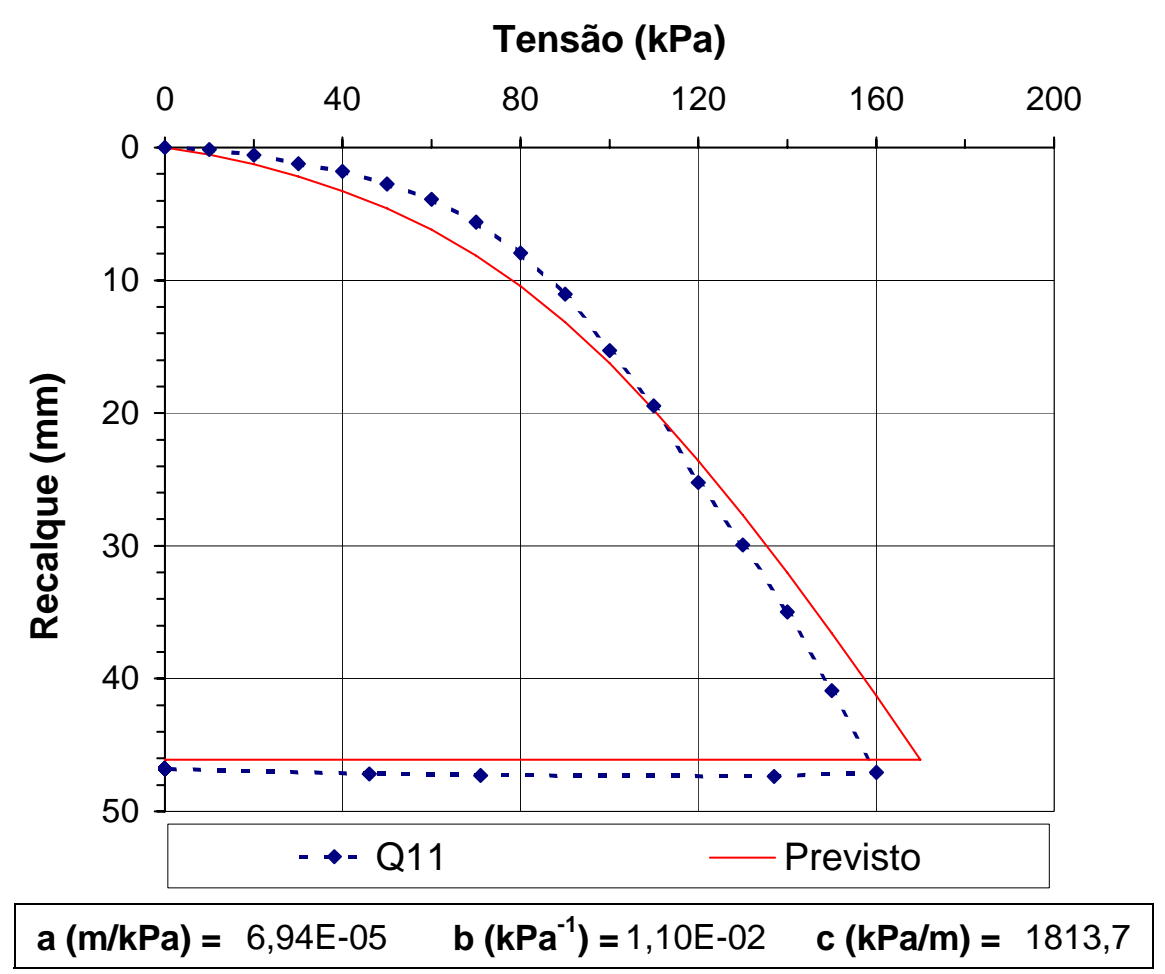

Figura 6.39 - Curvas tensão-recalque do ensaio rápido Q11 (sucção = 13 kPa), diâmetro de $0,4 \mathrm{~m}$ e na profundidade de $1,5 \mathrm{~m}$.

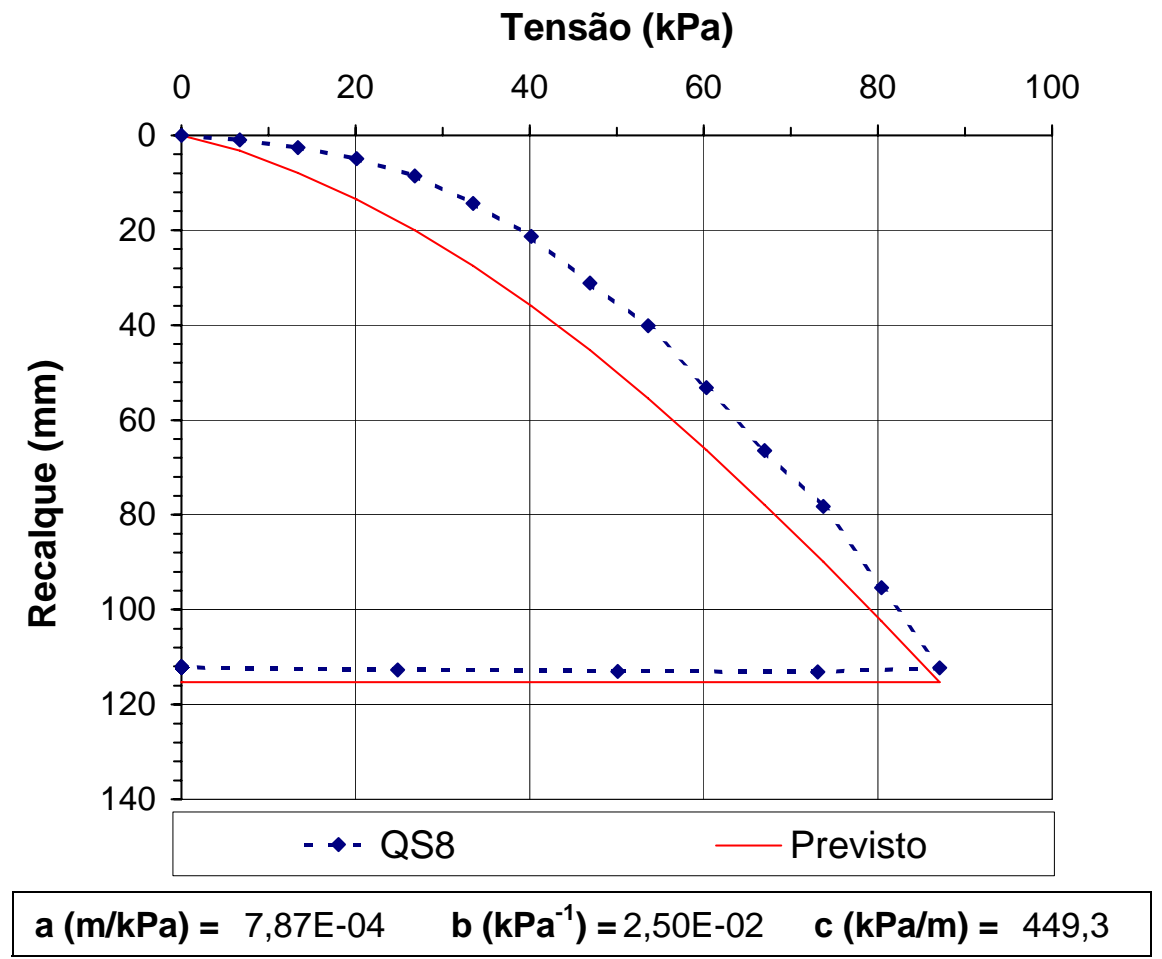

Figura 6.40 - Curvas tensão-recalque do ensaio rápido QS8 (sucção = 0 kPa), diâmetro de $1,5 \mathrm{~m}$ e na profundidade de $1,5 \mathrm{~m}$. 


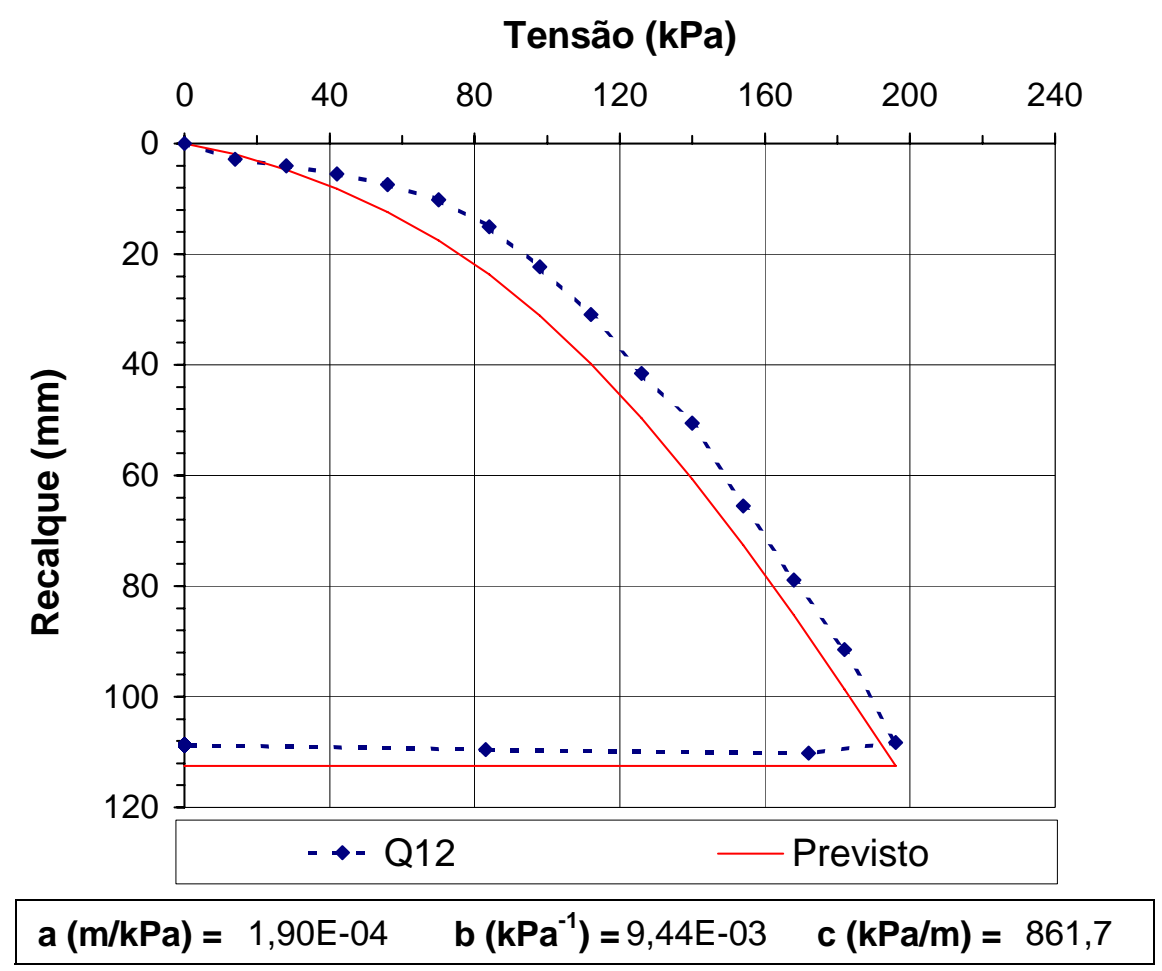

Figura 6.41 - Curvas tensão-recalque do ensaio rápido Q12 (sucção = 22 kPa), diâmetro de $1,5 \mathrm{~m}$ e na profundidade de $1,5 \mathrm{~m}$.

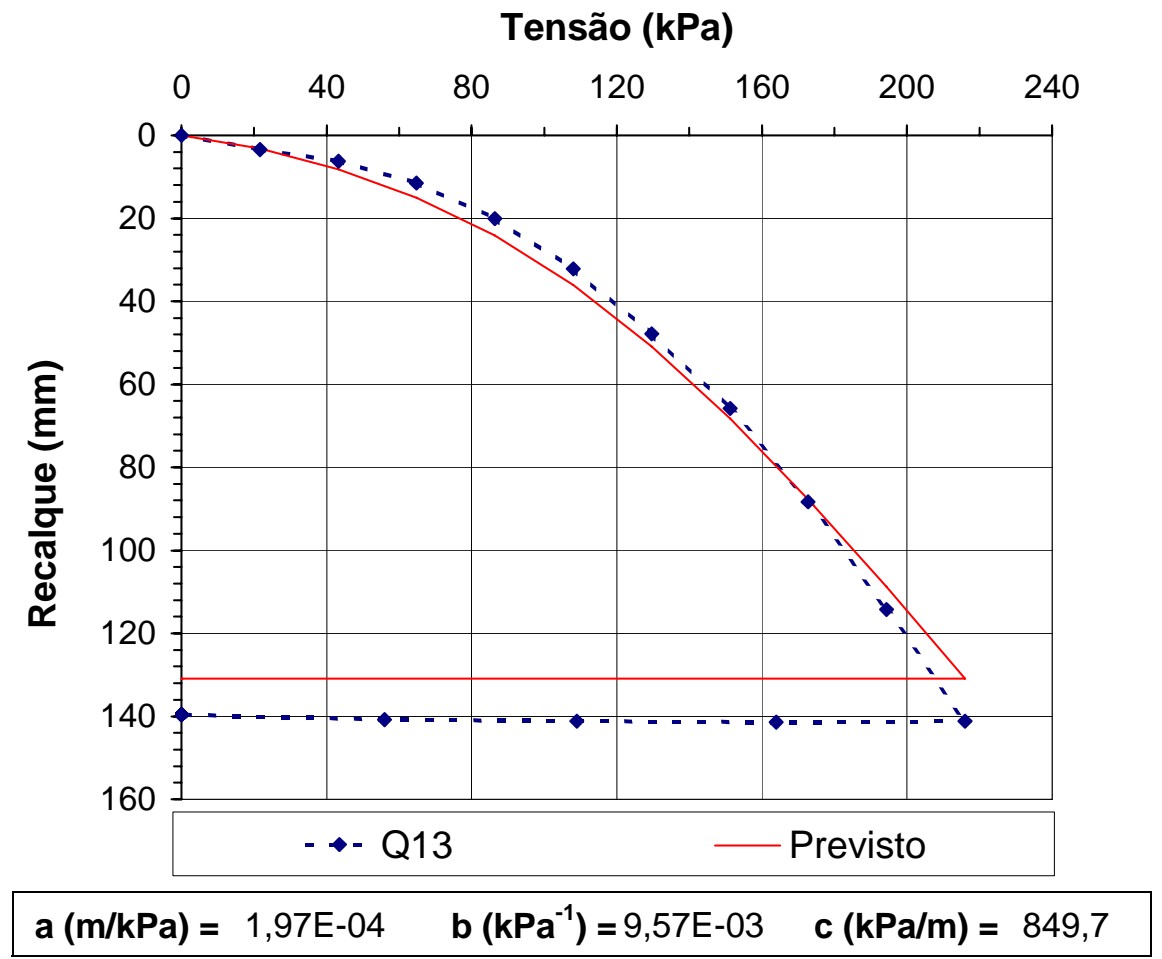

Figura 6.42 - Curvas tensão-recalque do ensaio rápido Q13 (sucção = 21 kPa), diâmetro de $1,5 \mathrm{~m}$ e na profundidade de $1,5 \mathrm{~m}$. 
Observa-se nas figuras dos itens 6.4.1 a 6.4.3, que geralmente a previsão realizada apresenta resultados bastante próximos da realidade medida através de provas de carga, ressaltando que algumas das curvas experimentais e previstas foram praticamente únicas. Verifica-se assim a aplicabilidade do método proposto para reproduzir o comportamento do sistema solo-placa neste tipo de solo, em função da sucção.

\subsection{COMPARAÇÕES ENTRE AS CURVAS TENSÃO-RECALQUE MEDIDAS E PREVISTAS}

Definindo como tensão de ruptura convencional $\left(\sigma_{\mathrm{r}}\right)$ aquela correspondente à tensão que provoca um recalque igual a D/30, onde $\mathrm{D}$ é o diâmetro da placa, fez-se uma comparação entre tais tensões previstas e obtidas experimentalmente, representada na Tabela 6.4. Pode ser verificado que de modo geral os valores foram previstos de maneira satisfatória, apresentando uma relação média entre as tensões de 0,96 para os ensaios inundados, e de 0,92 para os não inundados. Ambos os valores estão próximos da unidade e a favor da segurança. Os valores da Tabela 6.4 são apresentados na Figura 6.43 . 
Tabela 6.4 - Tensões de ruptura convencional medidas e previstas para os ensaios de placa (agrupadas de acordo com a suç̧ão).

\begin{tabular}{|c|c|c|c|c|c|c|}
\hline Ensaio & $\begin{array}{c}\text { Profundidade } \\
\text { (m) }\end{array}$ & $\begin{array}{c}\text { Diâmetro } \\
\text { (m) }\end{array}$ & $\begin{array}{c}\text { Sucção } \\
\text { (kPa) }\end{array}$ & $\frac{\sigma_{\mathrm{r}}(\mathrm{kPa})}{\text { medida }}$ & prevista & $\sigma_{\mathrm{r} \text { prev. }} / \sigma_{\mathrm{r} \text { med. }}$ \\
\hline SS1 & 1,5 & 0,8 & 0 & 65,7 & 46,3 & 0,70 \\
\hline SS2 & 1,5 & 0,8 & 0 & 43,0 & 46,3 & 1,08 \\
\hline SS3 & 1,5 & 0,8 & 0 & 56,5 & 46,3 & 0,82 \\
\hline QS1 & 1,5 & 0,8 & 0 & 60,7 & 48,2 & 0,79 \\
\hline QS2 & 1,5 & 0,8 & 0 & 62,5 & 48,2 & 0,77 \\
\hline MS1 & 1,5 & 0,8 & 0 & 62,5 & 48,2 & 0,77 \\
\hline MS2 & 1,5 & 0,8 & 0 & 69,5 & 48,2 & 0,69 \\
\hline MS3 & 1,5 & 0,8 & 0 & 51,8 & 49,1 & 0,95 \\
\hline QS3 & 4,0 & 0,8 & 0 & 129,1 & 131,2 & 1,02 \\
\hline QS4 & 6,0 & 0,8 & 0 & 144,6 & 160,5 & 1,11 \\
\hline QS5 & 6,0 & 0,8 & 0 & 169,7 & 163,2 & 0,96 \\
\hline QS6 & 1,5 & 0,2 & 0 & 19,3 & 37,0 & 1,92 \\
\hline QS7 & 1,5 & 0,4 & 0 & 43,7 & 42,2 & 0,97 \\
\hline QS8 & 1,5 & 1,5 & 0 & 58,7 & 50,0 & 0,85 \\
\hline & & & & & Média & 0,96 \\
\hline & & & & Desv & io Padrão & 0,31 \\
\hline & & & Coeficien & ite de Var & iação (\%) & 32,10 \\
\hline S1 & 1,5 & 0,8 & 10 & 106,0 & 87,1 & 0,82 \\
\hline $\mathrm{S} 2$ & 1,5 & 0,8 & 31 & 144,5 & 133,6 & 0,92 \\
\hline Q1 & 1,5 & 0,8 & 15 & 99,9 & 103,7 & 1,04 \\
\hline Q2 & 1,5 & 0,8 & 22 & 118,3 & 121,9 & 1,03 \\
\hline Q3 & 1,5 & 0,8 & 33 & 149,1 & 141,8 & 0,95 \\
\hline M1 & 1,5 & 0,8 & 28 & 169,7 & 132,7 & 0,78 \\
\hline Q4 & 4,0 & 0,8 & 18 & 185,1 & 177,0 & 0,96 \\
\hline Q5 & 4,0 & 0,8 & 28 & 210,3 & 203,4 & 0,97 \\
\hline Q6 & 6,0 & 0,8 & 12 & 179,0 & 187,7 & 1,05 \\
\hline Q7 & 6,0 & 0,8 & 15 & 236,3 & 194,9 & 0,82 \\
\hline Q8 & 1,5 & 0,2 & 15 & 90,3 & 84,5 & 0,93 \\
\hline Q9 & 1,5 & 0,2 & 17 & 115,9 & 88,8 & 0,77 \\
\hline Q10 & 1,5 & 0,4 & 12 & 112,5 & 86,9 & 0,77 \\
\hline Q11 & 1,5 & 0,4 & 13 & 95,4 & 90,6 & 0,95 \\
\hline Q12 & 1,5 & 1,5 & 22 & 139,1 & 126,4 & 0,91 \\
\hline Q13 & 1,5 & 1,5 & 21 & 132,2 & 128,3 & 0,97 \\
\hline \multirow{2}{*}{\multicolumn{6}{|c|}{$\begin{array}{r}\text { Média } \\
\text { Desvio Padrão }\end{array}$}} & 0,92 \\
\hline & & & & & & 0,09 \\
\hline \multicolumn{6}{|c|}{ Coeficiente de Variação (\%) } & 10,32 \\
\hline
\end{tabular}




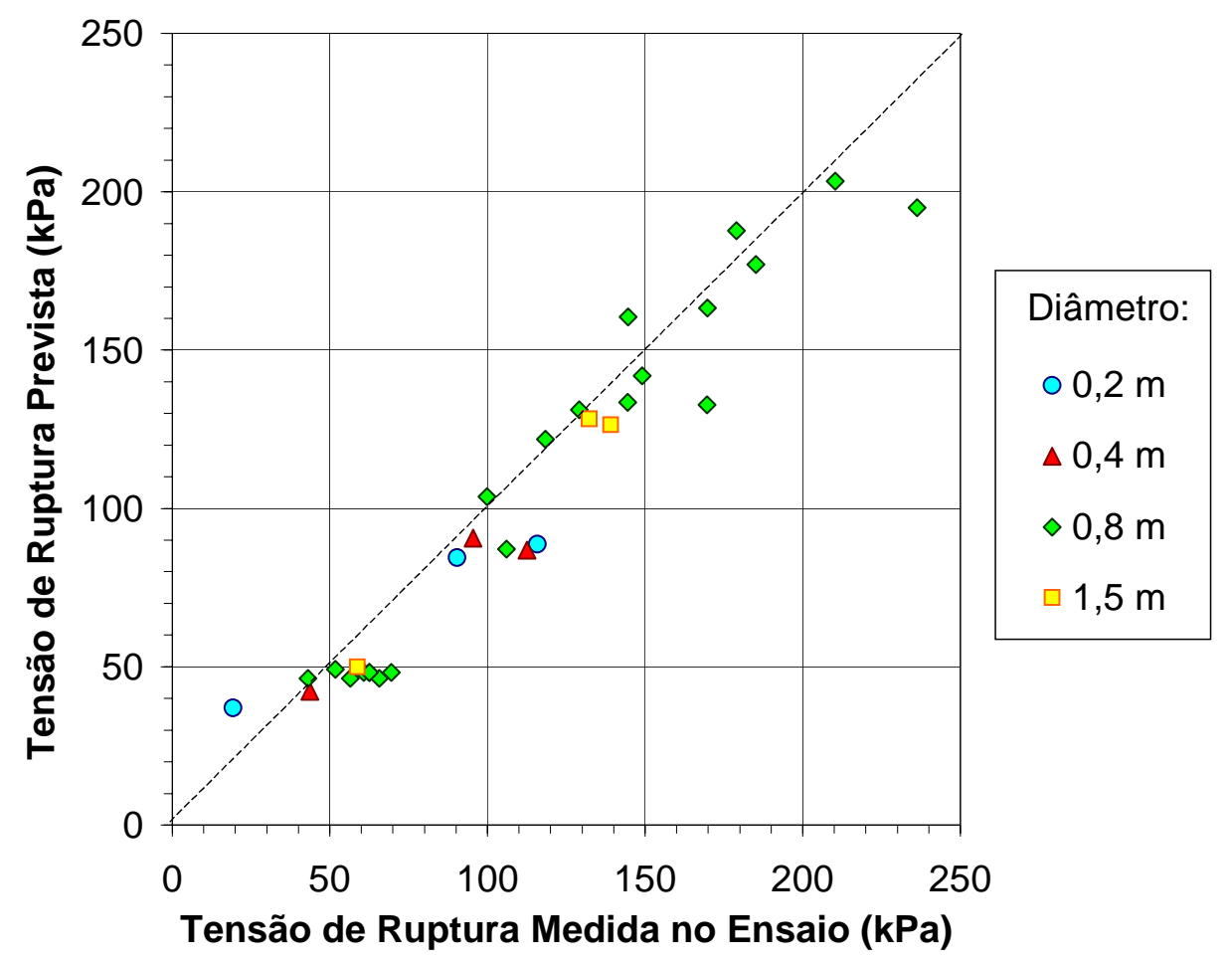

Figura 6.43 - Comparação entre as tensões de ruptura convencional medidas no ensaio e previstas.

Os recalques dos ensaios não inundados para a tensão admissível, obtida aplicando-se um coeficiente de segurança igual a dois à tensão de ruptura convencional prevista, são apresentados na Tabela 6.5. Na maioria dos casos o valor da relação entre o recalque previsto e medido foi superior a 1,0, sendo o valor médio igual a 1,95.

A relação $\rho_{\text {prev. }}$ / $\rho_{\text {med. }}$ deve ser observada cuidadosamente, pois para baixos valores de recalques medidos a relação pode apresentar um valor elevado enquanto que a diferença entre o medido e o previsto não é significativa. Por exemplo, na Tabela 6.5, o ensaio Q9 apresenta uma relação igual a 2,83, sendo que a diferença entre os recalques corresponde a apenas $1,1 \mathrm{~mm}$. 
Tabela 6.5 - Recalques previstos e medidos na tensão admissível prevista (ensaios não inundados com diferentes diâmetros e diferentes profundidades).

\begin{tabular}{ccccc}
\hline \multirow{2}{*}{ Ensaio } & $\begin{array}{c}\sigma_{\text {a prevista }} \\
(\mathbf{k P a})\end{array}$ & \multicolumn{2}{c}{ Recalque $-\boldsymbol{\rho} \mathbf{( m m )}$} & \multicolumn{1}{c}{$\rho_{\text {prev. }} / \rho_{\text {med. }}$} \\
\cline { 3 - 4 } & 44 & 9,1 & 6,6 & 1,38 \\
\hline S1 & 67 & 7,5 & 4,1 & 1,83 \\
\hline S2 & 52 & 8,7 & 6,8 & 1,28 \\
\hline Q1 & 61 & 7,8 & 2,9 & 2,69 \\
\hline Q2 & 71 & 7,4 & 3,9 & 1,90 \\
\hline Q3 & 66 & 8,2 & 3,4 & 2,41 \\
\hline M1 & 89 & 6,3 & 4,3 & 1,47 \\
\hline Q4 & 102 & 5,8 & 7,1 & 0,82 \\
\hline Q5 & 94 & 7,0 & 8,1 & 0,86 \\
\hline Q6 & 97 & 6,9 & 5,2 & 1,33 \\
\hline Q7 & 42 & 1,8 & 1,2 & 1,50 \\
\hline Q8 & 44 & 1,7 & 0,6 & 2,83 \\
\hline Q9 & 43 & 4,1 & 0,7 & 5,86 \\
\hline Q10 & 45 & 4,1 & 2,3 & 1,78 \\
\hline Q11 & 63 & 14,6 & 7,5 & 1,95 \\
\hline Q12 & 64 & 14,8 & 11,3 & 1,31 \\
\hline Q13 & & & Média & $\mathbf{1 , 9 5}$ \\
\hline & & & &
\end{tabular}

Uma outra forma de verificar a eficiência do método proposto baseia-se na determinação da energia de deformação armazenada no sistema $\left(V_{S}\right)$ durante a fase de carregamento. Conforme apresentado por Aoki (1997, 1998), no caso de estacas, esta energia corresponde à área entre a curva carga-recalque e o eixo dos recalques em um certo intervalo. A expressão analítica para o cálculo desta energia de deformação por unidade de área (para ensaio de placa), obtida pela integração da equação (6.1), é dada por:

$$
\mathrm{V}_{\mathrm{S}}=\frac{\rho}{\mathrm{b}}+\frac{\mathrm{c} \cdot \rho^{2}}{2}+\frac{\mathrm{a}}{\mathrm{b}^{2}} \cdot \ln \left(\frac{\mathrm{a}}{\mathrm{a}+\mathrm{b} \cdot \rho}\right)
$$

Outra forma de obtenção de $V_{S}$ é a integração numérica da área entre a curva carga-recalque e o eixo dos recalques. Fazendo-se esta integração para as curvas tensão recalque, tanto as experimentais quanto as previstas, limitadas o recalque 
correspondente a D/30, obtêm-se os valores de energia de deformação armazenada no sistema apresentados na Tabela 6.6. Pode-se verificar que os valores previstos apresentaram-se pouco inferiores aos medidos, apresentando uma relação média entre as energias previstas e medidas de 0,82 para os ensaios inundados, e de 0,85 para os não inundados. Ambos os valores estão relativamente próximos da unidade e a favor da segurança. Os dados da Tabela 6.6 são reproduzidos na Figura 6.44.

Tabela 6.6 - Valores de energia de deformação por unidade de área “medidos” e previstos as para os ensaios de placa (agrupadas de acordo com a sucção).

\begin{tabular}{|c|c|c|c|c|c|c|}
\hline Ensaio & $\begin{array}{c}\text { Profundidade } \\
\text { (m) }\end{array}$ & $\begin{array}{c}\text { Diâmetro } \\
\text { (m) }\end{array}$ & $\begin{array}{c}\text { Sucção } \\
(\mathbf{k P a})\end{array}$ & $\begin{array}{l}\mathrm{V}_{\mathrm{S}}\left(\mathrm{kJ} / \mathrm{m}^{2}\right) \\
\text { medida }\end{array}$ & prevista & $V_{\mathrm{S} \text { prev. }} / \mathrm{V}_{\mathrm{S} \text { med. }}$ \\
\hline SS1 & 1,5 & 0,8 & 0 & 1,36 & 0,72 & 0,53 \\
\hline SS2 & 1,5 & 0,8 & 0 & 0,87 & 0,72 & 0,83 \\
\hline SS3 & 1,5 & 0,8 & 0 & 1,07 & 0,72 & 0,67 \\
\hline QS1 & 1,5 & 0,8 & 0 & 1,17 & 0,76 & 0,65 \\
\hline QS2 & 1,5 & 0,8 & 0 & 1,22 & 0,76 & 0,62 \\
\hline MS1 & 1,5 & 0,8 & 0 & 1,15 & 0,73 & 0,64 \\
\hline MS2 & 1,5 & 0,8 & 0 & 1,36 & 0,73 & 0,54 \\
\hline MS3 & 1,5 & 0,8 & 0 & 0,97 & 0,74 & 0,76 \\
\hline QS3 & 4,0 & 0,8 & 0 & 2,16 & 2,18 & 1,01 \\
\hline QS4 & 6,0 & 0,8 & 0 & 2,67 & 2,57 & 0,96 \\
\hline QS5 & 6,0 & 0,8 & 0 & 3,07 & 2,63 & 0,86 \\
\hline QS6 & 1,5 & 0,2 & 0 & 0,09 & 0,16 & 1,83 \\
\hline QS7 & 1,5 & 0,4 & 0 & 0,38 & 0,34 & 0,89 \\
\hline \multirow[t]{4}{*}{ QS8 } & 1,5 & 1,5 & 0 & 2,01 & 1,48 & 0,74 \\
\hline & & & & & Média & 0,82 \\
\hline & & & & \multicolumn{2}{|c|}{ Desvio Padrão } & 0,33 \\
\hline & & & \multicolumn{3}{|c|}{ Coeficiente de Variação (\%) } & 39,54 \\
\hline S1 & 1,5 & 0,8 & 10 & 1,74 & 1,40 & 0,81 \\
\hline $\mathrm{S} 2$ & 1,5 & 0,8 & 31 & 2,77 & 2,29 & 0,83 \\
\hline Q1 & 1,5 & 0,8 & 15 & 1,76 & 1,71 & 0,97 \\
\hline Q2 & 1,5 & 0,8 & 22 & 2,48 & 2,06 & 0,83 \\
\hline Q3 & 1,5 & 0,8 & 33 & 2,84 & 2,46 & 0,87 \\
\hline M1 & 1,5 & 0,8 & 28 & 3,16 & 2,20 & 0,70 \\
\hline Q4 & 4,0 & 0,8 & 18 & 3,56 & 3,18 & 0,89 \\
\hline Q5 & 4,0 & 0,8 & 28 & 3,65 & 3,73 & 1,02 \\
\hline Q6 & 6,0 & 0,8 & 12 & 3,03 & 3,26 & 1,08 \\
\hline Q7 & 6,0 & 0,8 & 15 & 4,21 & 3,42 & 0,81 \\
\hline Q8 & 1,5 & 0,2 & 15 & 0,43 & 0,37 & 0,86 \\
\hline Q9 & 1,5 & 0,2 & 17 & 0,57 & 0,39 & 0,69 \\
\hline Q10 & 1,5 & 0,4 & 12 & 1,14 & 0,73 & 0,64 \\
\hline Q11 & 1,5 & 0,4 & 13 & 0,91 & 0,77 & 0,84 \\
\hline Q12 & 1,5 & 1,5 & 22 & 4,69 & 4,00 & 0,85 \\
\hline Q13 & 1,5 & 1,5 & 21 & 4,38 & 4,06 & 0,93 \\
\hline
\end{tabular}




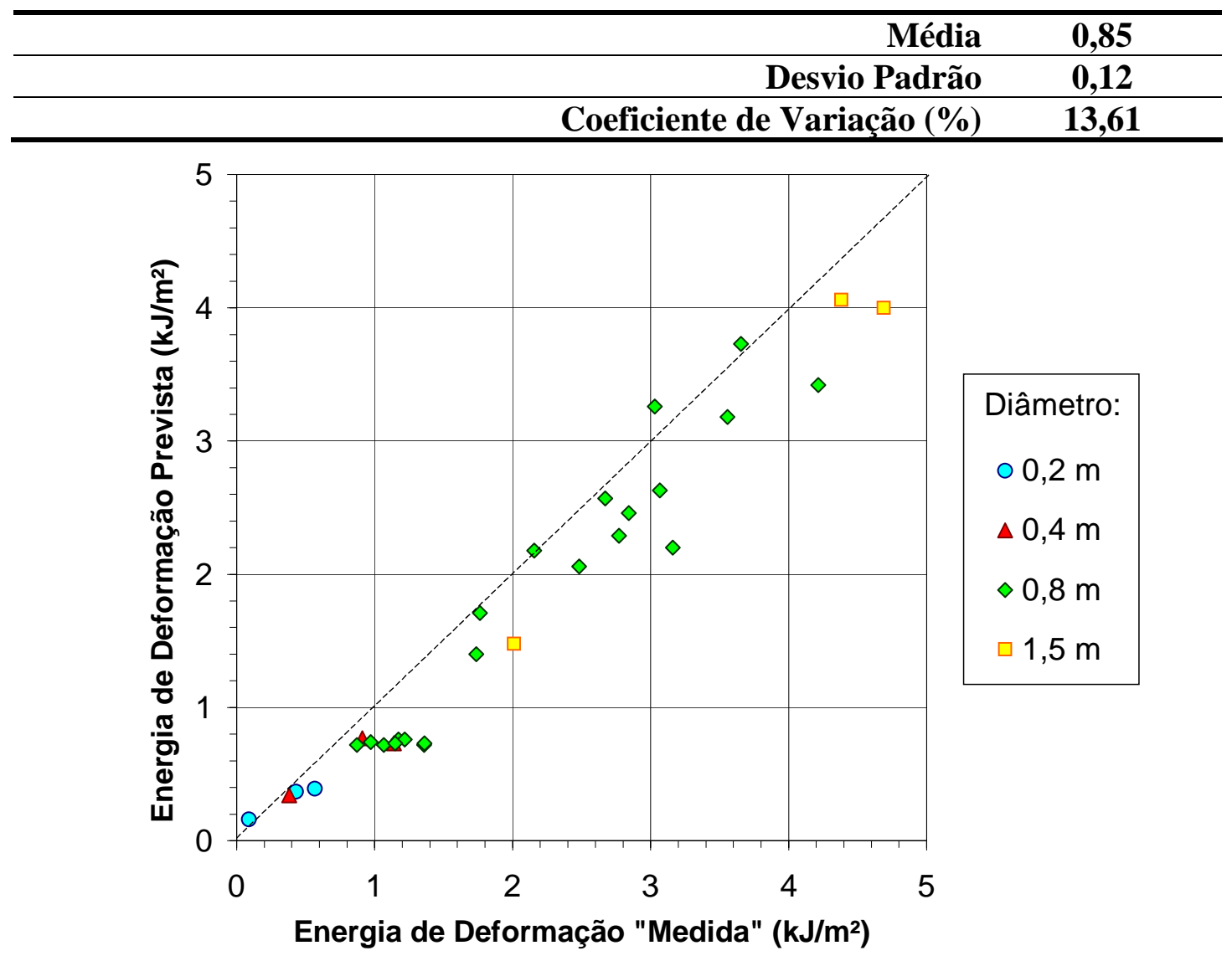

Figura 6.44 - Comparação entre as energias de deformação medidas e previstas.

\subsection{PREVISÕES ADICIONAIS DA CURVA TENSÃO-RECALQUE}

Neste item são apresentadas previsões adicionais de curvas tensão-recalque, variando-se a sucção do solo, a profundidade e o diâmetro da placa.

\subsubsection{INFLUÊNCIA DA SUCÇÃO E PROFUNDIDADE}

Para a placa de 0,80 m, instalada a 1,5, 4,0 e 6,0 m, realizaram-se previsões da curva tensão-recalque, com a variação da sucção no intervalo de 0 a 30 kPa.

A Figura 6.45 apresenta os gráficos correspondentes a profundidade de 1,5 m e aos valores de sucção de 0, 10, 20 e $30 \mathrm{kPa}$. Analisando essa figura, confirma-se o aumento da capacidade de carga e da rigidez do solo em função da sucção, uma vez que, para um mesmo nível de tensão aplicada, os recalques são menores para sucções 
maiores. Por exemplo, nos ensaios lentos para uma tensão de 50 kPa obtêm-se um recalque de $5 \mathrm{~mm}$ para uma sucção de $30 \mathrm{kPa}$ e de $30 \mathrm{~mm}$ para sucção nula.

Com relação à capacidade de carga, na profundidade de $1,5 \mathrm{~m}$, verifica-se que a tensão de ruptura convencional apresenta valores aproximadamente iguais a 45, 85, 110 e $130 \mathrm{kPa}$, respectivamente, para sucções de 0, 10, 20 e $30 \mathrm{kPa}$ (Figura 6.46). Nota-se um aumento significativo da capacidade de carga quando a sucção passa de 0 a $10 \mathrm{kPa}$. Após este nível de sucção, ocorrem acréscimos menos pronunciados de capacidade de carga, para mesmos incrementos de sucção.

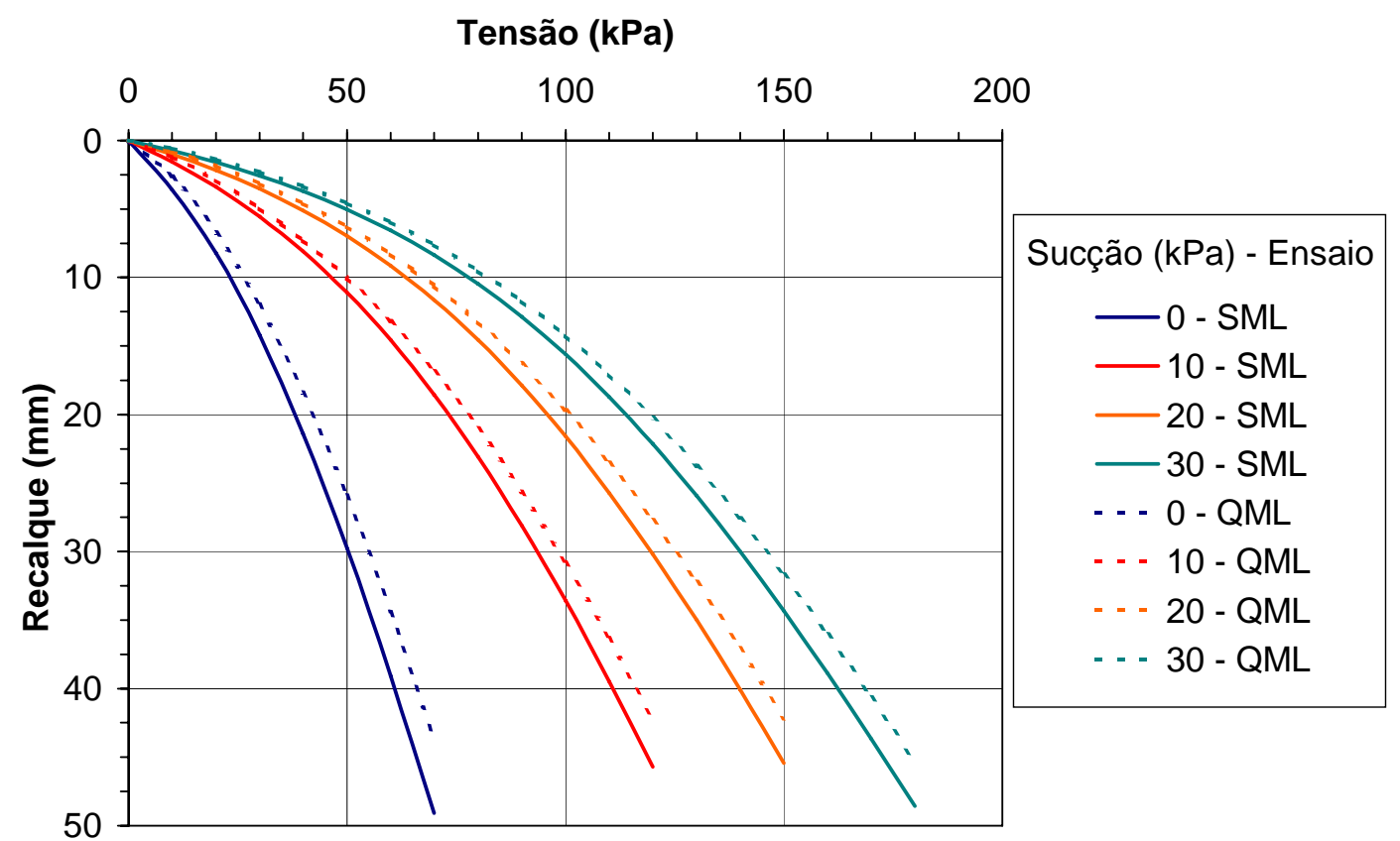

Figura 6.45 - Variação das curvas tensão-recalque com a sucção para ensaios de placa do tipo lento e rápido (diâmetro de 0,8 m e profundidade de 1,5 m). 


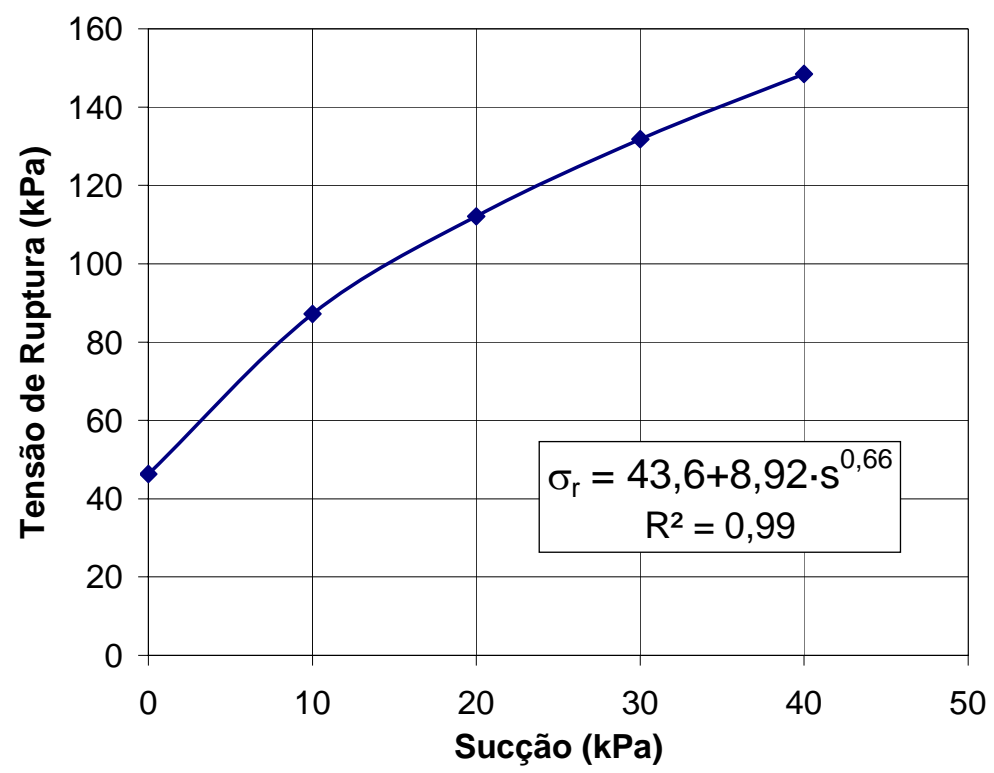

Figura 6.46 - Variação da tensão de ruptura com a sucção (diâmetro de $0,8 \mathrm{~m}$ e profundidade de $1,5 \mathrm{~m}$ ).

De modo similar, a Figura 6.47 apresenta os gráficos para a profundidade de 4,0 m e para sucções de 0, 10, 20 e 30 kPa. Para uma tensão de 150 kPa obtêm-se um recalque de $14 \mathrm{~mm}$ para uma sucção de $30 \mathrm{kPa}$ e de $35 \mathrm{~mm}$ para sucção igual a zero. Com relação à capacidade de carga, verifica-se que a tensão de ruptura convencional apresenta valores de 130, 150, 175 e $200 \mathrm{kPa}$, respectivamente, para sucções de 0, 10, 20 e $30 \mathrm{kPa}$ (Figura 6.48). Nota-se, que para esta profundidade, ocorre um aumento praticamente constante da capacidade de carga com a sucção.

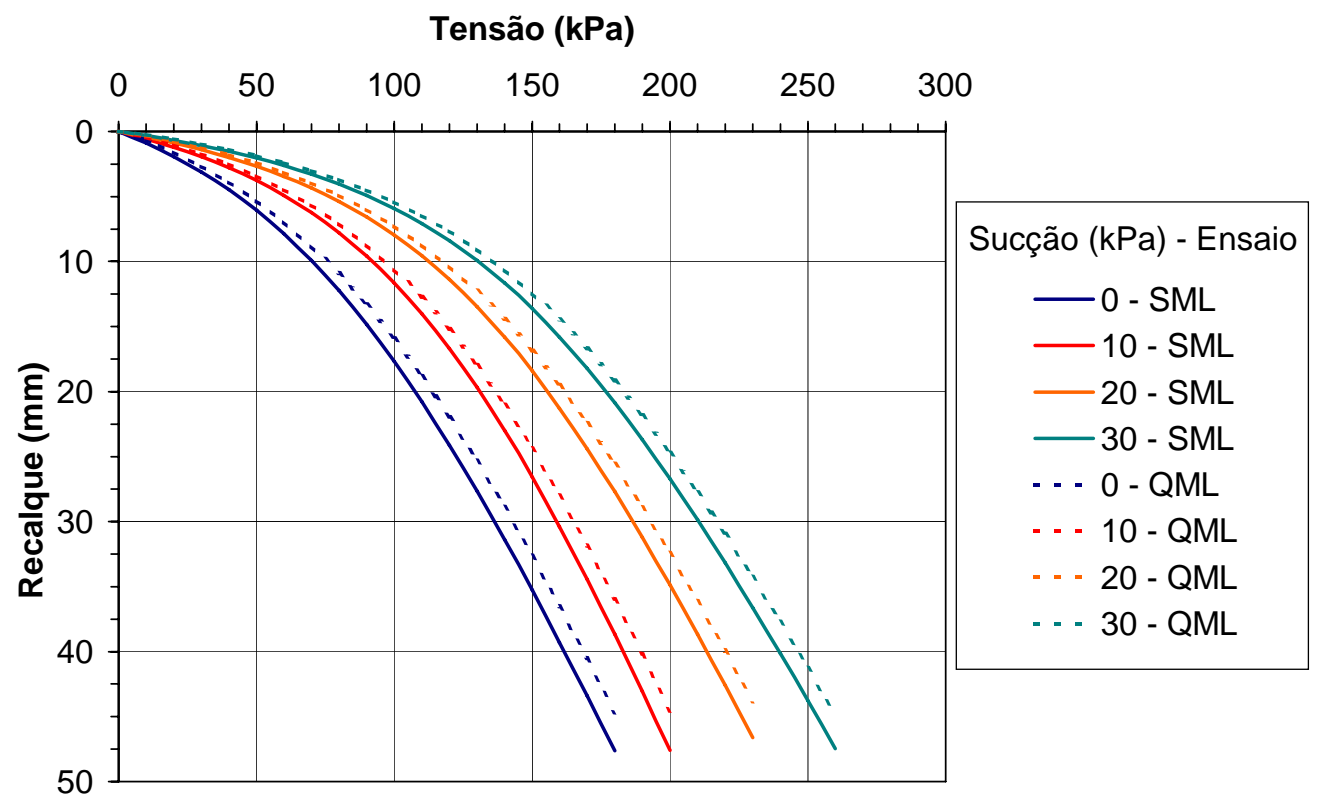

Figura 6.47 - Variação das curvas tensão-recalque com a sucção para ensaios de placa do tipo lento e rápido (diâmetro de 0,8 m e profundidade de 4,0 m). 


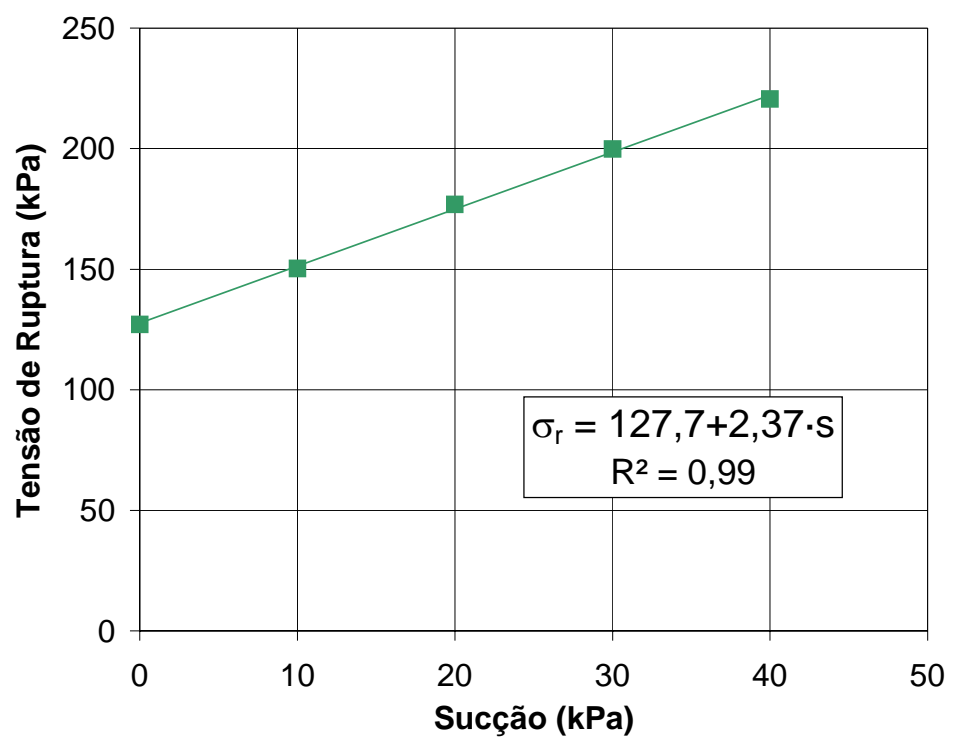

Figura 6.48 - Variação da tensão de ruptura com a sucção (diâmetro de 0,8 $\mathrm{m}$ e profundidade de 4,0 m).

Finalmente, a Figura 6.49 mostra os gráficos para a profundidade de 6,0 m e para as mesmas sucções das duas figuras anteriores. Para uma tensão de 150 kPa obtêmse um recalque de $12 \mathrm{~mm}$ para uma sucção de $30 \mathrm{kPa}$ e de $25 \mathrm{~mm}$ para sucção igual a zero. Com relação à capacidade de carga, pode-se observar que a tensão de ruptura convencional apresenta valores de 155, 175, 200 e $215 \mathrm{kPa}$, respectivamente, para sucções de 0, 10, 20 e $30 \mathrm{kPa}$ (Figura 6.50). Nota-se, que para a profundidade em questão, também ocorre um aumento praticamente constante da capacidade de carga com a sucção. 


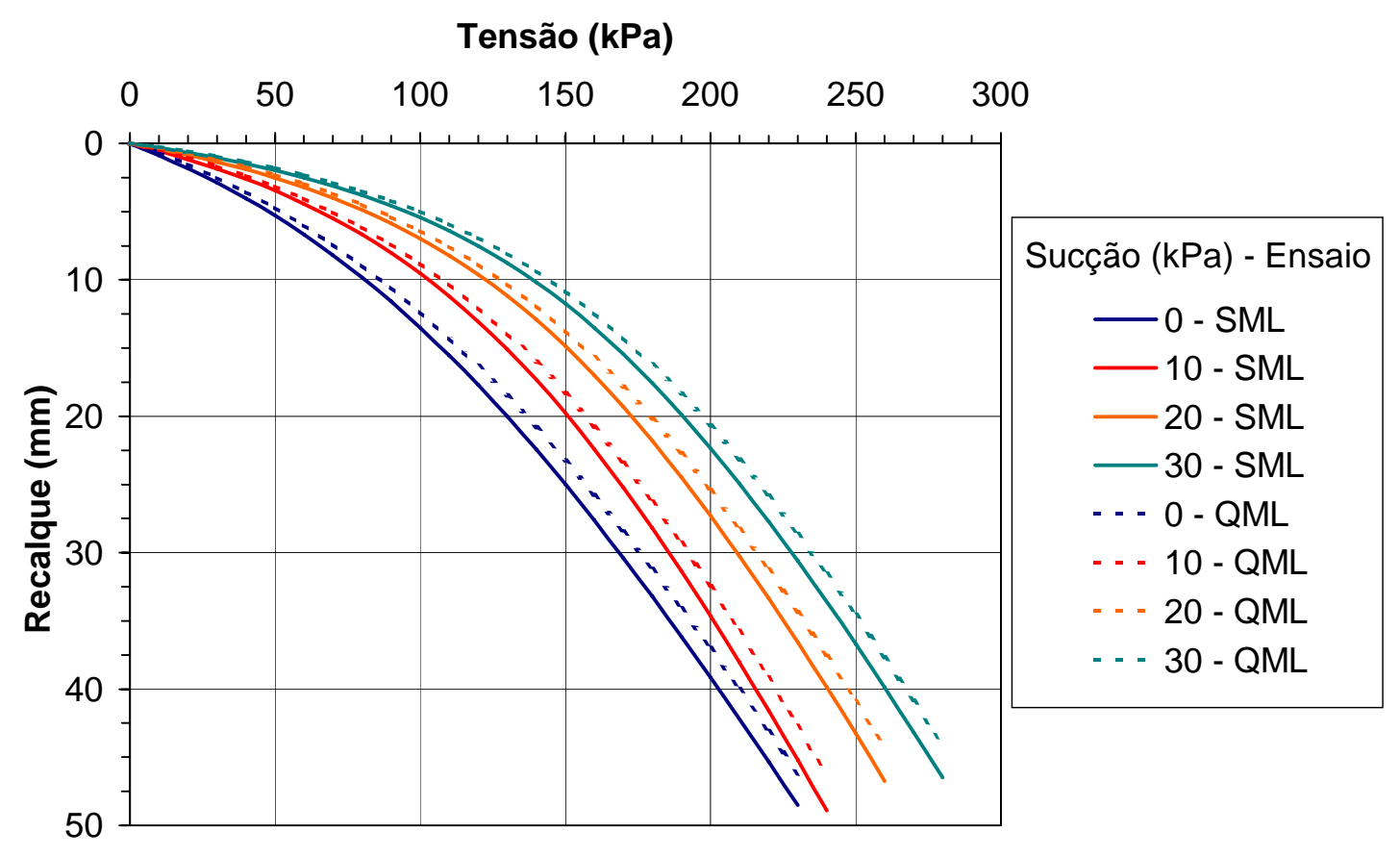

Figura 6.49 - Variação das curvas tensão-recalque com a sucção para ensaios de placa do tipo lento e rápido (diâmetro de 0,8 m e profundidade de 6,0 m).

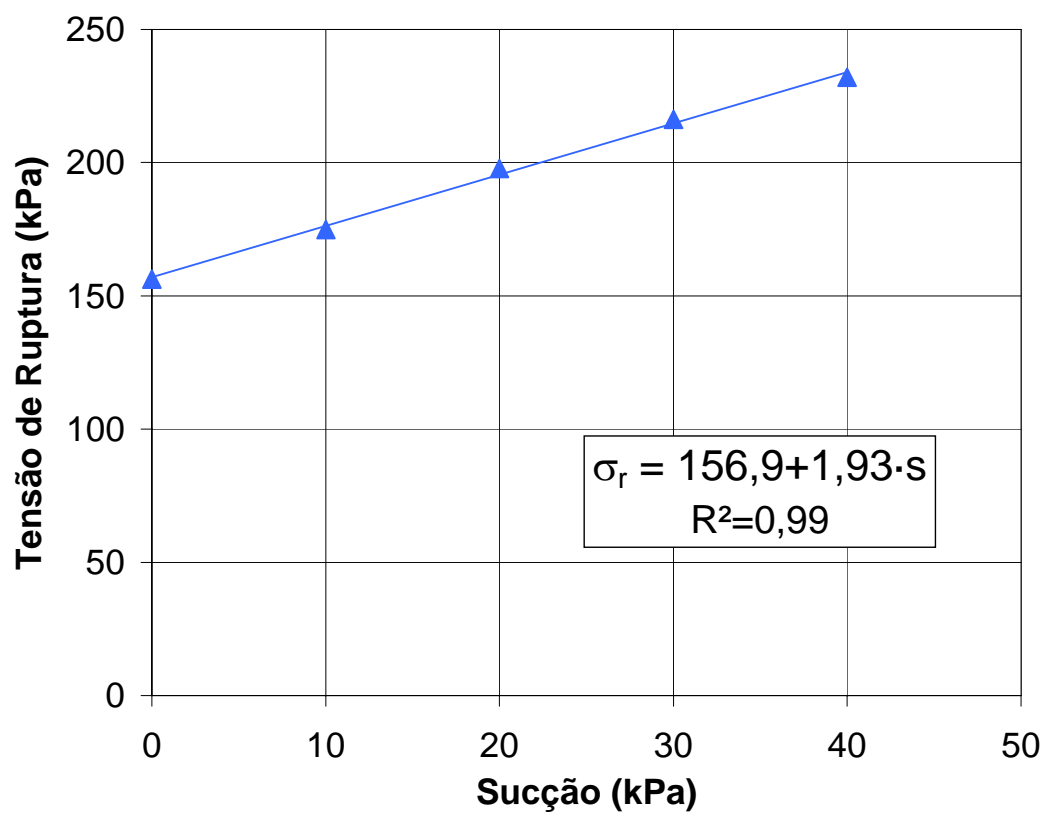

Figura 6.50 - Variação da tensão de ruptura com a sucção (diâmetro de 0,8 m e profundidade de 6,0 m). 
Analisando conjuntamente as Figura 6.46, 6.48 e 6.50, nota-se o aumento da capacidade de carga com a profundidade. Salienta-se que o aumento é mais significativo da profundidade de 1,5 para 4,0 m, do que da profundidade de 4,0 para 6,0 m, sendo em média igual a $94 \%$ e $15 \%$, respectivamente.

\subsubsection{INFLUÊNCIA DA SUCÇÃO E DO DIÂMETRO DA PLACA}

Verificou-se também com o método proposto, a influência do diâmetro da placa na curva tensão-recalque de ensaios lentos a 1,5 m de profundidade, mantendo-se constante a sucção. As Figuras 6.51 a 6.54 apresentam esta influência para as sucções de 0 a $30 \mathrm{kPa}$. Pode ser observado que quanto maior o diâmetro da placa maior será o recalque para um mesmo nível de tensão, por exemplo, para sucção nula e tensão aplicada de $60 \mathrm{kPa}$, os recalques correspondem a 19, 25, 39 e $72 \mathrm{~mm}$, para os diâmetros de $0,2,0,4,0,8$ e $1,5 \mathrm{~m}$, respectivamente.

Além disso, constata-se novamente que quanto maior o valor da sucção, maior é a capacidade de carga para um mesmo diâmetro.

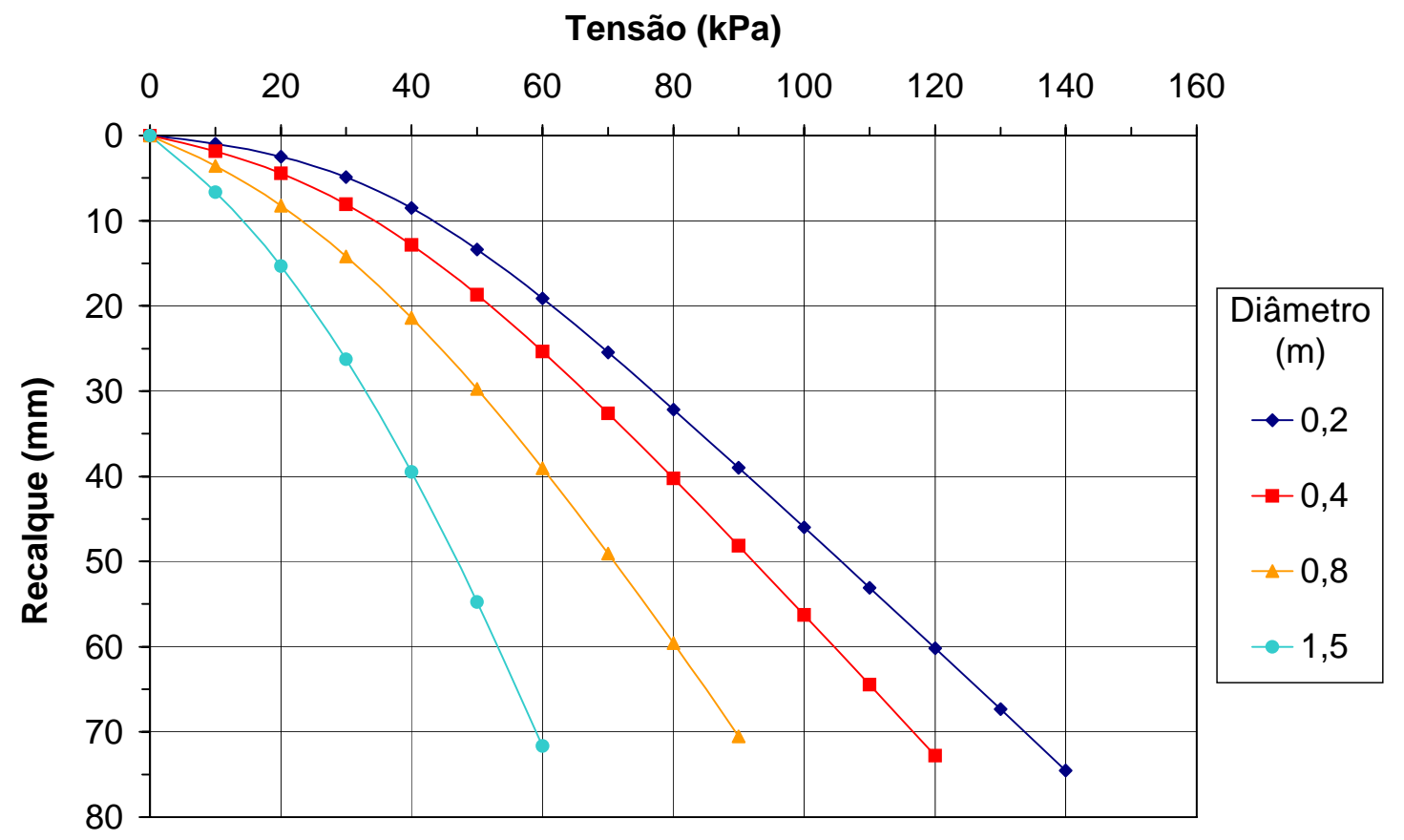

Figura 6.51 - Variação da curva tensão-recalque com o diâmetro da placa (profundidade de 1,5 m e sucção de $0 \mathrm{kPa}$ ) 


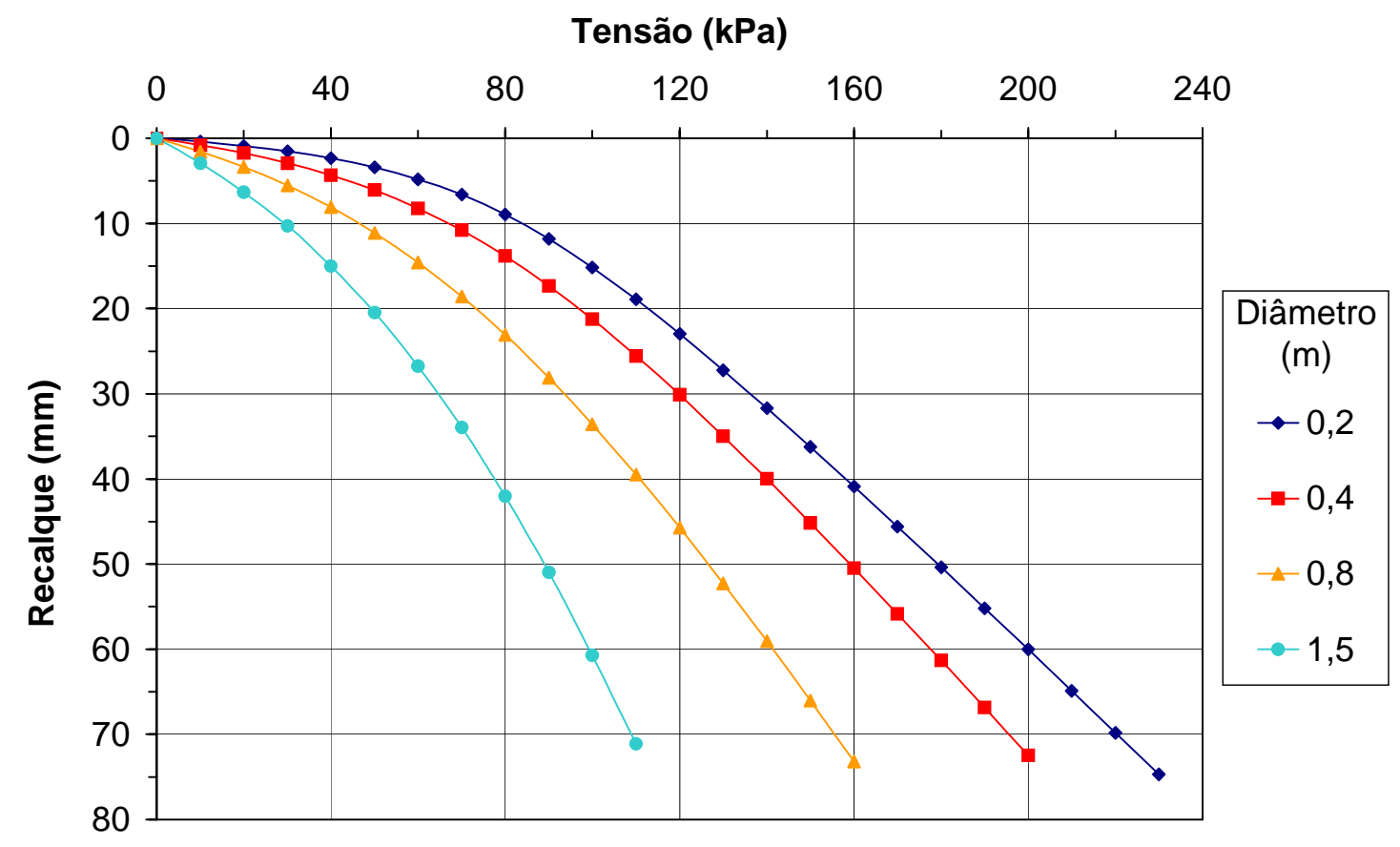

Figura 6.52 - Variação da curva tensão-recalque com o diâmetro da placa (profundidade de $1,5 \mathrm{~m}$ e sucção de $10 \mathrm{kPa}$ )

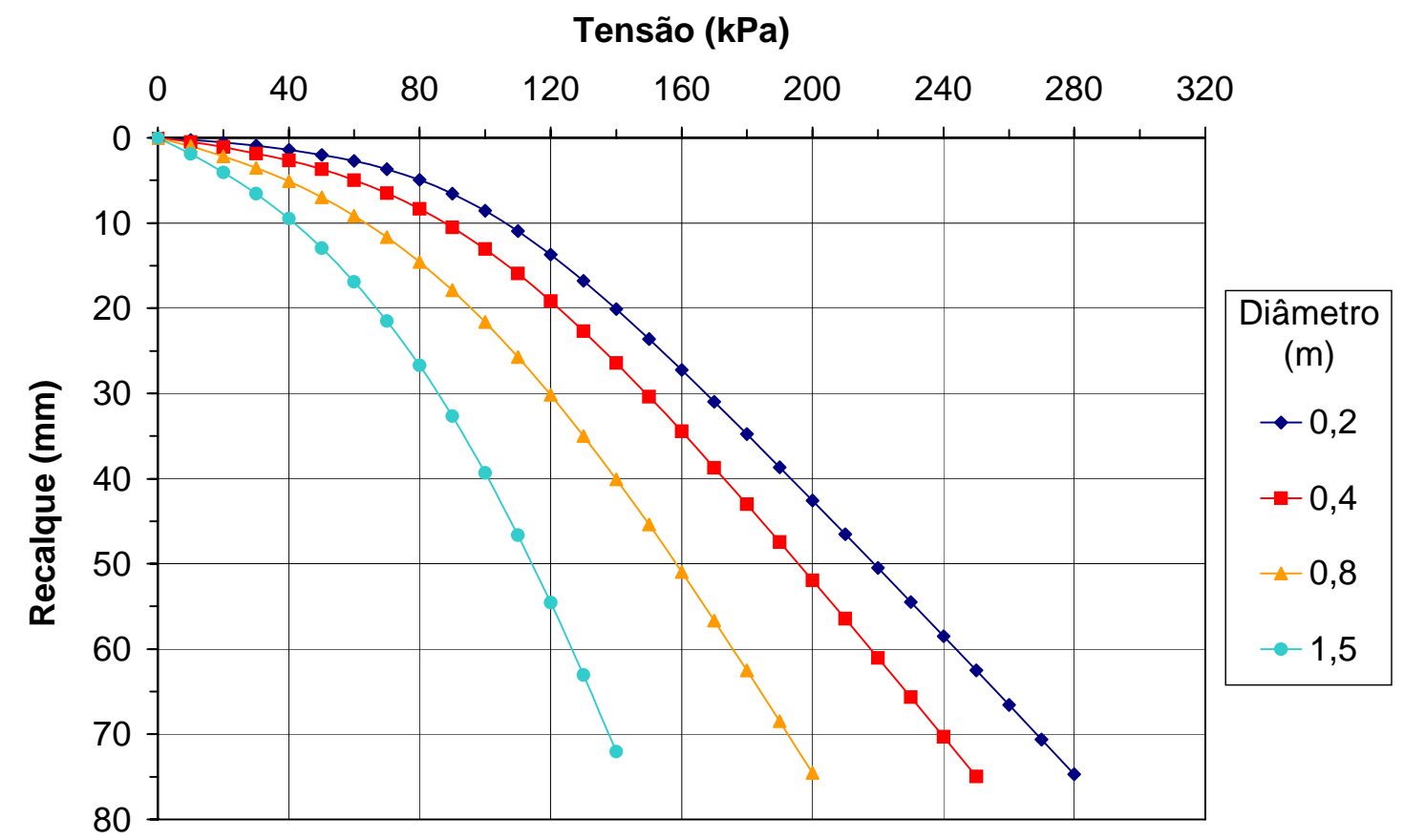

Figura 6.53 - Variação da curva tensão-recalque com o diâmetro da placa (profundidade de $1,5 \mathrm{~m}$ e sucção de $20 \mathrm{kPa}$ ) 


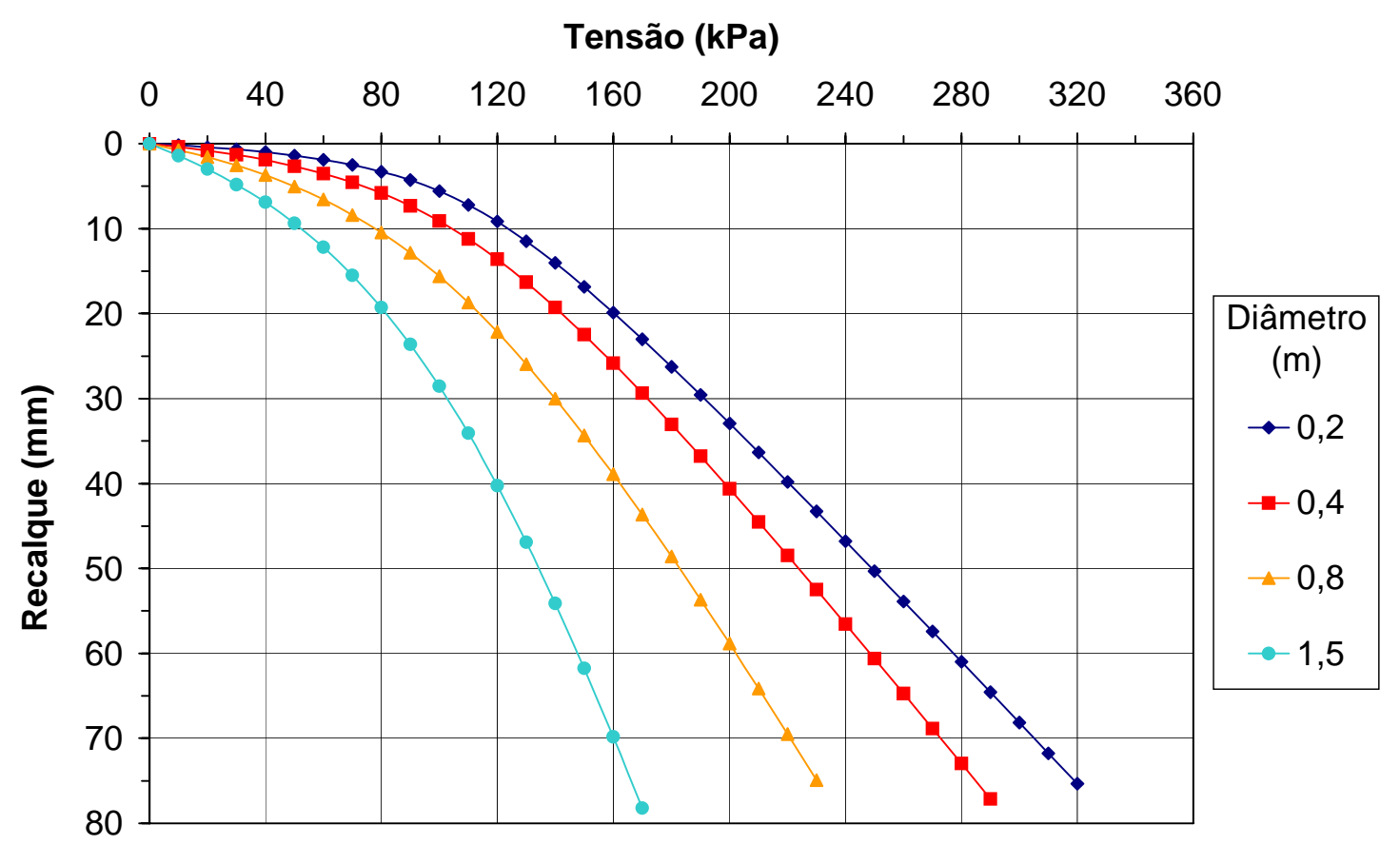

Figura 6.54 - Variação da curva tensão-recalque com o diâmetro da placa (profundidade de $1,5 \mathrm{~m}$ e sucção de $30 \mathrm{kPa}$ )

\section{INFLUÊNCIA DA SUCÇÃO NO MÓDULO DE DEFORMABILIDADE}

Neste capítulo será verificada a influência da sucção matricial no módulo de deformabilidade do solo do Campo Experimental de Fundações da EESC/USP, o qual, como visto anteriormente, apresenta a característica de ser pouco compacto, muito poroso e colapsível. O módulo de deformabilidade foi obtido em campo por meio dos resultados de provas de carga em placa com diâmetro de $0,8 \mathrm{~m}$, às profundidades de 1,5 4,0 e 6,0 m. Em laboratório foi obtido a partir de ensaios de compressão confinada e triaxiais, com sucção controlada, realizados por Machado (1998), em amostras indeformadas retiradas de várias profundidades.

Análises de capacidade de carga referentes aos ensaios de placa podem ser consultadas em Costa (1999) e Macacari (2001). 


\subsection{PROVAS DE CARGA EM PLACA}

O trecho inicial das curvas tensão-recalque, suposto linear, foi retroanalisado utilizando a expressão clássica da teoria da elasticidade para recalques de uma placa circular rígida em maciço semi-infinito de material homogêneo e isotrópico apresentada no item 2.3.1.4.

O coeficiente de Poisson considerado nesta análise foi igual a 0,20, sendo este o valor médio obtido através dos ensaios triaxiais.

Os valores do módulo de deformabilidade $\left(\mathrm{E}_{\mathrm{P}}\right)$ obtidos a partir dos ensaios de placa com diâmetro de $0,8 \mathrm{~m}$, considerando o trecho linear definido pela melhor regressão com no mínimo quatro pontos (RESNIK, 1995a), são mostrados na Tabela 7.1 e na Figura 7.1.

Tabela 7.1 - Módulos de deformabilidade obtidos nos ensaios de placa

\begin{tabular}{|c|c|c|c|c|}
\hline Ensaio & Profundidade (m) & Sucção (kPa) & & $E_{P}(k P a)$ \\
\hline SS1 & 1,5 & 0 & 7790 & \multirow{6}{*}{$E_{P \text { médio }}=4480$} \\
\hline SS2 & 1,5 & 0 & 3340 & \\
\hline SS3 & 1,5 & 0 & 3830 & \\
\hline MS1 & 1,5 & 0 & 3280 & \\
\hline MS2 & 1,5 & 0 & 4480 & \\
\hline MS3 & 1,5 & 0 & 4150 & \\
\hline S1 & 1,5 & 10 & \multicolumn{2}{|r|}{5330} \\
\hline $\mathrm{S} 2$ & 1,5 & 31 & \multicolumn{2}{|r|}{9640} \\
\hline M1 & 1,5 & 28 & \multicolumn{2}{|r|}{10170} \\
\hline QS1 & 1,5 & 0 & 5680 & \multirow{2}{*}{$E_{P \text { médio }}=5650$} \\
\hline QS2 & 1,5 & 0 & 5620 & \\
\hline Q1 & 1,5 & 15 & \multicolumn{2}{|r|}{7080} \\
\hline Q2 & 1,5 & 22 & \multicolumn{2}{|r|}{12440} \\
\hline Q3 & 1,5 & 33 & \multicolumn{2}{|r|}{13840} \\
\hline QS3 & 4,0 & 0 & \multicolumn{2}{|r|}{4710} \\
\hline Q4 & 4,0 & 18 & \multicolumn{2}{|r|}{11680} \\
\hline Q5 & 4,0 & 28 & \multicolumn{2}{|r|}{11420} \\
\hline QS4 & 6,0 & 0 & 8500 & \multirow{2}{*}{$E_{P \text { médio }}=8505$} \\
\hline QS5 & 6,0 & 0 & 8510 & \\
\hline Q6 & 6,0 & 12 & & 7220 \\
\hline Q7 & 6,0 & 15 & & 11780 \\
\hline
\end{tabular}




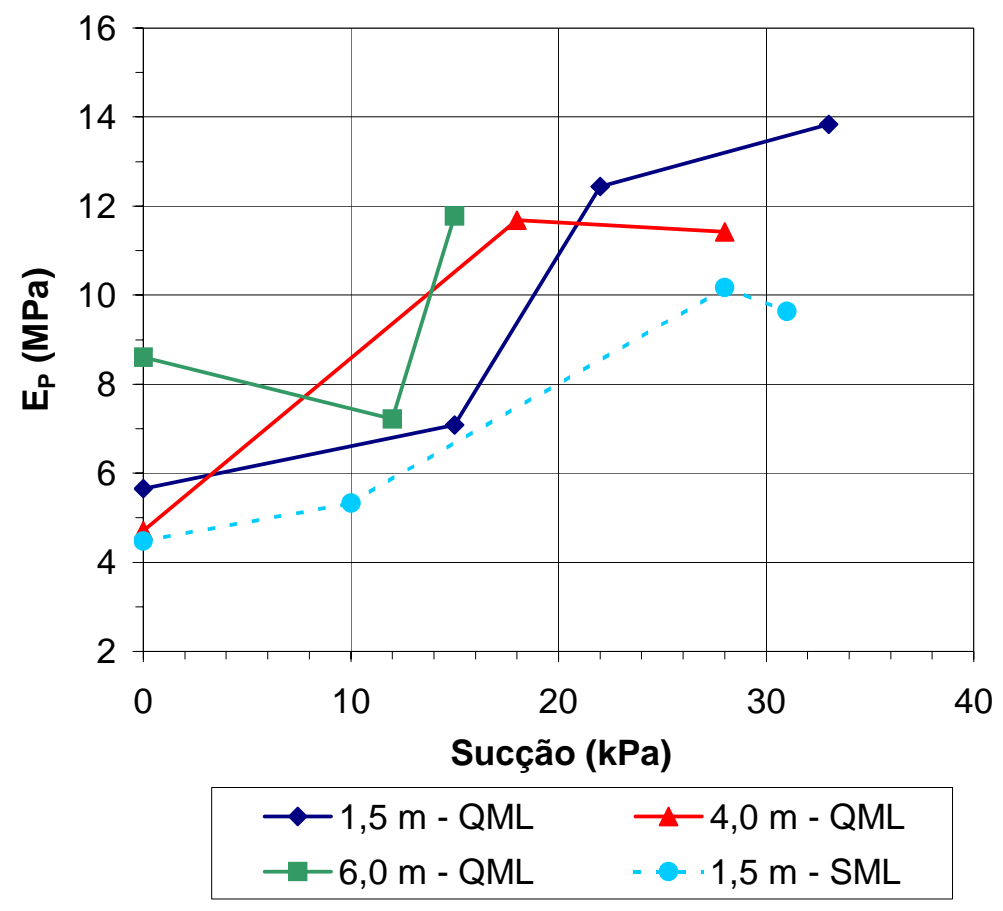

Figura 7.1 - Variação do módulo de deformabilidade com a sucção matricial (ensaios de placa em diferentes profundidades).

Estes resultados mostram, de modo geral, uma tendência de aumento do módulo de deformabilidade com a sucção matricial. Por exemplo, para os ensaios lentos a 1,5 m de profundidade, um aumento na sucção de $1 \mathrm{kPa}$ acarreta um acréscimo, em média, de 190 kPa no módulo de deformabilidade. Com relação aos ensaios rápidos, verifica-se que os módulos estão na faixa de 4 a $9 \mathrm{MPa}$, para sucções nulas, e entre 10 e $15 \mathrm{MPa}$, para sucções de $30 \mathrm{kPa}$. Além disso, o módulo não apresenta uma tendência nítida de variação com a profundidade.

O módulo determinado para os ensaios rápidos é maior do que para os lentos uma vez que a estabilização dos recalques não é atingida.

\subsection{ENSAIOS DE COMPRESSÃO CONFINADA}

Utilizando os resultados dos ensaios de compressão confinada de Machado (1998), apresentados no Anexo A, calculou-se o módulo edométrico (M) para diversas profundidades com o auxílio da equação (2.12) e obteve-se o módulo de deformabilidade utilizando a equação (2.13). Os módulos edométricos foram determinados para um nível de tensão de 57 a $104 \mathrm{kPa}$.

Os valores do módulo de deformabilidade obtidos em função da sucção são apresentados nas Figuras 7.2 a 7.4. De maneira geral, nestas figuras também se observa uma tendência de aumento do módulo edométrico com a sucção matricial. Porém, este aumento foi menos pronunciado nas profundidades de 5,0 e 7,0 m. 


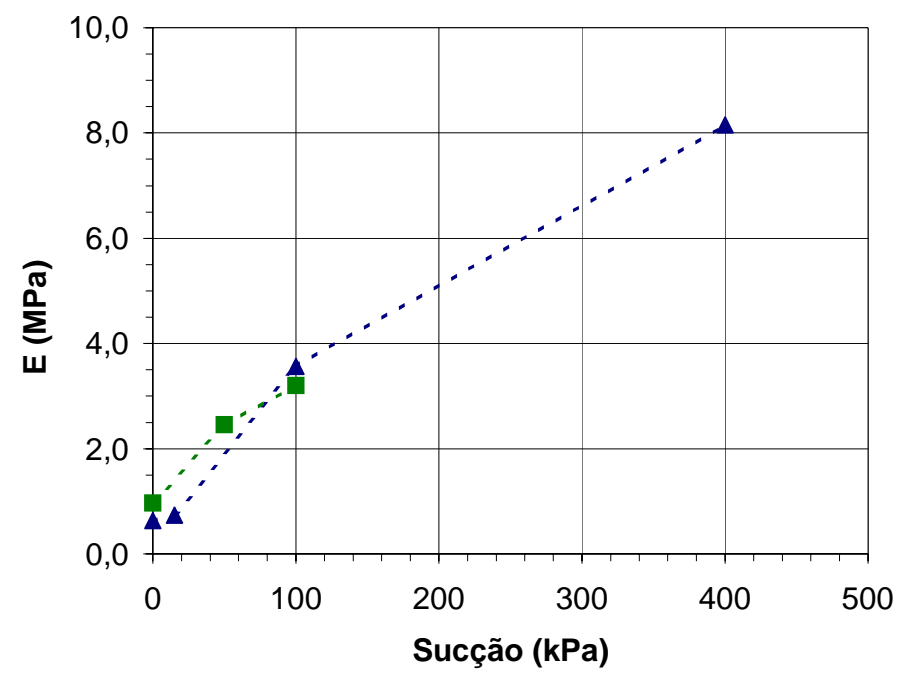

Figura 7.2 - Módulo de deformabilidade em função da sucção (profundidades de 1,0 e 2,0 m)

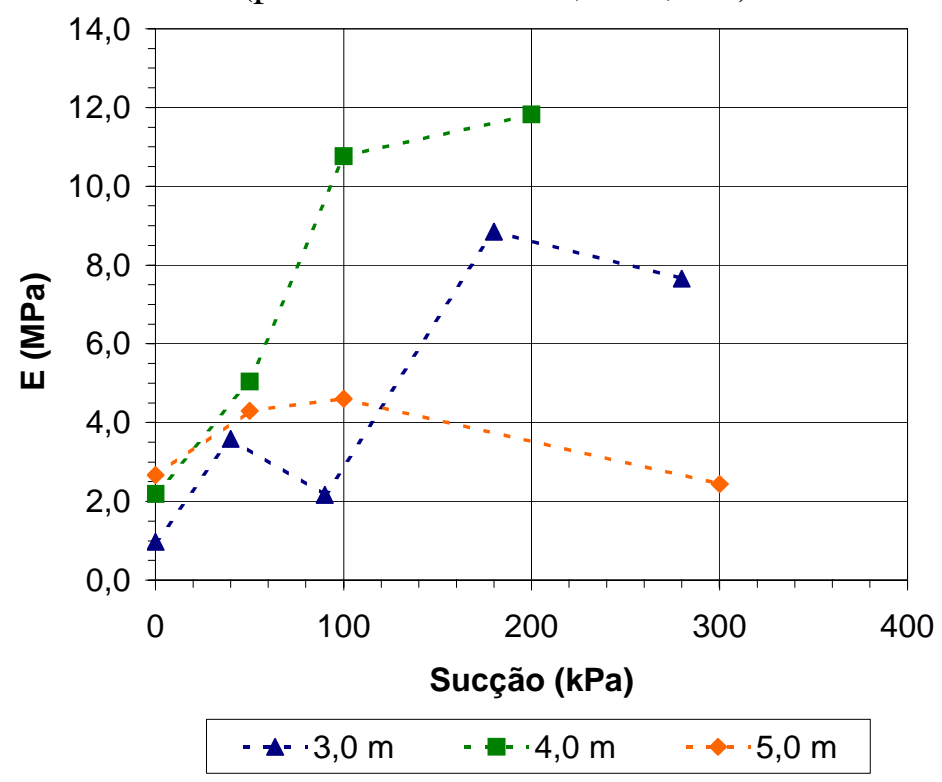

Figura 7.3 - Módulo de deformabilidade em função da sucção (profundidades de 3,0, 4,0 e 5,0 m). 


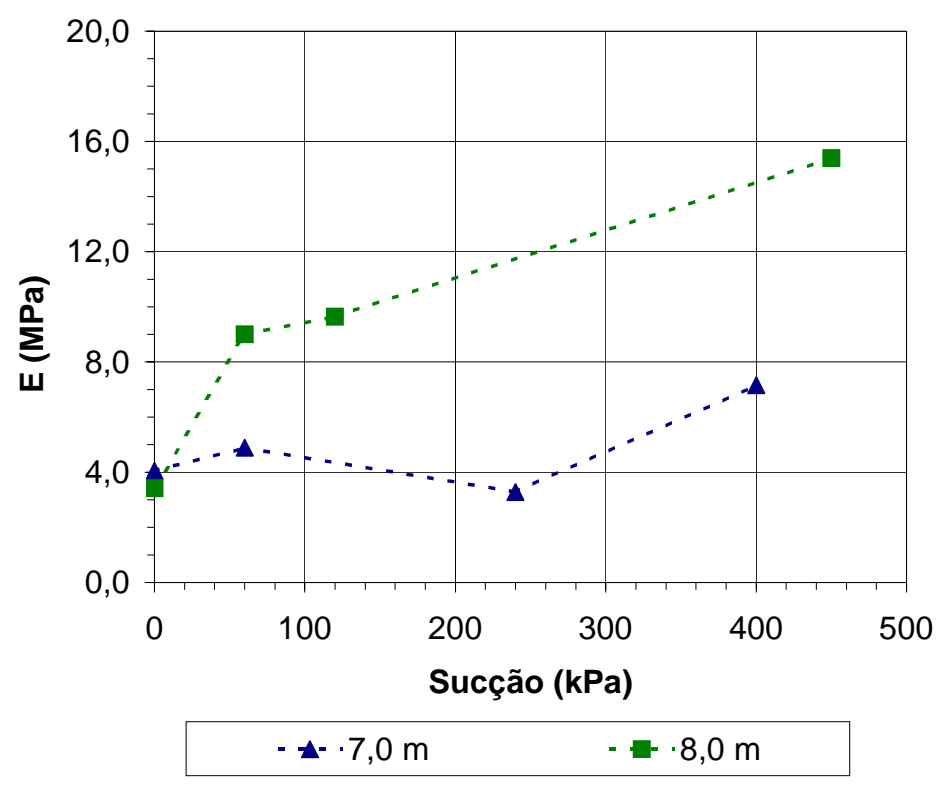

Figura 7.4 - Módulo de deformabilidade em função da sucção (profundidade de 7,0 e 8,0 m).

\subsection{ENSAIOS DE COMPRESSÃO TRIAXIAL}

Utilizando os resultados obtidos durante a fase de cisalhamento nos ensaios triaxiais de Machado (1998), apresentados no Anexo B, determinou-se o módulo de deformabilidade secante e o módulo tangente inicial, para as profundidades de 2,0, 5,0 e $8,0 \mathrm{~m}$.

A deformação axial correspondente a 50\% da tensão desviadora máxima foi utilizada para o cálculo do módulo de deformabilidade secante $\left(E_{50}\right)$. O módulo tangente inicial $\left(E_{0}\right)$ foi determinado por meio do ajuste hiperbólico das curvas tensãodeformação utilizando a formulação proposta por Kondner (1963). Em ambos os casos, considerou-se a tensão confinante igual a $50 \mathrm{kPa}$, uma vez que para os demais níveis de confinamento empregados as amostras já se encontravam deformadas pelo confinamento anterior.

Os valores obtidos são mostrados nas Figuras 7.5 e 7.6. Mais uma vez fica evidenciada a tendência de aumento do módulo de deformabilidade com a sucção matricial. Nota-se que este aumento foi menos pronunciado para a profundidade de 8,0 m, provavelmente por ser um solo de outra origem geológica. 


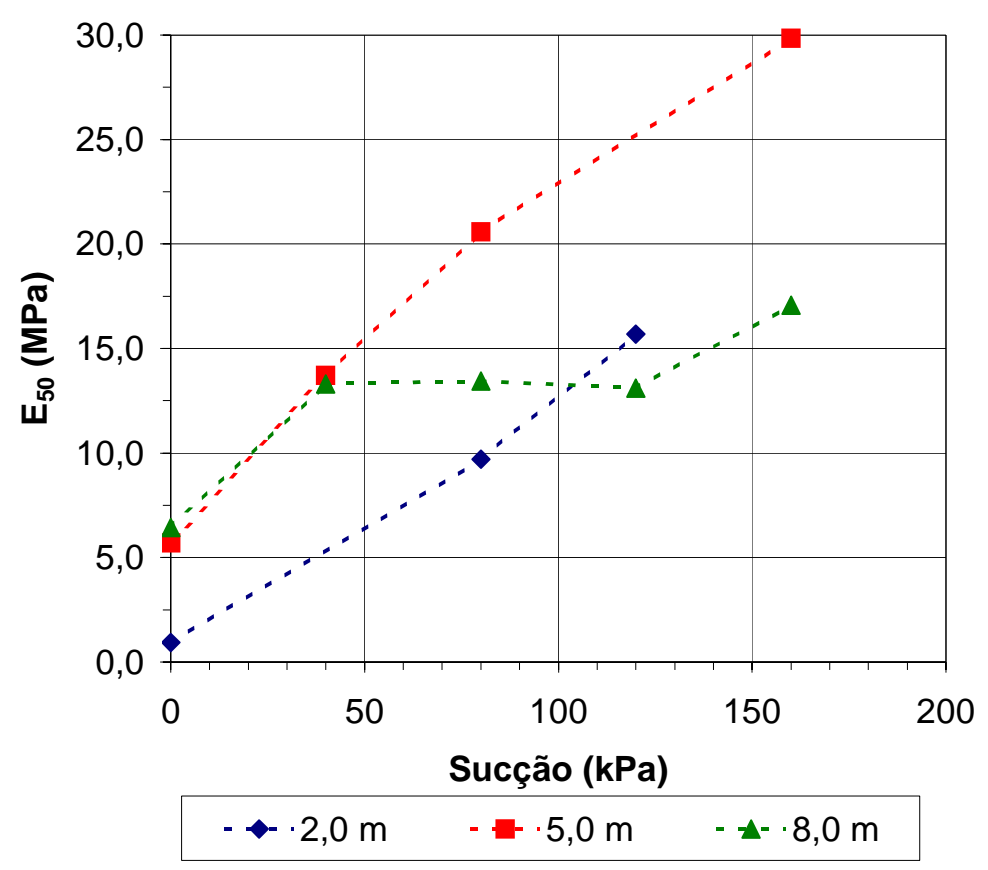

Figura 7.5 - Variação do módulo de deformabilidade secante obtido nos ensaios triaxiais com a suç̧ão.

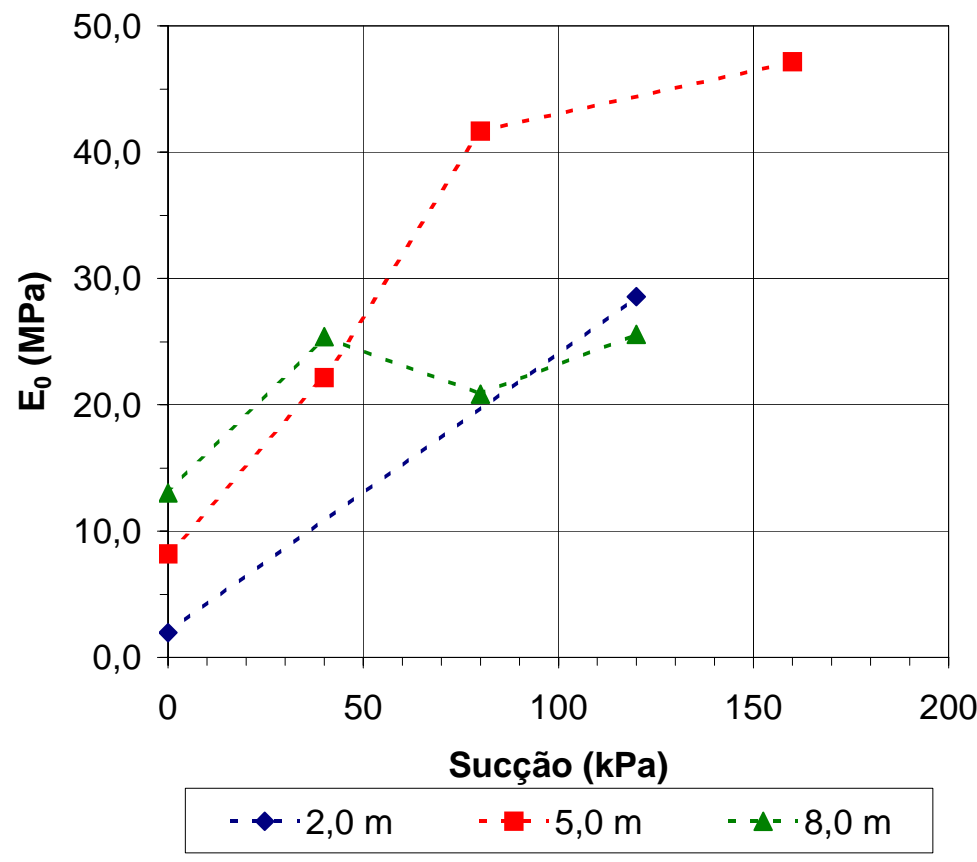

Figura 7.6 - Variação do módulo de deformabilidade tangente inicial obtido nos ensaios triaxiais com a sucção.

As equações que representam a variação do módulo tangente inicial com a sucção matricial para as profundidades de 2,0, 5,0 e 8,0 m, válidas para o intervalo de sucções de 0 a $80 \mathrm{kPa}$, foram apresentadas no item 6.2.

Para os níveis de sucção matricial aplicados nos diferentes tipos de ensaios, os resultados dos módulos de deformabilidade apresentaram uma tendência de aumento 
com a sucção matricial. Esta tendência de aumento deve ser menos pronunciada e atingir um valor máximo para sucções mais elevadas, segundo Jucá e Escario (1991).

\subsection{COMPARAÇÃO ENTRE OS RESULTADOS DE CAMPO E LABORATÓRIO}

Os módulos de deformabilidade obtidos nos diferentes ensaios, para sucções da ordem das constatadas em campo, são resumidos nas Figuras 7.7 e 7.8. O símbolo (E), mostrado nestas figuras, refere-se ao módulo de deformabilidade obtido a partir da relação com o módulo edométrico.

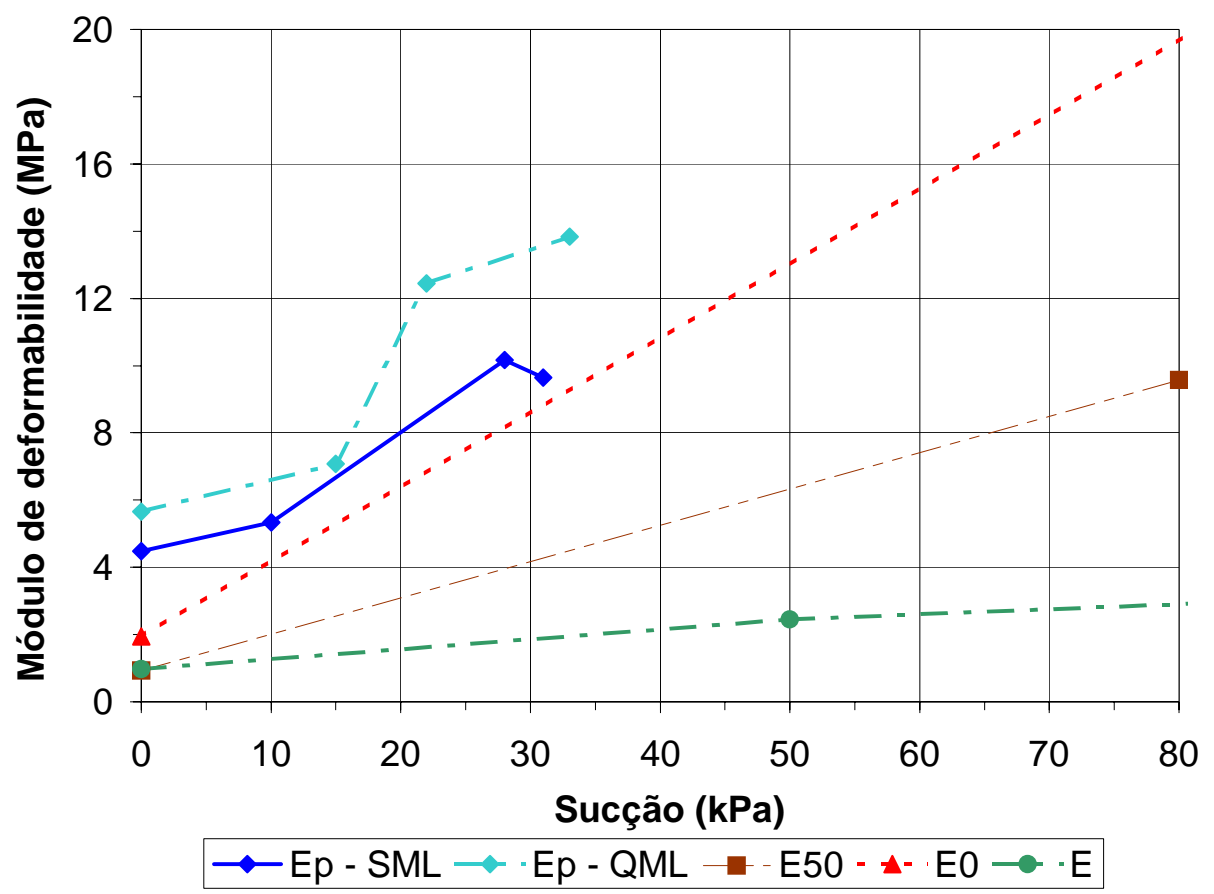

Figura 7.7 - Comparação entre os resultados de campo (profundidade de 1,5 m) e laboratório (profundidade de 2,0 m). 


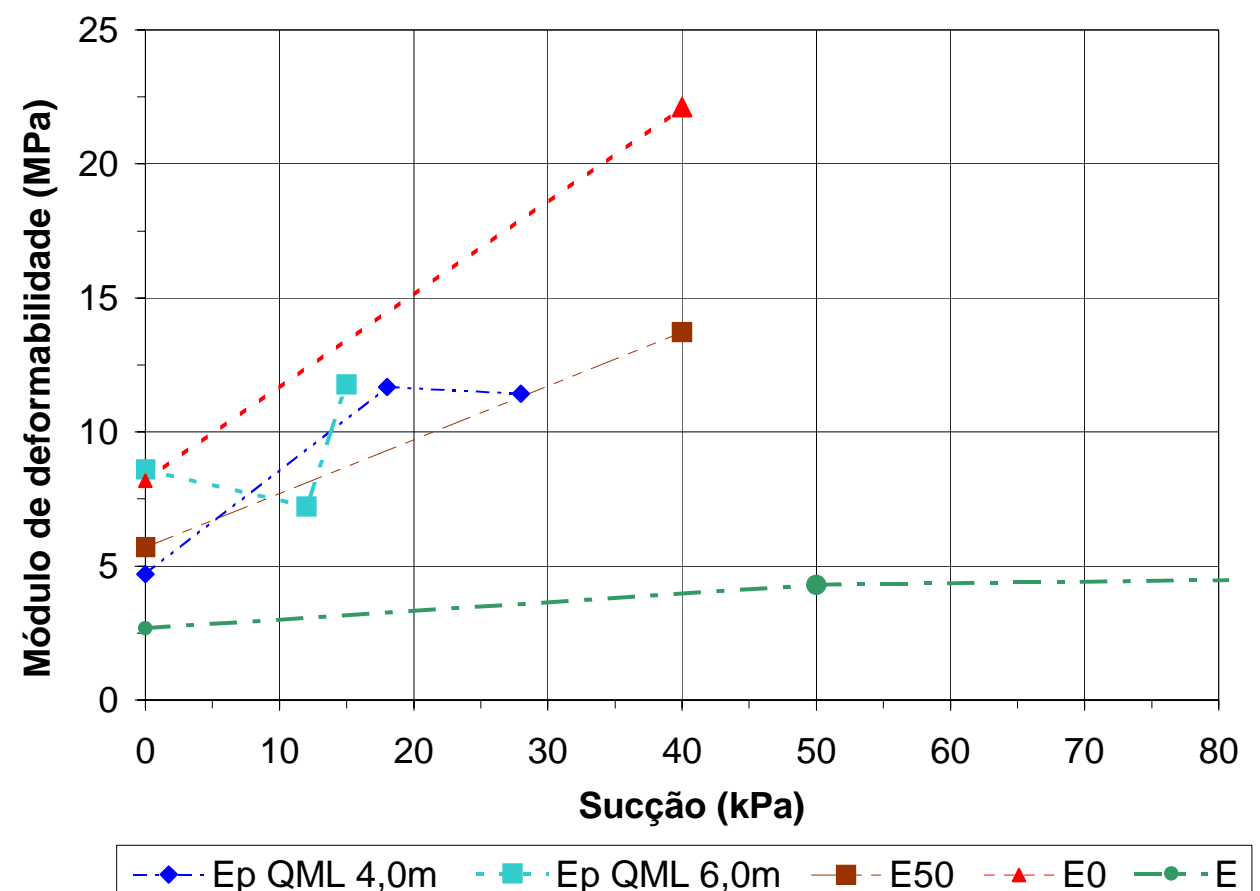

Figura 7.8 - Comparação entre os resultados de campo (profundidades de 4,0 e 6,0 m) e laboratório (profundidade de 5,0 m).

Observa-se na Figura 7.7 que o módulo tangente inicial $E_{0}$ foi o que apresentou uma melhor concordância com o módulo obtido nos ensaios de placa, especialmente com os do tipo lento.

Na Figura 7.8 pode-se verificar que o módulo obtido a partir dos ensaios de placa situou-se numa faixa de valores entre o módulo tangente inicial e o módulo secante.

Verificada a influência da sucção no módulo de deformabilidade em solos não saturados, pode-se dizer que a estimativa deste parâmetro a partir de correlações com resultados de ensaios que não consideram a sucção do solo, torna-se inadequada. 


\section{CONCLUSÕES}

Neste trabalho apresentou-se um método para a previsão da curva tensãorecalque de provas de carga em placa circular em solo não saturado, possibilitando variar a sucção matricial, a profundidade de assentamento e o diâmetro da placa. Constatou-se que o método de previsão é simples, de fácil aplicação e fornece resultados adequados quando comparados com os valores medidos.

O método foi calibrado para provas de carga em placa com diversos níveis de sucção, na profundidade de $1,5 \mathrm{~m}$ e com diâmetros desde $0,2 \mathrm{~m}$ até $1,5 \mathrm{~m}$, dispondose de ensaios de laboratório e de campo. Os ensaios de laboratório forneceram a tensão de cedência e o módulo de deformabilidade, ambos em função da sucção, e os de campo a determinação da relação c/ $\sigma_{y}$ em função do diâmetro da placa para a condição de solo inundado e não inundado.

Quando comparadas as curvas tensão-recalque medidas com as previstas, percebeu-se que elas apresentaram resultados próximos, ressaltando que algumas das curvas experimentais e previstas foram praticamente únicas. A relação entre a tensão de ruptura convencional medida e prevista para os ensaios inundados e não inundados apresentou, respectivamente, um valor médio igual a 0,96 e 0,92. Notou-se que ambos os valores foram previstos de maneira satisfatória e levemente a favor da segurança. A variação da relação entre as tensões medidas e previstas foi maior nos ensaios inundados, apresentando um coeficiente de variação de 32,1 \%, do que nos ensaios não inundados, nos quais o coeficiente de variação foi igual a 10,3 \%.

Os recalques para a tensão admissível nos ensaios não inundados apresentaram o valor da relação entre o recalque previsto e medido superior a 1,0, sendo o valor médio igual a 1,95. Entretanto, a relação $\rho_{\text {prev. }} / \rho_{\text {med. }}$ deve ser observada cuidadosamente, pois para baixos valores de recalques medidos a mesma pode apresentar um valor elevado, enquanto que a diferença entre o medido e o previsto não é significativa. 
Uma outra forma de verificação da eficiência do método proposto baseou-se na determinação da energia de deformação armazenada no sistema durante a fase de carregamento. Pode-se observar que as energias previstas apresentaram-se pouco inferiores aos valores medidos, com uma relação média de 0,82 para os ensaios inundados, e de 0,85 para os não inundados. Novamente, os valores estiveram próximos da unidade e a favor da segurança, porém, com uma dispersão maior nos ensaios inundados do que nos não inundados.

Portanto, verificou-se a aplicabilidade do método proposto em reproduzir o comportamento do sistema solo-placa, tanto para a condição de solo inundado como para a de não inundado.

A partir do comportamento previsto para os ensaios de placa, constatou-se o aumento da capacidade de carga e da rigidez do solo em função da sucção e da profundidade, uma vez que, para um mesmo nível de tensão aplicada, os recalques foram menores para sucções e profundidades maiores. A capacidade de carga apresentou em média um acréscimo de 24 kPa para uma variação de sucção de 10 kPa. Com relação à profundidade o aumento da capacidade de carga foi mais significativo da profundidade de 1,5 para 4,0 $\mathrm{m}$, do que da profundidade de 4,0 para 6,0 m, sendo em média igual a $94 \%$ e $15 \%$, respectivamente.

Pode-se observar também com o método proposto, mantendo-se constante a sucção para a profundidade de 1,5 m, a influência do diâmetro da placa na curva tensãorecalque. Verificou-se que quanto maior o diâmetro da placa maior será o recalque para um mesmo nível de tensão aplicada. $\mathrm{O}$ recalque de uma placa com diâmetro de $1,5 \mathrm{~m}$ foi aproximadamente $85 \%$ maior que o de uma placa de $0,8 \mathrm{~m}$.

Também, foi proposta uma correção aos recalques medidos nos estágios de ensaios com carregamento do tipo rápido para obtenção dos correspondentes recalques estabilizados de um ensaio lento. A correção aplicada a alguns ensaios rápidos apresentou recalques estabilizados, em média, 15 \% superiores aos medidos em estágios com duração de 15 minutos.

Quanto ao módulo de deformabilidade do solo analisado, obtido por meio de diversos ensaios de campo e de laboratório, observou-se uma tendência de aumento em função da sucção matricial. Para os resultados de campo, um aumento na sucção de $1 \mathrm{kPa}$ acarretou um acréscimo, em média, de $190 \mathrm{kPa}$ no módulo de deformabilidade. Assim, em solos não saturados qualquer estimativa deste módulo a partir de correlações com resultados de ensaios que não consideram a sucção do solo, torna-se inadequada.

Constatou-se que para a profundidade de 1,5 m os valores do módulo de deformabilidade obtidos por meio de ensaios de laboratório são menores que os 
determinados em campo, sendo o que mais se aproximou dos resultados de campo foi o módulo tangente inicial resultante dos ensaios triaxiais. Quanto aos módulos encontrados através dos ensaios de placa realizados nas profundidades de 4,0 e 6,0 m, estes se situaram numa faixa de valores entre o módulo tangente inicial e o módulo secante.

Como sugestão para pesquisas futuras propõe-se executar ensaios de placa com diâmetros diferentes de $0,80 \mathrm{~m}$ em profundidades superiores a $1,5 \mathrm{~m}$, a fim de avaliar o comportamento previsto do sistema solo-placa pela metodologia exposta neste trabalho. 


\section{REFERÊNCIAS BIBLIOGRÁFICAS}

AGNELLI, N. (1992). Estudo da colapsibilidade do solo de Bauru através de provas de carga diretas. 172p. Dissertação (Mestrado) - Escola de Engenharia de São Carlos, Universidade de São Paulo, São Carlos. 1992.

AGNELLI, N. (1997). Comportamento de um solo colapsível inundado com líquidos de diferentes composições químicas. 219p. Tese (Doutorado) - Escola de Engenharia de São Carlos, Universidade de São Paulo, São Carlos. 1997.

AOKI, N. (1997). Determinação da capacidade de carga última de estaca cravada em ensaio de carregamento dinâmico de energia crescente. 111 p. Tese (Doutorado) Escola de Engenharia de São Carlos, Universidade de São Paulo, São Carlos. 1997.

AOKI, N. (1998). Energia complementar como critério de ruptura de estaca cravada. Apresentado a ABMS (NRSP) e IESP, São Paulo, 1998.

ASSOCIAÇÃO BRASILEIRA DE NORMAS TÉCNICAS (1984). NBR 6489: Prova de carga direta sobre terreno de fundação. Rio de Janeiro.

BARATA, F.E. (1966). Ensaios de placa para fixação de taxa admissível de fundações diretas. In: CONGRESSO BRASILEIRO DE MECÂNICA DOS SOLOS, 3., 1966, Belo Horizonte. Anais... São Paulo: ABMS. v.1, p.III-1-37.

BARATA, F.E. (1984). Propriedades mecânicas dos solos: uma introdução ao projeto de fundações. Rio de Janeiro: Livros Técnicos e Científicos S.A.

BORTOLUCCI, A.A. (1983). Caracterização geológico-geotécnica da região urbana de São Carlos-SP a partir de sondagens de simples reconhecimento. 67p. Dissertação (Mestrado) - Escola de Engenharia de São Carlos, Universidade de São Paulo, São Carlos. 1983.

BOWLES, J.E. (1996). Foundation analysis and design. 5th ed. New York: McGrawHill. 
BRIAUD, J.L.; GIBBENS, R. (1999). Behavior of five large spread bootings on sand. Journal of the Geotechnical and Geoenvironmental Engineering. ASCE, v.125, n.9, p.787-796.

BROWN, P.T. (1988). Performance and interpretation of screw plate tests. Geotechnical Engineering. v.19, n.1, p.143-159, June.

CAMPOS, T.M.P. (1994). Equipamentos e técnicas para a determinação da sucção no campo. In: SIMPÓSIO SOBRE SOLOS NÃO SATURADOS, 2., 1994, Recife. Anais... AMSF-UFPE/ABMS-NE. v.1, p.9-18.

CARNEIRO, B.I.J. (1999). Comportamento de tubulões a céu aberto, instrumentados, em solo não saturado colapsível. Tese (Doutorado) - Escola de Engenharia de São Carlos, Universidade de São Paulo, São Carlos. 1999.

CARVALHO, D.; SOUZA, A. (1990). Análise do efeito do umedecimento do solo em fundações rasas e profundas em solos porosos. In: CONGRESSO BRASILEIRO DE GEOLOGIA DE ENGENHARIA, 6 / CONGRESSO BRASILEIRO DE MECÂNICA DOS SOLOS E ENGENHARIA DE FUNDAÇÕES, 9., 1990, Salvador. Anais... São Paulo: ABGE/ABMS. v.2, p.109-114.

CHIN, F. K. (1970). Estimation of the ultimate load of piles from tests not carried to faiture. In: SOUTHEAST ASIAN CONFERENCE ON SOIL ENGINEERING, 2., 1970, Singapore. Proceedings... p 81-90.

CINTRA, J. C. A. (1998). Fundações em solos colapsíveis. São Carlos: RiMa.

CINTRA, J.C.A.; AOKI, N.; ALBIERO, J.H. (2003). Tensão admissível em fundações diretas. São Carlos: RiMa.

CINTRA, J.C.A.; CARVALHO, D. ; GIACHETTI, H.L.; BORTOLUCCI, A.A.; ALBIERO, J.H. (1991). Campo experimental de fundações em São Carlos. In: SEMINÁRIO DE ENGENHARIA DE FUNDAÇÕES ESPECIAIS, 2., 1985, São Paulo. Anais... São Paulo: ABMS/ABEF. v.1, p.96-105.

CONCIANI, W. (1997). Estudo do colapso do solo através de ensaios de placa monitorados com tensiômetros e tomografia computadorizada. 181p. Tese (Doutorado) - Escola de Engenharia de São Carlos, Universidade de São Paulo, São Carlos. 1997.

CONCIANI, W.; HERRMANN Jr., P.S.P.; MACHADO, S.L.; SOARES, M.M. (1996). O uso da técnica de reflectometria no domínio do tempo (TDR) para determinação da umidade do solo in situ. Solos e rochas, São Paulo, v.19, n.3, p.189-199, dez.

COSTA, Y. D. J. (1999). Estudo do comportamento não saturado do solo através de ensaios de placa. 138p. Dissertação (Mestrado) - Escola de Engenharia de São Carlos, Universidade de São Paulo, São Carlos. 1999. 
D’APPOLONIA, D.J.; D’APPOLONIA, E.; BRISSETTE, R.F. (1968). Settlement of spread footings on sand. Journal of the Soil Mechanics and Foundation Division. ASCE, v.94, n.SM3, p.735-760.

DELAGE, P.; SURAJ DE SILVA, G.P.R.; LAURE, E. (1987). Un nouvel appareil triaxial pour lês sols non-saturés. In: EUROPEAN CONFERENCE ON SOIL MECHANICS AND FOUNDATION ENGINEERING, 9., 1987, Dublin. Proceedings... Rotterdam: A. A. Balkema. p.25-28.

EDIL, T.B.; MOTAN, S.E.; TOHA, F.X. (1981). Mechanical behavior and testing methods of unsaturated soils. In: YOUNG, R.N. (eds.). Laboratory Shear Strength of Soil. ASTM STP 740, p.114-129.

ENGER (1916). High unit pressures found in experiments on distribution of vertical loading through sand. Eng. Rec. v. 73.

FEDA, J. (1978). Stress in subsoil and methods of final settlement calculation. New York: Elsevier.

FELLENIUS, B.H. (1975). The load of piles and new proof testing procedure. Journal of the Geotechnical Engineering Division. ASCE, GT9, v.101, p.855-869, Sept.

FERREIRA, R.C.; PERES, J.E.E.; BENVENUTO, C. (1990). Uma análise de modelos geotécnicos para a previsão de recalques em solos colapsíveis. In: CONGRESSO BRASILEIRO DE GEOLOGIA DE ENGENHARIA, 6 / CONGRESSO BRASILEIRO DE MECÂNICA DOS SOLOS E ENGENHARIA DE FUNDAÇÕES, 9., 1990, Salvador. Anais... São Paulo: ABGE/ABMS. v.2, p.73-79.

FERREIRA, S.R.M.; LACERDA, W.A. (1993). Variação de volume em solo colapsível medidas em ensaios de laboratório e campo. Solos e Rochas, São Paulo, v.16, n.4. p.235-243.

FLEMING, P.M.; CAMPOS, T.M.P.; VARGAS Jr., E.A. (1994). Medida de sucção em encostas não saturadas através de tensiômetros automáticos. In: SIMPÓSIO SOBRE SOLOS NÃO SATURADOS, 2., 1994, Recife. Anais... AMSF-UFPE/ ABMS-NE. v.1, p.79-88.

FREDLUND, D.D.; XING, A (1994). Equations for the soil-water characteristics curve. Canadian Geotechnical Journal. v.31, n.4, p.521-532.

FREDLUND, D.G.; RAHARDJO, H. (1993). Soil Mechanics for Unsaturated Soils. New York: Jonh Wiley \& Sons.

GARDNER, R. (1937). A method of measuring the capillary tension of soil moisture over a wide moisture range. Soil Science. v.43, n.4, p.277-283. 
GOLDECK, A. J. (1925). The supporting value of sois as influenced by the bearing área. Proceedings. ASCE.

HAN, K. K.; WONG, K. S.; BROMS, B.B.; YAP, L. P. (1993). The origin and properties of bouldery clay in Singapore. Geotechnical Engineering. v.24, n.2, p. 151166, Dec.

HILF, J.W. (1956). An investigation of pore-water pressure in compacted cohesive soils. 654p. Ph.D. Dissertation. Tech. Memo., U.S. Dep. of the Interior, Bureau of Reclamation, Design and Construction Division, Denver, CO. 1956.

INSTITUTO DE PESQUISAS TECNOLÓGICAS (1954). Relatório Nº. 2269: Estudo das fundações para as futuras instalações da Escola de Engenharia de São Carlos. São Paulo.

ISMAEL, N.F.; AL-SANAD, H.A. (1993). Plate loading tests on weakly cemented surface desert sands. Geotechnical Engineering. v.24, n.2, p.133-150, Dec.

JUCÁ, J.F.T.; ESCARIO, V. (1991). Variation of the modulus of deformation of unsaturated soils with suction. In: EUROPEAN CONFERENCE ON SOIL MECHANICS AND FOUNDATION ENGINEERING, 10., 1991, Florence. Proceedings... v.1, p.121-124.

KONDNER, R.L. (1963). Hyperbolic stress-strain response: cohesive soils. Journal of the Soil Mechanics and Foundations Division. ASCE, v.89, n.SM1, p.115-143.

MACACARI, M.F. (2001). Variação da capacidade de carga com a sucção $e$ profundidade em ensaios de placa em solo colapsível. 96p. Dissertação (Mestrado) Escola de Engenharia de São Carlos, Universidade de São Paulo, São Carlos. 2001.

MACHADO, J. (1954). Estudos de recalques de fundações diretas em Santos. In: CONGRESSO BRASILEIRO DE MECÂNICA DOS SOLOS, 1., 1954, Porto Alegre. Anais... São Paulo: ABMS. v.2, p.166-174.

MACHADO, S.L. (1995). Estudo da compressão confinada e do colapso de um colúvio arenoso compacto. Dissertação (Mestrado) - Escola de Engenharia de São Carlos, Universidade de São Paulo, São Carlos. 1995.

MACHADO, S.L. (1998). Aplicações de conceitos de elastoplacidade a solos não satuados. 361p. Tese (Doutorado) - Escola de Engenharia de São Carlos. Universidade de São Paulo, São Carlos. 1998.

MAHMOUD, H.H.; HOUSTON, W.N.; HOUSTON, S.L. (1995). Apparatusand procedure for na in situ collapse test. Geotechnical Journal. v.18, n.4, p.431-440.

MARCHETTI, S. (1975). A new in situ test for the measurement of horizontal soil deformability. In: CONFERENCE ON IN SITU MEASUREMENTS OF SOIL PROPERTIES, 2., 1975, Raleigh, N.C. Proceedings... New York: ASCE. p.255-259. 
MARINHO, F. A. M. (1994). Medição de sucção com o método do papel filtro. In: CONGRESSO BRASILEIRO DE MECÂNICA DOS SOLOS E ENGENHARIA DE FUNDAÇÕES, 10., 1994, Foz do Iguaçú. Anais... São Paulo: ABMS. v.2, p.515-522.

MARINHO, F.A.M.; CHANDLER, R.J.; CRILLY, M.S. (1995). Stiffness measurements on an unsaturated high plasticity clay using bender elements. In: INTERNATIONAL CONFERENCE ON UNSATURATED SOILS, 1., 1995, Paris. Proceedings... v.2, p.535-539.

MASSAD, F. (1982). Método gráfico para o acompanhamento da evolução dos recalques com o tempo. In: CONGRESSO BRASILEIRO DE MECÂNICA DOS SOLOS E ENGENHARIA DE FUNDAÇÕES, 7., 1982, Olinda. Anais... São Paulo: ABMS. v.2, p.321-331.

MASSAD, F. (1986). Notes on the interpretation of failure load from routine pile load tests. Solos e Rochas, São Paulo. v.9 n.1, p.33-36.

MAZURKIEWICZ, B. K. (1972). Test loading of piles according to Polish Regulations. Swedish Academy of Engineering Sciences. Report. n.35, p.20.

MELLO, L.G.F.S.; CEPOLLINA, M. (1978). Sobre a interpretação de provas de carga sobre placas visando previsão de recalques. In: CONGRESSO BRASILEIRO DE MECÂNICA DOS SOLOS E ENGENHARIA DE FUNDAÇÕES, 6., 1978, Rio de Janeiro. Anais... São Paulo: ABMS. v.1, p.165-180.

MITCHELL, J.K.; GARDNER, W.S. (1975). In situ measurements of volume change characteristics. In: CONFERENCE IN SITU MEASUREMENTS OF SOIL PROPERTIES, 1., 1975, North Caroline. Proceedings... v.2, p.279.

NAKATA, S.; KAGE, S.; MARBA, R.C.; KASHIMOTO, N. (1982). Análise dos ensaios geotécnicos da área da Companhia Siderúrgica de Tubarão e dedução dos parâmetros para cálculo de fundação. In: CONGRESSO BRASILEIRO DE MECÂNICA DOS SOLOS E ENGENHARIA DE FUNDAÇÕES, 7., 1982, Olinda. Anais... São Paulo: ABMS. v.2, p.234-245.

NAPOLES NETO, A.D.F. (1954). Estudo de recalques de um grande castelo d'água fundado sobre solo residual mole. In: CONGRESSO BRASILEIRO DE MECÂNICA DOS SOLOS, 1., 1954, Porto Alegre. Anais... São Paulo: ABMS. v.2, p.175-188.

PINTO, C.S. (1996). Propriedades dos solos. In: HACHICH et al. (eds.). Fundações: teoria e prática. São Paulo: PINI. Cap.2, p.51-118.

REZNIK, Y.M. (1992). Determination of deformation properties of collapsible soils. Geotechnical Testing Journal, ASTM, v.15, n.3, p.248-255, Sept.

REZNIK, Y.M. (1993). Plate load tests of collapsible soils. Journal of Geotechnical Engineering, ASCE, v.119, n.3, p.608-615.

REZNIK, Y.M. (1994). A method for interpretation of plate load test results. Engineering Testing Journal. v.17, n.1, p.72-79, Mar. 
REZNIK, Y.M. (1995a). Rigid plate settlements on soils with varying deformation properties. Geotechnical Testing Journal. ASTM, v.18, n.2, p.194-203, June.

REZNIK, Y.M. (1995b). Comparison of results of oedometer and plate load tests performed on collapsible soils. Engineering Geology. v.39, n.1-2, p.17-30, May.

RICHARDS, B. G. (1974). Behavior of unsaturated soils. In: LEE, I. K. Soil Mechanics. New York: Elsevier. Cap. 4, p.112-157.

RICHARDS, L.A. (1928). The usefulness of capillary potential to soil moisture and plant investigators. Journal of the Agricultural Research. v.37, n.12, p.719-742.

RIDLEY, A.M.; DINEEN, K.; BURLAND, J.B.; VAUGHAN, P.R. (2003). Soil matrix suction: some examples of its measurement and application in geotechnical engineering. Géotechnique. v.53, n.2, p.241-253, Mar.

SANTOS, T. R. (2001). Atrito lateral e resistência de base em tubulões a céu aberto em solos colapsíveis. 171 p. Dissertação (Mestrado) - Escola de Engenharia de São Carlos, Universidade de São Paulo, São Carlos. 2001.

SCHULTZE, E. (1976). Session III/1 - Pile foundations. Oral Discussions. In: EUROPEAN CONFERENCE ON SOIL MECHANICS AND FOUNDATION ENGINEERING, 6., 1976, Vienna. Proceedings... v.2.2, p.183-184.

SCHNAID, F. (2000). Ensaios de campo e suas aplicações à engenharia de fundações. São Paulo: Oficina de Textos.

SCHNAID, F.; CONSOLI, N.C.; MANTARAS, F.M. (1995). O uso do ensaio pressiométrico na determinação de parâmetros de solos não saturados. Solos e Rochas, São Paulo, v.18, n.3, p.129-137, Dez.

SOUSA, L.C.M. (2003). Estudo experimental do comportamento de sapatas assentes em solo poroso reforçado. 133 p. Dissertação (Mestrado). Universidade de Brasília, Brasília. 2003.

SOUZA, A.; CINTRA, J.C.A. (1994). Fundações rasas no solo colapsível de Ilha Solteira-SP. In: CONGRESSO BRASILEIRO DE MECÂNICA DOS SOLOS E ENGENHARIA DE FUNDAÇÕES, 10., 1994, Foz do Iguaçu. Anais... São Paulo: ABMS. v.1, p.223-230.

SOWERS, G.F. (1962). Shallow foundations. In: LEONARDS, G.A. (ed.). Foundation engineering. New York: McGraw-Hill. Cap.6, p.525-632

TAKE, W.A.; BOLTON, M.D. (2003). Tensiometer saturation and the reliable measurement of soil suction. Géotechnique. v.53, n.2, p.159-172, Mar.

TARANTINO, A.; MONGIOVÌ, L. (2001). Experimental procedures and cavitation mechanisms in tensiometer measurements. Geotechnical and Geological Engineering. v.19, p.189-210, May. 
TAYLOR, D.W. (1948). Fundamentals of soil mechanics. New York: John Willey \& Sons.

TEIXEIRA, A. H.; GODOY, N. S. (1996). Análise, projeto e execução de fundações rasas. In: HACHICH et al. (eds.). Fundações: teoria e prática. São Paulo, PINI. Cap.7, p.227-264.

TERZAGHI, K. (1925). Erdbaumechanik. F. Deuticke, Viena.

TERZAGHI, K. (1932). Bodenpressung und Bettungziffer.[S.I.: s.n.].

TERZAGHI, K. (1943). Theoretical soil mechanics. New York: John Willey \& Sons.

TERZAGHI, K.; PECK, R.B. (1948). Soil mechanics in engineering practice. New York: John Willey \& Sons.

TOMLINSON, M. J. (1995). Foudation design and construction. 6th ed. Harlow, England: Longman Scientific \& Technical.

VAN DER VEEN, C. (1953). The bearing capacity of a pile. In: INTERNATIONAL CONFERENCE ON SOIL MECHANICS AND FOUNDATION ENGINEERING, 3., 1953, Zurich (Switzerland). Proceedings... v.2, p.84-90.

VARGAS, M. (1977). Introdução à Mecânica dos Solos. São Paulo: Mc Graw-Hill do Brasil Ltda.

VELLOSO D.A.; LOPES, F.R. (1996). Fundações. Rio de Janeiro: COPPE-UFRJ.

VELLOSO, P.P.C.; GRILLO, S.Q.; PENEDO, E.J. (1978). Observações sobre a capacidade de carga e módulo de deformação de solo por meio de provas de carga e ensaios de laboratório. In: CONGRESSO BRASILEIRO DE MECÂNICA DOS SOLOS E ENGENHARIA DE FUNDAÇÕES, 6., 1978, Rio de Janeiro. Anais... São Paulo: ABMS. v.1, p.305-328.

VILAR, O.M.; CINTRA, J.C.A.; PARAGUASSU, A.B.; MACHADO, S.L.; CARVALHO, M.F.; CARNEIRO, B.J.I. (1995). Ensaios de campo e de laboratório em solos não saturados.In: ENCONTRO SOBRE SOLOS NÃO SATURADOS, 1995, Porto Alegre. Anais... Porto Alegre: UFRGS. p.184-201.

WERNECK, M.L.G.; JARDIM, W.F.D.; ALMEIDA, M.S.S. (1980). Deformation modulus of a gneissic residual soil determined from plate loading tests. Solos e Rochas, São Paulo, v.2, n.2, p.3-16, ago. 
APÊNDICE A - Planilhas dos ensaios de placa 


\begin{tabular}{|c|c|c|c|c|c|c|c|}
\hline \multicolumn{8}{|c|}{ UNIVERSIDADE DE SÃO PAULO } \\
\hline \multicolumn{8}{|c|}{ ESCOLA DE ENGENHARIA DE SÃO CARLOS } \\
\hline \multicolumn{8}{|c|}{ DEPTO. DE GEOTECNIA - CAMPO EXPERIMENTAL DE FUNDAÇÕES } \\
\hline \multicolumn{8}{|c|}{$\begin{array}{l}\text { PROVA DE CARGA ESTÁTICA } \\
\end{array}$} \\
\hline \multicolumn{2}{|c|}{ Ensaio: $\quad$ SS1 } & & \multicolumn{3}{|c|}{ Tipo de Carregamento: } & SML \\
\hline \multicolumn{2}{|c|}{ Profundidade: } & \multicolumn{2}{|l|}{$1,5 \mathrm{~m}$} & \multicolumn{2}{|c|}{ Estado do solo: } & \multicolumn{2}{|c|}{ INUNDADO } \\
\hline $\begin{array}{l}\text { Sucção: } \\
\text { Diâmetro: }\end{array}$ & $\begin{array}{cc}0 & \mathrm{kPa} \\
80\end{array}$ & $\mathrm{~cm}$ & & $\begin{array}{l}\text { Reensaio: } \\
\text { Folha: }\end{array}$ & $\begin{array}{l}\text { NÃO } \\
1\end{array}$ & & \\
\hline $\begin{array}{l}\text { Tensão } \\
\text { (kPa) }\end{array}$ & $\begin{array}{l}\text { Início Carr. } \\
\text { (min) }\end{array}$ & $\begin{array}{c}\text { Tempo } \\
\text { (min) }\end{array}$ & $\begin{array}{l}\text { Recalque } \\
\text { (mm) }\end{array}$ & $\begin{array}{l}\text { Tensão } \\
\text { (kPa) }\end{array}$ & $\begin{array}{c}\text { Início Carr. } \\
\text { (min) }\end{array}$ & $\begin{array}{c}\text { Tempo } \\
\text { (min) }\end{array}$ & $\begin{array}{l}\text { Recalque } \\
\text { (mm) }\end{array}$ \\
\hline \multirow{11}{*}{10} & 00:00 & 0 & 0.02 & 40 & 05:00 & 0 & 1.85 \\
\hline & & 1 & 0,03 & & & 1 & 2,81 \\
\hline & & 2 & 0,03 & & & 2 & $\overline{3,04}$ \\
\hline & & 4 & 0,03 & & & 4 & 3,36 \\
\hline & & 6 & 0,03 & & & 6 & 3,51 \\
\hline & & 8 & 0,03 & & & 8 & 3,69 \\
\hline & & 12 & 0,03 & & & 12 & 3,85 \\
\hline & & 15 & 0,03 & & & 15 & 3,97 \\
\hline & & 30 & 0,04 & & & 30 & 4,16 \\
\hline & 01:00 & 60 & 0,04 & & & 60 & 4,36 \\
\hline & & & & & & 90 & 4,44 \\
\hline \multirow[t]{13}{*}{20} & 01:00 & 0 & 0,08 & & 07:00 & 120 & 4,50 \\
\hline & & 1 & - & & & & \\
\hline & & 2 & - & 50 & 07:00 & 0 & 5,02 \\
\hline & & 4 & - & & & 1 & 6,20 \\
\hline & & 6 & 0,14 & & & 2 & $\begin{array}{ll}6,78 \\
\end{array}$ \\
\hline & & 8 & 0,15 & & & 4 & 7,16 \\
\hline & & 12 & 0,16 & & & 6 & 7,60 \\
\hline & & 15 & 0,16 & & & 8 & - \\
\hline & & 30 & 0,18 & & & 12 & 8,14 \\
\hline & & 60 & 0,22 & & & 15 & 8,47 \\
\hline & & 90 & 0,23 & & & 30 & 9,03 \\
\hline & 03:00 & 120 & 0,23 & & & 60 & 9,68 \\
\hline & & & & & & 90 & 9,94 \\
\hline \multirow[t]{12}{*}{30} & 03:00 & 0 & 0,57 & & & 120 & 10,07 \\
\hline & & 1 & 0,87 & & & 150 & 10,14 \\
\hline & & 2 & 0,99 & & $\begin{array}{l}10: 00 \\
\end{array}$ & 180 & 10,20 \\
\hline & & 4 & 1,09 & & & & \\
\hline & & 6 & - & & & & \\
\hline & & 8 & 1,20 & & & & \\
\hline & & 12 & 1,28 & & & & \\
\hline & & 15 & 1,31 & & & & \\
\hline & & 30 & 1,40 & & & & \\
\hline & & 60 & 1,54 & & & & \\
\hline & & 90 & 1,57 & & & & \\
\hline & 05:00 & 120 & 1,59 & & & & \\
\hline & & & & & & & \\
\hline & & & & & & & \\
\hline & & & & & & & \\
\hline & & & & & & & \\
\hline & & & & & & & \\
\hline
\end{tabular}




\begin{tabular}{|c|c|c|c|c|c|c|c|}
\hline Ensaio: & SS1 & Prof.: & $1,5 \mathrm{~m}$ & Sucção: & $\begin{array}{ll}0 & \mathrm{kPa} \\
\end{array}$ & Folha: & 2 \\
\hline $\begin{array}{c}\text { Tensão } \\
(\mathrm{kPa})\end{array}$ & $\begin{array}{c}\text { Início Carr. } \\
\text { (min) }\end{array}$ & $\begin{array}{r}\text { Tempo } \\
(\mathrm{min})\end{array}$ & $\begin{array}{c}\text { Recalque } \\
(\mathrm{mm})\end{array}$ & $\begin{array}{c}\text { Tensão } \\
(\mathrm{kPa})\end{array}$ & $\begin{array}{c}\text { Início Carr. } \\
\text { (min) }\end{array}$ & $\begin{array}{c}\text { Tempo } \\
\text { (min) }\end{array}$ & $\begin{array}{c}\text { Recalque } \\
(\mathrm{mm})\end{array}$ \\
\hline & & & & & & & \\
\hline \multirow[t]{17}{*}{60} & $10: 00$ & 0 & 10,96 & 1D & $19: 30$ & 0 & 31,31 \\
\hline & & 1 & 11,04 & & & 1 & - \\
\hline & & 2 & - & & & 2 & 31,29 \\
\hline & & 4 & 12,75 & & & 4 & 31,28 \\
\hline & & 6 & - & & & 6 & 31,28 \\
\hline & & 8 & 13,96 & & & 8 & 31,27 \\
\hline & & 12 & 15,09 & & & 12 & 31,26 \\
\hline & & 15 & 15,59 & & & 15 & 31,26 \\
\hline & & 30 & 17,03 & 0 & $20: 00$ & 30 & 31,26 \\
\hline & & 60 & 18,03 & & & & \\
\hline & & 90 & 18,54 & & & & \\
\hline & & 120 & 18,85 & & & & \\
\hline & & 150 & 19,21 & & & & \\
\hline & & 180 & 19,32 & & & & \\
\hline & & 210 & 19,44 & & & & \\
\hline & $14: 00$ & 240 & 19,50 & & & & \\
\hline & & & & & & & \\
\hline \multirow[t]{18}{*}{70} & $14: 00$ & 0 & 21,18 & & & & \\
\hline & & 1 & 24,90 & & & & \\
\hline & & 2 & 25,36 & & & & \\
\hline & & 4 & 26,17 & & & & \\
\hline & & 6 & - & & & & \\
\hline & & 8 & 26,34 & & & & \\
\hline & & $\overline{12}$ & 27,21 & & & & \\
\hline & & 15 & 28,09 & & & & \\
\hline & & 30 & 28,55 & & & & \\
\hline & & 60 & 29,58 & & & & \\
\hline & & 90 & 30,09 & & & & \\
\hline & & 120 & 30,25 & & & & \\
\hline & & 150 & 30,98 & & & & \\
\hline & & 180 & 31,36 & & & & \\
\hline & & 210 & 31,74 & & & & \\
\hline & & 240 & 31,87 & & & & \\
\hline & & 270 & 31,95 & & & & \\
\hline & 19:00 & 300 & 32,01 & & & & \\
\hline \multirow{8}{*}{ Estab. } & $19 \cdot 00$ & 0 & 3195 & & & & \\
\hline & & 1 & 31,93 & & & & \\
\hline & & 2 & 31,93 & & & & \\
\hline & & 4 & - & & & & \\
\hline & & 6 & 31,93 & & & & \\
\hline & & 8 & - & & & & \\
\hline & & 12 & 31,93 & & & & \\
\hline & & 15 & 31,93 & & & & \\
\hline 35 & $19: 30$ & 30 & 31,93 & & & & \\
\hline & & & & & & & \\
\hline & & & & & & & \\
\hline & & & & & & & \\
\hline & & & & & & & \\
\hline
\end{tabular}




\begin{tabular}{|c|c|c|c|c|c|c|c|}
\hline \multicolumn{8}{|c|}{ UNIVERSIDADE DE SÃO PAULO } \\
\hline \multicolumn{8}{|c|}{ ESCOLA DE ENGENHARIA DE SÃO CARLOS } \\
\hline \multicolumn{8}{|c|}{ DEPTO. DE GEOTECNIA - CAMPO EXPERIMENTAL DE FUNDAÇÕES } \\
\hline \multicolumn{8}{|c|}{$\begin{array}{l}\text { PROVA DE CARGA ESTÁTICA } \\
\end{array}$} \\
\hline \multicolumn{2}{|c|}{ Ensaio: $\quad$ SS2 } & & \multicolumn{3}{|c|}{ Tipo de Carregamento: } & SML \\
\hline \multicolumn{2}{|c|}{ Profundidade: } & \multicolumn{2}{|l|}{$1,5 \mathrm{~m}$} & \multicolumn{2}{|c|}{ Estado do solo: } & \multicolumn{2}{|c|}{ INUNDADO } \\
\hline Sucção: & $0 \quad \mathrm{kPa}$ & & & Reensaio: & NÃO & & \\
\hline Diâmetro: & & $\mathrm{cm}$ & & Folha: & & & \\
\hline $\begin{array}{l}\text { Tensão } \\
(\mathrm{kPa})\end{array}$ & $\begin{array}{c}\text { Início Carr } \\
\text { (min) }\end{array}$ & $\begin{array}{c}\text { Tempo } \\
\text { (min) }\end{array}$ & $\begin{array}{l}\text { Recalque } \\
(\mathrm{mm})\end{array}$ & $\begin{array}{c}\text { Tensão } \\
(\mathrm{kPa})\end{array}$ & $\begin{array}{c}\text { Início Carr. } \\
\text { (min) }\end{array}$ & $\begin{array}{r}\text { Tempo } \\
\text { (min) }\end{array}$ & $\begin{array}{l}\text { Recalque } \\
(\mathrm{mm})\end{array}$ \\
\hline \multirow{9}{*}{4} & & & & & & & \\
\hline & 0:00:00 & 0 & 0,16 & 28 & 5:30:00 & 0 & 3,84 \\
\hline & & 1 & 0,16 & & & 1 & 4,08 \\
\hline & & 2 & 0,16 & & & 2 & 4,19 \\
\hline & & 4 & 0,16 & & & 4 & 4,33 \\
\hline & & 8 & 0,16 & & & 8 & 4,56 \\
\hline & & 15 & 0,16 & & & 15 & 4,77 \\
\hline & $0: 30: 00$ & 30 & 0,16 & & & 30 & 6,00 \\
\hline & & & & & & 60 & 6,21 \\
\hline \multirow[t]{9}{*}{12} & $0: 30: 00$ & 0 & 0,61 & & & 90 & 6,30 \\
\hline & & 1 & 0,69 & & & 120 & 6,33 \\
\hline & & 2 & 0,78 & & & 150 & 6,38 \\
\hline & & 4 & 0,78 & & 8:30:00 & 180 & 6,39 \\
\hline & & 8 & 0,79 & & & & \\
\hline & & 15 & 0,81 & 36 & 8:30:00 & 0 & 7,30 \\
\hline & & 30 & 0,82 & & & 1 & 7,81 \\
\hline & 1:30:00 & 60 & 0,82 & & & 2 & 8,34 \\
\hline & & & & & & 4 & 9,04 \\
\hline \multirow[t]{14}{*}{20} & 1:30:00 & 0 & 1,18 & & & 8 & 10,44 \\
\hline & & 1 & - & & & 15 & 11,26 \\
\hline & & 2 & 1,36 & & & 30 & 12,15 \\
\hline & & 4 & 1,48 & & & 60 & 12,98 \\
\hline & & 8 & - & & & 90 & 13,38 \\
\hline & & 15 & 2,00 & & & 120 & 13,62 \\
\hline & & 30 & 2,25 & & & 150 & 13,82 \\
\hline & & 60 & 2,44 & & & 180 & 13,98 \\
\hline & & 90 & 2,51 & & & 210 & 14,09 \\
\hline & & 120 & 2,61 & & & 240 & 14,14 \\
\hline & & 150 & 2,64 & & & 270 & 14,19 \\
\hline & & 180 & 2,66 & & & 300 & 14,23 \\
\hline & & 210 & 2,67 & & & 330 & 14,28 \\
\hline & 5:30:00 & 240 & 2,68 & & $14: 30: 00$ & 360 & 14,28 \\
\hline & & & & & & & \\
\hline & & & & & & & \\
\hline & & & & & & & \\
\hline & & & & & & & \\
\hline & & & & & & & \\
\hline & & & & & & & \\
\hline & & & & & & & \\
\hline & & & & & & & \\
\hline & & & & & & & \\
\hline & & & & & & & \\
\hline
\end{tabular}




\begin{tabular}{|c|c|c|c|c|c|c|c|}
\hline Ensaio: & SS2 & Prof.: & $1,5 \mathrm{~m}$ & Suç̧̃ão: & $\begin{array}{ll}0 & \mathrm{kPa}\end{array}$ & Folha: & $\overline{2}$ \\
\hline $\begin{array}{c}\text { Tensão } \\
(\mathrm{kPa})\end{array}$ & $\begin{array}{c}\text { Início Carr. } \\
\text { (min) }\end{array}$ & $\begin{array}{c}\text { Tempo } \\
(\mathrm{min})\end{array}$ & $\begin{array}{c}\text { Recalque } \\
(\mathrm{mm})\end{array}$ & $\begin{array}{c}\text { Tensão } \\
(\mathrm{kPa})\end{array}$ & $\begin{array}{c}\text { Início Carr. } \\
\text { (min) }\end{array}$ & $\begin{array}{c}\text { Tempo } \\
\text { (min) }\end{array}$ & $\begin{array}{c}\text { Recalque } \\
(\mathrm{mm})\end{array}$ \\
\hline \multirow{16}{*}{44} & & & & & & & \\
\hline & 14:30:00 & 0 & 15,08 & $1 \mathrm{D}$ & 27:00:00 & 0 & 43,27 \\
\hline & & 1 & 16,20 & & & 1 & 43,26 \\
\hline & & 2 & 16,95 & & & 2 & 43,26 \\
\hline & & 4 & 19,24 & & & 4 & 43,26 \\
\hline & & 8 & 21,03 & & & 8 & 43,26 \\
\hline & & 15 & 22,95 & & & 15 & 43,25 \\
\hline & & 30 & 25,11 & & & 30 & 43,24 \\
\hline & & 60 & 26,60 & 21 & 28:00:00 & 60 & 43,24 \\
\hline & & 90 & 27,40 & & & & \\
\hline & & 120 & 27,87 & $2 \mathrm{D}$ & 28:00:00 & 0 & 42,99 \\
\hline & & 150 & 28,09 & & & 1 & 42,94 \\
\hline & & 180 & 28,23 & & & 2 & 42,92 \\
\hline & & 210 & 28,34 & & & 4 & 42,89 \\
\hline & 18:30:00 & 240 & 28,36 & & & 8 & 42,88 \\
\hline & & & & & & 15 & 42,87 \\
\hline \multirow[t]{22}{*}{52} & $18: 30: 00$ & 0 & 29,65 & & & 30 & 42,85 \\
\hline & & 1 & 31,40 & & & 60 & 42,83 \\
\hline & & 2 & 32,65 & & & 90 & 42,83 \\
\hline & & 4 & 35,00 & 0 & $30: 00: 00$ & 120 & 42,82 \\
\hline & & 8 & 36,44 & & & & \\
\hline & & 15 & 37,19 & & & & \\
\hline & & 30 & 38,43 & & & & \\
\hline & & 60 & 39,28 & & & & \\
\hline & & 90 & 39,99 & & & & \\
\hline & & 120 & 40,13 & & & & \\
\hline & & 150 & 40,37 & & & & \\
\hline & & 180 & 40,79 & & & & \\
\hline & & 210 & 41,56 & & & & \\
\hline & & 240 & 42,29 & & & & \\
\hline & & 270 & 42,54 & & & & \\
\hline & & 300 & 42,73 & & & & \\
\hline & & 330 & 42,80 & & & & \\
\hline & & 360 & 42,86 & & & & \\
\hline & & 390 & 42,91 & & & & \\
\hline & & 420 & 42,97 & & & & \\
\hline & & 450 & 42,98 & & & & \\
\hline & $26: 30: 00$ & 480 & 42,99 & & & & \\
\hline \multirow{5}{*}{ Estab. } & & & & & & & \\
\hline & $26: 30: 00$ & 0 & 43,14 & & & & \\
\hline & & 5 & 43,25 & & & & \\
\hline & & 10 & 43,28 & & & & \\
\hline & & 15 & 43,28 & & & & \\
\hline 43 & 27:00:00 & 30 & 43,28 & & & & \\
\hline & & & & & & & \\
\hline & & & & & & & \\
\hline & & & & & & & \\
\hline & & & & & & & \\
\hline & & & & & & & \\
\hline & & & & & & & \\
\hline
\end{tabular}




\begin{tabular}{|c|c|c|c|c|c|c|c|}
\hline \multicolumn{8}{|c|}{ UNIVERSIDADE DE SÃO PAULO } \\
\hline \multicolumn{8}{|c|}{$\begin{array}{c}\text { ESCOLA DE ENGENHARIA DE SÃO CARLOS } \\
\end{array}$} \\
\hline \multicolumn{8}{|c|}{ DEPTO. DE GEOTECNIA - CAMPO EXPERIMENTAL DE FUNDAÇÕES } \\
\hline \multicolumn{8}{|c|}{$\begin{array}{l}\text { PROVA DE CARGA ESTÁTICA } \\
\end{array}$} \\
\hline \multicolumn{2}{|c|}{ Ensaio: $\quad$ SS3 } & & \multicolumn{3}{|c|}{ Tipo de Carregamento: } & SML \\
\hline \multicolumn{2}{|c|}{ Profundidade: } & \multicolumn{2}{|l|}{$1,5 \mathrm{~m}$} & \multicolumn{2}{|c|}{ Estado do solo: } & \\
\hline Sucção: & $0 \mathrm{kPa}$ & \multirow{2}{*}{\multicolumn{2}{|c|}{$\mathrm{cm}$}} & \multirow{2}{*}{\multicolumn{2}{|c|}{$\begin{array}{ll}\text { Reensaio: } & \text { NÃO } \\
\text { Folha: } & 1\end{array}$}} & \multirow{2}{*}{ INUNDAD } & \\
\hline \multicolumn{2}{|c|}{ Diâmetro: $\quad 80$} & & & & & & \\
\hline $\begin{array}{l}\text { Tensão } \\
(\mathrm{kPa})\end{array}$ & $\begin{array}{c}\text { Início Carr. } \\
\text { (min) }\end{array}$ & $\begin{array}{c}\text { Tempo } \\
\text { (min) }\end{array}$ & $\begin{array}{l}\text { Recalque } \\
(\mathrm{mm})\end{array}$ & $\begin{array}{l}\text { Tensão } \\
\text { (kPa) }\end{array}$ & $\begin{array}{c}\text { Início Carr. } \\
\text { (min) }\end{array}$ & $\begin{array}{c}\text { Tempo } \\
\text { (min) }\end{array}$ & $\begin{array}{l}\text { Recalque } \\
\text { (mm) }\end{array}$ \\
\hline & & & & & & & \\
\hline \multirow[t]{12}{*}{8} & 0:00:00 & 0 & 0,60 & 32 & 8:00:00 & 0 & 3,54 \\
\hline & & 1 & 0,86 & & & 1 & 3,73 \\
\hline & & 2 & 0,88 & & & 2 & 3,93 \\
\hline & & 4 & 0,92 & & & 4 & 4,26 \\
\hline & & 8 & 0,95 & & & 8 & 4,65 \\
\hline & & 15 & 0,97 & & & 15 & 4,95 \\
\hline & & 30 & 1,01 & & & 30 & 5,26 \\
\hline & & 60 & 1,05 & & & 60 & 5,42 \\
\hline & & 90 & 1,07 & & & 90 & 5,51 \\
\hline & & 120 & 1,09 & & 10:00:00 & 120 & 5,54 \\
\hline & & 150 & 1,09 & & & & \\
\hline & $3: 00: 00$ & 180 & 1,10 & & & & \\
\hline & & & & & & & \\
\hline \multirow[t]{12}{*}{16} & 3:00:00 & 0 & 1,36 & & & & \\
\hline & & 1 & 1,61 & & & & \\
\hline & & 2 & 1,71 & & & & \\
\hline & & 4 & 1,78 & & & & \\
\hline & & 8 & 1,87 & & & & \\
\hline & & 15 & 1,93 & & & & \\
\hline & & 30 & 2,01 & & & & \\
\hline & & 60 & 2,07 & & & & \\
\hline & & 90 & 2,09 & & & & \\
\hline & & 120 & 2,11 & & & & \\
\hline & & 150 & 2,12 & & & & \\
\hline & 6:00:00 & 180 & 2,13 & & & & \\
\hline & & & & & & & \\
\hline \multirow[t]{10}{*}{24} & 6:00:00 & 0 & 2,27 & & & & \\
\hline & & 1 & 2,57 & & & & \\
\hline & & 2 & 2,72 & & & & \\
\hline & & 4 & 2,87 & & & & \\
\hline & & 8 & 3,02 & & & & \\
\hline & & 15 & 3,15 & & & & \\
\hline & & 30 & 3,27 & & & & \\
\hline & & 60 & 3,36 & & & & \\
\hline & & 90 & 3,40 & & & & \\
\hline & 8:00:00 & 120 & 3,43 & & & & \\
\hline & & & & & & & \\
\hline & & & & & & & \\
\hline & & & & & & & \\
\hline & & & & & & & \\
\hline & & & & & & & \\
\hline
\end{tabular}




\begin{tabular}{|c|c|c|c|c|c|c|c|}
\hline Ensaio: & $\overline{\text { SS3 }}$ & |Prof.: & $1,5 \mathrm{~m}$ & Suçãã: & $\begin{array}{ll}0 & \mathrm{kPa}\end{array}$ & Folha: & $\overline{2}$ \\
\hline $\begin{array}{c}\text { Tensão } \\
(\mathrm{kPa})\end{array}$ & $\begin{array}{c}\text { Início Carr. } \\
\text { (min) }\end{array}$ & $\begin{array}{r}\text { Tempo } \\
\text { (min) }\end{array}$ & $\begin{array}{c}\text { Recalque } \\
(\mathrm{mm})\end{array}$ & $\begin{array}{c}\text { Tensão } \\
(\mathrm{kPa})\end{array}$ & $\begin{array}{c}\text { Início Carr. } \\
\text { (min) }\end{array}$ & $\begin{array}{c}\text { Tempo } \\
\text { (min) }\end{array}$ & $\begin{array}{c}\text { Recalque } \\
(\mathrm{mm})\end{array}$ \\
\hline & & & & & & & \\
\hline \multirow[t]{35}{*}{40} & 10:00:00 & 0 & 5,64 & 56 & 28:00:00 & 0 & 17,22 \\
\hline & & 1 & 5,97 & & & 1 & 17,40 \\
\hline & & 2 & 6,35 & & & 2 & 17,72 \\
\hline & & 4 & 6,88 & & & 4 & 18,64 \\
\hline & & 8 & 7,53 & & & 8 & 20,34 \\
\hline & & 15 & 8,12 & & & 15 & 21,88 \\
\hline & & 30 & 8,75 & & & 30 & 23,52 \\
\hline & & 60 & 9,16 & & & 60 & 24,84 \\
\hline & & 90 & 9,42 & & & 90 & 25,26 \\
\hline & & 120 & 9,61 & & & 120 & 25,52 \\
\hline & & 150 & 9,78 & & & 150 & 25,63 \\
\hline & & 180 & 9,95 & & $31: 00: 00$ & 180 & 25,79 \\
\hline & & 210 & 10,13 & & & & \\
\hline & & 240 & 10,26 & 64 & 31:00:00 & 0 & 25,86 \\
\hline & & 270 & 10,43 & & & 1 & 26,10 \\
\hline & & 300 & 10,52 & & & 2 & 26,44 \\
\hline & & 330 & 10,59 & & & 4 & 27,34 \\
\hline & & 360 & 10,64 & & & 8 & 29,08 \\
\hline & & 390 & 10,73 & & & 15 & 31,75 \\
\hline & & 420 & 10,78 & & & 30 & 33,40 \\
\hline & & 450 & 10,84 & & & 60 & 35,24 \\
\hline & & 480 & 10,93 & & & 90 & 36,16 \\
\hline & & 510 & 10,97 & & & 120 & 36,69 \\
\hline & & 540 & 11,00 & & & 150 & 36,78 \\
\hline & & 570 & 11,03 & & & 180 & 37,08 \\
\hline & & 600 & 11,05 & & & 210 & 37,31 \\
\hline & & 630 & 11,07 & & & 240 & 37,61 \\
\hline & & 660 & 11,09 & & & 270 & 37,87 \\
\hline & & 690 & 11,09 & & & 300 & 38,08 \\
\hline & & 720 & 11,10 & & & 330 & 38,24 \\
\hline & & 750 & 11,10 & & & 360 & 38,41 \\
\hline & & 780 & 11,10 & & & 390 & 38,55 \\
\hline & & 810 & 11,10 & & & 420 & 38,63 \\
\hline & $24: 00: 00$ & 840 & 11,10 & & & 450 & 38,72 \\
\hline & & & & & & 480 & 38,79 \\
\hline \multirow[t]{14}{*}{48} & 24:00:00 & 0 & 11,12 & & & 510 & 38,82 \\
\hline & & 1 & 11,17 & & & 540 & 38,86 \\
\hline & & 2 & 11,29 & & & 570 & 38,89 \\
\hline & & 4 & 11,57 & & 41:00:00 & 600 & 38,92 \\
\hline & & 8 & 12,62 & & & & \\
\hline & & 15 & 13,89 & & & & \\
\hline & & 30 & 15,06 & & & & \\
\hline & & 60 & 16,06 & & & & \\
\hline & & 90 & 16,59 & & & & \\
\hline & & 120 & 16,86 & & & & \\
\hline & & 150 & 16,92 & & & & \\
\hline & & 180 & 17,0275 & & & & \\
\hline & & 210 & 17,085 & & & & \\
\hline & $28: 00: 00$ & 240 & 17,1375 & & & & \\
\hline
\end{tabular}




\begin{tabular}{|c|c|c|c|c|c|c|c|}
\hline Ensaio: & SS3 & Prof.: & $1,5 \mathrm{~m}$ & Suç̧̃ão: & $\begin{array}{ll}0 & \mathrm{kPa}\end{array}$ & Folha: & $\overline{3}$ \\
\hline $\begin{array}{c}\text { Tensão } \\
(\mathrm{kPa})\end{array}$ & $\begin{array}{c}\text { Início Carr. } \\
\text { (min) }\end{array}$ & $\begin{array}{c}\begin{array}{c}\text { Tempo } \\
(\mathrm{min})\end{array} \\
\end{array}$ & $\begin{array}{c}\text { Recalque } \\
(\mathrm{mm})\end{array}$ & $\begin{array}{c}\text { Tensão } \\
(\mathrm{kPa})\end{array}$ & $\begin{array}{c}\text { Início Carr. } \\
\text { (min) }\end{array}$ & $\begin{array}{c}\text { Tempo } \\
\text { (min) }\end{array}$ & $\begin{array}{c}\text { Recalque } \\
(\mathrm{mm})\end{array}$ \\
\hline & & & & & & & \\
\hline \multirow[t]{18}{*}{72} & 41:00:00 & 0 & 38,97 & $2 \mathrm{D}$ & $49: 40: 00$ & 0 & 51,61 \\
\hline & & 1 & 39,01 & & & 1 & 51,33 \\
\hline & & 2 & 39,08 & & & 2 & 51,30 \\
\hline & & 4 & 39,23 & & & 4 & 51,28 \\
\hline & & 8 & 40,25 & & & 8 & 51,25 \\
\hline & & 15 & 43,37 & & & 15 & 51,23 \\
\hline & & 30 & 46,08 & & & 30 & 51,19 \\
\hline & & 60 & 48,64 & & & 60 & 51,17 \\
\hline & & 90 & 49,89 & 0 & 51:10:00 & 90 & 51,16 \\
\hline & & 120 & 50,52 & & & & \\
\hline & & 150 & 50,93 & & & & \\
\hline & & 180 & 51,20 & & & & \\
\hline & & 210 & 51,45 & & & & \\
\hline & & 240 & 51,61 & & & & \\
\hline & & 270 & 51,73 & & & & \\
\hline & & 300 & 51,80 & & & & \\
\hline & & 330 & 51,84 & & & & \\
\hline & $47: 00: 00$ & 360 & 51,94 & & & & \\
\hline & & & & & & & \\
\hline \multirow[t]{8}{*}{ Estab. } & $47: 00: 00$ & 0 & 51,94 & & & & \\
\hline & & 5 & 51,94 & & & & \\
\hline & & 10 & 51,94 & & & & \\
\hline & & 15 & 51,94 & & & & \\
\hline & & 20 & 51,94 & & & & \\
\hline & & 25 & 51,95 & & & & \\
\hline & & 30 & 51,95 & & & & \\
\hline & & 35 & 51,95 & & & & \\
\hline \multirow[t]{2}{*}{69} & 47:40:00 & 40 & 51,95 & & & & \\
\hline & & & & & & & \\
\hline \multirow[t]{9}{*}{ 1D } & $47: 40: 00$ & 0 & 51,87 & & & & \\
\hline & & 1 & 51,87 & & & & \\
\hline & & 2 & 51,86 & & & & \\
\hline & & 4 & 51,86 & & & & \\
\hline & & 8 & 51,85 & & & & \\
\hline & & 15 & 51,85 & & & & \\
\hline & & 30 & 51,83 & & & & \\
\hline & & 60 & 51,80 & & & & \\
\hline & & 90 & 51,80 & & & & \\
\hline 24 & 59:40:00 & 120 & 51,80 & & & & \\
\hline & & & & & & & \\
\hline & & & & & & & \\
\hline & & & & & & & \\
\hline & & & & & & & \\
\hline & & & & & & & \\
\hline & & & & & & & \\
\hline & & & & & & & \\
\hline & & & & & & & \\
\hline & & & & & & & \\
\hline & & & & & & & \\
\hline
\end{tabular}




\begin{tabular}{|c|c|c|c|c|c|c|c|}
\hline \multicolumn{8}{|c|}{ UNIVERSIDADE DE SÃO PAULO } \\
\hline \multicolumn{8}{|c|}{ ESCOLA DE ENGENHARIA DE SÃO CARLOS } \\
\hline \multicolumn{8}{|c|}{ DEPTO. DE GEOTECNIA - CAMPO EXPERIMENTAL DE FUNDAÇÕES } \\
\hline \multicolumn{8}{|c|}{$\begin{array}{l}\text { PROVA DE CARGA ESTÁTICA } \\
\end{array}$} \\
\hline \multicolumn{2}{|c|}{ Ensaio: $\quad \mathrm{S} 1$} & & \multicolumn{3}{|c|}{ Tipo de Carregamento: } & SML \\
\hline \multicolumn{2}{|c|}{ Profundidade: } & \multicolumn{2}{|l|}{$1,5 \mathrm{~m}$} & \multicolumn{2}{|c|}{ Estado do solo: } & \multicolumn{2}{|c|}{ NATURAL } \\
\hline $\begin{array}{l}\text { Sucção: } \\
\text { Diâmetro: }\end{array}$ & $\begin{array}{c}10 \mathrm{kPa} \\
80\end{array}$ & $\mathrm{~cm}$ & & $\begin{array}{l}\text { Reensaio: } \\
\text { Folha: }\end{array}$ & $\begin{array}{l}\text { NÃO } \\
1\end{array}$ & & \\
\hline $\begin{array}{l}\text { Tensão } \\
\text { (kPa) }\end{array}$ & $\begin{array}{c}\text { Início Carr. } \\
\text { (min) }\end{array}$ & $\begin{array}{c}\text { Tempo } \\
\text { (min) }\end{array}$ & $\begin{array}{l}\text { Recalque } \\
\text { (mm) }\end{array}$ & $\begin{array}{l}\text { Tensão } \\
\text { (kPa) }\end{array}$ & $\begin{array}{c}\text { Início Carr. } \\
\text { (min) }\end{array}$ & $\begin{array}{c}\text { Tempo } \\
\text { (min) }\end{array}$ & $\begin{array}{l}\text { Recalque } \\
\text { (mm) }\end{array}$ \\
\hline \multirow{9}{*}{10} & 0:00:00 & 0 & 2,92 & 40 & 4:30:00 & 0 & 4,90 \\
\hline & & 1 & 3,08 & & & 1 & 4,95 \\
\hline & & 2 & 3,09 & & & 2 & 4,99 \\
\hline & & 4 & 3,13 & & & 4 & 5,07 \\
\hline & & 8 & 3,17 & & & 8 & 5,20 \\
\hline & & 15 & $\overline{3,19}$ & & & 15 & 5,29 \\
\hline & & 30 & 3,31 & & & 30 & 5,39 \\
\hline & 1:00:00 & 60 & 3,32 & & & 60 & 5,47 \\
\hline & & & & & & 90 & 5,51 \\
\hline \multirow[t]{10}{*}{20} & 1:00:00 & 0 & 3,35 & & & 120 & 5,53 \\
\hline & & 1 & 3,40 & & & 150 & 5,55 \\
\hline & & 2 & 3,43 & & & 180 & 5,56 \\
\hline & & 4 & 3,47 & & & 210 & 5,58 \\
\hline & & 8 & 3,57 & & & 240 & 5,60 \\
\hline & & 15 & 3,61 & & & 270 & 5,60 \\
\hline & & 30 & 3,65 & & & 300 & 5,61 \\
\hline & & 60 & 3,68 & & & 330 & 5,62 \\
\hline & $2: 30: 00$ & 90 & 3,68 & & & 360 & 5,63 \\
\hline & & & & & & 390 & 5,64 \\
\hline \multirow[t]{17}{*}{30} & $2: 30: 00$ & 0 & 3,85 & & & 420 & 5,64 \\
\hline & & 1 & 4,37 & & & 450 & 5,66 \\
\hline & & 2 & 4,53 & & & 480 & 5,66 \\
\hline & & 4 & 4,66 & & & 510 & 5,68 \\
\hline & & 8 & - & & & 540 & 5,69 \\
\hline & & 15 & 4,77 & & & 570 & 5,71 \\
\hline & & 30 & 4,81 & & & 600 & 5,73 \\
\hline & & 60 & 4,83 & & & 630 & 5,74 \\
\hline & & 90 & 4,84 & & & 660 & 5,75 \\
\hline & 4:30:00 & 120 & 4,84 & & & 690 & 5,77 \\
\hline & & & & & & 720 & 5,78 \\
\hline & & & & & & 750 & 5,79 \\
\hline & & & & & & 780 & 5,81 \\
\hline & & & & & & 810 & 5,81 \\
\hline & & & & & & 840 & 5,82 \\
\hline & & & & & & 870 & 5,87 \\
\hline & & & & & 19:30:00 & 900 & 5,90 \\
\hline & & & & & & & \\
\hline & & & & & & & \\
\hline & & & & & & & \\
\hline & & & & & & & \\
\hline & & & & & & & \\
\hline
\end{tabular}




\begin{tabular}{|c|c|c|c|c|c|c|c|}
\hline Ensaio: & S1 & Prof.: & $1,5 \mathrm{~m}$ & Sucção: & $\begin{array}{ll}10 & \mathrm{kPa}\end{array}$ & Folha: & $\overline{2}$ \\
\hline $\begin{array}{c}\text { Tensão } \\
(\mathrm{kPa})\end{array}$ & $\begin{array}{c}\text { Início Carr. } \\
\text { (min) }\end{array}$ & $\begin{array}{r}\text { Tempo } \\
\text { (min) }\end{array}$ & $\begin{array}{c}\text { Recalque } \\
(\mathrm{mm})\end{array}$ & $\begin{array}{c}\text { Tensão } \\
(\mathrm{kPa})\end{array}$ & $\begin{array}{c}\text { Início Carr. } \\
\text { (min) }\end{array}$ & $\begin{array}{c}\begin{array}{c}\text { Tempo } \\
\text { (min) }\end{array} \\
\end{array}$ & $\begin{array}{c}\text { Recalque } \\
\text { (mm) }\end{array}$ \\
\hline & & & & & & & \\
\hline \multirow[t]{17}{*}{50} & 19:30:00 & 0 & 6,04 & 90 & 29:30:00 & 0 & 15,33 \\
\hline & & 1 & 6,54 & & & 1 & 15,49 \\
\hline & & 2 & 6,78 & & & 2 & 15,78 \\
\hline & & 4 & 7,02 & & & 4 & 16,47 \\
\hline & & 8 & 7,23 & & & 8 & 17,32 \\
\hline & & 15 & 7,38 & & & 15 & 17,92 \\
\hline & & 30 & 7,51 & & & 30 & 18,32 \\
\hline & & 60 & 7,63 & & & 60 & 18,71 \\
\hline & & 90 & 7,69 & & & 90 & 18,87 \\
\hline & & 120 & 7,75 & & & 120 & 18,95 \\
\hline & & 150 & 7,79 & & & 150 & 18,99 \\
\hline & & 180 & 7,83 & & $32: 30: 00$ & 180 & 19,03 \\
\hline & & 210 & 7,86 & & & & \\
\hline & & 240 & 7,88 & 100 & $32: 30: 00$ & 0 & 19,08 \\
\hline & & 270 & 7,88 & & & 1 & 19,11 \\
\hline & $24: 30: 00$ & 300 & 7,90 & & & 2 & 19,20 \\
\hline & & & & & & 4 & 19,79 \\
\hline \multirow[t]{8}{*}{60} & $24: 30: 00$ & 0 & 7,99 & & & 8 & 20,82 \\
\hline & & 1 & 8,51 & & & 15 & 21,74 \\
\hline & & 2 & 8,92 & & & 30 & 22,57 \\
\hline & & 4 & 9,25 & & & 60 & 23,09 \\
\hline & & 8 & 9,49 & & & 90 & 23,30 \\
\hline & & 15 & 9,64 & & & 120 & 23,42 \\
\hline & & 30 & 9,79 & & & 150 & 23,48 \\
\hline & $25: 30: 00$ & 60 & 9,89 & & $35: 30: 00$ & 180 & 23,53 \\
\hline \multirow{11}{*}{70} & $25 \cdot 30 \cdot 0$ & 0 & 1070 & 110 & $25 \cdot 20 \cdot 00$ & 0 & 2357 \\
\hline & 25.50 .00 & $\frac{0}{1}$ & $\frac{10, \angle 9}{11,04}$ & 110 & 35.50 .00 & $\frac{0}{1}$ & $\frac{23,5 / 1}{23,60}$ \\
\hline & & 2 & 11,21 & & & 2 & 23,67 \\
\hline & & 4 & 11,43 & & & 4 & 24,05 \\
\hline & & 8 & 11,72 & & & 8 & 25,47 \\
\hline & & 15 & 11,90 & & & 15 & 26,72 \\
\hline & & 30 & 12,07 & & & 30 & 27,71 \\
\hline & & 60 & 12,24 & & & 60 & 28,27 \\
\hline & & 90 & 12,32 & & & 90 & - \\
\hline & $27: 30: 00$ & 120 & 12,35 & & & 120 & 28,60 \\
\hline & & & & & & 150 & - \\
\hline \multirow[t]{10}{*}{80} & $27: 30: 00$ & 0 & 12,42 & & $38: 30: 00$ & 180 & 28,74 \\
\hline & & 1 & 12,66 & & & & \\
\hline & & 2 & 13,03 & & & & \\
\hline & & 4 & 13,63 & & & & \\
\hline & & 8 & 14,12 & & & & \\
\hline & & 15 & 14,53 & & & & \\
\hline & & 30 & 14,88 & & & & \\
\hline & & 60 & 15,08 & & & & \\
\hline & & 90 & 15,18 & & & & \\
\hline & 29:30:00 & 120 & 15,23 & & & & \\
\hline & & & & & & & \\
\hline & & & & & & & \\
\hline
\end{tabular}




\begin{tabular}{|c|c|c|c|c|c|c|c|}
\hline Ensaio: & S1 & |Prof.: & $1,5 \mathrm{~m}$ & Suçãa: & $\begin{array}{ll}10 & \mathrm{kPa}\end{array}$ & Folha: & $\overline{3}$ \\
\hline $\begin{array}{c}\text { Tensão } \\
(\mathrm{kPa})\end{array}$ & $\begin{array}{c}\text { Início Carr. } \\
\text { (min) }\end{array}$ & $\begin{array}{r}\text { Tempo } \\
\text { (min) }\end{array}$ & $\begin{array}{c}\text { Recalque } \\
(\mathrm{mm})\end{array}$ & $\begin{array}{c}\text { Tensão } \\
(\mathrm{kPa})\end{array}$ & $\begin{array}{c}\text { Início Carr. } \\
\text { (min) }\end{array}$ & $\begin{array}{c}\begin{array}{c}\text { Tempo } \\
\text { (min) }\end{array} \\
\end{array}$ & $\begin{array}{c}\text { Recalque } \\
\text { (mm) }\end{array}$ \\
\hline & & & & & & & \\
\hline \multirow[t]{12}{*}{120} & $38: 30: 00$ & 0 & 28,77 & 150 & $47: 30: 00$ & 0 & 47,56 \\
\hline & & 1 & 28,82 & & & 1 & 47,59 \\
\hline & & 2 & 28,90 & & & 2 & 47,63 \\
\hline & & 4 & 29,29 & & & 4 & 47,76 \\
\hline & & 8 & 30,75 & & & 8 & 48,70 \\
\hline & & 15 & 32,57 & & & 15 & 51,16 \\
\hline & & 30 & 33,58 & & & 30 & 53,14 \\
\hline & & 60 & 34,29 & & & 60 & 54,25 \\
\hline & & 90 & 34,59 & & & 90 & 54,64 \\
\hline & & 120 & 34,75 & & & 120 & 54,85 \\
\hline & & 150 & 34,85 & & & 150 & 54,95 \\
\hline & $41: 30: 00$ & 180 & 34,92 & & 50:30:00 & 180 & 55,01 \\
\hline \multirow[t]{13}{*}{130} & 41:30:00 & 0 & 34,97 & 160 & $50: 30: 00$ & 0 & 55,04 \\
\hline & & 1 & 35,00 & & & 1 & 55,07 \\
\hline & & 2 & 35,05 & & & 2 & 55,10 \\
\hline & & 4 & 35,27 & & & 4 & 55,16 \\
\hline & & 8 & 36,66 & & & 8 & 55,49 \\
\hline & & 15 & 38,57 & & & 15 & 56,77 \\
\hline & & 30 & 39,72 & & & 30 & 60,20 \\
\hline & & 60 & 40,52 & & & 60 & 60,94 \\
\hline & & 90 & 40,85 & & & 90 & 61,43 \\
\hline & & 120 & 40,97 & & & 120 & 61,63 \\
\hline & & 150 & 41,08 & & & 150 & 61,79 \\
\hline & 44:30:00 & 180 & 41,16 & & & 180 & 61,90 \\
\hline & & & & & & 210 & 61,98 \\
\hline \multirow[t]{23}{*}{140} & $44: 30: 00$ & 0 & 41,19 & & $54: 30: 00$ & 240 & 62,02 \\
\hline & & 1 & 41,22 & & & & \\
\hline & & 2 & 41,25 & 170 & 54:30:00 & 0 & 62,06 \\
\hline & & 4 & 41,34 & & & 1 & 62,08 \\
\hline & & 8 & 41,85 & & & 2 & 62,10 \\
\hline & & 15 & 43,63 & & & 4 & 62,14 \\
\hline & & 30 & 45,89 & & & 8 & 62,28 \\
\hline & & 60 & 47,01 & & $54: 45: 00$ & 15 & 63,13 \\
\hline & & 90 & 47,29 & & & & \\
\hline & & 120 & 47,42 & & & & \\
\hline & & 150 & 47,51 & Estab. & $54: 45: 00$ & 0 & 70,52 \\
\hline & 47:30:00 & 180 & 47,55 & & & 5 & 70,31 \\
\hline & & & & & & 10 & 70,59 \\
\hline & & & & & & 15 & 70,61 \\
\hline & & & & & & 25 & 70,61 \\
\hline & & & & & & 30 & 70,63 \\
\hline & & & & & & 35 & 70,64 \\
\hline & & & & & & 40 & 70,65 \\
\hline & & & & & & 45 & 70,65 \\
\hline & & & & 154 & 55:35:00 & 50 & 70,65 \\
\hline & & & & & & & \\
\hline & & & & & & & \\
\hline & & & & & & & \\
\hline
\end{tabular}




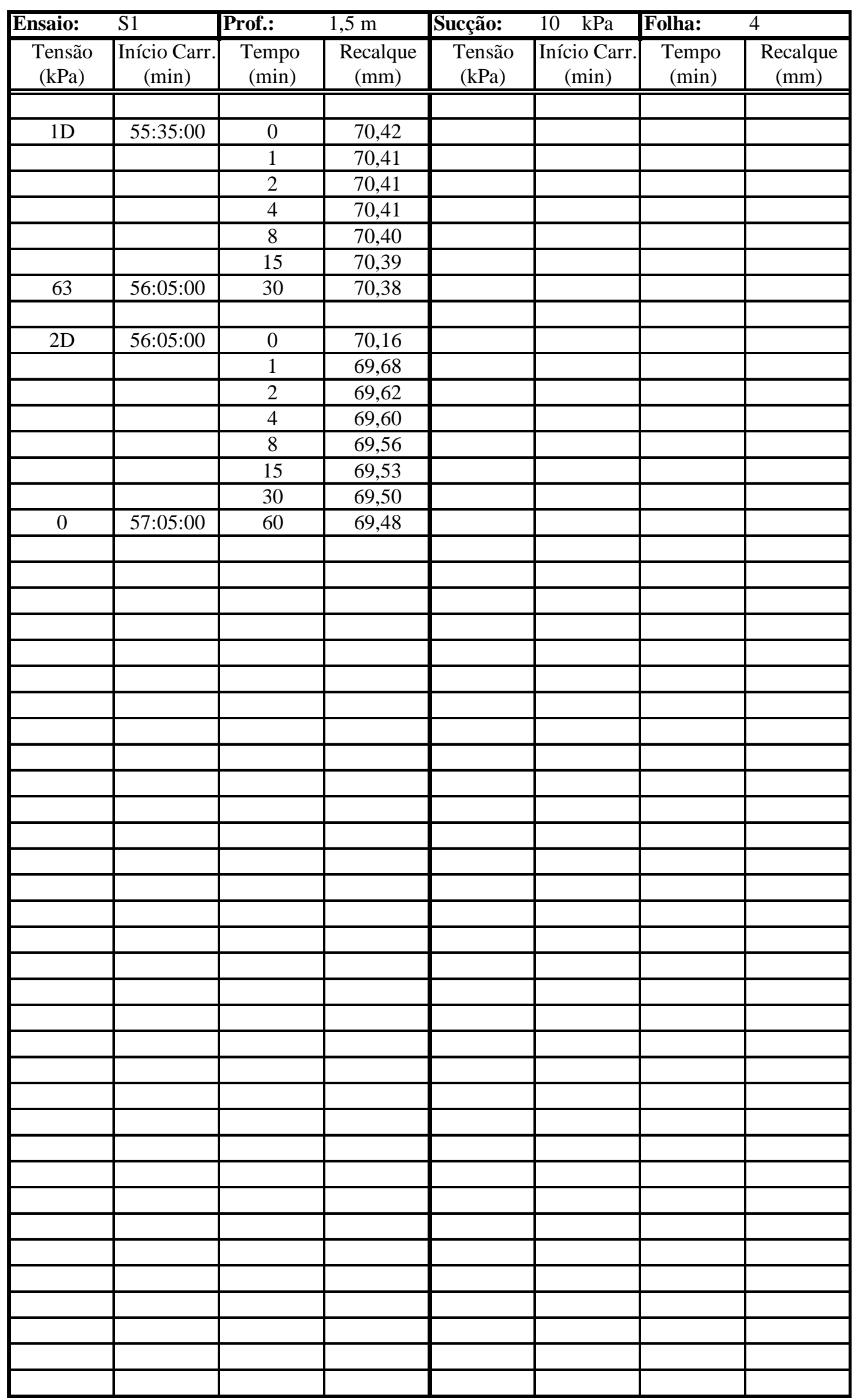




\begin{tabular}{|c|c|c|c|c|c|c|c|}
\hline \multicolumn{8}{|c|}{ UNIVERSIDADE DE SÃO PAULO } \\
\hline \multicolumn{8}{|c|}{$\begin{array}{l}\text { ESCOLA DE ENGENHARIA DE SÃO CARLOS } \\
\end{array}$} \\
\hline \multicolumn{8}{|c|}{ DEPTO. DE GEOTECNIA - CAMPO EXPERIMENTAL DE FUNDAÇÕES } \\
\hline \multicolumn{8}{|c|}{$\begin{array}{l}\text { PROVA DE CARGA ESTÁTICA } \\
\end{array}$} \\
\hline \multirow{2}{*}{\multicolumn{2}{|c|}{$\begin{array}{l}\text { Ensaio: S2 } \\
\text { Profundidade: }\end{array}$}} & & \multicolumn{3}{|c|}{ Tipo de Carregamento: } & \multirow{2}{*}{ SML } \\
\hline & & $1,5 \mathrm{~m}$ & & Estado do & solo: & \multirow[t]{3}{*}{ NATURAL } & \\
\hline Sucção: & $31 \mathrm{kPa}$ & & & \multirow{2}{*}{\multicolumn{2}{|c|}{$\begin{array}{ll}\text { Reensaio: } & N A ̃ O \\
\text { Folha: } & 1\end{array}$}} & & \\
\hline \multicolumn{2}{|c|}{ Diâmetro: $\quad 80$} & \multicolumn{2}{|l|}{$\mathrm{cm}$} & & & & \\
\hline $\begin{array}{c}\text { Tensão } \\
(\mathrm{kPa})\end{array}$ & $\begin{array}{c}\text { Início Carr. } \\
\text { (min) }\end{array}$ & $\begin{array}{c}\text { Tempo } \\
(\mathrm{min})\end{array}$ & $\begin{array}{l}\text { Recalque } \\
\text { (mm) }\end{array}$ & $\begin{array}{l}\text { Tensão } \\
\text { (kPa) }\end{array}$ & $\begin{array}{c}\text { Início Carr. } \\
\text { (min) }\end{array}$ & $\begin{array}{c}\text { Tempo } \\
\text { (min) }\end{array}$ & $\begin{array}{l}\text { Recalque } \\
(\mathrm{mm})\end{array}$ \\
\hline & & & & & & & \\
\hline \multirow[t]{11}{*}{12} & 0:00:00 & 0 & 0,37 & 60 & 6:00:00 & 0 & 2,78 \\
\hline & & 1 & 0,44 & & & 1 & 2,91 \\
\hline & & 2 & 0,46 & & & 2 & $\overline{3,01}$ \\
\hline & & 4 & 0,48 & & & 4 & 3,12 \\
\hline & & 8 & 0,50 & & & 8 & 3,22 \\
\hline & & 15 & 0,51 & & & 15 & 3,31 \\
\hline & & 30 & 0,52 & & & 30 & 3,39 \\
\hline & & 60 & 0,54 & & & 60 & 3,45 \\
\hline & & 90 & 0,54 & & & 90 & 3,49 \\
\hline & $2: 00: 00$ & 120 & 0,54 & & & 120 & 3,50 \\
\hline & & & & & & 150 & 3,52 \\
\hline \multirow[t]{8}{*}{24} & $2: 00: 00$ & 0 & 0,90 & & 9:00:00 & 180 & 3,53 \\
\hline & & 1 & 1,03 & & & & \\
\hline & & 2 & 1,08 & & & & \\
\hline & & 4 & 1,10 & & & & \\
\hline & & 8 & 1,14 & & & & \\
\hline & & 15 & 1,17 & & & & \\
\hline & & 30 & 1,21 & & & & \\
\hline & $3: 00: 00$ & 60 & 1,22 & & & & \\
\hline & & & & & & & \\
\hline \multirow[t]{8}{*}{36} & $3: 00: 00$ & 0 & 1,55 & & & & \\
\hline & & 1 & 1,76 & & & & \\
\hline & & 2 & 1,83 & & & & \\
\hline & & 4 & 1,88 & & & & \\
\hline & & 8 & 1,92 & & & & \\
\hline & & 15 & 1,96 & & & & \\
\hline & & 30 & 1,98 & & & & \\
\hline & 4:00:00 & 60 & 2,00 & & & & \\
\hline & & & & & & & \\
\hline \multirow[t]{10}{*}{48} & 4:00:00 & 0 & 2,18 & & & & \\
\hline & & 1 & 2,34 & & & & \\
\hline & & 2 & 2,39 & & & & \\
\hline & & 4 & 2,47 & & & & \\
\hline & & 8 & 2,52 & & & & \\
\hline & & 15 & 2,57 & & & & \\
\hline & & 30 & 2,62 & & & & \\
\hline & & 60 & 2,66 & & & & \\
\hline & & 90 & 2,675 & & & & \\
\hline & 6:00:00 & 120 & 2,6875 & & & & \\
\hline & & & & & & & \\
\hline & & & & & & & \\
\hline
\end{tabular}




\begin{tabular}{|c|c|c|c|c|c|c|c|}
\hline Ensaio: & S2 & Prof.: & $1,5 \mathrm{~m}$ & Sucção: & $31 \mathrm{kPa}$ & Folha: & 2 \\
\hline $\begin{array}{c}\text { Tensão } \\
(\mathrm{kPa})\end{array}$ & $\begin{array}{c}\text { Início Carr. } \\
\text { (min) }\end{array}$ & $\begin{array}{c}\text { Tempo } \\
(\mathrm{min})\end{array}$ & $\begin{array}{l}\text { Recalque } \\
(\mathrm{mm})\end{array}$ & $\begin{array}{c}\text { Tensão } \\
(\mathrm{kPa})\end{array}$ & $\begin{array}{c}\text { Início Carr. } \\
(\mathrm{min})\end{array}$ & $\begin{array}{r}\text { Tempo } \\
\text { (min) }\end{array}$ & $\begin{array}{l}\text { Recalque } \\
(\mathrm{mm})\end{array}$ \\
\hline \multirow{32}{*}{72} & & & & & & & \\
\hline & 9:00:00 & 0 & 3.60 & 96 & 26:00:00 & 0 & 5.88 \\
\hline & & 1 & 3.67 & & & 1 & 5.97 \\
\hline & & 2 & 3.75 & & & 2 & 6.10 \\
\hline & & 4 & 3.83 & & & 4 & 6.26 \\
\hline & & 8 & 3.98 & & & 8 & 6.68 \\
\hline & & 15 & 4.10 & & & 15 & 7.13 \\
\hline & & 30 & 4.23 & & & 30 & 7.51 \\
\hline & & 60 & 4.33 & & & 60 & 7.79 \\
\hline & & 90 & 4.37 & & & 90 & 7.92 \\
\hline & & 120 & 4.41 & & & 120 & 8.00 \\
\hline & & 150 & 4.43 & & & 150 & 8.05 \\
\hline & & 180 & 4.44 & & & 180 & 8.10 \\
\hline & & 210 & 4.46 & & & 210 & 8.11 \\
\hline & & 240 & 4.49 & & $30: 00: 00$ & 240 & 8.13 \\
\hline & & 270 & 4.51 & & & & \\
\hline & & 300 & 4.51 & 108 & $30: 00: 00$ & 0 & 8.20 \\
\hline & & 330 & 4.52 & & & 1 & 8.25 \\
\hline & & 360 & 4.53 & & & 2 & 8.32 \\
\hline & & 390 & 4.54 & & & 4 & 8.50 \\
\hline & & 420 & 4.55 & & & 8 & 9.06 \\
\hline & & 450 & 4.56 & & & 15 & 9.72 \\
\hline & & 480 & 4.56 & & & 30 & 10.33 \\
\hline & & 510 & 4.57 & & & 60 & 10.79 \\
\hline & & 540 & 4.58 & & & 90 & 10.99 \\
\hline & & 570 & 4.58 & & & 120 & 11.10 \\
\hline & & 600 & 4.58 & & & 150 & 11.17 \\
\hline & & 630 & 4.59 & & & 180 & 11.22 \\
\hline & & 660 & 4.59 & & & 210 & 11.27 \\
\hline & & 690 & 4.59 & & & 240 & 11.30 \\
\hline & 21:00:00 & 720 & 4.59 & & & 270 & 11.32 \\
\hline & & & & & $35:: 00$ & 300 & 11.33 \\
\hline \multirow[t]{16}{*}{84} & 21:00:00 & 0 & 4.62 & & & & \\
\hline & & 1 & 4.64 & & & & \\
\hline & & 2 & 4.65 & & & & \\
\hline & & 4 & 4.70 & & & & \\
\hline & & 8 & 4.80 & & & & \\
\hline & & 15 & 5.03 & & & & \\
\hline & & 30 & 5.28 & & & & \\
\hline & & 60 & 5.51 & & & & \\
\hline & & 90 & 5.61 & & & & \\
\hline & & 120 & 5.66 & & & & \\
\hline & & 150 & 5.70 & & & & \\
\hline & & 180 & 5.72 & & & & \\
\hline & & 210 & 5.74 & & & & \\
\hline & & 240 & 5.75 & & & & \\
\hline & & 270 & 5.76 & & & & \\
\hline & 26:00:00 & 300 & 5.7625 & & & & \\
\hline & & & & & & & \\
\hline & & & & & & & \\
\hline
\end{tabular}




\begin{tabular}{|c|c|c|c|c|c|c|c|}
\hline Ensaio: & $\overline{S 2}$ & |Prof.: & $1,5 \mathrm{~m}$ & Suçãa: & $\begin{array}{ll}31 & \mathrm{kPa}\end{array}$ & Folha: & $\overline{3}$ \\
\hline $\begin{array}{c}\text { Tensão } \\
(\mathrm{kPa})\end{array}$ & $\begin{array}{c}\text { Início Carr. } \\
\text { (min) }\end{array}$ & $\begin{array}{r}\begin{array}{r}\text { Tempo } \\
(\mathrm{min})\end{array} \\
\end{array}$ & $\begin{array}{c}\text { Recalque } \\
(\mathrm{mm})\end{array}$ & $\begin{array}{c}\text { Tensão } \\
(\mathrm{kPa})\end{array}$ & $\begin{array}{c}\text { Início Carr. } \\
\text { (min) }\end{array}$ & $\begin{array}{c}\begin{array}{c}\text { Tempo } \\
\text { (min) }\end{array} \\
\end{array}$ & $\begin{array}{c}\text { Recalque } \\
(\mathrm{mm})\end{array}$ \\
\hline & & & & & & & \\
\hline \multirow[t]{23}{*}{120} & $35: 00: 00$ & 0 & 11.39 & 144 & 48:00:00 & 0 & 20.69 \\
\hline & & 1 & 11.43 & & & 1 & 20.71 \\
\hline & & 2 & 11.46 & & & 2 & 20.74 \\
\hline & & 4 & 11.55 & & & 4 & 20.78 \\
\hline & & 8 & 11.81 & & & 8 & 20.99 \\
\hline & & 15 & 12.63 & & & 15 & 21.61 \\
\hline & & 30 & 13.82 & & & 30 & 23.53 \\
\hline & & 60 & 14.54 & & & 60 & 25.06 \\
\hline & & 90 & 14.81 & & & 90 & 25.58 \\
\hline & & 120 & 14.94 & & & 120 & 25.86 \\
\hline & & 150 & 15.06 & & & 150 & 26.03 \\
\hline & & 180 & 15.13 & & & 180 & 26.14 \\
\hline & & 210 & 15.20 & & & 210 & 26.25 \\
\hline & & 240 & 15.24 & & & 240 & 26.31 \\
\hline & & 270 & 15.28 & & & 270 & 26.37 \\
\hline & & 300 & 15.33 & & 53:00:00 & 300 & 26.42 \\
\hline & & 330 & 15.39 & & & & \\
\hline & & 360 & 15.41 & 156 & 53:00:00 & 0 & 26.45 \\
\hline & & 390 & 15.43 & & & 1 & 26.48 \\
\hline & & 420 & 15.46 & & & 2 & 26.50 \\
\hline & & 450 & 15.48 & & & 4 & 26.55 \\
\hline & 43:00:00 & 480 & 15.50 & & & 8 & 26.70 \\
\hline & & & & & & 15 & 27.23 \\
\hline \multirow[t]{16}{*}{132} & 43:00:00 & 0 & 15.54 & & & 30 & 28.94 \\
\hline & & 1 & 15.56 & & & 60 & 31.02 \\
\hline & & 2 & 15.59 & & & 90 & 31.72 \\
\hline & & 4 & 15.62 & & & 120 & 32.10 \\
\hline & & 8 & 15.75 & & & 150 & 32.32 \\
\hline & & 15 & 16.28 & & & 180 & 32.46 \\
\hline & & 30 & 17.97 & & & 210 & 32.56 \\
\hline & & 60 & 19.36 & & & 240 & 32.63 \\
\hline & & 90 & 19.87 & & & 270 & 32.68 \\
\hline & & 120 & 20.14 & & $58: 00: 00$ & 300 & 32.73 \\
\hline & & 150 & 20.33 & & & & \\
\hline & & 180 & 20.45 & & & & \\
\hline & & 210 & 20.52 & & & & \\
\hline & & 240 & 20.57 & & & & \\
\hline & & 270 & 20.62 & & & & \\
\hline & 48:00:00 & 300 & 20.66 & & & & \\
\hline & & & & & & & \\
\hline & & & & & & & \\
\hline & & & & & & & \\
\hline & & & & & & & \\
\hline & & & & & & & \\
\hline & & & & & & & \\
\hline & & & & & & & \\
\hline & & & & & & & \\
\hline & & & & & & & \\
\hline & & & & & & & \\
\hline
\end{tabular}




\begin{tabular}{|c|c|c|c|c|c|c|c|}
\hline Ensaio: & $\overline{\mathrm{S} 2}$ & Prof.: & $1,5 \mathrm{~m}$ & Sucção: & $31 \mathrm{kPa}$ & Folha: & $\overline{4}$ \\
\hline $\begin{array}{c}\text { Tensão } \\
(\mathrm{kPa})\end{array}$ & $\begin{array}{c}\text { Início Carr. } \\
\text { (min) }\end{array}$ & $\begin{array}{c}\text { Tempo } \\
(\mathrm{min})\end{array}$ & $\begin{array}{c}\text { Recalque } \\
(\mathrm{mm})\end{array}$ & $\begin{array}{c}\text { Tensão } \\
(\mathrm{kPa})\end{array}$ & $\begin{array}{c}\text { Início Carr. } \\
(\mathrm{min})\end{array}$ & $\begin{array}{r}\text { Tempo } \\
\text { (min) }\end{array}$ & $\begin{array}{c}\begin{array}{c}\text { Recalque } \\
(\mathrm{mm})\end{array} \\
\end{array}$ \\
\hline \multirow{21}{*}{168} & & & & & & & \\
\hline & 58:00:00 & 0 & 32.76 & 1D & 71:30:00 & 0 & 47.42 \\
\hline & & 1 & 32.79 & & & 1 & 47.41 \\
\hline & & 2 & 32.80 & & & 2 & 47.41 \\
\hline & & 4 & 32.85 & & & 4 & 47.40 \\
\hline & & 8 & 32.93 & & & 8 & 47.39 \\
\hline & & 15 & 33.14 & & & 15 & 47.38 \\
\hline & & 30 & 34.24 & 90 & $72: 00: 00$ & 30 & 47.38 \\
\hline & & 60 & 36.88 & & & & \\
\hline & & 90 & 37.85 & $2 \mathrm{D}$ & 72:00:00 & 0 & 46.61 \\
\hline & & 120 & 38.30 & & & 1 & 46.49 \\
\hline & & 150 & 38.57 & & & 2 & 46.46 \\
\hline & & 180 & 38.73 & & & 4 & 46.42 \\
\hline & & 210 & 38.86 & & & 8 & 46.38 \\
\hline & & 240 & 38.94 & & & 15 & 46.34 \\
\hline & & 270 & 39.02 & & & 30 & 46.30 \\
\hline & & 300 & 39.09 & & & 60 & 46.26 \\
\hline & & 330 & 39.14 & & & 90 & 46.26 \\
\hline & & 360 & 39.19 & 0 & 74:00:00 & 120 & 46.24 \\
\hline & & 390 & 39.23 & & & & \\
\hline & 65:00:00 & 420 & 39.26 & & & & \\
\hline \multirow{18}{*}{180} & $65 \cdot 00 \cdot 00$ & 0 & 3931 & & & & \\
\hline & & 1 & 39.32 & & & & \\
\hline & & 2 & 39.34 & & & & \\
\hline & & 4 & 39.37 & & & & \\
\hline & & 8 & 39.44 & & & & \\
\hline & & 15 & 39.62 & & & & \\
\hline & & 30 & 40.89 & & & & \\
\hline & & 60 & 44.78 & & & & \\
\hline & & 90 & 45.98 & & & & \\
\hline & & 120 & 46.55 & & & & \\
\hline & & 150 & 46.84 & & & & \\
\hline & & 180 & 47.05 & & & & \\
\hline & & 210 & 47.20 & & & & \\
\hline & & 240 & 47.30 & & & & \\
\hline & & 270 & 47.38 & & & & \\
\hline & & 300 & 47.43 & & & & \\
\hline & & 330 & 47.50 & & & & \\
\hline & $\begin{array}{l}71: 00: 00 \\
\end{array}$ & $\overline{360}$ & 47.55 & & & & \\
\hline \multirow{6}{*}{ Estab. } & $71 \cdot 00 \cdot 0$ & 0 & 4755 & & & & \\
\hline & & 5 & 47.55 & & & & \\
\hline & & 10 & 47.56 & & & & \\
\hline & & 15 & 47.57 & & & & \\
\hline & & 20 & 47.57 & & & & \\
\hline & & 25 & 47.57 & & & & \\
\hline 178 & 71:30:00 & 30 & 47.57 & & & & \\
\hline & & & & & & & \\
\hline & & & & & & & \\
\hline
\end{tabular}




\begin{tabular}{|c|c|c|c|c|c|c|c|}
\hline \multicolumn{8}{|c|}{ UNIVERSIDADE DE SÃO PAULO } \\
\hline \multicolumn{8}{|c|}{ ESCOLA DE ENGENHARIA DE SÃO CARLOS } \\
\hline \multicolumn{8}{|c|}{ DEPTO. DE GEOTECNIA - CAMPO EXPERIMENTAL DE FUNDAÇÕES } \\
\hline \multicolumn{8}{|c|}{$\begin{array}{c}\text { PROVA DE CARGA ESTÁTICA } \\
\end{array}$} \\
\hline \multicolumn{2}{|c|}{ Ensaio: $\quad$ QS1 } & & \multicolumn{3}{|c|}{ Tipo de Carregamento: } & QML \\
\hline \multicolumn{2}{|c|}{ Profundidade: } & \multicolumn{2}{|l|}{$1,5 \mathrm{~m}$} & \multicolumn{2}{|c|}{ Estado do solo: } & \multicolumn{2}{|c|}{ INUNDADO } \\
\hline $\begin{array}{l}\text { Sucção: } \\
\text { Diâmetro: }\end{array}$ & $\begin{array}{cc}0 & \mathrm{kPa} \\
80\end{array}$ & & & $\begin{array}{l}\text { Reensaio: } \\
\text { Folha: }\end{array}$ & $\begin{array}{l}\text { NÃO } \\
1\end{array}$ & & \\
\hline $\begin{array}{c}\text { Tensão } \\
(\mathrm{kPa})\end{array}$ & $\begin{array}{l}\text { Início Carr. } \\
\text { (min) }\end{array}$ & $\begin{array}{c}\text { Tempo } \\
\text { (min) }\end{array}$ & $\begin{array}{l}\text { Recalque } \\
\text { (mm) }\end{array}$ & $\begin{array}{c}\text { Tensão } \\
(\mathrm{kPa})\end{array}$ & $\begin{array}{c}\text { Início Carr. } \\
\text { (min) }\end{array}$ & $\begin{array}{r}\text { Tempo } \\
\text { (min) }\end{array}$ & $\begin{array}{l}\text { Recalque } \\
\text { (mm) }\end{array}$ \\
\hline & & & & & & & \\
\hline \multirow[t]{8}{*}{4} & 00:00 & 0 & 0,12 & 20 & 01:00 & 0 & 1,27 \\
\hline & & 1 & 0,14 & & & 1 & 1,48 \\
\hline & & 2 & 0,14 & & & 2 & 1,58 \\
\hline & & 3 & 0,14 & & & 3 & 1,61 \\
\hline & & 6 & 0,14 & & & 6 & 1,67 \\
\hline & & 9 & 0,15 & & & 9 & 1,70 \\
\hline & & 12 & 0,15 & & & 12 & 1,71 \\
\hline & 00:15 & 15 & 0,15 & & 01:15 & 15 & 1,74 \\
\hline & & & & & & & \\
\hline \multirow[t]{8}{*}{8} & 00:15 & 0 & 0,40 & 24 & 01:15 & 0 & 1,85 \\
\hline & & 1 & 0,41 & & & 1 & 2,05 \\
\hline & & 2 & 0,41 & & & 2 & 2,14 \\
\hline & & 3 & 0,41 & & & 3 & 2,19 \\
\hline & & 6 & 0,41 & & & 6 & 2,26 \\
\hline & & 9 & 0,41 & & & 9 & 2,31 \\
\hline & & 12 & 0,48 & & & 12 & 2,34 \\
\hline & $00: 30$ & 15 & 0,48 & & 01:30 & 15 & 2,36 \\
\hline \multirow[t]{8}{*}{12} & $00: 30$ & 0 & 0,50 & 28 & 01:30 & 0 & 2,50 \\
\hline & & 1 & 0,51 & & & 1 & 2,70 \\
\hline & & 2 & 0,52 & & & 2 & 2,80 \\
\hline & & 3 & 0,54 & & & 3 & 2,85 \\
\hline & & 6 & 0,55 & & & 6 & 2,97 \\
\hline & & 9 & 0,56 & & & 9 & 3,04 \\
\hline & & 12 & 0,56 & & & 12 & 3,08 \\
\hline & $00: 45$ & 15 & 0,56 & & 01:45 & 15 & 3,16 \\
\hline \multirow{8}{*}{16} & $00: 45$ & 0 & 0,78 & 32 & 01:45 & 0 & 3,31 \\
\hline & & 1 & 0,96 & & & 1 & 3,56 \\
\hline & & 2 & 0,99 & & & 2 & 3,71 \\
\hline & & 3 & 1,03 & & & 3 & 3,87 \\
\hline & & 6 & 1,09 & & & 6 & 3,99 \\
\hline & & 9 & 1,13 & & & 9 & 4,05 \\
\hline & & 12 & 1,16 & & & 12 & 4,17 \\
\hline & 01:00 & 15 & 1,17 & & 02:00 & 15 & 4,27 \\
\hline & & & & & & & \\
\hline & & & & & & & \\
\hline & & & & & & & \\
\hline & & & & & & & \\
\hline & & & & & & & \\
\hline & & & & & & & \\
\hline
\end{tabular}




\begin{tabular}{|c|c|c|c|c|c|c|c|}
\hline Ensaio: & $\overline{\mathrm{QS1}}$ & Prof.: & $1,5 \mathrm{~m}$ & Sucção: & $\begin{array}{ll}0 & \mathrm{kPa}\end{array}$ & Folha: & 2 \\
\hline $\begin{array}{c}\text { Tensão } \\
(\mathrm{kPa})\end{array}$ & $\begin{array}{c}\text { Início Carr. } \\
\text { (min) }\end{array}$ & $\begin{array}{c}\text { Tempo } \\
(\mathrm{min})\end{array}$ & $\begin{array}{l}\text { Recalque } \\
(\mathrm{mm})\end{array}$ & $\begin{array}{c}\text { Tensão } \\
(\mathrm{kPa})\end{array}$ & $\begin{array}{c}\text { Início Carr. } \\
(\mathrm{min})\end{array}$ & $\begin{array}{c}\text { Tempo } \\
\text { (min) }\end{array}$ & $\begin{array}{l}\text { Recalque } \\
(\mathrm{mm})\end{array}$ \\
\hline \multirow{9}{*}{36} & & & & & & & \\
\hline & 02:00 & 0 & 6,04 & 56 & 03:15 & 0 & 17,93 \\
\hline & & 1 & 6,16 & & & 1 & 18,55 \\
\hline & & 2 & 6,25 & & & 2 & 19,06 \\
\hline & & 3 & 6,32 & & & 3 & 19,47 \\
\hline & & 6 & 6,46 & & & 6 & 20,40 \\
\hline & & 9 & 6,57 & & & 9 & 21,00 \\
\hline & & 12 & 6,64 & & & 12 & 21,35 \\
\hline & 02:15 & 15 & 6,73 & & 03:30 & 15 & 21,61 \\
\hline \multirow{8}{*}{40} & $02: 15$ & 0 & 6,81 & 60 & 03:30 & 0 & 21,78 \\
\hline & & 1 & 7,15 & & & 1 & 22,39 \\
\hline & & 2 & 7,46 & & & 2 & 23,25 \\
\hline & & 3 & 7,75 & & & 3 & 23,66 \\
\hline & & 6 & 8,35 & & & 6 & 24,48 \\
\hline & & 9 & 8,58 & & & 9 & 25,20 \\
\hline & & 12 & 8,74 & & & 12 & 25,66 \\
\hline & 02:30 & 15 & 8,85 & & 03:45 & 15 & 25,97 \\
\hline \multirow[t]{8}{*}{44} & 02:30 & 0 & 8,93 & 64 & $03: 45$ & 0 & 26,09 \\
\hline & & 1 & 9,28 & & & 1 & 26,39 \\
\hline & & 2 & 9,70 & & & 2 & 26,85 \\
\hline & & 3 & 10,05 & & & 3 & 27,27 \\
\hline & & 6 & 10,49 & & & 6 & 28,18 \\
\hline & & 9 & 10,79 & & & 9 & 28,97 \\
\hline & & 12 & 11,00 & & & 12 & 29,28 \\
\hline & $02: 45$ & 15 & 11,12 & & 04:00 & 15 & 29,83 \\
\hline \multirow{8}{*}{48} & $02: 45$ & 0 & 11,25 & 68 & 04:00 & 0 & 29,98 \\
\hline & & 1 & 11,84 & & & 1 & 30,45 \\
\hline & & 2 & 12,29 & & & 2 & 31,07 \\
\hline & & 3 & 12,59 & & & 3 & 31,57 \\
\hline & & 6 & 13,25 & & & 6 & 32,65 \\
\hline & & 9 & 13,77 & & & 9 & \begin{tabular}{|l|}
33,34 \\
\end{tabular} \\
\hline & & 12 & 14,11 & & & 12 & 33,85 \\
\hline & 03:00 & 15 & 14,34 & & 04:15 & 15 & 34,18 \\
\hline \multirow[t]{8}{*}{52} & 03:00 & 0 & 14,52 & 72 & $04: 15$ & 0 & 34,30 \\
\hline & & 1 & 14,91 & & & 1 & 34,98 \\
\hline & & 2 & 15,26 & & & 2 & 35,59 \\
\hline & & 3 & 15,99 & & & 3 & 36,41 \\
\hline & & 6 & 16,76 & & & 6 & 37,65 \\
\hline & & 9 & $\begin{array}{l}17,18 \\
\end{array}$ & & & 9 & $\begin{array}{l}38,28 \\
\end{array}$ \\
\hline & & 12 & 17,51 & & & 12 & 38,75 \\
\hline & 03:15 & 15 & 17,68 & & 04:30 & 15 & 39,06 \\
\hline & & & & & & & \\
\hline & & & & & & & \\
\hline & & & & & & & \\
\hline & & & & & & & \\
\hline & & & & & & & \\
\hline
\end{tabular}




\begin{tabular}{|c|c|c|c|c|c|c|c|}
\hline Ensaio: & QS1 & Prof.: & $1,5 \mathrm{~m}$ & Sucção: & $\begin{array}{ll}0 & \mathrm{kPa} \\
\end{array}$ & Folha: & 3 \\
\hline $\begin{array}{c}\text { Tensão } \\
(\mathrm{kPa})\end{array}$ & $\begin{array}{c}\text { Início Carr. } \\
\text { (min) }\end{array}$ & $\begin{array}{c}\text { Tempo } \\
(\mathrm{min})\end{array}$ & $\begin{array}{c}\text { Recalque } \\
\text { (mm) }\end{array}$ & $\begin{array}{c}\text { Tensão } \\
(\mathrm{kPa})\end{array}$ & $\begin{array}{c}\text { Início Carr. } \\
\text { (min) }\end{array}$ & $\begin{array}{c}\text { Tempo } \\
(\mathrm{min})\end{array}$ & $\begin{array}{c}\text { Recalque } \\
(\mathrm{mm})\end{array}$ \\
\hline & & & & & & & \\
\hline \multirow[t]{8}{*}{76} & 04:30 & 0 & 39,24 & & & & \\
\hline & & 1 & 39,63 & & & & \\
\hline & & 2 & 40,15 & & & & \\
\hline & & 3 & 40,85 & & & & \\
\hline & & 6 & 41,86 & & & & \\
\hline & & 9 & 42,61 & & & & \\
\hline & & 12 & 43,11 & & & & \\
\hline & $04: 45$ & 15 & 43,88 & & & & \\
\hline & & & & & & & \\
\hline & & & & & & & \\
\hline \multirow{7}{*}{ Estab. } & 04:45 & 0 & 43,59 & & & & \\
\hline & & 1 & 43,58 & & & & \\
\hline & & 2 & 43,58 & & & & \\
\hline & & 3 & 43,58 & & & & \\
\hline & & 6 & 43,58 & & & & \\
\hline & & 9 & $\begin{array}{l}43,58 \\
\end{array}$ & & & & \\
\hline & & 12 & 43,58 & & & & \\
\hline \multirow[t]{2}{*}{38} & 05:00 & 15 & 43,58 & & & & \\
\hline & & & & & & & \\
\hline \multirow[t]{8}{*}{$1 \mathrm{D}$} & 05:00 & 0 & 43,17 & & & & \\
\hline & & 1 & 43,13 & & & & \\
\hline & & 2 & 43,09 & & & & \\
\hline & & 3 & 43,09 & & & & \\
\hline & & 6 & 43,06 & & & & \\
\hline & & 9 & 43,05 & & & & \\
\hline & & 12 & 43,04 & & & & \\
\hline & & 15 & 43,03 & & & & \\
\hline 0 & 05:30 & 30 & 43,02 & & & & \\
\hline & & & & & & & \\
\hline & & & & & & & \\
\hline & & & & & & & \\
\hline & & & & & & & \\
\hline & & & & & & & \\
\hline & & & & & & & \\
\hline & & & & & & & \\
\hline & & & & & & & \\
\hline & & & & & & & \\
\hline & & & & & & & \\
\hline & & & & & & & \\
\hline & & & & & & & \\
\hline & & & & & & & \\
\hline & & & & & & & \\
\hline & & & & & & & \\
\hline & & & & & & & \\
\hline & & & & & & & \\
\hline & & & & & & & \\
\hline & & & & & & & \\
\hline & & & & & & & \\
\hline & & & & & & & \\
\hline
\end{tabular}




\begin{tabular}{|c|c|c|c|c|c|c|c|}
\hline \multicolumn{8}{|c|}{ UNIVERSIDADE DE SÃO PAULO } \\
\hline \multicolumn{8}{|c|}{ ESCOLA DE ENGENHARIA DE SÃO CARLOS } \\
\hline \multicolumn{8}{|c|}{ DEPTO. DE GEOTECNIA - CAMPO EXPERIMENTAL DE FUNDAÇÕES } \\
\hline \multicolumn{8}{|c|}{$\begin{array}{c}\text { PROVA DE CARGA ESTÁTICA } \\
\end{array}$} \\
\hline \multicolumn{2}{|c|}{ Ensaio: $\quad$ QS2 } & & \multicolumn{3}{|c|}{ Tipo de Carregamento: } & QML \\
\hline \multicolumn{2}{|c|}{ Profundidade: } & \multicolumn{2}{|l|}{$1,5 \mathrm{~m}$} & \multicolumn{2}{|c|}{ Estado do solo: } & \multicolumn{2}{|c|}{ INUNDADO } \\
\hline $\begin{array}{l}\text { Sucção: } \\
\text { Diâmetro: }\end{array}$ & $\begin{array}{cc}0 & \mathrm{kPa} \\
80\end{array}$ & & & $\begin{array}{l}\text { Reensaio: } \\
\text { Folha: }\end{array}$ & $\begin{array}{l}\text { NÃO } \\
1\end{array}$ & & \\
\hline $\begin{array}{c}\text { Tensão } \\
(\mathrm{kPa})\end{array}$ & $\begin{array}{l}\text { Início Carr. } \\
\text { (min) }\end{array}$ & $\begin{array}{c}\text { Tempo } \\
\text { (min) }\end{array}$ & $\begin{array}{l}\text { Recalque } \\
\text { (mm) }\end{array}$ & $\begin{array}{c}\text { Tensão } \\
(\mathrm{kPa})\end{array}$ & $\begin{array}{c}\text { Início Carr. } \\
\text { (min) }\end{array}$ & $\begin{array}{r}\text { Tempo } \\
\text { (min) }\end{array}$ & $\begin{array}{l}\text { Recalque } \\
\text { (mm) }\end{array}$ \\
\hline & & & & & & & \\
\hline \multirow[t]{8}{*}{4} & 00:00 & 0 & 0,21 & 20 & 01:00 & 0 & 1,22 \\
\hline & & 1 & 0,23 & & & 1 & 1,37 \\
\hline & & 2 & 0,24 & & & 2 & 1,47 \\
\hline & & 3 & 0,24 & & & 3 & 1,55 \\
\hline & & 6 & 0,24 & & & 6 & 1,62 \\
\hline & & 9 & 0,24 & & & 9 & 1,69 \\
\hline & & 12 & 0,24 & & & 12 & 1,72 \\
\hline & 00:15 & 15 & 0,24 & & 01:15 & 15 & 1,74 \\
\hline & & & & & & & \\
\hline \multirow[t]{8}{*}{8} & 00:15 & 0 & 0,32 & 24 & 01:15 & 0 & 1,79 \\
\hline & & 1 & 0,39 & & & 1 & 1,93 \\
\hline & & 2 & 0,40 & & & 2 & 2,03 \\
\hline & & 3 & 0,42 & & & 3 & 2,11 \\
\hline & & 6 & 0,45 & & & 6 & 2,23 \\
\hline & & 9 & 0,46 & & & 9 & 2,33 \\
\hline & & 12 & 0,49 & & & 12 & 2,38 \\
\hline & $\begin{array}{l}00: 30 \\
\end{array}$ & 15 & 0,50 & & \begin{tabular}{l|l}
$01: 30$ \\
\end{tabular} & 15 & 2,44 \\
\hline \multirow{8}{*}{12} & & & & 28 & $01 \cdot 30$ & 0 & 252 \\
\hline & $00: 30$ & $\frac{0}{1}$ & $\frac{0,55}{0,64}$ & 28 & $01: 30$ & $\frac{0}{1}$ & $\frac{2,32}{2,64}$ \\
\hline & & 2 & 0,68 & & & 2 & 2,73 \\
\hline & & 3 & 0,70 & & & 3 & 2,83 \\
\hline & & 6 & 0,75 & & & 6 & 2,97 \\
\hline & & 9 & 0,77 & & & 9 & 3,08 \\
\hline & & 12 & 0,79 & & & 12 & 3,15 \\
\hline & $00: 45$ & 15 & 0,79 & & 01:45 & 15 & 3,19 \\
\hline \multirow{8}{*}{16} & $00: 45$ & 0 & 0,90 & 32 & 01:45 & 0 & 3,34 \\
\hline & & 1 & 0,98 & & & 1 & 3,62 \\
\hline & & 2 & 1,03 & & & 2 & 3,70 \\
\hline & & 3 & 1,06 & & & 3 & 3,88 \\
\hline & & 6 & 1,11 & & & 6 & 4,00 \\
\hline & & 9 & 1,14 & & & 9 & 4,11 \\
\hline & & 12 & 1,17 & & & 12 & 4,18 \\
\hline & 01:00 & 15 & 1,17 & & 02:00 & 15 & 4,23 \\
\hline & & & & & & & \\
\hline & & & & & & & \\
\hline & & & & & & & \\
\hline & & & & & & & \\
\hline & & & & & & & \\
\hline & & & & & & & \\
\hline
\end{tabular}




\begin{tabular}{|c|c|c|c|c|c|c|c|}
\hline Ensaio: & QS2 & Prof.: & $1,5 \mathrm{~m}$ & Sucção: & $0 \quad \mathrm{kPa}$ & Folha: & 2 \\
\hline $\begin{array}{c}\text { Tensão } \\
(\mathrm{kPa})\end{array}$ & $\begin{array}{c}\text { Início Carr. } \\
\text { (min) }\end{array}$ & $\begin{array}{r}\begin{array}{r}\text { Tempo } \\
(\mathrm{min})\end{array} \\
\end{array}$ & $\begin{array}{c}\text { Recalque } \\
(\mathrm{mm})\end{array}$ & $\begin{array}{c}\text { Tensão } \\
(\mathrm{kPa})\end{array}$ & $\begin{array}{c}\text { Início Carr. } \\
(\mathrm{min})\end{array}$ & $\begin{array}{c}\text { Tempo } \\
\text { (min) }\end{array}$ & $\begin{array}{c}\text { Recalque } \\
(\mathrm{mm})\end{array}$ \\
\hline & & & & & & & \\
\hline \multirow[t]{8}{*}{36} & $02: 00$ & 0 & 4,29 & 56 & $03: 15$ & 0 & 15,86 \\
\hline & & 1 & 4,49 & & & 1 & 16,37 \\
\hline & & 2 & 4,69 & & & 2 & 16,78 \\
\hline & & 3 & 4,83 & & & 3 & 17,25 \\
\hline & & 6 & 5,12 & & & 6 & 18,14 \\
\hline & & 9 & 5,29 & & & 9 & 18,70 \\
\hline & & 12 & 5,44 & & & 12 & 19,17 \\
\hline & $02: 15$ & 15 & 5,51 & & $03: 30$ & 15 & 19,47 \\
\hline & & & & & & & \\
\hline \multirow[t]{8}{*}{40} & $02: 15$ & 0 & 5,61 & 60 & $03: 30$ & 0 & 19,55 \\
\hline & & 1 & 5,82 & & & 1 & 20,28 \\
\hline & & 2 & 6,06 & & & 2 & 20,65 \\
\hline & & 3 & 6,11 & & & 3 & 21,10 \\
\hline & & 6 & 6,51 & & & 6 & 22,20 \\
\hline & & 9 & 6,85 & & & 9 & 22,88 \\
\hline & & 12 & 7,12 & & & 12 & 23,43 \\
\hline & $02: 30$ & 15 & 7,30 & & $03: 45$ & 15 & 23,78 \\
\hline & & & & & & & \\
\hline \multirow[t]{8}{*}{44} & $02: 30$ & 0 & 7,39 & 64 & $03: 45$ & 0 & 23,88 \\
\hline & & 1 & 7,61 & & & 1 & 24,46 \\
\hline & & 2 & 7,94 & & & 2 & 25,06 \\
\hline & & 3 & 8,25 & & & 3 & 25,55 \\
\hline & & 6 & 8,88 & & & 6 & 26,44 \\
\hline & & 9 & 9,23 & & & 9 & 27,51 \\
\hline & & 12 & 9,52 & & & 12 & 28,10 \\
\hline & $02: 45$ & 15 & 9,63 & & $04: 00$ & 15 & 28,49 \\
\hline \multirow[t]{8}{*}{48} & $02: 45$ & 0 & 9,78 & 68 & $04: 00$ & 0 & 28,55 \\
\hline & & 1 & 10,13 & & & 1 & 29,08 \\
\hline & & 2 & 10,49 & & & 2 & 29,70 \\
\hline & & 3 & 10,78 & & & 3 & 30,15 \\
\hline & & 6 & 11,48 & & & 6 & 30,42 \\
\hline & & 9 & 11,96 & & & 9 & 32,39 \\
\hline & & 12 & 12,22 & & & 12 & 33,05 \\
\hline & 03:00 & 15 & 12,43 & & $04: 15$ & 15 & 33,65 \\
\hline \multirow[t]{8}{*}{52} & 03:00 & 0 & 12,52 & 72 & $04: 15$ & 0 & 33,80 \\
\hline & & 1 & 13,02 & & & 1 & 34,46 \\
\hline & & 2 & 13,48 & & & 2 & 35,21 \\
\hline & & 3 & 13,96 & & & 3 & 35,94 \\
\hline & & 6 & - & & & 6 & 37,79 \\
\hline & & 9 & 15,19 & & & 9 & 38,72 \\
\hline & & 12 & 15,64 & & & 12 & 39,46 \\
\hline & $03: 15$ & 15 & 15,75 & & $04: 30$ & 15 & 40,06 \\
\hline & & & & & & & \\
\hline & & & & & & & \\
\hline & & & & & & & \\
\hline & & & & & & & \\
\hline & & & & & & & \\
\hline
\end{tabular}




\begin{tabular}{|c|c|c|c|c|c|c|c|}
\hline Ensaio: & QS2 & Prof.: & $1,5 \mathrm{~m}$ & Sucção: & $0 \mathrm{kPa}$ & Folha: & 3 \\
\hline $\begin{array}{c}\text { Tensão } \\
(\mathrm{kPa})\end{array}$ & $\begin{array}{c}\text { Início Carr. } \\
\text { (min) }\end{array}$ & $\begin{array}{r}\begin{array}{r}\text { Tempo } \\
(\mathrm{min})\end{array} \\
\end{array}$ & $\begin{array}{c}\text { Recalque } \\
(\mathrm{mm})\end{array}$ & $\begin{array}{c}\text { Tensão } \\
(\mathrm{kPa})\end{array}$ & $\begin{array}{c}\text { Início Carr. } \\
(\mathrm{min})\end{array}$ & $\begin{array}{c}\text { Tempo } \\
\text { (min) }\end{array}$ & $\begin{array}{c}\text { Recalque } \\
(\mathrm{mm})\end{array}$ \\
\hline & & & & & & & \\
\hline \multirow[t]{9}{*}{76} & $04: 30$ & 0 & 40,19 & Estab. & $06: 00$ & 0 & 71,96 \\
\hline & & 1 & 40,97 & & & 3 & 72,07 \\
\hline & & 2 & 42,03 & & & 6 & 72,11 \\
\hline & & 3 & 42,59 & & & 9 & 72,12 \\
\hline & & 6 & 43,99 & & & 12 & 72,13 \\
\hline & & 9 & 45,13 & & & 15 & 72,14 \\
\hline & & 12 & 45,88 & 76 & $06: 30$ & 30 & 72,14 \\
\hline & $04: 45$ & 15 & 46,43 & & & & \\
\hline & & & & $1 \mathrm{D}$ & $06: 30$ & 0 & 72,09 \\
\hline \multirow[t]{9}{*}{80} & $05: 00$ & 0 & 46,50 & & & 1 & 72,08 \\
\hline & & 1 & 47,06 & & & 2 & 72,08 \\
\hline & & 2 & 47,90 & & & 3 & 72,07 \\
\hline & & 3 & 48,50 & & & 6 & 72,07 \\
\hline & & 6 & 50,12 & & & 9 & 72,07 \\
\hline & & 9 & 51,27 & & & 12 & 72,07 \\
\hline & & 12 & 52,09 & 48 & $06: 45$ & 15 & 72,07 \\
\hline & $05: 15$ & 15 & 52,70 & & & & \\
\hline & & & & $2 \mathrm{D}$ & $06: 45$ & 0 & 72,01 \\
\hline \multirow[t]{9}{*}{84} & $05: 15$ & 0 & 52,89 & & & 1 & 71,99 \\
\hline & & 1 & 53,59 & & & 2 & 33,75 \\
\hline & & 2 & 54,39 & & & 3 & 71,99 \\
\hline & & 3 & 55,03 & & & 6 & 71,98 \\
\hline & & 6 & 56,74 & & & 9 & 71,97 \\
\hline & & 9 & 58,17 & & & 12 & 71,97 \\
\hline & & 12 & 58,79 & 34 & $07: 00$ & 15 & 71,97 \\
\hline & $05: 30$ & 15 & 59,49 & & & & \\
\hline & & & & $3 \mathrm{D}$ & $07: 00$ & 0 & 71,83 \\
\hline \multirow[t]{9}{*}{88} & $05: 30$ & 0 & 59,61 & & & 1 & 71,81 \\
\hline & & 1 & 60,19 & & & 2 & 71,81 \\
\hline & & 2 & 60,70 & & & 3 & 71,80 \\
\hline & & 3 & 61,32 & & & 6 & 71,80 \\
\hline & & 6 & 62,88 & & & 9 & 71,80 \\
\hline & & 9 & 64,10 & & & 12 & 71,79 \\
\hline & & 12 & 64,82 & 20 & $07: 15$ & 15 & 71,79 \\
\hline & $05: 45$ & 15 & 65,41 & & & & \\
\hline & & & & $4 \mathrm{D}$ & $07: 15$ & 0 & 71,71 \\
\hline \multirow[t]{8}{*}{92} & $05: 45$ & 0 & 65,86 & & & 1 & 71,53 \\
\hline & & 1 & 66,33 & & & 2 & 33,75 \\
\hline & & 2 & 66,82 & & & 3 & 71,46 \\
\hline & & 3 & 67,40 & & & 6 & 71,42 \\
\hline & & 6 & 69,16 & & & 9 & 71,40 \\
\hline & & 9 & 70,17 & & & 12 & 71,39 \\
\hline & & 12 & 71,12 & & & 15 & 71,39 \\
\hline & $06: 00$ & 15 & 71,86 & 0 & $07: 45$ & 30 & 71,39 \\
\hline & & & & & & & \\
\hline & & & & & & & \\
\hline & & & & & & & \\
\hline & & & & & & & \\
\hline & & & & & & & \\
\hline
\end{tabular}




\begin{tabular}{|c|c|c|c|c|c|c|c|}
\hline \multicolumn{8}{|c|}{ UNIVERSIDADE DE SÃO PAULO } \\
\hline \multicolumn{8}{|c|}{ ESCOLA DE ENGENHARIA DE SÃO CARLOS } \\
\hline \multicolumn{8}{|c|}{ DEPTO. DE GEOTECNIA - CAMPO EXPERIMENTAL DE FUNDAÇÕES } \\
\hline \multicolumn{8}{|c|}{$\begin{array}{l}\text { PROVA DE CARGA ESTÁTICA } \\
\end{array}$} \\
\hline \multicolumn{2}{|c|}{ Ensaio: $\quad$ Q1 } & & \multicolumn{3}{|c|}{ Tipo de Carregamento: } & QML \\
\hline \multicolumn{2}{|c|}{ Profundidade: } & \multicolumn{2}{|l|}{$1,5 \mathrm{~m}$} & \multicolumn{2}{|c|}{ Estado do solo: } & \multicolumn{2}{|c|}{ NATURAL } \\
\hline Sucção: & $15 \mathrm{kPa}$ & & & \multirow{2}{*}{\multicolumn{2}{|c|}{$\begin{array}{l}\text { Reensaio: } \\
\text { Folha: } \quad 1\end{array}$}} & \multicolumn{2}{|c|}{ NÃO } \\
\hline \multicolumn{3}{|c|}{ Diâmetro: $\quad 80$} & & & & & \\
\hline $\begin{array}{l}\text { Tensão } \\
(\mathrm{kPa})\end{array}$ & $\begin{array}{c}\text { Início Carr. } \\
\text { (min) }\end{array}$ & $\begin{array}{c}\text { Tempo } \\
\text { (min) }\end{array}$ & $\begin{array}{l}\text { Recalque } \\
\text { (mm) }\end{array}$ & $\begin{array}{l}\text { Tensão } \\
(\mathrm{kPa})\end{array}$ & $\begin{array}{c}\text { Início Carr. } \\
\text { (min) }\end{array}$ & $\begin{array}{r}\text { Tempo } \\
\text { (min) }\end{array}$ & $\begin{array}{l}\text { Recalque } \\
\text { (mm) }\end{array}$ \\
\hline \multirow[t]{8}{*}{6} & 00:00 & 0 & 0,32 & 30 & 01:00 & 0 & 2,87 \\
\hline & & 1 & 0,52 & & & 1 & 3,05 \\
\hline & & 2 & 0,54 & & & 2 & 3,12 \\
\hline & & 3 & 0,57 & & & 3 & 3,23 \\
\hline & & 6 & 0,59 & & & 6 & 3,26 \\
\hline & & 9 & 0,60 & & & 9 & 3,30 \\
\hline & & 12 & 0,61 & & & 12 & 3,34 \\
\hline & 00:15 & 15 & 0,62 & & 01:15 & 15 & 3,36 \\
\hline \multirow{9}{*}{12} & & & & & & & \\
\hline & 00:15 & 0 & 2,09 & 36 & 01:15 & 0 & 3,42 \\
\hline & & 1 & 2,10 & & & 1 & 3,77 \\
\hline & & 2 & 2,10 & & & 2 & 3,87 \\
\hline & & 3 & 2,10 & & & 3 & 3,90 \\
\hline & & 6 & 2,10 & & & 6 & 4,00 \\
\hline & & 9 & 2,10 & & & 9 & 4,06 \\
\hline & & 12 & 2,10 & & & 12 & - \\
\hline & $\begin{array}{l}00: 30 \\
\end{array}$ & 15 & 2,10 & & 01:30 & 15 & 4,12 \\
\hline \multirow{8}{*}{18} & $00: 30$ & 0 & 2,15 & 42 & 01:30 & 0 & 4,16 \\
\hline & & 1 & 2,17 & & & 1 & 4,50 \\
\hline & & 2 & 2,20 & & & 2 & 4,66 \\
\hline & & 3 & 2,20 & & & 3 & 4,74 \\
\hline & & 6 & 2,24 & & & 6 & 4,88 \\
\hline & & 9 & 2,27 & & & 9 & 4,96 \\
\hline & & 12 & 2,27 & & & 12 & 5,00 \\
\hline & $00: 45$ & 15 & 2,27 & & 01:45 & 15 & 5,04 \\
\hline \multirow{8}{*}{24} & $00 \cdot 45$ & 0 & 2,39 & 48 & $01: 45$ & 0 & 511 \\
\hline & & 1 & 2,61 & & & 1 & 5,39 \\
\hline & & 2 & 2,67 & & & 2 & 5,59 \\
\hline & & 3 & 2,71 & & & 3 & 5,72 \\
\hline & & 6 & 2,76 & & & 6 & 5,88 \\
\hline & & 9 & 2,80 & & & 9 & 5,94 \\
\hline & & 12 & 2,81 & & & 12 & 6,01 \\
\hline & 01:00 & 15 & 2,82 & & 02:00 & 15 & 6,05 \\
\hline & & & & & & & \\
\hline & & & & & & & \\
\hline & & & & & & & \\
\hline & & & & & & & \\
\hline & & & & & & & \\
\hline & & & & & & & \\
\hline
\end{tabular}




\begin{tabular}{|c|c|c|c|c|c|c|c|}
\hline Ensaio: & Q1 & Prof.: & $1,5 \mathrm{~m}$ & Sucção: & $15 \mathrm{kPa}$ & Folha: & 2 \\
\hline $\begin{array}{c}\text { Tensão } \\
(\mathrm{kPa})\end{array}$ & $\begin{array}{c}\text { Início Carr. } \\
\text { (min) }\end{array}$ & $\begin{array}{r}\begin{array}{r}\text { Tempo } \\
(\mathrm{min})\end{array} \\
\end{array}$ & $\begin{array}{c}\text { Recalque } \\
(\mathrm{mm})\end{array}$ & $\begin{array}{c}\text { Tensão } \\
(\mathrm{kPa})\end{array}$ & $\begin{array}{c}\text { Início Carr. } \\
(\mathrm{min})\end{array}$ & $\begin{array}{c}\text { Tempo } \\
\text { (min) }\end{array}$ & $\begin{array}{c}\text { Recalque } \\
(\mathrm{mm})\end{array}$ \\
\hline & & & & & & & \\
\hline \multirow[t]{8}{*}{54} & $02: 00$ & 0 & 6,10 & 84 & $03: 15$ & 0 & 15,69 \\
\hline & & 1 & 6,38 & & & 1 & 15,88 \\
\hline & & 2 & 6,61 & & & 2 & 16,45 \\
\hline & & 3 & 6,80 & & & 3 & 16,74 \\
\hline & & 6 & 7,05 & & & 6 & 17,47 \\
\hline & & 9 & 7,15 & & & 9 & 17,73 \\
\hline & & 12 & 7,24 & & & 12 & 17,98 \\
\hline & $02: 15$ & 15 & 7,30 & & $03: 30$ & 15 & 18,15 \\
\hline & & & & & & & \\
\hline \multirow[t]{8}{*}{60} & $02: 15$ & 0 & 7,37 & 90 & $03: 30$ & 0 & 18,22 \\
\hline & & 1 & 7,73 & & & 1 & 18,62 \\
\hline & & 2 & 8,07 & & & 2 & 19,20 \\
\hline & & 3 & 8,27 & & & 3 & 19,65 \\
\hline & & 6 & 8,54 & & & 6 & 20,45 \\
\hline & & 9 & 8,98 & & & 9 & 20,86 \\
\hline & & 12 & 9,08 & & & 12 & 21,09 \\
\hline & $02: 30$ & 15 & 9,16 & & $03: 45$ & 15 & 21,28 \\
\hline & & & & & & & \\
\hline \multirow[t]{8}{*}{66} & $02: 30$ & 0 & 9,20 & 96 & $03: 45$ & 0 & 21,33 \\
\hline & & 1 & 9,55 & & & 1 & 21,78 \\
\hline & & 2 & 9,57 & & & 2 & 22,28 \\
\hline & & 3 & - & & & 3 & 22,62 \\
\hline & & 6 & 9,91 & & & 6 & 23,48 \\
\hline & & 9 & 10,11 & & & 9 & 23,99 \\
\hline & & 12 & 10,26 & & & 12 & 24,30 \\
\hline & $02: 45$ & 15 & 10,36 & & $04: 00$ & 15 & 24,48 \\
\hline \multirow[t]{8}{*}{72} & $02: 45$ & 0 & 10,44 & 102 & $04: 00$ & 0 & 24,55 \\
\hline & & 1 & 10,86 & & & 1 & 24,94 \\
\hline & & 2 & 11,37 & & & 2 & 25,40 \\
\hline & & 3 & 11,75 & & & 3 & 25,80 \\
\hline & & 6 & 12,41 & & & 6 & 26,74 \\
\hline & & 9 & 12,66 & & & 9 & 27,24 \\
\hline & & 12 & 12,85 & & & 12 & 27,58 \\
\hline & 03:00 & 15 & 12,92 & & $04: 15$ & 15 & 27,83 \\
\hline \multirow[t]{8}{*}{78} & 03:00 & 0 & 12,98 & 108 & $04: 15$ & 0 & 27,93 \\
\hline & & 1 & 13,38 & & & 1 & 28,38 \\
\hline & & 2 & 13,82 & & & 2 & 28,94 \\
\hline & & 3 & 14,17 & & & 3 & 29,52 \\
\hline & & 6 & 14,80 & & & 6 & 30,50 \\
\hline & & 9 & 15,04 & & & 9 & 31,12 \\
\hline & & 12 & 15,50 & & & 12 & 31,49 \\
\hline & $03: 15$ & 15 & 15,65 & & $04: 30$ & 15 & 31,77 \\
\hline & & & & & & & \\
\hline & & & & & & & \\
\hline & & & & & & & \\
\hline & & & & & & & \\
\hline & & & & & & & \\
\hline
\end{tabular}




\begin{tabular}{|c|c|c|c|c|c|c|c|}
\hline Ensaio: & Q1 & Prof.: & $1,5 \mathrm{~m}$ & Sucção: & $15 \mathrm{kPa}$ & Folha: & 3 \\
\hline $\begin{array}{c}\text { Tensão } \\
(\mathrm{kPa})\end{array}$ & $\begin{array}{c}\text { Início Carr. } \\
\text { (min) }\end{array}$ & $\begin{array}{c}\text { Tempo } \\
\text { (min) }\end{array}$ & $\begin{array}{c}\text { Recalque } \\
\text { (mm) }\end{array}$ & $\begin{array}{c}\text { Tensão } \\
(\mathrm{kPa})\end{array}$ & $\begin{array}{c}\text { Início Carr. } \\
(\mathrm{min})\end{array}$ & $\begin{array}{c}\text { Tempo } \\
\text { (min) }\end{array}$ & $\begin{array}{c}\text { Recalque } \\
(\mathrm{mm})\end{array}$ \\
\hline & & & & & & & \\
\hline \multirow[t]{8}{*}{114} & 04:30 & 0 & 31,85 & $1 \mathrm{D}$ & $05: 55$ & 0 & 45,43 \\
\hline & & 1 & 32,32 & & & 1 & 45,43 \\
\hline & & 2 & 32,83 & & & 2 & 45,43 \\
\hline & & 3 & 33,34 & & & 3 & 45,43 \\
\hline & & 6 & 34,47 & & & 6 & 45,41 \\
\hline & & 9 & 35,09 & & & 9 & 45,41 \\
\hline & & 12 & 35,54 & & & 12 & 45,40 \\
\hline & 04:45 & 15 & 35,82 & 67 & 06:10 & 15 & 45,40 \\
\hline & & & & & & & \\
\hline \multirow[t]{8}{*}{120} & 04:45 & 0 & 35,91 & $2 \mathrm{D}$ & $06: 10$ & 0 & 45,25 \\
\hline & & 1 & 36,33 & & & 1 & - \\
\hline & & 2 & 37,07 & & & 2 & 45,23 \\
\hline & & 3 & 37,48 & & & 3 & 45,22 \\
\hline & & 6 & 38,61 & & & 6 & 45,22 \\
\hline & & 9 & 39,46 & & & 9 & 45,22 \\
\hline & & 12 & 39,91 & & & 12 & 45,21 \\
\hline & 05:00 & 15 & 40,25 & 36 & $06: 25$ & 15 & 45,21 \\
\hline & & & & & & & \\
\hline \multirow[t]{8}{*}{126} & $05: 00$ & 0 & 40,37 & $3 \mathrm{D}$ & $06: 25$ & 0 & 45,08 \\
\hline & & 1 & 40,85 & & & 1 & 45,05 \\
\hline & & 2 & 41,44 & & & 2 & - \\
\hline & & 3 & 42,06 & & & 3 & 45,03 \\
\hline & & 6 & 43,36 & & & 6 & 45,03 \\
\hline & & 9 & 44,19 & & & 9 & 45,01 \\
\hline & & 12 & 44,69 & & & 12 & 45,00 \\
\hline & $05: 15$ & 15 & 45,07 & 17 & 06:40 & 15 & 45,00 \\
\hline \multirow[t]{12}{*}{ Estab. } & $05: 15$ & 0 & 45,15 & $4 \mathrm{D}$ & $06: 40$ & 0 & 33,98 \\
\hline & & 1 & 45,22 & & & 1 & 44,66 \\
\hline & & 2 & 45,27 & & & 2 & 44,65 \\
\hline & & 3 & 45,30 & & & 3 & 44,62 \\
\hline & & 6 & 45,35 & & & 6 & - \\
\hline & & 9 & 45,39 & & & 9 & 44,60 \\
\hline & & 12 & 45,41 & & & 12 & 44,60 \\
\hline & & 15 & 45,44 & & & 15 & 44,59 \\
\hline & & 20 & - & 0 & $07: 10$ & 30 & 44,82 \\
\hline & & 25 & 45,47 & & & & \\
\hline & & 30 & 45,48 & & & & \\
\hline & & 35 & 45,49 & & & & \\
\hline 114 & $05: 55$ & 40 & 45,49 & & & & \\
\hline & & & & & & & \\
\hline & & & & & & & \\
\hline & & & & & & & \\
\hline & & & & & & & \\
\hline & & & & & & & \\
\hline & & & & & & & \\
\hline & & & & & & & \\
\hline & & & & & & & \\
\hline & & & & & & & \\
\hline
\end{tabular}




\begin{tabular}{|c|c|c|c|c|c|c|c|}
\hline \multicolumn{8}{|c|}{ UNIVERSIDADE DE SÃO PAULO } \\
\hline \multicolumn{8}{|c|}{ ESCOLA DE ENGENHARIA DE SÃO CARLOS } \\
\hline \multicolumn{8}{|c|}{ DEPTO. DE GEOTECNIA - CAMPO EXPERIMENTAL DE FUNDAÇÕES } \\
\hline \multicolumn{8}{|c|}{$\begin{array}{l}\text { PROVA DE CARGA ESTÁTICA } \\
\end{array}$} \\
\hline \multicolumn{2}{|c|}{ Ensaio: $\quad$ Q2 } & & \multicolumn{3}{|c|}{ Tipo de Carregamento: } & QML \\
\hline \multicolumn{2}{|c|}{ Profundidade: } & \multicolumn{2}{|l|}{$1,5 \mathrm{~m}$} & \multicolumn{2}{|c|}{ Estado do solo: } & \multicolumn{2}{|c|}{ NATURAL } \\
\hline $\begin{array}{l}\text { Sucção: } \\
\text { Diâmetro: }\end{array}$ & $\begin{array}{c}22 \mathrm{kPa} \\
80\end{array}$ & $\mathrm{~cm}$ & & $\begin{array}{l}\text { Reensaio: } \\
\text { Folha: }\end{array}$ & $\begin{array}{l}\text { NÃO } \\
1\end{array}$ & & \\
\hline $\begin{array}{l}\text { Tensão } \\
\text { (kPa) }\end{array}$ & $\begin{array}{c}\text { Início Carr. } \\
\text { (min) }\end{array}$ & $\begin{array}{c}\text { Tempo } \\
\text { (min) }\end{array}$ & $\begin{array}{l}\text { Recalque } \\
\text { (mm) }\end{array}$ & $\begin{array}{l}\text { Tensão } \\
(\mathrm{kPa})\end{array}$ & $\begin{array}{c}\text { Início Carr. } \\
\text { (min) }\end{array}$ & $\begin{array}{c}\text { Tempo } \\
\text { (min) }\end{array}$ & $\begin{array}{c}\text { Recalque } \\
(\mathrm{mm})\end{array}$ \\
\hline \multirow[t]{8}{*}{10} & 00:00 & 0 & 0,32 & 50 & 01:00 & 0 & 2,04 \\
\hline & & 1 & 0,38 & & & 1 & 2,13 \\
\hline & & 2 & 0,41 & & & 2 & - \\
\hline & & 3 & 0,42 & & & 3 & 2,21 \\
\hline & & 6 & 0,45 & & & 6 & 2,26 \\
\hline & & 9 & 0,45 & & & 9 & 2,30 \\
\hline & & 12 & 0,47 & & & 12 & 2,30 \\
\hline & $00: 15$ & 15 & 0,47 & & 01:15 & 15 & 2,31 \\
\hline & & & & & & & \\
\hline \multirow[t]{8}{*}{20} & $00: 15$ & 0 & 0,82 & 60 & $01: 15$ & 0 & 2,47 \\
\hline & & 1 & 0,91 & & & 1 & 2,59 \\
\hline & & 2 & 0,94 & & & 2 & 2,65 \\
\hline & & 3 & 0,96 & & & 3 & 2,69 \\
\hline & & 6 & 0,99 & & & 6 & 2,75 \\
\hline & & 9 & 0,99 & & & 9 & 2,80 \\
\hline & & 12 & 0,99 & & & 12 & 2,82 \\
\hline & $00: 30$ & 15 & 1,00 & & 01:30 & 15 & 2,84 \\
\hline \multirow{8}{*}{30} & $00: 30$ & 0 & 1,21 & 70 & 01:30 & 0 & 2,98 \\
\hline & & 1 & 1,31 & & & 1 & 3,17 \\
\hline & & 2 & 1,35 & & & 2 & 3,27 \\
\hline & & 3 & 1,37 & & & 3 & 3,34 \\
\hline & & 6 & 1,41 & & & 6 & 3,45 \\
\hline & & 9 & 1,42 & & & 9 & 3,50 \\
\hline & & 12 & 1,43 & & & 12 & 3,55 \\
\hline & $00: 45$ & 15 & 1,44 & & 01:45 & 15 & 3,57 \\
\hline \multirow{8}{*}{40} & $00: 45$ & 0 & 1,67 & 80 & 01:45 & 0 & 3,69 \\
\hline & & 1 & 1,78 & & & 1 & 4,11 \\
\hline & & 2 & 1,80 & & & 2 & 4,32 \\
\hline & & 3 & 1,83 & & & 3 & 4,46 \\
\hline & & 6 & 1,85 & & & 6 & 4,70 \\
\hline & & 9 & 1,87 & & & 9 & 4,83 \\
\hline & & 12 & 1,89 & & & 12 & 4,91 \\
\hline & $\begin{array}{l}01: 00 \\
\end{array}$ & 15 & 1,89 & & 02:00 & 15 & 4,95 \\
\hline & & & & & & & \\
\hline & & & & & & & \\
\hline & & & & & & & \\
\hline & & & & & & & \\
\hline & & & & & & & \\
\hline & & & & & & & \\
\hline
\end{tabular}




\begin{tabular}{|c|c|c|c|c|c|c|c|}
\hline Ensaio: & $\overline{\mathrm{Q} 2}$ & |Prof.: & $1,5 \mathrm{~m}$ & Suçãa: & $\begin{array}{ll}22 & \mathrm{kPa}\end{array}$ & Folha: & $\overline{2}$ \\
\hline $\begin{array}{c}\text { Tensão } \\
(\mathrm{kPa})\end{array}$ & $\begin{array}{c}\text { Início Carr. } \\
\text { (min) }\end{array}$ & $\begin{array}{r}\text { Tempo } \\
\text { (min) }\end{array}$ & $\begin{array}{c}\text { Recalque } \\
(\mathrm{mm})\end{array}$ & $\begin{array}{c}\text { Tensão } \\
(\mathrm{kPa})\end{array}$ & $\begin{array}{c}\text { Início Carr. } \\
\text { (min) }\end{array}$ & $\begin{array}{c}\begin{array}{c}\text { Tempo } \\
\text { (min) }\end{array} \\
\end{array}$ & $\begin{array}{c}\text { Recalque } \\
\text { (mm) }\end{array}$ \\
\hline & & & & & & & \\
\hline \multirow[t]{8}{*}{90} & 02:00 & 0 & 5,11 & 140 & $03: 15$ & 0 & 35,85 \\
\hline & & 1 & 5,74 & & & 1 & 36,30 \\
\hline & & 2 & 6,14 & & & 2 & 39,06 \\
\hline & & 3 & 6,40 & & & 3 & 40,16 \\
\hline & & 6 & 6,73 & & & 6 & 41,99 \\
\hline & & 9 & 6,93 & & & 9 & 42,90 \\
\hline & & 12 & 7,05 & & & 12 & 43,46 \\
\hline & $02: 15$ & 15 & 7,14 & & $03: 30$ & 15 & 43,72 \\
\hline & & & & & & & \\
\hline \multirow[t]{8}{*}{100} & $02: 15$ & 0 & 7,33 & 150 & 03:30 & 0 & 43,92 \\
\hline & & 1 & 8,65 & & & 1 & 45,73 \\
\hline & & 2 & 9,36 & & & 2 & 47,90 \\
\hline & & 3 & 9,87 & & & 3 & 48,72 \\
\hline & & 6 & 10,72 & & & 6 & 50,53 \\
\hline & & 9 & 11,35 & & & 9 & 51,45 \\
\hline & & 12 & 11,80 & & & 12 & 51,99 \\
\hline & $02: 30$ & 15 & 12,16 & & 03:45 & 15 & 52,38 \\
\hline \multirow{10}{*}{110} & & & & & & & \\
\hline & 02:30 & 0 & 12,54 & Estab. & $03: 45$ & 0 & 52,41 \\
\hline & & 1 & 15,66 & & & 5 & 52,58 \\
\hline & & 2 & 17,11 & & & 10 & 52,65 \\
\hline & & 3 & 17,93 & & & 15 & 52,68 \\
\hline & & 6 & 19,06 & & & 20 & 52,69 \\
\hline & & 9 & 19,62 & & & 25 & 52,71 \\
\hline & & 12 & 19,96 & & & 30 & 52,71 \\
\hline & $02: 45$ & 15 & 20,20 & & & 35 & 52,72 \\
\hline & & & & 136 & $04: 25$ & 40 & 52,72 \\
\hline \multirow[t]{9}{*}{120} & $02: 45$ & 0 & 20,43 & & & & \\
\hline & & 1 & 22,93 & 1D & $04: 25$ & 0 & 52,72 \\
\hline & & 2 & 24,34 & & & 1 & 52,72 \\
\hline & & 3 & 25,20 & & & 2 & 52,72 \\
\hline & & 6 & 26,63 & & & 3 & 52,72 \\
\hline & & 9 & 27,27 & & & 6 & 52,72 \\
\hline & & 12 & 27,70 & & & 9 & 52,72 \\
\hline & 03:00 & 15 & 27,98 & & & 12 & 52,72 \\
\hline & & & & 104 & 04:40 & 15 & 52,72 \\
\hline \multirow[t]{9}{*}{130} & 03:00 & 0 & 28,13 & & & & \\
\hline & & 1 & 29,89 & $2 \mathrm{D}$ & 04:40 & 0 & 52,61 \\
\hline & & 2 & 31,51 & & & 1 & 52,54 \\
\hline & & 3 & 32,76 & & & 2 & 52,52 \\
\hline & & 6 & 34,05 & & & 3 & 52,51 \\
\hline & & 9 & 34,86 & & & 6 & 52,50 \\
\hline & & 12 & 35,37 & & & 9 & 52,47 \\
\hline & 03:15 & 15 & 35,67 & & & 12 & 52,43 \\
\hline & & & & 52 & $04: 55$ & 15 & 52,43 \\
\hline & & & & & & & \\
\hline & & & & & & & \\
\hline & & & & & & & \\
\hline & & & & & & & \\
\hline
\end{tabular}




\begin{tabular}{|c|c|c|c|c|c|c|c|}
\hline Ensaio: & Q2 & Prof.: & $1,5 \mathrm{~m}$ & Sucção: & $\begin{array}{ll}22 & \mathrm{kPa} \\
\end{array}$ & Folha: & 3 \\
\hline $\begin{array}{c}\text { Tensão } \\
(\mathrm{kPa})\end{array}$ & $\begin{array}{c}\text { Início Carr. } \\
\text { (min) }\end{array}$ & $\begin{array}{c}\text { Tempo } \\
(\mathrm{min})\end{array}$ & $\begin{array}{c}\text { Recalque } \\
\text { (mm) }\end{array}$ & $\begin{array}{c}\text { Tensão } \\
(\mathrm{kPa})\end{array}$ & $\begin{array}{c}\text { Início Carr. } \\
\text { (min) }\end{array}$ & $\begin{array}{c}\text { Tempo } \\
(\mathrm{min})\end{array}$ & $\begin{array}{l}\text { Recalque } \\
(\mathrm{mm})\end{array}$ \\
\hline & & & & & & & \\
\hline \multirow[t]{7}{*}{$3 \mathrm{D}$} & 04:55 & 0 & 52,31 & & & & \\
\hline & & 1 & 52,27 & & & & \\
\hline & & 2 & 52,25 & & & & \\
\hline & & 3 & 52,24 & & & & \\
\hline & & 6 & 52,17 & & & & \\
\hline & & 9 & 52,15 & & & & \\
\hline & & 12 & 52,13 & & & & \\
\hline \multirow[t]{2}{*}{21} & $05: 10$ & 15 & 52,11 & & & & \\
\hline & & & & & & & \\
\hline \multirow[t]{8}{*}{$4 \mathrm{D}$} & $05: 10$ & 0 & 51,62 & & & & \\
\hline & & 1 & 51,49 & & & & \\
\hline & & 2 & 51,46 & & & & \\
\hline & & 3 & 51,43 & & & & \\
\hline & & 6 & 51,37 & & & & \\
\hline & & 9 & 51,36 & & & & \\
\hline & & 12 & 51,35 & & & & \\
\hline & & 15 & 51,33 & & & & \\
\hline 0 & 05:40 & 30 & 51,30 & & & & \\
\hline & & & & & & & \\
\hline & & & & & & & \\
\hline & & & & & & & \\
\hline & & & & & & & \\
\hline & & & & & & & \\
\hline & & & & & & & \\
\hline & & & & & & & \\
\hline & & & & & & & \\
\hline & & & & & & & \\
\hline & & & & & & & \\
\hline & & & & & & & \\
\hline & & & & & & & \\
\hline & & & & & & & \\
\hline & & & & & & & \\
\hline & & & & & & & \\
\hline & & & & & & & \\
\hline & & & & & & & \\
\hline & & & & & & & \\
\hline & & & & & & & \\
\hline & & & & & & & \\
\hline & & & & & & & \\
\hline & & & & & & & \\
\hline & & & & & & & \\
\hline & & & & & & & \\
\hline & & & & & & & \\
\hline & & & & & & & \\
\hline & & & & & & & \\
\hline & & & & & & & \\
\hline & & & & & & & \\
\hline & & & & & & & \\
\hline & & & & & & & \\
\hline
\end{tabular}




\begin{tabular}{|c|c|c|c|c|c|c|c|}
\hline \multicolumn{8}{|c|}{ UNIVERSIDADE DE SÃO PAULO } \\
\hline \multicolumn{8}{|c|}{ ESCOLA DE ENGENHARIA DE SÃO CARLOS } \\
\hline \multicolumn{8}{|c|}{ DEPTO. DE GEOTECNIA - CAMPO EXPERIMENTAL DE FUNDAÇÕES } \\
\hline \multicolumn{8}{|c|}{$\begin{array}{l}\text { PROVA DE CARGA ESTÁTICA } \\
\end{array}$} \\
\hline \multirow{2}{*}{\multicolumn{2}{|c|}{$\begin{array}{l}\text { Ensaio: Q3 } \\
\text { Profundidade: }\end{array}$}} & & \multicolumn{3}{|c|}{ Tipo de Carregamento: } & QML \\
\hline & & $1,5 \mathrm{~m}$ & & \multicolumn{2}{|c|}{ Estado do solo: } & \multicolumn{2}{|c|}{ NATURAL } \\
\hline \multicolumn{2}{|c|}{ Sucção: $\quad 33 \mathrm{kPa}$} & $\mathrm{cm}$ & & $\begin{array}{l}\text { Reensaio: } \\
\text { Folha: }\end{array}$ & $\begin{array}{l}\text { NÃO } \\
1\end{array}$ & & \\
\hline $\begin{array}{l}\text { Tensão } \\
(\mathrm{kPa})\end{array}$ & $\begin{array}{c}\text { Início Carr. } \\
\text { (min) }\end{array}$ & $\begin{array}{c}\text { Tempo } \\
\text { (min) }\end{array}$ & $\begin{array}{l}\text { Recalque } \\
\text { (mm) }\end{array}$ & $\begin{array}{l}\text { Tensão } \\
\text { (kPa) }\end{array}$ & $\begin{array}{c}\text { Início Carr. } \\
\text { (min) }\end{array}$ & $\begin{array}{c}\text { Tempo } \\
\text { (min) }\end{array}$ & $\begin{array}{l}\text { Recalque } \\
\text { (mm) }\end{array}$ \\
\hline \multirow{8}{*}{8} & 00:00 & 0 & 0.45 & 40 & 01:00 & 0 & 1.43 \\
\hline & & 1 & 0,49 & & & 1 & 1,51 \\
\hline & & 2 & 0,50 & & & 2 & 1,55 \\
\hline & & 3 & 0,50 & & & 3 & 1,58 \\
\hline & & 6 & 0,52 & & & 6 & 1,62 \\
\hline & & 9 & 0,52 & & & 9 & 1,63 \\
\hline & & 12 & 0,52 & & & 12 & 1,65 \\
\hline & 00:15 & 15 & 0,52 & & 01:15 & 15 & 1,66 \\
\hline & & & & & & & \\
\hline \multirow[t]{8}{*}{16} & $00: 15$ & 0 & 0,70 & 48 & $01: 15$ & 0 & 1,71 \\
\hline & & 1 & 0,77 & & & 1 & 1,79 \\
\hline & & 2 & 0,79 & & & 2 & 1,84 \\
\hline & & 3 & 0,80 & & & 3 & 1,87 \\
\hline & & 6 & 0,81 & & & 6 & 1,94 \\
\hline & & 9 & $\overline{0,82}$ & & & 9 & 1,97 \\
\hline & & 12 & 0,83 & & & 12 & 2,01 \\
\hline & 00:30 & 15 & 0,83 & & 01:30 & 15 & 2,02 \\
\hline \multirow{8}{*}{24} & $00: 30$ & 0 & 0,96 & 56 & 01:30 & 0 & 2,07 \\
\hline & & 1 & 1,02 & & & 1 & 2,16 \\
\hline & & 2 & 1,04 & & & 2 & 2,22 \\
\hline & & 3 & 1,05 & & & 3 & 2,27 \\
\hline & & 6 & 1,07 & & & 6 & 2,36 \\
\hline & & 9 & 1,08 & & & 9 & 2,42 \\
\hline & & 12 & 1,09 & & & 12 & 2,46 \\
\hline & $00: 45$ & 15 & 1,09 & & 01:45 & 15 & 2,49 \\
\hline \multirow[t]{8}{*}{32} & $00: 45$ & 0 & 1,20 & 64 & 01:45 & 0 & 2,53 \\
\hline & & 1 & 1,27 & & & 1 & 2,63 \\
\hline & & 2 & 1,29 & & & 2 & 2,73 \\
\hline & & 3 & 1,32 & & & 3 & 2,82 \\
\hline & & 6 & 1,34 & & & 6 & 2,94 \\
\hline & & 9 & 1,36 & & & 9 & - \\
\hline & & 12 & 1,37 & & & 12 & 3,09 \\
\hline & 01:00 & 15 & 1,37 & & 02:00 & 15 & 3,14 \\
\hline & & & & & & & \\
\hline & & & & & & & \\
\hline & & & & & & & \\
\hline & & & & & & & \\
\hline & & & & & & & \\
\hline & & & & & & & \\
\hline
\end{tabular}




\begin{tabular}{|c|c|c|c|c|c|c|c|}
\hline Ensaio: & $\overline{\mathrm{Q} 3}$ & |Prof.: & $1,5 \mathrm{~m}$ & Suçãa: & $33 \mathrm{kPa}$ & Folha: & $\overline{2}$ \\
\hline $\begin{array}{c}\text { Tensão } \\
(\mathrm{kPa})\end{array}$ & $\begin{array}{c}\text { Início Carr. } \\
\text { (min) }\end{array}$ & $\begin{array}{r}\text { Tempo } \\
\text { (min) }\end{array}$ & $\begin{array}{c}\text { Recalque } \\
(\mathrm{mm})\end{array}$ & $\begin{array}{c}\text { Tensão } \\
(\mathrm{kPa})\end{array}$ & $\begin{array}{c}\text { Início Carr. } \\
\text { (min) }\end{array}$ & $\begin{array}{c}\begin{array}{c}\text { Tempo } \\
\text { (min) }\end{array} \\
\end{array}$ & $\begin{array}{c}\text { Recalque } \\
\text { (mm) }\end{array}$ \\
\hline & & & & & & & \\
\hline \multirow[t]{8}{*}{72} & 02:00 & 0 & 3,19 & 112 & $03: 15$ & 0 & 10,11 \\
\hline & & 1 & 3,31 & & & 1 & 10,44 \\
\hline & & 2 & 3,43 & & & 2 & 10,75 \\
\hline & & 3 & 3,52 & & & 3 & 11,02 \\
\hline & & 6 & 3,72 & & & 6 & 11,63 \\
\hline & & 9 & 3,85 & & & 9 & 12,03 \\
\hline & & 12 & 3,95 & & & 12 & 12,33 \\
\hline & $02: 15$ & 15 & 4,02 & & $03: 30$ & 15 & 12,53 \\
\hline & & & & & & & \\
\hline \multirow[t]{8}{*}{80} & $02: 15$ & 0 & 4,08 & 120 & 03:30 & 0 & 12,61 \\
\hline & & 1 & 4,22 & & & 1 & 12,95 \\
\hline & & 2 & 4,37 & & & 2 & 13,16 \\
\hline & & 3 & 4,54 & & & 3 & 13,45 \\
\hline & & 6 & 4,74 & & & 6 & 14,09 \\
\hline & & 9 & 4,92 & & & 9 & 14,55 \\
\hline & & 12 & 5,06 & & & 12 & 14,91 \\
\hline & $02: 30$ & 15 & 5,15 & & 03:45 & 15 & 15,17 \\
\hline \multirow{9}{*}{88} & & & & & & & \\
\hline & $02: 30$ & 0 & 5,21 & 128 & $03: 45$ & 0 & 15,25 \\
\hline & & 1 & 5,40 & & & 1 & 15,55 \\
\hline & & 2 & 5,56 & & & 2 & 15,83 \\
\hline & & 3 & 5,74 & & & 3 & 16,11 \\
\hline & & 6 & 6,10 & & & 6 & 16,77 \\
\hline & & 9 & 6,35 & & & 9 & 17,27 \\
\hline & & 12 & 6,52 & & & 12 & 17,62 \\
\hline & $02: 45$ & 15 & 6,63 & & 04:00 & 15 & 17,88 \\
\hline \multirow{8}{*}{96} & $02 \cdot 45$ & 0 & 671 & 126 & 04.00 & 0 & 1795 \\
\hline & $0.4 \mathrm{~J}$ & 1 & $\begin{array}{l}0,71 \\
6,87\end{array}$ & 150 & 04.00 & 1 & $\frac{1,55}{18,28}$ \\
\hline & & 2 & 7,07 & & & 2 & 18,61 \\
\hline & & 3 & 7,22 & & & 3 & 18,92 \\
\hline & & 6 & 7,61 & & & 6 & 19,68 \\
\hline & & 9 & 7,87 & & & 9 & 20,20 \\
\hline & & 12 & 8,05 & & & 12 & 20,61 \\
\hline & 03:00 & 15 & 8,20 & & $04: 15$ & 15 & 20,92 \\
\hline \multirow[t]{8}{*}{104} & 03:00 & 0 & 8,26 & 144 & $04: 15$ & 0 & 21,00 \\
\hline & & 1 & 8,48 & & & 1 & 21,35 \\
\hline & & 2 & 8,68 & & & 2 & 21,69 \\
\hline & & 3 & 8,96 & & & 3 & 22,03 \\
\hline & & 6 & 9,30 & & & 6 & 22,88 \\
\hline & & 9 & 9,62 & & & 9 & 23,52 \\
\hline & & 12 & 9,87 & & & 12 & 23,94 \\
\hline & 03:15 & 15 & 10,03 & & 04:30 & 15 & 24,26 \\
\hline & & & & & & & \\
\hline & & & & & & & \\
\hline & & & & & & & \\
\hline & & & & & & & \\
\hline & & & & & & & \\
\hline
\end{tabular}




\begin{tabular}{|c|c|c|c|c|c|c|c|}
\hline Ensaio: & Q3 & Prof.: & $1,5 \mathrm{~m}$ & Sucção: & $33 \mathrm{kPa}$ & Folha: & 3 \\
\hline $\begin{array}{c}\text { Tensão } \\
(\mathrm{kPa})\end{array}$ & $\begin{array}{c}\text { Início Carr. } \\
\text { (min) }\end{array}$ & $\begin{array}{c}\text { Tempo } \\
\text { (min) }\end{array}$ & $\begin{array}{c}\text { Recalque } \\
\text { (mm) }\end{array}$ & $\begin{array}{c}\text { Tensão } \\
(\mathrm{kPa})\end{array}$ & $\begin{array}{c}\text { Início Carr. } \\
(\mathrm{min})\end{array}$ & $\begin{array}{c}\text { Tempo } \\
\text { (min) }\end{array}$ & $\begin{array}{c}\text { Recalque } \\
(\mathrm{mm})\end{array}$ \\
\hline & & & & & & & \\
\hline \multirow[t]{9}{*}{152} & 04:30 & 0 & 24,36 & Estab. & $05: 45$ & 0 & 44,43 \\
\hline & & 1 & 24,74 & & & 1 & 44,52 \\
\hline & & 2 & 25,14 & & & 2 & 44,57 \\
\hline & & 3 & 25,53 & & & 3 & 44,61 \\
\hline & & 6 & 26,46 & & & 6 & 44,67 \\
\hline & & 9 & 27,14 & & & 9 & 44,70 \\
\hline & & 12 & 27,65 & & & 12 & 44,73 \\
\hline & 04:45 & 15 & 28,06 & & & 15 & 44,74 \\
\hline & & & & 166 & $06: 03$ & 18 & 44,75 \\
\hline \multirow[t]{8}{*}{160} & $04: 45$ & 0 & 28,13 & & & & \\
\hline & & 1 & 28,47 & & & & \\
\hline & & 2 & 29,03 & $1 \mathrm{D}$ & $06: 03$ & 0 & 44,74 \\
\hline & & 3 & 29,25 & & & 1 & 44,74 \\
\hline & & 6 & 30,24 & & & 2 & 44,74 \\
\hline & & 9 & 30,94 & & & 3 & 44,74 \\
\hline & & 12 & 31,46 & & & 6 & 44,74 \\
\hline & 05:00 & 15 & 31,85 & 126 & 06:12 & 9 & 44,73 \\
\hline & & & & & & & \\
\hline \multirow[t]{8}{*}{168} & 05:00 & 0 & 31,94 & $2 \mathrm{D}$ & $06: 12$ & 0 & 44,47 \\
\hline & & 1 & 32,30 & & & 1 & 44,43 \\
\hline & & 2 & 32,73 & & & 2 & 44,42 \\
\hline & & 3 & 33,14 & & & 3 & 44,41 \\
\hline & & 6 & 34,11 & & & 6 & 44,41 \\
\hline & & 9 & 34,67 & & & 9 & 44,40 \\
\hline & & 12 & 35,44 & & & 12 & 44,39 \\
\hline & $05: 15$ & 15 & 35,85 & 50 & 06:27 & 15 & 44,39 \\
\hline & & & & & & & \\
\hline \multirow[t]{9}{*}{176} & $05: 15$ & 0 & 35,95 & & & & \\
\hline & & 1 & 36,27 & $3 \mathrm{D}$ & 06:27 & 0 & 43,79 \\
\hline & & 2 & 36,73 & & & 1 & 43,65 \\
\hline & & 3 & 37,15 & & & 2 & 43,61 \\
\hline & & 6 & 38,18 & & & 3 & 43,60 \\
\hline & & 9 & 38,97 & & & 6 & 43,55 \\
\hline & & 12 & 39,58 & & & 9 & 43,54 \\
\hline & 05:30 & 15 & 40,04 & & & 12 & 43,52 \\
\hline & & & & 0 & $06: 42$ & 15 & 43,52 \\
\hline \multirow[t]{8}{*}{184} & 05:30 & 0 & 40,12 & & & & \\
\hline & & 1 & 40,50 & & & & \\
\hline & & 2 & 40,94 & & & & \\
\hline & & 3 & 41,37 & & & & \\
\hline & & 6 & 42,48 & & & & \\
\hline & & 9 & 43,32 & & & & \\
\hline & & 12 & 43,94 & & & & \\
\hline & 05:45 & 15 & 44,43 & & & & \\
\hline & & & & & & & \\
\hline & & & & & & & \\
\hline & & & & & & & \\
\hline & & & & & & & \\
\hline & & & & & & & \\
\hline
\end{tabular}




\begin{tabular}{|c|c|c|c|c|c|c|c|}
\hline \multicolumn{8}{|c|}{ UNIVERSIDADE DE SÃO PAULO } \\
\hline \multicolumn{8}{|c|}{ ESCOLA DE ENGENHARIA DE SÃO CARLOS } \\
\hline \multicolumn{8}{|c|}{ DEPTO. DE GEOTECNIA - CAMPO EXPERIMENTAL DE FUNDAÇÕES } \\
\hline \multicolumn{8}{|c|}{ PROVA DE CARGA ESTÁTICA } \\
\hline \multicolumn{2}{|c|}{ Ensaio: $\quad$ MS1 } & & \multicolumn{3}{|c|}{ Tipo de Carregamento: } & MML \\
\hline \multicolumn{2}{|c|}{ Profundidade: } & \multicolumn{2}{|l|}{$1,5 \mathrm{~m}$} & \multicolumn{2}{|c|}{ Estado do solo: } & \multicolumn{2}{|c|}{ INUNDADO } \\
\hline $\begin{array}{l}\text { Sucção: } \\
\text { Diâmetro. }\end{array}$ & $0 \quad \mathrm{kPa}$ & & & Reensaio: & NÃO & & \\
\hline & & $\mathrm{cm}$ & & & & & \\
\hline $\begin{array}{c}\text { Tensão } \\
(\mathrm{kPa})\end{array}$ & $\begin{array}{l}\text { Início Carr. } \\
\text { (min) }\end{array}$ & $\begin{array}{c}\text { Tempo } \\
\text { (min) }\end{array}$ & $\begin{array}{l}\text { Recalque } \\
\text { (mm) }\end{array}$ & $\begin{array}{l}\text { Tensão } \\
\text { (kPa) }\end{array}$ & $\begin{array}{c}\text { Início Carr. } \\
\text { (min) }\end{array}$ & $\begin{array}{c}\text { Tempo } \\
\text { (min) }\end{array}$ & $\begin{array}{c}\text { Recalque } \\
(\mathrm{mm})\end{array}$ \\
\hline \multirow{10}{*}{8} & & & & & & & \\
\hline & 00:00 & 0 & 0,48 & 40 & 05:00 & 0 & $\frac{6,66}{720}$ \\
\hline & & 1 & 0,75 & & & 1 & 7,20 \\
\hline & & 2 & 0,77 & & & 2 & 7,72 \\
\hline & & 4 & 0,78 & & & 4 & 8,31 \\
\hline & & 8 & 0,88 & & & 8 & 8,96 \\
\hline & & 15 & 0,91 & & & 15 & 9,44 \\
\hline & & 30 & 0,91 & & & 30 & 9,72 \\
\hline & 01:00 & 60 & 0,92 & & & 60 & 9,90 \\
\hline & & & & & & 90 & 9,95 \\
\hline \multirow[t]{9}{*}{16} & $01: 00$ & 0 & 1,36 & & & 120 & 9,96 \\
\hline & & 1 & 1,81 & & & & \\
\hline & & 2 & 1,93 & 44 & 07:00 & 0 & 9,98 \\
\hline & & 4 & 2,02 & & & 1 & 9,99 \\
\hline & & 8 & 2,11 & & & 2 & 9,99 \\
\hline & & 15 & 2,16 & & & 3 & 10,00 \\
\hline & & 30 & 2,20 & & & 6 & 10,01 \\
\hline & $02: 00$ & 60 & 2,23 & & & 9 & 10,03 \\
\hline & & & & & & 12 & 10,05 \\
\hline \multirow[t]{10}{*}{24} & $02: 00$ & 0 & 2,66 & & $07: 15$ & 15 & 10,07 \\
\hline & & 1 & 3,31 & & & & \\
\hline & & 2 & 3,47 & 48 & 07:15 & 0 & 10,72 \\
\hline & & 4 & 3,59 & & & 1 & 10,46 \\
\hline & & 8 & 3,72 & & & 2 & 10,97 \\
\hline & & 15 & 3,84 & & & 3 & 11,48 \\
\hline & & 30 & 3,93 & & & 6 & 12,11 \\
\hline & & 60 & 4,07 & & & 9 & 12,52 \\
\hline & & 90 & 4,12 & & & 12 & 12,79 \\
\hline & 04:00 & 120 & 4,14 & & 07:30 & 15 & 12,96 \\
\hline \multirow[t]{8}{*}{32} & 04:00 & 0 & 4,30 & 52 & 07:30 & 0 & 13,29 \\
\hline & & 1 & 5,16 & & & 1 & 13,68 \\
\hline & & 2 & 5,46 & & & 2 & 14,40 \\
\hline & & 4 & 5,86 & & & 3 & 14,74 \\
\hline & & 8 & 6,15 & & & 6 & 15,54 \\
\hline & & 15 & 6,34 & & & 9 & 15,95 \\
\hline & & 30 & 6,52 & & & 12 & 16,21 \\
\hline & 05:00 & 60 & 6,58 & & $07: 45$ & 15 & 16,36 \\
\hline & & & & & & & \\
\hline & & & & & & & \\
\hline & & & & & & & \\
\hline & & & & & & & \\
\hline
\end{tabular}




\begin{tabular}{|c|c|c|c|c|c|c|c|}
\hline Ensaio: & MS1 & Prof.: & $1,5 \mathrm{~m}$ & Sucção: & $0 \quad \mathrm{kPa}$ & Folha: & 2 \\
\hline $\begin{array}{c}\text { Tensão } \\
(\mathrm{kPa})\end{array}$ & $\begin{array}{c}\text { Início Carr. } \\
\text { (min) }\end{array}$ & $\begin{array}{r}\begin{array}{r}\text { Tempo } \\
(\mathrm{min})\end{array} \\
\end{array}$ & $\begin{array}{c}\text { Recalque } \\
(\mathrm{mm})\end{array}$ & $\begin{array}{c}\text { Tensão } \\
(\mathrm{kPa})\end{array}$ & $\begin{array}{c}\text { Início Carr. } \\
(\mathrm{min})\end{array}$ & $\begin{array}{c}\text { Tempo } \\
\text { (min) }\end{array}$ & $\begin{array}{c}\text { Recalque } \\
(\mathrm{mm})\end{array}$ \\
\hline & & & & & & & \\
\hline \multirow[t]{8}{*}{56} & $07: 45$ & 0 & 16,53 & 76 & 09:00 & 0 & 37,59 \\
\hline & & 1 & 16,96 & & & 1 & 38,04 \\
\hline & & 2 & 17,43 & & & 2 & 38,56 \\
\hline & & 3 & 17,94 & & & 3 & 39,14 \\
\hline & & 6 & 18,72 & & & 6 & 40,54 \\
\hline & & 9 & 19,33 & & & 9 & 41,10 \\
\hline & & 12 & 19,65 & & & 12 & 41,71 \\
\hline & $08: 00$ & 15 & 19,86 & & 09:15 & 15 & 42,05 \\
\hline & & & & & & & \\
\hline \multirow[t]{8}{*}{60} & $08: 00$ & 0 & 20,03 & 80 & $09: 15$ & 0 & 42,22 \\
\hline & & 1 & 20,65 & & & 1 & 42,90 \\
\hline & & 2 & 21,23 & & & 2 & 43,50 \\
\hline & & 3 & 21,76 & & & 3 & 44,17 \\
\hline & & 6 & 22,84 & & & 6 & 45,31 \\
\hline & & 9 & 23,45 & & & 9 & 46,49 \\
\hline & & 12 & 23,83 & & & 12 & 47,05 \\
\hline & $08: 15$ & 15 & 24,05 & & $09: 30$ & 15 & 47,74 \\
\hline & & & & & & & \\
\hline \multirow[t]{9}{*}{64} & $08: 15$ & 0 & 24,20 & Estab. & $09: 30$ & 0 & 47,80 \\
\hline & & 1 & 24,61 & & & 3 & 47,99 \\
\hline & & 2 & 25,16 & & & 6 & 47,96 \\
\hline & & 3 & 25,75 & & & 9 & 47,97 \\
\hline & & 6 & 25,84 & & & 12 & 47,99 \\
\hline & & 9 & 27,47 & & & 15 & 48,00 \\
\hline & & 12 & 27,91 & & & 20 & 48,00 \\
\hline & $08: 30$ & 15 & 28,22 & & & 25 & 48,01 \\
\hline & & & & 70 & $10: 00$ & 30 & 48,01 \\
\hline \multirow[t]{9}{*}{68} & $08: 30$ & 0 & 28,45 & & & & \\
\hline & & 1 & 28,95 & $1 \mathrm{D}$ & $10: 00$ & 0 & 48,01 \\
\hline & & 2 & 29,64 & & & 1 & 48,01 \\
\hline & & 3 & 30,10 & & & 2 & 48,01 \\
\hline & & 6 & 31,16 & & & 3 & 48,01 \\
\hline & & 9 & 31,79 & & & 6 & 48,01 \\
\hline & & 12 & 32,21 & & & 9 & 48,01 \\
\hline & $08: 45$ & 15 & 32,52 & & & 12 & 48,01 \\
\hline & & & & 48 & $10: 15$ & 15 & 48,01 \\
\hline \multirow[t]{9}{*}{72} & $08: 45$ & 0 & 32,77 & & & & \\
\hline & & 1 & 33,33 & $2 \mathrm{D}$ & $10: 15$ & 0 & 47,80 \\
\hline & & 2 & 34,08 & & & 1 & 47,80 \\
\hline & & 3 & 34,54 & & & 2 & 47,80 \\
\hline & & 6 & 35,70 & & & 3 & 47,80 \\
\hline & & 9 & 36,48 & & & 6 & 47,80 \\
\hline & & 12 & 37,04 & & & 9 & 47,80 \\
\hline & 09:00 & 15 & 37,33 & & & 12 & 47,80 \\
\hline & & & & 34 & $10: 30$ & 15 & 47,80 \\
\hline & & & & & & & \\
\hline & & & & & & & \\
\hline & & & & & & & \\
\hline & & & & & & & \\
\hline
\end{tabular}




\begin{tabular}{|c|c|c|c|c|c|c|c|}
\hline Ensaio: & MS1 & Prof.: & $1,5 \mathrm{~m}$ & Sucção: & $\begin{array}{ll}0 & \mathrm{kPa} \\
\end{array}$ & Folha: & 3 \\
\hline $\begin{array}{c}\text { Tensão } \\
(\mathrm{kPa})\end{array}$ & $\begin{array}{c}\text { Início Carr. } \\
\text { (min) }\end{array}$ & $\begin{array}{c}\text { Tempo } \\
(\mathrm{min})\end{array}$ & $\begin{array}{c}\text { Recalque } \\
\text { (mm) }\end{array}$ & $\begin{array}{c}\text { Tensão } \\
(\mathrm{kPa})\end{array}$ & $\begin{array}{c}\text { Início Carr. } \\
\text { (min) }\end{array}$ & $\begin{array}{c}\text { Tempo } \\
(\mathrm{min})\end{array}$ & $\begin{array}{c}\begin{array}{c}\text { Recalque } \\
(\mathrm{mm})\end{array} \\
\end{array}$ \\
\hline & & & & & & & \\
\hline \multirow[t]{7}{*}{$3 \mathrm{D}$} & $10: 30$ & 0 & 47,78 & & & & \\
\hline & & 1 & 47,75 & & & & \\
\hline & & 2 & $\begin{array}{l}47,74 \\
\end{array}$ & & & & \\
\hline & & 3 & 47,74 & & & & \\
\hline & & 6 & 47,74 & & & & \\
\hline & & 9 & 47,73 & & & & \\
\hline & & 12 & 47,73 & & & & \\
\hline \multirow[t]{2}{*}{18} & $10: 45$ & 15 & 47,73 & & & & \\
\hline & & & & & & & \\
\hline \multirow[t]{8}{*}{$4 \mathrm{D}$} & $10: 45$ & 0 & 47,60 & & & & \\
\hline & & 1 & 47,60 & & & & \\
\hline & & 2 & 47,58 & & & & \\
\hline & & 3 & $\begin{array}{l}47,58 \\
\end{array}$ & & & & \\
\hline & & 6 & 47,57 & & & & \\
\hline & & 9 & 47,57 & & & & \\
\hline & & 12 & $\begin{array}{l}47,56 \\
\end{array}$ & & & & \\
\hline & & 15 & 47,56 & & & & \\
\hline 0 & $11: 15$ & 30 & 47,56 & & & & \\
\hline & & & & & & & \\
\hline & & & & & & & \\
\hline & & & & & & & \\
\hline & & & & & & & \\
\hline & & & & & & & \\
\hline & & & & & & & \\
\hline & & & & & & & \\
\hline & & & & & & & \\
\hline & & & & & & & \\
\hline & & & & & & & \\
\hline & & & & & & & \\
\hline & & & & & & & \\
\hline & & & & & & & \\
\hline & & & & & & & \\
\hline & & & & & & & \\
\hline & & & & & & & \\
\hline & & & & & & & \\
\hline & & & & & & & \\
\hline & & & & & & & \\
\hline & & & & & & & \\
\hline & & & & & & & \\
\hline & & & & & & & \\
\hline & & & & & & & \\
\hline & & & & & & & \\
\hline & & & & & & & \\
\hline & & & & & & & \\
\hline & & & & & & & \\
\hline & & & & & & & \\
\hline & & & & & & & \\
\hline & & & & & & & \\
\hline & & & & & & & \\
\hline
\end{tabular}




\begin{tabular}{|c|c|c|c|c|c|c|c|}
\hline \multicolumn{8}{|c|}{ UNIVERSIDADE DE SÃO PAULO } \\
\hline \multicolumn{8}{|c|}{ ESCOLA DE ENGENHARIA DE SÃO CARLOS } \\
\hline \multicolumn{8}{|c|}{ DEPTO. DE GEOTECNIA - CAMPO EXPERIMENTAL DE FUNDAÇÕES } \\
\hline \multicolumn{8}{|c|}{$\begin{array}{l}\text { PROVA DE CARGA ESTÁTICA } \\
\end{array}$} \\
\hline \multicolumn{4}{|l|}{ Ensaio: } & \multicolumn{3}{|c|}{ Tipo de Carregamento: } & MML \\
\hline \multicolumn{2}{|c|}{ Profundidade: } & \multicolumn{2}{|l|}{$1,5 \mathrm{~m}$} & \multicolumn{2}{|c|}{ Estado do solo: } & \multicolumn{2}{|c|}{ INUNDADO } \\
\hline $\begin{array}{l}\text { Sucção: } \\
\text { Diâmetro: }\end{array}$ & $\begin{array}{cc}0 & \mathrm{kPa} \\
80\end{array}$ & $\mathrm{~cm}$ & & $\begin{array}{l}\text { Reensaio: } \\
\text { Folha: }\end{array}$ & $\begin{array}{l}\text { NÃO } \\
1\end{array}$ & & \\
\hline $\begin{array}{l}\text { Tensão } \\
\text { (kPa) }\end{array}$ & $\begin{array}{c}\text { Início Carr. } \\
\text { (min) }\end{array}$ & $\begin{array}{c}\text { Tempo } \\
\text { (min) }\end{array}$ & $\begin{array}{l}\text { Recalque } \\
\text { (mm) }\end{array}$ & $\begin{array}{l}\text { Tensão } \\
\text { (kPa) }\end{array}$ & $\begin{array}{c}\text { Início Carr. } \\
\text { (min) }\end{array}$ & $\begin{array}{c}\text { Tempo } \\
\text { (min) }\end{array}$ & $\begin{array}{l}\text { Recalque } \\
\text { (mm) }\end{array}$ \\
\hline \multirow{9}{*}{8} & 0:00:00 & 0 & 0,23 & 32 & 7:00:00 & 0 & 2,50 \\
\hline & & 1 & 0,25 & & & 1 & 2,69 \\
\hline & & 2 & 0,28 & & & 2 & 2,85 \\
\hline & & 4 & 0,29 & & & 4 & 3,02 \\
\hline & & 8 & 0,39 & & & 8 & 3,23 \\
\hline & & 15 & 0,40 & & & 15 & 3,39 \\
\hline & & 30 & 0,43 & & & 30 & 3,55 \\
\hline & 1:00:00 & 60 & 0,43 & & & 60 & 3,70 \\
\hline & & & & & & 90 & 3,78 \\
\hline \multirow[t]{11}{*}{16} & 1:00:00 & 0 & 0,66 & & & 120 & 3,82 \\
\hline & & 1 & 0,88 & & & 150 & 3,85 \\
\hline & & 2 & 0,94 & & & 180 & 3,88 \\
\hline & & 4 & 0,99 & & & 210 & 3,91 \\
\hline & & 8 & 1,06 & & & 240 & 3,93 \\
\hline & & 15 & 1,11 & & & 270 & 3,96 \\
\hline & & 30 & 1,17 & & & 300 & 3,98 \\
\hline & & 60 & 1,25 & & & 330 & 4,01 \\
\hline & & 90 & 1,27 & & & 360 & 4,02 \\
\hline & 3:00:00 & 120 & 1,28 & & & 390 & 4,02 \\
\hline & & & & & & 420 & 4,03 \\
\hline \multirow[t]{14}{*}{24} & $3: 00: 00$ & 0 & 1,67 & & & 450 & 4,05 \\
\hline & & 1 & 1,87 & & & 480 & 4,06 \\
\hline & & 2 & 1,92 & & & 510 & 4,07 \\
\hline & & 4 & 1,98 & & & 540 & 4,08 \\
\hline & & 8 & 2,04 & & & 570 & 4,08 \\
\hline & & 15 & 2,09 & & & 600 & 4,09 \\
\hline & & 30 & 2,18 & & & 630 & 4,09 \\
\hline & & 60 & 2,29 & & 18:00:00 & 660 & 4,09 \\
\hline & & 90 & 2,34 & & & & \\
\hline & & 120 & 2,39 & & & & \\
\hline & & 150 & 2,40 & & & & \\
\hline & & 180 & 2,42 & & & & \\
\hline & & 210 & 2,43 & & & & \\
\hline & $7: 00: 00$ & 240 & 2,43 & & & & \\
\hline & & & & & & & \\
\hline & & & & & & & \\
\hline & & & & & & & \\
\hline & & & & & & & \\
\hline & & & & & & & \\
\hline & & & & & & & \\
\hline & & & & & & & \\
\hline
\end{tabular}




\begin{tabular}{|c|c|c|c|c|c|c|c|}
\hline Ensaio: & MS2 & Prof.: & $1,5 \mathrm{~m}$ & Sucção: & $\begin{array}{ll}0 & \mathrm{kPa}\end{array}$ & Folha: & 2 \\
\hline $\begin{array}{c}\text { Tensão } \\
(\mathrm{kPa})\end{array}$ & $\begin{array}{c}\text { Início Carr. } \\
\text { (min) }\end{array}$ & $\begin{array}{c}\text { Tempo } \\
(\mathrm{min})\end{array}$ & $\begin{array}{c}\text { Recalque } \\
\text { (mm) }\end{array}$ & $\begin{array}{c}\text { Tensão } \\
(\mathrm{kPa})\end{array}$ & $\begin{array}{c}\text { Início Carr. } \\
\text { (min) }\end{array}$ & $\begin{array}{c}\text { Tempo } \\
(\mathrm{min})\end{array}$ & $\begin{array}{c}\text { Recalque } \\
(\mathrm{mm})\end{array}$ \\
\hline \multirow{37}{*}{40} & & & & & & & \\
\hline & 18:00:00 & 0 & 4,11 & 48 & 33:15:00 & 0 & 6,76 \\
\hline & & 1 & 4,20 & & & 1 & 6,87 \\
\hline & & 2 & 4,34 & & & 2 & 7,00 \\
\hline & & 4 & 4,50 & & & 3 & 7,08 \\
\hline & & 8 & 4,73 & & & 6 & 7,39 \\
\hline & & 15 & $\overline{5,01}$ & & & 9 & 7,65 \\
\hline & & 30 & 5,31 & & & 12 & 7,88 \\
\hline & & 60 & 5,60 & & $33: 30: 00$ & 15 & 8,04 \\
\hline & & 90 & 5,74 & & & & \\
\hline & & 120 & 5,88 & 52 & 33:30:00 & 0 & 8,10 \\
\hline & & 150 & 5,94 & & & 1 & 8,34 \\
\hline & & 180 & 5,99 & & & 2 & 8,57 \\
\hline & & 210 & 6,03 & & & 3 & 8,75 \\
\hline & & 240 & 6,08 & & & 6 & 9,30 \\
\hline & & 270 & 6,15 & & & 9 & 9,69 \\
\hline & & 300 & 6,23 & & & 12 & 10,00 \\
\hline & & 330 & 6,27 & & 33:45:00 & 15 & 10,24 \\
\hline & & 360 & 6,29 & & & & \\
\hline & & 390 & 6,32 & 56 & $33: 45: 00$ & 0 & 10,30 \\
\hline & & 420 & 6,35 & & & 1 & 10,54 \\
\hline & & 450 & 6,40 & & & 2 & 10,85 \\
\hline & & 480 & 6,41 & & & 3 & 11,10 \\
\hline & & 510 & 6,42 & & & 6 & 11,76 \\
\hline & & 540 & 6,43 & & & 9 & 12,40 \\
\hline & & 570 & 6,45 & & & 12 & 12,81 \\
\hline & & 600 & 6,45 & & $34: 00: 00$ & 15 & 13,09 \\
\hline & & 630 & 6,47 & & & & \\
\hline & & 660 & 6,48 & 60 & 34:00:00 & 0 & 13,16 \\
\hline & & 690 & 6,49 & & & 1 & 13,55 \\
\hline & & $\overline{720}$ & 6,50 & & & 2 & 13,93 \\
\hline & & 750 & 6,50 & & & 3 & 14,23 \\
\hline & & 780 & 6,52 & & & 6 & 15,07 \\
\hline & & 810 & 6,53 & & & 9 & 15,75 \\
\hline & & 840 & 6,53 & & & 12 & 16,16 \\
\hline & & 870 & 6,54 & & $34: 15: 00$ & 15 & 16,45 \\
\hline & 33:00:00 & 900 & 6,54 & & & & \\
\hline & & & & 64 & 34:15:00 & 0 & 16,59 \\
\hline \multirow[t]{8}{*}{44} & 33:00:00 & 0 & 6,56 & & & 1 & 16,91 \\
\hline & & 1 & 6,57 & & & 2 & 17,46 \\
\hline & & 2 & 6,59 & & & 3 & 17,86 \\
\hline & & 3 & 6,60 & & & 6 & 14,57 \\
\hline & & 6 & 6,63 & & & 9 & 19,45 \\
\hline & & 9 & 6,66 & & & 12 & 19,85 \\
\hline & & 12 & 6,69 & & $34: 30: 00$ & 15 & 20,20 \\
\hline & 33:15:00 & 15 & 6,72 & & & & \\
\hline & & & & & & & \\
\hline & & & & & & & \\
\hline & & & & & & & \\
\hline & & & & & & & \\
\hline
\end{tabular}




\begin{tabular}{|c|c|c|c|c|c|c|c|}
\hline Ensaio: & MS2 & Prof.: & $1,5 \mathrm{~m}$ & Sucção: & $\begin{array}{ll}0 & \mathrm{kPa} \\
\end{array}$ & Folha: & 3 \\
\hline $\begin{array}{c}\text { Tensão } \\
(\mathrm{kPa})\end{array}$ & $\begin{array}{c}\text { Início Carr. } \\
\text { (min) }\end{array}$ & $\begin{array}{c}\text { Tempo } \\
\text { (min) }\end{array}$ & $\begin{array}{c}\text { Recalque } \\
(\mathrm{mm})\end{array}$ & $\begin{array}{c}\text { Tensão } \\
(\mathrm{kPa})\end{array}$ & $\begin{array}{c}\text { Início Carr. } \\
\text { (min) }\end{array}$ & $\begin{array}{c}\begin{array}{c}\text { Tempo } \\
\text { (min) }\end{array} \\
\end{array}$ & $\begin{array}{c}\text { Recalque } \\
(\mathrm{mm})\end{array}$ \\
\hline & & & & & & & \\
\hline \multirow[t]{9}{*}{68} & $34: 30: 00$ & 0 & 20,30 & Estab. & $35: 45: 00$ & 0 & 47,59 \\
\hline & & 1 & 20,60 & & & 1 & - \\
\hline & & 2 & 20,99 & & & 2 & 47,63 \\
\hline & & 3 & 21,37 & & & 3 & 47,65 \\
\hline & & 6 & 22,56 & & & 6 & 47,68 \\
\hline & & 9 & 23,49 & & & 9 & 47,69 \\
\hline & & 12 & 26,71 & & & 12 & 47,70 \\
\hline & $34: 45: 00$ & 15 & 24,71 & & & 15 & 47,71 \\
\hline & & & & & & 30 & 47,72 \\
\hline \multirow[t]{9}{*}{72} & $34: 45: 00$ & 0 & 24,85 & 62 & $36: 25: 00$ & 40 & 47,72 \\
\hline & & 1 & 25,45 & & & & \\
\hline & & 2 & 20,15 & $1 \mathrm{D}$ & $36: 25: 00$ & 0 & 47,71 \\
\hline & & 3 & 26,45 & & & 1 & 47,71 \\
\hline & & 6 & 27,70 & & & 2 & 47,71 \\
\hline & & 9 & 28,87 & & & 3 & 47,71 \\
\hline & & 12 & 29,53 & & & 6 & 47,71 \\
\hline & $35: 00: 00$ & 15 & 30,07 & & & 9 & 47,71 \\
\hline & & & & & & 12 & 47,71 \\
\hline \multirow[t]{9}{*}{76} & $35: 00: 00$ & 0 & 30,18 & 45 & $36: 40: 00$ & 15 & 47,71 \\
\hline & & 1 & 30,78 & & & & \\
\hline & & 2 & 31,33 & $2 \mathrm{D}$ & $36: 40: 00$ & 0 & 47,64 \\
\hline & & 3 & 31,87 & & & 1 & 47,64 \\
\hline & & 6 & 32,78 & & & 2 & 47,64 \\
\hline & & 9 & 34,04 & & & 3 & 47,63 \\
\hline & & 12 & 34,83 & & & 6 & 47,63 \\
\hline & $35: 15: 00$ & 15 & 35,50 & & & 9 & 47,62 \\
\hline & & & & & & 12 & 47,62 \\
\hline \multirow[t]{9}{*}{80} & $35: 15: 00$ & 0 & 35,66 & 31 & $36: 55: 00$ & 15 & 47,62 \\
\hline & & 1 & 36,31 & & & & \\
\hline & & 2 & 36,96 & $3 \mathrm{D}$ & $36: 55: 00$ & 0 & 47,53 \\
\hline & & 3 & 37,50 & & & 1 & 47,52 \\
\hline & & 6 & 38,80 & & & 2 & 47,51 \\
\hline & & 9 & 39,85 & & & 3 & 47,51 \\
\hline & & 12 & 40,70 & & & 6 & 47,50 \\
\hline & $35: 30: 00$ & 15 & 41,29 & & & 9 & 47,48 \\
\hline & & & & & & 12 & 47,48 \\
\hline \multirow[t]{13}{*}{84} & $35: 30: 00$ & 0 & 41,57 & 16 & $37: 10: 00$ & 15 & 47,48 \\
\hline & & 1 & 42,22 & & & & \\
\hline & & 2 & 42,81 & $4 \mathrm{D}$ & $37: 10: 00$ & 0 & 47,34 \\
\hline & & 3 & 43,34 & & & 1 & 47,27 \\
\hline & & 6 & 44,64 & & & 2 & 47,23 \\
\hline & & 9 & 45,85 & & & 3 & 47,22 \\
\hline & & 12 & 46,69 & & & 6 & 47,20 \\
\hline & $35: 45: 00$ & 15 & 47,50 & & & 9 & 47,18 \\
\hline & & & & & & 12 & 47,17 \\
\hline & & & & & & 15 & 47,16 \\
\hline & & & & 0 & $37: 40: 00$ & 30 & 47,15 \\
\hline & & & & & & & \\
\hline & & & & & & & \\
\hline
\end{tabular}




\begin{tabular}{|c|c|c|c|c|c|c|c|}
\hline \multicolumn{8}{|c|}{ UNIVERSIDADE DE SÃO PAULO } \\
\hline \multicolumn{8}{|c|}{ ESCOLA DE ENGENHARIA DE SÃO CARLOS } \\
\hline \multicolumn{8}{|c|}{ DEPTO. DE GEOTECNIA - CAMPO EXPERIMENTAL DE FUNDAÇÕES } \\
\hline \multicolumn{8}{|c|}{$\begin{array}{l}\text { PROVA DE CARGA ESTÁTICA } \\
\end{array}$} \\
\hline \multicolumn{2}{|c|}{ Ensaio: $\quad$ MS3 } & & \multicolumn{3}{|c|}{ Tipo de Carregamento: } & MML \\
\hline \multicolumn{2}{|c|}{ Profundidade: } & \multicolumn{2}{|l|}{$1,5 \mathrm{~m}$} & \multicolumn{2}{|c|}{ Estado do solo: } & \multicolumn{2}{|c|}{ INUNDADO } \\
\hline $\begin{array}{l}\text { Sucção: } \\
\text { Diâmetro. }\end{array}$ & $0 \quad \mathrm{kPa}$ & & & Reensaio: & NÃO & & \\
\hline & & $\mathrm{cm}$ & & & & & \\
\hline $\begin{array}{c}\text { Tensão } \\
(\mathrm{kPa})\end{array}$ & $\begin{array}{l}\text { Início Carr. } \\
\text { (min) }\end{array}$ & $\begin{array}{c}\text { Tempo } \\
\text { (min) }\end{array}$ & $\begin{array}{l}\text { Recalque } \\
\text { (mm) }\end{array}$ & $\begin{array}{l}\text { Tensão } \\
(\mathrm{kPa})\end{array}$ & $\begin{array}{c}\text { Início Carr. } \\
\text { (min) }\end{array}$ & $\begin{array}{c}\text { Tempo } \\
\text { (min) }\end{array}$ & $\begin{array}{c}\text { Recalque } \\
(\mathrm{mm})\end{array}$ \\
\hline \multirow{10}{*}{6} & & & & & & & \\
\hline & 00:00 & 0 & 0,15 & 30 & 06:30 & 0 & $\frac{4,22}{450}$ \\
\hline & & 1 & 0,22 & & & 1 & 4,59 \\
\hline & & 2 & 0,24 & & & 2 & 4,95 \\
\hline & & 4 & 0,43 & & & 4 & 5,27 \\
\hline & & 8 & 0,45 & & & 8 & 5,70 \\
\hline & & 15 & 0,47 & & & 15 & 6,10 \\
\hline & & 30 & 0,49 & & & 30 & 6,65 \\
\hline & 01:00 & 60 & 0,50 & & & 60 & 6,91 \\
\hline & & & & & & 90 & $\overline{7,04}$ \\
\hline \multirow[t]{13}{*}{12} & $01: 00$ & 0 & 0,65 & & & 120 & 7,09 \\
\hline & & 1 & 0,81 & & & 150 & 7,12 \\
\hline & & 2 & 0,87 & & $09: 30$ & 180 & 7,14 \\
\hline & & 4 & 0,96 & & & & \\
\hline & & 8 & 1,04 & 36 & 09:30 & 0 & 7,18 \\
\hline & & 15 & 1,10 & & & 1 & 7,27 \\
\hline & & 30 & 1,15 & & & 2 & 7,46 \\
\hline & & 60 & 1,20 & & & 4 & 8,14 \\
\hline & & 90 & 1,23 & & & 8 & 9,09 \\
\hline & & 120 & 1,24 & & & 15 & 9,79 \\
\hline & & 150 & 1,24 & & & 30 & 10,32 \\
\hline & 04:00 & 180 & 1,25 & & & 60 & 10,86 \\
\hline & & & & & & 90 & 11,16 \\
\hline \multirow[t]{8}{*}{18} & 04:00 & 0 & 1,30 & & & 120 & 11,30 \\
\hline & & 1 & 1,62 & & & 150 & 11,38 \\
\hline & & 2 & 1,86 & & & 180 & 11,44 \\
\hline & & 4 & 1,93 & & & 210 & 11,47 \\
\hline & & 8 & 2,07 & & $13: 30$ & 240 & 11,49 \\
\hline & & 15 & 2,13 & & & & \\
\hline & $04: 30$ & 30 & 2,18 & 42 & $13: 30$ & 0 & 11,55 \\
\hline & & & & & & 1 & 11,59 \\
\hline \multirow[t]{11}{*}{24} & $\begin{array}{l}04: 30 \\
\end{array}$ & 0 & 2,34 & & & 2 & 11,72 \\
\hline & & 1 & 2,72 & & & 3 & 11,98 \\
\hline & & 2 & 2,98 & & & 6 & 13,20 \\
\hline & & 4 & 3,22 & & & 9 & 14,15 \\
\hline & & 8 & 3,47 & & & 12 & 14,73 \\
\hline & & 15 & 3,64 & & $13: 45$ & 15 & 15,15 \\
\hline & & 30 & 3,89 & & & & \\
\hline & & 60 & 4,045 & & & & \\
\hline & & 90 & 4,11 & & & & \\
\hline & $06: 30$ & 120 & 4,1525 & & & & \\
\hline & & & & & & & \\
\hline
\end{tabular}




\begin{tabular}{|c|c|c|c|c|c|c|c|}
\hline Ensaio: & $\begin{array}{l}\text { MS3 } \\
\end{array}$ & Prof.: & $1,5 \mathrm{~m}$ & Sucção: & $\begin{array}{ll}0 & \mathrm{kPa}\end{array}$ & Folha: & 2 \\
\hline $\begin{array}{c}\text { Tensão } \\
(\mathrm{kPa})\end{array}$ & $\begin{array}{c}\text { Início Carr. } \\
\text { (min) }\end{array}$ & $\begin{array}{r}\text { Tempo } \\
\text { (min) }\end{array}$ & $\begin{array}{c}\text { Recalque } \\
(\mathrm{mm})\end{array}$ & $\begin{array}{c}\text { Tensão } \\
(\mathrm{kPa})\end{array}$ & $\begin{array}{c}\text { Início Carr. } \\
\text { (min) }\end{array}$ & $\begin{array}{c}\text { Tempo } \\
\text { (min) }\end{array}$ & $\begin{array}{c}\text { Recalque } \\
\text { (mm) }\end{array}$ \\
\hline & & & & & & & \\
\hline \multirow[t]{8}{*}{48} & $13: 45$ & 0 & 15,55 & $1 \mathrm{D}$ & $15: 25$ & 0 & 46,18 \\
\hline & & 1 & 17,05 & & & 1 & 46,18 \\
\hline & & 2 & 18,11 & & & 2 & 46,18 \\
\hline & & 3 & 18,96 & & & 3 & 46,18 \\
\hline & & 6 & 20,27 & & & 6 & 46,17 \\
\hline & & 9 & 21,13 & & & 9 & 46,17 \\
\hline & & 12 & 21,72 & & & 12 & 46,17 \\
\hline & $14: 00$ & 15 & 22,12 & 43 & $15: 40$ & 15 & 46,17 \\
\hline & & & & & & & \\
\hline \multirow[t]{8}{*}{54} & $14: 00$ & 0 & 22,35 & $2 \mathrm{D}$ & $15: 40$ & 0 & 46,10 \\
\hline & & 1 & 23,75 & & & 1 & 46,09 \\
\hline & & 2 & 24,94 & & & 2 & 46,09 \\
\hline & & 3 & 25,82 & & & 3 & 46,09 \\
\hline & & 6 & 27,41 & & & 6 & 46,09 \\
\hline & & 9 & 28,19 & & & 9 & 46,08 \\
\hline & & 12 & 28,83 & & & 12 & 46,08 \\
\hline & $14: 15$ & 15 & 29,36 & 28 & $15: 55$ & 15 & 46,08 \\
\hline & & & & & & & \\
\hline \multirow[t]{8}{*}{60} & $14: 15$ & $\overline{0}$ & 29,64 & $3 \mathrm{D}$ & $15: 55$ & 0 & 45,86 \\
\hline & & 1 & 30,96 & & & 1 & 45,83 \\
\hline & & 2 & 32,35 & & & 2 & 45,82 \\
\hline & & 3 & 33,42 & & & 3 & 45,81 \\
\hline & & 6 & 35,23 & & & 6 & 45,80 \\
\hline & & 9 & 36,17 & & & 9 & 45,79 \\
\hline & & 12 & 36,96 & & & 12 & 45,79 \\
\hline & 14:30 & 15 & 37,50 & 5 & $16: 10$ & 15 & 45,78 \\
\hline \multirow[t]{9}{*}{66} & $14: 30$ & 0 & 37,69 & $4 \mathrm{D}$ & $16: 10$ & 0 & 45,74 \\
\hline & & 5 & 38,97 & & & 1 & 45,71 \\
\hline & & 2 & 40,45 & & & 2 & 45,70 \\
\hline & & 3 & 41,60 & & & 3 & 45,70 \\
\hline & & 6 & 43,24 & & & 6 & 45,69 \\
\hline & & 9 & 44,34 & & & 9 & 45,68 \\
\hline & & 12 & 45,26 & & & 12 & 45,67 \\
\hline & $14: 45$ & 15 & 45,90 & & & 15 & 45,67 \\
\hline & & & & 0 & $16: 40$ & 30 & 45,65 \\
\hline \multirow[t]{8}{*}{ Estab. } & $14: 45$ & 0 & 45,94 & & & & \\
\hline & & 5 & 46,10 & & & & \\
\hline & & 10 & 46,15 & & & & \\
\hline & & 15 & 46,15 & & & & \\
\hline & & 20 & 46,17 & & & & \\
\hline & & 25 & 46,17 & & & & \\
\hline & & 30 & 46,18 & & & & \\
\hline & & 35 & 46,20 & & & & \\
\hline 57 & $15: 25$ & 40 & 46,20 & & & & \\
\hline & & & & & & & \\
\hline & & & & & & & \\
\hline & & & & & & & \\
\hline & & & & & & & \\
\hline
\end{tabular}




\begin{tabular}{|c|c|c|c|c|c|c|c|}
\hline \multicolumn{8}{|c|}{ UNIVERSIDADE DE SÃO PAULO } \\
\hline \multicolumn{8}{|c|}{$\begin{array}{c}\text { ESCOLA DE ENGENHARIA DE SÃO CARLOS } \\
\end{array}$} \\
\hline \multicolumn{8}{|c|}{ DEPTO. DE GEOTECNIA - CAMPO EXPERIMENTAL DE FUNDAÇÕES } \\
\hline \multicolumn{8}{|c|}{$\begin{array}{l}\text { PROVA DE CARGA ESTÁTICA } \\
\end{array}$} \\
\hline \multirow{2}{*}{\multicolumn{2}{|c|}{$\begin{array}{l}\text { Ensaio: M1 } \\
\text { Profundidade: }\end{array}$}} & & \multicolumn{3}{|c|}{ Tipo de Carregamento: } & \multirow{2}{*}{ MML } \\
\hline & & $1,5 \mathrm{~m}$ & & Estado do & solo: & \multirow[t]{3}{*}{ NATURAL } & \\
\hline Sucção: & $28 \mathrm{kPa}$ & & & \multirow{2}{*}{\multicolumn{2}{|c|}{$\begin{array}{ll}\text { Reensaio: } & N A ̃ O \\
\text { Folha: } & 1\end{array}$}} & & \\
\hline \multicolumn{2}{|c|}{ Diâmetro: $\quad 80$} & \multicolumn{2}{|l|}{$\mathrm{cm}$} & & & & \\
\hline $\begin{array}{l}\text { Tensão } \\
(\mathrm{kPa})\end{array}$ & $\begin{array}{c}\text { Início Carr. } \\
\text { (min) }\end{array}$ & $\begin{array}{c}\text { Tempo } \\
\text { (min) }\end{array}$ & $\begin{array}{l}\text { Recalque } \\
\text { (mm) }\end{array}$ & $\begin{array}{l}\text { Tensão } \\
\text { (kPa) }\end{array}$ & $\begin{array}{c}\text { Início Carr. } \\
\text { (min) }\end{array}$ & $\begin{array}{c}\text { Tempo } \\
\text { (min) }\end{array}$ & $\begin{array}{l}\text { Recalque } \\
(\mathrm{mm})\end{array}$ \\
\hline & & & & & & & \\
\hline \multirow[t]{12}{*}{16} & 0:00:00 & 0 & 0,67 & 64 & 6:00:00 & 0 & 2,52 \\
\hline & & 1 & 0,75 & & & 1 & 2,65 \\
\hline & & 2 & 0,78 & & & 2 & 2,74 \\
\hline & & 4 & 0,80 & & & 4 & 2,80 \\
\hline & & 8 & 0,81 & & & 8 & 2,91 \\
\hline & & 15 & 0,82 & & & 15 & $\overline{3,01}$ \\
\hline & & 30 & 0,85 & & & 30 & 3,10 \\
\hline & & 60 & 0,86 & & & 60 & 3,18 \\
\hline & & 90 & 0,87 & & & 90 & 3,21 \\
\hline & $2: 00: 00$ & 120 & 0,87 & & & 120 & 3,26 \\
\hline & & & & & & 150 & 3,28 \\
\hline & & & & & & 180 & 3,29 \\
\hline \multirow[t]{12}{*}{32} & 2:00:00 & 0 & 1,26 & & & 210 & 3,30 \\
\hline & & 1 & 1,42 & & 10:00:00 & 240 & 3,30 \\
\hline & & 2 & 1,45 & & & & \\
\hline & & 4 & 1,51 & 80 & 10:00:00 & 0 & 3,44 \\
\hline & & 8 & 1,55 & & & 1 & 3,55 \\
\hline & & 15 & 1,58 & & & 2 & 3,62 \\
\hline & & 30 & 1,61 & & & 4 & 3,73 \\
\hline & & 60 & 1,65 & & & 8 & 3,91 \\
\hline & & 90 & 1,67 & & & 15 & 4,09 \\
\hline & 4:00:00 & 120 & 1,67 & & & 30 & 4,26 \\
\hline & & & & & & 60 & 4,38 \\
\hline & & & & & & 90 & 4,44 \\
\hline \multirow[t]{10}{*}{48} & 4:00:00 & 0 & 1,85 & & & 120 & 4,49 \\
\hline & & 1 & 2,02 & & & 150 & 4,51 \\
\hline & & 2 & 2,07 & & & 180 & 4,54 \\
\hline & & 4 & 2,16 & & & 210 & 4,55 \\
\hline & & 8 & 2,23 & & $14: 00: 00$ & 240 & 4,55 \\
\hline & & 15 & 2,29 & & & & \\
\hline & & 30 & 2,35 & & & & \\
\hline & & 60 & 2,38 & & & & \\
\hline & & 90 & 2,41 & & & & \\
\hline & 6:00:00 & 120 & 2,41 & & & & \\
\hline & & & & & & & \\
\hline & & & & & & & \\
\hline & & & & & & & \\
\hline & & & & & & & \\
\hline & & & & & & & \\
\hline & & & & & & & \\
\hline & & & & & & & \\
\hline
\end{tabular}




\begin{tabular}{|c|c|c|c|c|c|c|c|}
\hline Ensaio: & M1 & |Prof.: & $1,5 \mathrm{~m}$ & Suçãã: & $\begin{array}{ll}28 & \mathrm{kPa}\end{array}$ & Folha: & $\overline{2}$ \\
\hline $\begin{array}{c}\text { Tensão } \\
(\mathrm{kPa})\end{array}$ & $\begin{array}{c}\text { Início Carr. } \\
\text { (min) }\end{array}$ & \begin{tabular}{|c}
$\begin{array}{r}\text { Tempo } \\
(\mathrm{min})\end{array}$ \\
\end{tabular} & $\begin{array}{c}\text { Recalque } \\
(\mathrm{mm})\end{array}$ & $\begin{array}{c}\text { Tensão } \\
(\mathrm{kPa})\end{array}$ & $\begin{array}{c}\text { Início Carr. } \\
\text { (min) }\end{array}$ & \begin{tabular}{|c}
$\begin{array}{c}\text { Tempo } \\
\text { (min) }\end{array}$ \\
\end{tabular} & $\begin{array}{c}\text { Recalque } \\
(\mathrm{mm})\end{array}$ \\
\hline \multirow{18}{*}{96} & & & & & & & \\
\hline & 14:00:00 & 0 & 4,66 & 128 & $24: 15: 00$ & 0 & 10,03 \\
\hline & & 1 & 4,73 & & & 1 & 10,07 \\
\hline & & 2 & 4,79 & & & 2 & 10,15 \\
\hline & & 4 & 4,95 & & & 3 & 10,27 \\
\hline & & 8 & 5,21 & & & 6 & 10,72 \\
\hline & & 15 & 5,50 & & & 9 & 11,09 \\
\hline & & 30 & 5,79 & & & 12 & 11,42 \\
\hline & & 60 & 6,08 & & $24: 30: 00$ & 15 & 11,71 \\
\hline & & 90 & 6,21 & & & & \\
\hline & & 120 & 6,32 & 136 & $24: 30: 00$ & 0 & 11,81 \\
\hline & & 150 & 6,40 & & & 1 & 12,20 \\
\hline & & 180 & 6,44 & & & 2 & 12,65 \\
\hline & & 210 & 6,47 & & & 3 & 12,94 \\
\hline & & 240 & 6,49 & & & 6 & 13,70 \\
\hline & & 270 & 6,50 & & & 9 & 14,22 \\
\hline & 19:00:00 & 300 & 6,51 & & & 12 & 14,61 \\
\hline & & & & & $24: 45: 00$ & 15 & 14,90 \\
\hline \multirow[t]{17}{*}{112} & 19:00:00 & 0 & 6,57 & & & & \\
\hline & & 1 & 6,63 & 144 & $24: 45: 00$ & 0 & 15,01 \\
\hline & & 2 & 6,73 & & & 1 & 15,21 \\
\hline & & 4 & 6,93 & & & 2 & 15,51 \\
\hline & & 8 & 7,38 & & & 3 & 15,80 \\
\hline & & 15 & 7,94 & & & 6 & 16,49 \\
\hline & & 30 & 8,64 & & & 9 & 16,97 \\
\hline & & 60 & 9,24 & & & 12 & 17,39 \\
\hline & & 90 & 9,40 & & $25: 00: 00$ & 15 & 17,68 \\
\hline & & 120 & 9,53 & & & & \\
\hline & & 150 & 9,62 & 152 & $25: 00: 00$ & 0 & 17,80 \\
\hline & & 180 & 9,66 & & & 1 & 18,16 \\
\hline & & 210 & 9,71 & & & 2 & 18,48 \\
\hline & & 240 & 9,77 & & & 3 & 18,88 \\
\hline & & 270 & 9,80 & & & 6 & 19,57 \\
\hline & $24: 00: 00$ & 300 & 9,80 & & & 9 & 20,32 \\
\hline & & & & & & 12 & 20,59 \\
\hline \multirow[t]{10}{*}{120} & 24:00:00 & 0 & 9,84 & & 25:15:00 & 15 & 20,90 \\
\hline & & 1 & 9,84 & & & & \\
\hline & & 2 & 9,86 & 160 & $25: 15: 00$ & 0 & 21,00 \\
\hline & & 3 & 9,86 & & & 1 & 21,32 \\
\hline & & 6 & 9,89 & & & 2 & 21,69 \\
\hline & & 9 & 9,92 & & & 3 & 21,95 \\
\hline & & 12 & 9,94 & & & 6 & 22,59 \\
\hline & $24: 15: 00$ & 15 & 9,96 & & & 9 & 22,95 \\
\hline & & & & & & 12 & 23,29 \\
\hline & & & & & $25: 30: 00$ & 15 & 23,53 \\
\hline & & & & & & & \\
\hline & & & & & & & \\
\hline & & & & & & & \\
\hline & & & & & & & \\
\hline & & & & & & & \\
\hline
\end{tabular}




\begin{tabular}{|c|c|c|c|c|c|c|c|}
\hline Ensaio: & M1 & Prof.: & $1,5 \mathrm{~m}$ & Sucção: & $28 \mathrm{kPa}$ & Folha: & 3 \\
\hline $\begin{array}{c}\text { Tensão } \\
(\mathrm{kPa})\end{array}$ & $\begin{array}{c}\text { Início Carr. } \\
\text { (min) }\end{array}$ & $\begin{array}{r}\text { Tempo } \\
(\mathrm{min})\end{array}$ & $\begin{array}{c}\text { Recalque } \\
\text { (mm) }\end{array}$ & $\begin{array}{c}\text { Tensão } \\
(\mathrm{kPa})\end{array}$ & $\begin{array}{c}\text { Início Carr } \\
\text { (min) }\end{array}$ & $\begin{array}{c}\text { Tempo } \\
\text { (min) }\end{array}$ & $\begin{array}{c}\text { Recalque } \\
\text { (mm) }\end{array}$ \\
\hline \multirow[t]{8}{*}{168} & $25: 30: 00$ & 0 & 23,62 & 208 & $26: 30: 00$ & 0 & 38,92 \\
\hline & & 1 & 23,85 & & & 1 & 39,23 \\
\hline & & 2 & 24,06 & & & 2 & 39,56 \\
\hline & & 3 & 24,27 & & & 3 & 39,87 \\
\hline & & 6 & 24,85 & & & 6 & 40,75 \\
\hline & & 9 & 25,33 & & & 9 & 41,32 \\
\hline & & 12 & 25,72 & & & 12 & 41,80 \\
\hline & $25: 45: 00$ & 15 & 26,03 & & $26: 45: 00$ & 15 & 42,19 \\
\hline \multirow[t]{8}{*}{176} & $25: 45: 00$ & 0 & 26,14 & 216 & $26: 45: 00$ & 0 & 42,34 \\
\hline & & 1 & 26,46 & & & 1 & 42,61 \\
\hline & & 2 & 26,69 & & & 2 & 42,88 \\
\hline & & 3 & 26,99 & & & 3 & 43,21 \\
\hline & & 6 & 27,76 & & & 6 & 44,11 \\
\hline & & 9 & 28,34 & & & 9 & 44,80 \\
\hline & & 12 & 28,79 & & & 12 & 45,35 \\
\hline & $26: 00: 00$ & 15 & 29,12 & & 27:00:00 & 15 & 45,82 \\
\hline \multirow[t]{9}{*}{184} & 26:00:00 & 0 & 29,24 & Estab. & 27:00:00 & 0 & 45,82 \\
\hline & & 1 & 29,55 & & & 1 & 45,89 \\
\hline & & 2 & 29,82 & & & 2 & 45,93 \\
\hline & & 3 & 30,29 & & & 3 & 45,96 \\
\hline & & 6 & 30,82 & & & 6 & 46,02 \\
\hline & & 9 & 31,36 & & & 9 & 46,06 \\
\hline & & 12 & 31,81 & & & 12 & 46,08 \\
\hline & $26: 15: 00$ & 15 & 32,17 & & & 15 & 46,09 \\
\hline & & & & & & 20 & 46,14 \\
\hline \multirow[t]{9}{*}{192} & 26:15:00 & 0 & 32,27 & & & 25 & 46,15 \\
\hline & & 1 & 32,58 & 192 & 27:30:00 & 30 & 46,15 \\
\hline & & 2 & 32,89 & & & & \\
\hline & & 3 & 33,21 & $1 \mathrm{D}$ & $27: 30: 00$ & 0 & 46,13 \\
\hline & & 6 & 34,04 & & & 1 & 46,12 \\
\hline & & 9 & 34,64 & & & 2 & 46,11 \\
\hline & & 12 & 35,16 & & & 3 & 46,11 \\
\hline & $26: 30: 00$ & 15 & 35,57 & & & 6 & 46,09 \\
\hline & & & & & & 9 & 46,09 \\
\hline \multirow[t]{8}{*}{200} & 26:30:00 & 0 & 35,67 & & & 12 & 46,09 \\
\hline & & 1 & 35,97 & 126,4 & $27: 45: 00$ & 15 & 46,09 \\
\hline & & 2 & 36,29 & & & & \\
\hline & & 3 & 36,65 & & & & \\
\hline & & 6 & 37,35 & & & & \\
\hline & & 9 & 37,96 & & & & \\
\hline & & 12 & 38,45 & & & & \\
\hline & & 15 & 38,83 & & & & \\
\hline & & & & & & & \\
\hline & & & & & & & \\
\hline & & & & & & & \\
\hline & & & & & & & \\
\hline & & & & & & & \\
\hline
\end{tabular}




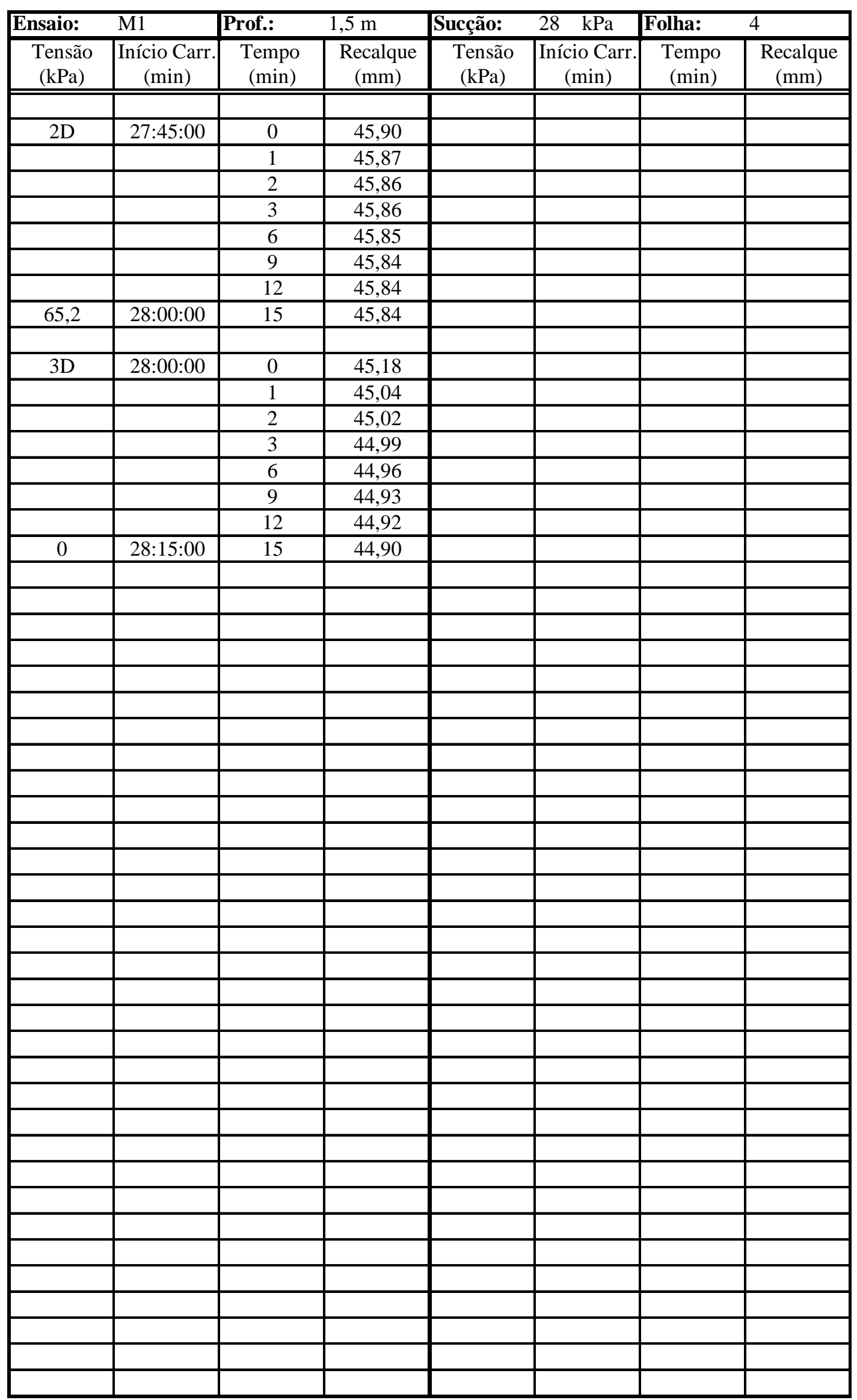




\begin{tabular}{|c|c|c|c|c|c|c|c|}
\hline \multicolumn{8}{|c|}{ UNIVERSIDADE DE SÃO PAULO } \\
\hline \multicolumn{8}{|c|}{ ESCOLA DE ENGENHARIA DE SÃO CARLOS } \\
\hline \multicolumn{8}{|c|}{ DEPTO. DE GEOTECNIA - CAMPO EXPERIMENTAL DE FUNDAÇÕES } \\
\hline \multicolumn{8}{|c|}{$\begin{array}{l}\text { PROVA DE CARGA ESTÁTICA } \\
\end{array}$} \\
\hline \multicolumn{4}{|c|}{ FKUVA UE } & \multicolumn{3}{|c|}{ Tipo de Carregamento: } & QML \\
\hline \multicolumn{2}{|c|}{ Profundidade: } & \multicolumn{2}{|l|}{$4 \mathrm{~m}$} & \multicolumn{2}{|c|}{ Estado do solo: } & \multicolumn{2}{|c|}{ INUNDADO } \\
\hline Sucção: & $0 \quad \mathrm{kPa}$ & & & Reensaio: & NÃO & & \\
\hline & & $\mathrm{cm}$ & & & & & \\
\hline $\begin{array}{c}\text { Tensão } \\
(\mathrm{kPa})\end{array}$ & $\begin{array}{c}\text { Início Carr. } \\
\text { (min) }\end{array}$ & $\begin{array}{r}\text { Tempo } \\
\text { (min) } \\
\end{array}$ & $\begin{array}{c}\text { Recalque } \\
(\mathrm{mm})\end{array}$ & $\begin{array}{c}\text { Tensão } \\
(\mathrm{kPa})\end{array}$ & $\begin{array}{c}\text { Início Carr. } \\
\text { (min) }\end{array}$ & $\begin{array}{r}\text { Tempo } \\
(\mathrm{min})\end{array}$ & $\begin{array}{c}\text { Recalque } \\
(\mathrm{mm})\end{array}$ \\
\hline \multirow[t]{8}{*}{6} & 00:00 & 0 & 0,72 & 30 & 01:00 & 0 & 3,62 \\
\hline & & 1 & 0,76 & & & 1 & 3,91 \\
\hline & & 2 & 0,77 & & & 2 & - \\
\hline & & 3 & 0,77 & & & 3 & 4,00 \\
\hline & & 6 & 0,79 & & & 6 & 4,09 \\
\hline & & 9 & 0,79 & & & 9 & 4,12 \\
\hline & & 12 & 0,79 & & & 12 & 4,13 \\
\hline & 00:15 & 15 & 0,79 & & 01:15 & 15 & 4,14 \\
\hline \multirow{9}{*}{12} & & & & & & & \\
\hline & $00: 15$ & 0 & 1,60 & 36 & 01:15 & 0 & 4,21 \\
\hline & & 1 & 1,75 & & & 1 & 4,46 \\
\hline & & 2 & 1,76 & & & 2 & 4,54 \\
\hline & & 3 & 1,76 & & & 3 & 4,59 \\
\hline & & 6 & 1,78 & & & 6 & 4,64 \\
\hline & & 9 & 1,78 & & & 9 & 4,66 \\
\hline & & 12 & 1,78 & & & 12 & 4,70 \\
\hline & 00:30 & 15 & 1,78 & & 01:30 & 15 & 4,71 \\
\hline \multirow{8}{*}{18} & $00: 30$ & 0 & 2,32 & 42 & 01:30 & 0 & 4.83 \\
\hline & & 1 & 2,55 & & & 1 & 5,07 \\
\hline & & 2 & 2,60 & & & 2 & 5,17 \\
\hline & & 3 & 2,63 & & & 3 & 5,21 \\
\hline & & 6 & 2,67 & & & 6 & 5,37 \\
\hline & & 9 & 2,68 & & & 9 & 5,40 \\
\hline & & 12 & 2,68 & & & 12 & 5,41 \\
\hline & $00: 45$ & 15 & 2,71 & & 01:45 & 15 & 5,42 \\
\hline \multirow{8}{*}{24} & $00 \cdot 45$ & 0 & 3.00 & 48 & $01: 45$ & 0 & 5.47 \\
\hline & & 1 & 3,30 & & & 1 & 5,62 \\
\hline & & 2 & 3,35 & & & 2 & 5,76 \\
\hline & & 3 & 3,38 & & & 3 & 5,84 \\
\hline & & 6 & 3,43 & & & 6 & 5,93 \\
\hline & & 9 & 3,45 & & & 9 & 6,04 \\
\hline & & 12 & 3,48 & & & 12 & 6,08 \\
\hline & 01:00 & 15 & 3,49 & & 02:00 & 15 & 6,09 \\
\hline & & & & & & & \\
\hline & & & & & & & \\
\hline & & & & & & & \\
\hline & & & & & & & \\
\hline & & & & & & & \\
\hline
\end{tabular}




\begin{tabular}{|c|c|c|c|c|c|c|c|}
\hline Ensaio: & QS3 & Prof.: & $4 \mathrm{~m}$ & Sucção: & $0 \quad \mathrm{kPa}$ & Folha: & 2 \\
\hline $\begin{array}{c}\text { Tensão } \\
(\mathrm{kPa})\end{array}$ & $\begin{array}{c}\text { Início Carr. } \\
\text { (min) }\end{array}$ & $\begin{array}{r}\begin{array}{r}\text { Tempo } \\
(\mathrm{min})\end{array} \\
\end{array}$ & $\begin{array}{c}\text { Recalque } \\
(\mathrm{mm})\end{array}$ & $\begin{array}{c}\text { Tensão } \\
(\mathrm{kPa})\end{array}$ & $\begin{array}{c}\text { Início Carr. } \\
(\mathrm{min})\end{array}$ & $\begin{array}{c}\text { Tempo } \\
\text { (min) }\end{array}$ & $\begin{array}{c}\text { Recalque } \\
(\mathrm{mm})\end{array}$ \\
\hline & & & & & & & \\
\hline \multirow[t]{8}{*}{54} & $02: 00$ & 0 & 6,12 & 84 & $03: 15$ & 0 & 10,28 \\
\hline & & 1 & 6,27 & & & 1 & 10,45 \\
\hline & & 2 & 6,36 & & & 2 & 10,62 \\
\hline & & 3 & 6,46 & & & 3 & 10,72 \\
\hline & & 6 & 6,60 & & & 6 & 10,93 \\
\hline & & 9 & 6,65 & & & 9 & 11,10 \\
\hline & & 12 & 6,75 & & & 12 & 11,23 \\
\hline & $02: 15$ & 15 & 6,77 & & $03: 30$ & 15 & 11,34 \\
\hline & & & & & & & \\
\hline \multirow[t]{8}{*}{60} & $02: 15$ & 0 & 6,82 & 90 & $03: 30$ & 0 & 11,38 \\
\hline & & 1 & 6,91 & & & 1 & 11,64 \\
\hline & & 2 & 6,98 & & & 2 & 11,87 \\
\hline & & 3 & 7,08 & & & 3 & 12,03 \\
\hline & & 6 & 7,25 & & & 6 & 12,27 \\
\hline & & 9 & 7,36 & & & 9 & 12,49 \\
\hline & & 12 & 7,42 & & & 12 & 12,64 \\
\hline & $02: 30$ & 15 & 7,45 & & $03: 45$ & 15 & 12,75 \\
\hline & & & & & & & \\
\hline \multirow[t]{8}{*}{66} & $02: 30$ & 0 & 7,50 & 96 & $03: 45$ & 0 & 12,79 \\
\hline & & 1 & 7,65 & & & 1 & 13,01 \\
\hline & & 2 & 7,72 & & & 2 & 13,23 \\
\hline & & 3 & 7,81 & & & 3 & 13,42 \\
\hline & & 6 & 7,96 & & & 6 & 13,83 \\
\hline & & 9 & 8,05 & & & 9 & 14,09 \\
\hline & & 12 & 8,11 & & & 12 & 14,24 \\
\hline & $02: 45$ & 15 & 8,17 & & $04: 00$ & 15 & 14,37 \\
\hline \multirow[t]{8}{*}{72} & $02: 45$ & 0 & 8,23 & 102 & $04: 00$ & 0 & 14,42 \\
\hline & & 1 & 8,40 & & & 1 & 14,75 \\
\hline & & 2 & 8,52 & & & 2 & 15,10 \\
\hline & & 3 & 8,64 & & & 3 & 15,40 \\
\hline & & 6 & 8,82 & & & 6 & 15,95 \\
\hline & & 9 & 8,97 & & & 9 & 16,21 \\
\hline & & 12 & 9,04 & & & 12 & 16,43 \\
\hline & 03:00 & 15 & 9,09 & & $04: 15$ & 15 & 16,59 \\
\hline \multirow[t]{8}{*}{78} & 03:00 & 0 & 9,14 & 108 & $04: 15$ & 0 & 16,64 \\
\hline & & 1 & 9,36 & & & 1 & 16,84 \\
\hline & & 2 & 9,50 & & & 2 & 17,08 \\
\hline & & 3 & 9,63 & & & 3 & 17,37 \\
\hline & & 6 & 9,87 & & & 6 & 17,87 \\
\hline & & 9 & 10,03 & & & 9 & 18,22 \\
\hline & & 12 & 10,14 & & & 12 & 18,49 \\
\hline & $03: 15$ & 15 & 10,22 & & $04: 30$ & 15 & 18,66 \\
\hline & & & & & & & \\
\hline & & & & & & & \\
\hline & & & & & & & \\
\hline & & & & & & & \\
\hline & & & & & & & \\
\hline
\end{tabular}




\begin{tabular}{|c|c|c|c|c|c|c|c|}
\hline Ensaio: & QS3 & Prof.: & $4 \mathrm{~m}$ & Sucção: & $\begin{array}{ll}0 & \mathrm{kPa}\end{array}$ & Folha: & 3 \\
\hline $\begin{array}{c}\text { Tensão } \\
(\mathrm{kPa})\end{array}$ & $\begin{array}{c}\text { Início Carr. } \\
\text { (min) }\end{array}$ & $\begin{array}{r}\text { Tempo } \\
(\mathrm{min})\end{array}$ & $\begin{array}{c}\text { Recalque } \\
(\mathrm{mm})\end{array}$ & $\begin{array}{c}\text { Tensão } \\
(\mathrm{kPa})\end{array}$ & $\begin{array}{c}\text { Início Carr. } \\
(\mathrm{min})\end{array}$ & $\begin{array}{c}\text { Tempo } \\
(\mathrm{min})\end{array}$ & $\begin{array}{c}\text { Recalque } \\
(\mathrm{mm})\end{array}$ \\
\hline \multirow{8}{*}{114} & $04 \cdot 20$ & 0 & 1870 & 144 & $05 \cdot 45$ & 0 & 3076 \\
\hline & 04.50 & $\frac{0}{1}$ & $\frac{10,70}{1896}$ & 144 & $03.4 \mathrm{~J}$ & $\frac{0}{1}$ & $\frac{50,10}{3107}$ \\
\hline & & 2 & 19,17 & & & 2 & 31,41 \\
\hline & & 3 & 19,43 & & & 3 & 31,73 \\
\hline & & 6 & 19,98 & & & 6 & 32,33 \\
\hline & & 9 & 20,39 & & & 9 & 32,87 \\
\hline & & 12 & 20,67 & & & 12 & 33,28 \\
\hline & $04: 45$ & 15 & 20,88 & & 06:00 & 15 & 33,57 \\
\hline \multirow[t]{8}{*}{120} & 04:45 & 0 & 20,93 & 150 & 06:00 & 0 & 33,64 \\
\hline & & 1 & 21,16 & & & 1 & 33,93 \\
\hline & & 2 & 21,44 & & & 2 & 34,26 \\
\hline & & 3 & 21,68 & & & 3 & 34,51 \\
\hline & & 6 & 22,26 & & & 6 & 35,25 \\
\hline & & 9 & 22,56 & & & 9 & 35,83 \\
\hline & & 12 & 22,85 & & & 12 & 36,26 \\
\hline & 05:00 & 15 & 23,08 & & 06:15 & 15 & 36,57 \\
\hline \multirow[t]{8}{*}{126} & 05:00 & 0 & 23,13 & 156 & 06:15 & 0 & 36,63 \\
\hline & & 1 & 23,33 & & & 1 & 36,94 \\
\hline & & 2 & 23,56 & & & 2 & 37,30 \\
\hline & & 3 & 23,90 & & & 3 & 37,63 \\
\hline & & 6 & 24,45 & & & 6 & 38,39 \\
\hline & & 9 & 24,82 & & & 9 & 38,99 \\
\hline & & 12 & 25,03 & & & 12 & 39,46 \\
\hline & 05:15 & 15 & 25,24 & & $06: 30$ & 15 & 39,78 \\
\hline \multirow[t]{8}{*}{132} & 05:15 & 0 & 25,28 & 162 & 06:30 & 0 & 39,84 \\
\hline & & 1 & 25,56 & & & 1 & 40,07 \\
\hline & & 2 & 26,12 & & & 2 & 40,39 \\
\hline & & 3 & 26,34 & & & 3 & 40,69 \\
\hline & & 6 & 26,98 & & & 6 & 41,49 \\
\hline & & 9 & 27,44 & & & 9 & 42,08 \\
\hline & & 12 & 27,78 & & & 12 & 42,54 \\
\hline & $05: 30$ & 15 & 28,00 & & $06: 45$ & 15 & 42,85 \\
\hline \multirow[t]{9}{*}{138} & 05:30 & 0 & 28,05 & & & & \\
\hline & & 1 & 28,34 & 168 & $06: 45$ & 0 & 42,90 \\
\hline & & 2 & 28,65 & & & 1 & 43,27 \\
\hline & & 3 & 28,91 & & & 2 & 43,58 \\
\hline & & 6 & 29,56 & & & 3 & 43,93 \\
\hline & & 9 & 30,06 & & & 6 & 44,79 \\
\hline & & 12 & 30,46 & & & 9 & 45,58 \\
\hline & $05: 45$ & 15 & 30,70 & & & 12 & 45,81 \\
\hline & & & & & 07:00 & 15 & 46,21 \\
\hline & & & & & & & \\
\hline & & & & & & & \\
\hline & & & & & & & \\
\hline & & & & & & & \\
\hline
\end{tabular}




\begin{tabular}{|c|c|c|c|c|c|c|c|}
\hline Ensaio: & $\overline{\mathrm{QS} 3}$ & Prof.: & $4 \mathrm{~m}$ & Sucção: & $\begin{array}{ll}0 & \mathrm{kPa} \\
\end{array}$ & Folha: & 4 \\
\hline $\begin{array}{c}\text { Tensão } \\
(\mathrm{kPa})\end{array}$ & $\begin{array}{c}\text { Início Carr. } \\
\text { (min) }\end{array}$ & $\begin{array}{c}\text { Tempo } \\
(\mathrm{min})\end{array}$ & $\begin{array}{c}\text { Recalque } \\
\text { (mm) }\end{array}$ & $\begin{array}{c}\text { Tensão } \\
(\mathrm{kPa})\end{array}$ & $\begin{array}{c}\text { Início Carr. } \\
\text { (min) }\end{array}$ & $\begin{array}{c}\text { Tempo } \\
(\mathrm{min})\end{array}$ & $\begin{array}{l}\text { Recalque } \\
(\mathrm{mm})\end{array}$ \\
\hline & & & & & & & \\
\hline \multirow[t]{7}{*}{ Estab. } & 07:00 & 0 & 46,21 & & & & \\
\hline & & 1 & 46,29 & & & & \\
\hline & & 2 & $\begin{array}{l}46,32 \\
\end{array}$ & & & & \\
\hline & & 3 & 46,35 & & & & \\
\hline & & 6 & 46,40 & & & & \\
\hline & & 9 & 46,43 & & & & \\
\hline & & 12 & 46,45 & & & & \\
\hline \multirow[t]{2}{*}{156} & $07: 15$ & 15 & 46,47 & & & & \\
\hline & & & & & & & \\
\hline \multirow[t]{7}{*}{$1 \mathrm{D}$} & $07: 15$ & 0 & 46,34 & & & & \\
\hline & & 1 & 46,33 & & & & \\
\hline & & 2 & 46,33 & & & & \\
\hline & & 3 & 46,33 & & & & \\
\hline & & 6 & $\begin{array}{l}46,33 \\
\end{array}$ & & & & \\
\hline & & 9 & $\begin{array}{l}46,33 \\
\end{array}$ & & & & \\
\hline & & 12 & 46,33 & & & & \\
\hline \multirow[t]{2}{*}{74} & 07:30 & 15 & 46,33 & & & & \\
\hline & & & & & & & \\
\hline \multirow[t]{7}{*}{$2 \mathrm{D}$} & $07: 30$ & 0 & 44,23 & & & & \\
\hline & & 1 & 44,13 & & & & \\
\hline & & 2 & - & & & & \\
\hline & & 3 & 44,04 & & & & \\
\hline & & 6 & 44,00 & & & & \\
\hline & & 9 & 43,98 & & & & \\
\hline & & 12 & $\begin{array}{l}43,98 \\
\end{array}$ & & & & \\
\hline \multirow[t]{2}{*}{0} & 07:45 & 15 & 43,98 & & & & \\
\hline & & & & & & & \\
\hline & & & & & & & \\
\hline & & & & & & & \\
\hline & & & & & & & \\
\hline & & & & & & & \\
\hline & & & & & & & \\
\hline & & & & & & & \\
\hline & & & & & & & \\
\hline & & & & & & & \\
\hline & & & & & & & \\
\hline & & & & & & & \\
\hline & & & & & & & \\
\hline & & & & & & & \\
\hline & & & & & & & \\
\hline & & & & & & & \\
\hline & & & & & & & \\
\hline & & & & & & & \\
\hline & & & & & & & \\
\hline & & & & & & & \\
\hline & & & & & & & \\
\hline & & & & & & & \\
\hline & & & & & & & \\
\hline
\end{tabular}




\begin{tabular}{|c|c|c|c|c|c|c|c|}
\hline \multicolumn{8}{|c|}{ UNIVERSIDADE DE SÃO PAULO } \\
\hline \multicolumn{8}{|c|}{ ESCOLA DE ENGENHARIA DE SÃO CARLOS } \\
\hline \multicolumn{8}{|c|}{ DEPTO. DE GEOTECNIA - CAMPO EXPERIMENTAL DE FUNDAÇÕES } \\
\hline \multicolumn{8}{|c|}{$\begin{array}{l}\text { PROVA DE CARGA ESTÁTICA } \\
\end{array}$} \\
\hline \multirow{2}{*}{\multicolumn{2}{|c|}{$\begin{array}{l}\text { Ensaio: Q4 } \\
\text { Profundidade: }\end{array}$}} & & \multicolumn{3}{|c|}{ Tipo de Carregamento: } & QML \\
\hline & & $4 \mathrm{~m}$ & & \multicolumn{2}{|c|}{ Estado do solo: } & \multicolumn{2}{|c|}{ NATURAL } \\
\hline $\begin{array}{l}\text { Sucção: } \\
\text { Diâmetro: }\end{array}$ & $\begin{array}{c}18 \mathrm{kPa} \\
80\end{array}$ & $\mathrm{~cm}$ & & $\begin{array}{l}\text { Reensaio: } \\
\text { Folha: }\end{array}$ & $\begin{array}{l}\text { NÃO } \\
1\end{array}$ & & \\
\hline $\begin{array}{l}\text { Tensão } \\
(\mathrm{kPa})\end{array}$ & $\begin{array}{l}\text { Início Carr. } \\
\text { (min) }\end{array}$ & $\begin{array}{c}\text { Tempo } \\
\text { (min) }\end{array}$ & $\begin{array}{l}\text { Recalque } \\
\text { (mm) }\end{array}$ & $\begin{array}{l}\text { Tensão } \\
(\mathrm{kPa})\end{array}$ & $\begin{array}{c}\text { Início Carr. } \\
\text { (min) }\end{array}$ & $\begin{array}{c}\text { Tempo } \\
\text { (min) }\end{array}$ & $\begin{array}{l}\text { Recalque } \\
\text { (mm) }\end{array}$ \\
\hline \multirow{8}{*}{8} & $00: 00$ & 0 & 0.12 & 40 & 01:00 & 0 & 1.58 \\
\hline & & 1 & 0,12 & & & 1 & 1,64 \\
\hline & & 2 & 0,13 & & & 2 & 1,68 \\
\hline & & 3 & 0,13 & & & 3 & 1,70 \\
\hline & & 6 & 0,13 & & & 6 & 1,73 \\
\hline & & 9 & 0,13 & & & 9 & 1,75 \\
\hline & & 12 & 0,13 & & & 12 & 1,76 \\
\hline & 00:15 & 15 & 0,13 & & 01:15 & 15 & 1,77 \\
\hline & & & & & & & \\
\hline \multirow[t]{8}{*}{16} & $00: 15$ & 0 & 0,25 & 48 & $01: 15$ & 0 & 1,86 \\
\hline & & 1 & 0,30 & & & 1 & 2,01 \\
\hline & & 2 & 0,33 & & & 2 & 2,05 \\
\hline & & 3 & 0,35 & & & 3 & 2,08 \\
\hline & & 6 & 0,36 & & & 6 & 2,12 \\
\hline & & 9 & 0,37 & & & 9 & 2,14 \\
\hline & & 12 & 0,39 & & & 12 & 2,16 \\
\hline & $\begin{array}{l}00: 30 \\
\end{array}$ & 15 & 0,39 & & \begin{tabular}{l|l}
$01: 30$ \\
\end{tabular} & 15 & 2,17 \\
\hline \multirow{8}{*}{24} & $00: 30$ & 0 & 0,69 & 56 & 01:30 & 0 & 2,22 \\
\hline & & 1 & 0,82 & & & 1 & 2,37 \\
\hline & & 2 & 0,87 & & & 2 & 2,42 \\
\hline & & 3 & 0,90 & & & 3 & 2,46 \\
\hline & & 6 & 0,92 & & & 6 & 2,50 \\
\hline & & 9 & 0,93 & & & 9 & 2,52 \\
\hline & & 12 & 0,95 & & & 12 & 2,54 \\
\hline & $00: 45$ & 15 & 0,96 & & 01:45 & 15 & 2,54 \\
\hline \multirow{8}{*}{32} & $00: 45$ & 0 & 1.17 & 64 & $01: 45$ & 0 & 2.61 \\
\hline & & 1 & 1,31 & & & 1 & 2,72 \\
\hline & & 2 & 1,32 & & & 2 & 2,78 \\
\hline & & 3 & 1,38 & & & 3 & 2,82 \\
\hline & & 6 & 1,40 & & & 6 & 2,86 \\
\hline & & 9 & 1,41 & & & 9 & 2,90 \\
\hline & & 12 & 1,42 & & & 12 & 2,92 \\
\hline & 01:00 & 15 & 1,45 & & 02:00 & 15 & 2,93 \\
\hline & & & & & & & \\
\hline & & & & & & & \\
\hline & & & & & & & \\
\hline & & & & & & & \\
\hline & & & & & & & \\
\hline & & & & & & & \\
\hline
\end{tabular}




\begin{tabular}{|c|c|c|c|c|c|c|c|}
\hline Ensaio: & Q4 & Prof.: & $4 \mathrm{~m}$ & Sucção: & $18 \mathrm{kPa}$ & Folha: & 2 \\
\hline $\begin{array}{c}\text { Tensão } \\
(\mathrm{kPa})\end{array}$ & $\begin{array}{c}\text { Início Carr. } \\
\text { (min) }\end{array}$ & $\begin{array}{r}\begin{array}{r}\text { Tempo } \\
(\mathrm{min})\end{array} \\
\end{array}$ & $\begin{array}{c}\text { Recalque } \\
(\mathrm{mm})\end{array}$ & $\begin{array}{c}\text { Tensão } \\
(\mathrm{kPa})\end{array}$ & $\begin{array}{c}\text { Início Carr. } \\
\text { (min) }\end{array}$ & $\begin{array}{c}\text { Tempo } \\
\text { (min) }\end{array}$ & $\begin{array}{c}\text { Recalque } \\
(\mathrm{mm})\end{array}$ \\
\hline & & & & & & & \\
\hline \multirow[t]{8}{*}{72} & $02: 00$ & 0 & 3,02 & 112 & $03: 15$ & 0 & 5,65 \\
\hline & & 1 & 3,08 & & & 1 & 5,80 \\
\hline & & 2 & 3,14 & & & 2 & 5,96 \\
\hline & & 3 & 3,18 & & & 3 & 6,06 \\
\hline & & 6 & 3,24 & & & 6 & 6,29 \\
\hline & & 9 & 3,27 & & & 9 & 6,40 \\
\hline & & 12 & 3,31 & & & 12 & 6,48 \\
\hline & $02: 15$ & 15 & 3,33 & & $03: 30$ & 15 & 6,55 \\
\hline & & & & & & & \\
\hline \multirow[t]{8}{*}{80} & $02: 15$ & 0 & 3,37 & 120 & $03: 30$ & 0 & 6,61 \\
\hline & & 1 & 3,50 & & & 1 & 6,75 \\
\hline & & 2 & 3,57 & & & 2 & - \\
\hline & & 3 & 3,62 & & & 3 & 7,06 \\
\hline & & 6 & 3,71 & & & 6 & 7,38 \\
\hline & & 9 & 3,74 & & & 9 & 7,53 \\
\hline & & 12 & 3,77 & & & 12 & 7,66 \\
\hline & $02: 30$ & 15 & 3,79 & & $03: 45$ & 15 & 7,73 \\
\hline & & & & & & & \\
\hline \multirow[t]{8}{*}{88} & $02: 30$ & 0 & 3,84 & 128 & $03: 45$ & 0 & 7,77 \\
\hline & & 1 & 3,94 & & & 1 & 7,96 \\
\hline & & 2 & 4,02 & & & 2 & 8,20 \\
\hline & & 3 & 4,07 & & & 3 & 8,36 \\
\hline & & 6 & 4,18 & & & 6 & 8,65 \\
\hline & & 9 & 4,23 & & & 9 & 8,86 \\
\hline & & 12 & 4,27 & & & 12 & 8,98 \\
\hline & $02: 45$ & 15 & 4,29 & & $04: 00$ & 15 & 9,07 \\
\hline \multirow[t]{8}{*}{96} & $02: 45$ & 0 & 4,35 & 136 & $04: 00$ & 0 & 9,13 \\
\hline & & 1 & - & & & 1 & 9,31 \\
\hline & & 2 & 4,57 & & & 2 & 9,50 \\
\hline & & 3 & 4,63 & & & 3 & 9,67 \\
\hline & & 6 & 4,76 & & & 6 & 10,12 \\
\hline & & 9 & 4,84 & & & 9 & 10,38 \\
\hline & & 12 & 4,89 & & & 12 & 10,61 \\
\hline & 03:00 & 15 & 4,93 & & $04: 15$ & 15 & 10,74 \\
\hline \multirow[t]{8}{*}{104} & 03:00 & 0 & 4,98 & 144 & $04: 15$ & 0 & 10,79 \\
\hline & & 1 & 5,10 & & & 1 & 11,03 \\
\hline & & 2 & 5,15 & & & 2 & 11,25 \\
\hline & & 3 & 5,26 & & & 3 & 11,50 \\
\hline & & 6 & 5,40 & & & 6 & 11,94 \\
\hline & & 9 & 5,50 & & & 9 & 12,24 \\
\hline & & 12 & 5,57 & & & 12 & 12,45 \\
\hline & $03: 15$ & 15 & 5,61 & & $04: 30$ & 15 & 12,60 \\
\hline & & & & & & & \\
\hline & & & & & & & \\
\hline & & & & & & & \\
\hline & & & & & & & \\
\hline & & & & & & & \\
\hline
\end{tabular}




\begin{tabular}{|c|c|c|c|c|c|c|c|}
\hline Ensaio: & Q4 & Prof.: & $4 \mathrm{~m}$ & Sucção: & $18 \mathrm{kPa}$ & Folha: & 3 \\
\hline $\begin{array}{c}\text { Tensão } \\
(\mathrm{kPa})\end{array}$ & $\begin{array}{c}\text { Início Carr. } \\
\text { (min) }\end{array}$ & $\begin{array}{r}\begin{array}{r}\text { Tempo } \\
(\mathrm{min})\end{array} \\
\end{array}$ & $\begin{array}{c}\text { Recalque } \\
(\mathrm{mm})\end{array}$ & $\begin{array}{c}\text { Tensão } \\
(\mathrm{kPa})\end{array}$ & $\begin{array}{c}\text { Início Carr. } \\
\text { (min) }\end{array}$ & $\begin{array}{c}\text { Tempo } \\
\text { (min) }\end{array}$ & $\begin{array}{c}\text { Recalque } \\
(\mathrm{mm})\end{array}$ \\
\hline & & & & & & & \\
\hline \multirow[t]{8}{*}{152} & $04: 30$ & 0 & 12,67 & 192 & $05: 45$ & 0 & 26,19 \\
\hline & & 1 & 12,96 & & & 1 & 26,55 \\
\hline & & 2 & 13,28 & & & 2 & 27,05 \\
\hline & & 3 & 13,51 & & & 3 & 27,56 \\
\hline & & 6 & 14,10 & & & 6 & 28,56 \\
\hline & & 9 & 14,39 & & & 9 & 29,23 \\
\hline & & 12 & 14,59 & & & 12 & 29,66 \\
\hline & $04: 45$ & 15 & 14,76 & & $06: 00$ & 15 & 29,98 \\
\hline & & & & & & & \\
\hline \multirow[t]{8}{*}{160} & $04: 45$ & 0 & 14,83 & 200 & $06: 00$ & 0 & 30,05 \\
\hline & & 1 & 15,01 & & & 1 & 30,39 \\
\hline & & 2 & 15,24 & & & 2 & 30,68 \\
\hline & & 3 & 15,51 & & & 3 & 31,01 \\
\hline & & 6 & 16,08 & & & 6 & 32,01 \\
\hline & & 9 & 16,49 & & & 9 & 32,62 \\
\hline & & 12 & 16,80 & & & 12 & 33,03 \\
\hline & $05: 00$ & 15 & 17,07 & & $06: 15$ & 15 & 33,39 \\
\hline \multirow{9}{*}{168} & & & & & & & \\
\hline & 05:00 & 0 & 17,16 & 208 & 06:15 & 0 & 33,45 \\
\hline & & 1 & 17,59 & & & 1 & 33,84 \\
\hline & & 2 & 18,02 & & & 2 & 34,30 \\
\hline & & 3 & 18,32 & & & 3 & 34,67 \\
\hline & & 6 & 19,01 & & & 6 & 35,70 \\
\hline & & 9 & 19,47 & & & 9 & 36,32 \\
\hline & & 12 & 19,79 & & & 12 & 36,84 \\
\hline & $05: 15$ & 15 & 20,01 & & $06: 30$ & 15 & 37,23 \\
\hline \multirow[t]{8}{*}{176} & $05: 15$ & 0 & 20,09 & 216 & $06: 30$ & 0 & 37,32 \\
\hline & & 1 & 20,34 & & & 1 & 37,76 \\
\hline & & 2 & 20,70 & & & 2 & 38,24 \\
\hline & & 3 & 21,05 & & & 3 & 38,70 \\
\hline & & 6 & 21,87 & & & 6 & 39,79 \\
\hline & & 9 & 22,41 & & & 9 & 40,53 \\
\hline & & 12 & 22,70 & & & 12 & 41,05 \\
\hline & $05: 30$ & 15 & 22,96 & & $06: 45$ & 15 & 41,45 \\
\hline \multirow[t]{9}{*}{184} & $05: 30$ & 0 & 23,02 & & & & \\
\hline & & 1 & 23,37 & 224 & $06: 45$ & 0 & 41,56 \\
\hline & & 2 & 23,77 & & & 1 & 42,03 \\
\hline & & 3 & 24,16 & & & 2 & 42,47 \\
\hline & & 6 & 24,78 & & & 3 & 42,93 \\
\hline & & 9 & 25,58 & & & 6 & 44,02 \\
\hline & & 12 & 25,87 & & & 9 & 44,77 \\
\hline & $05: 45$ & 15 & 26,13 & & & 12 & 45,30 \\
\hline & & & & & $07: 00$ & 15 & 45,66 \\
\hline & & & & & & & \\
\hline & & & & & & & \\
\hline & & & & & & & \\
\hline & & & & & & & \\
\hline
\end{tabular}




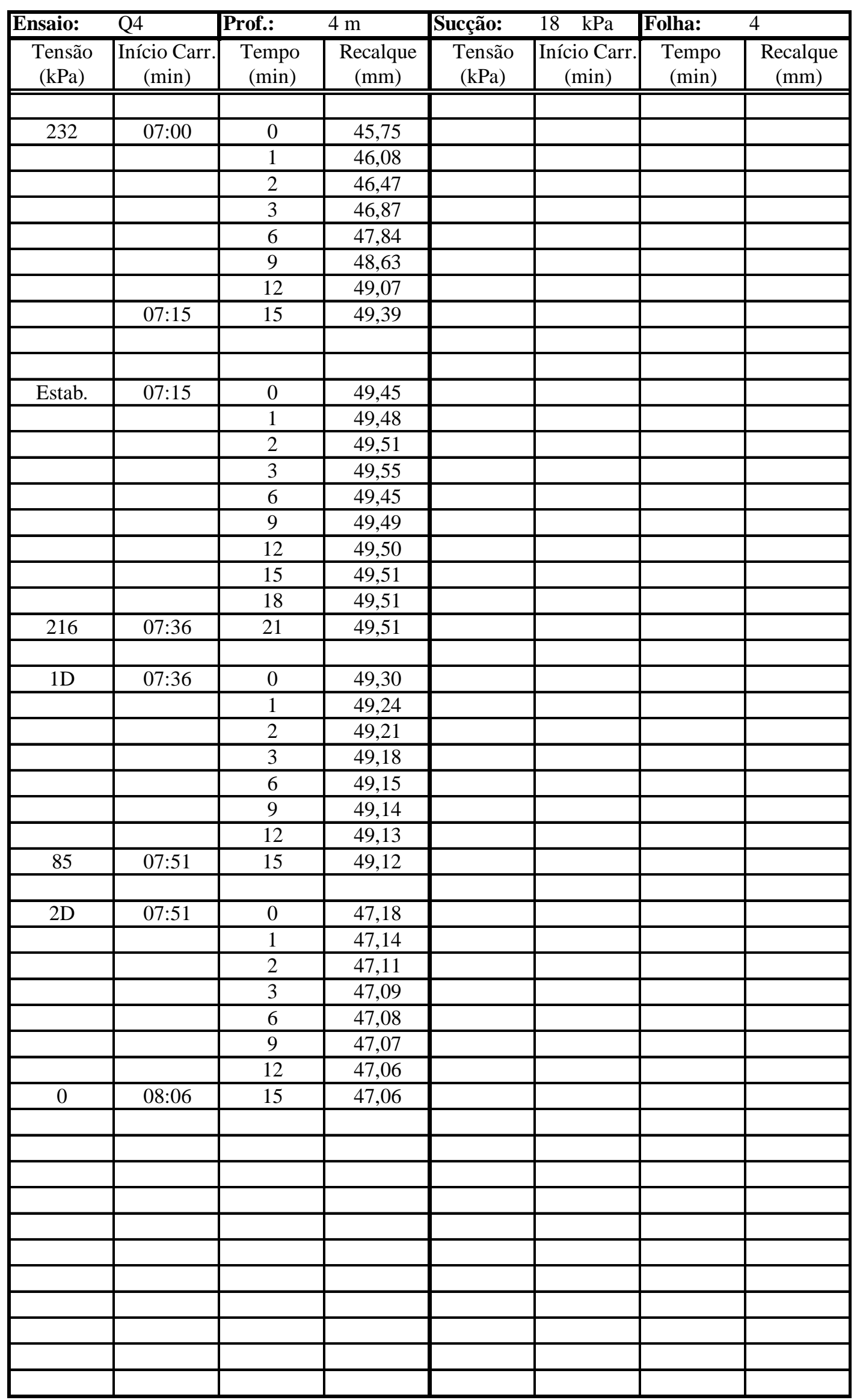




\begin{tabular}{|c|c|c|c|c|c|c|c|}
\hline \multicolumn{8}{|c|}{ UNIVERSIDADE DE SÃO PAULO } \\
\hline \multicolumn{8}{|c|}{ ESCOLA DE ENGENHARIA DE SÃO CARLOS } \\
\hline \multicolumn{8}{|c|}{ DEPTO. DE GEOTECNIA - CAMPO EXPERIMENTAL DE FUNDAÇÕES } \\
\hline \multicolumn{8}{|c|}{$\begin{array}{l}\text { PROVA DE CARGA ESTÁTICA } \\
\end{array}$} \\
\hline \multirow{2}{*}{\multicolumn{2}{|c|}{$\begin{array}{l}\text { Ensaio: Q5 } \\
\text { Profundidade: }\end{array}$}} & & \multicolumn{3}{|c|}{ Tipo de Carregamento: } & QML \\
\hline & & 4,0 m & & \multicolumn{2}{|c|}{ Estado do solo: } & \multicolumn{2}{|c|}{ NATURAL } \\
\hline \multicolumn{2}{|c|}{ Sucção: $\quad 28 \quad \mathrm{kPa}$} & $\mathrm{cm}$ & & $\begin{array}{l}\text { Reensaio: } \\
\text { Folha: }\end{array}$ & $\begin{array}{l}\text { NÃO } \\
1\end{array}$ & & \\
\hline $\begin{array}{l}\text { Tensão } \\
(\mathrm{kPa})\end{array}$ & $\begin{array}{c}\text { Início Carr. } \\
\text { (min) }\end{array}$ & $\begin{array}{c}\text { Tempo } \\
\text { (min) }\end{array}$ & $\begin{array}{l}\text { Recalque } \\
\text { (mm) }\end{array}$ & $\begin{array}{l}\text { Tensão } \\
(\mathrm{kPa})\end{array}$ & $\begin{array}{c}\text { Início Carr. } \\
\text { (min) }\end{array}$ & $\begin{array}{c}\text { Tempo } \\
\text { (min) }\end{array}$ & $\begin{array}{l}\text { Recalque } \\
\text { (mm) }\end{array}$ \\
\hline \multirow[t]{8}{*}{12} & 0:00:00 & 0 & 0,92 & 60 & 1:00:00 & 0 & 4,35 \\
\hline & & 1 & 0,96 & & & 1 & 4,54 \\
\hline & & 2 & 0,99 & & & 2 & 4,61 \\
\hline & & 3 & 0,99 & & & 3 & 4,67 \\
\hline & & 6 & 0,99 & & & 6 & 4,74 \\
\hline & & 9 & 0,99 & & & 9 & 4,75 \\
\hline & & 12 & 0,99 & & & 12 & 4,77 \\
\hline & 0:15:00 & 15 & 0,99 & & 1:15:00 & 15 & 4,77 \\
\hline & & & & & & & \\
\hline \multirow[t]{8}{*}{24} & $0: 15: 00$ & 0 & 1,98 & 72 & 1:15:00 & 0 & 4,92 \\
\hline & & 1 & 2,17 & & & 1 & 5,07 \\
\hline & & 2 & 2,23 & & & 2 & 5,14 \\
\hline & & 3 & 2,24 & & & 3 & 5,19 \\
\hline & & 6 & 2,27 & & & 6 & 5,26 \\
\hline & & 9 & 2,30 & & & 9 & 5,32 \\
\hline & & 12 & 2,30 & & & 12 & 5,33 \\
\hline & $0: 30: 00$ & 15 & 2,31 & & 1:30:00 & 15 & 5,33 \\
\hline \multirow{8}{*}{36} & 0:30:00 & 0 & 3,02 & 84 & 1:30:00 & 0 & 5,48 \\
\hline & & 1 & 3,29 & & & 1 & 5,71 \\
\hline & & 2 & 3,32 & & & 2 & 5,79 \\
\hline & & 3 & 3,36 & & & 3 & 5,84 \\
\hline & & 6 & 3,39 & & & 6 & 5,92 \\
\hline & & 9 & 3,41 & & & 9 & 5,97 \\
\hline & & 12 & 3,42 & & & 12 & 6,00 \\
\hline & $0: 45: 00$ & 15 & 3,43 & & 1:45:00 & 15 & 6,01 \\
\hline & & & & & & & \\
\hline \multirow[t]{8}{*}{48} & $0: 45: 00$ & 0 & 3,72 & 96 & 1:45:00 & 0 & 6,13 \\
\hline & & 1 & 3,98 & & & 1 & 6,36 \\
\hline & & 2 & 4,05 & & & 2 & 6,46 \\
\hline & & 3 & 4,08 & & & 3 & 6,53 \\
\hline & & 6 & 4,13 & & & 6 & 6,64 \\
\hline & & 9 & 4,14 & & & 9 & 6,69 \\
\hline & & 12 & 4,16 & & & 12 & 6,72 \\
\hline & 1:00:00 & 15 & 4,16 & & $2: 00: 00$ & 15 & 6,75 \\
\hline & & & & & & & \\
\hline & & & & & & & \\
\hline & & & & & & & \\
\hline & & & & & & & \\
\hline & & & & & & & \\
\hline
\end{tabular}




\begin{tabular}{|c|c|c|c|c|c|c|c|}
\hline Ensaio: & Q5 & Prof.: & $4,0 \mathrm{~m}$ & Sucção: & $28 \mathrm{kPa}$ & Folha: & 2 \\
\hline $\begin{array}{c}\text { Tensão } \\
(\mathrm{kPa})\end{array}$ & $\begin{array}{c}\text { Início Carr. } \\
\text { (min) }\end{array}$ & $\begin{array}{r}\text { Tempo } \\
(\mathrm{min})\end{array}$ & $\begin{array}{c}\text { Recalque } \\
\text { (mm) }\end{array}$ & $\begin{array}{c}\text { Tensão } \\
(\mathrm{kPa})\end{array}$ & $\begin{array}{c}\text { Início Carr } \\
\text { (min) }\end{array}$ & $\begin{array}{c}\text { Tempo } \\
\text { (min) }\end{array}$ & $\begin{array}{c}\text { Recalque } \\
\text { (mm) }\end{array}$ \\
\hline \multirow{8}{*}{108} & $2: 00: 00$ & 0 & 6.87 & 168 & $3 \cdot 15 \cdot 00$ & 0 & 1294 \\
\hline & & 1 & 7,03 & & & 1 & 13,37 \\
\hline & & 2 & 7,17 & & & 2 & 13,83 \\
\hline & & 3 & 7,22 & & & 3 & 14,14 \\
\hline & & 6 & 7,34 & & & 6 & 14,64 \\
\hline & & 9 & 7,40 & & & 9 & 14,91 \\
\hline & & 12 & 7,43 & & & 12 & 15,11 \\
\hline & $2: 15: 00$ & 15 & 7,46 & & 3:30:00 & 15 & 15,20 \\
\hline \multirow[t]{8}{*}{120} & $2: 15: 00$ & 0 & 7,62 & 180 & $3: 30: 00$ & 0 & 15,32 \\
\hline & & 1 & 7,82 & & & 1 & 15,89 \\
\hline & & 2 & 7,93 & & & 2 & 16,37 \\
\hline & & 3 & 8,02 & & & 3 & 16,69 \\
\hline & & 6 & 8,15 & & & 6 & 17,33 \\
\hline & & 9 & 8,23 & & & 9 & 17,70 \\
\hline & & 12 & 8,28 & & & 12 & 17,87 \\
\hline & 2:30:00 & 15 & 8,31 & & $3: 45: 00$ & 15 & 18,04 \\
\hline \multirow[t]{8}{*}{132} & $2: 30: 00$ & 0 & 8,41 & 192 & $3: 45: 00$ & 0 & 18,18 \\
\hline & & 1 & 8,63 & & & 1 & 18,71 \\
\hline & & 2 & 8,79 & & & 2 & 19,35 \\
\hline & & 3 & 8,91 & & & 3 & 19,79 \\
\hline & & 6 & 9,12 & & & 6 & 20,56 \\
\hline & & 9 & 9,24 & & & 9 & 20,92 \\
\hline & & 12 & 9,29 & & & 12 & 21,18 \\
\hline & $2: 45: 00$ & 15 & 9,35 & & 4:00:00 & 15 & 21,33 \\
\hline \multirow[t]{8}{*}{144} & $2: 45: 00$ & 0 & 9,42 & 204 & 4:00:00 & 0 & 21,45 \\
\hline & & 1 & 9,72 & & & 1 & 21,90 \\
\hline & & 2 & 10,00 & & & 2 & 22,47 \\
\hline & & 3 & 10,18 & & & 3 & 22,93 \\
\hline & & 6 & 10,43 & & & 6 & 23,73 \\
\hline & & 9 & 10,59 & & & 9 & 24,18 \\
\hline & & 12 & 10,69 & & & 12 & 24,46 \\
\hline & $3: 00: 00$ & 15 & 10,78 & & $4: 15: 00$ & 15 & 24,66 \\
\hline \multirow[t]{8}{*}{156} & $3: 00: 00$ & 0 & 10,90 & 216 & $4: 15: 00$ & 0 & 24,76 \\
\hline & & 1 & 11,36 & & & 1 & 25,31 \\
\hline & & 2 & 11,76 & & & 2 & 25,96 \\
\hline & & 3 & 12,01 & & & 3 & 26,48 \\
\hline & & 6 & 12,38 & & & 6 & 27,38 \\
\hline & & 9 & 12,59 & & & 9 & 27,88 \\
\hline & & 12 & 12,74 & & & 12 & 28,13 \\
\hline & $3: 15: 00$ & 15 & 12,82 & & $4: 30: 00$ & 15 & 28,34 \\
\hline & & & & & & & \\
\hline & & & & & & & \\
\hline & & & & & & & \\
\hline & & & & & & & \\
\hline & & & & & & & \\
\hline
\end{tabular}




\begin{tabular}{|c|c|c|c|c|c|c|c|}
\hline Ensaio: & Q5 & Prof.: & $4,0 \mathrm{~m}$ & Suç̧̃ão: & $28 \mathrm{kPa}$ & Folha: & $\overline{3}$ \\
\hline $\begin{array}{c}\text { Tensão } \\
(\mathrm{kPa})\end{array}$ & $\begin{array}{c}\text { Início Carr. } \\
\text { (min) }\end{array}$ & $\begin{array}{c}\text { Tempo } \\
(\mathrm{min})\end{array}$ & $\begin{array}{c}\text { Recalque } \\
(\mathrm{mm})\end{array}$ & $\begin{array}{c}\text { Tensão } \\
(\mathrm{kPa})\end{array}$ & $\begin{array}{c}\text { Início Carr. } \\
\text { (min) }\end{array}$ & $\begin{array}{c}\text { Tempo } \\
\text { (min) }\end{array}$ & $\begin{array}{c}\text { Recalque } \\
(\mathrm{mm})\end{array}$ \\
\hline \multirow{9}{*}{228} & & & & & & & \\
\hline & 4:30:00 & 0 & 28,40 & 1D & 5:48:00 & 0 & 45,80 \\
\hline & & 1 & 28,91 & & & 1 & 45,78 \\
\hline & & 2 & 29,49 & & & 2 & 45,77 \\
\hline & & 3 & 30,05 & & & 3 & 45,77 \\
\hline & & 6 & 31,10 & & & 6 & 45,77 \\
\hline & & 9 & 31,66 & & & 9 & 45,77 \\
\hline & & 12 & 32,06 & & & 12 & 45,77 \\
\hline & $4: 45: 00$ & 15 & 32,31 & 118 & 6:03:00 & 15 & 45,77 \\
\hline \multirow{8}{*}{240} & $4: 45: 00$ & 0 & 32,38 & $2 \mathrm{D}$ & 6:03:00 & 0 & 43,57 \\
\hline & & 1 & 32,84 & & & 1 & 43,53 \\
\hline & & 2 & 33,55 & & & 2 & 43,52 \\
\hline & & 3 & 34,03 & & & 3 & 43,52 \\
\hline & & 6 & 35,13 & & & 6 & 43,51 \\
\hline & & 9 & $\begin{array}{l}35,74 \\
\end{array}$ & & & 9 & 43,50 \\
\hline & & 12 & 36,15 & & & 12 & 43,50 \\
\hline & 5:00:00 & 15 & 36,46 & 0 & 6:18:00 & 15 & 43,50 \\
\hline \multirow{9}{*}{252} & & & & & & & \\
\hline & 5:00:00 & 0 & 36,61 & & & & \\
\hline & & 1 & 37,13 & & & & \\
\hline & & 2 & 37,78 & & & & \\
\hline & & 3 & 38,39 & & & & \\
\hline & & 6 & 39,56 & & & & \\
\hline & & 9 & 40,22 & & & & \\
\hline & & 12 & 40,63 & & & & \\
\hline & 5:15:00 & 15 & 40,95 & & & & \\
\hline & & & & & & & \\
\hline \multirow[t]{8}{*}{264} & $5: 15: 00$ & 0 & 41,10 & & & & \\
\hline & & 1 & 41,70 & & & & \\
\hline & & 2 & 42,36 & & & & \\
\hline & & 3 & 43,02 & & & & \\
\hline & & 6 & 44,25 & & & & \\
\hline & & 9 & 44,98 & & & & \\
\hline & & 12 & 45,43 & & & & \\
\hline & $5: 30: 00$ & 15 & 45,79 & & & & \\
\hline \multirow{9}{*}{ Estab. } & & & & & & & \\
\hline & $5: 30: 00$ & 0 & 45,79 & & & & \\
\hline & & 1 & 45,84 & & & & \\
\hline & & 2 & 45,88 & & & & \\
\hline & & 3 & 45,90 & & & & \\
\hline & & 6 & 45,99 & & & & \\
\hline & & 9 & 46,04 & & & & \\
\hline & & 12 & 46,05 & & & & \\
\hline & & 15 & 46,06 & & & & \\
\hline 250 & 5:48:00 & 18 & 46,06 & & & & \\
\hline & & & & & & & \\
\hline & & & & & & & \\
\hline & & & & & & & \\
\hline & & & & & & & \\
\hline
\end{tabular}




\begin{tabular}{|c|c|c|c|c|c|c|c|}
\hline \multicolumn{8}{|c|}{ UNIVERSIDADE DE SÃO PAULO } \\
\hline \multicolumn{8}{|c|}{ ESCOLA DE ENGENHARIA DE SÃO CARLOS } \\
\hline \multicolumn{8}{|c|}{ DEPTO. DE GEOTECNIA - CAMPO EXPERIMENTAL DE FUNDAÇÕES } \\
\hline \multicolumn{8}{|c|}{$\begin{array}{l}\text { PROVA DE CARGA ESTÁTICA } \\
\end{array}$} \\
\hline \multirow{2}{*}{\multicolumn{2}{|c|}{ Profundidade: }} & & \multicolumn{3}{|c|}{ Tipo de Carregamento: } & QML \\
\hline & & \multicolumn{2}{|l|}{$6,0 \mathrm{~m}$} & \multicolumn{2}{|c|}{ Estado do solo: } & \multicolumn{2}{|c|}{ INUNDADO } \\
\hline $\begin{array}{l}\text { Sucção: } \\
\text { Diâmetro: }\end{array}$ & $\begin{array}{cc}0 & \mathrm{kPa} \\
80\end{array}$ & $\mathrm{~cm}$ & & $\begin{array}{l}\text { Reensaio: } \\
\text { Folha: }\end{array}$ & $\begin{array}{l}\text { NÃO } \\
1\end{array}$ & & \\
\hline $\begin{array}{l}\text { Tensão } \\
\text { (kPa) }\end{array}$ & $\begin{array}{l}\text { Início Carr. } \\
\text { (min) }\end{array}$ & $\begin{array}{c}\text { Tempo } \\
\text { (min) }\end{array}$ & $\begin{array}{l}\text { Recalque } \\
\text { (mm) }\end{array}$ & $\begin{array}{l}\text { Tensão } \\
(\mathrm{kPa})\end{array}$ & $\begin{array}{c}\text { Início Carr. } \\
\text { (min) }\end{array}$ & $\begin{array}{c}\text { Tempo } \\
\text { (min) }\end{array}$ & $\begin{array}{c}\text { Recalque } \\
(\mathrm{mm})\end{array}$ \\
\hline \multirow{8}{*}{6} & $00: 00$ & 0 & 0.07 & 30 & 01:00 & 0 & 1,22 \\
\hline & & 1 & 0,08 & & & 1 & 1,26 \\
\hline & & 2 & 0,09 & & & 2 & 1,30 \\
\hline & & 3 & 0,09 & & & 3 & 1,33 \\
\hline & & 6 & 0,09 & & & 6 & 1,37 \\
\hline & & 9 & 0,10 & & & 9 & 1,40 \\
\hline & & 12 & 0,10 & & & 12 & 1,42 \\
\hline & 00:15 & 15 & 0,10 & & 01:15 & 15 & 1,43 \\
\hline & & & & & & & \\
\hline \multirow[t]{9}{*}{12} & $00: 15$ & 0 & 0,22 & & & & \\
\hline & & 1 & 0,26 & 36 & 01:15 & 0 & 1,63 \\
\hline & & 2 & 0,28 & & & 1 & 1,68 \\
\hline & & 3 & 0,29 & & & 2 & 1,73 \\
\hline & & 6 & 0,30 & & & 3 & 1,76 \\
\hline & & 9 & 0,31 & & & 6 & 1,81 \\
\hline & & 12 & 0,31 & & & 9 & 1,83 \\
\hline & $00: 30$ & 15 & 0,32 & & & 12 & 1,84 \\
\hline & & & & & 01:30 & 15 & 1,86 \\
\hline \multirow[t]{9}{*}{18} & $00: 30$ & 0 & 0,48 & & & & \\
\hline & & 1 & 0,53 & 42 & 01:30 & 0 & 1,94 \\
\hline & & 2 & 0,56 & & & 1 & 2,03 \\
\hline & & 3 & 0,58 & & & 2 & 2,08 \\
\hline & & 6 & 0,60 & & & 3 & 2,13 \\
\hline & & 9 & 0,61 & & & 6 & 2,20 \\
\hline & & 12 & 0,62 & & & 9 & 2,21 \\
\hline & $00: 45$ & 15 & 0,63 & & & 12 & 2,23 \\
\hline & & & & & $01: 45$ & 15 & 2,27 \\
\hline \multirow[t]{9}{*}{24} & $00: 45$ & 0 & 0,74 & & & & \\
\hline & & 1 & 0,88 & 48 & $01: 45$ & 0 & 2,32 \\
\hline & & 2 & 0,95 & & & 1 & 2,43 \\
\hline & & 3 & 0,93 & & & 2 & 2,49 \\
\hline & & 6 & 0,98 & & & 3 & 2,53 \\
\hline & & 9 & 0,99 & & & 6 & 2,61 \\
\hline & & 12 & 1,00 & & & 9 & 2,64 \\
\hline & \begin{tabular}{l|l}
$01: 00$ \\
\end{tabular} & 15 & 1,01 & & & 12 & 2,67 \\
\hline & & & & & 02:00 & 15 & 2,69 \\
\hline & & & & & & & \\
\hline & & & & & & & \\
\hline & & & & & & & \\
\hline & & & & & & & \\
\hline & & & & & & & \\
\hline
\end{tabular}




\begin{tabular}{|c|c|c|c|c|c|c|c|}
\hline Ensaio: & QS4 & Prof.: & $6,0 \mathrm{~m}$ & Sucção: & $\begin{array}{ll}0 & \mathrm{kPa}\end{array}$ & Folha: & 2 \\
\hline $\begin{array}{c}\text { Tensão } \\
(\mathrm{kPa})\end{array}$ & $\begin{array}{c}\text { Início Carr. } \\
\text { (min) }\end{array}$ & $\begin{array}{r}\begin{array}{r}\text { Tempo } \\
(\mathrm{min})\end{array} \\
\end{array}$ & $\begin{array}{c}\begin{array}{c}\text { Recalque } \\
(\mathrm{mm})\end{array} \\
\end{array}$ & $\begin{array}{c}\text { Tensão } \\
(\mathrm{kPa})\end{array}$ & $\begin{array}{c}\text { Início Carr. } \\
\text { (min) }\end{array}$ & $\begin{array}{c}\text { Tempo } \\
\text { (min) }\end{array}$ & $\begin{array}{c}\text { Recalque } \\
(\mathrm{mm})\end{array}$ \\
\hline & & & & & & & \\
\hline \multirow[t]{8}{*}{54} & $02: 00$ & 0 & 2,74 & 84 & $03: 15$ & 0 & 6,07 \\
\hline & & 1 & 2,85 & & & 1 & 6,24 \\
\hline & & 2 & 2,95 & & & 2 & 6,40 \\
\hline & & 3 & 2,99 & & & 3 & 6,51 \\
\hline & & 6 & 3,10 & & & 6 & 6,75 \\
\hline & & 9 & 3,14 & & & 9 & 6,90 \\
\hline & & 12 & 3,18 & & & 12 & 7,00 \\
\hline & $02: 15$ & 15 & 3,21 & & $03: 30$ & 15 & 7,07 \\
\hline & & & & & & & \\
\hline \multirow[t]{8}{*}{60} & $02: 15$ & 0 & 3,23 & 90 & $03: 30$ & 0 & 7,13 \\
\hline & & 1 & 3,36 & & & 1 & 7,30 \\
\hline & & 2 & 3,42 & & & 2 & 7,48 \\
\hline & & 3 & 3,48 & & & 3 & 7,62 \\
\hline & & 6 & 3,59 & & & 6 & 7,94 \\
\hline & & 9 & 3,63 & & & 9 & 8,11 \\
\hline & & 12 & 3,68 & & & 12 & 8,25 \\
\hline & $02: 30$ & 15 & 3,72 & & $03: 45$ & 15 & 8,34 \\
\hline & & & & & & & \\
\hline \multirow[t]{8}{*}{66} & $02: 30$ & 0 & 3,76 & 96 & $03: 45$ & 0 & 8,39 \\
\hline & & 1 & 3,89 & & & 1 & 8,59 \\
\hline & & 2 & 3,99 & & & 2 & 8,79 \\
\hline & & 3 & 4,07 & & & 3 & 8,95 \\
\hline & & 6 & 4,19 & & & 6 & 9,32 \\
\hline & & 9 & 4,27 & & & 9 & 9,55 \\
\hline & & 12 & 4,32 & & & 12 & 9,71 \\
\hline & $02: 45$ & 15 & 4,36 & & $04: 00$ & 15 & 9,83 \\
\hline \multirow[t]{8}{*}{72} & $02: 45$ & 0 & 4,41 & 102 & $04: 00$ & 0 & 9,89 \\
\hline & & 1 & 4,54 & & & 1 & 10,15 \\
\hline & & 2 & 4,62 & & & 2 & 10,37 \\
\hline & & 3 & 4,72 & & & 3 & 10,63 \\
\hline & & 6 & 4,89 & & & 6 & 11,07 \\
\hline & & 9 & 4,98 & & & 9 & 11,34 \\
\hline & & 12 & 5,05 & & & 12 & 11,53 \\
\hline & 03:00 & 15 & 5,10 & & $04: 15$ & 15 & 11,67 \\
\hline \multirow[t]{8}{*}{78} & 03:00 & 0 & 5,14 & 108 & $04: 15$ & 0 & 11,71 \\
\hline & & 1 & 5,28 & & & 1 & 11,98 \\
\hline & & 2 & 5,43 & & & 2 & 12,19 \\
\hline & & 3 & 5,54 & & & 3 & 12,40 \\
\hline & & 6 & 5,74 & & & 6 & 12,85 \\
\hline & & 9 & 5,86 & & & 9 & 13,11 \\
\hline & & 12 & 5,97 & & & 12 & 13,31 \\
\hline & $03: 15$ & 15 & 6,02 & & $04: 30$ & 15 & 13,45 \\
\hline & & & & & & & \\
\hline & & & & & & & \\
\hline & & & & & & & \\
\hline & & & & & & & \\
\hline & & & & & & & \\
\hline
\end{tabular}




\begin{tabular}{|c|c|c|c|c|c|c|c|}
\hline Ensaio: & QS4 & Prof.: & $6,0 \mathrm{~m}$ & Sucção: & $\begin{array}{ll}0 & \mathrm{kPa}\end{array}$ & Folha: & 3 \\
\hline $\begin{array}{c}\text { Tensão } \\
(\mathrm{kPa})\end{array}$ & $\begin{array}{c}\text { Início Carr. } \\
\text { (min) }\end{array}$ & $\begin{array}{r}\begin{array}{r}\text { Tempo } \\
(\mathrm{min})\end{array} \\
\end{array}$ & $\begin{array}{c}\begin{array}{c}\text { Recalque } \\
(\mathrm{mm})\end{array} \\
\end{array}$ & $\begin{array}{c}\text { Tensão } \\
(\mathrm{kPa})\end{array}$ & $\begin{array}{c}\text { Início Carr. } \\
\text { (min) }\end{array}$ & $\begin{array}{c}\text { Tempo } \\
\text { (min) }\end{array}$ & $\begin{array}{c}\text { Recalque } \\
(\mathrm{mm})\end{array}$ \\
\hline & & & & & & & \\
\hline \multirow[t]{8}{*}{114} & $04: 30$ & 0 & 13,51 & 144 & $05: 45$ & 0 & 24,19 \\
\hline & & 1 & 13,75 & & & 1 & 24,41 \\
\hline & & 2 & 14,01 & & & 2 & 24,67 \\
\hline & & 3 & 14,25 & & & 3 & 24,92 \\
\hline & & 6 & 14,72 & & & 6 & 25,54 \\
\hline & & 9 & 15,04 & & & 9 & 25,94 \\
\hline & & 12 & 15,27 & & & 12 & 26,22 \\
\hline & $04: 45$ & 15 & 15,44 & & $06: 00$ & 15 & 26,44 \\
\hline & & & & & & & \\
\hline \multirow[t]{8}{*}{120} & $04: 45$ & 0 & 15,50 & 150 & $06: 00$ & 0 & 26,51 \\
\hline & & 1 & 15,76 & & & 1 & 26,77 \\
\hline & & 2 & 16,04 & & & 2 & 27,03 \\
\hline & & 3 & 16,27 & & & 3 & 27,28 \\
\hline & & 6 & 16,77 & & & 6 & 27,89 \\
\hline & & 9 & 17,78 & & & 9 & 28,33 \\
\hline & & 12 & 17,35 & & & 12 & 28,65 \\
\hline & $05: 00$ & 15 & 17,53 & & $06: 15$ & 15 & 28,88 \\
\hline & & & & & & & \\
\hline \multirow[t]{9}{*}{126} & $05: 00$ & 0 & 17,58 & & & & \\
\hline & & 1 & 17,80 & 156 & $06: 15$ & 0 & 28,93 \\
\hline & & 2 & 18,01 & & & 1 & 29,18 \\
\hline & & 3 & 18,23 & & & 2 & 29,45 \\
\hline & & 6 & 18,75 & & & 3 & 29,68 \\
\hline & & 9 & 19,09 & & & 6 & 30,31 \\
\hline & & 12 & 19,35 & & & 9 & 30,76 \\
\hline & $05: 15$ & 15 & 19,55 & & & 12 & 31,08 \\
\hline & & & & & $06: 30$ & 15 & 31,33 \\
\hline \multirow[t]{9}{*}{132} & $05: 15$ & 0 & 19,61 & & & & \\
\hline & & 1 & 19,86 & 162 & $06: 30$ & 0 & 31,39 \\
\hline & & 2 & 20,13 & & & 1 & 31,68 \\
\hline & & 3 & 20,37 & & & 2 & 31,91 \\
\hline & & 6 & 20,96 & & & 3 & 32,16 \\
\hline & & 9 & 21,34 & & & 6 & 32,79 \\
\hline & & 12 & 21,65 & & & 9 & 33,23 \\
\hline & $05: 30$ & 15 & 21,82 & & & 12 & 33,58 \\
\hline & & & & & $06: 45$ & 15 & 33,83 \\
\hline \multirow[t]{13}{*}{138} & $05: 30$ & 0 & 21,87 & & & & \\
\hline & & 1 & 22,11 & & & & \\
\hline & & 2 & 22,37 & 168 & $06: 45$ & 0 & 33,88 \\
\hline & & 3 & 22,61 & & & 1 & 34,11 \\
\hline & & 6 & 23,22 & & & 2 & 34,38 \\
\hline & & 9 & 23,62 & & & 3 & 34,66 \\
\hline & & 12 & 23,91 & & & 6 & 35,26 \\
\hline & $05: 45$ & 15 & 24,13 & & & 9 & 35,71 \\
\hline & & & & & & 12 & 36,05 \\
\hline & & & & & $07: 00$ & 15 & 36,31 \\
\hline & & & & & & & \\
\hline & & & & & & & \\
\hline & & & & & & & \\
\hline
\end{tabular}




\begin{tabular}{|c|c|c|c|c|c|c|c|}
\hline Ensaio: & QS4 & Prof.: & $6,0 \mathrm{~m}$ & Sucção: & $\begin{array}{ll}0 & \mathrm{kPa}\end{array}$ & Folha: & 4 \\
\hline $\begin{array}{c}\text { Tensão } \\
(\mathrm{kPa})\end{array}$ & $\begin{array}{c}\text { Início Carr. } \\
\text { (min) }\end{array}$ & $\begin{array}{r}\text { Tempo } \\
(\mathrm{min})\end{array}$ & $\begin{array}{c}\text { Recalque } \\
\text { (mm) }\end{array}$ & $\begin{array}{c}\text { Tensão } \\
(\mathrm{kPa})\end{array}$ & $\begin{array}{c}\text { Início Carr } \\
\text { (min) }\end{array}$ & $\begin{array}{c}\text { Tempo } \\
\text { (min) }\end{array}$ & $\begin{array}{c}\text { Recalque } \\
(\mathrm{mm})\end{array}$ \\
\hline \multirow[t]{8}{*}{174} & 07:00 & 0 & 36,35 & $1 \mathrm{D}$ & $08: 20$ & 0 & 46,91 \\
\hline & & 1 & 36,62 & & & 1 & 46,90 \\
\hline & & 2 & 36,91 & & & 2 & 46,90 \\
\hline & & 3 & 37,18 & & & 3 & 46,90 \\
\hline & & 6 & 37,84 & & & 6 & 46,90 \\
\hline & & 9 & 38,32 & 120 & $08: 29$ & 9 & 46,89 \\
\hline & & 12 & 38,67 & & & & \\
\hline & 07:15 & 15 & 38,93 & & & & \\
\hline \multirow{9}{*}{180} & & & & & & & \\
\hline & $07: 15$ & 0 & 38,98 & $2 \mathrm{D}$ & $08: 29$ & 0 & 46,45 \\
\hline & & 1 & 39,22 & & & 1 & 46,43 \\
\hline & & 2 & 39,47 & & & 2 & 46,42 \\
\hline & & 3 & 39,73 & & & 3 & 46,41 \\
\hline & & 6 & 40,35 & & & 6 & 46,41 \\
\hline & & 9 & 40,83 & 44 & $08: 38$ & 9 & 46,40 \\
\hline & & 12 & 41,19 & & & & \\
\hline & 07:30 & 15 & 41,45 & & & & \\
\hline \multirow{9}{*}{186} & & & & & & & 1404 \\
\hline & 07:30 & 0 & 41,51 & $3 \mathrm{D}$ & 08:38 & 0 & 44,94 \\
\hline & & 1 & 41,75 & & & 1 & 44,93 \\
\hline & & 2 & 42,01 & & & 2 & 44,92 \\
\hline & & 3 & 42,28 & & & 3 & 44,92 \\
\hline & & 6 & 42,94 & & & 6 & 44,91 \\
\hline & & 9 & 43,44 & 0 & $08: 47$ & 9 & 44,90 \\
\hline & & 12 & 43,82 & & & & \\
\hline & $07: 45$ & 15 & 44,09 & & & & \\
\hline \multirow{9}{*}{192} & & & & & & & \\
\hline & 07:45 & 0 & 44,15 & & & & \\
\hline & & 1 & 44,39 & & & & \\
\hline & & 2 & 44,67 & & & & \\
\hline & & 3 & 44,92 & & & & \\
\hline & & 6 & 45,57 & & & & \\
\hline & & 9 & 46,05 & & & & \\
\hline & & 12 & 46,42 & & & & \\
\hline & 08:00 & 15 & 46,72 & & & & \\
\hline & & & & & & & \\
\hline \multirow{9}{*}{ Estab. } & & & & & & & \\
\hline & 08:00 & 0 & 46,72 & & & & \\
\hline & & 1 & 46,78 & & & & \\
\hline & & 2 & 46,81 & & & & \\
\hline & & 3 & 46,84 & & & & \\
\hline & & 6 & 46,89 & & & & \\
\hline & & 9 & 46,93 & & & & \\
\hline & & 12 & 46,96 & & & & \\
\hline & & 15 & 46,97 & & & & \\
\hline 178 & $08: 20$ & 20 & 46,98 & & & & \\
\hline & & & & & & & \\
\hline & & & & & & & \\
\hline & & & & & & & \\
\hline
\end{tabular}




\begin{tabular}{|c|c|c|c|c|c|c|c|}
\hline \multicolumn{8}{|c|}{ UNIVERSIDADE DE SÃO PAULO } \\
\hline \multicolumn{8}{|c|}{ ESCOLA DE ENGENHARIA DE SÃO CARLOS } \\
\hline \multicolumn{8}{|c|}{ DEPTO. DE GEOTECNIA - CAMPO EXPERIMENTAL DE FUNDAÇÕES } \\
\hline \multicolumn{8}{|c|}{$\begin{array}{l}\text { PROVA DE CARGA ESTÁTICA } \\
\end{array}$} \\
\hline \multicolumn{4}{|c|}{ FRUVADE CF } & \multicolumn{3}{|c|}{ Tipo de Carregamento: } & QML \\
\hline \multicolumn{2}{|c|}{ Profundidade: } & \multicolumn{2}{|l|}{$6,0 \mathrm{~m}$} & \multicolumn{2}{|c|}{ Estado do solo: } & \multicolumn{2}{|c|}{ INUNDADO } \\
\hline $\begin{array}{l}\text { Sucção: } \\
\text { Diâmetro: }\end{array}$ & $\begin{array}{cc}0 & \mathrm{kPa} \\
80\end{array}$ & $\mathrm{~cm}$ & & $\begin{array}{l}\text { Reensaio: } \\
\text { Folha: }\end{array}$ & $\begin{array}{l}\text { NÃO } \\
1\end{array}$ & & \\
\hline $\begin{array}{l}\text { Tensão } \\
\text { (kPa) }\end{array}$ & $\begin{array}{l}\text { Início Carr. } \\
\text { (min) }\end{array}$ & $\begin{array}{c}\text { Tempo } \\
\text { (min) }\end{array}$ & $\begin{array}{c}\text { Recalque } \\
\text { (mm) }\end{array}$ & $\begin{array}{l}\text { Tensão } \\
(\mathrm{kPa})\end{array}$ & $\begin{array}{c}\text { Início Carr. } \\
\text { (min) }\end{array}$ & $\begin{array}{c}\text { Tempo } \\
\text { (min) }\end{array}$ & $\begin{array}{c}\text { Recalque } \\
(\mathrm{mm})\end{array}$ \\
\hline \multirow{8}{*}{10} & $00: 00$ & 0 & 0,36 & 50 & 01:00 & 0 & 2.90 \\
\hline & & 1 & 0,37 & & & 1 & 3,10 \\
\hline & & 2 & 0,37 & & & 2 & 3,18 \\
\hline & & 3 & 0,37 & & & 3 & 3,23 \\
\hline & & 6 & 0,38 & & & 6 & 3,29 \\
\hline & & 9 & 0,38 & & & 9 & 3,34 \\
\hline & & 12 & 0,38 & & & 12 & 3,38 \\
\hline & 00:15 & 15 & 0,38 & & 01:15 & 15 & 3,40 \\
\hline & & & & & & & \\
\hline \multirow[t]{8}{*}{20} & $00: 15$ & 0 & 0,92 & 60 & $01: 15$ & 0 & 3,48 \\
\hline & & 1 & 1,05 & & & 1 & 3,67 \\
\hline & & 2 & 1,06 & & & 2 & 3,75 \\
\hline & & 3 & 1,09 & & & 3 & 3,79 \\
\hline & & 6 & 1,13 & & & 6 & 3,87 \\
\hline & & 9 & 1,14 & & & 9 & 3,91 \\
\hline & & 12 & 1,15 & & & 12 & 3,93 \\
\hline & $\begin{array}{l}00: 30 \\
\end{array}$ & 15 & 1,15 & & \begin{tabular}{l|l}
$01: 30$ \\
\end{tabular} & 15 & 3,95 \\
\hline \multirow{8}{*}{30} & $00: 30$ & 0 & 1.65 & 70 & 01:30 & 0 & 403 \\
\hline & & 1 & 1,84 & & & 1 & 4,16 \\
\hline & & 2 & 1,88 & & & 2 & 4,24 \\
\hline & & 3 & 1,90 & & & 3 & 4,32 \\
\hline & & 6 & 1,95 & & & 6 & 4,39 \\
\hline & & 9 & 1,96 & & & 9 & 4,45 \\
\hline & & 12 & 1,98 & & & 12 & 4,48 \\
\hline & $00: 45$ & 15 & 1,99 & & 01:45 & 15 & 4,53 \\
\hline \multirow{8}{*}{40} & $00: 45$ & 0 & 2.26 & 80 & 01:45 & 0 & 4,59 \\
\hline & & 1 & 2,53 & & & 1 & 4,77 \\
\hline & & 2 & 2,62 & & & 2 & 4,90 \\
\hline & & 3 & 2,62 & & & 3 & 4,99 \\
\hline & & 6 & 2,69 & & & 6 & 5,14 \\
\hline & & 9 & 2,71 & & & 9 & 5,20 \\
\hline & & 12 & 2,76 & & & 12 & 5,25 \\
\hline & 01:00 & 15 & 2,76 & & 02:00 & 15 & 5,29 \\
\hline & & & & & & & \\
\hline & & & & & & & \\
\hline & & & & & & & \\
\hline & & & & & & & \\
\hline & & & & & & & \\
\hline & & & & & & & \\
\hline
\end{tabular}




\begin{tabular}{|c|c|c|c|c|c|c|c|}
\hline Ensaio: & QS5 & Prof.: & $6,0 \mathrm{~m}$ & Sucção: & $\begin{array}{ll}0 & \mathrm{kPa}\end{array}$ & Folha: & 2 \\
\hline $\begin{array}{c}\text { Tensão } \\
(\mathrm{kPa})\end{array}$ & $\begin{array}{c}\text { Início Carr. } \\
\text { (min) }\end{array}$ & $\begin{array}{r}\begin{array}{r}\text { Tempo } \\
(\mathrm{min})\end{array} \\
\end{array}$ & $\begin{array}{c}\begin{array}{c}\text { Recalque } \\
(\mathrm{mm})\end{array} \\
\end{array}$ & $\begin{array}{c}\text { Tensão } \\
(\mathrm{kPa})\end{array}$ & $\begin{array}{c}\text { Início Carr. } \\
\text { (min) }\end{array}$ & $\begin{array}{c}\text { Tempo } \\
\text { (min) }\end{array}$ & $\begin{array}{c}\text { Recalque } \\
(\mathrm{mm})\end{array}$ \\
\hline & & & & & & & \\
\hline \multirow[t]{8}{*}{90} & $02: 00$ & 0 & 5,36 & 140 & $03: 15$ & 0 & 14,32 \\
\hline & & 1 & 5,57 & & & 1 & 14,65 \\
\hline & & 2 & 5,78 & & & 2 & 15,00 \\
\hline & & 3 & 5,87 & & & 3 & 15,40 \\
\hline & & 6 & 6,07 & & & 6 & 15,90 \\
\hline & & 9 & 6,21 & & & 9 & 16,35 \\
\hline & & 12 & 6,32 & & & 12 & 16,67 \\
\hline & $02: 15$ & 15 & 6,36 & & $03: 30$ & 15 & 16,92 \\
\hline & & & & & & & \\
\hline \multirow[t]{8}{*}{100} & $02: 15$ & 0 & 6,41 & 150 & $03: 30$ & 0 & 17,01 \\
\hline & & 1 & 6,62 & & & 1 & 17,47 \\
\hline & & 2 & 6,83 & & & 2 & 17,94 \\
\hline & & 3 & 6,99 & & & 3 & 18,20 \\
\hline & & 6 & 7,23 & & & 6 & 18,97 \\
\hline & & 9 & 7,45 & & & 9 & 19,47 \\
\hline & & 12 & 7,58 & & & 12 & 19,81 \\
\hline & $02: 30$ & 15 & 7,71 & & $03: 45$ & 15 & 20,08 \\
\hline & & & & & & & \\
\hline \multirow[t]{8}{*}{110} & $02: 30$ & 0 & 7,85 & 160 & $03: 45$ & 0 & 20,18 \\
\hline & & 1 & 8,17 & & & 1 & 20,76 \\
\hline & & 2 & 8,41 & & & 2 & 21,09 \\
\hline & & 3 & 8,62 & & & 3 & 21,44 \\
\hline & & 6 & 9,06 & & & 6 & 22,19 \\
\hline & & 9 & 9,28 & & & 9 & 22,74 \\
\hline & & 12 & 9,44 & & & 12 & 23,14 \\
\hline & $02: 45$ & 15 & 9,56 & & $04: 00$ & 15 & 23,43 \\
\hline \multirow[t]{8}{*}{120} & $02: 45$ & 0 & 9,65 & 170 & $04: 00$ & 0 & 23,64 \\
\hline & & 1 & 10,00 & & & 1 & 24,02 \\
\hline & & 2 & 10,29 & & & 2 & 24,44 \\
\hline & & 3 & 10,55 & & & 3 & 24,74 \\
\hline & & 6 & 11,09 & & & 6 & 25,55 \\
\hline & & 9 & 11,39 & & & 9 & 26,01 \\
\hline & & 12 & 11,58 & & & 12 & 26,44 \\
\hline & 03:00 & 15 & 11,77 & & $04: 15$ & 15 & 26,75 \\
\hline \multirow[t]{8}{*}{130} & 03:00 & 0 & 11,88 & 180 & $04: 15$ & 0 & 26,88 \\
\hline & & 1 & 12,26 & & & 1 & 27,24 \\
\hline & & 2 & 12,59 & & & 2 & 27,73 \\
\hline & & 3 & 12,85 & & & 3 & 28,10 \\
\hline & & 6 & 13,37 & & & 6 & 29,05 \\
\hline & & 9 & 13,71 & & & 9 & 29,67 \\
\hline & & 12 & 13,98 & & & 12 & 30,14 \\
\hline & $03: 15$ & 15 & 14,19 & & $04: 30$ & 15 & 30,51 \\
\hline & & & & & & & \\
\hline & & & & & & & \\
\hline & & & & & & & \\
\hline & & & & & & & \\
\hline & & & & & & & \\
\hline
\end{tabular}




\begin{tabular}{|c|c|c|c|c|c|c|c|}
\hline Ensaio: & QS5 & Prof.: & $6,0 \mathrm{~m}$ & Suç̧̃ão: & $\begin{array}{ll}0 & \mathrm{kPa}\end{array}$ & Folha: & $\overline{3}$ \\
\hline $\begin{array}{c}\text { Tensão } \\
(\mathrm{kPa})\end{array}$ & $\begin{array}{c}\text { Início Carr. } \\
\text { (min) }\end{array}$ & $\begin{array}{c}\text { Tempo } \\
(\mathrm{min})\end{array}$ & $\begin{array}{c}\text { Recalque } \\
(\mathrm{mm})\end{array}$ & $\begin{array}{c}\text { Tensão } \\
(\mathrm{kPa})\end{array}$ & $\begin{array}{c}\text { Início Carr. } \\
\text { (min) }\end{array}$ & $\begin{array}{c}\text { Tempo } \\
\text { (min) }\end{array}$ & $\begin{array}{c}\text { Recalque } \\
(\mathrm{mm})\end{array}$ \\
\hline & & & & & & & \\
\hline \multirow[t]{8}{*}{190} & $04: 30$ & 0 & 30,66 & $1 \mathrm{D}$ & $05: 45$ & 0 & 44,90 \\
\hline & & 1 & 31,27 & & & 1 & 44,90 \\
\hline & & 2 & 31,81 & & & 2 & 44,89 \\
\hline & & 3 & 32,29 & & & 3 & 44,89 \\
\hline & & 6 & 33,24 & & & 6 & 44,88 \\
\hline & & 9 & 33,89 & & & 9 & 44,87 \\
\hline & & 12 & 34,41 & & & 12 & 44,87 \\
\hline & $04: 45$ & 15 & 34,81 & 118 & 06:00 & 15 & 44,87 \\
\hline \multirow[t]{8}{*}{200} & $04: 45$ & 0 & 34,95 & $2 \mathrm{D}$ & 06:00 & 0 & 44,63 \\
\hline & & 1 & 35,53 & & & 1 & 44,60 \\
\hline & & 2 & 36,04 & & & 2 & 44,60 \\
\hline & & 3 & 36,55 & & & 3 & 44,60 \\
\hline & & 6 & 37,67 & & & 6 & 44,59 \\
\hline & & 9 & $\begin{array}{l}38,48 \\
\end{array}$ & & & 9 & 44,57 \\
\hline & & 12 & 39,04 & & & 12 & 44,56 \\
\hline & 05:00 & 15 & 39,45 & 58 & $06: 15$ & 15 & 44,56 \\
\hline & & & & & & & \\
\hline \multirow[t]{8}{*}{210} & 05:00 & 0 & 39,66 & & & & \\
\hline & & 1 & 40,16 & & & & \\
\hline & & 2 & 40,82 & & & & \\
\hline & & 3 & 41,30 & & & & \\
\hline & & 6 & 42,51 & & & & \\
\hline & & 9 & 43,35 & & & & \\
\hline & & 12 & 44,01 & & & & \\
\hline & $05: 15$ & 15 & 44,57 & & & & \\
\hline & & & & & & & \\
\hline \multirow[t]{10}{*}{ Estab. } & $05: 15$ & 0 & 44,57 & & & & \\
\hline & & 1 & 44,64 & & & & \\
\hline & & 2 & 44,69 & & & & \\
\hline & & 3 & 44,74 & & & & \\
\hline & & 6 & 44,82 & & & & \\
\hline & & 9 & 44,85 & & & & \\
\hline & & 12 & 44,87 & & & & \\
\hline & & 15 & 44,90 & & & & \\
\hline & & 20 & 44,92 & & & & \\
\hline & & 25 & 44,93 & & & & \\
\hline 192 & $05: 45$ & 30 & 44,94 & & & & \\
\hline & & & & & & & \\
\hline & & & & & & & \\
\hline & & & & & & & \\
\hline & & & & & & & \\
\hline & & & & & & & \\
\hline & & & & & & & \\
\hline & & & & & & & \\
\hline & & & & & & & \\
\hline & & & & & & & \\
\hline & & & & & & & \\
\hline & & & & & & & \\
\hline
\end{tabular}




\begin{tabular}{|c|c|c|c|c|c|c|c|}
\hline \multicolumn{8}{|c|}{ UNIVERSIDADE DE SÃO PAULO } \\
\hline \multicolumn{8}{|c|}{ ESCOLA DE ENGENHARIA DE SÃO CARLOS } \\
\hline \multicolumn{8}{|c|}{ DEPTO. DE GEOTECNIA - CAMPO EXPERIMENTAL DE FUNDAÇÕES } \\
\hline \multicolumn{8}{|c|}{$\begin{array}{l}\text { PROVA DE CARGA ESTÁTICA } \\
\end{array}$} \\
\hline \multirow{2}{*}{\multicolumn{2}{|c|}{$\begin{array}{l}\text { Ensaio: Q6 } \\
\text { Profundidade: }\end{array}$}} & & \multicolumn{3}{|c|}{ Tipo de Carregamento: } & QML \\
\hline & & $6,0 \mathrm{~m}$ & & \multicolumn{2}{|c|}{ Estado do solo: } & \multicolumn{2}{|c|}{ NATURAL } \\
\hline $\begin{array}{l}\text { Sucção: } \\
\text { Diâmetro: }\end{array}$ & $\begin{array}{c}12 \mathrm{kPa} \\
80\end{array}$ & $\mathrm{~cm}$ & & $\begin{array}{l}\text { Reensaio: } \\
\text { Folha: }\end{array}$ & $\begin{array}{l}\text { NÃO } \\
1\end{array}$ & & \\
\hline $\begin{array}{l}\text { Tensão } \\
(\mathrm{kPa})\end{array}$ & $\begin{array}{l}\text { Início Carr. } \\
\text { (min) }\end{array}$ & $\begin{array}{c}\text { Tempo } \\
\text { (min) }\end{array}$ & $\begin{array}{l}\text { Recalque } \\
\text { (mm) }\end{array}$ & $\begin{array}{l}\text { Tensão } \\
(\mathrm{kPa})\end{array}$ & $\begin{array}{c}\text { Início Carr. } \\
\text { (min) }\end{array}$ & $\begin{array}{c}\text { Tempo } \\
\text { (min) }\end{array}$ & $\begin{array}{c}\text { Recalque } \\
(\mathrm{mm})\end{array}$ \\
\hline \multirow[t]{8}{*}{12} & 00:00 & 0 & 0,32 & 60 & 01:00 & 0 & 4,20 \\
\hline & & 1 & 0,39 & & & 1 & 4,59 \\
\hline & & 2 & 0,40 & & & 2 & 4,71 \\
\hline & & 3 & 0,41 & & & 3 & 4,78 \\
\hline & & 6 & 0,42 & & & 6 & 4,88 \\
\hline & & 9 & 0,43 & & & 9 & 4,93 \\
\hline & & 12 & 0,43 & & & 12 & 4,96 \\
\hline & 00:15 & 15 & 0,44 & & 01:15 & 15 & 4,98 \\
\hline & & & & & & & \\
\hline \multirow[t]{8}{*}{24} & $00: 15$ & 0 & 1,24 & 72 & $01: 15$ & 0 & 5,12 \\
\hline & & 1 & 1,43 & & & 1 & 5,44 \\
\hline & & 2 & 1,51 & & & 2 & 5,58 \\
\hline & & 3 & 1,55 & & & 3 & 5,66 \\
\hline & & 6 & 1,59 & & & 6 & 5,78 \\
\hline & & 9 & 1,61 & & & 9 & 5,84 \\
\hline & & 12 & 1,66 & & & 12 & 5,87 \\
\hline & 00:30 & 15 & 1,67 & & 01:30 & 15 & 5,91 \\
\hline \multirow[t]{8}{*}{36} & $00: 30$ & 0 & 2,32 & 84 & 01:30 & 0 & 6,06 \\
\hline & & 1 & 2,67 & & & 1 & 6,42 \\
\hline & & 2 & 2,75 & & & 2 & 6,59 \\
\hline & & 3 & 2,79 & & & 3 & 6,67 \\
\hline & & 6 & 2,86 & & & 6 & 6,81 \\
\hline & & 9 & 2,90 & & & 9 & 6,91 \\
\hline & & 12 & 2,92 & & & 12 & 6,95 \\
\hline & $00: 45$ & 15 & 2,94 & & 01:45 & 15 & 6,97 \\
\hline & & & & & & & \\
\hline \multirow[t]{8}{*}{48} & $00: 45$ & 0 & 3,26 & 96 & 01:45 & 0 & 7,14 \\
\hline & & 1 & 3,67 & & & 1 & 7,56 \\
\hline & & 2 & 3,76 & & & 2 & 7,78 \\
\hline & & 3 & 3,82 & & & 3 & 7,92 \\
\hline & & 6 & 3,90 & & & 6 & 8,12 \\
\hline & & 9 & 3,94 & & & 9 & 8,22 \\
\hline & & 12 & 3,98 & & & 12 & 8,28 \\
\hline & 01:00 & 15 & 3,99 & & 02:00 & 15 & 8,34 \\
\hline & & & & & & & \\
\hline & & & & & & & \\
\hline & & & & & & & \\
\hline & & & & & & & \\
\hline & & & & & & & \\
\hline
\end{tabular}




\begin{tabular}{|c|c|c|c|c|c|c|c|}
\hline Ensaio: & Q6 & Prof.: & $6,0 \mathrm{~m}$ & Sucção: & $12 \mathrm{kPa}$ & Folha: & 2 \\
\hline $\begin{array}{c}\text { Tensão } \\
(\mathrm{kPa})\end{array}$ & $\begin{array}{c}\text { Início Carr. } \\
\text { (min) }\end{array}$ & $\begin{array}{r}\text { Tempo } \\
(\mathrm{min})\end{array}$ & $\begin{array}{c}\text { Recalque } \\
\text { (mm) }\end{array}$ & $\begin{array}{c}\text { Tensão } \\
(\mathrm{kPa})\end{array}$ & $\begin{array}{c}\text { Início Carr } \\
\text { (min) }\end{array}$ & $\begin{array}{c}\text { Tempo } \\
\text { (min) }\end{array}$ & $\begin{array}{c}\text { Recalque } \\
\text { (mm) }\end{array}$ \\
\hline \multirow{8}{*}{108} & 02:00 & 0 & 8,51 & 168 & $03: 15$ & 0 & 2061 \\
\hline & & 1 & 9,02 & & & 1 & 21,22 \\
\hline & & 2 & 9,32 & & & 2 & 21,76 \\
\hline & & 3 & 9,51 & & & 3 & 22,19 \\
\hline & & 6 & 9,75 & & & 6 & 22,85 \\
\hline & & 9 & 9,89 & & & 9 & 23,20 \\
\hline & & 12 & 9,98 & & & 12 & 23,46 \\
\hline & 02:15 & 15 & 10,05 & & 03:30 & 15 & 23,63 \\
\hline \multirow[t]{8}{*}{120} & $02: 15$ & 0 & 10,25 & 180 & 03:30 & 0 & 23,74 \\
\hline & & 1 & 10,97 & & & 1 & 24,30 \\
\hline & & 2 & 11,41 & & & 2 & 24,86 \\
\hline & & 3 & 11,59 & & & 3 & 25,26 \\
\hline & & 6 & 11,97 & & & 6 & 26,00 \\
\hline & & 9 & 12,17 & & & 9 & 26,46 \\
\hline & & 12 & 12,29 & & & 12 & 26,78 \\
\hline & 02:30 & 15 & 12,36 & & $03: 45$ & 15 & 26,96 \\
\hline \multirow[t]{8}{*}{132} & $02: 30$ & 0 & 12,54 & 192 & $03: 45$ & 0 & 27,08 \\
\hline & & 1 & 13,21 & & & 1 & 27,77 \\
\hline & & 2 & 13,62 & & & 2 & 28,43 \\
\hline & & 3 & 13,90 & & & 3 & 28,92 \\
\hline & & 6 & 14,37 & & & 6 & 29,77 \\
\hline & & 9 & 14,60 & & & 9 & 30,27 \\
\hline & & 12 & 14,77 & & & 12 & 30,59 \\
\hline & $02: 45$ & 15 & 14,89 & & 04:00 & 15 & 30,80 \\
\hline \multirow[t]{8}{*}{144} & $02: 45$ & 0 & 15,04 & 204 & 04:00 & 0 & 30,93 \\
\hline & & 1 & 15,76 & & & 1 & 31,51 \\
\hline & & 2 & 16,01 & & & 2 & 32,11 \\
\hline & & 3 & 16,32 & & & 3 & 32,58 \\
\hline & & 6 & 16,87 & & & 6 & 33,48 \\
\hline & & 9 & 17,12 & & & 9 & 34,01 \\
\hline & & 12 & 17,31 & & & 12 & 34,40 \\
\hline & 03:00 & 15 & 17,42 & & $04: 15$ & 15 & 34,65 \\
\hline \multirow[t]{8}{*}{156} & 03:00 & 0 & 17,61 & 216 & $04: 15$ & 0 & 34,78 \\
\hline & & 1 & 18,27 & & & 1 & 35,36 \\
\hline & & 2 & 18,80 & & & 2 & 35,94 \\
\hline & & 3 & 19,16 & & & 3 & 36,47 \\
\hline & & 6 & 19,77 & & & 6 & 37,45 \\
\hline & & 9 & 20,12 & & & 9 & 38,00 \\
\hline & & 12 & 20,36 & & & 12 & 38,39 \\
\hline & $03: 15$ & 15 & 20,50 & & $04: 30$ & 15 & 38,70 \\
\hline & & & & & & & \\
\hline & & & & & & & \\
\hline & & & & & & & \\
\hline & & & & & & & \\
\hline & & & & & & & \\
\hline
\end{tabular}




\begin{tabular}{|c|c|c|c|c|c|c|c|}
\hline Ensaio: & $\overline{\mathrm{Q} 6}$ & Prof.: & $6,0 \mathrm{~m}$ & Suç̧ão: & $12 \mathrm{kPa}$ & Folha: & 3 \\
\hline $\begin{array}{c}\text { Tensão } \\
(\mathrm{kPa})\end{array}$ & $\begin{array}{c}\text { Início Carr. } \\
\text { (min) }\end{array}$ & $\begin{array}{r}\text { Tempo } \\
(\mathrm{min})\end{array}$ & $\begin{array}{c}\text { Recalque } \\
(\mathrm{mm})\end{array}$ & $\begin{array}{c}\text { Tensão } \\
(\mathrm{kPa})\end{array}$ & $\begin{array}{c}\text { Início Carr. } \\
\text { (min) }\end{array}$ & $\begin{array}{c}\text { Tempo } \\
\text { (min) }\end{array}$ & $\begin{array}{c}\text { Recalque } \\
(\mathrm{mm})\end{array}$ \\
\hline & & & & & & & \\
\hline \multirow[t]{8}{*}{228} & $04: 30$ & 0 & 38,82 & $2 \mathrm{D}$ & $05: 48$ & 0 & 47,53 \\
\hline & & 1 & 39,42 & & & 1 & 47,53 \\
\hline & & 2 & 39,87 & & & 2 & 47,53 \\
\hline & & 3 & 40,46 & & & 3 & 47,53 \\
\hline & & 6 & 41,46 & & & 6 & 47,53 \\
\hline & & 9 & 42,07 & & & 9 & 47,53 \\
\hline & & 12 & 42,47 & & & 12 & 47,53 \\
\hline & $04: 45$ & 15 & 42,74 & 0 & 06:03 & 15 & 47,53 \\
\hline \multirow{8}{*}{240} & $04: 45$ & 0 & 42.87 & & & & \\
\hline & & 1 & 43,36 & & & & \\
\hline & & 2 & 43,86 & & & & \\
\hline & & 3 & 44,31 & & & & \\
\hline & & 6 & 45,33 & & & & \\
\hline & & 9 & 45,96 & & & & \\
\hline & & 12 & 46,41 & & & & \\
\hline & 05:00 & 15 & 46,64 & & & & \\
\hline & & & & & & & \\
\hline \multirow[t]{8}{*}{252} & $05: 00$ & 0 & 47,03 & & & & \\
\hline & & 1 & 47,41 & & & & \\
\hline & & 2 & 47,74 & & & & \\
\hline & & 3 & 48,21 & & & & \\
\hline & & 6 & 47,53 & & & & \\
\hline & & 9 & 47,53 & & & & \\
\hline & & 12 & 47,53 & & & & \\
\hline & $05: 15$ & 15 & 47,53 & & & & \\
\hline & & & & & & & \\
\hline \multirow[t]{8}{*}{ Estab. } & $05: 15$ & 0 & 47,53 & & & & \\
\hline & & 1 & 47,53 & & & & \\
\hline & & 2 & 47,53 & & & & \\
\hline & & 3 & 47,53 & & & & \\
\hline & & 6 & 47,53 & & & & \\
\hline & & 9 & 47,53 & & & & \\
\hline & & 12 & 47,53 & & & & \\
\hline & & 15 & 47,53 & & & & \\
\hline \multirow[t]{2}{*}{238} & $05: 33$ & 18 & 47,53 & & & & \\
\hline & & & & & & & \\
\hline \multirow[t]{7}{*}{$1 \mathrm{D}$} & $05: 33$ & 0 & 47,53 & & & & \\
\hline & & 1 & 47,53 & & & & \\
\hline & & 2 & 47,53 & & & & \\
\hline & & 3 & 47,53 & & & & \\
\hline & & 6 & 47,53 & & & & \\
\hline & & 9 & 47,53 & & & & \\
\hline & & 12 & 47,53 & & & & \\
\hline 85 & $05: 48$ & 15 & 47,53 & & & & \\
\hline & & & & & & & \\
\hline & & & & & & & \\
\hline & & & & & & & \\
\hline & & & & & & & \\
\hline
\end{tabular}




\begin{tabular}{|c|c|c|c|c|c|c|c|}
\hline \multicolumn{8}{|c|}{ UNIVERSIDADE DE SÃO PAULO } \\
\hline \multicolumn{8}{|c|}{$\begin{array}{c}\text { ESCOLA DE ENGENHARIA DE SÃO CARLOS } \\
\end{array}$} \\
\hline \multicolumn{8}{|c|}{ DEPTO. DE GEOTECNIA - CAMPO EXPERIMENTAL DE FUNDAÇÕES } \\
\hline \multicolumn{8}{|c|}{ PROVA DE CARGA ESTÁTICA } \\
\hline \multirow{2}{*}{\multicolumn{2}{|c|}{$\begin{array}{l}\text { Ensaio: Q7 } \\
\text { Profundidade: }\end{array}$}} & & \multicolumn{3}{|c|}{ Tipo de Carregamento: } & QML \\
\hline & & $6 \mathrm{~m}$ & & \multicolumn{2}{|c|}{ Estado do solo: } & \multicolumn{2}{|c|}{ NATURAL } \\
\hline Sucção: & $15 \mathrm{kPa}$ & & & Reensaio: & NÃO & & \\
\hline Diâmetro: & 80 & $\mathrm{~cm}$ & & Folha: & 1 & & \\
\hline $\begin{array}{l}\text { Tensão } \\
(\mathrm{kPa})\end{array}$ & $\begin{array}{l}\text { Início Carr. } \\
\text { (min) }\end{array}$ & $\begin{array}{c}\text { Tempo } \\
\text { (min) }\end{array}$ & $\begin{array}{l}\text { Recalque } \\
\text { (mm) }\end{array}$ & $\begin{array}{l}\text { Tensão } \\
(\mathrm{kPa})\end{array}$ & $\begin{array}{c}\text { Início Carr. } \\
\text { (min) }\end{array}$ & $\begin{array}{c}\text { Tempo } \\
\text { (min) }\end{array}$ & $\begin{array}{l}\text { Recalque } \\
\text { (mm) }\end{array}$ \\
\hline & & & & & & & \\
\hline \multirow[t]{8}{*}{12} & 00:00 & 0 & 0,35 & 60 & 01:00 & 0 & 2,63 \\
\hline & & 1 & 0,37 & & & 1 & 2,87 \\
\hline & & 2 & 0,37 & & & 2 & 2,93 \\
\hline & & 3 & 0,37 & & & 3 & 2,93 \\
\hline & & 6 & 0,37 & & & 6 & 3,02 \\
\hline & & 9 & 0,37 & & & 9 & 3,04 \\
\hline & & 12 & 0,37 & & & 12 & 3,05 \\
\hline & 00:15 & 15 & 0,37 & & 01:15 & 15 & 3,06 \\
\hline & & & & & & & \\
\hline \multirow[t]{8}{*}{24} & $00: 15$ & 0 & 0,73 & 72 & $01: 15$ & 0 & 3,21 \\
\hline & & 1 & 0,76 & & & 1 & 3,45 \\
\hline & & 2 & 0,77 & & & 2 & 3,52 \\
\hline & & 3 & 0,81 & & & 3 & 3,56 \\
\hline & & 6 & 0,81 & & & 6 & 3,62 \\
\hline & & 9 & 0,82 & & & 9 & 3,66 \\
\hline & & 12 & 0,82 & & & 12 & 3,69 \\
\hline & 00:30 & 15 & 0,83 & & 01:30 & 15 & 3,71 \\
\hline \multirow{8}{*}{36} & 00:30 & 0 & 1,34 & 84 & 01:30 & 0 & 3,86 \\
\hline & 00.00 & 1 & $\frac{1,04}{1,50}$ & 04 & 01.50 & 1 & 4,08 \\
\hline & & 2 & 1,52 & & & 2 & 4,14 \\
\hline & & 3 & 1,57 & & & 3 & 4,19 \\
\hline & & 6 & 1,60 & & & 6 & 4,28 \\
\hline & & 9 & 1,61 & & & 9 & 4,35 \\
\hline & & 12 & 1,63 & & & 12 & 4,37 \\
\hline & $00: 45$ & 15 & 1,66 & & 01:45 & 15 & 4,37 \\
\hline \multirow[t]{8}{*}{48} & $00: 45$ & 0 & 2,01 & 96 & 01:45 & 0 & 4,47 \\
\hline & & 1 & 2,21 & & & 1 & 4,73 \\
\hline & & 2 & 2,25 & & & 2 & 4,81 \\
\hline & & 3 & 2,30 & & & 3 & 4,87 \\
\hline & & 6 & 2,31 & & & 6 & 4,98 \\
\hline & & 9 & 2,37 & & & 9 & 5,04 \\
\hline & & 12 & 2,38 & & & 12 & 5,06 \\
\hline & 01:00 & 15 & 2,39 & & 02:00 & 15 & 5,08 \\
\hline & & & & & & & \\
\hline & & & & & & & \\
\hline & & & & & & & \\
\hline & & & & & & & \\
\hline & & & & & & & \\
\hline & & & & & & & \\
\hline
\end{tabular}




\begin{tabular}{|c|c|c|c|c|c|c|c|}
\hline Ensaio: & Q7 & Prof.: & $6 \mathrm{~m}$ & Sucção: & $15 \mathrm{kPa}$ & Folha: & 2 \\
\hline $\begin{array}{c}\text { Tensão } \\
(\mathrm{kPa})\end{array}$ & $\begin{array}{c}\text { Início Carr. } \\
\text { (min) }\end{array}$ & $\begin{array}{c}\text { Tempo } \\
(\mathrm{min})\end{array}$ & $\begin{array}{c}\text { Recalque } \\
(\mathrm{mm})\end{array}$ & $\begin{array}{c}\text { Tensão } \\
(\mathrm{kPa})\end{array}$ & $\begin{array}{c}\text { Início Carr. } \\
\text { (min) }\end{array}$ & $\begin{array}{c}\text { Tempo } \\
\text { (min) }\end{array}$ & $\begin{array}{c}\text { Recalque } \\
(\mathrm{mm})\end{array}$ \\
\hline \multirow{8}{*}{108} & $02 \cdot 00$ & 0 & & 160 & $02 \cdot 11$ & 0 & \\
\hline & & 1 & 5,46 & & & 1 & 10,79 \\
\hline & & 2 & 5,59 & & & 2 & 11,06 \\
\hline & & 3 & 5,66 & & & 3 & 11,25 \\
\hline & & 6 & 5,81 & & & 6 & 11,62 \\
\hline & & 9 & 5,87 & & & 9 & 11,83 \\
\hline & & 12 & 5,93 & & & 12 & 11,96 \\
\hline & $02: 15$ & 15 & 5,97 & & 03:30 & 15 & 12,06 \\
\hline \multirow{8}{*}{120} & $02: 15$ & 0 & 6.03 & 180 & 03:30 & 0 & 12.14 \\
\hline & & 1 & 6,31 & & & 1 & 12,44 \\
\hline & & 2 & 6,46 & & & 2 & 12,78 \\
\hline & & 3 & 6,54 & & & 3 & 13,02 \\
\hline & & 6 & 6,70 & & & 6 & 13,42 \\
\hline & & 9 & 6,78 & & & 9 & 13,67 \\
\hline & & 12 & 6,84 & & & 12 & 13,85 \\
\hline & 02:30 & 15 & 6,85 & & 03:45 & 15 & 13,94 \\
\hline \multirow{9}{*}{132} & & & & & & & \\
\hline & $02: 30$ & 0 & 6,98 & 192 & $03: 45$ & 0 & 14,01 \\
\hline & & 1 & 7,27 & & & 1 & 14,42 \\
\hline & & 2 & 7,43 & & & 2 & 14,82 \\
\hline & & 3 & 7,53 & & & 3 & 15,13 \\
\hline & & 6 & 7,70 & & & 6 & 15,67 \\
\hline & & 9 & 7,80 & & & 9 & 15,97 \\
\hline & & 12 & 7,86 & & & 12 & 16,17 \\
\hline & $02: 45$ & 15 & 7,91 & & 04:00 & 15 & 16,29 \\
\hline \multirow[t]{8}{*}{144} & $02: 45$ & 0 & 7,96 & 204 & 04:00 & 0 & 16,35 \\
\hline & & 1 & 8,19 & & & 1 & 16,72 \\
\hline & & 2 & 8,38 & & & 2 & 17,12 \\
\hline & & 3 & 8,50 & & & 3 & 17,48 \\
\hline & & 6 & 8,72 & & & 6 & 18,05 \\
\hline & & 9 & 8,84 & & & 9 & 18,36 \\
\hline & & 12 & 8,92 & & & 12 & 18,59 \\
\hline & 03:00 & 15 & 8,97 & & $04: 15$ & 15 & 18,76 \\
\hline \multirow{8}{*}{156} & 03:00 & 0 & 9,04 & 216 & $04: 15$ & 0 & 18.87 \\
\hline & & 1 & 9,37 & & & 1 & 19,24 \\
\hline & & 2 & 9,62 & & & 2 & 19,65 \\
\hline & & 3 & 9,78 & & & 3 & 20,00 \\
\hline & & 6 & 10,08 & & & 6 & 20,64 \\
\hline & & 9 & 10,25 & & & 9 & 21,03 \\
\hline & & 12 & 10,37 & & & 12 & 21,28 \\
\hline & 03:15 & 15 & 10,43 & & 04:30 & 15 & 21,47 \\
\hline & & & & & & & \\
\hline & & & & & & & \\
\hline & & & & & & & \\
\hline & & & & & & & \\
\hline & & & & & & & \\
\hline
\end{tabular}




\begin{tabular}{|c|c|c|c|c|c|c|c|}
\hline Ensaio: & Q7 & Prof.: & $6 \mathrm{~m}$ & Sucção: & $15 \mathrm{kPa}$ & Folha: & 3 \\
\hline $\begin{array}{c}\text { Tensão } \\
(\mathrm{kPa})\end{array}$ & $\begin{array}{c}\text { Início Carr. } \\
\text { (min) }\end{array}$ & $\begin{array}{c}\text { Tempo } \\
(\mathrm{min})\end{array}$ & $\begin{array}{c}\text { Recalque } \\
(\mathrm{mm})\end{array}$ & $\begin{array}{c}\text { Tensão } \\
(\mathrm{kPa})\end{array}$ & $\begin{array}{c}\text { Início Carr } \\
\text { (min) }\end{array}$ & $\begin{array}{c}\text { Tempo } \\
\text { (min) }\end{array}$ & $\begin{array}{c}\text { Recalque } \\
(\mathrm{mm})\end{array}$ \\
\hline \multirow{8}{*}{228} & $04: 30$ & 0 & 21,53 & 288 & $05 \cdot 45$ & 0 & 3886 \\
\hline & & 1 & 21,97 & & & 1 & 39,39 \\
\hline & & 2 & 22,38 & & & 2 & 39,92 \\
\hline & & 3 & 22,74 & & & 3 & 40,40 \\
\hline & & 6 & 23,48 & & & 6 & 40,96 \\
\hline & & 9 & 23,92 & & & 9 & 42,14 \\
\hline & & 12 & 24,21 & & & 12 & 42,60 \\
\hline & $04: 45$ & 15 & 24,42 & & 06:00 & 15 & 42,93 \\
\hline \multirow[t]{8}{*}{240} & $04: 45$ & 0 & 24,49 & 300 & 06:00 & 0 & 43,04 \\
\hline & & 1 & 24,94 & & & 1 & 43,48 \\
\hline & & 2 & 25,43 & & & 2 & 44,04 \\
\hline & & 3 & 25,85 & & & 3 & 44,51 \\
\hline & & 6 & 26,65 & & & 6 & 45,67 \\
\hline & & 9 & 27,13 & & & 9 & 46,40 \\
\hline & & 12 & 27,45 & & & 12 & 46,86 \\
\hline & 05:00 & 15 & 27,67 & & $06: 15$ & 15 & 47,22 \\
\hline \multirow[t]{9}{*}{252} & 05:00 & 0 & 27,78 & Estab. & $06: 15$ & 0 & 47,22 \\
\hline & & 1 & 28,20 & & & 1 & 47,29 \\
\hline & & 2 & 28,64 & & & 2 & 47,34 \\
\hline & & 3 & 29,04 & & & 3 & 47,37 \\
\hline & & 6 & 29,89 & & & 6 & 47,44 \\
\hline & & 9 & 30,38 & & & 9 & 47,49 \\
\hline & & 12 & 30,77 & & & 12 & 47,54 \\
\hline & 05:15 & 15 & 31,01 & & & 15 & 47,55 \\
\hline & & & & & & 18 & 47,57 \\
\hline \multirow[t]{9}{*}{264} & 05:15 & 0 & 31,09 & 286 & $06: 36$ & 21 & 47,58 \\
\hline & & 1 & 31,55 & & & & \\
\hline & & 2 & 32,10 & $1 \mathrm{D}$ & $06: 36$ & 0 & 47,21 \\
\hline & & 3 & 32,52 & & & 1 & 47,19 \\
\hline & & 6 & 33,48 & & & 2 & 47,18 \\
\hline & & 9 & 34,08 & & & 3 & 47,18 \\
\hline & & 12 & 34,47 & & & 6 & 47,17 \\
\hline & $05: 30$ & 15 & 34,77 & & & 9 & 47,16 \\
\hline & & & & & & 12 & 47,16 \\
\hline \multirow[t]{8}{*}{276} & $05: 30$ & 0 & 34,85 & 138 & $06: 51$ & 15 & 47,16 \\
\hline & & 1 & 35,35 & & & & \\
\hline & & 2 & 35,82 & & & & \\
\hline & & 3 & 36,33 & & & & \\
\hline & & 6 & 37,37 & & & & \\
\hline & & 9 & 38,02 & & & & \\
\hline & & 12 & 38,47 & & & & \\
\hline & $05: 45$ & 15 & 38,78 & & & & \\
\hline & & & & & & & \\
\hline & & & & & & & \\
\hline & & & & & & & \\
\hline & & & & & & & \\
\hline & & & & & & & \\
\hline
\end{tabular}


APÊNDICE B - Coeficientes de adensamento 
Coeficientes de adensamento - Ensaios de Machado (1995)

\begin{tabular}{|c|c|c|c|c|c|}
\hline \multicolumn{3}{|c|}{ SUCÇÃO = 0 kPa } & \multicolumn{3}{|c|}{ SUCÇÃO = $60 \mathrm{kPa}$} \\
\hline Tensão (kPa) & $t_{90}(\mathrm{~min})$ & $\mathrm{c}_{\mathrm{v}}^{*}\left(\mathrm{~cm}^{2} / \mathrm{s}\right)$ & Tensão (kPa) & $t_{90}(\mathrm{~min})$ & $\mathrm{c}_{\mathrm{v}}{ }^{*}\left(\mathrm{~cm}^{2} / \mathrm{s}\right)$ \\
\hline 19,8 & 0,1020 & 0,22 & 20,6 & 0,0900 & 0,25 \\
\hline 39,6 & 0,0900 & 0,24 & 41,2 & 0,1024 & $\mathbf{0 , 2 1}$ \\
\hline 79,2 & 0,0960 & 0,23 & 82,4 & 0,1444 & 0,15 \\
\hline 158,5 & 0,0900 & 0,24 & 164,8 & 0,1764 & 0,12 \\
\hline 317 & 0,0900 & 0,23 & 329,6 & 0,0841 & 0,25 \\
\hline 634 & 0,0841 & 0,24 & & & \\
\hline 1268 & 0,0900 & 0,22 & & & \\
\hline \multicolumn{3}{|c|}{ Média } & \multicolumn{3}{|c|}{ Média } \\
\hline \multicolumn{3}{|c|}{ Desv. Pad. } & \multicolumn{3}{|c|}{ Desv. Pad. } \\
\hline \multicolumn{3}{|c|}{$\mathrm{cV}(\%)$} & \multicolumn{3}{|c|}{$\mathrm{cV}(\%)$} \\
\hline \multicolumn{3}{|c|}{ SUCÇÃO = $120 \mathrm{kPa}$} & \multicolumn{3}{|c|}{ SUCÇÃO = $240 \mathrm{kPa}$} \\
\hline Tensão (kPa) & $t_{90}(\min )$ & $\mathrm{c}_{\mathrm{v}}^{*}\left(\mathrm{~cm}^{2} / \mathrm{s}\right)$ & Tensão (kPa) & $t_{90}(\min )$ & $\mathrm{c}_{\mathrm{v}}{ }^{*}\left(\mathrm{~cm}^{2} / \mathrm{s}\right)$ \\
\hline 20,6 & 0,0900 & 0,25 & 20,6 & 0,0900 & 0,25 \\
\hline 41,2 & 0,1089 & 0,20 & 41,2 & 0,1024 & 0,21 \\
\hline 82,4 & 0,1024 & 0,21 & 82,4 & 0,0961 & 0,23 \\
\hline 164,8 & 0,0961 & 0,23 & 164,8 & 0,0841 & 0,26 \\
\hline 329,6 & 0,1089 & $\mathbf{0 , 2 0}$ & 329,6 & 0,0841 & 0,26 \\
\hline 659,2 & 0,0961 & 0,23 & 659,2 & 0,0841 & 0,25 \\
\hline \multirow[t]{2}{*}{1318,4} & 0,0900 & 0,21 & 1318,4 & 0,0900 & 0,22 \\
\hline & & & 2636,8 & 0,09 & 0,21 \\
\hline \multicolumn{3}{|c|}{ Média } & \multicolumn{3}{|c|}{ Média } \\
\hline \multicolumn{3}{|c|}{ Desv. Pad. } & \multicolumn{3}{|c|}{ Desv. Pad. } \\
\hline \multicolumn{3}{|c|}{$\mathrm{CV}(\%)$} & \multicolumn{3}{|c|}{$\mathrm{cV}(\%)$} \\
\hline \multicolumn{3}{|c|}{ SUCÇÃO =350 kPa } & \multicolumn{3}{|c|}{ SUCÇÃO = 500 kPa } \\
\hline Tensão (kPa) & $t_{90}(\min )$ & $\mathrm{c}_{\mathrm{v}}^{*}\left(\mathrm{~cm}^{2} / \mathrm{s}\right)$ & Tensão (kPa) & $t_{90}(\min )$ & $\mathrm{c}_{\mathrm{v}}^{*}\left(\mathrm{~cm}^{2} / \mathrm{s}\right)$ \\
\hline 20,6 & 0,0900 & 0,25 & 23,1 & 0,0900 & 0,25 \\
\hline 41,2 & 0,0900 & 0,24 & 46,3 & 0,0841 & 0,26 \\
\hline 82,5 & 0,0900 & 0,24 & 92,6 & 0,0900 & 0,24 \\
\hline 164,8 & 0,0841 & 0,26 & 185,2 & 0,0900 & 0,24 \\
\hline 329,6 & 0,0900 & 0,24 & 370,2 & 0,0900 & 0,24 \\
\hline 659,2 & 0,0900 & 0,24 & 740,2 & 0,0841 & 0,25 \\
\hline 1318,4 & 0,0900 & 0,23 & 1481 & 0,0841 & 0,24 \\
\hline \multirow[t]{4}{*}{2636,8} & 0,3721 & 0,05 & & & \\
\hline & Média & 0,24 & & Média & 0,25 \\
\hline & Desv. Pad. & 0,01 & & Desv. Pad. & 0,01 \\
\hline & cV (\%) & 4,12 & & CV (\%) & 3,01 \\
\hline
\end{tabular}


Coeficientes de adensamento - Ensaios de Alfaro (2004)

\begin{tabular}{|c|c|c|c|c|c|}
\hline \multicolumn{3}{|c|}{ SUCÇÃO = 0 kPa } & \multicolumn{3}{|c|}{ SUCÇÃO = $45 \mathrm{kPa}$} \\
\hline Tensão (kPa) & $t_{90}(\mathrm{~min})$ & $\mathrm{c}_{\mathrm{v}}{ }^{*}\left(\mathrm{~cm}^{2} / \mathrm{s}\right)$ & Tensão (kPa) & $t_{90}(\mathrm{~min})$ & $\mathrm{c}_{\mathrm{v}} *\left(\mathrm{~cm}^{2} / \mathrm{s}\right)$ \\
\hline 3,9 & 0,0841 & 0,26 & 11,8 & 0,0900 & 0,24 \\
\hline 10,4 & 0,0900 & 0,24 & 50,4 & 0,0900 & 0,24 \\
\hline 22,7 & 0,1225 & $\mathbf{0 , 1 8}$ & 101,8 & 0,1089 & $\mathbf{0 , 2 0}$ \\
\hline 48,1 & 0,1225 & 0,18 & 204,4 & 0,0900 & 0,24 \\
\hline 100,2 & 0,1600 & $\mathbf{0 , 1 4}$ & 409,8 & 0,0900 & 0,23 \\
\hline 201,0 & 0,1089 & $\mathbf{0 , 2 0}$ & 821,9 & 0,0961 & 0,21 \\
\hline 402,6 & 0,1225 & $\mathbf{0 , 1 7}$ & 1647,6 & 0,0900 & 0,22 \\
\hline 785,8 & 0,0900 & 0,22 & & & \\
\hline 1583,2 & 0,0900 & 0,23 & & & \\
\hline \multicolumn{3}{|c|}{ Média } & \multicolumn{3}{|c|}{ Média } \\
\hline \multicolumn{3}{|c|}{ Desv. Pad. } & \multicolumn{3}{|c|}{ Desv. Pad. } \\
\hline \multicolumn{3}{|c|}{$\begin{array}{ll}\mathrm{cV}(\%) & 19,97 \\
\end{array}$} & \multicolumn{2}{|r|}{$\mathrm{cv}(\%)$} & 7,31 \\
\hline & \multicolumn{3}{|c|}{ SUCÇÃO = $105 \mathrm{kPa}$} & & \\
\hline & Tensão (kPa) & $t_{90}(\min )$ & $\mathrm{c}_{\mathrm{v}}^{*}\left(\mathrm{~cm}^{2} / \mathrm{s}\right)$ & & \\
\hline & 10,1 & 0,0900 & 0,24 & & \\
\hline & 22,9 & 0,0900 & 0,25 & & \\
\hline & 48,7 & 0,0841 & 0,26 & & \\
\hline & 100,1 & 0,0900 & 0,24 & & \\
\hline & 202,6 & 0,0900 & 0,24 & & \\
\hline & 408,0 & 0,0900 & 0,24 & & \\
\hline & 820,2 & 0,0900 & 0,23 & & \\
\hline & 1645,8 & 0,0961 & 0,21 & & \\
\hline & & Média & 0,24 & & \\
\hline & & Desv. Pad. & 0,01 & & \\
\hline & & cV (\%) & 5,86 & & \\
\hline
\end{tabular}


APÊNDICE C - Coeficientes de Poisson 


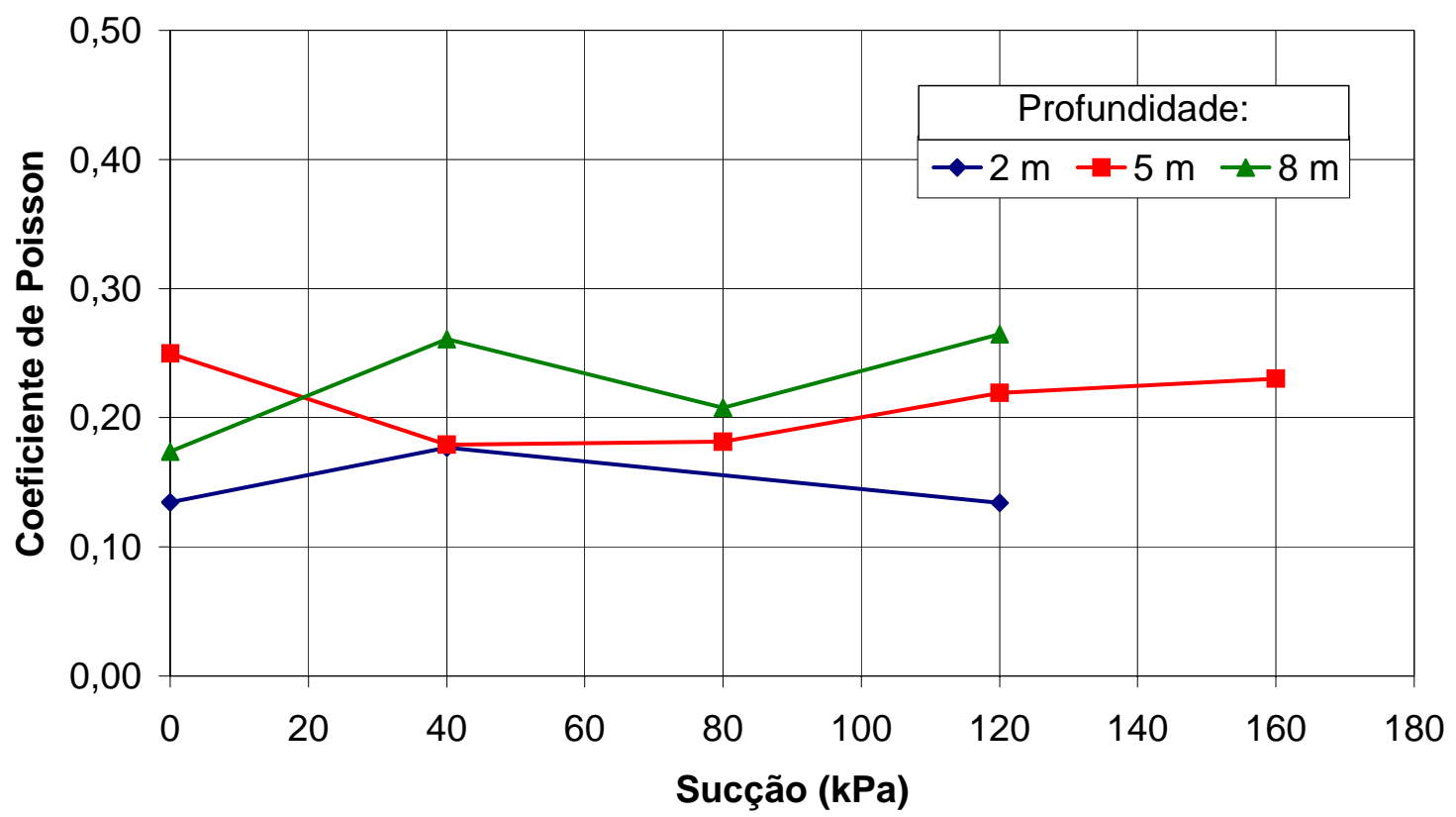

Coeficiente de Poisson em função da sucção e da profundidade. 
ANEXO A - Resultados dos ensaios de compressão confinada 


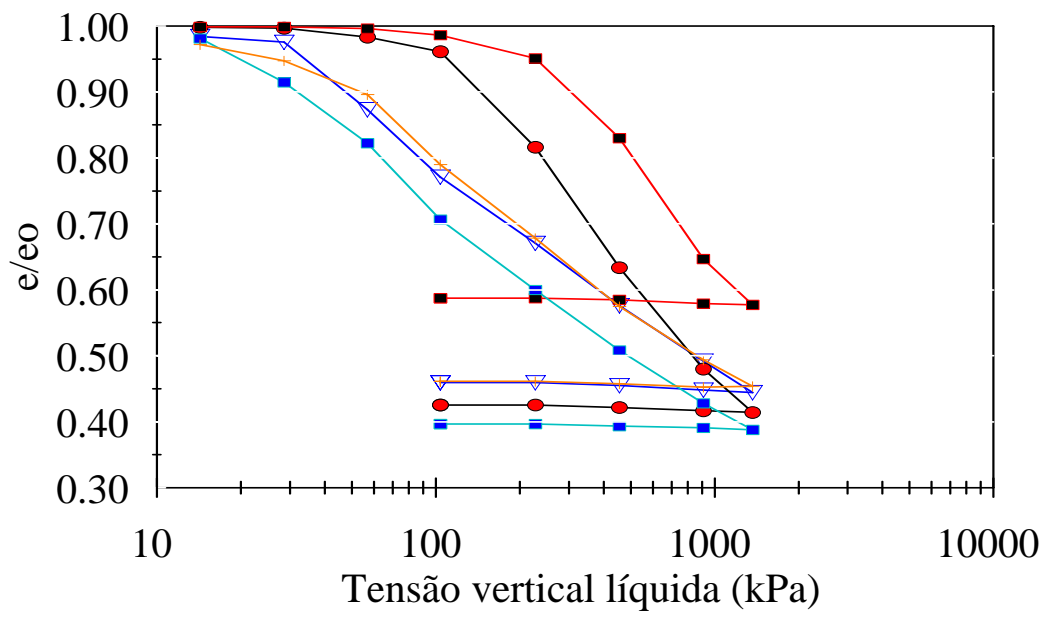

$\nabla$ sucção $=15 \mathrm{kPa}$ - - Sucção $=100 \mathrm{kPa}-$ - Sucção $=400 \mathrm{kPa}$

-- Solo saturado $\quad+$ Umidade natural

Figura A.1 - Curvas $\left(\mathrm{e} / \mathrm{e}_{\mathrm{o}}\right) \times\left(\sigma_{\mathrm{v}}-\mathrm{u}_{\mathrm{a}}\right)$ obtidas para a profundidade de 1,0 m (MACHADO, 1998).

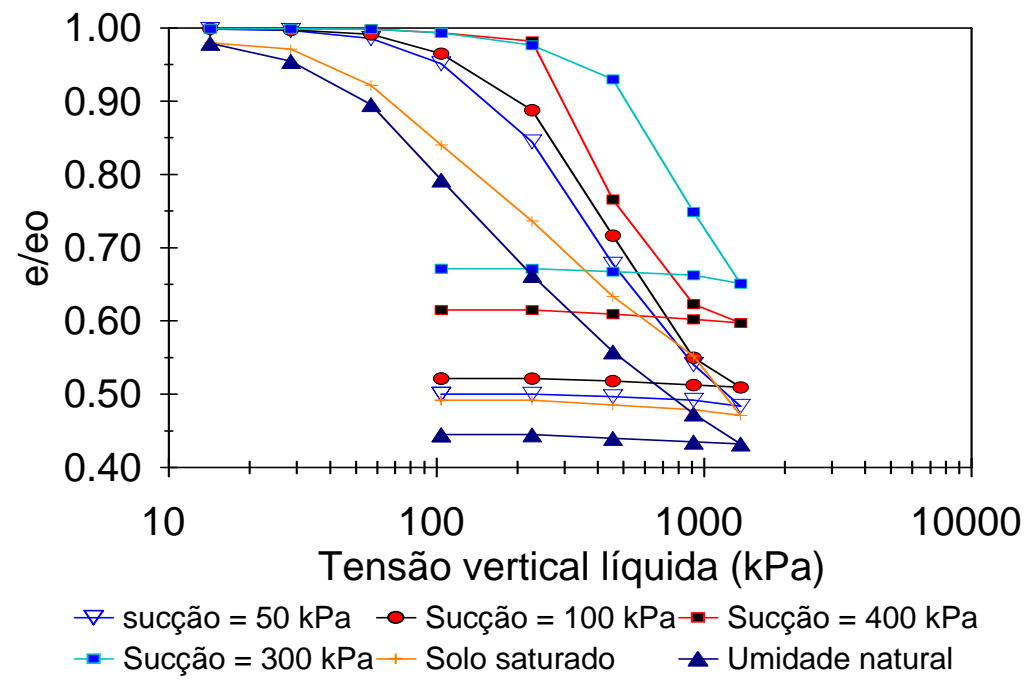

Figura A.2 - Curvas $\left(\mathrm{e} / \mathrm{e}_{\mathrm{o}}\right)$ x $\left(\sigma_{\mathrm{v}}-\mathrm{u}_{\mathrm{a}}\right)$ obtidas para a profundidade de $2,0 \mathrm{~m}$ (MACHADO, 1998). 


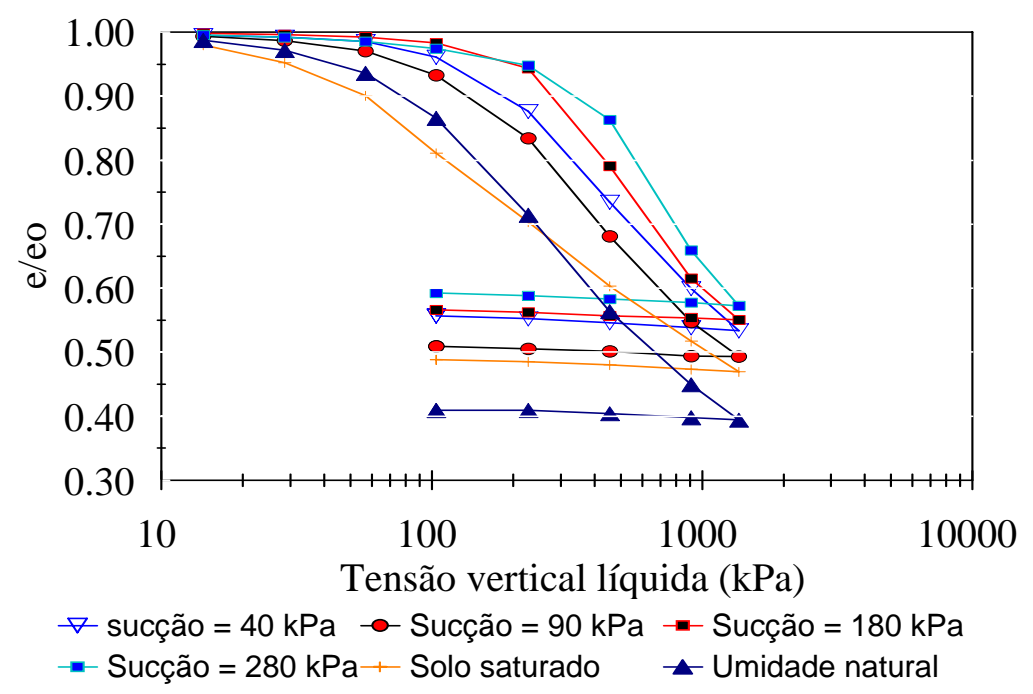

Figura A.3 - Curvas $\left(\mathrm{e} / \mathrm{e}_{\mathrm{o}}\right) \mathrm{x}\left(\sigma_{\mathrm{v}}-\mathrm{u}_{\mathrm{a}}\right)$ obtidas para a profundidade de 3,0 m (MACHADO, 1998).

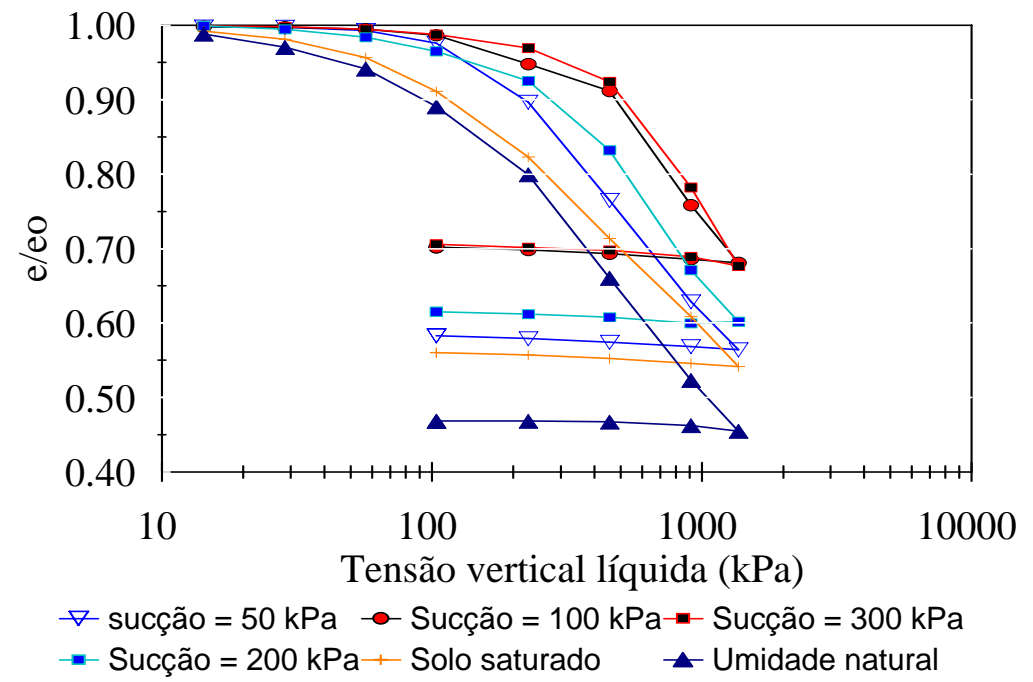

Figura A.4 - Curvas $\left(\mathrm{e} / \mathrm{e}_{0}\right)$ x $\left(\sigma_{v}-\mathrm{u}_{\mathrm{a}}\right)$ obtidas para a profundidade de $4,0 \mathrm{~m}$ (MACHADO, 1998). 


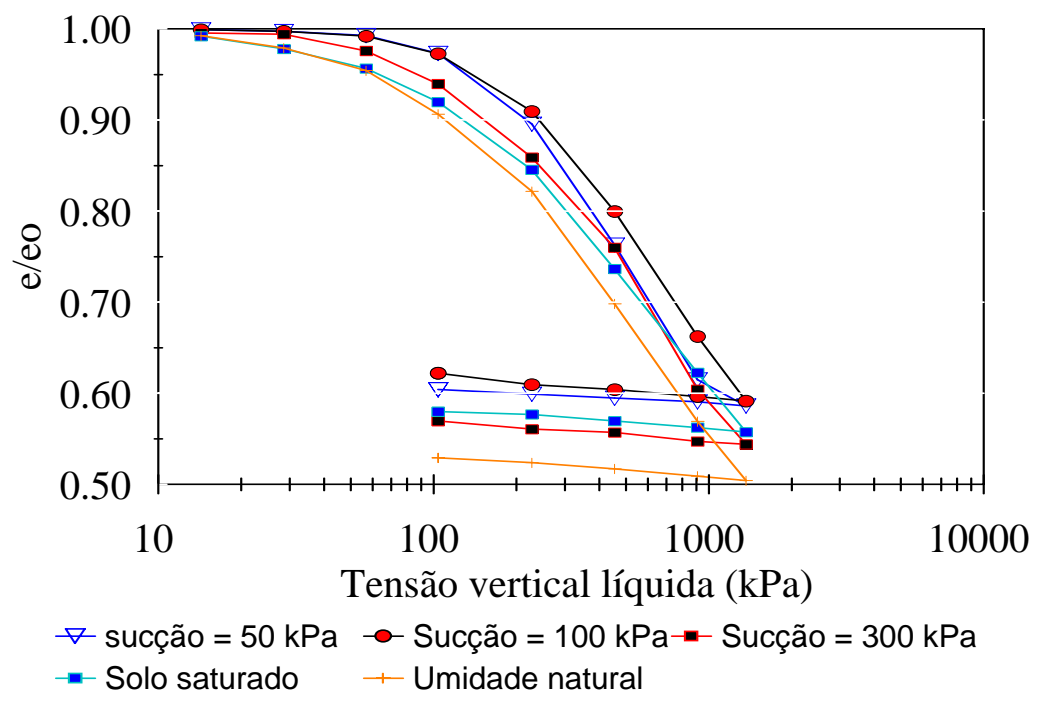

Figura A.5 - Curvas $\left(\mathrm{e} / \mathrm{e}_{\mathrm{o}}\right) \mathrm{x}\left(\sigma_{\mathrm{v}}-\mathrm{u}_{\mathrm{a}}\right)$ obtidas para a profundidade de 5,0 m (MACHADO, 1998).

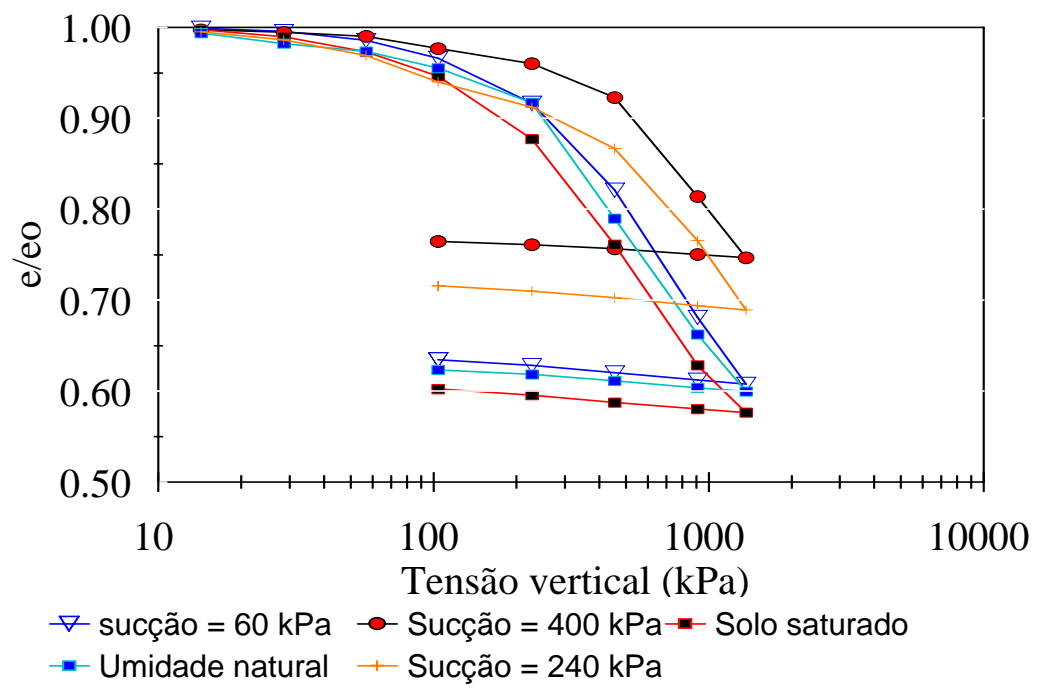

Figura A.6 - Curvas $\left(\mathrm{e} / \mathrm{e}_{\mathrm{o}}\right) \times\left(\sigma_{\mathrm{v}}-\mathrm{u}_{\mathrm{a}}\right)$ obtidas para a profundidade de 7,0 m (MACHADO, 1998). 


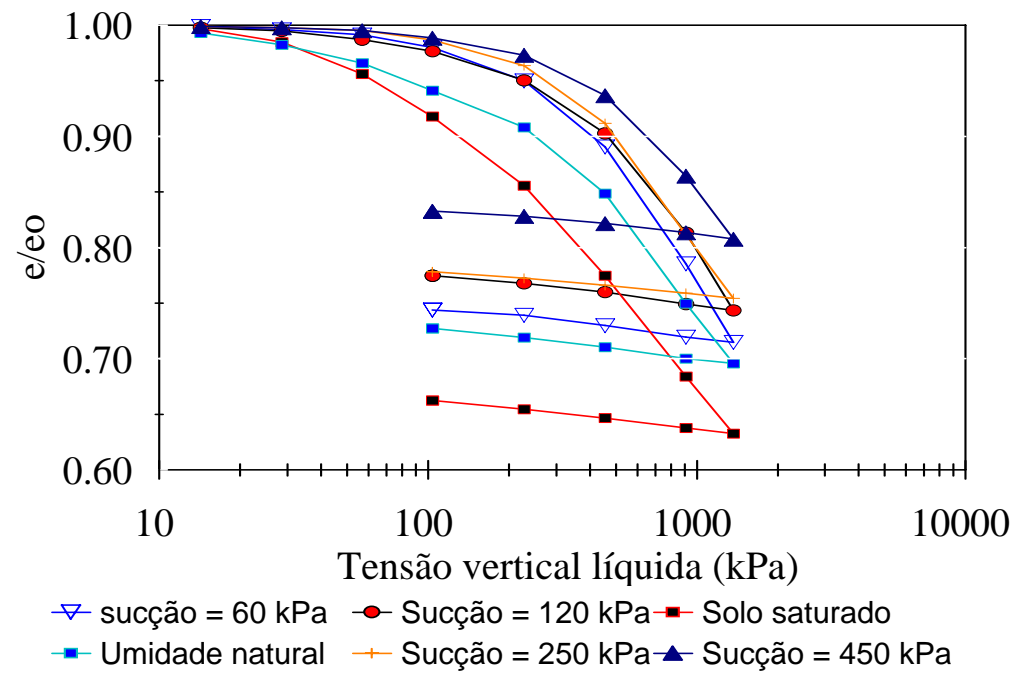

Figura A.7 - Curvas $\left(\mathrm{e} / \mathrm{e}_{\mathrm{o}}\right) \times\left(\sigma_{\mathrm{v}}-\mathrm{u}_{\mathrm{a}}\right)$ obtidas para a profundidade de 8,0 m (MACHADO, 1998). 
ANEXO B - Resultados dos ensaios de compressão triaxial 


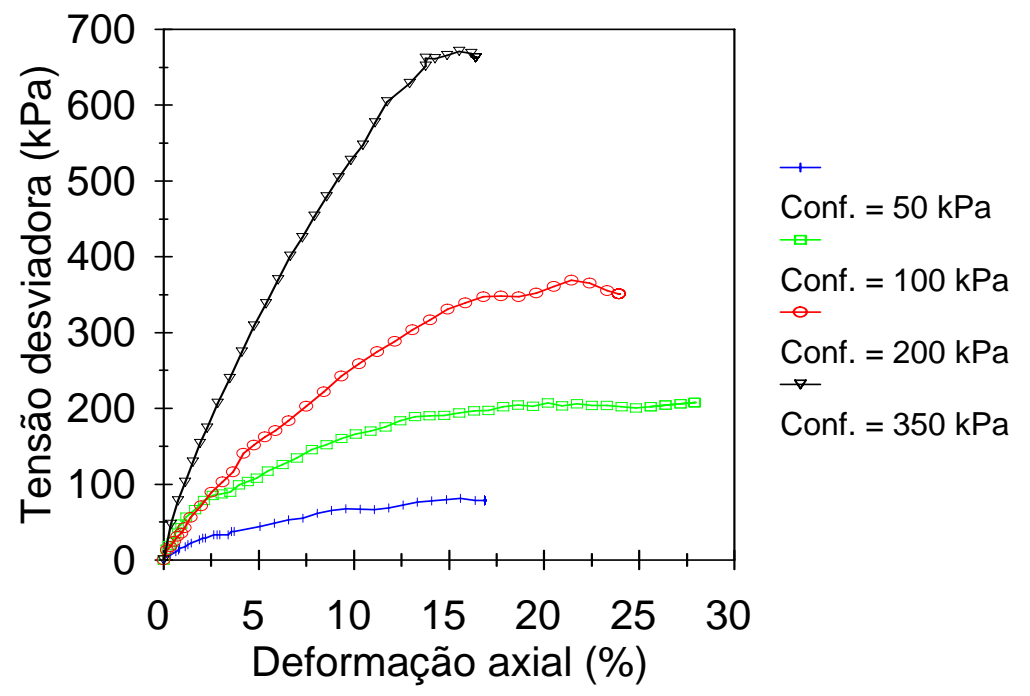

Figura B.1 - Resultados dos ensaios CID sat para a profundidade de 2,0 m, sucção nula (MACHADO, 1998).

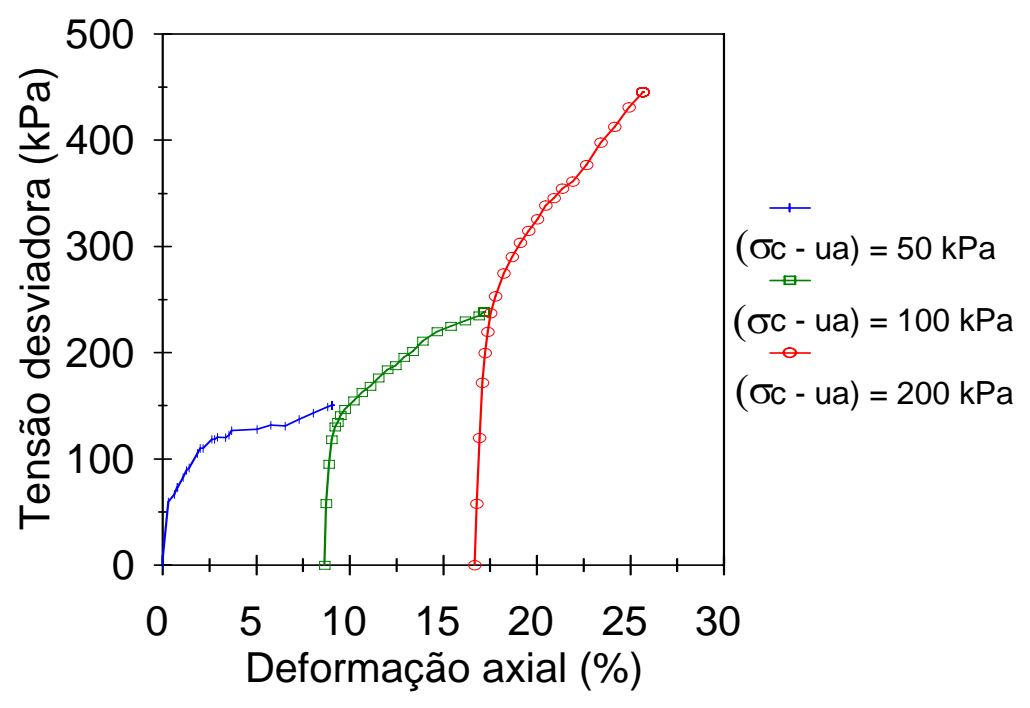

Figura B.2 - Resultados dos ensaios triaxiais em estágios múltiplos e com controle de sucção para a profundidade de 2,0 m, sucção de 80 kPa (MACHADO, 1998). 


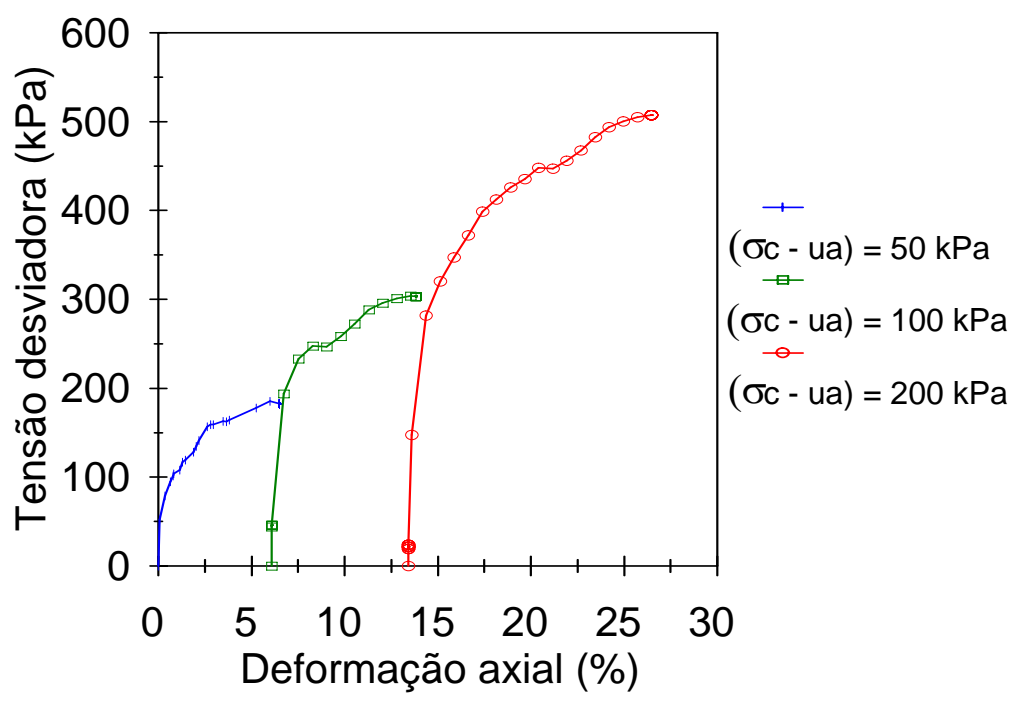

Figura B.3 - Resultados dos ensaios triaxiais em estágios múltiplos e com controle de sucção para a profundidade de 2,0 m, sucção de $120 \mathrm{kPa}$ (MACHADO, 1998).

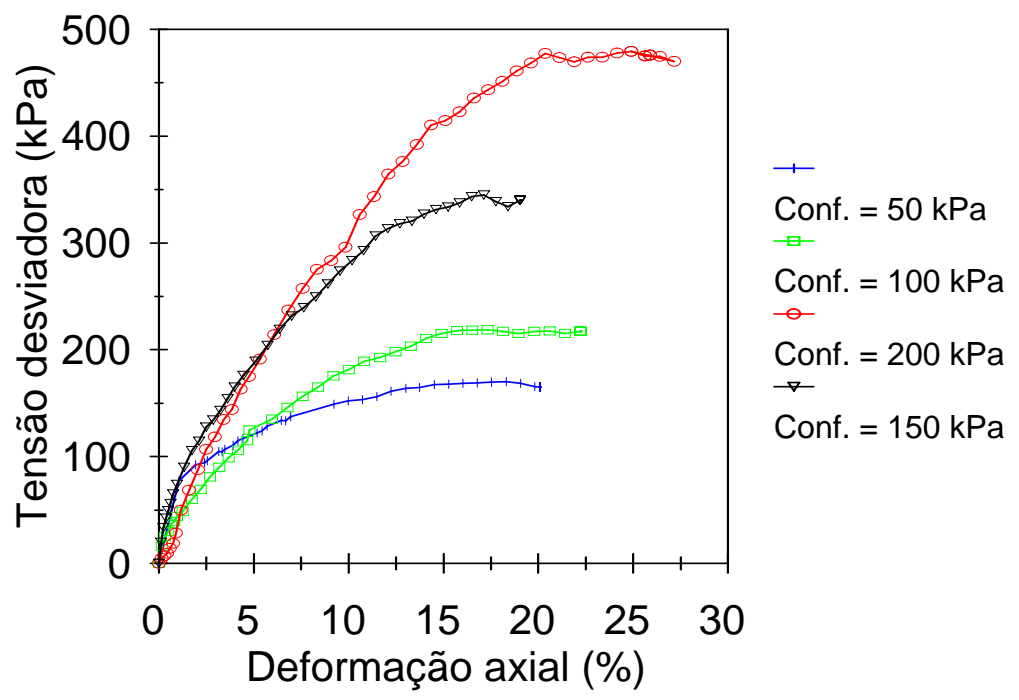

Figura B.4 - Resultados dos ensaios CID sat para a profundidade de 5,0 m, sucção nula (MACHADO, 1998). 


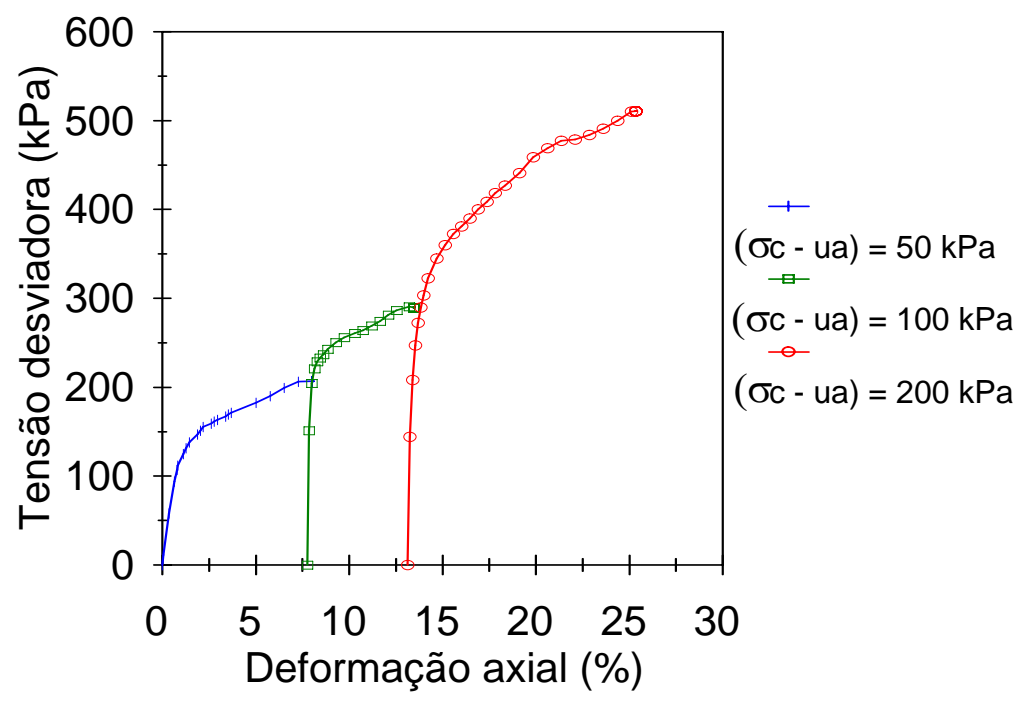

Figura B.5 - Resultados dos ensaios triaxiais em estágios múltiplos e com controle de sucção para a profundidade de 5,0 m, sucção de 40 kPa (MACHADO, 1998).

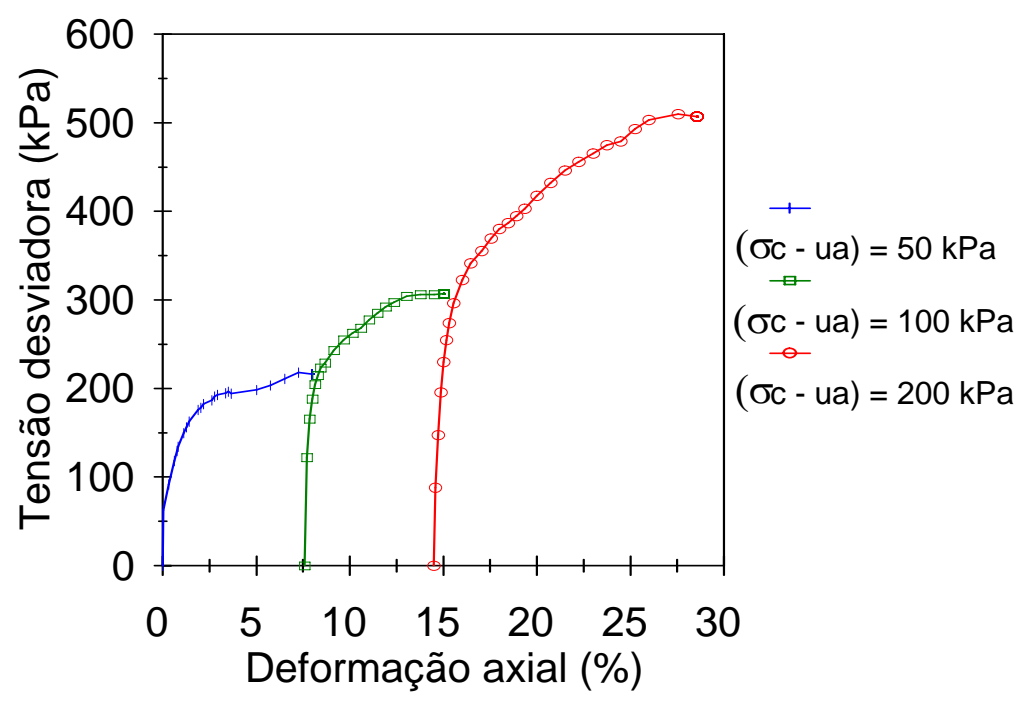

Figura B.6 - Resultados dos ensaios triaxiais em estágios múltiplos e com controle de sucção para a profundidade de 5,0 m, sucção de 80 kPa (MACHADO, 1998). 


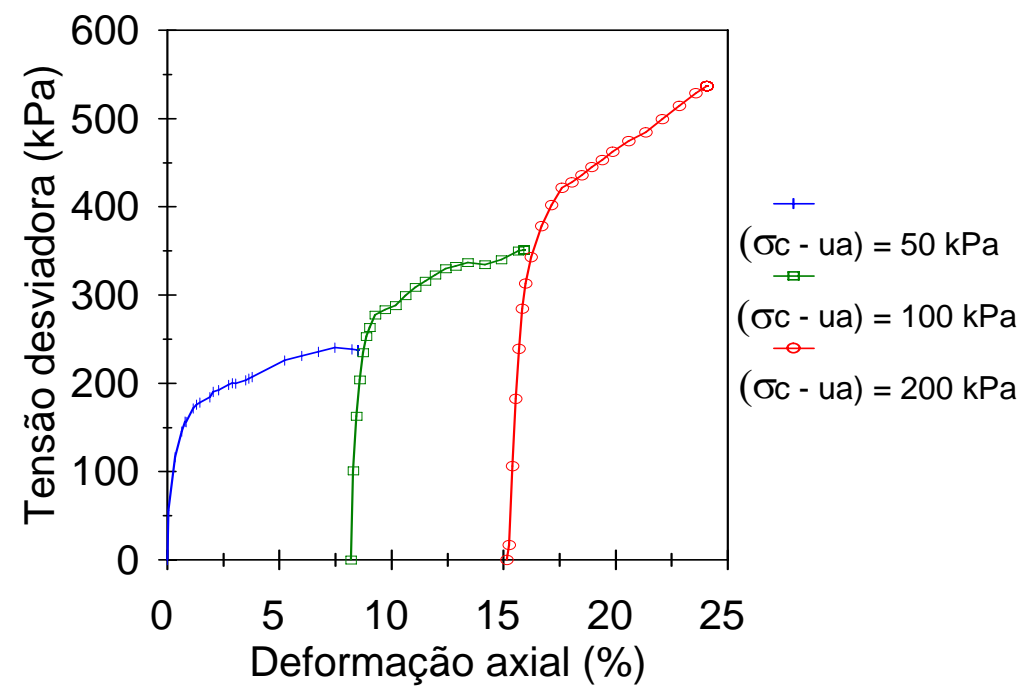

Figura B.7 - Resultados dos ensaios triaxiais em estágios múltiplos e com controle de sucção para a profundidade de 5,0 m, sucção de 160 kPa (MACHADO, 1998).

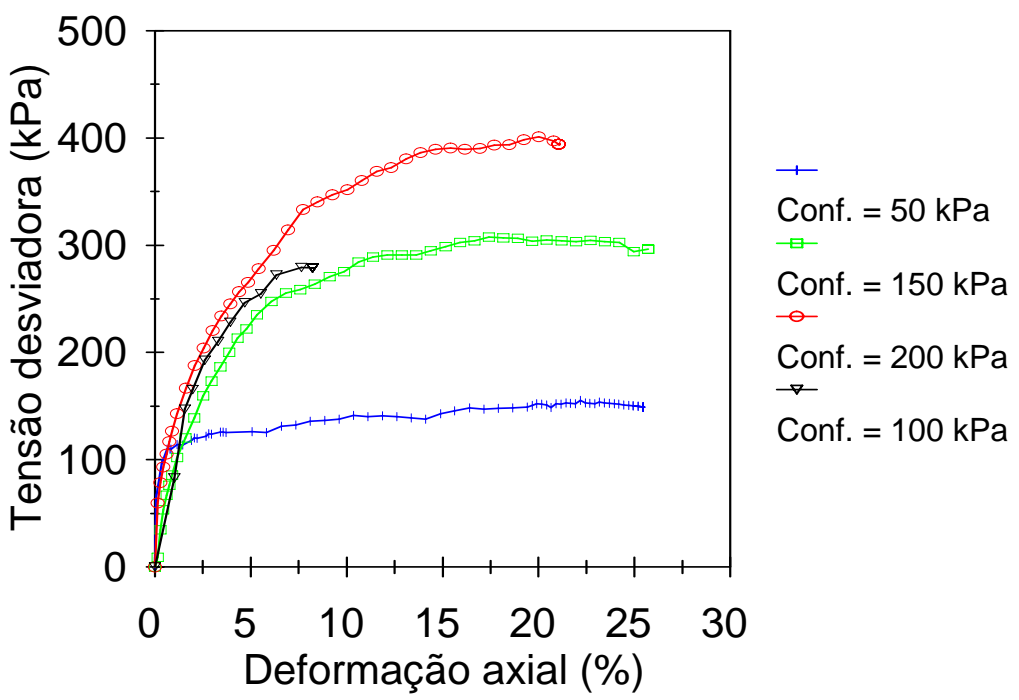

Figura B.8 - Resultados dos ensaios CID $_{\text {sat }}$ para a profundidade de 8,0 m, sucção nula (MACHADO, 1998). 


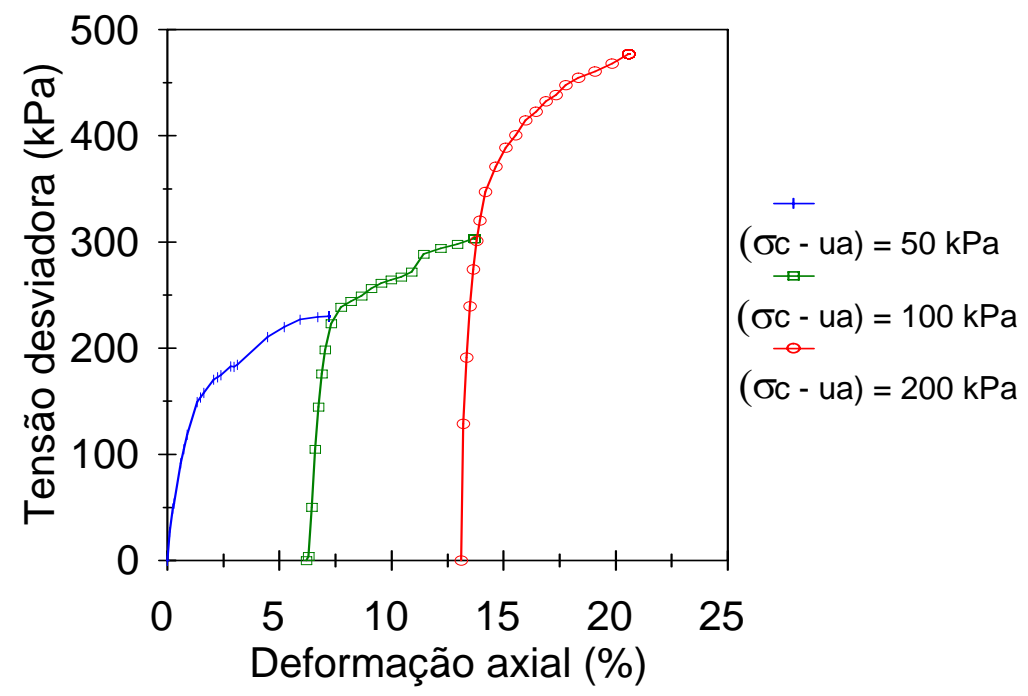

Figura B.9 - Resultados dos ensaios triaxiais em estágios múltiplos e com controle de sucção para a profundidade de 8,0 m, sucção de 40 kPa (MACHADO, 1998).

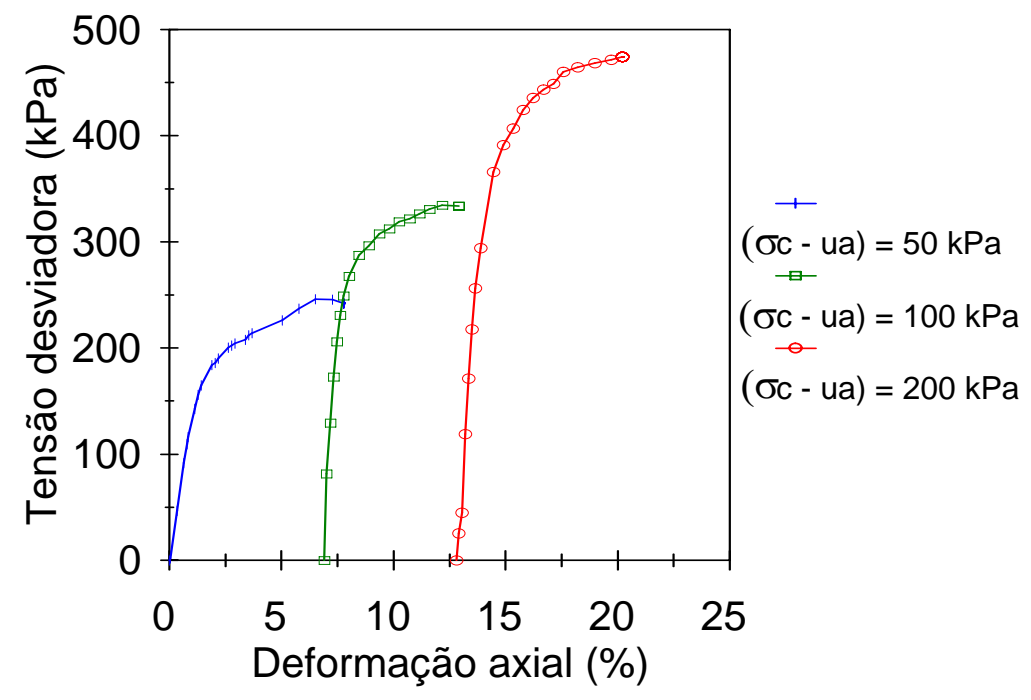

Figura B.10 - Resultados dos ensaios triaxiais em estágios múltiplos e com controle de sucção para a profundidade de 8,0 m, sucção de 80 kPa (MACHADO, 1998). 


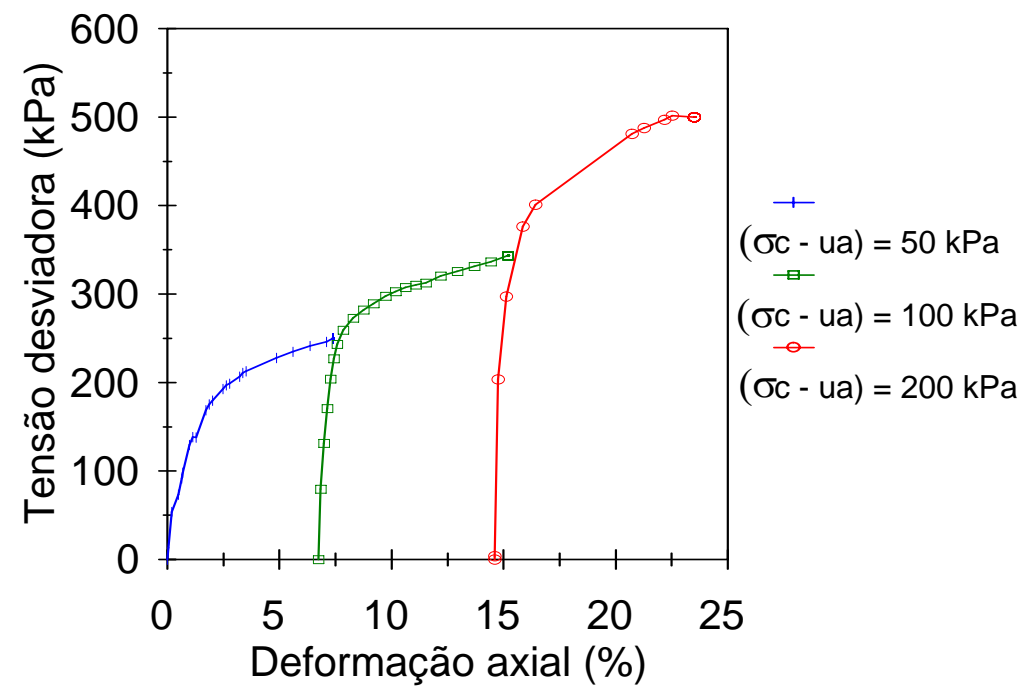

Figura B.11 - Resultados dos ensaios triaxiais em estágios múltiplos e com controle de suç̧ão para a profundidade de 8,0 m, sucção de 120 kPa (MACHADO, 1998).

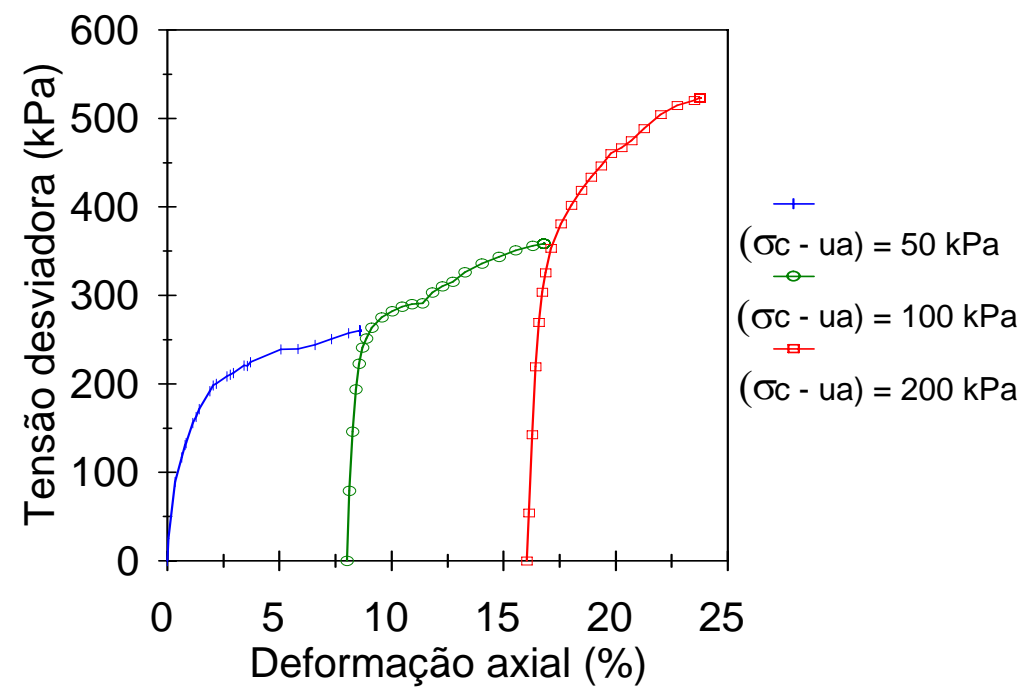

Figura B.12 - Resultados dos ensaios triaxiais em estágios múltiplos e com controle de sucção para a profundidade de 8,0 m, sucção de 160 kPa (MACHADO, 1998). 